\title{
The 'nazification' and 'denazification' of the courts in Belgium, Luxembourg and the Netherlands
}

Citation for published version (APA):

Michielsen, J. N. M. E. (2004). The 'nazification' and 'denazification' of the courts in Belgium, Luxembourg and the Netherlands. [Doctoral Thesis, Maastricht University]. Datawyse / Universitaire Pers Maastricht. https://doi.org/10.26481/dis.20041222jm

Document status and date:

Published: 01/01/2004

DOI:

10.26481/dis.20041222jm

Document Version:

Publisher's PDF, also known as Version of record

\section{Please check the document version of this publication:}

- A submitted manuscript is the version of the article upon submission and before peer-review. There can be important differences between the submitted version and the official published version of record.

People interested in the research are advised to contact the author for the final version of the publication, or visit the DOI to the publisher's website.

- The final author version and the galley proof are versions of the publication after peer review.

- The final published version features the final layout of the paper including the volume, issue and page numbers.

Link to publication

\footnotetext{
General rights rights.

- You may freely distribute the URL identifying the publication in the public portal. please follow below link for the End User Agreement:

www.umlib.nl/taverne-license

Take down policy

If you believe that this document breaches copyright please contact us at:

repository@maastrichtuniversity.nl

providing details and we will investigate your claim.
}

Copyright and moral rights for the publications made accessible in the public portal are retained by the authors and/or other copyright owners and it is a condition of accessing publications that users recognise and abide by the legal requirements associated with these

- Users may download and print one copy of any publication from the public portal for the purpose of private study or research.

- You may not further distribute the material or use it for any profit-making activity or commercial gain

If the publication is distributed under the terms of Article $25 \mathrm{fa}$ of the Dutch Copyright Act, indicated by the "Taverne" license above, 


\section{THE 'NAZIFICATION' AND 'DENAZIFICATION' OF THE COURTS IN BELGIUM, LUXEMBOURG AND THE NETHERL ANDS}

The Belgian, Luxembourg and Netherlands courts and their reactions to occupation measures and neasures from their governments returning from exile 
Copyright and explanation pictures cover

Front cover images:

Top image (Belgium) President Jamar, courtesy of the Cow de cassation.

Middle image (Luxembourg) President Faber, courtesy of the Parquet General a la Cour Superieure de austice.

Bottom image (The Netherlands) President Visser, courtesy of NIOD.

ISBN: 9052784361

Copyright 02004 J.M.N.E. Michielsen

All rights reserved to the author J.N.M.E. Michielsen. No part of this publication may be reproduced, stored or introduced into a retrieval system, or transmitted, in any form or by any means (electronic, mechanical, photocopying, recording or otherwise), without the prior written permission of the author/copyright owner. 


\section{THE 'NAZIFICATION' AND 'DENAZIFICATION' OF THE COURTS IN BELGIUM, LUXEMBOURG AND THE NETHERLANDS}

The Belgian, Luxembourg and Netherlands courts and their reactions to occupation measures and measures from their governments returaing from exile

\section{PROEFSCHRIFT}

ter verkrijging van de graad van doctor aan de Universiteit Maastricht, op gezag van de Rector Magnificus, Prof. Mr. G.P.M.F. Mols volgens het besluit van het College van Decanen, in het openbaar te verdedigen op woensdag 22 december 2004 om 12:00 uur door

Joeri Nicolaas Maria Elisabeth Michielsen

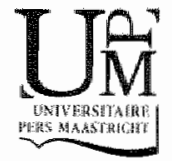




\section{Promotores:}

Prof. Mr Gerard-René de Groot

Prof. Dr. Hilcegard Schneider

\section{Beoordelingscommissie:}

Prof. Mr Remco van Rhee (voorzitter)

Prof. Dr. Louis Berkvens

Prof. David Fraser (University of Nottingham, United Kingdom)

Prof. Dr. Herman Van Goethem (Universiteit Antwerpen, België)

Prof. Mr Frits Stroink 
Those who cannot remember the past are condemned to repeat it.

George Santayana, The Life of Reason, Volume 1, 1905

To Steven,

For Love and Suppont

To John B., Midwife

Veur mien femillie Nefuurlek! 



\section{PREFACE}

Wherever the interest in a certain topic may come from and however deep the interest goes will probably be hard to trace. What can be said for certain is that how the courts in countries in occupied Europe functioned has been a topic that continued to interest me and in researching and writing about it, interest has not abated. At some point it is time to let go though, if only to allow a fresh breeze of new thoughts associated with new topics to create new angles from which to return to one's initial interest.

For now work on this topic has come to an end and no matter how much enriching solitude was needed in order to create it, many were present to offer support, help and knowledge. The following is therefore not the fulfillment of an obligatory custom, but rather an honest expression of gratitude.

I am very much indebted to both my supervisors Hildegard Schneider and René de Groot. Throughout my studies I have been privileged to enjoy their unabating and enthusiastic furtherance. When this book was merely in its infancy and surrounded by vague ideas I enjoyed what seemed like their blind and continuous support for its realization. My first and most special thanks goes to both of you.

Marion Koene-Gorren was instrumental in executing a project dealing with numerics and providing extra source materials. Even more highly valued is the time she took to reflect with me on this topic and I sincerely hope for her collaboration in the future on projects of joint interest. Marion, de hèls ein vaan in'ch tegood!

Several people, some of whom I could unfortunately only be in touch with via email, commented on earlier drafts of this book. In no particular order I am very grateful to Sjoerd Faber, Michael Bazyler, Remco van Rhee, Louis Berkvens, Paul Dostert, David Fraser and Herman van Goethem. A special thanks to Frits Stroink.

Also many archivists and librarians were helpful beyond the call of duty. I would specifically like to thank Maarten van Rhijn, Laurens Oldersma, Sierk Plantinga, Serge Hoffmann, Karel Velle and many others who were patient and willing to help with my enquiries. II am also very grateful to Ms. Evelyn Hartogs, court registrar at the Netherlands Supreme Court, for her interest in furthering my research.

Others helped me along of whom I only recall by name Etiënne Verhoeyen and Edvard Raskin. A special thanks as well to Cees Flinterman for his contribution to the publication of nyy work. And a very warm thank you to Pierre Bakkes, Ton van de Wijngaard, Flor Aarts en Dhr. Kurris for their watchful eye on the use of my Limbourgish spelling and grammar. Many thanks to Ida Wendt for meticulously reading my manuscript. I'll reciprocate. Quid pro quo! Credit and sincere thanks for the layout goes to Marjo Mullers.

Most importantly, I would like to thank my partner Steven Tallman. He never stopped supporting me in writing this book and for his presence and support I am deeply grateful.

However, what will be presented to you is my work, which also means that any mistakes are my responsibility alone. 



\section{TABLE OF CONTENTS}

Preface.

Table of contents iii

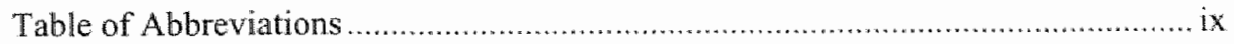

Introduction 1

Chapter 1

Invasion, Occupation and Administration on the occupied Territory ............... 5

1.1 Invasions and Governments into exile .................................................... 5

1.2 Belgium and the Militärverwaltung ........................................................6

1.2.1 The national administration on the occupied territory .................................6

1.2.2 The occupant's administration; type, organization, goal ............................. \&

1.2.3 Modus vivendi; a system of administration for the occupation .................... 10

1.3 Luxembourg and the Chef der Zivilverwaltwng..................................... 13

1.3 .1 The national administration on the occupied territory........................... 13

1.3.2 The occupant's administration; type, organization, goal ............................ 16

1.3.3 Modus vivendi: a system of administration for the occupation ...................... 17

1.4 The Netherlands and the Zivilverwaltung ................................................ 19

1.4.1 The national administration on the occupied territory ............................... 19

1.4.2 The occupant's adninistration; type, organization, goal ............................ 22

1.4.3 Modus vivendi; a system of administration for the occupation .....................23

1.5 Conclusion; administration at the start of the occupation and the position

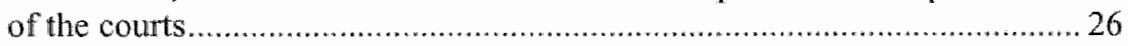

\section{Chapter 2}

The Belgian Courts during the Occupation .............................................. 29

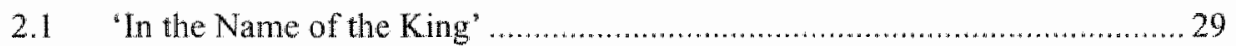

2.2 Judicial personnel and the prohibition to abandon post ............................ 30

2.3 Measures against Belgian judges of Jewish ancestry ................................... 32

2.4 Limitation of competencies and first crisis cases involving illegal possession of arms............................................................................. 35

2.5 Appointments during the occupation .................................................... 39

2.6 Regulation concerning statutory age limit and removals from office ........... 44

2.7 The Cour de cassation and suspension or arrest of judges for ex officio acts................................................................................. 47

2.8 Courts and the first applications of occupation measures ........................... 50

2.9 First judicial crisis; measures concerning economic crimes and judicial review ............................................................................................ 55

2.10 The courts and measures concerning forced deployment of labor ................68

2.11 Second judicial crisis; measures altering the political structure and judicial review. 
2.12 The Cour de cassation and atrocities in detention camps ............................8 80

2.13 Crisis over interference of an $S S$ member in court proceedings at the Arlon Tribunal ................................................................................. 80

2.14 The Cour de cassation and the occupant's policy of hostage taking ............81

2.15 Second crisis on competence to try cases involving illegal possession of

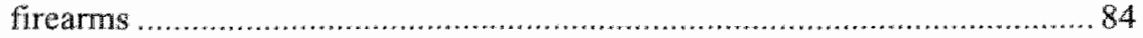

2.16 Concluding remarks on the Belgian courts during the occupation ................90

\section{Chapter 3}

The Luxembourg Courts during the Occupation .............................................. 95

3.1 'In the Name of the People' ............................................................... 95

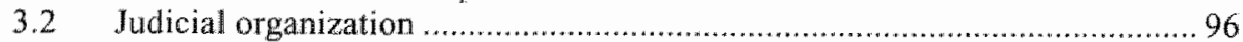

3.3 Measures against Luxembourg judges of Jewish ancestry ....................... 100

3.4 Limitation of competencies ................................................................. 100

3.5 Appointments; German judges in Luxembourg courts ............................... 101

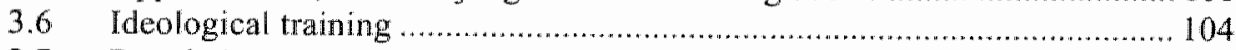

3.7 Regulation concerning statutory age limit.............................................. 105

3.8 Introduction of German law into the Luxembourg legal system; judicial

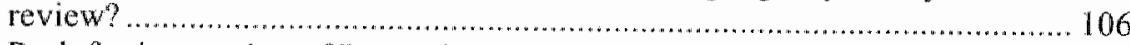

3.9 Push for integration of Luxembourg courts into the German judicial

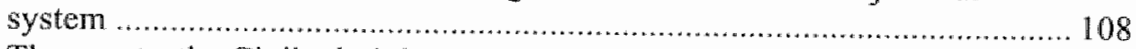

3.10 The courts, the Civil administration's push for annexation and the national strike

3.11 More plans for further judicia] integration into Nazi-Germany and end of occupation....

3.12 Concluding remarks on the Luxembourg courts during the occupation......... 117

Chapter 4

\section{The Netherlands Courts during the Occupation}

4.1 "In the Name of the Queen'?

4.2 Courts and the first applications of occupation measures

4.3 Measures against Netherlands judges of Jewish ancestry

4.4. Limitation of competencies

46 Regulation concen

4.6 Regulation concerning statutory age limit .............................................. 141 penal provisions

4.8 Establishment courts to try economic crimes and judicial review? ............... 149

4.9 The courts' application of measures against Netherlands nationals of Jewish ancestry

4.10 The courts, atrocities in detention camps and …................................... 158

4.11 The courts and atrocities in detention camps and removals from office ........... 159

4.12 The courts and measures concernion camps continued ............................. 165

4.13 Moving the seat of courts concerning forced deployment of labor ................ 168

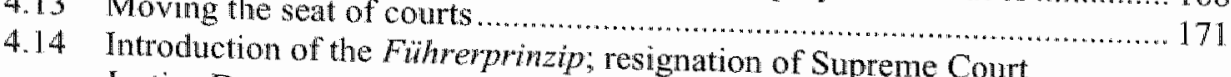
Justice Donner..... 
4.15 The courts and some last-minute challenges to the validity of occupation legislation.

4.16 Hostage taking and execution of judges; Justice Hülsmann and Vice-President Dons ............................................................................... 179

4.17 Concluding remarks on the Netherlands courts during the occupation.

Chapter 5

\section{Comparing the Belgian, Luxembourg and Netherlands Courts' Attitudes} toward the Occupant's 'Nazification' Measures.

5.1 The Belgian, Luxembourg and Netherlands courts' positivist attitude ....... 187

5.1.1 Preliminary remarks ..................................................................... 187

5.1.2 Similar measures in Belgium, Luxembourg and The Netherlands.............. 191

5.1.3 Measures common to Belgium and The Netherlands................................. 195

5.2 Positivist attitude and organization of courts to resist execution of occupation policies

5.3 Positivism and ability to organize allowed courts to resist the occupant's policies?

Chapter 6

Governments in and returning from Exile 203

6.1 Governments-in-exile during the occupation ........................................ 203

6.2 The Belgian Government in and returning from exile .............................. 206

6.2 .1 Brief history of the Belgian Government-in-exile...................................206

6.2 .2 Administration in exile; legal basis .......................................................207

6.2.3 The Belgian Government returning from exile ........................................ 209

6.3 The Luxembourg Government in and returning from exile ........................210

6.3.1 Brief history of the Luxembourg Government-in-exile ............................2 210

6.3.2 Administration in exile; legal basis ...................................................... 211

6.3.3 The Luxembourg Government retuming from exile ................................ 212

6.4 The Netherlands Govemment in and returning from exile......................... 214

6.4.1 Brief history of the Netherlands Government-in-exile .............................. 214

6.4 .2 Administration in exile; legal basis .................................................... 214

6.4.3 The Netherlands Govermment returning from exile ................................. 215

6.5 Conclusion; return of the Governments from exile and the position of the courts.

\section{Chapter 7}

"Denazification" of Belgian, Luxembourg and Netherlands Courts..

7.1 Belgium

7.1.1 Belgian courts and judicial review of exile measures?

7.1.2 Measures abolishing occupation measures directed at the courts ............... 226

7.1.3 Measures dealing with occupation personnel policy ............................... 228

7.1.4 Concluding remarks on the Belgian courts and 'denazification' measures.. 232

7.2 Luxembourg ................................................................................ 233

7.2.1 Luxembourg courts and judicial review of exile measures? ..................... 233 
7.2.2 Measures abolishing occupation measures directed at the coarts .............. 234

7.2.3 Measures dealing with occupation personnel policy ................................ 237

7.2.4 Concluding remarks on the Luxembourg courts and 'denazification' measures............................................................................................ 241

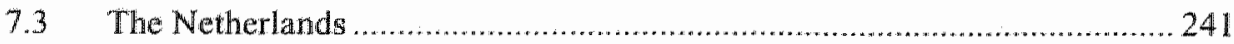

7.3.1 Netherlands courts and judicial review of exile measures?........................ 241.

7.3.2 Measures abolishing occupation measures directed at courts ..................... 242

7.3.3 Measures dealing with occupation personnel policy ................................2.243

7.3.4 The postwar period, the Supreme Court and its occupation policy

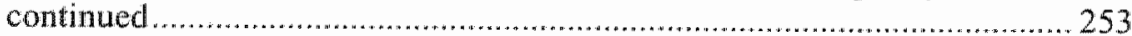

7.3.5 The Supreme Court and judicial review of exile measures? ....................... 255

7.3.6 Solving the crisis around the Supreme Court ................................................ 258

7.3.7 Concluding remarks on the Netherlands courts and 'denazification' measures

7.4 Comparing the Belgian, Luxembourg and Netherlands courts" attitudes towards their exile Government's "denazification' measures

\section{Chapter 8}

Conclusion

8.1 Belgian courts during the occupation and postwar period 263

8.2 Luxembourg courts during the occupation and postwar period ........................264

8.3 Netherlands courts during the occupation and postwar period.....................2. 265

8.4 Comparing the Belgian, Luxembourg and Netherlands courts during the occupation and postwar period.

8.5 Courts, the law and reasons not to apply Jaw during an occupation and postwar period.

Chapter 9

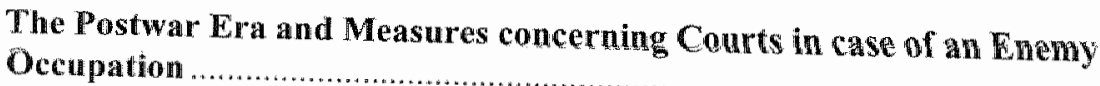

9. I. Introduction

9.2 International law developments since World War Two

The Netherlands

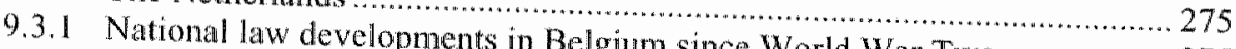

9.3.2 National Jaw developments in Belgum since World War Two ................. 275

9.3.3 National law developments in Luxembourg since World War Two ........... 278

9.4 Legal framework forments in the Netherlands since World War Two....... 278

9.4.1 National administratio courts to function during an enemy occupation?.. 282

9.4 .2 Courts during an enemy occupation enemy occupation........................... 282

9.4 .3 The application of existing law dion ................................................ 284

enectpation......

Limbourgish Summary

Dutch Summary 
Annex 1: List of translations Belgium................................................................. 309

Annex 2: List of translations Luxembourg .......................................................... 319

Annex 3: List of translations Netherlands ............................................................323

Annex 4: Overview personnel policy Belgium ………....................................... 337

Annex 5: Overview personnel policy Luxembourg ................................................ 339

Annex 6: Overview personnel policy Netherlands ............................................ 341

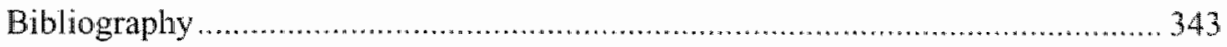

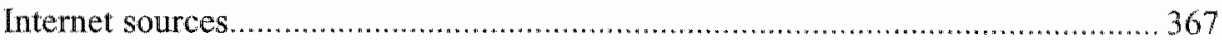

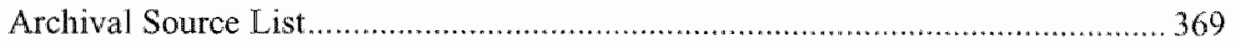

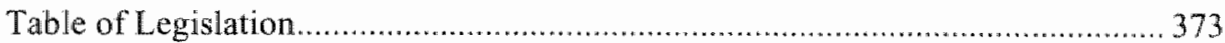

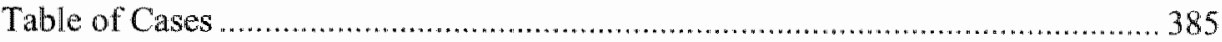

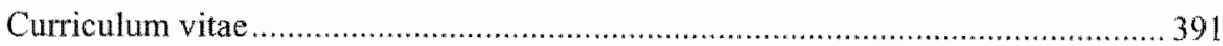





\section{TABLE OF ABBREVIATIONS}

Afd.

ARB

$B P C$

Burg. Kamer

CABR

Cass.

CEGES/SOMA

c.

CEPAG

Ch.

CNAA

d.d.

Doc.

EPU

ff.

FF.

HEK

HTK

HR

inv.
Afdeling

Algemene Raad van Beroep

Belgian Penal Code

Burgerlijke Kamer

Centraal Archief Bijzondere Rechtspleging

Cassation

Centre d'Études et de Documentation Guerres et Societés Contemporaines, Studie- en documentatiecentrum Oorlog en hedendaagse Maatschappij

contre

Commission belge pour l'Étude des Problèmes d'Après Guerre

Chambre

Corporation Nationale de l'Agriculture et de l'Alimentation

de dato

Document

Épuration

faisant fonction

and following

Handelingen Eerste Kamer

Handelingen Tweede Kamer

Hoge Raad

inventaris 
IdT

$\mathrm{KB}$

LPC

M.

Mém.

MIC

Mon.

MP

$\mathrm{MP}^{\mathrm{P}}$

MVA

NIOD

N.O.R

$N$ I

NJB

No.

$\mathrm{NPC}$

Nir.

$\mathrm{NSB}$

NSDAP

NSRB

OKH

OKW

Para.

Pas.
Joumal des Tribunaux

Koninkligk Besluit

Luxembourg Penal Code

Monsieur

Mémorial

Microfiche

Moniteur

Member of Parliament

Members of Parliament

Memorie van Antwoord

Nederlands Instituut voor Oorlogsdocumentatie

Nederlandse Oorlogsrechtspraak

Nederlandse Jurisprudentie

Nederlands Juristenblad

Numeto

Netherlands Penal Code

Nummer

Nationaal Socialistische Beweging

Nationalsozialistische Deutsche Arbeiter Partei

Nationalsozialistischer Rechtswahrerbund

Oberkommando des Heeres

Oberkommando der Wehrmacht

paragraph

Pasicrisie 
p.

pp.

ref.

resp.

$\mathrm{RO}$

$\mathrm{S}$.

$\mathrm{SD}$

Stb.

SS

$\mathrm{VdB}$

VNV

Vo.

VoBl.

Wnd.

WvhR page

pages

reférence

respectively

Rechterlijke Organisatie

Seite

Sicherheitsdienst

Staatsblad

Schutzstaffel

Volksdeutsche Bewegung

Vlaams Nationaal Verbond

Verordnung

Verordnungsblatt

Waarnemend

Weekblad van het Recht 



\section{INTRODUCTION}

War fascinates for the mere fact that the nature of the force employed for the puppose of warfare cannot be subject to rules, though rules might limit the use of that force. What then, in the case of an occupied country being under the control of a foreign power, would the position be of that occupied country? How would it deal with that occupation and the fact that the occupant would have this total control over it, due to the force of warfare at the latter's disposal?

My training as a lawyer determined the direction in which I could research an aspect of these questions. The question how rules influence the relationship of an occupied country with its occupant is nowhere more apparent than in the relationship between the occupant and the courts of the occupied country. An occupant will need to dictate rules in order to administer the occupied territory and may need to resort to the use of force in order to make sure these rules are obeyed. Unless the occupant were to decide to use his force to install an adninistration of his own, he will need to use the occupied country's institutions to enforce his measures. For numerous reasons, some of which will be touched upon later, the German occupant during World War Two used, as much as possible, the institutions of the occupied country, in order to have his measures executed. Whether or not the occupied country would comply was unsure, but the occupant could always resort to force against those organs or public officials of the occupied country that refused to execute his orders. But how would the occupied country use rules to influence its relationship with the occupant, where the rules of the occupier could be backed up by force employed for warfare?

The courts were one crucial link in assuring the rest of the state apparatus would enforce the occupant's orders. In democratic societies, courts not only decided in numerous individual cases whether and how certain rules would be applied. A court's refusal in some instances to apply a certain measure might also mean a refusal from other organs of the state to apply that measure. As a result, the courts were at the nexus of the occupant's relationship with the accupied country. It is therefore the courts' relationship with the occupant that will be at the heart of this research, whereby only the ordinary courts dealing with civil and criminal law cases will be examined.

This history of the courts during the occupation of World War Two will mostly be written chronologically in order not to disturb a description of the flow of events. Of course the description will not be exhaustive, but will aim to be as inclusive as possible. Although in some jurisdictions several publications have touched on the topic or dealt with parts of it, in no jurisctiction a more comprehensive description of the history of the civil and criminal courts during the occupation has been made.

In order to describe the "nazification" of the courts the research will look at the measures the national socialist occupant took regarding the position and functioning of the courts. These might of course include measures that were not inspired by national socialist ideology, but were necessary to conduct differing policies of the national socialist occupant. For 'denazification' the measures the Government returning from exile took that affected the courts will be researched, mainly attempting to rid the courts of occupation measures that had altered their position and functioning. The courts' reactions to these measures will be highlighted, being the aim of this research. 
In order to enable comparison between different countries, similar measures in all jurisdictions will be compared. These will be measures affecting the position and functioning of the courts during and immediately after the occupation.

More specifically the prewar legal system, including prewar national measures dealing with the functioning of the state during occupation and international law on occupation will be taken into account. Possible measures the occupant, the national administration on the occupied territory and the postwar Government took affecting the courts' powers of review, personnel policy, independence and competencies will also be included.

Due to the already mentioned lack of a major description of a history of the courts during that era, a more detailed analysis of the position and functioning of the courts during this period is also not avallable. The data from the description and the comparison will therefore be used to analyze the courts' reaction to occupation and postwar measures aimed at their position and functioning. The final chapter will reflect on postwar measures dealing with the position and functioning of courts in preparation of new national legislation dealing with a possible future occupation.

The assumption or thesis from which this research will be conducted is that the courts' positivist attitude' towards legal measures made it impossible to resist being a mere executive tool for the policies of the occupant and the government returning from exile. Courts will be assumed to have extended the doctrine of supremacy of acts of parliament, which did not allow courts to review these measures, to measures resulting from the occupant or the government returning from exile. This would have put the courts in a position whereby the only choice was to apply the measures, regardless of their legal validity or morality. Prewar national measures will be assumed to have furthered this attitude of the courts, resulting in the courts" unwillingness or near impossibility to resist even the most heinous occupation and postwar measures.

In further defining this topic the research will be limited to Belgium, ${ }^{2}$ Luxembourg and The Netherlands. France is envisaged as a follow up project. A valid comparison between these jurisdictions can be made. Historically Belgium, Luxembourg and The Netherlands have had constitutional and legal systems based upon the French constitutional model. The position of the courts in the constitutional arrangements and the organization of the courts, as well as their competencies, although not similar, are rooted in the same tradition, making these four jurisdictions suitable subjects for comparison.

There certainly are differences between these jurisdictions as well. The position of the courts in their national constitutional systems was not the same, nor was their

Positivism is to be understood as opposite to a natural law approacly (see also Kelsen, p. 1014). Positvism (in an English defintion from Hart, p. 244-245) means that "... all law emanates from a legally unlimited sovereign legislative person or body.' This means '... there can be no theoretical disagreements or controversy as to what constitutes the 'grounds' of law. In Hant"." opinion (see Hart, p. 213-237) legal positivism could extend to national and international law
systems.

It should be noted here that immediately after the occupation of Belgium, Nazi-Germany reannexed Eupen, Malmedy and Moresnet, which were territories that had been ceded to Belgium as reparation after the First World War. Also, two departments in the north of France, Nord and Pas-de-Calais, were put under the control of the occupant's administration in Belgium. These areas require more study, but are not relevant for this research. For a small study on the courts in the two French déportoments see also Rousseau, p. 859-886. 
measure of independence or their competencies. These differences might impact the kind of reaction or the force of the reaction of the courts to occupation measures. Also the difference in prewar national measures to prepare the State for occupation might have played a role in determining the courts' reaction to occupation measures. Furthermore, the nature of the occupant's administration differed in all three jurisdictions. This could, of course, also account for differences in relationships of the courts with their occupant's administration. In comparing the Belgian, Luxembourg and Netherlands courts' relationships with their occupant's administrations, these differences will be taken into account.

The sources to be consulted for this research will be rather diverse. International law, especially the IVth Hague Convention and jurisprudence on the international law of occupation, national laws like constitutions, acts of parliament, civil and penal (procedural) codes and govermmental and ministerial decrees will be used. Regulations the occupant issued, as well as decrees the national authorities on the occupied territory enacted and case law of the courts will be examined. These were the official ways in which the actors involved, the occupant's administration, the national authorities, the courts and the government communicated with each other and usually gave a final statement on their position concerning a certain issue.

Another way, in which these actors communicated, was in the exchange of correspondence. Furthermore, in order to understand more of the background of the positions these actors took towards each other is to look at reports from the occupant's administration, minutes of meetings and protocols of Parliament, national adninistrations on the occupied territory, courts and the Government.

More information might be gathered from personal archives containing information on the position these judicial officers or the judicial organ to which they belonged held towards the occupant's admimistration or the Government returning from exile. Purge files of individual judges might contain useful information. Assessing indiviclual cases will amount to a clearer picture on how exile legislation in practice determined how was dealt with members of the courts.

Other sources will include literature on the topic, including publications of judges concerning the occupation period or the postwar period, reports in law journals and the (underground) press. Where still possible interviews with those in office during the occupation will be conducted.

The outcome of this research will be presented in English. Unfortunately, there are hardly any translations into English of the legal materials, especially legislation, of the occupation and postwar era from the Belgian, Luxembourg and Netherlands jurisdictions. Only in recent decades, translations of major legal texts have been made into English, also American English. At least for some of the legal teminology these can be used as a reference as to how to translate these legal concepts into English. These recent translations will be used, but nevertheless deviated from if necessary, in order to describe the concepts in the legal environment of the 1940 s. However, if national concepts resemble more an existing Anglo-English, Scottish-English or even a European law English concept, those will be opted for rather than an American term if that enhances the clarity of expression or description of the concept involved. This also in order to preserve the distinctiveness of the national legal system described. Annexed will be a list of translated terminology. 



\section{CHAPTER 1}

\section{INVASION, OCCUPATION AND ADMINISTRATION ON THE OCCUPIED TERRITORY}

\subsection{INVASIONS AND GOVERNMENTS INTO EXILE}

On 10 May 1940 Nazi-Germany invaded Belgium, Luxembourg and The Netherlands, as well as other European countries. The rapid German advance had surprised everyone, not in the least the High Command of the German Army (OKH), ${ }^{3}$ which had been planning in detail the occupation of the conquered territories.

In May 1940 German army groups A and B were equipped with units ready to take over the administration of the occupied territories. Shortly before the invasion of the Low Countries, the German Armed Forces extracted a promise from Hitler that their occupation would be a 'non-political' one, meaning that the Belgium, Luxembourg and The Netherlands would be put under a military administration."

The Netherlands surrendered on May 15 and the administrative unit of Army group B installed itself in The Hague. Already on 10 May the High Command of the German Armed Forces (OKW) had issued a decree subjecting the occupied territories of The Netherlands and Belgium to a German Military administration. ${ }^{5}$ However, contrary to Hitler's promise, soon after the invasion a Civil administration was installed in The Netherlands, heralding a victory for the SS and the NSDAP.

The Netherlands Queen, some of her entourage and also the Government fled the country. Initially the idea was that the Queen should be brought into safety. The part of The Netherlands that seemed safest and where also French troops had come to the aid of Netherlands troops was the province of Zeeland. After reports of bombardments of Zeeland's major ports the ship with the Queen on board set sail for England. ${ }^{7}$ The Queen and her Government would spend the occupation in exile in London. Chapter 6.4 will deal with the Netherlands Government in and returning from exile.

After the loss of The Netherlands to a civil administration, the German Armed Forces consolidated their hold on Belgium, Luxembourg and parts of northern France. On 30 May the Military authority"s seat was moved from The Hague to Brussels and on 1 June General von Falkenhausen was installed as Military commander for Belgium, Luxembourg and the areas in the north of France just behind the lines of the advancing army. ${ }^{8}$ Some Belgian territories had been excluded from his jurisdiction. Already a few days after the invasion Nazi-Germany annexed the cantons of Eupen and Malmedy, as well as Moresnet and the adjoining areas." These

Oberkommando des Heeres. For a list of translations see Annexes $1-3$ and for the abbrevia. tions see the List of Abbreviations.

Gotovitch/Gérard-Libois, p. 128.

Heeresgruppen-Verordnungsblatt für die besetzten Gebiete, Oproep an de bevolking van Neder]and en België d.d. 10 mei 1940 (Opperbevelhebber van het Duitse leger).

Isacker (deel 1), p. II-55-59.

Posthumus Meyjes, p. 74

Reeder/Hailer, p. 25.

Reeder/Hailer, p. 25. 
territories had been ceded to Belgium as reparations after the First World War. Several days before the armistice agreement with France had been signed on 22 June, the Military administration in Brussels learned it would retain control over only two departments in the north of France, namely the départements Nord and Pas de Cal. ais." As late as 25 May, Himmler had tried in vain to persuade Hitler to install a civil. administration in Belgium ${ }^{12}$ and in June. Hitler apparently still contemplated putting at least the Flemish-speaking part of Belgium under a civil administration and the French-speaking part under a military one.

The Belgian Government, except for the King, the Prime Minister and three other Ministers, had fled to Ostende on 16 May and one day later, on the advice of the French Government, to Le Havre. Before Belgium's surrender on 28 May the Government ended up in exile, first in France, but soon after in London. Chapter 6.2 will briefly address the Belgian Government in and retuming from exile.

Luxembourg was also wrested from the influence of the occupant's Military administration in Brussels. 14 During the summer of 1940 a civil administration was installed in Luxembourg. The news that Hitler had personally severed the links between occupied Luxembourg and the Military administration in Brussels would only reach Military commander von Falkenhausen on 7 August via a radio broadcast. ${ }^{5}$ Any remaining influence von Falkenhausen had had in Luxembourg ceased on 30 October. ${ }^{16}$

During a secret meeting in the beginning of 1940 the Luxembourg Government had already decided to leave the country if it were to be invaded. ${ }^{17}$ Together with Grand Duchess Charlotte and her family the Government fled to France during the night of 10 May. Via Spain and Portugal they headed for the United Kingdom, the United States of America and Canada. More information on Luxembourg's Government in and returning from exile will be provided in Chapter 6.3 .

\subsection{BeLGIUM AND THE MLITARVERWALTUNG}

\subsubsection{The national administration on the occupied territory}

Immediately after the German invasion, the Government fled into exile, except initially for Prime Minister Hubert Pierlot and 3 other Ministers. They had remained in Belgium to stay in close contact with the King, who was heading the Belgian army and with whom they still had meetings on 20,21 and 25 Many. Being at odds with the Government over the reaction towards the German advance, the King requested the

\footnotetext{
14 Herdeg, p. 22

1) Gotovitch/Gerad-Libois, p. 130 . Although there are various theories why these departements were administered from Brussels and not Paris, which focus on either the Flemish-speaking means for the Germans to put pressure on the Vichy government (see this has no further bearing on the topic at hand.

K.wiet, p. 63

Gotowitch/Gerand-Libois, p. 130, Jonghe, p. 41, 114-120.

lsacken (doel l), p. lll-18-20.

Gotovitchocratd-Libots, p. 130 .

Jonghe, $p .56-57$.

Waturer, p. 220.
} 
Govermment to collectively tender its resignation. The Government refused. ${ }^{\prime}$ Failing to convince the King to accompany them and continue the war from abroad, these four Ministers went into exile. ${ }^{19}$ On 28 May 1940, the Belgian King unconditionally surrendered his army. ${ }^{20}$ The same day 13 Ministers of his Government-in-exile in Paris during a meeting in Council decided unanimously that the King was in a position of impossibility to reign, since he was in enemy captivity " Furthermore, after its final session on 10 May, many members of Parliament had fled to France ${ }^{22}$ and therefore it was impossible to convene Parliament in occupied Belgium.

Nevertheless, Belgian national, regional and local public institutions were obliged to remain functioning. In case of mobilization of the arny the Statute on the duties of public officials during wartime $(1935)^{23}$ applied. Every public officer, if not drafted into the army, was obliged to put himself at the disposal of his superior and direct all his activities to the execution of his superior"s orders. ${ }^{24}$ A public official's abandonment of post contrary to his superior's orders or authorization was punishable by imprisonment of a month, up to a year, without prejudice to any disciplinary sanctions.

Furthermore, all public officials had been handed a Booklet on civil mobilization, ${ }^{25}$ which contained instructions on what kind of attitude to adopt towards the enemy and the obligation to temain in office. ${ }^{26}$ Public officials were not to pose any resistance against the invader. Those who would be allowed to remain in office despite the occupation were to conform their attitude to articles 42 - 56 Hague Convention. If the occupant would require them, they could formally and in writing declare to exercise their tasks conscientiously and loyally and to omit any activity hindering the occupant's administration. If the occupant were to impose acts upon him that were incompatible with their duty of loyalty towards the fatherland, the public offlcial was to abstain from exercising his office. ${ }^{27}$

On 10 May 1940 a govemmental proposal had passed almost without debate in the Belgian Parliament's Chamber of Representatives and Senate. ${ }^{28}$ It was distributed to the Belgian national authorities, together with a letter from the Minister of Justice on 15 May $1940 .^{29}$ However, this Statute on Delegation $(1940)^{30}$ was so new that

18 Verhoeyen, p. 23; Velaers/Goethem, p. 230-241; Judices, p. 6; Gotoviteh/Gérard-Libois, p. 103; Duvieusart, p. 14 describes how the King wanted to have the opportunity to appoint new Ministers, which would in effect be a dismissal of the old Ministers. Goethem, p. 52-57 citing Minister De Schrywer's diaries. For the King"s point of view see Leopold III. See also Ministère des Affaires Etrangères de Belgique. See also Goethem, p. 66-73 citing Minister De Schryver's diaries.

Arrêté-loi du 28 mai 1940, Moniteur belge du 18-30 mai 1940. See also Fayat, p. 2.

Conway, Collaboratie, p. 22 .

Loi du 5 mars 1935, concernant les devoirs des fonctionnaires en temps de guerre, Mon. du 15 mars 1935 .

Article 1, Loi du 5 mars 1935, ibid.

Livet de mobilisation crile, which included the full text of the Stante on the dutics of public officials during wartime (1935), as well as the Hague Convention.

See also Verhoeyen, p. 57.

See also Charles/Dasnoy, p. 26.

Smolders, Législation Tome I, p. 10.

Rijksarchief te Beveren, Rechtbank van Eerste Aanleg te Antwerpen, no. 149 Circulaure van de Minister van Justitie in verband met overheveling bevoegdheden in werband met oorlog. 
there was no interpretative practice. The persons who could give some background on interpretation had mostly fled for the advancing German army. Even Parliament when voting on the bill on 10 May 1940 had not seen its legislative history. "They were in the possession of Secretary General of Justice Enst de Bunswyck, who had followed his Minister to France.

Nevertheless, the object and purpose of the Statute on Delegation (1940) was to assure the normal functioning of the local authorities in case of a war in derogation of peace-time rules of supervision of the administration. The statute's articles 2 and 3 provided for a Provincial Governor who was cut off from the central authorities due to military operations, to exercise the supervisory powers of the King's Government. If the Provincial Governor had left his office, the Provincial executive could exercise the supervisory powers of the King and the Provincial Governor. ${ }^{32}$ The same principle for delegation of powers in wartime and when cut off from its supervising authorities applied to municipalities. ${ }^{33}$

So far, the practice and legislation from experiences in World War One had been followed. ${ }^{34}$ However, article 5 of the Statute on Delegation (1940) was new and applied to cases not foreseen by articles 2 and 3 . It stated that a magistrate or public official or a collegiate of magistrates or public officials could, when cut off from a superior, exercise within the scope of his professional activities and in urgent matters all the attributes of this superior.

The Secretaries General and the Cour de cassation were therefore the only representatives of the Belgian State at a national level still exercising their public office to await the arrival of the occupant"s administration. ${ }^{35}$ Besides the new Statute on Delegation (1940) and some rules in the Booklet on civil mobilization, hardly any instructions were left that could help the Secretaries General or the Court to determine how the Belgian Government wanted them to deal with the occupant's administration. ${ }^{36}$

\subsubsection{The occupant's administration; type, organization, goal}

After invading and occupying a country, the occupant has the duty to establish an administration. According to the IVth Hague Convention of $1907^{37}$ and especially its

kopie Brief II Mei 1940 van de Minister van Justitie aan de Eerste Voorzitter van het Hof van. Beroep te Brussel.

Loi dı 10 mai 1940 concemant délégations de pouvoir (not published in Monitewr, but see Smolders, Législation, Tome $I_{n}$ p. 10 ff.). See also Leclercq, Loi; Rédlaction JdT, Loi.

CEGESSOMA, Conseil de Législation, MIC 74, Mathieu, G., Etude sur la Délégarion des Pownoirs en Temps de Gherre, p. 20. See also Rapport au conseil Arrêté-1oi du 1 mai 1944 interprétatif de l'article 5 de la loi du 10 mai 1940 relatif aux délégations de pouwoirs en temps de guerre, Mon. I septembre 1944.

Loi du 10 mai 1940, Article 2, alinéas a et b.

Loi du 10 mai 1940 . Article 3.

Smolders, Législation Tome I, p. 10 .

For the position of the King during the occupation see Velaers/Goethem, p. $612-656$.

Charlesidasnoy, p. 16.

Vth Hague Convention respecting the Laws and Customs of War on Land and the Annex to the Convention conceming Regulations respecting the Laws and Customs of War on Land. The annexed Regulation will be referred to as the IVth Hague Convention or simply the Hagne Convention unless stipulated otherwise. All parties involved, Belgium, Germany, Lux- 
article 43 , during an occupation the occupant is obliged to restore and ensure public order and public safety. In order to assure public order and public safety the Hague Convention's article 43 granted the occupant a right of administration over the occupied territory. What type of administration should be installed is not clear from the article and also the scope of its powers has not been circumscribed, leaving both issues for scholarly contention. Opinions differ and have changed over time as to whether the occupant could only establish a military administration or is allowed to set up a separate civil administration as well. ${ }^{39}$

The occupant's administration installed in Belgium on 30 May 1940 was a military one and as such directly bound by orders originating from the High Command of the German Army (OKH). ${ }^{40}$ Although gradually the OKH would loose its influence to the High Command of the Armed Forces (OKW), which was under Hitler's direct control, military administrations in the occupied countries would remain under direct control of a military authority and were only indirectly under the control of Hitler. Alexander Freiherr von Falkenhausen was appointed head of the Military administration in Belgium on 1 June.

The administration consisted of two main units and several units for special assignments. ${ }^{41}$ One was the military unit, which dealt with military matters and was headed by won Harbou. Reeder was in charge of the civil-administrative unit, which was divided into two departments, and dealt with civil aspects of the military administration. ${ }^{42}$ Due to the fact that the civil-administrative unit dealt with not only political matters, but also the Belgian economy and its contribution to the war effort, Reeder's unit was seen as the more important of the two. ${ }^{43}$

This double structure of the military administration at the national level in Belgium was mirrored at provincial and district level as well, assuring that the Belgian administration at every level had a German counterpart supervising and directing it. $4{ }^{5}$ Instead of taking charge of the administration itself, the Military administration su-

embourg and The Netherlands had signed and ratified the treaty, whereby only Germany had made a reservation, namely to its article 44 (see Treaty Series No. 539, Convention between the United States and ather Powers respecting the laws and customs of war on land, Govemment Printing Office Washington, 1910). Fron the preamble it is clear that the contracting parties intended to replace the customary international law in force before the adoption of the Convention (see also Nispen tot Sevenaer, p. 205,305-306), which would indicate that Germany was nevertheless bound to article 44 on the basis of customary international law. International law also made a distinction between invasion and occupation (see e.g. Oppenheim. War, para. 167, p. 206-207 'Occupation is invasion p/tas taking possession of enemy country for the purpose of holding it, at any rate temporarily"), but the criteria for occupation will be presumed amply satisfied.

3is See e.g. Beer Poortugael, p. 175; Spaight, p. 321; Oppenheim, Wat, 210 and Verzijl, p. 172 , 211 as the more contemporary one, who all claim that the occupant's administration should be a military one. By contrast, Scholtens, Staatsrecht, p. 12, Benvenisti, p. 26.31 and also the practice he outlines from WW II onwards show a tendency towards more civil administrations with extended powers. Jonghe, p. 15.

Reeder/Hailer, p. 26; Verhoeyen, p. 13-14.

Reeder/Hailer, p. 26.

Jonghe, p. 65-66.

Herdeg, p. 32; Verhoeyen, p. 13.

Reeder/Hailer, p. 27. 
pervised and directed the Belgrian administration. ${ }^{46}$ It had several units of German police at its disposal, but never enough to maintain order in occupied Belgium. ${ }^{47}$ The occupant employed 700 German staff in 1940,1166 by the end of 1941 and 830 at the beginning of $19422^{48}$ The augmentation of personnel was apparently necessary to organize the Belgian economy, in order to increase its contribution to the German war effort ${ }^{49}$ which was the main task assigned to von Falkenhausen and his Military administration. ${ }^{50}$ Additionally, von Falkenhausen was instructed to further the emancipation of the Flemish part of the population, since the Nazis considered the Flemish a "lost Germanic nation'." A political task was expressly off limits and all political questions that arose thad to be reported to the High Command of the German Armed Forces. Only after having received instructions the Military administration was allowed to continue dealing with that political issue. ${ }^{52}$

The occupant's administration in Belgium, though staffed with military personnel, ${ }^{53}$ was not a homogeneous block, but rather divided into a vehement anti-Nazi group, an intermediate group and a pro-Nazi black. ${ }^{54}$ Most of the resistance against the Nazis seemed to cluster around the military unit, whereas the civil-administrative unit was seen as the more pro-Nazi part of the administration. Furthermore, several different German agencies were given powers by Hitler to directly intervene in Belgium, resulting in a "disuniformity" of administration of occupied Belgium and the Military administration slowly loosing its grip on policies in certain areas. ${ }^{5.5}$ According to Reeder, not the Germans, but their enemies were practicing the Führer principle. The Military administration, so Reeder, continuously lacked any system, but that was not due to tactics as the Belgians might have thought. ${ }^{56}$

Near the end of the occupation on 18 July 1944 a Civil administration headed by Reichskommissar Grohé would replace the Military administration for the remaining 47 days of occupation. ${ }^{57}$

\subsubsection{Modus vivendi; a system of administration for the occupation}

The first official meeting in Belgium between representatives of the occupying forces and the Secretaries General took place on 22 May. ${ }^{58}$ The question of the powers of the Secretaries General was put on the table and on 2 June 1940 the Military admini-

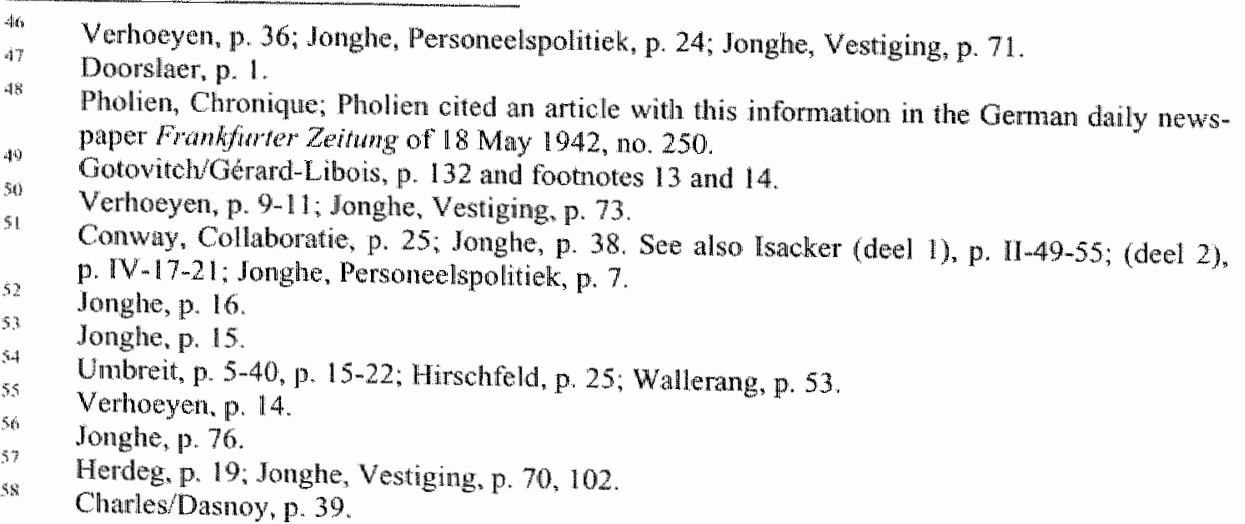


stration once again asked the Secretaries General whether they possessed lawmaking powers. 59

This question was one of extreme delicacy, since the Germans, when occupying Belgium in 1914-1918, had been obliged to take over the whole administration of Belgium on a central level. The Belgian government, in a law enacted before the 1914 occupation, had decided that in case of an occupation governmental authority would only be exercised at a local regional or local level, thereby rendering the administration of Belgium extremely difficult and labor intensive for the occupying power. The Belgians at that point ran the risk of a complete dismantling of their already heterogeneous State and a resultant spilt up into a separately administered northern Flemish and southern Walloon part.

The Secretaries General were very hesitant and Secretary General of the Interior Vossen was of the opinion that the powers of the Secretaries General were limited by the delegation given to each individual Secretary General. This meant the execution of all administrative matters and signing, on behalf on the minister and in conformity with existing Belgian legislation and regulations, every matter except the ones requiring the Minister's countersignature. ${ }^{61}$ Quizzing Prime Minister Pierlot before his departure from Brussels on the exact meaning of the above-mentioned article 5 Statute on Delegation (1940), Secretary General Delmer learned that he was not allowed in any way to undertake a modification of the rules of administrative organization established by law. He was also not allowed to act within the framework of the law if this were to serve the plans of the occupying force ${ }^{62}$

Unsatisfied with the limited approach the Secretaries General took toward their lawmaking powers, the Military administration proposed the Secretaries General a possible lawmaking power of the King. ${ }^{63}$ The Secretaries General replied unfavorably. ${ }^{64}$ Also a subsequent offer from the Military administration to delegate its powers under article 43 Hague Convention was discussed, but the Secretaries General did not seriously consider and even unanimously reject that proposal. ${ }^{6.5}$

Sensing that the German military administration desired to govern via the Belgian national authorities the committee of Secretaries General mandated their colleagues Hubrecht and Delhaye to consult some magistrates concerning their real powers under Belgian law. The Military administration encouraged the Secretaries

Gotovitch/Gérard-Libois, p. 188.

See also Passelecq, p. 5-10; Pirenne/Vauthier, p. 205-212.

Gotovitch/Gérard-Libois, p. 186.

Gotovitch/Gérard-Libois, p. 187.

See Velaers/Goethem, p. 487-498 for a more detailed account of ewents concerning the King, the Secretaries General and the occupant. Although plans for a new Government including the King and a new Constitution were made during the first months of the occupation these were not put into effect. Gotovitch/Gérard-Libois, p. 186-187.

CEGES/SOMA, Documents Zéro, ref. AA 1.078, dossier 1034/14, Note au sujet d'une délégattion éventuelle de pouvoirs par l"autorité allemande aux Secrétaires Généraux du 9 juin 1940. See also Leclercq, p. 66, 67; Gotovitch/Gérard-Libois, p. 188; Verhoeyen, p. 37. 
General and informed them that in The Netherlands their counterparts now had very extensive powers, reaching beyond the scope of ministerial administrative matters. ${ }^{67}$

On 3 June and in subsequent days several members of the Brussels ruling political and economic élite were consulted. These included the Presidents of the Cour de cassation and the Brussels Cour d'appel and Tribunal, as well as Cour d'appel Justice Schuind and Procurator General Gesché and Advocate General Hayoit de Termicourt of the Cour de cassation ${ }^{68}$ From the consultations emerged on 9 June that these ruling élites, under the prevailing circumstances, were of the opinion that the Secretaries General had the power to enact measures via decrees imperatively necessary for the administration of the country. ${ }^{69}$ A statement, largely from the hand of Justice Schuind, interpreted the Statute on Delegation (1940) as attributing to the Secretaries General the power to enact measures via decree on every matter concerning general, Ministerial and Royal regulations. The Secretaries General were deemed, under the prevailing circumstances, to be the most qualified organs on the occupied territory to assure the exercise of the legislative powers and royal powers. ${ }^{70}$

In consultation with the Military administration a protocol was drafted, outlining the modus vivendi that was to govern the relationship between Secretaries General and the occupant's administration. This protocol was signed on 12 June. However, only Secretaries General Vossen, Hubrecht and Delhaye signed on behalf of all the other Secretaries General, in the presence of Reeder and another German official. The Military administration viewed the protocol as a declaration of the Secretaries General of which it only had to take notice, but did not need to sign. ${ }^{71}$ The President of Belgium's Supreme Court is reported to have unofficially consented to the content of the protocol. ${ }^{72}$

The protocol outlined the relationship between the two administrations. The Secretaries General recognized that German Regulations enacted in accordance with the Hague Convention had to be executed like Belgian legislation. They also agreed to submit any kind of envisaged measure to the Military administration before publication. ${ }^{73}$ Also, the Secretaries General consented to the fact that certain kinds of decrees were excluded from their competencies. These were especially decrees dealing with purely political matters, amendments to the legislation dealing with language matters, ${ }^{74}$ issues of administrative organization of the State other than for economic reasons and decrees dealing with purely military matters. In these cases the Military administration would enact and execute Regulations under its own responsibility. Furthermore, and more importantly, the Secretaries General claimed their decrees would have force of law. ${ }^{75}$

Charles Dasnoy, p. 40. See Chapter 1.5 .3 for the powers of the Netherlands Secretaries General. Meant were those powers the Secretaries General were delegated on 29 May on the basis
of Verordnung $1940 / 3$.

Charles/Dasnoy, p. 47-48; Verhoeyen, p. 37.

Delandsheere/Ooms, p. 85-86.

Gotovitch/Gérard-Libois, p. 192.

Charles/Dasnoy, p. 50.

See allso Verhoeyen, p. 38. As regards the occupant's duty to protect an occupied country's language see Verraes, Tome
l, p. 181 .

Charles/Dasnoy, p. 28, 50: Hanquet, p. 38-54 
One of the questions that had not been dealt with in the protocol was the appointment of Secretaries General. Article 5 Statute on Delegation (1940) could provide a solution for problems of succession in that a public official who could legally represent his superior would exercise, in case of urgency and within the framework of his professional activities, all the attributes of his superior. According to Belgian administrative tradition and most departmental regulations, a Secretary General would then be replaced by one of his subordinate Directors General. ${ }^{76}$ Therefore, during the occupation, only those Secretaries General appointed by the Belgian Govermment, or their subordinates appointed according to Belgian law and representing them, could legally exercise the powers under the Statute of Delegation (1940). ${ }^{7}$

The Secretaries General nevertheless chose a system of co-optation. After the retirement of Secretary General of Justice Emst de Bunswyck, the Military administration wanted the Flemish nationalist, Romsée, in that position, but Romsée did not have the support of a majority of the Secretaries General. The Military administration gave in, apparently needing the support of the Belgian Judiciary, whose most influential members were also opposed to Romsée. However, in exchange for the Secretaries General and the Judiciary's choice for Secretary General of Justice, Romsée was appointed Secretary General of the Interior. Gaston Schuind, a French-speaking judge of the Brussels appeals court was appointed Secretary General of Justice. "In May 1943 out of the eleven Secretaries General that were in office on 10 May 1940 , only three were still in office. The others had been removed from office and the organization of the Ministries had been severely altered. ${ }^{79}$

\subsection{LUXEMBOURG AND THE CHEF DER ZIVLVERWALTUNG}

\subsubsection{The national administration on the occupied territory}

Since there was no executive in Luxembourg due to the flight of the Grand Duchess and the Government, the German Ambassador to Luxembourg and several German

36

Ockreint, p. 47, footnote 2.

Cass. 7 awril 1941; Pas., 1941, 1, 136; Revue Adninistration, 1941, p. 315, Cass 26 actobre 1941, Pas. 1941, 1, 382; Cass. 30 mars 1942; Pas. 1942, 1, 75; conclusions de M. l'avocat ge néral précédent l'arrêt du 3 novembre 1941; Pas. 1941, I, 407, Revue Administration, 1942, p. 113. See also Ockrent "p. 44, footnote 1; See also Pacte, p. 121. For a ruling contrary to the Con de cassation"s consistent case- law see Brussels Cour d'appel arrêt inedit tu 22 octabre 1942, published in: Ockrent, p. 44-46.

Raskin, p. 188- 192 .

CEGESSOMA, CEPAG, ref. AA 830/192, Doc CC/12, Avis de M. Henri E.A.M. Rolin, Président de la Cour dle cassation, sur la question "du sort à réserver sur arrêtés pris par les Secrêtaires-généraux", p. 2. Charles/Dasnoy, p. 307, On 10 May 1940 the following Secretaries General were in office. I. Hubrect, Ministry of Justice, Van Orshoven, Ministry of Agriculture, R. Delhaye, Ministry of Public Health, G. Raven, Ministry of Economic Affairs, Van Overstraeten, Ministry of Communications, M. Van Hecke, Ministry of Colonies, J. Vossen, Ministry of the Interior, J. Vossen, Ministry of Foreign Affairs, M. Nyns, Ministry of Education, O. Plismier, Ministry of Finances, A. Delmer, Ministry of Public Works and C. Verwilghen, Ministry of Labor and Social Security. After Hubrecht, the Ministry of Justice was headed by A. Ernst de Bunswyck from 2-8-1940 until 31-1-1941. E. Wauters from 3-2-1941 until 31-3-1941, G. Schuind from 4-4-1941 until 17-9-1943 and R. De Foy from 1-10-1943 until the liberation. 
Generals approached the Luxembourg authorities to establish a new executive. Luxembourg"s Parliament felt wit was indispensable to create a governmental body able to fulfill the role that in normal times a Government would exercise. During a meeting the Governmental Commission was established." Parliament adopted a Resolution, ${ }^{82}$ allowing the Secretary General of the Government, Wehrer, to execute all governmental functions. Its members were the Councilors or highest civil servants in the country that would function as a de facto Government. The Governmental Commission would co-operate with the German Military administration to try to solve all cument problems.

Belginm had shared information with Luxembourg on preparations of what would become the Statute on Delegation (1940). ${ }^{84}$ Although Minister Bech of Luxembourg had been given the draft text of this Belgian law around the end of March, the invasion prevented it from being studied properly and introduced. ${ }^{85}$ Minister Bech had informed Secretary General Wehrer in January of 1940 that in case of an invasion the Government would retreat to the opposite border and leave the territory if Luxembourg were completely occupied. Four to five weeks before the invasion Prime Minister Dupong informed the Conseillers de Gowvermment that if the Goverrment due to invasion could not exercise its functions, these Councilors were the Government's 'natural representatives'. No further instructions were given. ${ }^{86}$

However, already in 1938 and 1939 when the events leading up to the Second World War were unfolding in Europe, the Luxembourg Government had requested and obtained special powers from Parliament. If necessary, the Government had been authorized to enact emergency measures. ${ }^{87}$ This was done on the basis of the Statutes of 28 September $1938^{88}$ and 29 August $1939^{89}$ concerning the extension of the powers of the executive. ${ }^{90}$ The Governmental Commission, after 23 May called Administrative Commission," would exercise all powers conferred on the Government via

Conseil National de la Résistance, Archives personelles de M. le Président P. Dostert, Papiers Wehrer, Memorandum betreffend das gegen Regienungsrat Albert Wehrer eingeleitete Dienststrafverfahren, p. 1; Conseil National de la Résistance, Archives personelles de M. le Président P. Dostert, Papiers Wehrer, Aide mémoire sur les événements politiques de mai à octobre 1940; la mission et l'activitế politiques de la commission administrative, 15 mai 1945 , p. 4 .

Wallerang, p. 49

Resolution votée par la Chambre des députés et approuvée par le Conseil d'Etat dans leurs rếunions du 16 mai 1940, Mém. 1940, No. 31, p. 325-326.

Dostert, P., Verwaltung, p. 11 ; Majerus, Guerre, p. 21.

See Chapter 1.2.1.

Conseil National de la Résistance, Archives personelles de M. le Président P. Dostert, Papiers Wehrer, Aide mémoire sur les éwénements pollitiques de mai à octobre 1940 ; la mission et lactivite politiques de la commission administrative, $\$ 5$ mai 1945, p. 2 .

Conseil National de la Résistance, Archives personeiles de M. le Président P. Dostert, Papiers

Wehrer, Aide mémoire sur les événements politiques de mai à octobre 1940; la mission êt l'activité politicues de la conmission administrative, 15 mai 1945 , p. 1,4

Hang, p. 5.

Loil du 23 septembre 1938 , portant extension de la compétence du pouvoir exécutif, Mém. $1938, \mathrm{p}, 103$. Loi du 29 août 1939, portant extension de la compétence da pouvoir exécutif, Mém. 1939 ,
p. 837 .

Majerus, Guerre, p. 9.

Majerus, Guerre, p. 22: Raths, Grand-Duché, p. 254 
special legislation ${ }^{92}$ and was allowed to exercise its powers via governmental decrees. However, any decision of the Administrative Commission of a legislative nature had to be immediately communicated to Parliament. ${ }^{93}$ Furthermore, Secretary General Wehrer was authorized to appoint the four Councilors of Govemment, ${ }^{94}$ and therefore the members of the Governmental Commission, subject to the approval of Parliament. ${ }^{95}$ Due to the fact that its powers extended to legislative, regulatory and administrative matters, the Administrative Commission had more powers than the regular Luxembourg Government had ever had. ${ }^{96}$

Parliament's and the Commission's aim were to maintain Luxembourg"s statehood and independence as well as assure the continued functioning of public services. To that effect the Luxembourg Parliament, on the initiative of its President, Reuter, had a telegram sent to the Grand Duchess in Lisbon to request her return to Luxembourg. Although the Government-in-exile was split on the question, it was decided the Grand Duchess would remain in exile. Furthermore, already the day after the invasion on 11 May, during the afternoon session, the President of the Luxembourg Parliament, Reuter protested against the violation of Luxembourg's neutrality. ${ }^{100}$ On 19 July Reuter, together with the President of the Administrative Commission, Wehrer, also arranged for a letter to be sent to Hitler, ${ }^{101}$ signed by all Members

92 Loi du 28 septembre 1938, portant extension de la compétence du pouvouir exécutif, Mém. 1938 , No. 65, p. $1099-1100$ and Loi du 29 août 1939 , portant extension de la compétence du pouvoir exécutif, Mếm. 1939, p. 837-838.

93 Conseil National de la Résistance, Archives personelles de M. le Président P. Dostert. Papiers Wehrer, Aide mémoire sur les événements politiques de mai à octobre 1940; la mission et l'activité politiques de la commission administrative, 15 mai 1945, p. 6. Parliament established a committee to remain closely involved with the Governmental and later Administrative Commission.

The Administrative Commission consisted of President Wehrer and four Councilors. Wehrer was responsible for General Affairs, Foreign Affairs and Justice. Jean Metzdorff occupied himself with Interior Affairs, Public works, Transport and electricity, Joseph Camen with Finances, Labor, Social Security, Public Assistance and Sanitation. Louis Simmer dentl with Education, Arts and Sciences and Relligious. Affairs, whereas Mathias Putz was in charge of Agriculture and Viticulture, Commerce, Industry and Trades. Résolution votée par la Chambre des députés et approuvée par le Conseil d"Etat dans leurs réunions du 16 mai 1940, Mém. 1940, No. 31, p. 325-326. Wehrer, p. 223-224.

Wehrer, p. 224.

Haag, p. 6-7; Dostert, P., Verwaltung, p. 12; Conseil National de la Résistance, Archives personelles de M. le Président P. Dostert, Papiers Wehrer, Aide mémoire sur les événenumts politiques de mai à octobre 1940; la mission et l'activité politiques de la commission administrative, 15 mai 1945, p. 18 .

Cerf, Députes, p. 503-504. This is omitted from an official publication of the Luxembourg Government-in-exile; See Govemment of Luxembourg, p. 43. See also Calmes/Bossaert, p. $377-378$.

Protestation de la Chambre des Députés; Allocution prononcée al la séance du 11 mal 1940 par Monsieur le Président Reuter. Pas. 1951, Supplément se rapportani à la période d'occupation du 10 mai 1940 au 10 septembre 1944, Volume XXIla., p. 5. See also Cerf, Députés, p. 499. For Luxembourg's neutrality see amongst others Eyschen, M.P.; Majerus, Luxembourg; Wampach.

101 This date was mentioned by Cerf, Députes, p. 501. 
of Parliament as well as the Administrative Commission. ${ }^{102}$ In this letter Hitler was informed of Luxembourg"s desire for independence. The letter remained unanswered. In August the German secret police intercepted a second attempt to send a letter expressing Luxembourg's desire for independence before it could be sent. ${ }^{104}$

\subsubsection{The occupant"s administration; type, organization, goal}

Initially the Administrative Commission dealt with a Military administration, which had been installed as the occupant's administration. On 29 July 1940, after a tenweek period, which was too short to have had any significant influence on Luxembourg's administration, ${ }^{105}$ Gauleiter Gustav Simon as Chef of the Civil administration replaced the Military administration. ${ }^{106}$ On 6 August a troop of 800 German police entered Luxembourg underlining the change of the occupant's administration. 107

Simon was a German national, a former teacher and a member of the Nazi party since $1925 .{ }^{108}$ Though in the beginning still under the supervision of the Military commander in Brussels, from 2 August onwards Simon was under direct orders of Hitler ${ }^{109}$ on the basis of a secret Füher decree. 110 The Ministries of the German Reich still challenged the authority of the Chef of the Civil administration, but in September and October Hitler clearly decided the power struggle in favor of Simon, granting him sole authority over the occupation of Luxembourg. 111

Civil administrations were different from military ones in that they were only competent in areas of civil affairs. For military matters a civil administration had to tolerate a commander of the German Armed Forces ${ }^{112}$ within its jurisdiction. Also their personnel would mainly be recruited from loyal member of the German Nazi party. "The goal of a civil administration was not only to realize the economic and demographic potential of the occupied area, but also to actively deal with political questions and solve them in a manner expedient to closely aligning the occupied state with Nazi-Gemany. "Furthermore, a second secret Füher Decree from 18 October 1940 gave the Chefs of the Civil administrations in Luxembourg, the Alsace and in

192. Cerf "buration, p. 93. Cerf quotes from the unpublished memoires of Wehrer. See Conseil National de la Résistance, Archives personelles de M. le Ptésident P. Dostert. Papiers Wehrer, Aide mémoire sur les événements politiques de mai à octobre 1940; la mission et l'activité politiques de lat commission administrative, 15 mai 1945 , p. 18.

Raths/Dostert, p. 59 .

Raths, Grand-Duche, p. 255-256; Raths Dostert, p. 59; Cerf, Députés, p. 504.
Dostert, Biesatzungspolitik, p. 375.

Raths, Grand-Duche, p. 255. Majerus, Guerre, p. 26 dates Simon's appointment as 2 August
1940.

Majerus, Guerre, p. 26; Wallerang, p. 55.

Raths, Simon, p. 79-80; Dostert, P., Selbstbehauptung, p. 70.

Wallerang, p. 52 .

Dostert, P., Verwaltung, p. 13; Wallerang, p. 53-55; Dostert, P., Besatzungspolitik, p. 376.
Wallerang, p. 52-53.

See Herdeg, p. 37. In Luxembourg, Alsace and Lorraine this was the $O K H$, which meant that these areas were not treated as occupied, but rather as 'annexed'
Jonghe ${ }_{\mathrm{w}}, 15$.

Jonghe, p. 16. 
Lomaine broad discretion to conduct a policy of "germanisation". "These civil administrations were therefore more powerful than a purely military one.

Simon sought to administer Luxembourg directly througth the appointment of German nationals to Luxembourg public office. Via decree of 15 August 1940 the Chef of the Civil administration accorded himself the right to appoint Luxembourg officials retroactively from 10 May 1940 . Any kind of judicial recourse against his decisions was excluded. ${ }^{116}$ During the month of October 1940 Simon succeded in appointing enough German civil servants to control Luxembourg's organs of state dealing with economic, administrative and judicial matters. ${ }^{117}$

\subsubsection{Modus vivendi: a system of administration for the occupation}

Already in the afternoon of 10 May German Generals Gullmann and Aulleb as well as the commander of the German Military administration Turner had a meeting with the Luxembourg authorities in order to find a mode of co-operation between the two sides. ${ }^{118}$ Even though immediately after the invasion the occupant publicly supported the newly established Governmental Commission, the German secret police doubted this quasi-Govemment's loyalty towards Nazi-Germany, pointing out its President was a Freemason. ${ }^{119}$ Already ten days after the start of the occupation the Military administration made a first attempt to deprive the Governmental Commission of its legislative powers, being ordered by superiors in Berlin to withdraw its previously granted recognition. The Military administration now declared all legislative powers to be in the hands of the occupant's administration, but immediate protests of Wehrer made the Military authority reverse its decision. However, the Governmental Commission had to change its name into Administrative Commission and gradually all its powers would be eroded. ${ }^{120}$

After the installation of the Civil administration Simon did not waste much time in trying to integrate Luxembourg into Nazi-Germany. Already on 13 August 1940 he started appointing German nationals to public office in Luxembourg and was talking about a new legal statute for the country. In Simon's opinion, after the flight of the Grand Duchess and her Government, the Luxembourg Constitution had ceased to exist. All traditional politicall parties were banned." He also thought Luxembourg civil servants now owed loyalty and allegiance to the Civil administration and the organs it instituted and on 27 August had them sign a declaration of loyalty. ${ }^{122}$ Civil servants that had not signed the declaration by 10 September would be suspended

Dostert, P., Verwaltung, p. 13; Wallerang, p. 53-55; Dostert, P., Besatzungspolitik, p. 376.

Verondrung über Mafnahmen auf dem Gebiete des. Beamtenrechits vom 15. August 1940 ,

VoBl. Nr. I vonn I September 1940. S. 2. See also Majerus, Guerre, p. 34.

19 Majerus Guere, p. 38. More on appointments to Luxembourg courts in Chapter 3.5.

in Dostert, $P_{4}$, Verwalung, $\mathrm{p}, 11$.

1;y Wehter, p. 223 .

120 Majerus, Guerre, p. 24; Wallerang, p. 49

21 Varordnung uber die Auflosung der politischen Parteien in Luxemburg vom 23,8. 1940. VoB1. $1940,5,3$

122 Wallerang, p. 56.
} 
from their duties, pending other unspecified measures. ${ }^{23}$ All civil servants are reported to have signed this declaration, including all judges. ${ }^{124}$

After resistance of state officials to Simon"s preparations to incorporate Luxembourg into Nazi-Germany, Parliament and the Council of State were dissolved on 22 October $19400^{125}$ The same day Simon established a Special Criminal Tribunal dealing with disciplinary charges against civil servants. ${ }^{125}$ Two days later Wehrer was notified of his dismissal as President of the Administrative Commission, was arrested after protesting and deported to Nazi-Germany. ${ }^{27}$ The Civil administration placed the Administrative Commission under direct supervision of the Chef of the Civil administration, virtually terminating its independent existence. ${ }^{128}$ Moreover, Simon installed German commissioners at every Luxembourg governmental department, as well as the courts, who took over the management of affairs without regard for the Luxembourg nationals in charge. ${ }^{129}$ The whole Luxembourg State apparatus had to disappear and be replaced by a fully German administration. ${ }^{30}$ Municipalities and counties were reformed. ${ }^{131}$ By 31 December 1940 Simon had usurped all powers of the Administrative Commission. From 1 January 1941 he would exercise these powers directly. ${ }^{132}$

Via Fuhrer Decree of 24 January 1941 the German area of Koblenz-Trier was re-named Gau Moselland for administrative purposes and Luxembourg was de facto incorporated into this administrative unit. ${ }^{133}$ If not already by the end of October 1940, certainly by New Year's Day 1941 the Luxembourg State had been completely dismantled and the Civil administration controlled all governmental services. ${ }^{134}$

Simon proclaimed Nazi-Germany's annexation of Luxembourg on 30 August 1942. Nazi-Germany never officially proclaimed annexation of Luxembourg, ${ }^{135} \mathrm{a}$ ]-

Majens, Guerre, p. 33-35.

See Propria Causa, p. 31 .

Verordnung über die Auflösung der Abgeordnetenkanmer und des Staatsrates in Luxemburg vom 22. Oktober 1940, VoBI. Nr. 52 vom 29 Oktober 1940, S. 278. See also Raths, GrandDuché, p. 259; Majerus, p. 39; Cerf, Députés, p. 505.

Verordnung über die Einrichtung eines Sonderstrafgerichts in Luxemburg vom 22, Oktober 1940, VoBl. 1940, S. 278; Erste Durchfithrungsverordnung zur Verordnung über die Einrichtung eines Sonderdienststrafgerichts rom 22,10. 1940, VoBI. Nr 66 vom 11. Dezember 1940, S. 375. See also Wehrer, p. 230-231; Majerus, Guerre, p. 39; Wallerang, p. 57.

Raths, Grand-Duche, p. 259.

Bekunntmachung vom 25. November 1940 äber die Verwaltungskommission, Mém. 1940, No. 63, p. 729.

Wehrer, p. 230 .

Dostert, P., Verwaltung, p. 14.

Verordnung über den Verwaltungsaufbau in Luxemburg vom 14 . November 1940, VoBl. 1940, S. 291; Erste Durchftürungsverordnung zur Verordnung vom 14 . Nowember 1940 über den Verwaltungsaufbau in Luxemburg (Gemeinderecht) vom 15. November 1940. VoBll. 1940, 5. 292; Zweite Durchführungsverordnung zur Verordnung wom 14. November 1940 über den Verwaltungsaufbau in Luxemburg (Landkreise, Verschiedenes) vom 16. November 1940, VoBl. 1940, S. 295; Anordnung über die gemeindliche Neugliederung des Kreises Diekirch vom 27. Februar 1942 , VoB1. 1942, S. 62.

Bekanntmachung, betreffend die Verwaltungskommission und das "Mémonial", Mém. 1940, $\mathrm{No}^{6} 68$, p. 789

Raths, Grand-Duche, p. 261; Government of Luxembourg, p. 54; Fletcher.

See also Majerus, Guerre, p. 339440 .

Herdeg, p. 120. 
though Gauleiter Simon did proclaim that the Luxembourg State did not exist anymore. ${ }^{136}$ Luxembourg was, however, never completely incorporated into NaziGermany's state structure. Plans to completely merge parts of Luxembourg's territory with an adjacent Germany territory and constitute a single German administrative unit failed to be executed. Most probably Simon's reluctance to loose his fiefdom, as well as the fact that the administrative reform of the German State along Nazi lines was not implemented might have prevented an official annexation of Luxembourg. ${ }^{137}$ For the duration of the occupation Simon never ceased to administer Luxembourg as Chef of the Civil administration.

\subsection{THE NETHERLANDS AND THE ZWILVERWALTUNG}

\subsubsection{The national administration on the occupied territory}

While the Queen and Government were preparing to flee into exile on 10 May 1940, the Lower House of the Netherlands Parliament held an emergency session. Only 38 of its $100^{138}$ members were present and after a short speech by its chairman the session was adjourned. ${ }^{139}$ The Government did not attend the meeting, not being convinced of its usefulness. ${ }^{140}$ This was in stark contrast to the attitude of Belgian Government, which not only had convened Parliament, but had also requested its cooperation in adopting emergency legislation. ${ }^{141}$

Before Ministers Steenberghe and van Rhijn joined the rest of the Government into exile, they delegated all governmental authority to the commander in chief of the Netherlands Armed Forces, General Winkelman. ${ }^{142}$ The Secretaries General of the Ministries and thereby the civilian administration of the country were placed under the orders of General Winkelman. ${ }^{143}$

From 13 until 29 May, on the basis of some undefined, unwritten basis General Winkelman was entrusted with the highest state authority and powers. ${ }^{144}$ This, how-

Majerus, Guerre, p. 45; Anordmung zur Personenstandscaufhahme, Luxemburger Zeitung Nr. $282 / 83$ vom $11 / 12$. Oktober 1941 . See also paragraph 3 of the 4 . Verordnung betreffendic Maßnahmen auf dem Gebiete der Strafrechtspflege vom 31. Oktober 1941, VoBI. Nr. 75 vom 12. November 1941, S. 483, where Simon considered the 'former' Luxembourg nationality not to be a 'foreign' nationality.

Romeyk, p. 4118-419.

Article 84 Netherlands Constitution 1938.

See Donker, p. 362.

Welderen, p. 4; Brandhof, p. 10; Gerbrandy, p. 6 stated that it was factually impossible for the Government to attend.

Also the Norwegian Government adopted the same attitude as the Belgian Govermment 10m wards its Parliament. See also Welderen, p. 4-5.

Gerbrandy, p. 5; Jong, (deel 4-1), p. 40, 116; Verzijl, p. 203.

Scholtens, Staatsrecht, p. 10; Posthumus Meyjes, p. 203. See also Ruiter, p. 129, who stated that Winkelman initially wanted to use his powers to set up a small commission entrusted with civil administration and invited Donner, a Justice at the Supreme Court, to become a member. The commission was never established.

See also Kwiet, p. 71. Biegel, p. 11, 13-14, who at the time could not have been aware of the Government"s oral delegation of powers, assumed that as long as the occupant allowed the nathtional organs, in this case the commander in chief of the Netherlands armed forces, to exercise administrative powers, the commander was de facto exercising Netherlands sovereignty on behalf of the occupant, who had obtained this right under article 43 Hague Convention. 
ever, could only mean that Winkelman was delegated those powers the Government possessed on the basis of the Constitution ${ }^{1 / 5}$ or Netherlands legislation. Legally, the Government could not delegate more powers than it possessed either via constintional or parliamentary provision, ${ }^{146}$ if any at all. The War Act (1899) ${ }^{1.47}$ hardly em. powered the Government in such a way as to possess legislative powers in case of emergency. Rather, it authorized a Netherlands Military Authority during wartime to exercise nartowly circumscribed powers and to enact decrees to maintain public order, within the framework of the Constitution and parliamentary statutory provisions. The Military Administration's powers were furthermore not to exceed those powers most commonly within the jurisdiction of the provinces or municipalities. The only exceptions to this, as the Supreme Court confirmed, were narrowly circumscribed in provisions of the War Act (1899). ${ }^{\mid 48}$ As a result, this statute could not have served as a legal basis for a delegation of governmental powers, ${ }^{149}$ and it is therefore unclear which legal basis was used.

For the Netherlands administration some written instructions had been left on how to deal with an enemy occupation. The Council of Ministers had adopted these Instructions $^{150}$ that were based upon the IVth Hague Convention ${ }^{151}$ in May 1937, in absolute secrecy so as not to compromise The Netherlands' strict policy of neutrality. The great majority of civill servants, at least at provincial and municipallevel, were unaware of their existence. ${ }^{152}$ However, soon after the capitulation on 15 May the Instructions were handed out. ${ }^{153}$ Some viewed the Instructions, especially concerning to what extent the Netherlands national authorities should co-operate with the occupant, as incomplete and dated from the start. ${ }^{154}$

The Netherlands Constitution referred to will be the Constitution as amended in 1938 , Koninklijk Besluit van 25 februari 1938, Stb. 300. See also Dassen; Bohtlingk; Savomin Lohman; Pot, Staatsrecht; Thorbecke. Biegel, p. 4-5.

Wet van 23 Mei 1899, houdende bepalingen ter uitwoering van art. 187 der Grondwet, Stb. $1899,128$.

Hoge Raad 28 juni 1915, NJ 1915, 713.

Biegel, p. 3-4.

Aamwijzingen; Instructions of the Netherlands Government from 1937 based on the IVth Hague Convention of 1907 concerning the behaviour organs of state had to adopt towards the enemy in case of an enemy attack; text in: Bosch, p. $387 \mathrm{ff}$.

Landoorlogreglement annexed to the Verdrag nopens de wetten en gebruiken van de oorlog te land, Stb. 1910, no. 73.

Sikkes, p. 66.

Waalewijn, p. 40. Al least those organs of State subordinate to the Ministry of Justice seemed to be in possession of the Instructions (see Rijksarchief in Noord-Brabant, Arrondissementsrechtbank Breda 1940-1949, toegang 808 inv. 309 brief 8 April 1940 of the Minister van Justitie aan de Autoriteiten. Colleges en Ambtenaren, ressorterende onder het Departement van Justitie, no. 676), as well as for the Ministry's leading civil servants (see Enquetecommissie Regeringsbeletd 1940-1945, Verhoor J.P. Hooykaas, p. 595-605, 603). Also the Supreme Court at least from 30 May 1940 (see Archief Hoge Raad der Nederlanden, Notulen Algemene Vergaderingen wan 1921-1958, Algemeene Vergadering van den Hoogen Raad der Nederlanden op Vrijdag $30 \mathrm{Mei} 1940$, des voormiddags te $10 \mathrm{uur}, \mathrm{p}$. 16) and the "s-Hertogenbosch Court of Appeal from May 1940 onwards (see Archief Gerechtshof 's-Hertogenbosch, Benoemingen 1938-1948, akte Mei 1940) were in possession of these Instructions.

Randwijk, p. 382. 
The legal status of these Instructions was also questionable. Adopted by the Council of Ministers, without either involvement of Parliament or even on the basis of a delegation of Parliament, these Instructions amounted to nothing more than the Government's interpretation of the provisions of the Hague Convention. In form these Instructions could be nothing more than a regular circular or governmental instruction to civil servants. Whether any direct or indirect legal effects would flow from these Instructions was highly questionable. ${ }^{155}$

The Instructions prescribed, amongst others that in case of a hostile attack, govenment officials, in the interest of the population, should remain at their posts and perform their duties as well as possible under the changed circumstances. However, those officials who would be more useful to the enemy than to the general populattion, ${ }^{156}$ were to lay down their office. ${ }^{157}$ Except in the case of impossibility subsequent instructions of the Netherlands Government still had to be executed. ${ }^{158}$ The Netherlands authorities were obliged to object to the enemy's violations of international law and in the worst case choose death or agony over assisting him. ${ }^{154} \mathrm{Neither}$ violence, nor threat of violence, should persuade a Netherlands citizen to give information about the Netherlands army or defense. ${ }^{100}$

When in 1942 and 1943 the attitude of the Netherlands officials slackened more and more and many were increasingly collaborating with the occupant ${ }^{k+1}$ in May 1943 some officials published a Commentary to the Instructions. ${ }^{162}$ Published in the underground press and smuggled to London, the Netherlands Government-in-exile recognized the Commentary as the authentic interpretation of the Instructions, which was communicated via Radio Orange in London to the occupied territory. The Commentary first underlined that the Instructions were still valid and in force, still bound Netherlands officials and force majeure could in principle only be assumed in exceptional cases. ${ }^{163}$ The most important modification was, however, that public officials should refuse to execute any measure of the occupant advantageous to his war effort. Furthermore, public officers were not allowed to resign from office anymore, since too many others were willing to take over their place. ${ }^{164}$ However, neither the Instructions nor the Commentary were be able to solve the moral problems the occupation posed to many individuals ${ }^{165}$ nor provide clear-cut answers in their contacts with the occupant's administration.

15.5 Not until 1948 the Netherlands Central Appeals Court for the public service and for social security matters accepted that circulars or instructions could be binding (CRvB II mei 1948, $A B 1948,507$ ), whereby ten years later (CRvB 30 september $1958, A B 1960,459)$ this binding foree was demied again (See also Sikkes, p. 26; Belinfante, p. 75).

Instruction 1(1), see supra note 150 .

Instruction 31 , ibid.

Instruction 6 , ibid.

Instruction 18 , ibid.

Instruction 19, ibid.

Bosch, p. 386.

See Bosch, p. 395-397.

Commentaries 2 and 3, ibid.

Commentary 5 , ibid.

Warmbrunn, p. 122. 


\subsubsection{The occupant"s administration; type, organization, goal}

On 25 May Hitler replaced von Falkenhausen's Military administration, which had been established in The Hague on 15 May, with a Civil administration. Arthur SeyssInquart became Reichskommissar for the occupied Netherlands territories. ${ }^{16} \mathrm{Al}$ though also a civil administration, it was different from the one established in Luxembourg. A civil administration with a "chef was seen as the most intrusive form of occupation administration, followed by a Reichskommissar. ${ }^{167}$ This was also expressed in the political tasks of these civil administrations. Reichskommissar SeyssInquart's political assignment was to carefully lead The Netherlands into a nationalsocialist direction, ${ }^{168}$ which was less severe than the task of "germanisation" and the de facto annexation of Luxembourg" $s$ Chef of the Civil administration. ${ }^{169}$

In order to assist the Reichskommissar in his task 4 Commissioners General ${ }^{170}$ were appointed, whose position gave the Nazi party and the SS a direct hand in the German administration of The Netherlands to the detriment of Seyss-Inquart's powers. Comparable to Belgium, also other agencies in Nazi-Germany tried to influence the German administration of The Netherlands. ${ }^{171}$

Furthermore, in every province in The Netherlands, as well as in Amsterdam and Rotterdam, representatives of the Reichshommissar were stationed. These "little Reichskommissars' were the highest German representatives at local level and were authorized to review all administrative decisions of the Netherlands administrative organs in their province and if necessary nullify them. They were answerable to the Civil administration at national level and certain administrative decisions had to be submitted to the Reichskommissar before enactment. 172

In 1941, the part of the occupant's administration dealing with supervision of the Netherlands administration consisted of 1596 personnel, which included employees, civil servants, office personnel and others. ${ }^{173}$ A year later this number had risen

1.66

Paragraph \des Führer-Erlasses vom 18. Mai 1940, Reichsgesetzblat, Teil 1, S. 778; Verordnung 1940/1 des Führers über die Ausübung der Regierungsbefugnisse in den Niederlanden vom 18. Mai 1940, VoBI. 1940, S. 2. See also Scholtes, p. 11.

แัง ชั:

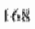

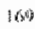

174

Herdeg p. 344-37.

Mazal. p. I 3 .

See 1.3 .2

The Generakommisare or Commissioners General should not be confused with the Secretarles Genenal or secretarissm-generaw. The Secretaries General were Netherlands nationals and the highest-ranking civil servants at the Netherlands ministries, in charge of those Minis tries. The four Commissoners General were German nationals, although only one was a national of the old German State whereas the others were nationals of the former Austrian State. According to Regulation $1940 / 4$ of 3 June 1940 there was a General Commissioner for Administration and Justice Affairs, Dr. Wimmer, one for Security Affairs, Ravter, one for Fi nance and Economic Afairs, Dr. H. Fischböck and one for Special Affars, Schmidt. W. Rutterbusch replaced Schnid in Jun 1943 after the later died in France under mysterious circumstances (see Gollin, p. 133). The General Commissioners rewiewed the work of the Netherlands Secretaries General on bethalf of the Reichskommiso Seyss-lnquart, German ministries or organs of the German Nazi Party NSDAP.

Hirschfeld, p. 25-30; Kwiet, p. 57, 80-81; Umbreit, p. 15. NB Chapter 1.3.2 Luxembourg's Chef of the Civil arministration had been able to defintively fend off interference from other
German agencies.

Hirschfeld, p. 26.

Herdeg, p. 36 . 
to about 2000 , of which one third was Dutch personnel mainly involved in lower ranking position like office help, courier or chauffeur. It was argued that for supervision of the Netherlands administration 200 German administrators would have sufficed. ${ }^{134}$ However, the main reason why more administrators were enployed was probably that the occupant's administration wished to have it close grip on every part of the Netherlands administration. ${ }^{175}$

For the enforcement of its decisions the occupant's administration could use about 3000 German police, ${ }^{176} 20.000$ Waffen-SS and some auxiliary units of the Sicherheitspolizei, Sicherheitsdienst and Abwelr. The Waffen-SS and Geman police were only deployed in cases of severe civil unrest, like for example the Aprill and May strikes of $1943 .{ }^{177}$ This meant that on a day-to-day basis the other units of several hundred German men were used to maintain order amongst 9 million Netherlands citizens. ${ }^{178}$

\subsubsection{Modus vivendi; a system of administration for the occupation}

During the first couple of days of the occupation the occupant's administration would rarely contact the Netherlands civil authorities to give instructions. ${ }^{179}$ On $28 \mathrm{May}$, a few days after the Civil administration had been installed, the Secretaries Cieneral, but not General Winkelman, received an invitation from the occupant to celebrate the capitulation of The Netherlands. After consulting Winkelman, the Secretaries General conditionally accepted. The day after, Seyss-Inquart informed the Secretaries General of the fact that General Winkelman would have no role in the administration of the country, since Seyss-Inquart had taken over the highest govemmental authority. The Reichskommissar also told them that he expected them to remain in office and to faithfully fulfill their duties, without sabotaging the occupant "s administration and gave them the opportunity to step down without any further consequences. ${ }^{2}$.

In consultation with Winkelman the Secretaries General accepted these conditions and remained in office," 181 influenced by uncertainty about whether Winkelman had actually obtained a delegation of governmental powers, fearing the occupant would not tolerate General Winke/man much longer anyway and anxious to prevent a schism within their own ranks. ${ }^{182}$ Moreover, before fleeing to London, several Ministers had orally instructed their main civil servants to come to some kind of modus operandi with the Germans in the interest of the population. General Winkelman was of the same opinion and authorized the Secretaries General to reach an agreement with Seyss-Inquart. ${ }^{183}$

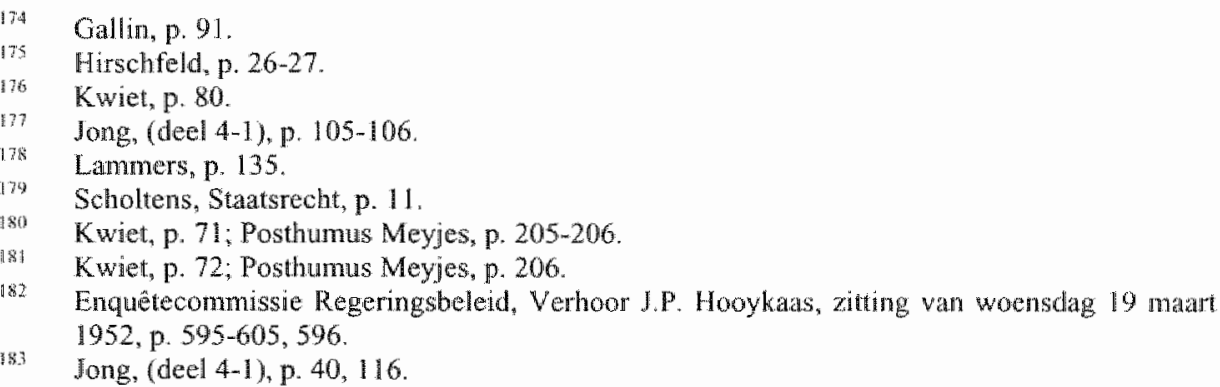


Having assured himself of the co-operation of the Netherlands authorities, on 29 May Seyss-Inquart assumed all powers granted to the Queen and the Government in the Netherlands Constitution and legislation and announced his measures would have force of law. ${ }^{184}$ The Secretaries General were already delegated some of his powers, mainly those executing Netherlands legislation and regulations of the Reichskommissar, subject to his approval before publication. ${ }^{185}$ At the end of June the Reichskommissar delegated general powers to the Secretaries General to enact measures with force of law to maintain public order and safeguard public life and to enact penal provisions, ${ }^{186}$ but retained discretion to narrow their scope or repeal them. ${ }^{187}$ In a few regulations Seyss-Inquart would delegate to single Secretaries General specific powers to e.g. change the borders of municipalities ${ }^{188}$ or to draft a budget. ${ }^{189}$

For the 'correct exercise' of their duties the Secretaries General had been made answerable to the Reichskommissar. ${ }^{190}$ The Secretaries General were authorized to appoint lower ranking officials, although the Reichskommissar reserved the power to override them. ${ }^{101}$ The Reichskommissar had also usurped all powers to appoint all high-ranking public officials, including the Secretaries General and judges. At the Ministry of Justice, the Civil administration succeded in appointing Schrieke, a member of the Netherlands national socialist movement (NSB), on 1 July $1941 .{ }^{192}$

164 Paragraph 1 Verordnung $1940 / 3$ des Reichskommissars der besetzten niederländischen Gebite ïber die Ausübung der Regienungsbefugnisse in den Niederlanden vom 29 . Mai 1940 , VOBI., S. 8 .

Paragraph 3(2) Verordnung 1940/3, ibid. See also Scholtes, p. 16; Biegel, p. 18.

186 Verordnung 1940/23 des Reichskommissars für die besetzten niederländischen Gebiete über die Befugnisse der Generalsekretäre der niederländischen Ministerien wom 2I. Juni 1940 , VOB1., S. 55 .

127 Scholtens, Staatsrecht, p. $24-25$.

188 3. Verordnung 1940/79 des Reichskommissars für die besetzten niederländischen Gebiete uber besondere verwaltungsrechtliche Maßnahmen vom 1. August 1940, VoBL. 1940, S. 246. See Chapter 2.11 for the Belgian reaction to a modification of the borders of municipalities.

18. Verordnung $₫ 940 / 194$ des Reichskommissars für die besetzten niederländischen Gebiete über die Feststellung und Änderung von Haushaltsplänen und über die Feststellung von Rechnungen des States, der Statsfonds und der Stantsbetriebe vom 31. Oktober 1940, VoBI. 1940, S. 560 .

190 Paragraph 3(2) Verordnung 1940/3, supra note 184. See also Scholtens, Staatsreeht, p. 21

japt Erlass 1940/4 des Reichskommissars für die besetzten niederländischen Gebiete uiber den organisatorischen Aufbau der Dienstitellen des Reichskommissars vom 3. Juni 1940, VoBI. S. 11: Verordnung 1940/108 Vierte Verordnung des Reichskommissars für die besetzten niederländischen Gebiete über besondere verwaltungsrechtliche Malhahmen vom 20 August 1940, VoBi., S. 338; See also Herdeg, p. 46-47. More on the appointment of judges in Chapter
4.5

1\%: On 10 May 1940 the following persons were in office as Secretary General: A.M. Snouck Hungronje, Foreign and General Affairs, charmain of the committee of Secretaries Generai; J.C. Tenkink, Justice; K.J. Frederiks, Interior; G.A. van Poelje, Education, Arts and Science; L.I.A. Trip Finance; C. Ringeling, Defence; D.G. W. Spitzen, Public Works; H.M. Hirschfeld, Trade, Industry, Water Transport and also Agriculnure and Fisheries; A.L. Scholtes (from 30 August 1940 A.R. Verwey) Social Affairs; O.E.W. Six, Colonies. In December 1943 only Frederiks, Hirschfeld, Six and Verwey were still in office. Newly appointed Secretaries General and members of the NSB were van Dam, Goedewagen, Rost van Tonningen and Schrieke. See Hirschfeld, p. 133. At the Ministry of Justice J.C. Tenkink was Secretary General until March 1941, after which Hooykas was appointed, who was replaced by J. Schrieke who was in office from 1 July 1941 until the end of the occupation. See also Jong, (deel 6-2), 
Schrieke's predecessor, Secretary General of Justice Hooykaas, contended that legally speaking, in accepting the occupant's delegation of powers, the Secretaries General had become German civil servants. Other Secretaries General had their own opinions about the new situation, ranging from serving the two lords of the Netherlands Government and the occupant to serving the national interest, which was not necessarily equal to the occupant's or the Netherlands Government's interests. ${ }^{193}$

The same day the Secretaries General accepted a delegation of general powers, the Reichskommissar suspended the activities of both chambers of Parliament indefinitely ${ }^{194}$ and abolished the Council of State ${ }^{195}$ At provincial and municipal level the representative organs were initially not suspended, but mid-1941 Seyss-Inquart also ordered their dissolution. ${ }^{196}$ On 19 August 1940, via circular, ${ }^{197}$ the Secretary General of Justice banned the Queen's name from all official acts of state and titles of public office, completing a transformation of the Netherlands administration at the beginning of the occupation.

Especially in the beginning at the provincial and local levels, co-operation between the occupant"s administration and the Netherlands administration went smoothly. Reports of the Reichskommissar and German Armed Forces underlined that the Netherlands administration loyally co-operated with the Civil administration. ${ }^{198}$ In order to assure loyal co-operation the Secretary General of Justice instructed the public prosecutor services to meticulously apply and adhere to not only Netherlands legislation, but even more so measures the Secretaries General or the Civil administration had enacted. ${ }^{199}$

p. 673-674; Hirschfeld, p. 124-125; Scholtens, Secretarissen-Generaal, p. 407. See Barnouw on Secretary General Rost van Tonningen.

Enquêtecommissie Regeringsbeleid, Verhoor J.P. Hooykaas, zitting van woensdag 19 maan 1952, p. 595-605, 597; Postlumus Meyjes, p. 204; Verzill, p. 212-213.

Verordnung $1940 / 22$ des Reichskommissars fur die besetzten niederländischen Gebiete zur Sicherung der Tätigkeiten des Statsrats sowie einiger öfentlichrechtlicher Vertretungskör* perschaften wom 21 . Juni 1940, VoBl., S. 54.

Paragraph 2 der Verordnung $1940 / 22$ des Reichskommissars für die bexethten niederländischen Gebiete zur Sicherung der Tätigkeiten des Statsrats sowie einiger offentlichrechtlicher Vertretungskörperschatten vom 21. Juni 1940, VoBI., S. 54.

19\% Paragraph 2(2) and 2(3) Verordnung $194 / 152$ des Reichskommissars für die besetzen niederländischen Gebiete über besondere verwaltungsrechtliche Malnahmen vom 11. August 1941 , VoBi., S. 637. Circulaire Secretaris-Generaal van het Departement van Justitie d.d. 19 Augustus 1940, Afd. A.S., no. 1133, cited in: Hermans, p. 23. Hirschfeld, p. 129 2.09 .56 , inv. 12 , Circulaire met Brief 16 November 1940 van de Secretaris General van Justitie aan de Heeren Procureurs-Generaal bij de Gerechtshoven. 


\subsection{CONCLUSION; ADMINISTRATION AT THE START OF THE OCCUPATION AND THE POSTION OF THE COURTS}

The main question here is what the differences between the administrations at the beginning of the occupation were that had a bearing on the position of the Belgian, Luxembourg and Netherlands courts? ${ }^{200}$

The type of administration the occupant had set up and the measures it would take to implement its goal would likely affect the courts. Chapter 2 will deal with measures the Belgian courts had to contend with during the occupation, Chapter 3 with the Luxembourg courts and Chapter 4 with the Netherlands courts. Chapter 5 will llook at which measures were different and which were similar and the latter will be used to compare the reactions of the Belgian, Luxembourg and Netherlands courts. What can be said here about the differences in the occupant's administration is that in Belgium and the Netherlands a system of supervision was set up, whereby the occupant guided and directed and only interfered when necessary. In Luxembourg the situation was different. Due to its geographic and demographic characteristics, ${ }^{201}$ the Chef of the Civil administration was able to administer the country directly, certainly from 1 January 1941 onwards. His appointment of German civil servants to public office in Luxembourg, including the courts, as will be elaborated on in Chapter 3.5, severely compromised the Luxembourg courts' ability to respond to occupation measures from the outset.

There were also differences at the start of the occupation as regards national legislation and measures, including those dealing with the administration of the country in case of an enemy occupation. Where national law from the pre-war era itself might account for differences in courts' reactions, this will be discussed when dealing with the relevant topic. However, the measures concerning the administration of the country in case of an occupation and the different ways in which national administrations related to the occupant already spelled some differences for the courts in Belgium, Luxembourg and the Netherlands.

The reason for installing different types of admimistrations in occupied countries is not completely clear, but the absence or presence of the Head of State and/or Government seemed to hawe infuenced that clyoice. Luxembourg. the Alsace and Lorraine were probably given Che fs of Civil administrations to prepare for annexation, but not to ruffle france too much by way of a direct annexation (sce Herdeg, p. 30). Absence of the Head of State and the Government has been offered as another explamation for the installation of civil administrations. In the case of Luxembourg, the fact that the Grand Duchess and Government had fled the country at least resulted in Nazi-Germany's refusal to treat Luxembourg similar to Denmark, namely as an occupied, neutral country (see Wallerang, p. 49) The flight of the Netherlands Government and Queen to London could be a reason for Hitler's change of 'The Netherlands' military administration into a civil one (Zee, p. 151-153; Jonghe, p. 74; Herdeg, p. 47). Also in Luxembourg. as well as in Norway (see Herdeg, p. 17), the Head of State and the Government had fled and subsequently a civil administration was installed (Kwiet, p. 63) In Belgium on the other hand the King had refused to leave his country, crossing Hitler's plans (Umbreit, p. 11 12; Jonghe, Vestiging. p. 103-107), and in France Pétain's Vichy Government was established in the south. In Belgitum and France Hitler installed a military administration.

Luxembourg's geographic size in 1940 was 2,586 square killometers, compared to Belgium's 30,506 and the Netherlands 34,181. Furthermore, Luxembourg's population in 1940 was 300,000 , whereas Belgium's was 8,3 million and in The Netherlands the population was 8,8 million (see Herdeg, p. 21) 
Contrary to Luxembourg and The Netherlands, in Belgium high-ranking members of the courts played an active role in setting up a national administration for the duration of the occupation. The newly acquired lawmaking powers of the Secretaries General on the basis of the Statute on Delegation (1940) allowed for the fabric of the Belgian state to remain intact. ${ }^{202}$ Not only the lawmaking powers would remain in Belgian hands. Also the courts and the public prosecutor service, as well as appointments to their offices, would be linked to the Secretaries General and not be placed directly under German military rule. The public prosecutor service would still have its normal dependence on the Belgian executive. As a result, the Belgian courts would have a higher vested interest in maintaining this system of administration than their Luxembourg or Netherlands counterparts, since its independent position from the occupant relied on it.

Although the Luxembourg Parliament attempted to set up a similar style of cooperation with the occupant, the virulent type of administration the occupant had established in Luxembourg within half a year replaced it with direct rule. The national administration was subordinated to and incorporated into the Civil administration ${ }^{203}$ and increasingly infiltrated by German civil servants, a tendency that could not escape the courts, as will be discussed in Chapter 3.5. The Luxembourg courts were therefore directly linked to the Chef of the Civil administration and increasingly had to function in a State that was rapidly dismantled.

The position of the Netherlands administration and courts was somewhere in between the Belgian and Luxembourg situations. In part due to an insufficient legal basis in national law, unclear Instructions on that issue and the oral instructions from the Government before departure, the Secretaries General accepted a delegation of powers from the occupant. The result was that the Netherlands administration, as well as the courts became directly dependent on the Civil administration. Also the Reichskommissar's powers of appointment of high offices made the administration and the courts directly dependent on the occupant. However, the occupant mainly supervised the Netherlands administration and did not resort to direct rulle. Also, in spite of certain modifications, the Netherlands State and administration were largely left intact, ${ }^{204}$ which meant that Netherlands courts still mainly dealt with a Netherlands administration.

\footnotetext{
202 See also Herdeg, p. 50.

203. See also Herdeg, p. 37, 47.48.

204 See also Herdeg, p. 18
} 



\section{CHAPTER 2}

\section{THE BELGIAN COURTS DURING THE OCCUPATION}

\section{1. "IN THE NAME OF THE KING"}

On 10 June 1940 the Belgian Govemment-in-exile enacted a Legislative Decree ${ }^{205}$ ordering the courts to replace rendering Justice "In the Name of the King" with "In the Name of the Belgian People'. In addition to having suspended the King from exercising his duties due to an impossibility to reign, ${ }^{206}$ this decree would also in effect set him aside as Head of State. Moreover, the Govemment ondered a change in the ath of office, replacing a pledge of loyalty to the King with one of loyalty to the Government. $^{207}$

The Legislative Decree on the King's impossibility, though contrary to the intent of the constitutional provision on which it was based, ${ }^{206}$ could nevertheless find some justification in international law, ${ }^{2019}$ which stated that a King in enemy captivity could not negotiate a valid peace treaty. Howewer, the June 10 decree was a direct violation of article 30 Belgian Constitution, which clearly stated that Justice should be rendered 'In the Name of the King'. In any case, if the Legislative Deorees were to have the same legal status as a statute enacted by the Belgian Parliament, ${ }^{210}$ article 28 Belgian Constitution prohibited the courts from assessing their constitutionality and courts would have to apply the June 10 decree.

The June 10 decrees met with heavy resistance from the civil service, diplomats and military officers. ${ }^{21}$ The courts plainly refused to abide by them. ${ }^{212}$ The Government-in-exile had no choice but to reverse its decision and on 23 August $1940^{213}$ decided to repeal the previous decrees, acknowledging that the King remained Head of State.

205 Arrêté-loi du 28 mai 1940 , Mon. 18 et 30 mai 1940.

wo This situation had never arisen under Belgian constitutional law and therefore the legall stattus of decrees of the Government in exile with the King in an impossibility to reign was unclear. See also Chapters 1.2 .1 and 6.2 .2 .

207 Arrête-loi du 10 juin 1940, déterminant la fomule du serment préscrit par le décret du 20 juillet 1831, Mon. du 9-11 juin 1940. See also Velaers/Goethem. p. 274

$25 \overline{9}$ The legislative history of article 82 Belgian Constitution showed that its intent was to be able to replace the King in case of mental illness. See Ganshof, Regering, p. 394; Velaes/Goethem, p. 275. After the occupation a broader interpretation would be accepted (see Chapter 7.1.1 and Velaers (Goethem, p. 276-277).

See also Fayat, p. 2, footnote 2. See Benvenisti, p. 17-18 for the conditions concerning validity of exile legislation on the occupied territory during the occupation. See also Benwenisti, $p$. 192-194 on the Bellgian courts" refusal to accept applicability of exile decrees on Belgitum's occupied territory during World War Ome.

See Chapter 6.2 .2 for a further discussion of exile measures.

Velaers/Goethem, p. 274.

Lourveaux, p. 622; Velaers/Goethem, p. 275.

Arrêté-loi du 23 aoũt 1940, abrogent les arrêtés-lojs du 28 mai réglant la formule exécutoire des arrêts at jugements des cours et tribunaux, des ordonnances, mandats de justice et de tous actes emportants exécution parée et du 10 juin 1940 déterminant la formule du serment préscrit par le dêcret du 20 juillet 1831 , Mon. du 26 a ân 1940. 
In several ways throughout the occupation the courts would continue to acknowledge the King as Head of State and thereby pledge allegiance to Belgian sovereignty of which he was the remaining main symbol. The oath of office was honored and all Belgian civil servants, including judges, were obliged to take this oath. When laking the oath, Loyalty to the King and obedience to the Constitution and the laws of the Belgian people was affirmed. ${ }^{214}$ Those judges appointed and sworn into office during the occupation also took this oath ${ }^{215}$ And when commemorating the capitulation of the Belgian army on 28 May 1941, the Cour de cassation unanimously adopted a declaration of loyalty to the King. This declaration, together with a declaration of support from the leading members of the Cours d'appel and their public prosecutor services, was sent to the King. ${ }^{216}$ Throughout the occupation the Belgian courts pledged loyalty to the King, even though he would remain in enemy captivity. 217

This was in accordance with the tasks the President of Belgium's Supreme Court, the Cour de cassation, had formulated for the courts for the time of the occupation. In December 1940 President Jamar had already stated that the courts were an essential element in the maintenance of public order and economic life. Belgian laws continued to exist, local administration exercised their duties and the courts functroned according to their tradition of impartiality. Jamar called for unity amongst the Belgians, attachment to their institutions and their administrations and respectfully expressed loyalty to the King in captivity. ${ }^{218}$

This meant that the Belgian courts throughout the whole occupation clearly and unambiguously demonstrated their attachment to Belgian sovereignty and expressly underlined that they would exercise their powers only in the name of the representative of that sovereignty who had remained in Belgium, namely the Belgian King.

\subsection{JUDICIAL PERSONNEL AND THE PROHIBITION TO ABANDON POST}

Immediately after the German invasion, there was a popular exodus to France. The Military administration enacted a regulation ${ }^{219}$ stating that public officials, including members of the Government, ${ }^{220}$ returning to office after having fled could only exercise their functions after specific approval of the Military commander. ${ }^{221}$ The Military commander also reserved the right to disallow certain other persons not men-

\footnotetext{
214 "Vous jurez fidelite au Roi, obeissance a la constitution et aux lois du peuple belge."

See a.g. Greffe Cour de cassation, Registro des Assemblées genérales du 17 juin $1937 \ldots 28$ decembre 1940 , Audiance solennelle et publique 16 mai 1940; Greffe Cour d'appel de Liege, Régintre des Assemblés générales du 10-11-1936 an 13-2-1958. Assemblée généale publique le jeudi chn septembre mil neuf cent quarante, $p .42$ Greffe Cour de cassation Registre des Assemblés générales du 28 décembre 1940 - 8 juillet 1942, Proces Verbal L'An mil meuf cent quarante-un, le vingt-sept mai. Grefte Cour de cassation, Registre des Assemblées générales da 17 juin 1937 - 28 décembre 1940. Assemblée genérale publique du 16 décembre 1940.

Greffe Cour de assation, Registre des Assemblëes générales du 17 juin 1937 - 28 décembre 1940. Assemblé générale et publique du 16 décombre 1940 . Verondnung iber die Ausibung offentlicher Tätigkeiten in Belgien vom 18. Jult 1940, VoB1.
S. 131 .

$220 \quad$ See also Velaers/Goethem, p. $515-516$.

Paragraph 2 , ibid.
} 
tioned in this regulation to exercise their public office. ${ }^{222}$ An unpublished decision of the Chef of the Military administration further described the category of civil servants involved. ${ }^{22}$ Persons who had been disallowed to exereise their office would have to be removed from office by 31 December 1940 or retired as the case might be $^{224}$ This unpublished decision was sent to the chairman of the committee of Secretaries General and amongst others the Secretary General for Justice. ${ }^{225}$ Justices on the bench of civil and penal courts that were implicated by this decision were the President and the Presidents of the Chambers of the Cour de cassation, the President and Presidents of the Chambers of the Cours d'appel as well as the Presidents of the Tribunaux.

Judges who had abandoned their posts were also in breach of Belgian legislation. The Statute on Duties of Civil Servants during Wartime (1935) ${ }^{26}$ determined that every person holding a public office and not drafted during mobilization of the army was obliged to direct all his activities at fulfilling the orders of his superiors at whose disposal he had to put himself. ${ }^{27}$ Those judges drafted in the army were held as prisoners of war after Belgium's surrender, ${ }^{228}$ due to which several offices were vacant.

How many judges abandoned post is unknown, but this appears to have been an exception rather than the rule. Nevertheless, in Nivelles and Louvain the whole prosecutor office was missing and in two districts of a province the Judiciary was not functioning at all, since the judicial officers had fled. ${ }^{22 \%}$ Within the circuit of the Gent Cour d'appel a President of a Tribunal ${ }^{230}$ and the subordinate Justice of the Peace, as well as both his deputies ${ }^{2.11}$ were missing.

222

Paragraph 3, ibid

Paragraph 1, Bekanntmachung über die Ausïbung öffentlicher Tätigkeiten in Belgien vom 19. September 1940, VoBl., S. 224.

Paragraphen 2 und 3, Verordmung zur Ergänzung der Verordnung über die Ausübung öffentlicher Tätigkeiten in Belgien wom 19. Dezember 1940, Vol31., S. 445.

CEGES/SOMA, Tätigkeitsbericht Nr. 8 der Militärverwaltung für den Monat August 1940 , Anlage B. N.B. It has to be kept in mind that these reports, as well as the Abrchlupberichte were drafted for the OKH, which had given von Falkenhausen's Military administration its mandate and to which the Military administration was subordinated and had to report to directly. Therefore, these reports, more than actual and objective status reports, also contained the Military administration's own assessment of its performance in Belgium.

See Chapter 1.2.1 and the Statute on the duties of public officials during wartime (1935). The Cour de cassation explicitly held the statute applicable to members of the Judiciary (Cass. 24 mars 1941; Pas. 1941, 1, 93. See also Cass. 24 mars 1941; Pas 1941, I, 95; Cass 8 avril 1941; Pas. 1941, 1, 139), including members of courts (Cass. 5 mai 1941; Pas. 1941, 1, 172).

Smolders, Législation, Tome 11, 10.563-564. See also Chapter 1.2.1.

See e.g. Rijksarchief te Beveren, Rechtbank van Eerste Aanleg te Antwerpen A. 2000, no. 273 Krijgsgevangen magistraten 1940-1941, Brief vom 27. Juli 1940 vom Gerichtspräsidenten des Gerichts erster Instanz Antwerp an dem Herm Befehlshaber des Kriegsgefangenenlagers Oflag VII B, no. 1692 .

Delandsheere/Ooms, Tome $\mathrm{l}_{3}$ p. 89; Verhoeyen, p. 57.

Rijksarchief te Beveren, Rechtbank van Eerste Aamleg te Oudenaarde 1918-1972 A 2000, no. 6 Onderrichtingen in werband met de oorlog 1939-1944, Brief I September 1940 wan de Raadsheer-onderzoeker aan de Hoofdgriffier van de Rechtbank van Eerste Aanleg te X.

Rijksarchief te Beveren, Rechtbank van Eerste Aanlegt te Oudenaarde 1918-1972 A 2000, no. 6 Onderrichtingen in werband met de oorlog 1939-1944, Vordering tot voorloopige aanstelling in het Kanton $X$ van een titelvoerende Vrederechter. 
Already starting on 12 June, those judges that had fled were brought before commissions especially set up to deal with abandonment of office. Courts, amongst others the Cours d appel in Liege and Brussels tried and convicted judges that had abandoned post. Some of these cases, one dealing with a Vice President of a Tribunal and one with an examining magistrate, were tried before the Cour de cassation. ${ }^{232}$ Attomeys were in turn appointed to those offices to fill the vacancies. ${ }^{233}$

Nevertheless, enough benches seem to have been vacant to slow the pace of the judicial process at the beginning of the occupation and impair the functioning of the courts. $^{234}$ This was also due to the occupant's measure prohibiting the return of judges who had fled, as well as judges being drafted into the army and subsequently held as prisoners of war.

\subsection{MEASURES AGANST BELGIAN JUDGES OF JEWISH ANCESTRY}

Other measures also resulted in vacancies at the courts. One of two regulations enacted against Jews on 28 October $1940^{235}$ dealt with a prohibition for Belgian officials of Jewish ancestry to exercise any public office. The Secretary General of Justice on 9 November requested a recommendation from the Council for legislative affairs $^{236}$ on how to deal with the Military administration's measures concerning the Jews.

The Council's advice of 21 November ${ }^{237}$ considered that the principle of equality before the law meant that without distinction people were admissible for public office. Furthermore, the freedom of religion as expressed in articles 6 and 14 Belgian Constitution and the irremovability of judges of article 100 Belgian Constitution were basic principles of Belgian public law and fundamental to Belgium's administrative and judicial organization. Any participation in the execution of these regulations would exceed the legal powers of the Secretaries General and break their oath of office, as well as constitute a violation of Article 118 bis BPC, which prohibited aiding the enemy in transforming Belgium"s political institutions. in 1911 and had only consultative powers. The Royal Decree was not published in the Monitew. However, it is refened to in the Act of Parlisment establishng the Consen d btat (see Loi du 23 decembre 1946 , Mon. le 9 janvier 1947), for which the Conncil for legishative affirs had been a predecessor and substitute (Holthöter, p. 74). Raonl Hayoit de Temmicourt, Advocate General at the Con de cassation presided over the Council for legislative affairs from the beginning of the occupation untill its dissolution by the occupation administration ater on during the occepation. (Ontrive e.a. p. 138). Although only allowed to render recommendations, the fact that the members of the Councill were semor high-ranking members of all three branches of state, the Council's recommendations carried considerable weight. CEGES/SOMA, Papiers Vossen 192.-1952, MIC 74, afschrif-vertaling Brief 21 Novemben 1940 van de Secretaris van het Vaste Comite van den Rad van Wotgeving $R$. Hayoit aan de Secretaris Generaal van Justitie en Letre de $\mathrm{M}$. Hayoit de Termicourt a $\mathrm{M}$. le secrétaire gé-
néral au Ministère de la Justice du 2 l novembre 1940.
} 
Nevertheless, so the Council, not every expression given to these regulations would be participation. The person against whom the occupant directed his measure and whom the occupant forced to comply with this measure did not participate in its execution. Examples of non-participation were submission of persons to the obligations and prohibitions the regulations imposed on them, like the municipal administrations keeping a register of Belgian national of Jewish ancestry for declarations spontaneously made by those affected and the public posting of the regulations. However, Belgian public officials were prohibited to initiate, investigate or complement measures in order to assure the effectiveness of these regulations.

Concerning the removal from office of Belgian nationals of Jewish ancestry the Council remarked no co-operation could be granted, since the occupant's regulation was contrary to the aforementioned legal principles. The text of the regulations should be transmitted to the subordinated public officials with the invitation to those who were going to register as Jews to notify their superiors of their intent to do so. They should furthermore be requested to indicate any intention to retire from office.

The approach the Council for legislative affairs proposed to take was a middle road between the rules of its own legal order and its obligations under international law. Article 43 Hague Convention allowed the occupant to enact rules though limited to the maintenance of public order and safety, while respecting the laws in force in the occupied country. The exact meaning of this provision has been unclear and has changed over time. ${ }^{238}$ The national institutions of an occupied country, if willing to function under the occupant, ${ }^{239}$ were obliged to follow his orders, as long as these did not run counter to their patriotic duty and their conscience, ${ }^{240}$ or possibly violate the laws of war. ${ }^{24}$ Furthermore, the occupant did have the right to remove civill servants of the occupied country from office, although removing a group appears contrary to international law. ${ }^{242}$ Since these rules were in any case a violation of Belgium's legal order, the Council for legislative affairs in effect recommended Belgian national institutions should not execute the order, but also could not hinder the occupant in executing it. However, in leaving the decision to comply to those alfected by the German measure and not indicating whether the Belgian administration would offer support in case a public official of Jewish ancestry was not willing to comply, those affected were put in an extremely difficult position.

The Belgian courts protested against the occupant's measure. The Cour de cassation together with Adwocate General Hayoit de Termicourt sent a letter on 19 November 1940 to von Falkenhausen, declaring the regulations concening Jews contrary to principles of Belgian constitutional law and legislation. Belgium still existed as a State and although under the Hague Convention the Military administration had legislative powers, these were limited to measures concerning the maintenance of public order and public life. The President of the Court requested a meeting with von

\footnotetext{
23 Bernvenisti, $7.7-31$.

234 Spaght, p. 360-361; Verraes, Tome 1, p. 177-178; Oppenhem, War, p. $211-2112$

240 Ber Poortugael, p. 176-177.

24 Bordwell, p. 300 ; Francois, p. 445.

24: Bordwell, p. 306. See Chapter 4.3 for the apparent illegality on the basis of intemational law.
} 
Falkenhausen to discuss the issue. Also the Presidents and of the prosecutor's offices at the Cours $d^{\prime \prime}$ appel delivered a written protest against the regulation. ${ }^{243}$

In a letter dated 26 November 1940, the General of the Infantry, on behalf of von Falkenhausen, confirmed receipt of several letters of protest. He curtly informed the President of the Cour de cassation that amending the regulations enacted on 28 October 1940 concerning measures against Jews was not possible. The General further stated that a meeting would in his opinion not lead to any results, closing, as far as the Military administration was concerned, any discussion on the subject. ${ }^{24}$

The Belgian administration seemed to have followed the Councill for legislative affairs's recommendation in dealing with the German measure. ${ }^{245}$ Secretary Schuind claimed not to have removed any judges from office, but only to have notified those judges affected by the regulation of any subsequent decision the Military administration had taken. ${ }^{246}$ Presumably by 4 April 1941, when Schuind was appointed Secretary General of Justice, most members of Jewish ancestry had already been removed from office. ${ }^{247}$ However, Schuind did accuse his predecessor of having removed a Brussels Tribunal judge of Jewish ancestry from office. ${ }^{248}$

Schuind"s accusation might not be entirely correct, but the following event might be illustrative of what happened. An urgent letter from his predecessor was sent to the Procurator General at the Brussels Cour d'appel informing him of the German measure. ${ }^{249}$ Judges of Jewish ancestry had to cease exercising their duties by 31 December 1940 and would then be suspended. Those wishing to enjoy the proposal of suspension, so the Secretary General, would have to hand in a request before 10 December.

Subsequently, the President of the Antwerp Tribumal received a phone call from the Procurator General at the Brussels Cour $d$ 'appel. The Procurator General orally instructed the President to urge any members or personnel of his court of Jewish ancestry to resign. This would be in their best interest, so the Procurator General, since this way they would at least receive a pension, which was questionable in case they were suspended and possibly removed from office. The President of the Antwerp Tribunal presumed that the Procurator General acted with the permission of the President of the Cour d'appel in this matter, but nevertheless thought it necessary to

CEGES/SOMA, Appendix to Jahresbericht Mai 1940/1941 des Militärbefehishabers in Bel. gien und in Nordfrankreich, Letter of 26 November 1940 on behalf of the Military commander in Belgium and the north of France to the President of the Cour de cassation.

lbid.

See alsw Geet, p. $83-84$ concerning one of Belgium's police force's (Rijkswach) attitude, where the regulations against Jews were only announced, but no cooperation was given concerning their implementation.

Archives Auditorat Géneral, Cour militaire, Dossier Schuind, no. 572.B.47, Carton 4, farde $\mathrm{X}$, no. 14, Proces-Verbal d'interrogatoire de Gaston Schuind le 8 mai 1945. Compare to Chapter 4.3 . In The Netherlands measures against public officers of Jewish ancestry had been enacted at around the same time and at the end of February 1941 all had been
removed from office. Archives Auditorat Général, Cour militaire, Dossier Schuind, no. 572.B.47, Carton 4, Farde $\mathrm{X}$, no. 14, Procès-Verbal d'interrogatoire de Gaston Schuind le 8 mail 1945.

Rijksarchief te Beveren, Rechtbank van Eerste Aanleg te Antwerpen A 2000, no. 152 Stukken in verband met Jodenverordeningen, afschift Brief 25 November 1940 van de Secretaris Ge20.472. Justitie aan de Procureur Generaal bij het Hof van Beroep te Brussel, C., No. 
inform the latter. He would, however, contact those who might, in his view, profit from this advice. ${ }^{250}$

It is doubtful whether a procurator general at an appeals court would act without instructions from superiors in such a delicate matter. Even if the Brussels Procurator General acted on his own authority, it is unlikely he would not have contacted all courts in his circuit, which, with the cities of Brussels and Antwerp, most probably had more judges of Jewish ancestry than other parts of Belgium. The policy the Council for legislative affairs had recommended made it extremely difficult for those affected to refuse to comply with the German measures. The urgent request by their direct superiors to resign would render a refusal virtually impossible and in effect force Belgian nationals of Jewish ancestry to comply with the occupant's measure.

The courts did protest and were discouraged from pursuing the matter further with the Military administration, but after this seemed to have accepted the removal of their colleagues of Jewish ancestry as inevitable. This is in stark contrast to their attitude as regands judges or judicial officers who were arrested or suspended from office for certain acts of office. ${ }^{251}$ In the latter cases the Cou de cassation, even though the occupant has the right to remove civil servants of the occupied country from office, ${ }^{252}$ threatened to suspend its duties if the suspension or arrest did not come undone. In case of the judges of Jewish ancestry no act of office, legal or illegal was involved and nevertheless suspension would follow.

How many Belgian judges of Jewish ancestry were suspended from office on the basis of the German measure or under these circumstances opted to resign from office on the basis of the Belgian administration's recommendation is unknown.

\subsection{LIMITATION OF COMPETENCIES AND FIRST CRISIS CASES INVOLVING ILLEGAL POSSESSION OF ARMS}

During an occupation international law allows the occupant to exclude crintes committed against him, his army or institutions, as well as those committed by members of his army or institutions from the jurisdiction of the occupied country's court and to transfer these cases to war tribunals. ${ }^{253}$ During World War Two the occupant hardly limited the Belgian courts" competencies in civil matters, ${ }^{254}$ but certain crininal matters were either partly or completely excluded.

Already on 10 May 1940 Belgian courts were excluded from trying criminal matters concerning offences committed against the German Armed Forces and its

\footnotetext{
256 Rijksarchief te Beveren, Rechtbank van Eerste Aanleg te Antwerpen A. 2000, no. 152 Stukken in verband met Jodenverordeningen. Brief 13 December 1940 van de Voorzitter der Rechlbank te Antwerpen aan de Eerste Voorzitter wan het Hof wan Beroep te Brussel, no. 3097. None of the judges at this court indicated to have been affected by this measure. See Rijksarchief te Beveren, Rechtbank van Eerste Aanleg te Antwerpen A 2000, no. 152 Situken in verband met Jodenverordeningen, Brief 14 December 1940 van de Voorzitter der Rechtbank Antwerpen alan de Eerste Voorzitter van het Hof van Beroep te Brussel, no, 3107.

25 See Chapters 2.7 and 2.15.

25. Bondwell, p. 306

25: Verraes, Tome I, p. 180-181; Spaight, p. 357-358; Beer Poortugael, p. 178; Oppenheim, War, p. 214; Verzilil, p. 243; François, p. 445.

254 CEGES/SOMA, Abschlulbericht der Militärverwaltung, 6. Tei! Die belgische Justiz und Gesetzgebung, p. 98 .
} 
organizations. ${ }^{255}$ These matters would belong to the exclusive jurisdiction of the German war tribunals. Simce hardly disputed under international law, ${ }^{256}$ these measures will therefore not have solicited a reaction from the Belgian courts. For cases involving German nationals that did not belong to the German Armed Forces or any of its organizations and had their domicile in Belgum, Belgian courts remained competent, whereby proceedings could only be initiated and sentencing executed with the consent of the Military administration. The legal situation under international law with regards to nationals of the occupant who did not belong to his forces or institutions is not very clear. ${ }^{257}$ However, the Military administration reported this specific arrangement allowing the Belgian courts to exercise their competencies worked well and did not cause any problems. ${ }^{258}$

Violations of regulations of the Military administration would be exclusively tried before German war tribunals, due to the continuous refusal of the Belgian courts during and after the occupation to apply the Military administration's regulations. ${ }^{250}$

For several other types of crimes some sort of system of concurrent competencies between the Belgian and the German courts would emerge, which would often prove problematic. ${ }^{260}$ International law did not provide for a specific treaty provision concerning the competencies of domestic courts during an occupation and the powers of the occupant to change these competencies. Jurisprudes differed in opinion on the topic. Some allowed the occupant to exclude from the competencies of the domestic courts all cases relating to his own safety, but insisted the domestic courts" other civil and penal competencies remained unaltered. ${ }^{261}$ Others allowed for exclusion of competencies "for military purposes or for the maintenance of public order and safety", but maintained that domestic courts should not be constrained in pronouncing verdicts for the competencies left to them ${ }^{262}$ and were allowed to determine whether that was the case. ${ }^{263}$ This meant that international law provided the Belgian authorities and the Belgian courts with some leeway to argue with the occupant over a possible exclusion of competencies, especially as regards those that did not directly involve the occupant's safety.

259

Verordnung über die Einfihhrung deutschen Strafrechts und strafrechtlicher Bestimmungen in den von deurschen Truppen besetzten Gebiete der Niederlande und Belgiens vom 10.5.1940, VoBl. 1940-1944, S. 7; Beksuntmachung fur das besetzte Gebiet vom 10.5.1940, VoB1., 1940-1944, S. 4.

Benvenisti, p. 20-21; Verraes, Tome I, p. 180-181; Spaight, p. 358; Beer Poortugael, p. 178; Oppenhem. War, p. 214-215; Vereijl, p. 243; François, p. 445; Drooghenbroeck, p. 1, 16 See Benvenisti, p. $20-21$.

CEGES/SOMA. AbschlnßBbericht der Militärverwaltung, 6. Teil Die belgische Justiz und Gesetzgebung, p. 98.

See also Chapter 2.8 .

Louveaux, p. 652; CEGES/SOMA, Abschlubbericht der Militärverwaltung, 6. Teil Die belgische Justiz und Gesetzgebung, p. 99.

Verraes. Tome I, p. 180; Spaight, p. 358; Beer Poortugael, p. 178 explicitly endorsed the exclusion of the domestic courts' competencies of cases involving the occupant's safety, but only seemed to imply more exchusions were not possible; Verzijl, p. 243; Drooghenbroeck, p. 10 cited some authors taking this position and cited others taking the position that civil and commercial law shonld remain intact and criminal laws could be altered.

Oppenheim, War, p. 214-215; Bordwell, p. $301-303$.

Drooghenbroeck. p. 19. 
The occupant extended the German war tribunals' competencies to cases concerning certain types of "economic crimes", illegal possession of arms and acts of sabotage. ${ }^{264}$ For most of these offences, on the basis of Belgian law, Belgian courts were competent as well.

The occupant's reason for concurrent competence in these areas was that the Military administration relied upon the Belgian administration and courts to be able to administer the occupied country. Excluding the Belgian courts" competencies to try cases where Belgian authorities had already done the preparatory work might also compromise the exercise of the other Belgian authorities" duties. ${ }^{265}$

In several ways the Military administration nevertheless tried to influence the functioning of the Belgian courts when dealing with cases where they had concurrent competence. As regards certain 'economic crimes', like price usury, the Military administration complained that sentencing was too mill, that the amount of smaller cases dominated the prosecution and the bigger usury crimes were not tried. Initially the occupant requested the Secretary General of Justice to instruct the courts to shorten the proceedings. ${ }^{266}$ In December 1940 the Military administration again complained that the continuing slow pace of the Belgian Judiciary hindered the effectiveness of measures on the monitoring of prices. It requested the Secretaries General to introduce a more effective administrative criminal proceeding dealing with these cases, ${ }^{267}$ but the Secretaries General replied with constitutional objections. ${ }^{26 \mathrm{~K}}$

Eventually the Secretaries General would enacted a decree establishing a Belgian administrative procedure. ${ }^{269}$ Initially recourse was still possible to the ordinary courts, but this was later on abolished via regulation of the Military administration on 2 August 1941. ${ }^{270}$ Instead, the accused was given the choice to be tried by the ordinary courts or the administrative courts, but the minimum sentence for the ordinary

264 Verordnung über Waffenbesitz im Besetzten Gebiet worn 10.5.1940, VoBI. 1940-1944, S. 3; Verordnung über Ablieferung von Waffen vom 27. Dezember 1941, VoBI. 1940-1944, S. 813; Verordnung über Waffengebrauch vom 7. September 1942, VoB1. 1940-1944, S. 1026; Verordnung zum Schutze des inneren Friedens und der Besatzungsmacht (Schutzverordrung) vom 28. April 1943. VoB1. 1940-1944, S. 1293. See also CEGES/SOMA, Tatigkeitsbericht $\mathrm{Nr}$. 20 der Militărverwaltung für die Zeit vom 15 März - 1. Juni 1942, p. A10. A. 1 .

CEGES/SOMA, AbschluBbericht der Miltärverwaltung, 6. Teil Die belgische Justiz und Gesetzgebung, p. 26 . CEGES/SOMA, Tätigkeitsbericht Nr. II der Militărvenwaltung für den Monal November 1940, p. $47-48$.

See also Verordnung über das Ordnungsstrafrecht in Belgien vom, vom 18. Dezember 1940, VoBl. $1940-1944$, S. 445 .

CEGES/SOMA, Tätigkeitsbericht Nr. 12 der Militärverwaltung für den Monat Dezember 1940, p. 43.

26\% See Arrêté No. 141 du 15 février 1941 instituant une procédure administrative en matière dee répression des infractions concernant le ravitaillement, le rationnement et la fixation des prix, Recueil des arrêtes des Secretaires Généraux 1941 Tome I, p. 686: Arrêté No. 162 du 25 fé. vrier 1941 pris en exécution de celui du 15 février 1941, instituant une procédure administrative en matière de répression des infractions concenant le ravitail tement, le rationnement ef la fixation des prix, Recueil des arrêtes des Secrétaires Gếnéxaux 1941 Tome 1, p. 816.

2. Verordnung über das Ordnungsstrafrecht in Belgien vom 2. August 1941, VoBI. 1940. 1944, S. 691 . 
courts was set at one year, rendering trial by the ordinary courts only a theoretical aption. $^{27 !}$

In the case of food coupon falsifications, the Military administration reported that in 1942 the situation got out of hand in such a way that it saw the distribution system endangered. The sentences of the Belgian courts were deemed not severe enough to be a proper deterrent. On 16 March 1942 the occupant therefore enacted a regulation $^{272}$ making food coupon falsification punishable by death. This also meant that the competence to try these cases was taken away from the Belgian courts and handed over to the German war tribunals. Their verdicts did work as a deterrent, so the Military administration, but the German police lacked the means to properly investigate all alleged breaches of this regulation. The Belgian police now refused to cooperate with the Military administration, since that would mean having to hand over its own nationals to the enemy. A compromise was reached whereby the Secretaries General agreed to enact a new decree on 11 December 1942, increasing the minimum sentence ${ }^{273}$ in return for which the Belgian courts regained their lost competence in this field. ${ }^{274}$

In order to maximize its influence over the Belgian courts in areas of concurrent competence the occupant allowed the German war tribunals at any moment to have a case transferred from the Belgian courts. Even against a res judicata judgment of the Belgian courts, the German war tribunals could open new proceedings. The Military administration maintained this did not violate the legal principle of ne-bis-in-iden, since it viewed the German war tribunals as hierarchically superior to Belgian courts. This also implied that against a res judicata judgment of a German court no proceedings in a Belgian could be started. The Military administration alleged the Belgian courts accepted this. ${ }^{275}$

However, in the area of illegal possession of firearms, throughout the occupation, Belgian courts would protest when being excluded from trying these cases and attempt to regain that competence. ${ }^{276}$ From the beginning of the occupation the prohibition on the use of arms had been stipulated in several German regulations, ${ }^{27 \%}$ which were amended throughout the occupation. Illegal possession of arms was sub-

271

CEGES/SOMA, Abschlubbericht der Militärverwaltung, 6. Teil Die belgische Justiz und Gesetzgebung, p. 56.

272 Varordnung gegen die Fälschung von Lebensmittelmarken und -bezugscheinen vom 16 . März 1942, VoB1. 1940-1944, S. 859 .

27 Arret No. 778 du 11 décembre 1942 concernant la répression du faux et de certaines autres infractions en matiere de timbres et autres titres de ravitaillement Recueil des arrêtes des Secrétaires Généraux 1942 Tome III. p. 3720.

Gesetzgebung, p. 58 .

$2 T^{3}$

CEGES/SOMA, Abschlußbericht der Militärverwaltung, 6. Teil Die belgische Justiz und Gesetzgebung, p. 99.

276 See also Chapter 2.15.

27 Verordnung über Waffenbesitz im besetzten Gebiet vom 10.5.1940, VoBl 1940-1944, 3 Verordnung ïber Ablieferung von Waffen vom 27. Dezember 1941, VoBl. 1940-1944, S. 813; Verordnung über Waffengebranch vom 7. September 1942, VoBI. 1940-1944, S. 1026; Verordnung zum Schutze des inneren Friedens und der Besatzungsmacht (Schutzverordnungy vom 28. April 1943, VoB1. 1940-1944, S. 1293. 
ject to long-term imprisonment or the death penalty. On the basis of these regulations, the German war tribunals considered themselves competent in these matters. ${ }^{278}$

The Belgian courts contested any exclusivity of this competence for the German war tribunals, possessing their own competence under Belgian law to try these cases. ${ }^{279}$ The first incident occurred at the end of January 1941 . The former mayor of the municipality of Herstal had been killed during an attack in Liège in the night of the 13-14 January 1941. The culprits, detained by the Belgian Judiciary, were released on 30 January via order of the Military administration.

The Cour de cassation was informed of these developments and during subsequent meetings on 5 and 15 February and 3 March informed itself more fully of the facts and followed the unfolding events. The Procurator General at the Cour de Cassation and the King's Prosecutor of the Liège Tribunal met with the local German official who had given the release order. The Cour de cassation protested in a letter to von Falkenhausen, but decided not to take further action until a response had been given. During the Cour de cassation's plenary session on 6 March the Procurator General informed the Court that the criminal investigation against the culprits had been opened and could proceed its nomal course. The Court therefore decided the matter closed. ${ }^{280}$

The Cour de cassation, when not put in a position of impossibility due to a German measure completely excluding part of its jurisdiction, clearly did not allow for the Military administration to interfere in the exercise of its obligations under Belgian law. Furthermore, the Court could argue under international law that since this case merely involved Belgian nationals, it belonged to the competence of the Belgian courts.

However, the separate administrative procedure for certain economic crimes was something the Belgian courts were not inclined to accept, as will be elaborated on in Chapter 2.9. Also, as will be further discussed in Chapter 2.15, cases dealing with illegal possession of firearms would remain particularly conflict prone and Belgian courts were not going to hand over certain competencies to try its own citizens very easily.

\subsection{APPOINTMENTS DURING THE OCCUPATION}

Before the occupation, article 99 Belgian Constitution provided for the King to appoint all judges. In practice the Minister of Justice would exercise this royal power. The procedure was that justices of the peace ${ }^{281}$ and judges of the Tribunaux were directly appointed. Justices of the Cours d'appel and the Presidents and Vice Presidents of the Tribunaux were appointed on the basis of double lists. The courts with the vacancy presented one list, the Provincial Council where the court had its seat the

\footnotetext{
27 CEGES/SOMA. AbschluSbericht der Militärverwaltung, 6. Teil Dje belgische Justiz und Gesetzgebung, p. 27.

379 The actual possession of arms was made punishable by Loi du 3 janvier 1933 relative a la fabrication, au commerce et au port des armes et au commerce des munitions, Mon. du 22 juin 1933.

230 Greffe Cour de cassation, Registre des Assemblées générales du 28 décembre 1940 - 8 juillet 1942, Assemblếe générale en Chambre du Conseil du quatre février 1941

$2 \times 1$ Article 4 Loi du 18 juin 1869 rémprimée en vertu de l'arrêté royal du 22 féwrièr 1892, Mor le 13 mars 1892 . See also Loi du 13 juin 1924.
} 
other. ${ }^{282}$ In case of a wacancy at the Cour de cassation, the Senate and the Cour de cassarion would each provide a list with candidates. At least fifteen days before the appointment the lists had to be made public. The Cours d'appel and the Cour de cassation chose from among their colleagues their Presidents and Vice Presidents.

During the occupation this procedure for obvious reasons could not work anymore. The Secretary General of Justice enacted a decree on 20 December 1940 , modifying a of decree of 6 November $1939,{ }^{284}$ which originally allowed the $\mathrm{King}$, for the duration of the mobilization of the army, to nominate judges and their deputies. The modification assured the Secretary General could fill the vacamcies that had occurred due to the mobilization. Article 5 Statute on Delegation (1940) did not allow the Secretaries General to appoint magistrates, not even on a temporary basis, and therefore using the 1939 decree as a basis for appointment seemed to be prechuded. Since it was nevertheless necessary to assure the continuation of the functioning of the Judiciary, the Secretary General of Justice created the new procedure, which did not allow him to appoint, but rather nominate judges. The difference was due to the fact that regular appointments were impossible under the circumstances. The Presidents of the Tribunawx, on the advice of the President of the Cour $d$ 'appel and with the consent of the Secretary General of Justice could have attomeys exercise the office of judge or deputy judge. The decree of 1939 had already provided for attomeys to exercise the office of judge in case of mobilization, but only in exceptional circumstances. The modification made the exception into a rule. Although not completely in compliance with Belgian law, this legal basis allowed for a nomination procedure to remain in Belgian hands, instead of being dependent on the occupant. 285

Secretary General Ernst de Bunswyck made some nominations of judges within the first couple of months of the occupation. ${ }^{286}$ One nomination of a judge at the Brussels Tribunal raised protests from the Flemish nationalists of the VNV. Once the Military administration wanted to interfere in the nomination procedure, Enst de Bunswyck apparently halted the procedure. ${ }^{287}$

The Military administration had several reasons it wanted to increase its influence on the nominations. One was to act on its instructions to further the emancipation of the Flemish part of the population ${ }^{288}$ and remedy what it perceived to be the existing disparity between Flemish and Walloon appointments within the Judici-

Article 70 e.a. Loi du 18 juin 1869 réinprimểe en vertu de l'arrêté royal du 22 févrrier 1892, Mon. le 13 mars 1892 . See also Loi du 13 juin 1924.

Arrếté No. 433 du 20 décembre 1940 modifiant l'artêté-loi du 6 novembre 1939, relative au remplacement temporaire des magistrates appelés ou rappels sous les armes, Recueil des arrêtes des Secrétaires Généraux 1940 Tome II, p. 1970.

Arrêté-loi du 6 novembre 1939 relatif au remplacement temporaire des magistrats appelés ou rappelés sous les ames, Receuil des lois et arrêtés royaux 1939, p. 818 .

As was the case for Luxembourg due to the fact that the Chef of the Civil administration had usturped all powers (see Chapters 1.3.3 and 3.5) and The Netherlands, due to the fact that the Netherlands national authorities had accepted a delegation of powers from the Reichskommissar (see Chapters 1.4.3 and 4.5). Delandsheere/Ooms, Tone I, p. 93.

CEGES/SOMA, Papiers Schuind, MIC 51, Mémoire "Au ministère de la Justice pendant l'occupation allemande. L'action de M. Schuind, secrétaire-général.", p. 9

See Chapter 1.2.2. 
ary. ${ }^{289}$ Ernst de Bunswyck's nominations were also criticized, since the political affiliation of the nominees was unacceptable to the Military administration. ${ }^{290}$ After about 9 months of occupation, the Secretaries General still seemed to be reasonably in control of their policies and the Military administration's grip on the Belgian administration was not that strong yet that they could push through large numbers of appointments favorable to the occupant.

The Military administration admitted it had to relinquish exercising the right to appoint civil servants. This did not mean it did not seek to influence appointments and therefore the Military administration devised the policy that only with its consent appointments could be made. ${ }^{291}$ It was ambiguous whether all appointments or only those concerning key positions would require the consent of the occupant"s administration. In the former case it would be problematic for the occupant to acquire all the necessary information on candidates. In April 1941 the Military administration issued a directive ${ }^{292}$ prescribing which nominations for judicial office would require its consent. For courts these included the President of the Cour de cassation and Presidents of the Chambers of the Cour de cassation, Presidents of the Cours diappel and Tribunaux and Presidents of the Chambers of the Cours d'appel and Tribunaux. ${ }^{293}$

On his appointment to office, Secretary General Schuind signaled he would consent to the German directive allowing the Military administration a veto over the nomination of judges. Like Ernst de Bunswyck, his stance was also that he could not make regular appointments, but rather nominations to office. Schuind used the Statute on the powers of public officials during wartime (1935) as a basis and obtained the Military administration"s agreement. ${ }^{294}$

Although Schuind had recognized the Military administration's right to veto a proposed nomination, he was also weary to preserve absolute freedom in nominating judges. Therefore, Schuind notified the Military administration of the nominations only by publication in the Belgian Official Journal. On 11 September 1942 Schuind nominated 14 judicial officers, some to the Brussels Tribunal and some to the prosecutor's office at the Brussels Tribunal. ${ }^{29.5}$

The Military administration claimed its veto power gave it: influence to have several capable Flemish lawyers nominated that were favorable to the occupant. At the end of 1941 in the circuit of the Gent Cour d appel one President of a Tribunal and 6 public prosecutors favorable to German policies were nominated. In Wallonia

289 CEGES/SOMA, Tätigkeitsbericht Nr. 11 der Militarverwaltung für den Monat November 1940, p. 47 and 48.

CEGES/SOMA. Tätigkeitsbericht Nur. 14 der Militärverwaltung für den Monat Februar 1941. p. 51 .

29. CEGES/SOMA, AbschluBbericht der Militärverwallung, 6. Teil Die belgische Justiz und Gesetzgebuing, p. 9.

24: CEGES/SOMA, Abschlubbericht der Militärverwaltung, 6. Teil Die belgische Justiz und Gesetzgebung, p. 10, Anordnung vom 04.04.41. It is interesting to note here that also the appointment of members of the Council for legislative affairs required consent of the occupation administration. tuigingsstukken 333, Note complémentaire; Au Ministère de la Justice pendant l'occupation allemande; l'action de M. Schuind, Secrétaire générall, p. 6. 
the Military administration complained that the dominant collaborationist Rexist movement was unable to supply any capable lawyers. ${ }^{296}$

However, the occupant was apparently not able to influence most of the nominations to the courts. The collaborationist movements heavily criticized the fact that strongly 'anglophile' judges and public prosecutors had been nominated in Flanders. In response the Military administration sought to influence the nominations by ex-

once again to interfere with the nomination of judges. The Ministry of Justice was ordered to inform the Military administration of any imminent nominations of judges at least two weeks in advance. This in order to give the Military administration the opportunity to raise objections, without expressly having to consent to the nominations of judges or public prosecutors not mentioned in the directive. ${ }^{297}$

Schuind's reaction was that this was impossible and halted the procedure. The Millitary administration would have requested advice from the main collaborationist movements VNV and Rex. Their advice would then have dominated the procedure, giving them in effect control over the nominations. After a month the occupant apparently desisted from being notified in advance of any envisaged nomination and retracted its order. On 20 January 1943 Schuind contimued the procedure. ${ }^{208}$

This situation lasted until Secretary General Schuind was replaced in the fall of 1943. The Military administration again ordered that for all judicial nominations the consent of the Military administration was sought. The newly appointed Secretary General of Justice De Foy also resisted any interference in the nomination procedure. ${ }^{299}$ He requested the Military administration to delay this ordler until several other important measures had been enacted. When these measures had been put into force, the Military administration issued a directive on 16 March 1944, ordering the Ministry of Justice to seek the occupant's consent for every judicial nomination. De Foy attempted to circumvent the new directive. He applied the Statute on the powers of public officials during wartime (1935) in such a way that public prosecutors and judges would only temporarily and for a prescribed, limited amount of time adminis-

CEGES/SOMA, Abschlubbericht der Militärverwaltung, 6. Teil Die belgische Justiz und Gesetzgebung, p. 11. The final report mentions 4 Prosecutors of the King (Gent, Brugge, leper and Veurne), one President of at the Brugge Tribunal, one jumior King's Prosecutor (Gent) and one junior Procurator General (Gent). Also the appointment of 7 leading civil servants is mentioned. The final teport mentioned that in other Flemish eircuits similar successes were made, although no specifics were given.

Archives Auditorat Général, Cour militaire, Dossier Schuind, no. 572. B.47, Carton Overtuigingsstukken 333, Note complémentaire; Au Ministère de la Justice pendant l'occupation allemande; l'action de M. Schuind, Secrétaire général, p. 14.

CEGES/SOMA. Papiers Schuind, MIC 51, Mémoire "Au ministère de la Justice pendant l'occupation allemande. L'action de M. Schuind, secrétaire-général.", p. 9; Archives Auditorat Général, Cour militaire, Dossier Schuind, no. 572.B.47, Carton 12, Farde XXII, no. 37, Proces-verbal d'interrogatoire de Gaston Schuind du 3 Octobre 1946, p. 3; Archives Auditorat Gé̉néral, Cour militaire, Dossier Schuind, no. 572.B.47. Carton Overtuigingsstukken 333 , Note complémentaire; Au Ministère de la Justice pendant l'occupation allemande; l'action de CEGES/SOMA, Papiers Schuind, MIC 51, Mémoire "Au ministère de la Justice pendant loccupation allemande. L"action de M. Schuind, secrétaire-général.", p. 9. 
ter vacant offices, thereby avoiding having to make new nominations and to seek the occupant's consent. 300

This affected the courts in that between May 1940 and September 1944272 new judges were nominated, which amounted to almost a third of the total amount of judges, excluding the deputies, in office. ${ }^{301}$ of the total of 1258 judges, including deputy judges, in office in 1940 at least $72 \%$ would still be in office at the end of the occupation. ${ }^{302}$ Moreover, the more senior offices in the court hierarchy" appeared to only become vacant after the occupation. "The recollection of the Belgian courts" decision to strike and the resulting chaos afterwards, including the harsh sentences of the German military tribunals during the end of World War One was one reason to remain in office. ${ }^{304}$ Moreover, there was also a legall obligation under the Statute on

Math CEGES/SOMA, Abschlufbericht der Militärverwaltung, 6. Teil Die belgische Justiz und Gesetzgebung, p. 14.

30 Huyse/Hoflack, p. 131.

302 See ANNEX 4. The first official figures in the immediate postwar era were not released until 1946. In spite of retirement, the effect of purges (see chapter 7.1.3) and other reasons due to which offices might have become vacant due to the occupation circumstances 903 out of the 1258 prewar appointees were still in office.

303 Neither the registres of the Cour de cassation (see Greffe Cour de cassation), the Gent Cou" d'appel (see Griffie Beroepshof Gent) nor the Liège Cou d'appel (see Greffe Cour d"appel de Liège) record any appointments during the occupation period, whereas these were usually faithfully recorded. The archives from the occupation period of the Brussels Cour d'appel are apparently lost (see infra note 507). The Cour de cassation did not request replacement for Vice President Rolin, whom it had removed from office during the occupation due to the fact that he had joined the Government into exile and contrary to Belgian law had therefore not been able to exercise his duties for several months (see Greffe Cour de cassation, Registre des Assemblées générales du 28 décembre 1940-8 juillet 1942, Assemblée générale et publique du Samédi 28 décembre 1940). This request was not made until after the occupation (see Greffe Cour de cassation, Registre des Assemblées générales du 15-9-1944-24-6-1949, Audience publique et solennelle du mardi 23 Janwier 1945, p. 43). In the circuit of Liege, the Liëge Cou d'appel after the occupation on 22 November 1944 drew up lists of recommendations for the vacancies of the presidency of the Tribumawx of Liege, Huy, Namur, Dinant, Arm lon, Marche and Neufchateau, as well as the vice presidency of the Liege Tribunal (see Creffe Cour d"appel de Liège, Registre des Assemblees générales du 10-11-1936 au 13-2-1958, p. 65). Also immediately after the occupation on 17 October 1944 an election for the presidency was held at the Liège Cour d'appel (see Greffe Cour d'appel de Liège, Registre des Assemblèes générales du 10-11-1936 au 13-2-1958, p. 61). The following December lists of rec. ommendations were made for vacancies at the Cour d'appel itself (see Greffe Cour d'appel de Liège, Registre des Assemblées genérales du 10-11-1936 au 13.2.1958, p. 67b) In the circuit of Gent, the Gent Cour d'appel did not elect a President until 30 September 1944 (see Griffie Beroepshof Gent, Register Algemeene Vergaderingen 9 oktober 1941 - 27 juni 1967. Algemeene, plechtige en openbare wergadering van het Hof wan Beroep te Gent van Zaterdag dertigsten September 1900 vier en veertig). On 8 December 1944 Lists of recommendations were made for the positions of Presidents of the Brugge and Dendermonde Tribunaux and the positions of Vice Presidents of the Dendermonde en Gent Tribumaux (see Griffie Berwepshof Gemt, Register Algemeene Vergaderingen 9 oktober 1941 - 27 juni 1967, Plechtige, algemeene en openbare vergadering van het Hof van Beroep te Gent van Vrujdag achsten December October 1900 vier en veertig). List of recommendations for positions at the Gent Cour d appel would not be made until 1945. Again, for the Brussels Cour d'appel and its circuit these records do not seem to be available. 
Duties of Civil Servants during Wartime $(1935)^{305}$ to remain in office. ${ }^{306}$ Those civil servants, including judges, not drafted into the arny were obliged to remain at their posts. The retirement of the President of the Brussels Cour d'appel, Comte de Lichtervelde, and the Presidents of the Cour d'appel's chambers during the occupation was seen as contrary to the provisions of the Booklet on civil mobilization of the Belgian Government and the practice of the preceding war ${ }^{307}$ However, this legal provision obliged those members of the Belgian courts not drafted into the army to close ranks in order not to allow for the opportunity to have collaborators appointed to judicial office. ${ }^{308}$ Furthermore, the collabotationist movements' strong objections to the nominations, the rather limited number of judges purged after the occupation, ${ }^{30 \%}$ as well as the high number of prewar appointees still in office at the end of the war indicate that the occupant's measures and policies to influence the courts" personnel policies failed.

\subsection{REGULATION CONCERNING STATUTORY AGE LIMIT AND REMOVALS FROM OFFICHE}

Nevertheless intending to get a firmer grip on personnel policy, in March 1941 the occupation administration enacted a regulation concerning early retirement of civil servants. ${ }^{310}$ The Cour de cassation was sent a copy a few days after its enactment. ${ }^{311}$ The regulation, which aimed at the rejuvenation of the civil servant apparatus, provided that civill servants would retire at the end of the month during which they turned $60 .^{312}$ Members of the courts were explicitly excluded from this regulation, but it was indicated that a special measure for members of courts would follow. The Cour de cassation decided that since this regulation did not affect the courts, an intervention with von Falkenhausen was not yet necessary. ${ }^{313}$

The consequence of such a regulation would be disastrous for the Belgian courts. Belgian judges were appointed for life, ${ }^{314}$ limited to 70 years of age for Tribu-

yng

3016

36?

.94

lins

I 10

by

Loi du 5 mars 1935 concernant les devoirs des fonctionnaires en temps de guerre, Mon. da 15 mars 1935.

See Chapters 1.2 .1 and 2.2 as regards the Statute on the duties of public officials during wartime (1935). See also Verhoeyen, p. 57, Smolders, Législation, Tome II, p. 563-564.

Pholien, Chronique, p. 45. See also Chapter 1.2.1.

Janssens, p. 9.

See Chapter $7,1,3$

Verordnung gegen die Überalterung der offentlichen Verwaltung in Belgien vom 7 . März 1941, VoBI.. S. 529.

Greffe Cour de cassation, Registre des Assemblées générales du 28 décembre 1940 - 8 juillet 1942, Assemblée générale en Chambre du Conseil du 12 mars 1941.

This regulation affected the King's Prosecutors in Nivelle, Liège, Louvain, Mons, Charleroi, Malines, Marche, Verviers. Gent, Hasselt, Bruges and Vewme. However, generally no new public prosecutors were appointed, but the Procurators General would designate the substitute King"s Prosecutors to exercise the office of their retired superior, preventing the appoimtment of collaborators (see Verhoeyen, p. 58). This was of course in line with the Statute on Delegation (1940) (see Chapter 1.2.1).

Grefle Cour de cassation, Registre des Assemblées générales du 28 décembre 1940 - 8 juillet 1942. Assemblée générale en Chambre du Conseil du 15 mars 1941. Article 100 Belgian Constitution. See also Article 4 Loi du 18 juin 1869 réimprimée en vertu
de l'arrêté royal du 22 février 1892 , Mon. le 13 mars 1892 . 
nal judges, 72 for Cour d'appel justices and 75 for justices at the Cour de cassation. ${ }^{35}$ Early retirement meant that almost the entire Cour de cassation, a major part of the Cours d'appel and the majority of Presidents and judges at the Thibwar would have to be replaced. ${ }^{316}$

Problematic for the Military administration was that due to the shortage of lawyers, most of the public prosecutors over 60 years of age had to be allowed to remain in office. Although the Military administration lamented the atritude of the whole Judiciary, a lack of progeny prevented it from extencling the early retirement measure to the courts. ${ }^{317}$ Furthermore, Secretary General Schuind when appointed apparently insisted this measure would not be enforced against the courts. ${ }^{318}$

Another personnel policy objective of the Mititary administration as regards the Belgian courts was to assure that judges opposed to the occupant's policies were removed from office. For this the Military administration knew it could not rely on the cooperation of the Belgian Ministry of Justice, not only because the Ministry would not issue the dismissal, ${ }^{319}$ but also because it was bound by extensive procedural requirements. The Military administration therefore took the decision concerning removal from office, but wonld have the Belgian administration execute it. The decision was issued in the form of a prohibition for the justice in question to exercise his official duties. ${ }^{320}$ In this manner, amongst others, Justice of the Peace Libiez at Pâturages, President Gottigny of the Oudenaarde Tribunal and Justice Thienpont of the Gent Cour d' appel were removed from office. ${ }^{321}$

Moreover, a display of anti-German behavion did not only lead to a prohibition for a judge to exercise his office, but sometimes also to arrest and trial by a German war tribunal. In January 1941 the Military administration took measures against two judges for 'anti-German behavior'. The German war tribunals sentenced one judge to 3 months imprisonment, the other to 4 weeks. ${ }^{322}$ Also in February two judicial officers were convicted for anti-German expressions. ${ }^{323}$ During the course of the occupation Judge Ulrix of the Tongeren Tribunal, Judge Goigniaux of the Arlon Tribunal

315 Article 1, Loi du 25 juillet 1867, relative à la mise à la retraite des magistrats, Mon. du 27 juillet 1867 .

316 Archives Auditorat Général, Cour militaire, Dossier Schuind, no. 572.B.47, Carton Overtuigingsstukken 333, Note complémentaire; Au Ministère de la Justice pendant l'occupation allemande; laction de M. Schuind, Secrétaire général, p. 50. CEGES/SOMA, Tatigkeitsbericht Nr. 17 der Militärerwaltung für die Zeil vom 1 . Iuni -1 . September 1941, p. 38; Verhoeyen, p. 41 also mentioned that the Belgian courts were too powerful due to which the occupant did not extend the early retirement regulation to jidiges. CEGES/SOMA, Papiers Schuind, MIC 51, Mémoire "Au ministere de la Justice pendant I'occupation allemande. L'action de M. Schuind, secrétare-général." "p. 4; Archives A ulditorat Gêneral, Cour militaire, Dossier Schuind, no. 572.B.47, Carton Overtuigingsstukken 333, Note complémentaire; Au Ministère de lát Justice pendant l'occupation allemande: l'action de M. Schuind, Secrétaire général, p. 51-52.

See also Archives Auditorat Général, Cour nilitaire, Dossier Schuind, no. 572.B.47, Carton 4, Farde $X$. no. 14, Procès-Verbal d'interrogatoire de Gaston Schuind le 8 mai 1945.

CEGES/SOMA, AbschluBbericht der Miliärverwaltung, 6. Teil Die belgische Justiz und Gesetzgebung, p. 15.

Louveaux, p. 642 .

CEGESSOMA, Tätigkeitsbericht Nr. 14 der Militärverwaltung für den Monat Febnuar 1941, p. 51

323 CEGESISOMA, Tätigkeitsbericht Nr. 15 der Militärverwaltung für den Monat März 1941, p. $\mathbb{B} 29$. 
and Judges Van der Meersch and Merschie of the Oudenaarde Tribunal were removed from office and convicted by German war tribunalls for "anti-German expressions'. Even more judges were arrested and later released. ${ }^{324}$ Vice President Devos of the Brussels Cour d'appel was removed from office ${ }^{325}$ for a display of patriotism at the Universite Libre de Bruxelles, due to which he was convicted and sentenced to pay a stiff fine. He apparently escaped prison due to his high age ${ }^{326}$ Secretary General Schuind was able to assure judges the Military administration had removed from office would receive an allowance. ${ }^{327}$

According to the Military administration, the Belgian Judiciary quietly accepted these practices, as long as the judges in custody were handed over to and tried by the German war tribunals. If judges were taken into custody, but not tried in front of a German war tribunal, the Belgian Judiciary apparently did put up some kind of resistance. $^{32 \%}$

If judges in these cases had indeed violated regulations of the German administration, there was not much the Belgian courts could do. In their capacity as judges, being civil servants of the occupied State, international law allowed for the occupant to depose them. ${ }^{320}$ Furthermore, if these officials failed in the exercise of their duties, international law allowed the occupant to subject them to summary punishment and in case of treason to be handed over to a court. ${ }^{330}$ Besides, as the inhabitants of an occupied country, judges had to abstain from any hostile act or the encouragement of one against the occupant. ${ }^{331}$

On the other hand, in cases where judges were suspended or arrested for an act of office and the Cour de cassation was not convinced judges had acted outside the scope of their official duties, it would intervene with the Military administration. It would even threaten to suspend its duties if the judge in question was not released and re-instated in office. Nevertheless, also if acting outside the scope of their competencies, the Court might intervene. Chapter 2.7 will elaborate on some examples.

The Military administration claimed not to have been influenced by any act of resistance by the Belgian. Judiciary. In deciding on whether to take prominent judges into custody only in very urgent cases an arrest would be made, "in onder to avoid any unnecessary conflicts". The arrests were often made when hostages were needed and the Military administration gave this as a reason for the arrests, which it claimed prevented the courts from questioning the measure. If there were any problems regarding arrests of judges, the Military administration put the blame with other German agencies operating in Belgium, which apparently acted independently of the

Lonverux, p. 642.

Louvediux, p. 642

Pholien, p. 45.

See Archives Auditorat Général, Cour millitaire, Dossier Schuind, no. 572. B.47, Carton 4, Farde $X$, no. 14, Process-Verball d'interrogatoire de Gaston Schuind le 8 mai 1945 .

CEGES/SOMA, Abschlußbericht der Militärwerwaltung, 6. Teil Die belgische Justiz und Gesetzgebung, p. 20

Bordwell, p. 306; Spaight, p. 358; Verraes, Tone 1, p. 172; Oppenhein, War, p. 214. For a contrary opinion see Rolin, Tome I, p. 453.

Beer Poortugal, p. 176; Rolin, Tome J, p. 441.

Rolin, Tome I, p. 429 
Military administration and did not report to or notify the Military administration of the intended arrests. ${ }^{332}$

From the beginning of the occupation the Cour de cassation protested frequently and persistently against the occupant's policy of hostage taking, as will be elaborated on in Chapter 2.14. Also, the Cour de cassation held the Military administration accountable for actions of other German agencies. This is illustrated by the case of SS interference in proceedings at the Arlon Tribumal in Chapter 2.13.

\subsection{THE COUR DE CASSATION AND SUSPENSION OR ARREST OF JUDGES FOR EX OFFICTO ACTS}

In cases where judges had acted within their official capacity and in compliance with Belgian law, the Belgian Supreme Court protested against attempts of the Military administration to suspend or arrest a member of the courts and resisted their removal from office.

An incident at the Gent Tribunal prompted the Cour de Cassation to intervene with von Falkenhausen. The Gent Cour d'appel's President and Procurator General informed the President of the Cour de Cassation that via executive order the German regional military commander had provisionally prohibited the Vice President of the Gent Tribunal to exercise his duties. The regional commander contended that the Vice President had long been criticizing a decree dealing with the supply of food and for weeks had been pretending to have found a way of not applying measures dealing with illegal slaughter. In a judgment the Vice President had now declared that the decree of the Secretaries General was invalid as regards its penal provisions. This had provoked the German commander, who subsequently suspended the Vice President and requested von Falkenhausen to permanently remove him from office. ${ }^{33}$

During the plenary meeting of the Cour de cassation the Vice President's judgment was read out aloud. The Vice President had declared the measure illegal, since it modified provisions of the legislative decree of 27 October 1939 , the Penal Code and the Statute concerning remand in custody. The courts, so the Vice President, were therefore not obliged to apply this measure. However, as also the Cour de Cassation noted, the Vice President did apply the penal provisions contained in the legislative decree of 27 October 1939 to the case.

The Cour de Cassation considered the military commander's onder an attack on the independence and dignity of the courts, which was motivated by other, unmentioned reasons than those provided in the commander's order. The Court envisaged suspending its duties from Monday onwards and decided to intervene with von Falkenhausen via the Secretary General of Justice. The Gent Cour d'appel"s President and Procurator General were given complementary advice, awaiting the results of the intervention with von Falkenhausen.

During the following plenary session on Saturday 27 September 1941, the Court noted that it still persisted in its intention to suspend its duties from Monday on-

32 CEGES/SOMA. Abschlußbericht der Militärverwaltung. 6. Teil Die belgische Justiz und Gesetzgebung, p. 20.21.

333 Greffe Cour de cassation, Registre des Assemblées générales du 28 décembre 1940 - 8 juille 1942, Assemblée génẻrale en Chambre du Conseil du 26 septembre 1941. 
wards. Justice Louveaux and Advocate General Comil were to urgently contact the Secretary General of Justice and the Court would reconvene on Monday moming.

The Secretary General mediated between the Count and the Military administration. As a goodwill gesture the Court and the Procurator General considered to halt the decision to suspend their duties on Monday for the time being, so as not to impair the ongoing negotiations. However, the Court underlined that in a similar case the Court would not consent to how the current situation had developed, considering that the judge should have been effectively reinstated in the exercise of his public duties immediately afterwards, either in a criminal or a civil chamber.

Von Falkenhausen, probably understanding the severity with which the Cour de cassation viewed the situation, now insisted on direct negotiations with the Court. ${ }^{3.4}$ During a meeting with representatives of the Court von Falkenhausen pointed out that the Vice President's prior judgments had not questioned the validity of the measures of the Secretaries General. The Court was also urged to see this as an isolated incident, whereby from that time on the courts would be left their independence. From the Court's perspective, however, the Vice President in declaring judgment the way he had, had acted with the independence inherent to his public duties, on a controversy of a purely legal nature. The Court would not give in and the Military administration took a formal decision to allow the Vice President to take up office again. 335

Another act of the Military administration involving an examining magistrate of the Tribunal in Oudenaarde also prompted the Cour de cassation to hand a written protest to von Falkenhausen. Judge Stevigny had given Belgian police the order to discontinue the arrest of three youngsters who had been detained a few hours earlier. German police had arrested three Belgian civilians and needing to continue on their rounds handed them over to the Belgian police of Denderleeuw, instructing them to place the three in custody. ${ }^{3.37}$ In arriving at the police station for a different matter Judge Stevigny was also informed of the charges brought against the three arrested Belgians. After having tried in vain to contact the King's Prosecutor at the Oudenaarde Tribunal Stevigny, on his own authority as examining magistrate, decided to release the three arrested Belgians. The Military administration saw this as illegal interference in its affairs and had the examining magistrate arrested. Proceedings were started before the German war tribunal for illegal release of prisoners.

The Cow de cassation intervened, arguing that Stévigny had been arrested for an act of office, which had been in conformity with the law. ${ }^{358}$ The three young Belgians had been arrested for violation of the Military administration's regulations on forced labor. The Court argued that Belgian authorities were not obliged to cooperate in the implementation of German measures concerning labor deployment, something

H.

Greffe Cour de cassation, Registre des Assemblées générales du 28 décembre 1940 - 8 juillet 1942. Séance du lundi 6 octobre 1941 à 9 heures du matin.

Greffe Cour de cassation, Registre des Assemblées générales du 28 décembre $1940-8$ julllet 1942, Séance du lundi 13 octobre 1941 à 9 heures du matin.

CEGESISOMA. Archives Hayoit de Termicourt, MIC 48, no. 51, Lettre de M. le premier président de la Cour de cassation Jamar er $M$. I'avocat général Hayoit de Termicourt ff pour le procureur général à M. le général von Falkenlaausen du 30 juin 1944.

See also Doorslaer, p. 113 .

Greffe Cour de cassation, Registre des Assemblées générales du 13 septembre 1942 - 11 juillet 1944, Assemblée générale en Chambre du 30 juin 1944. 
the German authorities had expressly permitted. In any case, Judge Stevigny could have been of the opinion that he was lawfully exercising his duties, within the scope of his competencies. Even if his opinion were wrong, his trial before a German war tribunal would be for an ex officio act, which would be difficult to accept for the Belgian courts. President Jamar and Procurator General Hayoit de Termicourt pointed out that formal instructions of the Belgian authorities prohibited Belgian organs to participate in the detention of Belgians in these cases. The Military administration had admitted these instructions were not only based on Belgian law, but also the imperative duty of conscience. Judge Stévigny had acted in accordance with Belgian law and since there was no violation of Belgian law at hand and the Military administration had not suspended the application of the Belgian provisions at issue, Stevigny had acted according to his legal obligations. The Court also argued that if a mistake had been made the German police had made it, since they should never have given their suspect into the custody of the Belgian police. Also in this case, the Cour de cassation reminded the Military administration that punishing Stévigny for exercising his official duties would render impossible the functioning of the Belgian Judiciary. ${ }^{339}$

The Military administration could not agree with the Cout's reasoning and was of the opinion that the examining magistrate had acted outside the scope of his competencies. According to the Military administration, when it persisted, the Procurator General at the Cour de cassation acknowledged the weakness of the Belgian position, now informally disapproving of the judge's behavior. He instructed the prosecution service to refrain from interfering in similar cases and requested the Military administration to stay proceedings against the magistrate. This request, so the Military administration, was considered, since the Procurator General's instructions to the prosecution service would be far more effective than any proceedings brought before a German war tribunal could ever be. ${ }^{340}$

Problematic in the Cour de cassation's reasoning had been that article $155 \mathrm{Bel}-$ gian Penal Code and article 616 Belgian Code of Criminal Procedure instructed an examining magistrate to free or bring before a court, within his district, a suspect detained by Belgians for violation of Belgian laws. In this case, the suspects had been detained by German and not Belgian police, for a violation of a regulation of the Military administration and not Belgian legislation. Judge Stévigny had been aware of both of these aspects and nevertheless released the Belgian youths. This also meant that the Cour de cassation could not claim Stevigny made an error of judgment, something inherent to the exercise of office and therefore his action could not still be seen as an act of office. Being fully aware of the facts and the applicable law in the situation, Stévigny had knowingly acted outside the competencies of his office and thus exposed himself to disciplinary charges from the Military administration. Therefore, the Court and the Procurator General's only way out of the situation was to offer that the guidelines for arrest in these cases were amended, possibly aiding Stévigny"s release. 24-6-1949, Audience publique et solennelle du 23 janvier 1945, p. 43.

340 CEGES/SOMA, Abschlufbericht der Militärverwaltung. 6. Teil Die belgische Justiz und Gesetzgebung, p. 24-25.
} 
The President of the Cour de cassation accompanied the Procurator General to Gent where the German war tribunal was located to negotiate with the presiding German judge in the case, who alone could decide on whether or not proceedings were stayed. The presiding German judge contacted the Military administration and agreed to stay proceedings as soon as the Military administration was satisfied with the drafted text amending the instructions the Procurator General would send to the prosecution service. The Military administration's approval of the instructions led to the staying of proceedings and the release of the Belgian judge on 11 Jully. ${ }^{341}$

The Cour de cassation presumably made an error of judgment, since it seems unlikely it would have used the threat to suspend its duties if it had known from the beginning that it had no legal defense. Invoking this threat too often and especially without good legal reasons would harm the credibility of the Court and the use of this threat. What is relevant about this example is that the Court, even after its Procurator General informally conceded the weakness of its position, proceeded with and succeeded in its attempt to get Stévigny released. However, this case also shows that in their mutual relations law played an important part and the Court would try to use the law as a means to persuade the Military administration to reverse a policy decision. The case involving the Vice President of the Gent Tribunal shows that in adhering to the law, the Court was in fact able to get a measure of the Military administration reversed. The case concerning Judge Stévigny moreover shows that even where the law could not be used to induce the occupant to change his mind, the Court, together with the Prosecutor General, resorted to other means and thus was able to have the occupant reverse one of his measures.

The question is whether the Prosecutor General's adaptation of the instructions to his subordinates clarifying the rules of arrest tarnished the success of obtaining Stévigny's release. Considering the fact that the Belgian Judiciary consistently refused jurisdiction regarding arrest, prosecution or trial over violations of regulations of the Military administration, as will be elaborated on in Chapter 2.8, and the Prosecutor General"s adlaptation of instructions merely clarified this, Stévigny's release did not come at a high price.

\subsection{COURTS AND THE FIRST APPLICATIONS OF OCCUPATION MEASURES}

The system of administration set up during the occupation in Belgium resulted in two different types of occupation measures. The occupant would enact measures by virtue of the fact of the occupation of the country and limited by the provisions of the Hague Convention, especially its article $43 .^{342}$ The Belgian Secretaries General would enact measures on the basis of the powers derived from the Statute on Delegation (1940).

CEGES/SOMA, Abschlußbericht der Militärverwaltung, 6. Teil Die belgische Justiz und Gesetzgebung, p. 24-25. For the release see also Rijksarchief te Beveren, Rechtbank van Eerste Aanleg te Oudenaarde 1918-1972 A 2000, no. 6 Onderrichtingen in verband met de oorlog 1939-1944, Brief 14 Juli 1944 van de Voorzitter van en de Procureur des Konings bij de Rechtbank wan Eerste Aanleg te Oudenaarde aan de Secretaris Generaal van het Ministerie van Justitie, 115 Burg. $/ 44$. 
The Belgian courts more or less openly refused to apply the regulations enacted by the Military administration. ${ }^{34}$ This notwithstanding that the Military administration was in principle of the opinion that the Belgian courts should apply its regulations. ${ }^{344}$ Since the Belgian courts could not completely ignore the occupant's regulations, they adopted a practical solution. Where a German regulation existed, Belgian courts applied Belgian law, which seemed to work and as far as the Military administration was concerned and did not cause any problems. ${ }^{3.5}$

However, in cases where no equivalent for a Gernnan measure existed in Belgian law, the courts could not ignore the measure. Suffice it to say here that the courts never regarded the German measure as Belgian law or similar to Belgian law and therefore refused to apply it in pending cases. However, the courts gave some kind of factual effect to the German measures, as will be elaborated on in Chapter 2.11. ${ }^{346}$ This solution satisfied the Military administration. ${ }^{34}$ ?

The fact that the occupant tolerated this practice of the Belgian courts did not mean it did not seek to change it. In trying to counter this tendency the Military administration tried to exclude the Belgian Judiciary from 'guarding important warrelated public tasks', to the advantage of its own administration. As illustrated earlier, ${ }^{348}$ the occupant had persuaded the Secretaries General create a separate administrative procedure and it engaged the local military administrations and German war tribunals in several legal areas formerly belonging to the jurisdiction of the Belgian Judiciary. ${ }^{3.9}$

Nevertheless, the Belgian courts refused to apply the occupant's measures, as they did after the occupation had ended, maintaining that Belgian courts could not participate in the application of war measures. ${ }^{350}$ Since Belgian courts were only allowed to apply Belgian law, ${ }^{351}$ the occupant's measure fell foul of both requirements.

34.3

CEGES/SOMA, Tätigkeitsbericht Nr. 20 der Militärvenwaltung für die Zeut wom $15 \mathrm{März}-1$. Juni 1942, p. Al0-A11.

CEGES/SOMA, AbschlußBericht der Militärverwaltung, 6. Teil Die belgische Justiz und Gesetzgebung, p. $58-59$.

CEGES/SOMA, Tätigkeitsbericht Nr. 20 der Militärverwaltung für die Zeit wom $15 \mathrm{Mär} z-1$. Juni 1942, p. A 10 -All. See also Outrive e.a., p. 137-140 for the refusal of the Belgian atministration to apply the occupant's regulations if they only served the occupant's inilitary and political interests.

See Cass. 1 févner 1943; Pas. 1943, 1, 44 (Commune de Borgerhout ett Ville d'Anvets e. Consorts Bousson).

CEGES/SOMA, Abschlußbericht der Militärverwaltung. 6. Teil Die belgische Justiz wnd Gesetzgebung. p. 84 .

See Chapter 2.4 .

CEGES/SOMA, Tätigkeitsbericht Nr. 20 der Militärverwaltung für die Zeit vom $15 \mathrm{Mär}-1$.

Juni 1942, p. A 10-A11. See also Chapter 2.15 for the reaction of the Belgian conirs to the limitation of their competencies.

Cass. (1 re Ch.) arrêt du 30 novembre 1944, in: JdT 1946-1947, p. 124-125.

Already during WW 1 the Cour de cassation had held that it could not rule on the basis of a measure that did not emanate from an organ established under Belgian law (see Cass. 21 janwer 1918; Pas. 1918,1, 177). No specific provision could be found prohibiting Belgian courts from applying foreign law. However, article 138 Loi du 15 avril 1878 apportant des modifications aux lois relatives à l'organisation des Cours d'assises et au Code d'instruction criminelle, Mon. du 17 avril 1878, instructs judges to proceed as prescribed by law. Laws are the expression of the will of the nation, from which all powers are derived according to Article 25 Belgian Constitution and which are exercised collectively by the King and both Houses of the 
Firsty, his measures were factual and not legal and secondly they were not Belgian measures.

The decrees the Secretaries General enacted were seen as Belgian laws, since the legislator, by virtue of the Statute on Delegation (1940) had enacted certain law making powers to the Secretaries General. ${ }^{352}$ Nevertheless, before the Cour $d$ 'appel and subsequently before the Cour de cassation the validity of a decree enacted by the Secretary General of Agriculture fixing a maximum price for the sale of milk was challenged. The legality of the measure was questioned within the Belgian legal community and the Council of the Bar Association even expressly declared it would challenge the validity of the decree in court. ${ }^{35}$

On 4 January 1941 the Brussels Cour $d^{\prime}$ appel ${ }^{354}$ considered the Secretary Generall competent to enact the decree. On 16 May 1940, Delhaye had been delegated the powers to fulfil the function of Secretary General at the Ministry of Nourishment, allowing him on the basis of article 5 of the Statute on Delegation (1940) to enact the decree at issue. After a textual comparison with articles 1 through 4 and 6 and 7 of the statute, the Cour d'appel ruled that with article 5 the legislator had intended for public officials to exercise powers other than those of administrative supervision. For the Secretaries General these were notably those within the competence of the Ministers as members of the executive.

The delegation was subject to several conditions. Firstly, there had to be a necessary condition of urgency. This condition was not further elaborated. The second condition was that the public official had to be acting within the framework of his professional capacity, meaning that his competence was limited to the competence of the superior he could replace. Furthermore, he could not impinge on the sphere of professional capacity of other magistrates or public officials. Therefore, a Secretary General's professional capacity consisted of all the actions within the sphere of his Department, notably enacting decrees and executing legislation, for which he could fulfill all the functions of the Minister. The Brussels appeals court then proceeded to review the decree for compliance with the legislation it was based on. In reviewing the decree with the statute on which it was based, the Cour d'appel came to the conclusion that in this case the wording of the statute precluded the courts from reviewing a fixed price for milk.

The Cour de cassation rendered its judgment in this case on 7 April $1941^{3.55}$ It remarked that article 5 Statute on Delegation (1940) attributed to the Secretaries General, in absence of their superiors, those superiors" competencies necessary to assure the continuation of public life as embodied by the Belgian constitution and the entirety of Belgian legislation. Furthermore, article 43 Hague Convention allowed an occupant to take all measures necessary to maintain public order and public life while

Belgian Parliament (article 26 Belgian Constitution). Therefore, courts could only apply acts cmanating from Belgian anthorities.

See Chapter 1 2.2.3

CEGESSOMA, Documents Zéro, ref. AA 1078, no. 1034/38, Conseil de l'Ordre, Résolution du 14 mars 1941 relative à la procédure administrative en matiere de répression des infractions concernant le Ravitailtement.

Cour d'appel Bruxelles (9e ch.), arrêt du 4 janvier 1941, published in: Smolders, Jurisprudence, p. $16-19$.

Cass. (2e ch.), arrêt du 7 avril 1941, published in: Smolders, Jurisprudence, p. $11-14$ (Anthoine et consorts). 
respecting, as much as possible, except in case of absolute impossibility, the laws in force in that country. From this the Coum de cassation deduced that in case of an oocupation the continuation of public life had to be, in every way possible, exerted by the national authorities, acting in that capacity. The Statute on Delegation (1940) was therefore in accordance with the spirit of the Hague Convention.

The Belgian Supreme Court then turned to the text of article 5 and especially the expression "all the attributes of this authority". "In the case of the Secretaries General this meant that within the scope of their professional activities and in case of urgency, in order to administer the country, they were allowed to take the same measures that their Ministers could have legally taken. The Secretaries General were involved in the preparation, decision and execution of measures where the Minister in normal times, as head of the Department could intervene, as confirmed by the text of Royal Decree of 15 May 1940 of the appointment of a Secretary General. The Cour de cassation, under certain conditions, confinmed the powers of the Secretaries General to enact decrees under article 5 Statute of Delegation (1940). However, in affirming the decree was in compliance with the legislation it was based, the Court also asserted its powers under Article 107 Belgian Constitution to review decrees the Secretaries General enacted.

Both the Cour de cassation and the Cour d'appel, accepted article 5 Statute on Delegation (1940) as a legal basis for the decrees of the Secretaries General, subject to limitations of the decrees being within the scope of their professional activities and enacted in case of urgency. These two conditions gave the courts leeway to review decrees. Furthermore, both courts, although upholding the decree, clearly reviewed its compliance with the legislation it was based on, using their powers under article 107 Belgian Constitution and indicating not to hesitate to use their powers of review.

Nevertheless, avoiding a direct conflict with the Military administration, the courts had not explicitly stated that measures of the Secretaries General did not have force of law and would therefore be beyond the powers of scrutiny of the courts. Even thongh the use of their powers implicitly showed the courts did not view these decrees as having force of law, they were upheld and the Military administration might have also wanted to avoid a conflict until the courts' actions would jeopardize its administration of Belgium.

The Cour de cassation never recognized that decrees based on the Statute on Delegation (1940) possessed force of law. ${ }^{357}$ Its case-law throughout the occupation stated that the nature of the powers conferred on the Secretaries General was such that it authorized them to enact administrative measures that their Minister could have legally enacted if he had remained in office. ${ }^{358}$ The powers of the Secretaries General did not extend beyond the powers given to their Minister, which meant they could only enact measures within the competence of their Department. ${ }^{350}$ As a result, even if the Statute on Delegation (1940) did not confer on them legislative powers. the Secretaries General were nevertheless in a position to enact measures of an administrative nature. The term 'administratives should be interpreted broadly, includ-

\footnotetext{
35 "toutes lles attributions de cette autorite".

35 See also Ockrent, p. 61 ff.

3 Cass. 7 avril 1941; Pas. 1941,1, 136; Cass. 20 octobre $1941 ;$ Pas. $1941,1,382$

C3ass. 30 mars 1942; Pas., 1942, 1,$75 ;$ Cass 28 juillet 1943 (deux arrêts); Pas, $1943,1,303$ et 305.
} 
ing those measures that in normal times would belong to the exclusive province of the legislator. The purpose of Article 5 Statute on Delegation (1940) was to assure the continuation of the executive and legislative powers for the administration of the country. ${ }^{360}$

Article 5 Statute on Delegation (1940) sought to assure the normal functioning, by Belgians, of public life according to Belgium's national institutions in accordance with article 43 Hague Convention. However, the functioning of these institutions should be in accordance with the Constitution and the entirety of Belgian legislation $^{361}$ and excluded every measure of a political nature and every other measure that would run counter to either the Constitution or the basic principles of national legislation. ${ }^{362}$ Therefore, the powers of the Secretaries General to enact measures that in normal times belonged to the province of the legislator, did not include the power to enact measures of a different nature, especially a political nature, or those that tended to transform Belgium's political institutions.

If the Secretaries were not exercising powers that in normal times belonged to the province of the legislator, their decrees were subject to judicial review by the courts. Being public administrative officials, their decrees, even if dealing with matters belonging in normal times to the legislator, were subject to article 107 Belgian Constitution. Article 7 Statute on Delegation (1940) confirmed this in that measures taken on the basis of that statute could be annulled by Royal Decree after the occupation had ended.

Finally, the Statute on Delegation (1940) expressly limited the Secretaries General' exercise of powers to cases of necessary urgency. The appreciation of fulfillment of this condition was left to the discretion of the enactor of the measure, except for cases of abuse of powers, which was for the courts to determine. ${ }^{363}$ Beyond the scope of the exception the courts were also not allowed to review the necessity and urgency of a decree if affirmed by the decree or not denied in its text. ${ }^{364}$

Once the occupation progressed towards the end of 1941 , several courts started to deviate from the judgments of the Cour de cassation and the Brussels Cour d'appel mentioned above. ${ }^{365}$ On 6 November 1941 the Charleroi Tribunal ${ }^{366}$ ruled that ewen where the decrees of the Secretaries General were contrary to existing legislation, including Acts of Parliament, courts were obliged to apply them. The Gent Cour d'appel's judgment on 31 October $1941^{367}$ contended that the state of necessity conferred upon the Secretaries General the right to exercise the State's legislative powers. Even the Brussels Cour d'appel seemed to be wavering now. In a judgment

3.til

Conclusions de M. l"avocat général Hayoit de Termicourt précédant l'arrét du 3 novembre 1941. Pas., 1941, 1, 407; Revue Administration, 1942, p. 113; Cass. I février 1943; Pas. 1943. 1, 44; Cass., 25 août 1943; Pas, $1943,1,337$.

Cass. 7 avril 1941: Pas., 1941, 1, 136; Cass., 20 actobre 1941: Pas. 1941, 1, 382.

Cass. 30 mars 1942; Pas. 1942, I, 75; Cass. 28 juillet 1943 (deux arrêts); Pas, 1943, I, 303 et 305

Cass. 10 février 1943; Pas, 1943, 1, 61

Cass. 10 février 1943; Pass, $1943,1,61$

See also CEGES/SOMA, ref. BA L 1/3, Gotovitch, José, Note relative à la Magistrature sous I"Occupation de septembre 1972 (not published).

366

367

Beroepshof Gent (3e Kamer), arrest van 31 oktober 1941, cited in: CEGES/SOMA, Papiers Vossen 1921-1952, MIC 74. Mathieu, G., Ende sur la Délégation des Powvoirs en Temps de
Gurere, p. 66. 
of 15 December $1941^{368}$ it stated that "within the framework of their professional activities', the competencies of the Secrotaries General were of the same nature as the occupant's competencies of fact provided for by article 43 Hague Convention. This meant that with some limitation or other, the tendency seemed to be that courts, at least in some areas, would treat measures of the Secretaries General as if having force of law and would refrain from reviewing them.

\subsection{FIRST JUDICIAL CRISIS; MEASURES CONCERNING ECONOMIC CRIMES AND JUDICIAL REVIEW}

The question aver the powers of the Secretaries General and the courts powers of review came to a head in the middle of 1942 over the issue of the country's food supply and the decrees the Secretaries General had enacted to organize food distribution. The Secretaries General had enacted several measures, including one on 12 Fabruary 1941 concerning the establishment of an agricultural council. (CNAA) and an administrative criminal procedure to counter violations of its measures regulating food supply. ${ }^{363}$

In the beginning of 1942, before the Justice of the Peace in Louveigne, near Liège, Paul Tschoffen, former Belgian Minister, on behalf of 121 fammers, argued that in case of an occupation article 43 Hague Convention provided that sovereignty would resort to the occupant. The occupant would assume the powers to enact measures, including generally binding measures in the form of regulations, in order to maintain public order, taking account of the national legislation in force. However, article 43 did not provide for a dual legislative power, which could not exist, since this would contradict the indivisibility of the sovereignty of the state and therefore the measures of the Secretaries General could not be of the same nature as acts of parliament. Tschoffen challenged the constitutionality of the decree establishing an administrative criminal proceeding, probably intending to go before the Cow de cassation in order to get an explicit ruling on the status of the decrees of the Secretaries General.

The Louveigne Justice of the Peace, Hanson, in his judgment on 20 February of $1942^{170}$ stated that the source of power of the Secretaries Gieneral was not a delegation of legislative power since the Belgian constitutional regime did not allow for such a delegation. The basis for the powers of the Secretaries General was a simple extension of the regulatory powers of an attribution of competence emanating from the legislative power. As a result, one of the decrees dealing with regulating food supply, the decree concerning the CNAA was ruled unconstitutional.

34. Cour d'appel de Bruxelles ( 9 e Ch.) 15 décembre 1941, cited in: CEGES/SOMA, Papiers Vossen 1921-1952, MC 74, Mathieu, G., Ende sur la Delegation des Pouvoirs en Temps de Guerne, p. 70 .

sal See e.g. Anrêté No. 161 du 20 révrier 1941 transférant à la Corporation nationale de l'agriculture et de l'alimentation les attributions de l'office national des debouches agricoles et horticoles, Recueil des arrêtes des Secrétaires Généraux 1941 Tome 1, p. 812; Arrêté No. 663 du 30 juillet 1941 instituant des commissions d'arbitrage pres la Corporation nationale de l'agriculture et de l'alimentation, Recueil des arrêtes des Secrétares Généraux 1941 Tome II, p. 3456.

37i) Justice de Paix, Louveigné, 20 février 1942, cited in: CEOES/SOMA, Papiers Vossen 1921 .

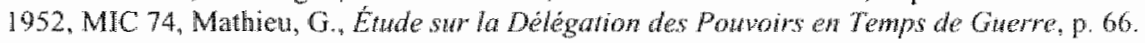


The same day a Justice of the Peace in Walcourt came to a similar conclusion, ${ }^{37}$ and on 15 April the Justice of the Peace of the first canton of Schaerbeek in the case of Meymans $v$. CNAA ${ }^{372}$ rendered the same kind of judgment. In the spring of 1942, in several courts at the same time, the validity of these decrees dealing with ecomonic crimes was directly challenged. Within a couple of weeks, several hundred of such cases were pending. ${ }^{373}$ On 20 April the Military administration arrested Hanson, the Justice of the Peace of Louveigne, who had rendered the first judgment invalidating the decree of the Secretaries General. Copies of the judgment were confiscated and he was transferred to al prison in Essen, Germany, where he died on 26 March 1944 due to an acrial bombardment. ${ }^{374}$ The occupant had initially detained Judge Paulsen, who had rendered a judgment in Antwerp against the CNAA, ${ }^{37}$ but Paulsen was released and brutally killed later on during the occupation as a result of his judgment. ${ }^{376}$

On 30 March 1942 the Cour de cassation in the case of Hallew et Consorts ${ }^{377}$ rendered a judgment concerning the question of the competencies of the Belgian Secretaries General. ${ }^{378}$ In principle the Cour de cassation explicitly recognized the powers of the Secretaries General to enact measures, even though it held that the Statute on Delegation (1940) did not grant the Secretaries General the powers of the legislator. However, the grant of powers in article 5 of the 1940 Statute would be illusory and unworkable, especially in case of a long-term occupation, if it could not serve as a legal basis for the Secretaries General to enact measures that the legislator enacted in normal times. Although the Secretaries General did not possess the powers of the legislator, they could nevertheless enact measures that nomally belonged to the province of the legislator. These measures were of an administrative nature, albeit in the broad sense of the term, which meant that any measures concerning the political organization of the country, as well as any measure touching upon the Constitution or fundamental principles of national legislation were excluded. Moreover, each Secretary General could only act within the framework of his competencies. The courts were competent to review the measures the Secretaries General enacted, except for the urgency to enact the measure, if stated explicitly or could be inferred from the text.

In dealing with the admissibility of the case, the Cour de cassation now struck at the heart of the Military administration's occupation policy. The decree that was challenged was the one establishing a two-tier administrative jurisdiction dealing with economic crimes concerning the food supply. Although allowing for recourse to

\footnotetext{
3) Cited in: CEGES/SOMA. Papiers Vossen 1921-1952, MIC 74. Mathieu, G., Etude sur la Délégution des Ponvoirs en Temps de Guerre, p. 67.

m. CEOES/SOMA, Documents Zéro, ref. AA 1078, no. 1034/55, Justice de Paix Schaerbeek lle canton), 15 avril 1942 .

3!) CEGESSOMA. Abschlubbericht der Militärverwaltung, 6. Teil Die belgische Justiz nnd Gesetzgebung, p. 68 .

374 Lotuvearix, p. 626 .

375 CEOES/SOMA, Ministerie van Justitie Secretariaat-Generaal AA 1467, inv. 19, lettre de M. le Secrétaire Genéral au Ministère de la Justice à Oberkriegsverwaitungsrat Randenborgh du 21 septembre 1942.

37. Delandsheere/Ooms, Tome III, p. 354-355.

37 Cass (2e Ch.) 30 mars 1942; Pas. 1942, I, 82

77. See also Smolders, Jurisprudence, p. 537-538.
} 
the ordinary courts for a decision of this administrative jurisdiction, article 21 of the decree excluded recourse to the Cour de cassarion. The Court ruled the case was nevertheless admissible, since article $2 \mathrm{~L}$ was deemed to be alien to the object and purpose of the decree, could therefore not be legally justified and by virtue of article 107 Belgian Constitution not applied by the courts. Taken in its entirety the Court upheld the decree, but invalidated the exclusion of recourse to cassation.

The Military administration's reaction to the Hallew et Consorts caso was that it had not won a great deal by this verdict. The confirmation of the powers of the Secretaries General to enact measures was followed by several conditions strictly limiting those powers. Furthermore, the only authority that could make a decision on whether these conditions had been met were the courts and ultimately the Cour de cassation, which had pulled the political question of whether a measure of the Secretaries Gieneral was legal and therefore had legal effects onto itself. ${ }^{3 \%}$ This posed an extra hurdle in trying to administer the country, since the courts might retroactively declare a measure invalid. At the pace the Belgian Judiciary worked, it conld take months before a court would render a decision on the legal validity of the measure, let alone the Cour de cassarion, creating a situation of legal uncertainty. ${ }^{330}$ More importantly, the Military administration was of the opinion that decrees of the Secretaries General had to be seen as replacing Acts of Parliament and were therefore beyond the scope of judicial review. ${ }^{381}$ In the protocol signed at the beginning of the occupation the Secretaries General had declared that their decrees would be of a legislative nature and President Jamar of the Cour de cassation had unofficially consented to this protocol. 382

Furthermore, the occupant feared this decision of the Belgian Supreme Court might incite some lawyers to challenge every other important measure enacted by the Secretaries General, in essence halting any effective administration of the country. ${ }^{383}$ At that point the Military administration started considering granting force of law to the decrees of the Secretaries General, effectively prohibiting the courts to exercise any judicial review. A concomitant draft regulation was sent to Secretaries General with the request to state their position by April $15^{384}$

The situation aggravated, due to the fact that after the Cour de cassation's judgment the attorneys of the administrative jurisdiction dealing with economic crimes also resigned from office, whereupon the administrative proceedings estab. lished under decrees of the Secretaries General came to a halt. ${ }^{365}$

17. CEGES/SOMA, Abschlußbericht der Militärverwaltung, 6. Teil Die belgische Justiz und Gesetzgebung, p. 71; Archives Auditorat Général, Cour militaire, Dossier Schuind, no. 572.B.47, Carton Overtuigingsstukken 333, Farde II, letter from Reeder to Schuind 10 April 1942 , p. 1 .

Archives Auditorat Général, Cour militaire, Dossier Schuind, no. 572.B.47, Carton Overtuigingsstukken 333, Farde II, letter from Reeder to Schuind 10 April 1942, p. 2.

39. Archives Auditorat Général, Cour militaire, Dossier Schuind, no. 572.B.47, Carton Overtuigingsstukken 333, Farde II, letter from Reeder to Schuind 10 April 1942, p. 2.

1.2: See also Chapter 1.2.3.

3\$3 CEGES/SOMA, Abschlußbericht der Militärverwaltung, 6. Teil Die belgische fustiz und Gesetzgebung, p. 72.

3 A. Archives Auditorat Général, Cour militaire, Dossier Schuind, no. 572.B.47. Carton Overtuigingsstukken 333, Farde II, letter from Reeder to Schuind 10 A pril 1942, p. 2 -3.

38: CEGES/SOMA. AbschluBbericht der Militärverwaltung, 6. Teil Die belgische Justiz und Gesetzgebung, p. 73 . 
In responding to the Military administration's envisaged regulation the Secretaries General proposed to remedy each subsequent new challenge to a decree by giving it force of law via a regulation of the Military administration. For the occupant this did not remedy the problem completely, but only solved it until a similar problem arose. On 14 May 1942, the Military administration enacted the Regulation prohibiting judicial review ${ }^{386}$ for any measure of the Secretaries General enacted on the basis of the Statute on Delegation (1940) and arrested several attomeys involved in challenging the powers of the Secretaries General. ${ }^{387}$

The Cour de Cassation's President and Procurator General protested the next morning to General von Falkenhausen. The regulation would oblige the courts to apply the measures of the Secretaries General, without possibility to review for compliance with the Constitution or an Act of Parliament. Since these measures contained penal provisions, their application would be independent from an Act of Parliament. The Court contended that reviewing an executive act for compliance with an Act of Parliament was a fundamental principle of judicial organization, which necessitated the courts' full independence in order to be able to safeguard the rights of the accused. It could therefore not be asked of the courts, without changing their nature, to apply a sanction contrary to an Act of Parliament. Therefore, under the current situation, the Court declared it was impossible to hear cases brought against judgments that requested the application of penal or other constraining measures contained in decrees of the Secretaries General. ${ }^{388}$

After its plenary meeting on 20 May $1942^{389}$ the Cour de cassation issued a statement indicating that the Military administration's regulation changed the legal nature of the decrees of the Secretaries General due to which they ceased to be decrees of a Belgian executive. If these decrees would then legally become measures of the Military administration, the Belgian courts would not be able to apply them as emanating from sovereign Belgian organs. The Court referred to the fact that a fundamental rule of cassation was that violations of Belgian legislation had to be at stake. Article 2 of the regulation stated the legal nature of the decrees of the Secretaries General would not be changed. But the prohibition to determine the decrees' legality meant that for the walidity of the measure and therefore for its application in a certain case the regulation had to be applied. Furthermore, the application of penal provisions in the measure was linked to the legality of the measure as well. Only a measure's conformity with the legislation on which it was based allowed for a valid application of its penal provisions. This meant that if the legality of the measure could not be determined, it could only be applied, if at all, on the basis of the occupant's regulation.

Verordmung über die Anwendung von Verordnungen der Generalsekretäre, vom 1.4. Mai 1942, VoBL. 1940-1944, S. 915

CEGLSSOMA, Papiers Schund, MIC 51, Mémoire "Au ministère de la Justice pendant l'occupation allemande. Laction de M. Schuind, secrétaire-général.", p. 27; Delandsheere/Ooms, Tome II, p. 211.

Greffe Cour de cassation, Cour de cassation, Registre des Assemblées génêrales du 28 dé. cembre 1940 - 8 juillet 1942. Assemblée générale en Chambre du Conseil du 19 mai 1942.

Archives Auditorat Général, Cour militaire, Dossier Schuind, no. 572.B.47, Carton Overtuigingsstulken 334. Local 4 XI, no. 2, Procès-yerbal de l'Assemblée générale de la Cour de cassation en chambre du conseil du 20 mai 1942, p. 1 ; text also in: Delandsheere/Oons, Tome
II, p. 215 . 
The Cour de cassation further reasoned that in being embedded in Belgium's fundamental legislation, the judicial power was an expression of Belgian sovereignty. In Belgium, judicial review of measures for conformity with Acts of Parliament before applying a punishment or other constraining measure was a fundamental principle of the judicial organization. In being able to safeguard the rights of the individual, the independence of the courts was ensured. It could therefore not be expected of the courts to apply a sanction contrary to legislation, without changing its character and ignoring its raison d'être. The Cour de cassation underlined that judicial review was embedded in Belgian tradition, predating the Constitution. For those reasons the occupant's regulation obliged the Belgian courts to abstain from trying cases inwolwing the application of penal provisions from measures enacted by a Secretary General.

The Military administration prohibited the Court from making its statement public, considering it a call for a strike. ${ }^{390}$ Furthermore, the Military administration considered that its regulations, also the Regulation of 14 May 1942, constituted an obligation for the courts. It now insisted that the Belgian courts accepted as Belgian laws within their jurisdiction the decrees of the Secretaries General taken on the basis of the Statute on Delegation (1940). ${ }^{391}$

Although the Cour de cassarion's statement was not published during the occupation, it was rapidly known to courts around the country, who, in the opinion of the occupant, used it as a guideline for their own position as regards his regulation. The result was that all cases involving decrees of the Secretaries General were adjourned until a later, undetermined date. The consequence of this was that the Secretaries General could not administer the country anymore if their decrees were not applied.

In response the occupant announced that salary payments would be discontinued, ${ }^{392}$ threatened to arrest and execute 10 judges and depont the rest of the judges refusing to exercise their duties to the east. ${ }^{393}$ The Secretary General of Justice refused to rellay the Military administration's threat of sanctions against the courts. Schuind informed the occupant that he was not in a position to execute these measures and would not be able to continue exercising his office if such measures were taken against the courts. Reeder, the Chef of the Military administration therefore had to communicate his threat of sanctions via a press conference. ${ }^{394}$

The Secretary General of Justice tried to mediate between the Cour de cassation and the Military administration, recognizing that the administration of the Secretaries

390 CEGES/SOMA, Documents Zéro, ref. AA 1078, no. 1034/156, letter Reeder to Schuind of 29 May 1942; CEGES/SOMA, Papiers Schuind, MIC 51. Mémoire "Au ministère de la Justice pendant l'occupation allemande. L'action de M. Schuind, secrétaire-général.", p. 24.

$3 y_{1}$ CEGES/SOMA, Documents Zéro, ref. AA 1078, no. 1034/155, lettre de M. le secrétaire géneral Schuind à M. le procureur général près la Cour d’appel de Bruxelles du 30 mai 1942; Rijksarchief te Beveren, Parket bij de Rechtbank van Eerste Aanleg te Mechelen 0000 , no. 849 , brief $30 \mathrm{Mei} 1942$ van de Secretaris Generaal van het Ministerie van Justitie aan de Prow cureur Generaal bij het Hof wan Beroep te Brussel.

393 CEGES/SOMA, Documents, Zéro, ref. AA 1078, no. 1034/156, lettre de Reeder à M. te secrếtaire génếral Schuind dı 29 mai 1942.

39 Archives Auditorat Général, Cour militaire, Dossier Schund, no. 572.13.47, Carton 12, Farde XXIII, no. 31, lettre de $\mathrm{M}$. le secrétaire général Schuind à $\mathrm{M}$. le subsitut de l'auditeur général Faurès du 8 juillet 1946, p. 1 .

3ï4 CEGES/SOMA. Papiers Schuind, MIC 51, Mémoire "Au ministère de la Justice pendant l'accupation allemande. L'action de M. Schuind, secrétaire-général.", p. 24; Charles/Dasnoy. p. 139. 
General depended on the application of their decrees by the courts and tried to persuade the Court to end the strike. ${ }^{395}$ He appealed to the fact that the wellbeing of the Belgian people should be the highest law of the land, as also expressed by the Council for legislative affairs when issuing a recommendation on the legal basis of the powers of the Secretaries General. ${ }^{396}$ President Jamar of the Cour de cassation was reminded of the protocol signed by the Secretaries General and the fact that the Court knew it had not been signed until after "authorizing consultations'. Schuind tried to persuade the Court in referring to amongst others the deplorable situation of nourishment and distribution in Belgium and the hardships for the Belgian population when deprived of judicial recourse or if subjected to a German court system. He speciffically mentioned that his interference dealt with the strike and not the content of the judgment. ${ }^{397}$ Furthermore, Schuind reminded Jamar that during the first days of the occupation, the Procurator General had informed the Court that the only mission of the Court was to deal with the legality of judgments of the lower courts. The Court was not to be entrusted by way of command the assurance for the execution of constitutional and legal provisions of the different judicial organs.

The little legal argumentation revolved around article 43 Hague Convention and the fact that the agents of the occupied state were given a certain latitude to determine whether their conscience permitted them to comply with the occupant's meas ures of public order. Schuind in essence argued that the Court should let the Secretaries General, as agents of the state, deal with the situation. Besides, the legislator, by way of the Statute on the powers of public officials during wartime (1935), had ordered all public officers, including judicial officers, to not abandon office and devote all their energies to the public good.

The Secretaries General feared the regulation portrayed them as administrators in the service of the Military administration and not as independent administrators representing the Belgian State and exercising Belgium's sovereignty. The impression of dependence on the Germans would only increase if their decrees could only have force of law when enforced via regulation of the Military administration. For the Secretaries General this was comparable to suicide. ${ }^{398}$ It was therefore of paramount importance for the Secretaries General to find a 'Belgian solution' to this crisis, namely a legal basis in Belgian law for their administration by decree. ${ }^{339}$

Pressure was building to find a solution, since the unrest was spreading to other courts in Belgium. The $10^{\mathrm{in}}$ Chamber of the Brussels Cour d'appel had requested its

Archives Auditorat Générn, Cour militaire, Dossier Schuind, no. 572.B.47, Carton Overtuigingsstukken 334, Local $4 \mathrm{XI}$, no. 7, lettre de $\mathrm{M}$. le Secrétaire générale Schuind à $\mathrm{M}$. le premier président Jamar du 31 mail 1942, p. $4-5$.

See CEGES/SOMA, Archives Hayoit de Termicourt, MIC 48, no. 16, Le Comité permanent du Conseil de Législation au Secrétaire général du Ministère de la Justice, Avis concernant la nomination éventuelle de bourgmestres-fonctionnaires du 16 octobre 1940 . Archives Auditorat Général, Cour militaire, Dossier Schuind, no. 572.B.47, Carton Overtuigingssukken 334 , Local 4 XI, no. 7, lettre de M. le Secrétaire générale Schuind à M. le premier président Januar du 31 mai 1942, p. $1-2$. Archives Auditorat Général, Cour militaire, Dossier Schuind, no. 572.B.47. Carton Overtuigingsstukken 334 , Local $4 \mathrm{XI}$, no. 7, Jettre de $\mathrm{M}$. le Secrétaire générale Schuind à $\mathrm{M}$. le premier president Jamar du 3 juin 1942, p. 1-2. migingsstukken 334, Local 4 XI, no. 7, lettre de M. le Secrétaire génerale Schuind à M. le premier president Jamar du 31 mai 1942, p. 1. 
acting President Convent to convene a plenary meeting, suspecting the President and the Procurator General knew the contents of the statement of the Cour de cassation"s plenary meeting, but suppressed any information about it ${ }^{400}$ The minutes of the Cour de cassation's meeting had been sent to the different public prosecutor offices before the Military administration's prohibition of their publication had reached the Court. ${ }^{40 !}$ After the prohibition of their publication the Procurator General at the Brussels Cour a'appel notified all subordinate public prosecutors that these could not be used during a plenary meeting at their courts. ${ }^{402}$ Although Convent convened a meeting of the Brussels Cour d'appel and acting Procurator General Collard, who was present à titre persomel, this meeting on 11 June 1942 was only unofficial. ${ }^{403}$ Procurator General Collard's stance during the meeting can be presumed as known, being of the opinion that all the decrees that the Cour de cassarion had not declared illegal should be applied and their legality assumed. ${ }^{\text {th: }}$ Collard also held the vicw that the Belgian Supreme Court's statement of the plenary meeting was only preliminary and that the results of the Court's final decision should be waited for. Secretary General Schuind urged Collard to assure the continuation of the administration of justice. ${ }^{405}$

On 4 June Schuind presented a proposal to solve the crisis. ${ }^{406}$ The Statute of 7 September 1939 on the King's special powers ${ }^{407}$ allowed the King during war times, in case of urgency and after consultation of the Council of Ministers to enact measures with the force of law in certain areas. These areas included public order, public health, food supply, levying taxes and even justice affairs. The construction would be that the Secretaries General would by delegation be acting on behalf of the King and the Council of Ministers. The decrees would be enacted under the Statute on Dellegation (1940) and via the Statute on the King's special powers (1939) would obtain

400 CEGES/SOMA, Documents Zéro, ref. AA 1078, no. 1034/161, lettre de M. le conseiller Loppens à M. le premier prẻsident ff Convent du 15 juin 1.942 ; no. $1034 / 159$, Proces-verbaal der zitting van de 10 e Kamer van het Hof van Beroep te Brussel van 5 jun 1942. Rijksarchief te Beveren, Parket bij de Rechtbank van Eerste Aanleg te Mechelen 0000, no. 849, lettre de $M$. le premier président de la Cour de cassation a $M$. le procureur général près de ta Cour de cassation du 30 mai 1942.

Rijksarchief te Beweren, Parket bij de Rechtbank van Eerste Aanleg te Mechelen 0000, no. 849, brief 4 Juni 1942 van de Procureur Gieneraal Collard aan de Procureur des Konings bij de Rechibank van Eerste Aanleg te Mechelen, no, Z.3/2. CEGES/SOMA, Documents Zéro, ref. AA 1078, no. 1034/161, lettre de M. le conseiller Lop* pens ä $\mathrm{M}$. le premier président ff Convent du 15 juin 1942 . CEGES/SOMA, Documents Zéro, ref. AA 1078, no. 1034/164, lettre de M. le procureur général Collard près la Cour d'appel de Bruxelles ì M. le procureur du Roi du 4 juin 1942; Rijksarchief te Beveren, Parket bij de Rechibank van Eerste Aanleg te Mechelien 0000, no. 849 , brief 4 Juni 1942 van de Procureur Generaal Collard aan de Procureur des Konings bij de Rechtbank van Eerste Aanleg te Mechelen, no. Z.3/2.

Rijksarchief te Beveren, Parket bij de Rechtbank van Eerste Aanley te Mechelen 0000, no. 849, lettre de M. le secrétaire général au Ministère de la Justice à M. le procureur général près de la Cour d'appel de Bruxelles.

Archives Auditoratt Géneral, Cour militaire, Dossier Schuind, no. 572, B,47, Carton Overtum gingsstukken 334, Local $4 \mathrm{XI}$, no. 12, lettre de M. le premier président Jamar à M. le Secrétaire générale Schuind du 4 juin 1942; Charles/Dasnoy, p. 142; Delandsheere/Ooms, Tome II. p. 242-249.

Loi du 7 septembre 1939 domant au Roi des pouvoirs extraordinaires, Mon, du 8 septembre 1939, p. $472-476$ 
force of law, putting these measures beyond the courts' competencies to exercise judicial review.

The question was, however, whether these decrees based on the 1939 Statute would have force of law. During the First World War, the King had enjoyed special powers to enact legislative decrees, which the Cowr de cassation after the war had. held to be on the same footing as Acts of Parliament. The reason was that since the King during. WW I was the only part of the legislative branch not under occupation, he was allowed, under the responsibility of his Ministers, to exercise all legislative powers in order to defend the territory and the vital interests of the nation. ${ }^{408}$ However, the legislative decrees enacted by the King during World War One were of a different nature than the ones emanating from the Statute on the King's special powers (1939). The legislative decrecs enacted between 1914-1918 were, according to the Cour de cassation, based upon a constitutional text, notably article 26 Belgian Constitution. ${ }^{\text {ang }}$ The decrees taken on the basis of the Statute on the King's special powers (1939) were evidently not. Their basis was legislation enacted according to the proper constitutional procedures and therefore could only be seen as the execution of that statute. Being an execution of a statute, in the hierarchy of legal norms, these decrees could never be equal in rank to a statute. ${ }^{410}$ The Council for legislative affairs advised against decrees taken on the basis of the Statute on the King's special powers (1939) having force of law, ${ }^{411}$ Schuind nevertheless maintained that such measures would possess force of law. ${ }^{412}$

The Cour de cassation agreed to the Secretaries General exercising the prerogatives of the King under the Statute on the King's special powers (1939). ${ }^{413}$ However, it insisted that since the exercise of these prerogatives was only within the framework of the Statute on Delegation (1940), the courts retained the power to review whether the decrees had a political content or changed the political structure of the country. Nevertheless, the Court admitted that measures taken on the basis of the Statute on the King's special powers (1939) could have force of law, in the sense mentioned in the protocols of the Senate. ${ }^{44}$ The Senate, when discussing the bill, had decided that due to a state of necessity Article 107 Belgian Constitution would not be applicable to measures taken on the basis of the Statute on the King's special powers $(1939)^{4.15}$

\footnotetext{
106

Casss. 11 Pevrior 1919, Revue Administration, 1919, p. 193.

loid.

Seo also Ockrent, p. 38.

Charles/Dasmoy, p. 134-136.

Charles/Dasnoy, p. 143.

Archives Auditorat Gifneral, Cour miltane, Dossier Schund, no. 572.B.47, Carton Overtuighugstuktien 334 , Local $4 \mathrm{XI}$, no. 12, letre de M. le premier president Jamar à M. le secretaine genérale Schuind du 4 juin 1942.

Archives Alwitorat General, Cour militaire, Dossier Schund, no. 572.13.47, Carton Overrugingsstukken 334, Local 4 XI, no. 12, letre de M. te premier président Jamar à M. le secretaire generale schuind du 4 juin $1942, \mathrm{p}$. 3. The protocols of the Senate mentioned by the Court in this leter are: D.P. Senat, 2e Sess, extr. 1939, no. 13. See aho Greffe Cour de cassation, Registre des Assemblés generales du 28 décembre $1940-8$ juillet 1942 , Assemblée generahe en Chambre du Conseil du 3 juin 1942, Delandsheere/Ooms, Tone II, p. 269.

Loi dn 7 septembre 1939, domant at Roi des pouvoirs extraordinares, Mon. du 8 septembre 1939, 111 Rapport fait au nom de la Commission spéciale du Sénat (1), p. 472-476, p. 474 para. 10; Aroté du 19 juin 1942 mépriman les abatages clandestins ef le commerce illicite en viande, Pasinomia 1942, 467, Exposé des motifs, para. 15.
} 
This meant that the Court would still invalidate certain decrees of the Secretaries General if they reformed the political order or allowed newlly established organizations to enact measures with penal sanctions. ${ }^{416}$

This was not acceptable to the Military administration. It wanted a clear and unambiguous situation, basically pressing for a guarantee from the Cour de cassation it would refrain from any review of decrees taken on the basis of the 1939 Statute. Since the situation now seemed in complete deadlock the Secretary General of Justice considered tendering his resignation. ${ }^{417}$

In the beginning of June the Military administration discovered a strike fund that had been collecting money since 1940 to prepare for spreading passive resistance within the national administration. Most of the money had been distributed to the different Cours $d$ "appel. The money of the strike fund that had not yet been distributed was confiscated. ${ }^{418}$ Justices Fauquel and Louveaux, as well as Advocate General Cornil, all three at the Cour de cassation, were arrested in connection with preparing the judicial strike and organizing the payments to the magistrates. This, according to the Military administration, not only exposed the intentions of the Judiciary, but also deprived it of the funds for any envisaged strike. Fauquel was released the same night, but Louveaux and Cornil were detained for several days at the St. Gilles prison. ${ }^{419}$

The Secretaries General were now unanimously of the opinion that if the committee of Secretaries General would base a decree on Statute on the King's special powers (1939), the courts lacked the right of review under article 107 Belgian Constitution and increased their pressure upon the Cour de cassation ${ }^{420}$ Schuind told the Court the Military administration was willing to compromise and suggested a solution under which the Court would save face, namely a suspension of the Regulation prohibiting judicial review if the Court would agree not to review decrees taken on the basis of the 1939 Statute. Belgium's industrial, commercial, financial and religious leaders were, according to Schuind, also eager to find a solution to this judicial crisis. $^{421}$

Archives Auditorat Général, Cour militaire, Dossier Schuind, no. 572, B.47, Carton Overtuigingsstukken 334 , Local $4 \mathrm{XI}$, no. 14 , lettre de M. le premier président Jamar à M. le secrétaire générale Schuind du 12 juin 1942; Greffe Cour de cassation, Registre des Assemblées générales du 28 décembre 1940 - 8 juillet 1942. Assemblée gênérale en Chambre du Conseil du 12 juin 1942 .

CEGESSOMA, Abschlußbericht der Militärverwaltung, 6. Teil Die belgische Justiz and Gesetzgebung, p. 77 .

CEGES/SOMA, AbschluBbericht der Militärwerwaltung, 6. Teil Die belgische Justiz und Gesetzgebung, p. 77.

Greffe Cour de cassation, Registre des Assemblées générales du 15-9-1944 - 24-6-1949, Audience publique et solennelle du 23 janvier 1945, p. 43; Charles/Dasnoy, p. 150; CEGESISOMA, Abschlubbericht der Militärverwaltung, 6. Teil Die belgische Justiz und Ge. setzgebung, p. 77 .

Arehives Auditorat Général, Cour militaire, Dossier Schuind, no. 572.B.47, Carton Overtuigingsstukken 334, Local 4 XI, no. 15, lettre de M. le secrétaire génerale Schuind a M. le premier président Jamar du 23 juin 1942, p. 1.

Archives Auditorat Général, Cour militaire, Dossier Schund, no, 572.B.47, Carton Overtuigingsstukken 334 , Local $4 \mathrm{XI}$, no. 15, lettre de M. le secrétaire genérale Schuind à M. le premier président Jamar du 23 juin 1942, p. 5. 
On 25 June the Court responded, ${ }^{\text {A2 } 2}$ stating that the Statute on Delegation (1940) remained the primary source for delegation of powers and the Statute on the King's special powers (1939) could only apply on the basis of the former. Even when acting in committee, the Secretaries General could not transform the political institutions or reform the political order. Since the law prohibited every magistrate to participate in the application of a measure contrary to his duty of loyalty to his fatherland, the courts could not apply such a decree even if taken on the basis of the Statute on the King's special powers (1939). This solution Jarnar offered for the judicial crisis did, in the eyes of the Cour de cassation, presuppose that the Military administration's Regulation would not be maintaned.

The Military administration rejected the compromise the Cour de cassation had offered on June 30. Since the Military administration recognized that no public officer was obliged to apply a measure contrary to his conscience, this statement was superfluous. It would furthermore merely incite certain people to new, inconsiderate and spectacular attitudes. Moreover, although in principle not opposed to repealing the regulation, if this were to become public knowledge it would only excite the spirits of certain groups of people. The Military administration added that if that same day a revised letter from the Cour de cassation would not be directed to von Falkenhausen, it would consider attempts to find a Belgian solution to the crisis failed. ${ }^{423}$

The same day President Jamar gave in ${ }^{424}$ and the Cour de cassation, in plenary meeting on $8 \mathrm{July},{ }^{425}$ consented. ${ }^{426}$ On 1 July the Military administration suspended its Regulation of 14 May 1942 , but did not repeal it. ${ }^{42}$ Even this suspension was as such never published in the Journal for Occupied Belgium, ${ }^{428}$ though it was distributed to the public prosecutor's offices. ${ }^{429}$ The attorneys who had been arrested at the beginning of the crisis were released and the Court resumed its activities. ${ }^{430}$

422 Archives Auditorat Général, Cour militaire, Dossier Schuind, no. 572.18.47, Carton Overtuigingsstukken 334 , Local 4 XI, no. 16 , lettre de M. le premier président Jamar à M. le secrétaire générale Schuind du 25 juin 1942.

Archives Auditorat Général, Cour militaire, Dossier Schuind, no. 572.B.47, Carton Overtuigingsstukken 334 , Local $4 \mathrm{XI}$, no. 17 , lettre de $\mathrm{M}$. le secrétare générale Schuind à $\mathrm{M}$. le premier président Jamar du 30 juin 1942.

Archives Auditorat Général, Cour militaine, Dossier Schuind, no. 572.B.47, Cartion Overtuigingsstukken 334, Local 4 XI, no. 20, Jettre de M. le Chef de l"Administration Militaire Reeder a M. le secrétaire générale Schuind du 1 juillet 1942; Delandsheere/ Ooms, Tome II, 1946, p. 272-273, lettre de M. le premier président Jamar à M. le secrétaire générale Schuind du 30 juin 1942; Charies/Dasnoy, p. 29.

Greffe Cour de cassation, Registre des Assemblées générales du 28 décembre 1940 - 8 juillet 1942. Réunion des Chambres assemblées en date du 8 juillet 1942.

Archives Auditorat General, Cour militaire, Dossier Schuind, no. 572.B.47, Carton Over-

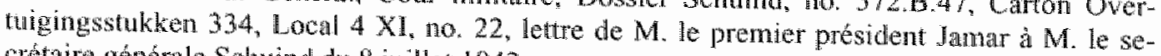
crétaire générale Schuind du \& juillet 1942 .

CEGES/SOMA, Docmments Zéro, ref. AA 1078, no. 1034/181; CEGES/SOMA, Archives Hayoit de Termicourt, MIC 48, no. 25, lettre de $M$. le chef de l'administration militaire Reeder a M. le secrétaire général Schuind du 1 juillet 1942; CEGES/SOMA, AbschluRbericht der Militäverwaltung, 6. Teil Die belgische Justiz und Gesetzgebung, p. 79.
Pacte, p. 123 .

Rijksarchief te Beveren, Parket bij de Rechtbank van Eerste Aanleg te Mechelen 0000, no. 849, brief 16 December 1942 de Procureur Generaal van het Parket van het Hof van Beroep te Brussel an de Procureur des Konings bij de Rechibank van Eerste Aanleg te Brussel, no. Z 
In a subsequent judgment ${ }^{41}$ the Cour de cassation expressly stated that the Statute on the King's special powers (1939) did not confer legislative powers, but rather special powers. The fact that measures enacted under the statute had force of law", did not mean that these were legislative powers, but rather that the courts were excluded from using their powers under Article 107 and review the decrees' constitutionality. Furthermore, the Court ruled that the measures enacted under the statute had to be in conformity with the Statute on Delegation (1940), the ultimate and single source for delegation of powers to the Secretaries General. The courts were therefore not allowed to rule on the urgency or necessity of the measure, which would be a joint decision of the Secretaries General in committee. However, if the committee of Secretaries General had not affirmed the urgency or necessity, or it was not clear from the text, the measure could be reviewed for compliance with the Constitution and Acts of Parliament. Also, although there was a restriction conceming constitutional review of these measures, the courts could nevertheless review whether the measure fell within the scope of the statute, meaning its formal text or its spirit. The Court reiterated that the statute did not alter the nature of the special powers the Seeretaries General enjoyed under the Statute of Delegation (1940), but did alter the extent of constitutional control the courts could exercise.

The Cour de cassation was in an awkward position. Its President had in formally consented to the protocol before the Secretaries General had signed it at the beginning of the occupation, including the stipulation that the measures of the Secretaries Generall on the basis of the Statute on Delegation (1940) had force of law. Also, it was losing the support of the lower courts. Two out of three Cours d'appel, as well as other courts had started to grant force of law to the decrees of the Secretaries General. And at the height of the crisis, support for the Supreme Court was waning, most notably from the side of the Secretaries General, who unanimously pressured the Cour de cassation to agree to the proposed Belgian solution.

Legally speaking there were many arguments it favor of the Cour de cassation's initial stance. For several reasons the Statute on Delegation (1940) could not have delegated powers to enact measures with force of law. Article 5 of the statute made clear that subordinates could only exercise all the atributes of his superiors within the scope of his professional activities. These superiors, the Ministers, were in London, functioning as the Government-in-exile and had been recognized as Belgium's legitimate powers exercising Belgium's sovereignty. ${ }^{432}$ The indivisibility of sovereignty made it unlikely that Parliament had wanted several Belgian authorities to separately exercise legislative powers at the same time. Furthermore, the statute on Delegation (1940) in its articles 2 and 3 did also not award legislative powers to Provincial Governors or Mayor when cut off from their supervisors, but merely administrative supervisory powers. Moreover, under ordinary circumstances Belgium's Ministers would not have exercised Belgium's sovereign powers. Being cut off from their superiors during wartime meant that the Secretaries General could only exercise those powers the Ministers normally had at their disposal. Besides, article 43 Hague

6/6, bijlage afschrift Brief vom 1. Juli 1942 Militärverwaltungschef Reeder an den Generalsekretär des Belgischen Justizministeriums.

Gorissen, p. 176-177.

Cass. 27 janvier 1943; Pas. 1943, 1, 33; Revue Administration, 1943, p. 173.

See Chapter 6.2 
Convention also stated that in case of occupation, legislative powers on the occupied territory passed in fact into the hands of the occupant. The national administration on the occupied country could therefore not exercise legislative powers on the basis of its own legislation anymore, being bound by the factual transfer of those powers to the occupant. ${ }^{433}$

Problematic was that the Statute on the King's special powers (1939), under article 1 clearly stated that measures based on it would have force of law. The statute was clearly harking back to World War One when only part of Belgium's territory had been occupied and the King lacked a clear statutory delegation of legislative powers. The intention of the Lower House was to assure continuity of the legislative powers of the state, under special circumstances, by one of the legislative branches of the State. Article 26 Belgian Constitution mentioned only the King, the Lower House and the Upper House of Parliament as part of the legislative branch and not the Council of Ministers. Of course the King's powers were exercised in the Council of Ministers, but Parliament apparently thought it necessary to explicitly mention this in article $\mathbb{l}$ of the statute. This was exactly because the Council of Ministers was not part of the legislative branch.".

The Statute on Delegation (1940) was the legal basis which allowed a Secretary General to exercise his Minister's powers. Since the Statute on the King's special powers (1939) only delegated legislative powers to the King in case of special circumstances and not to the Council of Ministers, it is questionable whether the Secretaries General could exercise the powers granted under that statute.

An easy conclusion to draw now would be that at least after the first judicial crisis, if not already before, the Secretaries General were in fact exercising a legislative power based on the occupant's factual legislative powers as described in article 43. Hague Convention. In the absence of a legislative power in national legislation, the exercise of legislative powers by the committee of Secretaries General could therefore only be on the basis of the occupant"s powers. The Statute on the King"s special powers (1939) would then be a mere fig's leaf or mask ${ }^{435}$

The above-mentioned conclusion, however, is supported by the fact that under Belgian constitutional law, the Constitution does not allow for a formal delegation of legislative powers. ${ }^{4 h}$ The King already possessed legislative powers and therefore, the Statute on the King's special powers (1939) did not delegate legislative powers to him. ${ }^{437}$ Both the Lower ${ }^{438}$ and the Upper ${ }^{439}$ House's intended to authorize him, under

4.3. Verraes, Tome I, p, 167-168, 174; Rolin, Tome I, p. 449; Meurer, p. 235-237.

s.44 See Chapter 6.2.2 to see in how far this would also be an issue for the powers of the Government-in-exile. See also CEGES/SOMA, Papiers Vossen 1921-1952, MIC 74, Extrait de l'avis donné le 16 octobre 1940 par le Comité Permanent de Législation concemant l'interprétation de l'article 5 de la loi du 10 mai 1940, p. 1, referring to the Secretaries General as mere agents of the executive power and Leclereq, Loi, p. 16 ; Philippart.

Pacte, p. 121-121. However, the contention that the Secretaries General atso in law exercised the powers of the occupant is not correct.

See Loi du 7 septembre 1939, donnant au Roi des pouvoirs extraordinaires, Mon. du 8 septembre 1939. III Rapport fait au non de la Commission spéciale du Sénat (1), parâ 14. See also Cass. 6 février 1890; Pas, 1891, I, 5: D.P. Chambre, S.O. 1944/1945, 21 mars 1945, No. 74, p. 16.

See D.P. Chambre, S.O. 1944/1945, 21 mars 1945, No. 74, p. 17. For a contrasting opinion see Wodon, p. 52-57. Wodon in essence argued that the King's legislative powers, which only consisted of assenting to legislation Parliament had passed, had become a pure formality. This 
special circumstances, to exercise these powers without their involvement. Furthermore, normally a legal act derived from an Act of Parliament cannot have the same legal status as that Act of Parliament. 401 At least the Upper House of Parliament's intention was then to confer a 'force of law' on measures based on the 1939 Statute, not as a delegation of legislative powers, but merely to put them beyond the courts" powers of review under article 107 Belgian Constitution. ${ }^{41}$

Therefore, for several reasons the Secretaries General could not exercise the powers of the 1939 Statute. Firstly, Article 43 Hague Convention provided that the legislative powers on the occupied territory passed in fact into the hands of the occupant. Secondly, since the State's legislative powers could not be delegated, the Secretaries General could not acquire these powers, not even being organs of the legislative power. ${ }^{42}$

This meant that on the basis of international and Belgian constitutional law, the Cour de cassation should not have allowed the Secretaries General to take measures based on the 1939 Statute. In allowing the Secretaries General to do so, the Cour de cassation violated Belgium's legal order. The Court, being a legal institution, bound by the law and expected in its considerations to only take into account legislation, is expressly banned from taking policy considerations into account. ${ }^{4.3}$ This cannot mean, especially for a supreme court under the extraordinary circumstances of an occupation, that other considerations would not come into play. Most legal rules are made for ordinary, peacetime circumstances and even those made for special circumstances, like the 1939 and the 1940 Statutes, would not be able to provide a solution for every situation. Legally speaking the Court's option would therefore only be strict

had rendered his legislative powers purely ceremonial, due to which these could not be the baw sis on which he had been able to exercise legislative powers during World War One. "The King's executive powers, which had not become ceremonial, could nevertheless also not serve as a basis for his exercise of legislative powers. Wodon therefore concluded that this exercise was based on the Prééminence royale, in essence due to King's role as Head of State. How ever, this was contrary to the Con de cassation's ruling that the basis for the King's exercise of legislative powers lay in the fact that he was one of three legislative organs (see Cass. 11 feverier 1919, Pas. 1919, 1, 9). Furthemore, this Préeninence royale was surely tied to the person of the Monarch and was something that, like legislative powers, could not be delegated. This also meant that the Council of Minister, as organs of the executive, as well as the Secretaries General in delegation from their direct superiors, could therefore on this basis and the fact that the Council of Ministers was an executive organ, not exercise legistative powers. See Meyer, p. 299 concurring that Wodon's analysis rested on a wrong analysis of the position of the King within Belgian constitutional law.

See Loi du 7 septembre 1939 , donnant au Roi des pouvoirs extraordinaires, Mon. du 8 septembre 1939, II Rapport de la Commission de la Chambre (1), para 3. The Lower House"s commission referred to case-law stating this principle, which it in the following paragraph confirmed and subsequently unanimously adopted this report. See Loi da 7 septembre 1939, donnant au Roi des pouvoirs extraordinaires, Mon. du 8 septembre 1939. III Rapport fait au nom de la Commission spéciale du Sénat (1), para 26. See also Ockrent, p. 157

44 See Loi du 7 septembre 1939, donnant an Roi des pouvoirs extraordinaires, Mon. du 8 septembre 1939, III Rapport fait au nom de la Commission spéciale du Sénat (1), para 10. cernant l'interprétation de l'article 5 de la loi du 10 mai 1940 , p. 1 , referring to the Secretaries General as mere agents of the executive power.

443 Articles 28 and 30 Belgian Constitution. See also Hoon, p. 66. 
adherence to its constitutional rules. Beyond legal considerations, the only other option was 40 allow for an unconstitutional Belgian administration to continue.

The consequences of strict adherence would most likely have been disastrous. The Belgian administration would lack a legal basis acceptable to the occupant and therefore would not be able to administer anymore. It was highly unlikely that by mid-1942 the Secretaries General would accept an official delegation of powers from the occupant, having completely dismissed the idea at the beginning of the occupation. ${ }^{4}$ Besides, article 118 bis BPC stood in the way, which prohibited aiding the enemy in transforming the State. During the occupation of World War One, the German occupant had administered the State at a national level ${ }^{445}$ and had taken over the administration of Justice when the courts went on strike. 4 . This would be a very likely outcome of the current judicial crisis if no Belgian solution would be found.

On the other hand, allowing the Secretaries General to administer the country on an unconstitutional basis would at least allow for the adrninistration to remain in Belgian hands. Although the 1939 Statute would only mask the occupant's power behind it, as long as the Secretaries General in charge were Belgian appointees the Secretaries General would still act as a buffer and prevent direct Gernan administration of the country. This would, however, depend on the Secretaries General in office to counter policies only favorable to the occupant, which would become more diffcult once the occupant would be able to appoint Secretaries General favorable or at least not contrary to his policies. Already in July 1942 out of the original twelve Secretaries General in office on 10 May 1940 , only three remained, the others having been appointed with the consent of the occupant.

Legally speaking, the Cour de cassation had violated the Belgian constitutional order in not using its powers to assure the Secretaries General would adhere to Belgium"s constitutional law. It abandoned strict adherence to Belgian law in dealing with its national administration and indirectly with the occupant, allowing for measures enacted during the occupation to be applied contrary to Belgium's Iegal order. Practically speaking, the Court's decision to give in to all the pressure meant it had opted for "le moindre mal" or the least worst solution to this first judicial crisis at the end of June 1942.

\subsection{THE COURTS AND MEASURES CONCERNING FORCED DEPLOYMENT OF LABOR}

On 6 October 1942 the occupant enacted a regulation dealing with the forced deployment of labor in Germany. ${ }^{448}$ The Military administration recognized its previous policy to recruit Belgians more or less voluntarily had failed. A case concerning an aspect of this woluntary labor deployment was brought before the Brussels Cour

\footnotetext{
새난ㄷㄴ

fis Se Chapter 1.2 .3

CEGES/SOMA. Papiers Vossen 1921-1952, MC 74, Mathieu, G., Etude sur la Délégarion des Ponmirs en Temps de Guene, p. 2. See also Chapter 1.2.3.

44 Promer Vauthier, p. $238 \mathrm{ff}$; Passeleco, p. $75 \mathrm{ff}$

47 CEGES/SOMA, CEPAG, ret. AA 830/192, Avis de M. Henri E.A.M. Rolin, Président de la Cour de cassation, sur la question "du sort à réserver sur anêtés pris par les Secrétainesgenertaux" "p. 2; Chartes/Dasnoy, p. 307. beiten von besonderer Bedeutung wom 6 . Oktober $1942, \mathrm{VoB1}, 1940.1944, \mathrm{~S} .1059$.
} 
d'appel. Belgian workers sent to Nazi-Germany were required to sign an employ" ment contract and required to hand in their rationing cards at the municipal hall before departure. If they returned from Germany, although still under a contractual obligation to work there, the Ministry of Agriculture and Food Supply in a circular had prohibited the municipalities from re-issuing their rationing cards. In its judgment on 9 September 1942 the Brussels appeals court held the circular to be a violation of a Ministerial Decree of 1 March 1940 and the refusal to re-issue the rationing card a violation of legal provisions. ${ }^{449}$

Seeing his efforts to voluntarily recruit Belgian workers thwarted, the occupant enacted his new regulation commanding Belgian labor. The Belgian authorities, especially the national police, were put under pressure to execute this regulation and aid the Military administration in arresting those Belgian nationals refusing to comply. ${ }^{450}$ The committee of Secretaries General prohibited Belgian authorities to assist in the execution of this regulation ${ }^{451}$ and protested to the Military administration, followed by the President of Cour de Cassation, as well as the Procurator General and their counterparts at the Cours d'appel and the Presidents of the bar associations. ${ }^{452}$ Von Falkenhausen was told that the actions concerning the forced deployment of labor were contrary to the Hague Convention and more specifically its articles 43,46 and 52. Although article 52 Hague Convention allowed some form of forced labor on the occupied territory, this only extended to a local commander ordering inhabitants to perform certain actions locally and solely with respect to the needs of the occupation army, barring participation in actual war actions. Also article $115 \mathrm{BPC}$ was referred to, which prohibited Belgian nationals to aid the enemy. Besides being contrary to international and Belgian law, it was pointed out that the forced deployment of labor was also contrary to universal conscience. The Cour de cassation, the Belgian appeals courts and other lawyers denied the Military administration had the legal right to force Belgian citizens to co-operate, directly or indirectly, in Germany's war production. Both the public prosecutor in Nivelles, as well as the Secretaries General issued a circular prohibiting Belgian officials to assist in the execution of the new regulation on forced labor deployment. ${ }^{453}$ German police arrested the King's Prosecutor in Mons for his refusal to assist in the execution of this regulation. ${ }^{4.54}$

CEGES/SOMA, Archives Hayoit de Termicourt, MIC 48, nos. 45 et 46 , lettres des premiers présidents, procureurs généraux et bâtonniers près la Cour de cassation et les Cours d'appel in M. le général won Falkenhausen des 16 septembre et 16 novembre 1942. Delandsheere/Ooms, Tome II, p. 427 mentions 16 October 1942, but no letter from the Cous de cassation for 16 October was found. See also Greffe Cour de cassation, Registre des Assemblées générales du 13 septembre 1942 - 11 juillet 1944, lettre du premier président de la Cour de cassation Jamar à $M$. le gérnéral von Falkenhausen du 20 mars 1943. to cooperate in the execution of these measures, since these were not based in Belgian law and a violation of article $115 \mathrm{BPC}$. 
Not having received a reply to their earlier plights, Jamar and Hayoit de Termicourt once again wrote von Falkenhausen on 20 March 1943 . 455 They reiterated their protest against the measures subjecting Belgian nationals to forced labor in Germany and insisted on the suspension of these measures. Von Falkenhausen was reminded of the fact that for the second time in 25 years Germany had reduced the Belgians to servitude. Being at the top of the judicial hierarchy, the only regularly constituted national organ whose actions were not paralyzed, the Cour de cassation thought it had the obligation towards itself and towards the nation to denounce this injustice. It repeated that the Military administration's measures were contrary to the Hague Convention and imperative obligations of conscience. Finally the Military administration responded, once on 23 April and once on 22 May 1943. ${ }^{456}$ However, the result was that a collaborator was appointed head of Belgium's national police and Secretary General Schuind would be removed from office on 17 September 1943 for his continuous refusal to allow the Belgian authorities to execute the forced labor regulation. 457

Even though the occupant's measures concerning labor deployment did not directly touch upon the functioning or the position of the courts, the Cour de cassation's repeated attempts to engage the occupant in a discussion on the legality of his actions succeeded. Through its protests based on legal argumentation the Court at least sought to influence the occupant's policies.

\subsection{SECOND JUDICIAL CRISIS; MEASURES ALTERING THE POLITICAL STRUCTURE AND JUDICIAL REVIEW}

In allowing the Secretaries General to enact measures with force of law under the 1939 Statute, a crisis had been averted for the time being. However, the fire was still smoldering in that measures based on the Statute on Delegation (1940) were still subject to the courts' review and the situation escalated again as 1942 drew to a close.

Romsee, a Secretary General whose appointment the Military administration had favored, could not persuade a majority of his colleagues to agree on his proposal of merging big cities and surrounding municipalities into agglomerations with one single administrative structure. On his own authority, based on the Statute on Delegation (1940), Romsee enacted the decree concerning the formation of greaterAntwerp, for which Antwerp and the surrounding suburbs would merge into one administrative entity. ${ }^{48}$ The same kind of decree was enwisaged for Brussels, Louvain,

CEGES/SOMA, Archives Hayoit de Termicourt, MIC 48, nos. 48,56, lettre de M. le premier président de la Cour de cassation Jamar et M. Yavocat général Hayoit de Termicourt ff pour le procureur général à M. le général von Falkenhausen du 20 mars 1943; lettre de $M$. le procureur général près la Cour de cassation à M. I'auditeur général près la Cour militaire da 22 décembre 1949. See also Delandsheere/Ooms, Tome III, p. 92-94.

CEGES/SOMA, Archives Hayoit de "Termicont, MlC 48, no. 56, lettre de M. le procureur général près la Cour de cassation à M. l'auditeur général près la Cour militaire du 22 décembre 1949 . Geet, p. 8.8 .

Arrêté No. 806 du 15 septembre 1941 créant le Grand-Anvers, Recuell des arrêtes des Secrétaires Généraux 1941 Tome III, p. 686; Arêté No. 1031 du 30 decembre 1941 concernant l"unification du Grand-Anvers, Recueil des arrêtes des Secrétaires Géneraux 1941 Tome III, p. 5090 . 
Gent, Liege and Charleroi. ${ }^{459}$ The Secretaries General had informed the Military administration of the fact that the Statute on the King's special powers (1939) and also the Statute on Delegation (1940) did not allow for such a political measure to be enacted.

At the end of 1942 the $6^{\text {th }}$ Chamber of the Brussels Cour d'appel, presided over by Justice Simon and with Justices Ooms and Mommaert on the bench was confronted with this decree concerning the agglomeration of Greater-Antwerp. Hearings had been held on 2, 9 and 10 October and the judgment would be rendered on 27 November. ${ }^{460}$ Sabbe, the public prosecutor in the case, raised the question of admissibility of the newly formed municipality of Greater-Antwerp. Gentzke, the legal affairs official at the Brussels regional department of the Military administration, fearing the appeals court would not deal with the issue. On 27 November he sent a letter in effect ordering the court to suspend the proceedings in this case for 2 months. After having been informed of this undiplomatic letter, his colleague at the national level of the Military administration, von Randenborgh, sent a more diplomatic letter via the Ministry of Justice on 27 November, but in essence also requesting the court to suspend proceedings for two months. ${ }^{46 !}$

At the end of 1942 also before the Cour de cassation a similar case was pending involving the municipality of Borgerhout, which had been merged into the newly created Greater-Antwerp. It was scheduled to hand a judgment in the case on $26 \mathrm{No}$ vember 1942 November, but the Military administration similarly requested the Cour de cassation on 24 November to suspend proceedings in this case for two months. ${ }^{* 12}$

The Millitary administration foresaw that the courts would use their power to review decrees enacted on the basis of the Statute on Delegation (1940). Anxious to avoid another judicial crisis so soon after the previous one the Military administration was tempted to have recourse to its Regulation of 14 May 1942 prohibiting the review of the legality of decrees of the Secretaries General enacted under the Statute on Delegation (1940). However, since the Secretaries General, before the enactment of the decree, had informed the occupant of its political nature, the Military administration felt it was not in a position to use the regulation to stop judicial review. The tactics of the Military administration to prevent another judicial crisis were therefore geared towards getting a stay of both courts' proceedings. The occupant was hoping to buy some time for the Secretary General of the Interior to find a majority within the committee of Secretaries General for his decree to be based on the 1939 Statute. ${ }^{463}$ The Belgian Supreme Court seemed to comply without difficulty and also the $6^{\text {th }}$ Chamber of the Brussels Cour d'appel had received the message apparently without putting up resistance. .64 $^{4}$

\footnotetext{
45

Louveaux, p. 634

Louveaux, p. 635

CEGES/SOMA, Papiers Schuind, MIC 51. Mémoire "An ministère de la Justice pendand l'occupation allemande. L'action de M. Schuind, secrétaire "général.", p. 29-30; Louveaux. p. 635 .

462 CEGES/SOMA, Papiers Schuind, MIC 51 , Mémoire "Au ministere de la Justice pendant l'occupation allemande. L'action de M. Schuind, secrétaire-général,", p. 29; Louveaux. p. 638 .

A63. Louveaux, p. 637

4kat CEGES/SOMA, Abschlufbericht der Militärverwaltung, 6. Teil Die belgische Justiz und Gesetzgebung, p. 81 .
} 
The Cour de cassation convened in a plenary meeting on 26 November 1942 to discuss the Military administration's request. It considered the Military administration's request and recognized that its motive was to avoid disorder in the country, which might result from the Court's ruling. The Court clearly indicated that if its judgment were actually such that it deemed the decree contrary to Belgian legislation, the responsibility for disorderly events that could follow from its judgment did not lie with the Court, but the illegality of the decree. It was obliged to suspend proceedings, but would only do so if after expiration of the 2 -month period it would be able to resume the case. If normal resumption were to prove impossible, this obstacle would be seen as an impossibility to try the case and consequently an impossibility to exercise its functions. 4.5

On behalf of the Secretaries General, Schuind sent a letter to the Military administration protesting against the Military administration's interference in Belgian court proceedings and stating the interference showed disrespect for the fundamental laws of the Belgian people. Schuind also expressed the hope that this obstacle would only be temporary and that the Cour de cassation would be able to judge the case freely after two months. ${ }^{466}$

The letter containing the order to suspend the proceedings must have nuffled some feathers at the Brussels Cour d'appel. The court was plainly ordered not to render judgment for two months, but was also told that these "necessary historical developments' [i.e. the formation of the agglomerations - YM] would not be stopped. ${ }^{467}$ The appeals court met in a plenary meeting on 30 November. ${ }^{468}$ It was either not informed about the imperative nature of the Military administration's letter, ${ }^{+469}$ was mislead as regards the letter's true intentions due to a translation mistake made by the services of the prosecutor's office ${ }^{470}$ or was simply vexed and refused to accept the demand made. The Cour d'appel considered the occupant's letter an attack on its independence and allowed its $6^{\text {th }}$ Chamber the exclusive and free decision to set a date, after deliberations, to pronounce judgment. If there were any hindrance for the $6^{\text {th }}$ Chamber to exercise its duties, a similar hindrance would constitute for the whole court an impossibility to exercise its functions. ${ }^{471}$

Grefto Cour de cassation, Registre des Assemblées générales du 13 septembre $1942-11$ juillet 1944. Assemblẻe générale en Chambre du Conseil du 26 Novembre 1942; Archives Auditorat Général, Cour nilitatre, Dossier Schuind, no. 572. B.47, Carton 4, Farde X, no. 9, Cour de cassation, Expédition du procès-verbal de l"Assemblée générate en Chambre du Conseil tame le 26 novembre 1942, p. 3. See also Louveaux, p. 637. Archives Anditorat Genéral, Cour militaire, Dossier Schuind, no. 572.B.47. Carton 4, Farde $X$, no. 8, letter of 25 November 1942. See also Charles/Dasnoy. p. 155.

Archives Auditorat Général, Cour militaire, Dossier Schuind, no. 572.13.47, Carton 4, Farde $X$, no. 10, letter of 27 Nowember 1942 .

Archives Auditorat Génêral, Cour milinire, Dossier Schuind, no. 572.B.47, Carton 4 , Farde $X$, no. 13. Extrait du régistre anx procès-verbax des audiences solennelles et assemblées générales de la Cour d'appel de Bruxelles. Chartes/Dasnoy, p. 158.

CEOES/SOMA, Papiers Schuind, MIC 51, Mémoire "Au ministère de la Justice pendant l'occupation allemande. L'action de M. Schuind, secrétaire-général.", p. 30.

Archives Auditorat Général, Cour militaire, Dossier Schuind, no. 572.B.47, Carton 4, Farde $X$. no. 13. Extrait du régistre aux procès-verbaux des audiences solennelles et assemblées générales de la Cour d"appel de Bruxelles, p. 3-4. See also Louveanx, p. 635; Deland-
sheere/Oons, Tome I1, p. 527-530. 
On the 11 December 1942 Justices Simon, Ooms and Mommaert of the $6^{\text {th }}$ Chamber of the Brussels Cour d'appel rendered their judgment. The appeals court argued that the decrees dealing with the creation of Greater-Antwerp ${ }^{472}$ were based on article 5 Statute on Delegation (1940). This provision, so the Court, did not delegate any power to enact measures with the force of law. Article 5 only delegated those powers necessary to achieve an aim set by the legislator; but the Secretaries General could only exercise these powers within the framework of their professional activities and in case of urgency. Article 107 Belgian Constitution obliged the courts to review the legality and constitutionality of a decree based on a statute to determine whether a decree was enacted ulro vires. ${ }^{473}$ According to the Constitution and custom, only Parliament could alter the borders of the state, provinces and municipalities. Neither text nor spirit of the Statute on Delegation (1940) indicated the legislator intended to diverge from the strict adherence to this custom. Also, continuation of Belgian public life did not justify a civil servant's amendment of Belgium's political régime existing before May 10 1940. The Brussels Coum d'appel therefore ruled that the decrees concerning the establishment of Greater-Antwerp were contrary to Belgium"s Constitution and legislation. ${ }^{474}$

The Secretary General of Justice seemed to be taken by surprise. On 14 December 1942 Schuind described his disbelief and his disagreement to the President of the Brussels Cour d'appel about the fact that its $6^{\text {th }}$ Chamber had defied the Military administration's order, even though the Cour de cassation had heeded to it. ${ }^{75}$ Schuind pointed out that in January 1919 Justice Remy had propounded that the occupant could completely put the courts of the occupied country on non-active. ${ }^{476}$ The occupant could also limit the courts" competencies, as long as the courts were of the opinion they could still perform their remaining duties in dignity or that they could support the occupant"s action in order to ensure the judicial service would be continued. Furthermore, as Schuind pointed out, Procurator General Terlinden in his opinion to a case in 1916 had also stated that the legal authorities of an occupied country were not excluded from the general obligation to conform to the measures the occupant had taken under article 43 Hague Convention. ${ }^{477}$ Article 43 foresaw that also the courts obeyed an occupant's measures, which might entail an injunction or prohibition directly addressed to them in view and within the limits of this article. Advocate General Leclerq had added to that in 1918 that even though the courts were not obliged to apply the occupant's regulations, they were nevertheless held to abide by them. 478

472 Artêté No. 806 du 15 septembre 1941 créant le Grand-Anvers, Recueil des arrêtes des Secrétaires Généraux 194\| Tome III, p. 686; Artêté No. 1031 du 30 décembre 1941 concenant l'unification du Grand-Anwers, Recueil des arreates des Secrétaires Généraux 1941 Tome III, p. 5090 . See also Dabin; Soenens; Tayart de Borms. Archives Auditorat Génetral, Cour militaire, Dossier Schuind, no. 572.B.47, Carton 4. Farde X, no. 14, Uitspraak 6e Kamer Hof van Beroep te Brussel van II december 1942. Archives Auditorat Général, Cour militaire, Dossier Schuind, no. 572.B.47. Carton 4, Farde $X$, no. 23 .

Conclusions de M. le procureur général Tertinden précédant l'arrêt du 20 mai 1916; Pas., $1915-1916,1,375$.

478 Conclusions de M. l'avocat général Leclercq précédant l'antêt du 21 janvier 1918; Pas. 1918 , 1. p. 194. 
Conceming the question whether an act by the occupant was within the scope of article 43 Hague Convention, Schuind referred to jurisprudence. Rolin had argued that there were certain conditions under which courts were to abstain from reviewing a measure of the accupant for compliance with article $43{ }^{479}$ Schuind did not as such express an opinion about the Court's action, but only wanted to direct the Court's attention to these legal theoretical bases, no doubt wanting to refrain from interfering in the judicial process.

The Council for legislative affairs, in a recommendation sought by the Secretary General of the Interior on 26 February 1942, had already dealt with a similar question. It had been asked whether the members of Belgium's police services were obliged to execute regulations of the Military administration. According to the Council for legislative affairs a Belgian public officer was, by virtue of article 43 Hague Convention, under an obligation to execute the occupant's orders based on the Hague Convention, even if there were no equivalent provisions in Belgian legislation. ${ }^{480}$

The Military administration regarded the judgment of the Brussels appeals court as a political attack on itself, which immediately demanded a countermeasure. In the night of 11 December, the night after the judgment was rendered, Justices Simon, Ooms and Mommaerts were arrested. ${ }^{481}$ Every press statement of the judgment was immediately censured. ${ }^{482}$ On 12 December the King's Prosecutor and three judges of the Brussels Tribunal were arrested and taken hostage. ${ }^{483}$ Together with 22 other magistrates and attorneys they were held at the Citadel in Huy ${ }^{484}$ The Military administration denied this had anything to do with the judgment these judges had rendered. $^{485}$

The Cour de cassarion convened in an emergency meeting on 12 December and decided to stay its work until further notice. ${ }^{486}$ The Brussels Cour d'appel followed suit in the afternoon and suspended its activities. Also the Brussels Tribunal joined the strike. ${ }^{487}$ The Cour dappel met in plenary meeting again on 13 December, concluding that in the present state of affairs it was unable to fulfil its duties until the possibility to freely render judgments was fully assured. That same day the supervisory council of the Brussels bar association held a meeting. It declared itself unanimously in support of the courts' position and stated its members would provisionally abstain from pleading before the courts. ${ }^{\star *}$ The prosecutor's office at the Brussels

al? 7 i

140

Ain:

Rolin, Tome $I_{2}$ p. 445-446.

Archives Auditorat Général, Cour militaire. Dossier Schuind, no. 572 B.47. Carton 12, Fardle XXIII, no. 4/3, Avis du Comité permanent du Conseil de Législation du 26 février 1942, p. 4. CEGES/SOMA, Papiers Schuind, MIC 51, Mémoire "Au ministère de la Justice pendant l'occupation allemande. L'action de M. Schuind, secrétaire-général.", p. 30 . See also Goris,
p. 178 .

CEGESSOMA, Abschlußbericht der Militärverwaltung, 6. Teil Die belgische Justiz und

CEGES/SOMA, Papiers Schuind, MIC 51, Mémoire "Au ministère de la Justice pendant

l'occupation allemande. L'action de M. Schuind, secrétaire-général.", p. 30.

Pholien, Chronique, p. 45.

Charles/Dasnoy, p. 157 .

Greffe Cour de cassation, Registre des Assemblées générales du 13 septembre 1942 - 11

juillet 1944, Assemblée générale en Chambre du Conseil du 12 décembre 1942.

Delandsheerelooms. Tome II, p. 530

Smolders, Tome VI, p. 26. 
Cour d'appel unanimously decided to remain in office and assure the maintenance of public order. ${ }^{489}$

The Military administration did not think the reaction of the Cous de cassation and the Brussels Cour d'appel justified and considered the position of the Cont de cassation weak and untenable. In its opinion neither the request to suspend proceed ings nor the arrest of the judges was interference with the actual adjudicatory process. The request to suspend proceeding merely dealt with procedural aspects and not the content of the pending case. The Military administration therefore decided to notify the Ministry of Justice on 13 December of the fact that against any person staying his work and not resuming it unconditionally by noon of 17 December, severe measures would be taken. This would necessarily have repercussions for the whole of public life in Belgium. In order to communicate the firmness of its position the occupant added that no negotiations were possible. ${ }^{400}$

On 10 December 1942 the Military administration had already enacted a Regulation on the protection of labor peace. ${ }^{401}$ Breach of this regulation would result in severe punishment with as maximum punishment the death penalty. In an official statement of 1,5 December the Military administration pointed out that the Regulation on the protection of labor peace was necessary in order to protect public order. Furthermore, the regulation not only applied to the labor classes, but also the public service, including the courts and the liberal professions. ${ }^{402}$

The Secretaries General were divided on the issue with Romsée pressing to remedy the crisis by agreeing to base the decree concerning the agglomerations on the 1939 Statute, putting it beyond the courts' powers of review. The other Secretaries General were reluctant to do so and decided to have a commission examine the question of the decrees concerning the agglomerations. ${ }^{403}$ Furthermore, the Secretaries General requested Schuind to contact the appeals court and urge it to resume its duties. 49

On 16 December 1942 the Brussels appeals court convened a plenary meeting. Expressing confidence in the fact that the Secretaries General would properly deal with the situation and would also be able to persuade the Military administration to release the hostages, it decided to resume its activities. According to Secretary Gen* eral Schuind the court also understood the error at the basis of the judicial crisis. ${ }^{45}$ Schuind had also tried to approach the Cour de cassation, but received no reply to the three letters he had sent. ${ }^{4 \%}$

\footnotetext{
4\$9 CEGES/SOMA, Papiers Schuind, MIC 51, Mémoire "Au ministère de la Justice pendant l'occupation allemande. Laction de M. Schuind, secrétaire-général.", p. 30.

4 Cho Chles/Dasnoy, p. 156; Louveaux, p. 636.

491 Verordnung zum Schutz des Arbeitsfriedens vom 10. Dezember 1942, VoBl. 1940-1944, S. 1109 .

42 CEGES/SOMA, Papiers Schuind, MIC 51, Mémoire "Au ministère de la Justice pendant I"occupation allemande. L'action de M. Schuind, secrétaire-général.", p. 31.

493 lbid

4\%4 Charles/Dasnoy, p. 160-163.

4 CEGES/SOMA, Papiers Schuind, MIC 51, Mémoire "Au ministère de la dustice pendant l"occupation allemande. L"action de M. Schuind, secrétaire-général.", p. 31 .

$\$$ Delandsheere/Ooms, Tome II, p. 547.
} 
The Cour de cassation also convened on 16 December to formulate a reply. ${ }^{497}$ it was of the opinion that the occupant clearly intended to impose a 2-month suspension of proceedings. The Court nevertheless deemed the letter the occupant had sent to the Brussels Cour d'appel not as clear-cut due to which the Brussels court's judgment could not be seen as a provocation. The Justices of the Brussels sixth chamber had been insufficiently infomed about the intent of the Military administration's letter and the circumstances surrounding the pending case. Due to the difference in circumstances the Brussels court could have viewed the occupant's letter as an invitation to examine whether it would be in the public interest to postpone its judgment in the pending case.

On 17 December the Cour de cassation informed the Secretary General that the Brussels appeals court had merely interpreted the Military administration's letter independently. ${ }^{4} 8 \mathrm{~B}$ Even if the appeals court had erred in fact, it had committed this error in good faith. Furthermore, the Justices of the $6^{\text {th }}$ Chamber merely conformed to the request of the Cour d'appel's plenary meeting. The Brussels court"s ruling could therefore not be seen as a provocation of the Military administration, due to which the arrest of the Justices was without cause. The same day, the Secretary General of Justice assured the Court that the release of the two Justices was immanent, upon which the Court decided to resume its duties. ${ }^{493}$

Howewer, the question of the release of the Brussels Justices was not resolved until January, although Justice Simon was released fairly soon on health grounds. Schuind apparently on 17 December had been negotiating again for the release of Justices Ooms and Mommaerts. Since he was convinced that their release was immanent, he had made his conviction public. It is not clear whether the Cour d'appel was notified of this. Nevertheless, Schuind contended that under the pretext that Radio London and some magistrates had proclaimed that the courts had made their resumption of work conditional on the release of the arrested judges, the Military administration delayed their release. ${ }^{500}$ Consequently, the other two Brussels Justices were not released until 4 Janwary $1943 .^{50 !}$

The Secretaries General were unsuccessful in finding a solution for the problem of the decree concerning the agglomerations. The commission it envisaged to examine the question of the decree concerning the agglomerations did not meet. Persons invited to sit on the commission asked to be excused. ${ }^{502}$ In any case, the recommendation of that commission was not to be binding upon the Secretaries General, ${ }^{503}$ nor could it be on the courts. As the mayors of 19 municipalities had already pointed out

\footnotetext{
(4)" Grefé Cour de cassation, Registre des Assemblées générales du 13 septembre $1942-11$ juillet 1944. Assemblée générále en Chambre du Conseil du 16 décembre 1942. Grefte Cour de cassation, Registre des Assemblées générales du 13 septembre 1942 - 11 juillet 1944, lettre de M. le premier président de la Cour de cassation à M. le secrétaire général du Ministére de la Justice du 17 décenbre 1942. Greffe Cour de cassation, Registre des Assemblées générales du 13 septembre 1942 - 11 juillet 1944, Assemblée gênérale en Chambre du Conseil da 17 décembre 1942. CEGES/SOMA, Papiers Schuind, MIC 51, Mémoire "Au ministère de la Justice pendant l'occupation allemande. L'action de M. Schuind, secrểtaire-général.", p. 31

Louveaux, p. 637 , footnote 40.

Delandsheere/Oonus, Tome II, p. 547.

Charles/Dasnoy, p. 163.
} 
in a letter first to Romsée and later to all Secretaries General, ${ }^{504}$ the legislative history of the Statute on the King's special powers (1939) clearly indicated a prohibition for this kind of legislation.

In spite of the pressure the Military administration put on the committee of Secretaries General to find a possibility to enact the decree and have it outside the reach of judicial review, the Secretary General of the Interior was unable to solicit a majority for his decree amongst his colleagues.

Therefore, on 26 January 1943 , the Military administration enacted a regulation, which stated that the Secretary General's decree concerning the agglomerations had to be applied in order to maintain public order ${ }^{505}$ Furthermore, the regulation declared that the newly formed municipalities were to be considered as formed under Belgian law and that the Belgian courts were competent to rule on any controversies arising under the decree.

When the Cour de cassation finally rendered its judgment, ${ }^{\text {s.to }}$ it ruled the decree of the Secretary General of the Interior was contrary to Belgian law. Due to the fact that it altered Belgium's political institutions, it went beyond the scope of the Statute on Delegation (1940) on which it was based. However, the occupant's Regulation of 26 January 1943 temporarily made it impossible for the institutions of the annexed municipality of Borgerhout to exercise its rights. Due to force majewre Borgerhout was obliged to let the municipality of Antwerp legally represent it.

The fire that had been smoldering since the end of the first judicial crisis ignited this second crisis. Whatever the exact reason was for the Brussels Cour d'appel to defy the occupant's direct order, it was not directly related to Secretary General Romsée's decree, but rather the Military administration's order for suspension of proceedings. Due to the loss of the archives of the Brussels Cour d'appel over that period, ${ }^{507}$ the exact reason for the appeals court's defiance of that order will probably never be known. However, presumably at the heart of this crisis was a misunderstanding. As also Secretary General Schuind pointed out, the Military administration's order to suspend proceedings for two months was not contrary to the occupant's powers under international law and also did not mean the occupant's direct interference with the outcome of the case. The courts' independent appreciation of the case was not directly interfered with, which the Cour de cassation acknowledged, since it abided by the order on the condition it would be able to pronounce judgment after the expiration of the two months. A translation mistake seems to be the most logical reason why the Cour d'appel did not interpret the occupant's letter as containing a direct order. The occupant's legal affairs representative at a national level, Von Randenborgh, presumably sent the same letter to each court. The Cour de cassation's contention that the letter sent to the appeals court was not as clear-cut must therefore have been based on a translation mistake made by the Belgian services. That some kind of misunderstanding was at the heart of this crisis is supported by the fact that

\footnotetext{
stit Delandsheere/Ooms, Tome II, p. 373

sus Verordmung über die Neugliederung von Gemeinden, wom 26. Januar 1943, VoB1. 1940-1944, S. 1139

5月. Cass. I février 1943; Pas. 1943, I, 44 (Commune de Borgerhout et Ville d'Auvers c. Consorts Boussoni).

sil? Author's archive, brief 28 april 2003 van de angewezen voorzitter van hel Hof van Beroep to Brussel aan de auteur, no. $\$ 468$. NB Louveaux, p. 635 referred for some of his information to the archives of the Brussels Cour d"appel!
} 
the Cour d'appel resumed its activities even though it could not yet have been given any guarantee for the release of its arrested colleagues. ${ }^{508}$

The Cour de cassation's efforts to have the arrested judges released eventually paid off, but its reputation of acting within the scope of the law, in this case international law, had been damaged, which meant some loss of its moral authority. This must have led to a weakening of its standing with the occupant and as a result a loss of influence on the occupant, as far as it had such influence, in future dealings with the Military administration. Equally important, the Cour de cassation's standing with its subordinate courts must have been imparred. Although the suspension of its duties was not due to the Military administration's suspension order, it was due to the arrest of the Brussels judges who had mistakenly ignored the suspension order. Comforting though it must have been for lower courts that its Supreme Court would provide guidance and support, it is doubtful how many courts would join a strike on the basis of insufficient legal or moral grounds. From then on courts would probably not automatically follow the Cour de cassation's lead in suspending its duties. Already concerning this strike, besides the Brussels Tribunal no other court joined it and even the Brussels Cour d'appel caved in after 5 days. Also the Military administration must have been aware of this.

The Cour de cassation's loss of standing must have influenced its ruling in the case concerning Romsée's agglomeration decree. The decree was clearly outside the scope of the powers of the Secretary General on the basis of the Statute on Delegation (1940), dealing with the political matter of organization of the State, which was exclusively reserved for the Legislator. The Court was correct in declaring the decree illegal, as was its refusal to accept the order contained in the occupant's regulation to accept the Greater-Antwerp agglomeration as formed under Belgian law. The decree did not emanate from the Belgian Legislator and could therefore not be treated as Belgian law, in spite of the occupant's order. However, in giving factual effect to the occupant's regulation by invoking force majeure and allowing the newly formed agglomeration of Greater Antwerp to represent the dismantled municipality of Borgerhout, the Cour de cassation co-operated in the execution of the occupant's transformation of Belgium's institutions and legal organization. The Court used force majeure as a justification to set aside article $118 \mathrm{bis} \mathrm{BPC}$, which prohibited this kind of aid to the enemy.

What would have been the options for the Cour de cassation though? The occupant used his powers of occupation, limited under article 43 Hague Convention, to enact a measure ordering the courts to apply the decree concerning the agglomerations. If the Court were to have reviewed the occupant's measure for compliance with article 43 Hague Convention and would have ruled it u/tra vires for falling foul of its condition of being a public order measure, it would have sparked another judicial crisis. The Hague Convention does not explicitly affirm a domestic court's power of review of an occupant's measures for compliance with article 43 Hague Convention. Jurisprudence on the topic is unclear, ${ }^{509}$ providing at best a very am-

sos

300

See above. The Brussels Cour d'appel resumed its duties on 16 December, whereas Secretary General Schuind obtained any such guarantee on 17 December at the earliest.

Rolin, Tome 1, p. 442 condemned a Brussels Tribumal ruling during the occupation of WW I, in which it had reviewed an occupation measure, but on p. 446 seems to leave an opening for measures of a particularly abusive and heinous nature. Beer Poortugael, p. 174-183 was silent 
biguous legal justification to exercise review. Even if the Court would have reviewed the measure, there was no reason not to regard it as a public order measure, which it had already recognized during its plenary meeting. Furthermore, during World War One the Cour de cassation had already denied the courts could review occupation measures for compliance with article 43 Hague Convention. ${ }^{510}$ Reviewing the occupation measure was therefore not an option.

However, under intemational law" the Cour de cassation still had the option to resign on grounds of conscientious objections to the Military administration"s regulation or conflict with its national law, particularly article 118 bis BPC. A threat to resign would undoubtedly also have led to another judicial crisis with the same possible consequences as might have been the result from the first judicial crisis " And it was doubtful whether the Cour de cassation could still command enough moral authority and support from its subordinate courts, having already gone through two damaging judicial crises. After the first one the courts had lost most of their rewew powers. The Cour de cassation had possibly started and continued the second one after a misunderstanding and to the outside world must have appeared to cave in before all Brussells Justices had been released.

Nevertheless, in accepting the factual effect of the occupant's measure as regards the agglomeration decree, the powers of the Secretaries General were exposed as being based upon the power of the occupant and not derived from Belgian law. Not only the Statute on Delegation (1940), but also the Statute on the King's special powers (1939) could not credibly serve as a mask anymore behind which the Secretaries General could hide the real basis of their powers as derived from the occupant and his power due to the occupation. It was clear that from now on a regulation from the occupant would back up any decree of the Secretaries General contrary to Belgian legislation.

on the issue when dealing with article 43 Hague Conwention. Oppenheim, War, p. $210-211$ when dealing with article 43 Hague Convention and p. 214.216 when dealing with the position of the domestic courts also did not touch the issue. Bordwell, Part II, Chapter VII did not discuss the issue. Werziji, p. 175-177 related how courts during an occupation are reluctant 10 review occupation measures, but tended to do so after the occupation ended. Benvenisti, p. 192-197 described the refusal of courts on occupied territories during World War One and Two to review the accupant's measures for compliance with article 43 Hague Convention. However, Benvenisti's contention on p. 194-195 that the 'Cour de cassation consistently refused to pass judgment on measures dictated by the occupant through the Belgian secretaries. general' is incorrect.

Cass. 20 mai 1916; Belgique judiciare 1919, cons. 167 e. a.; See also Rolin, Tome I, p. 442 446, Verzijl p. 176, Benvenisti, p. 192-193.

51 See Spaight, p. 358 who recognized the judges refusal to sit; Rolin, Tome I, p. 446, who seemed to recognize resignation, but newertheless thought this option might not be in the int terest of the occupied country; Beer Poortugael, p. 176 who recognized the right of civil servarts to lay down their office in case of conscientious objection; Oppenheim, War, p. 214 stated that an occupant "may not compel [civil servants - JM] to carry on their functions..."; Bordwell, p. 307 who stated that civil serwants are "entitled to resign (...) if they feel that the continuance of their functions is inconsistent with their duty to their own country...' 


\subsection{THE COUR DE CASSATION AND ATROCITIES IN DETENTION CAMPS}

Another issue occupying the Cour de cassation in mid-1943 was the suffering of detainees in detention camps, especially Breendonck, as well as their subjection to interrogations by the police. The Belgian resistance in the guise of the Front de I'Independence informed the Belgian Judiciary via a letter of 14 May' 1943 of the horrors committed in the detention camps and by the German police in the course of interrogations. ${ }^{513}$ On 20 July 1943 Jamar and Hayoit de Termicourt underlined they did not question the Military administration"s authority to conduct interrogations nor did they want to discuss the detentions. $5 / 4$ What they did want to point out was the maltreatment inflicted during some of the interrogations or during detention on Belgian nationals. Some of this maltreatment had occurred at the hands of Belgian nationals who by decision of the Military administration had been withdrawn from jurisdiction of the Belgian courts. However, the necessity to ensure its own security, so the Court, did not legitimize the Military aclministration to let German nationals and even less Belgian nationals employ violence. Belgium's Supreme Court appealed to the Military commander, being convinced of the fact these kinds of maltreatment did not meet his approval and would be judged contrary to military tradition as well as basic requirments of justice. Jamar and Hayoit de Termicourt fimished by reminding von Falkenhausen that the war would not last eternally. These acts that they now denounced raised indignation and resentment that could have regrettable consequences in the future.

During the month of August Advocate General Hayoit de Termicourt learned from a reliable source that the highest German authorities had ordered an investigation at the camp of Breendonck. The situation was said to have improved afterwards, which was confirmed in a reply von Falkenhausen sent on 16 September 1943 to the Court. $^{515}$

Although not directly impairing the functioning of the courts, the execution of sentences was of concern to the courts, since the severity of the execution might influence a court's determination of the applicable sentence. In presenting the Military administration with legal principles and moral arguments, the Cour de cassation succeeded in persuading the Military administration to change its policy.

\subsection{CIISIS OVER INTERFERENCE OF AN SS MEMBER IN COURT PROCEEDINGS AT THE ARLON TRIBUNAL}

In March 1944 the Cour de cassation convened to be informed about incidents that took place at the Arlon Tribumal and decided to request the Secretary General of Justice for more information. ${ }^{516}$ During a session of the Tribunal"s juvenile chamber on

\footnotetext{
\$1.3 CEGES/SOMA, Archives Hiayoit de Temicourt, MIC 48, no. 59, lettre du front de l'indépendence à la magistrature du 14 mai 1943.

314 CEGES/SOMA, Archives Hayoit de Temicourt, MIC 48, no. 49, lettre de M. le premier président de la Cour de cassation Jamar et M. l'avocat général Hayoit de Termicourt ff pour le procureur général à M. le général won Falkenhausen du 20 juillet 1943. lbid:

376 Greffe Cour de cassation, Registre des Assemblées générales du 13 septembre 1942 - 11 juillet 1944, Assemblées générales en Chambre du Conseil des 18, 23 et 24 mars 1944.
} 
2 March 1944 a Belgian citizen, and member of the Waffen-SS, interfered in the proceedings while the court was in session and made severe threats against the judge, waving a gun. Judge André excluded him from the audience and was subsequently arrested, together with the junior King's Prosecutor and the court registrar, but released the same day due to intervention of the local German military commander.

The Cour de Cassation informed the Secretary General of Justice that due to the fact that this person was a member of the Waffen-SS the Belgian courts did not have competence to try him. The Court requested the Secretary General to inform the occupant of this incident and to either permit the Belgian Judiciary to deal with this matter or to take measures itself in order to restore the dignity of the Belgian Judiciary. In the view of the Court this was indispensable for the Judiciary in order to be able to continue its duties. This was even more urgent, since judge Andre thad been arrested again on 10 March. 517

A delegation of the Cour de cassation met twice with representatives of the Military administration. The occupant denied there was a link between the arrests and the incident, but declared that the member of the Waffen-SS would be tried before a Waffen-SS tribunal. If proven guilty he would be disciplined, which in turn could lead to his transfer away from Arlon. The Court was promised measures would be taken to prevent a recurrence of such an incident. ${ }^{518}$

Jamar and Hayoit de Termicourt were assigned the task of monitoring the implementation of these measures. When two weeks later judge André was still detained and accusations against him had still not been lifted, the Court informed the Secretary General that if the Arlon Tribunal was not given satisfaction, it would consider suspending its duties. The Military administration's response was to release the judge in spite of the accusations against him. Proceedings against the member of the Waffen-SS were commenced on 20 April in Brussels. ${ }^{519}$

The Court again succeeded with legal argumentation backed up by a threat of strike in having the Military administration reverse an arrest and insisting it would not accept interference in the functioning of the courts. And although the occupant had excluded these kinds of cases from the competencies of the Belgian courts at the beginning of the occupation, 520 the Cour de cassation nevertheless sought to ensure this case was tried.

\subsection{THE COUR DE CASS ATION AND THE OCCUPANT"S POLICY OF HOSTAGE TAKING}

As the occupation progressed, the Military administration in certain instances made use of intimidation to try to persuade judges not to rule unfavorably. Apparenily, if the outcome of a case was not acceptable to the Military administration, it would request the case file and the names of the judges rendering the judgment. The names

\footnotetext{
51) Greffe Cour de cassation, Registre des Assemblées générales du 13 septembre 1942 - 11 juillet 1944, Assemblées générales en Chambre du Conseil des 3 et 6 avril 1944.

$\$ 18$ Greffe Cour de cassation, Registre des Assemblées générales du 13 septembre 1942 - II juillet 1944. Assemblées générales on Chambre du Conseil des 3 el 6 avril 1944.

sis Greffe Cour de cassation, Registre des Assemblées générales du 13 septembre 1942 - 11 juillet 1944, Assemblées générales en Chambre du Conseil du 20 avril 1944.

50 See Chapter 2.4 .
} 
of the judges would be placed on special lists. These special lists prioritized who should serve as a hostage on the next occasion. ${ }^{521}$ Von Falkemhausen was of the opinion this was in compliance with international law, since the hostages were used to fend off attacks from the population. ${ }^{522}$

Besides the fact that in more and more situations the hostages were killed, the functioning of the courts was also impaired. In the curcuit of the Brussels Cour d'appel 57 judicial officers and 10 registrars, besides being taken away from their families, were not able to exercise their functions for a shorter or longer period of time $^{523}$ The occupant had designated a further 11 magistrates to accompany the German army's supply trains. This resulted in a regular psychosis for persecution amongst the civil servants, accusing their superiors of not doing anything against this situation. The Cour de cassation and the Secretaries Generall did protest, already in July $1941,{ }^{524}$ but their protests seemed to fall onto deaf ears. ${ }^{525}$

Late December 1942, during the last judicial crisis, President Jamar and Advocate General Hayoit de Termicourt protested against an announcement of the Military administration in Liège. ${ }^{526}$ Apparently an attack against the German army in Liège had resulted in four casualties. The Military administration's response was to take hostages and threaten that if by noon on 3 January 1943 the perpetrators were not found 15 of the hostages would be executed. Jamar and Hayoit de Termicourt pointed out to von Falkenhausen that his powers to do so under international law were limited. According to natural law as well as positive law, no one could be punished for a crime in which that person had not participated. All jurisprudes, regardless of nationality, were unanimously of the opinion that even if taking hostages were permissible, they could never be executed. Furthermore, article 50 Hague Convention prohibited the application of any collective punishment against the population for reason of individual facts for which the population could not be held collectively responsible and article 46 Hague Convention imposed upon the occupant the obligation to respect the life of the individual. The Cour de cassation stated it did not wish to make any distinction between the hostages taken in Liège. As Belgian nationals they should all be able to count on its vigilance to assure the respect of fundamental legal rules.

The Military administration did not send a reply. ${ }^{527}$ Trying to avert a catastrophe, Jamar and Hayoit de Termicourt visited the Chef of the King's Cabinet, to request a royal intervention in order to head off the execution of the hostages. Appar-

521

CEGES/SOMA, AbschluBbericht der Militärverwaltung, 6. Teil Die belgische Justiz und Gesetzgebung, p. 20-21.

Louveatux, p. 643.

Louveaux, p. 645. However, in Huyse/Hoflack, p. 13268 judges and 10 court registrars are mentioned.

CEGES/SOMA, Archives ITayoit de Termicourt, MIC 48, no. 37, lettre de M. le secrétare général Schuind a M. le premier président de la Cour de cassation Janar du 26 juillet 1941.

Louveaux, p. 645.

CEGES/SOMA, Archives Hayoit de Termicourt, MIC 48, no. 47, lettre de M. le premier président de la Conr de cassation Jamar ot M. l'avocat général Hayoit de Termicourt ff pour le procureur général à M. le général von Falkenhausen du 31 décembre 1942. See also Gorissen, p. 180.

CEGES/SOMA, Archives Hayoit de Termicourt, MIC 48, no. 56, lettre de M. le procureur général près la Cour de cassation à M. l'auditeur général près la Cour militaire du 22 décembre 1949. 
ently the Cabinet of the King had already been informed. On 11 Jatuuary Jamar received a reassuring letter from the King's Cabinet and by the end of January the hostages were released. ${ }^{528}$

On 23 January 1943 the Cour de cassation sent another letter to the Secretaries General, complaining that the taking hostage of judicial officers was now becoming very systematic. If the hostage taking continued, the Court threatened it would have to examine whether its dignity would allow it to continue functioning.

The hostage taking did continue and the court did not suspend the exercise of its duties, but in April 1944 once again addressed von Falkenhausen. ${ }^{50}$ Numerous Belgian nationals, including members of the Judiciary, had been taken hostage. These hostages had been forced to spend the night in trains that were parked at important railway stations in the country. The Military administration now based these actions on paragraph 5 of its Regulation of 28 April 1943. ${ }^{531}$ The Court contended that this article did not allow for these kinds of measures, since it only allowed for measures of surveillance and protection and not these expiatory measures. Besides this, principles of international law and notions of justice were opposed to the occupant's actions in this situation. Explation supposed a personal wrongdoing, in the absence of which a measure taken against a person would be contrary to the notion of justice. In addition, an occupant could never use civilians to protect himself against an act of war of his enemy, as supported by article 23, first indent Hague Convention. Von Falkenhausen responded via letter on 17 May 1944 announcing the suspension of the measures against which the protest was directed. ${ }^{532}$

Nevertheless, in spite of the Court's protests, the hostage taking continued and the Court had now seen proof of the fact that some hostages had been executed without a prior judgment. In July 1944 Jamar and Hayoit de Termicourt once again vigorously protested. ${ }^{53}$ They wrote von Falkenhausen that they had learned that during the month of April 1944 Gustave Morren, a court registrar at the Tribunal in Louvain had been executed. The Military administration stated that Mr. Morren had been executed as a reprisal for terrorist acts, which in the occupant' opinion did not require a judicial death sentence.

The Court concluded that Mr. Morren had been executed withoul a trial and objected vigorously. This act was not only contrary to article 46 Hague Convention, which imposed the obligation to respect the lives of individuals, but also against the fundamental nules of justice and humanity. Being submitted to the rigors of military

528 Hid

52\% Lonveaux, p. 645 .

53: CEGES/SOMA, Arehives Hayoit de Temicourt, MIC 48, no. 50, lettre de M. le premier président de la Cour de cassation Jamar el M. l"avocat général Hayout dé "Termicoust fl pou" le procureur général à M. le général von Falkenhausen du 25 avril 1944.

53 Verordnumg zum Schutze des inneren Friedens und der Besatzungsmacht (Schutzverordnung) vom 28. April 1943, VoBl. 1940-1944, S. 1293.

53. CEGES/SOMA, Archives Hayoit de Termicount, MIC 48, no. 56, lettre de M. le procureur général près la Cour de cassation à M. l'auditeur général près la Cour militaire du 22 décembre 1949 .

53 CEGES/SOMA, Archives Hayoit de Termicourt, MIC 48, no. 52, lettre de M. le premier président de la Cour de cassation Janar et M. l"avocat général Hayoi de Termicourt fl pour le procureur gènéral à M. le général von Falkenhausen du 11 juillet 1944; Greffe Conur de cassation, Registre des Assemblées genérales du 13 septembre 1942 - 11 juillet 1944. Assemblée généralle en Chambre du Conseil du 11 juillet 1944. 
tribunals of the occupant was already hard on the inhabitants of an occupied territory, but being executed without a trial, without a possibility to defend himself and without the guarantee of justice was to refuse him the first of his basic rights. The Cour de cassation ended the letter by stating that victims might fall, but their death had never choked the voice of justice. The Court received no reply to this letter of protest. Since this was near the end of the Military administration's rule over Belgium in July 1944 and just before the installation of a Civil administration, von Falkenhausen might already have left the country. ${ }^{534}$

The Cour de cassation clearly demonstrated that the Military administration's policy of hostage taking of judicial officers in order to intimidate and attempt to influence the functioning of the courts did not deter it. Not only were the hostages from the hostage situation at the end of 1942 released in January 1943 and not executed, in May 1944 the Military administration also repealed its Regulation of 28 April 1943 on which it had based some of its actions. Although unable to stop the Military administration in taking hostages, the Court, with legal argumentation, attempted to counter the occupants aftempts to influence its functioning and occasionally succeeded in changing the occupant's policy decisions.

\subsection{SECOND CRISIS ON COMPETENCE TO TRY CASES INVOLVING ILLEGAL POSSESSION OF FIREARMS}

After the first clash in the beginning of $1941,{ }^{535}$ in May 1944 another major clash occurred between the Cour de cassation and the Military administration concerning the competence to try cases involving the use of firearms. During the occupation, friction over this issue had never subsided. ${ }^{536}$ The main cause was a secret decree, which Hitler had enacted at the end of 1941 , expressly handing competence to the German war tribunals in the occupied territories to try cases dealing with illegal possession of arms. Such cases were to be seen as a criminal act against the occupation authorities and therefore punishable by death. The German war tribunals subsequently laid claim to exclusive competence in trying cases involving illegal arms possession. $^{537}$

In Belgium an increasing number of attacks on members of collaborationist movements had occurred in the summer of 1942 . Since these attacks only involved Belgian nationals, the Belgian judicial authorities and courts considered they were exclusively competent, but the Military administration deplored the Belgian authorities' handling of these cases. ${ }^{3 / 3}$ Moreover, the Belgian awthorities were not keen on exercising their duties in these kinds of cases, ${ }^{539}$ expecting the German war tribunals would request to have the case transferred to them for trial. This would not only be tantamount to handing its own citizens over to German courts, but also facilitating

59 CEGES/SOMA. Archives Hayoit de Termicourt, MIC 48, no. 56, lettre de M. le procureur génèral près la Cour de cassation à M. l'auditeur général près la Cour militaire du 22 décembre 1949 
their trial, which was contrary to article 121 bis BPC. In October 1942 Secretary General Schuind tried to persuade the Belgian Judiciary to nevertheless prosecute and try these cases. ${ }^{540}$ Since the German police in Belgium was not equipped to handle all these cases, the Military administration had decided to provisionally give the guarantee that Belgian courts would be allowed to try cases Belgian authorities had investigated. $^{54 !}$ However, this guarantee was made conditional on results and harsh punishment of the perpetrators. ${ }^{542}$ In spite of the guarantee, at least in one instance the German police did not abstain from interfering in an investigation conducted by an examining magistrate in Wallonia. ${ }^{543}$ There was no record of the Cow de cassation taking action, but the transfer of competencies in these cases might not have taken effect just then.

Initially the German war tribunals seemed to accept this approach, but in November 1942 the newly appointed President of the German war tribunal objected. In his opinion leaving this competence to the Belgian courts was contrary to the Fithrer's secret decree and he therefore claimed exclusive competence in any case involving illegal possession of arms. The Military administration, fearing the Belgian Judiciary and pollice would resort back to their previous passive attitude in investigating these cases, issued an order on 12 Jamuary $1943^{544}$ provisionally allowing the Belgian authorities to deal with these cases. Additionally it sought to persuade the Secretaries General to increase the penalty for these cases. The German war tribunals were instructed to request a decision from the competent German legal departments monitoring the Belgian Judjciary, if they intended to have a case transferred from the Belgian courts. ${ }^{54,5}$

The Secretary General of Justice was only prepared to issue a decree increasing the penalty if the Military administration would give him a written guarantee that cases concerning illegal possession of arms involving solely Belgian nationals would belong to the exclusive jurisdiction of the Belgian courts. The Belgian Judiciary had urged the Secretary General to make this request, feeling the need, due to the bad experiences involving earlier assurances the Military administration had given. ${ }^{546}$ Due to the Fihrer's secret Decree the occupant could not give this guarantee, which resulted in the fact that Schuind refused to enact a decree increasing the penalty and the Belgian Judiciary temaining very passive in dealing with cases concerning illegal

Archives Auditorat Général, Cour militaire, Dossier Schuind, no. 572.B.47, Carton Overtuigingsstukken 333, Farde II, no. 9, letter from Schuind to the prosecutors general of Brussels, Gent and Liège 9 October 1942 Geet, p. 111-112; Doorslaer, p. 111.

CEGES/SOMA, Abschußbericht der Militärverwaitung, 6. Teil Die belgische Justiz und Gesetzgebung, p. 30-31.

Archives Auditorat Général, Cour militaire, Dossier Schuind, no. 572.B.47, Carton Overtuigingsstukken 333, Farde II, no. 47, lettre du juge d"instruction délêgué M. Henry Marcq à M. le Procureur du Roi à Dinant concerning questions of the German sectet police (Gestapo) about the inwestigation into a political nurder that had occurred on 19 October 1942. This order has not been published in the Verordmugrgsblatt.

CEGES/SOMA, Abschlußbericht der Militarwerwaltung, 6. Teil Die belgische Justiz und Gesetzgebung, p. 30-31.

CEGES/SOMA, Abschlubbericht der Militärwerwaltung, 6. Teil Die belgische Justiz und Gesetzgebung, p. 31 . 
possession of ams. ${ }^{547}$ Complicating the issue was a decree the Belgian Governmentin-exile had enacted and which was apparently well known to the Belgian population due to the fact it had been announced on the English radio. The exile decree ${ }^{548}$ increased the punishment under article 121 bis $\mathrm{BPC}$ prohibiting Belgian authorities to hand Belgian nationals over to the enemy. ${ }^{549}$

On 19 July 1943 a member of the Military administration nevertheless confirmed in writing to the Belgian authorities that crimes involving illegal possession of arms implicating only Belgian nationals, organizations or property would belong to the exclusive jurisdiction of the Belgian courts. ${ }^{550}$ Von Falkenhausen confirmed this in October. ${ }^{551}$ Any discharge of a suspect in these cases should however be reported to the local Military administration for review. The German police retained the opportunity to arrest suspects in cases of illegal arms possession, but the German war tribunals could only try these cases after explicit consent of von Falkenhausen. ${ }^{552}$ The decision was made subject to approval from von Falkenhausen's superiors in Germany, the possibility for the occupant to at all times during these proceedings be informed of their progress and for all suspects convicted for illegal arms possession to serve their sentence in the same prison facility. In order to avoid repercussions against an examining magistrate signing the release of a suspect the Military administration consented to a demand from the Belgian authorities. Notification of releases would be done to the German legal departments monitoring the Belgian Judiciary at regional and local level during the already occurring regular oral briefings between these Geman departments and the Belgian prosecution service. ${ }^{553}$

This approach led to a dramatic increase in arrests of suspects, as well as an increase in pumishments. Between October 1943 and February 1944 about 1500 sus. pects were taken into custody. "However, on 28 January 1944 the High Command. of the German Armed Forces (OKW) issued an order demanding that cases concening illegal arms possessions involving only Belgian nationals be withdrawn from the competence of the Belgian courts by 15 March 1944.55 The Military administration tried to persuade the $\mathrm{OKW}$ to countermand its order and initially got an extension until 1 April 1944. In spite of its objections on 4 April the Military administration was forced to order the transfer of all competencies conceming cases involving ille-

$5+1$

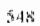

S)

55 내?

51

5.52

58

CEOES/SOMA, Abschlablbericht der Miltarverwaltung, 6. Teil Die belgische Justiz und Gesetzgeburg. p. 32.

Antétéloi du 17 decembre 1942 portant additions ou modifications aux articles 113.117 , 118 bis et 121 bis du Code penal, Mon. du 29 décombre. CECESSOMA, AbschluBbericht der Milntäverwaltung, 6. Ten Die belgische fustiz und
Gesetzgebung, p. $35-36$.

Geat, p. 134.

Dootsiat: D. 112.

CEGES/SOMA, Abschlubbericht der Miliaverwaltang, 6. Teil Die belgische Justiz und Gesutzgebung, p. 37; Geet, p. 135 CEGCSSOMA. Abschlubberich der Miliarverwaltung, 6. Teil Die belgische Justiz und
Giesctzgebung, p. 39 . CEGES/SOMA, AbschuBbericht der Militurvenwallung, 6. Teul Die belgische Justiz und
Gesetzgebung, p. 42 .

This is not mentioned in Geet, p. 36. Geet assumed that the Belgian authorities, including the courts, would retain competent to irvestigute, prosecute and try these cases until the end of the
occupation. 
gal possession of arms to the German war tribunals. 55 One of the reasons the OKW instructed the Military administration to give was that the Belgian Judiciary allegedly did not adhere to the agreement reached in October 1943. The Military administration claimed to possess several circulars of chief public prosecutors which stated that since prosecution of suspects of illegal possession of arms was now an exclusively Belgian affair notification of German authonities was not necessary. The Mimistry of Justice was also informed that withdrawal of the competence from the Belgian Judiciary was also due to objections raised by higher military authorities in Germany. ${ }^{557}$

The consequence was that not only the Belgian Judiciary, but also the Belgian police, invoking Article $12 \mathrm{lbis} \mathrm{BPC}$, again refused any cooperation in cases involving illegal arms possession. From the beginning of April 1944 not a single person was arrested on charges of illegal arms possession. The Military administration apm parently considered the option of arresting leading figures of the Belgian Judiciary and taking a possible resulting judicial strike for granted. However, it decided against this option, since it did not think this would in any way further the goal of persuading the Belgian authorities to investigate cases concerning illegal arms possession. If the leading judicial officers were arrested, the Belgian authorities charged with investigation and dependent on these leading judicial officers for instructions would be paralyzed due to a conflict of conscience. No measure of force would be able to persuade the Belgian authorities to investigate cases concerning illegal arms possession. Most police officers investigating these kinds of cases were not supervised by the Military administration and could therefore not be forced to investigate and report, if they did not do so out of their own motion. The Military administration felt it had reached the limits of the usefulness of the use of force. ${ }^{558}$

For the Military administration the only option open to it seemed to split off the Belgian police forces from the Belgian Judiciary. The occupant argued that if the Belgian police acted on behalf of orders from the Milltary administration it was at least under moral compulsion to execute the latter"s orders. Under article 71 BPC no violation of article 121 bis would occur where a person was in a state of insanity at the time the fact occurred or he was constraint by a force he could not resist. The Military administration claimed that also the chief public prosecutors could consent to this interpretation, ${ }^{55 \%}$ but no proof was found for this.

The Millary administration now tried to persuade the Secretary General of Justice to distribute a circular to the Belgian police authorities. The circular would have to publicly endorse the views of the Military administration as regards the legality of its orders by Belgian national authorities. The Secretary General declined, stating that since Article $71 \mathrm{BPC}$ was an exception to the general rule, only the Belgian courts, in each individual cases and depending on the facts of the case, could decide on its applicability. Without an explicit consent of the Belgian courts the Belgian police au-

Sys See also Doorslaer, p. 113.

57 CEGES/SOMA, Abschlubberich der Militarverwaltung, 6. Teil Die belgische Justiz und Gesetzgebung, p. 45 .

5\% CEGESSOMA, AbschuBberich der Militarverwaltung, 6. Teil Die belgische Justiz und Gesetzgebung, p. 47 .

5s CEGESTOMA, Abschinbericht der Milianerwaltung, 6. Tell Die belgische Justiz und Gesetzgebung, p. 50 . 
thorities would not feel confident Article $12 \mathrm{lbis} \mathrm{BPC}$ would not be enforced against them and possibly refuse to execute any German orders.

The courts were directly involved in this dispute in May 1944. On 19 and 22 of May 1944 the Cow de cassation met in plenary meeting. ${ }^{560}$ The King's Prosecutor in Courtrai, Mostaent, ${ }^{561}$ had been requested to issue an arrest warrant against two persons the Belgian police had caught while attempting to commit a theft with the aide of fire arms. In refusing to issue the warant, the King's Prosecutor had acted in accordance with his superior's instructions. These instructions had been issued after the Military administration on 4 April had again excluded the Belgian courts from prosecuting and trying cases involving possession of arms. Advocate General Hayoit de Termicourt reported during the plenary meeting that the King's Prosecutor, who had acted in accordance with his legal duties, had been detained for his refusal and not been released in spite of protests. He stated that the Judiciary could not exercise its functions with the dignity, authority and independence that were imperatively required and could therefore only conclude that the Court should suspend its deliberations. ${ }^{5 \times 22}$ Without having reached agreement on the course of action to take, a letter sent by the Secretary General of Justice made the Court postpone the meeting until 22 May.

On Saturday 20 May Jamar, Hayoit de Termicourt and the Secretary General of Justice had a meeting with General Freedrich, Vice President of the Military administration. Freedrich declared that the German authorities did not allow for its decision of 4 April 1944 to be repealed and told the Belgian authorities to offer new suggestions to combat acts of violence committed with arms, after which the King's Prosecutor from Courtrai would be released. All three Belgians present at the meeting stated that the release of the prosecutor and the acts of violence were two distinct issues. In not requesting an examining magistrate for an arrest warrant, the King's Prosecutor had only followed his superior's instructions. The measure taken against him was therefore without justification. Hayoit de Termicourt stated that if the Military administration were to take any measures, they would have to be against him, being the chief public prosecutor in the country and issuer of these instructions. ${ }^{563}$

Since the Military administration had not responded to the Court's plight the scheduled plenary meeting for 22 May was still on. While the Court was deliberating about which action to take the Secretary General of Justice informed Hayoit de Termicourt that von Falkenhausen would recommend the release of the King's Prosecutor. The Cour de cassation adjourned its meeting after it had obtained confimation of the King's Prosecutor's release from the Gent Cour d'appel. ${ }^{564}$

On 26 .hune the Military administration was informed of the fact that Hitler had personally approved handing over competence to the Belgian courts in matters concerning illegal arms possession involving only Belgian nationals. A request of the

CEGES/SOMA. Archives Hayoit de Termicourt, MIC 48, no, 54, 55. Procès-verbal de l'asemblée générate en chambre kh conseil des 19 et 22 mai 1944; Greffe Cour de cassation. Registre des Assemblées générales du 13 septembre 1942 - 11 juillet 1944, Assemblées générales en Chambre du Conseil des 19 et 22 mai 1944.

sti See also Doorslaer, p. 113.

56: Regarding the Belgian courts' independence see Mast, Indépendence; Mast, Monopole. See also Rénny.

55.3 Greffe Cour de cassation, smpra note 560.

Shat lbid. 
Military administration via the Sicherheitspolizet had apparently gotten through to Hitler. However, the Military administration in Belgium did not report directly to Hitler. The order of the High Command of the Geman Armed Forces (OKW) not to grant the Belgian courts competence was still in force. "The Military administration needed to get this order countermanded first, before it could grant the competence back to the Belgian Judiciary. ${ }^{565}$ It did not have the opportunity to do so anymore since the Military administration was dissolved and a Civil administration was installed in July 1944.

The Cour de cassation, distressed about the fact that only those attacks against the occupant or collaborationist movements were prosecuted, wrote Reichskommissar Grohe. Recognizing the fact that these crimes had been excluded from its jurisdiction, rendering it impotent to take any legal action, the Court declared it would take any action at its disposal. Since the Court had found out that the planners of the gruesome acts it described in the letter came from the occupant"s ranks, in this case the $S S$, it reminded the Reichskommissar of his duty to take appropriate and rigorous action. $^{566}$

The Reichskommissar reported directly to Hitler and was therefore not bound by the orders of the OKW. Under strict conditions he was therefore able and willing to hand back competence to the Belgian courts to try cases dealing with illegal arms possession solely involving Belgian nationals. ${ }^{567}$

Not accepting a complete exclusion of its competence to try cases involving the illegal possession of firearms, the Cour de cassarion was constantly either directly or indirectly involved in challenging the occupant's policy in this area. The courts stood in the background of the negotiations with the occupant, since Belgian public officials would seriously have to count on being convicted in case of a violation of the Belgian Penal Code's prohibition to hand over nationals to the enemy. Moreover, the Court's handling of the incident involving the King's Prosecutor of Courtrai showed that the Court was able to reverse the public prosecutor's detention, again underlining its ability to reverse the occupant's measures taken against judicial officers for acts of office. ${ }^{568}$ More importantly, the courts were constantly involved in protecting their competence to try cases involving illegal possession of firearms, using the law and its refusal to co-operate with the occupant, at various times succeeding in retaining or regaining that competence. Most notably even. when dealing with a more intrusiwe form of the occupant's administration, namely the Reichskommissar, the Belgian courts succeeded in regaining their competence in these cases.

\footnotetext{
ss. CEGES/SOMA. Abschlußbericht der Militärverwaltung, 6. Teil Die belgische Justiz und Gesetzgebung, p. 53.

54 CEGESSOMA, Archives Hayoit de Termicourt, MIC 48, no. 53, lettre de M. le premier president de la Cour de cassation Jamar et M. l'avacat géneral Hayoit de Termicourt ff pour lo procureur général à M. le commissaire du Reich Grohé du 24 août 1944.

56.7 CEGES/SOMA, Abschlußbericht der Militärverwaltung, 6. Teil Die belgische Justiz und Gesetzgebung, p. 54 .

Sorit See also 2.7
} 


\subsection{CONCLUDNG REMARKS ON THE BELGLAN COURTS DURING THE OCCUPATION}

The Statute on Delegation (1940) allowed for the Belgian legal system and the Belgian courts to function independently from direct measures the occupant enacted. Via the Secretaries General the occupant nevertheless inserted part of his policies into the Belgian legal system. Those policies the occupant could not persuade the Secretaries General to introduce would be enacted via a regulation of his Military administration, which the Belgian courts would not recognize as Belgian laws and therefore not apply. This meant that Belgian authorities in principle should have refused their cooperation in the execution of these measures, especially where aiding the occupant would have resulted in e.g. handing over Belgian nationals or transforming Belgium"s political institutions. Whether and to what extent this has happened is beyond the scope of this research, but it should be noted here that the occupant was very much aware of the dilemma this posed for the Bellgian authorities. More importantly, especially in the beginning of the occupation, in negotiating with the Secretaries General the occupant knew the courts stood in the background and might invalidate one of his policies the Secretaries General had enacted that went beyond the scope of their powers.

Although the occupant throughout the occupation tried to persuade the Belgian courts to apply his regulations as Belgian laws, his attempts failed and Belgian courts would therefore not execute his policies contained in the regulations. In substituting Belgian law where a measure from the occupant existed, the courts merely executed policies present in Belgium's legal order previously devised by its own Legislator and not the German occupant. The Belgian courts in this respect strictly adhered to their legal order, which only allowed them to apply Belgian law and resist direct application of war measures and the occupant"s policies.

The occupant failed in forcing Belgian courts to recognize as Belgian law decrees of the Secretaries General purportedly based upon the Statute on Delegation (1940), but which the courts held to be thtra vires. However, in the case regarding Romsée"s agglomeration decree, the Cour de cassation allowed for some factual of fect to be given to the occupant's regulation and Romsée's illegal decree it backed up. Since intemational law required courts in an occupied country to obey the occtpant"s orders, it was impossible for the Cour de cassation to resist a part of the occupant's policies as regards the agglomerations to be recognized in court. Nevertheless, in granting some factual effect the Belgian courts also violated a Belgian criminal provision prohibiting to aid the enemy in transforming Belgium's political institutions.

However, the Court resisted the occupant's order to recognize the illegal decree as Belgian law, avoiding its full application and the courts becoming involved in ruling on cases and controversies arising under the agglomeration decree. In not dealing with these controversies the courts refused to facilitate the establishment of these new political institutions and therefore did also not facilitate the occupant's administration of the country. The Court's refusal was based on national and international law, which enabled it to resist giving any legal effect to the illegal decree and therefore resist the execution of most of the occupant's policies contained in that decree.

The situation was different for the Statute on the King's special powers (1939). Under Belgian constitutional law only the King would have been allowed to use the 
powers contained in this statute and a delegation of these powers was not possible. Therefore, the Cour de cassation, in violation of Belgian law, aided in the execution of the occupant's policies contained in the decrees based on the 1939 Statute. International law did not require the Court to allow the Secretaries General to use the 1939 Statute and as a result relinquish its powers of judicial review over the measures the Secretaries General enacted. There was also no other obligation under intermational law, which could justify an impossibility to adhere to Belgian law. To the contrary; article 43 Hague Convention obliged the factual transfer of sovereignty and its corollary legislative powers on the occupied territory to the occupant. As a result, international law also precluded the Secretaries General from exercising Belgium's legislative powers contained in the 1.939 Statute. The Court might have had other practical or political reasons, but deviation from strict adherence to legal rules caused the Belgian courts to execute the occupant's policies contained in decrees illegally based on the 1939 Statute.

Besides the courts' powers of review there were other policies from the occupant that had an effect on the Belgian courts" functioning and position.

In cases of illegal possession of arms, where Belgian courts had some kind of concurrent competence with the German war tribunals and the occupant tried to exclude the Belgian competence, the courts intervened. The inability of the German police to prosecute all cases helped the courts and the public prosecutor service to negotiate via the Secretaries General to allow the Belgian courts to regain that competence at times. Also the refusal of the other Belgian authorities to investigate these cases if the Belgian courts were excluded from trying them was one of the main reasons why this competence would be handed back. However, the Belgian courts and authorities, on the basis of international law, took the position that Belgian courts should be allowed to try at least cases where only Belgian nationals were involved and the safety of the occupant's army or institutions was not directly threatened. If the Belgian courts had not taken this position the other Belgian authorities might have interpreted this as an endorsement to hand over these cases to the German authorities. The courts' refusal to accept being excluded from trying these cases must have influenced the other Belgian authorities' attitude, also believing the courts might consider this a violation of Belgium's penal provision prohibiting to hand over nationals to the enemy. International law was the basis with which the Belgian courts and the other Belgian authorities sought to avoid giving into the occupant's demands in the struggle over this competence.

The occupant used both the policies of arrest and hostage taking as a ways to intimidate the courts as regards their execution of the occupant's policies via application of the decrees of the Secretaries General. In cases where judges were arrested for ex officio acts, the Cou de cassation also interfered and succeded in persuading the occupant to reverse his decision on the basis of the arrested judges having acted within the confines of the law. For cases beyond the authority of their office, international law allowed for the removal from office and possible arrest and trial of judges. Nevertheless, at least in one such a case the Cour de cassation got involved and succeeded in persuading the occupant to reverse his decision. Also in the case of hostage taking, where the Cour de cassation only had varying success, the influence it lad on the occupant's policies was due to its insistence on applicable law. In how far the occupant's intimidation influenced individual nembers of the Judiciary when dealing with concrete cases is impossible to research. However, the occupant's policies of 
intimidation to influence the courts" functioning did not prevent the Cour de cassation, relying upon national or international law, to protest and occasionally and periodically reverse some of them.

The Cour de cassation's attempts to influence the occupant's policies would have been less credible and less effective without additionally threatening to suspend its duties. The Court's threat was based on international law, which obliged the occupant to refrain from interfering in the content of proceedings and allowed judges to resign from office in case of conscicntious objections to the occupant's policies. However, the credibility of this threat heavily depended on the Cour de cassation being able to command leadership over its subordinate courts. Undeniably the Cour de cassation assumed leadership for issues that affected individual judges at different levels of the judicial hierarchy and threatened the functioning of the courts. Certainly during the first judicial crisis the lower courts followed its supreme court's lead and deferred hearing cases based on decrees for which the legality was disputed. However, the outcome of the first crisus was a failure for the courts in that they lost their powers of review over measures the Secretaries General enacted. And after the first couple of days into the second judicial crisis, the Cour de cassation was the only remaining court still on strike. The Cour d'appel had resumed its duties and also other courts must not have understood what the strike was about, since international law allowed the occupant to order suspension of proceedings. Furthermore, once the Court resumed its duties, to the lower courts it must have seemed this happened without succeeding in getting a concession from the occupant. Two of the three arrested Brussels judges were not released until weeks later.

Both judicial crises seemed to have ended in failure for the courts, which must have diminished the credibility of the Cour de cassation to successfully invoke a threat to lead other courts into suspending their duties. Notably after the second judicial crisis the Court of course did invoke this threat in certain instances, but never actually suspended its duties anymore. Moreover, the regulation ordering the courts to apply the Romsée decree on agglomerations should have been cause for the Court to threaten to suspend its duties. The regulation prohibiting courts to exercise judicial review that was at the heart of the first judicial crisis was of a similar nature to this one and did prompt the Court to strike.

The Com de cassation's leadership also depended on whether the accupant would succeed in influencing personnel policy. If the occupant were to succeed in appointing his supporters to the Cour de cassation or the lower courts, it would also have impaired the Court's ability to exercise leadership and organize the suspension of dutes to reinforce its negotiating position with the occupant. The fact that the Belgian administration had found a legal basis in Belgian law for the appointment procedure during the occupation helped the courts. Subsequent Secretaries General of Justice were able to fend off too much interference of the occupant when vacancies occurred due to for example the abandonment of post and the drafting of judges into the army at the beginning of the occupation. The legal obligation to remain in office if not drafted into the army helped to avoid vacancies, but the courts were limited in their abilities to prevent vacancies and thus the temptation for the occupant to interfere in appointments. In cases where judges were removed from office for ex officio acts the Cour de cassation was able to interfere successfully. However, except for some cases, the Court could not do much when judges were removed from office for acts unrelated to the exercise of their office. Where judges had been removed from 
office on the basis of Jewish ancestry the Belgian courts' attitude was in stark contrast to the resistance the Cour de cassation put up for removal of judges for ex officio acts and is incomprehensible and inexcusable. Nevertheless, at least $72 \%$ of prewar appointees were still in office in 1946, indicating an even higher percentage of these Belgian judges had remained in office during the occupation.

With few exceptions the Belgian courts' most senior members, the Justices of the Cour de cassation and the Cours d'appel remained in office during the occupation. Aided by the fact that the occupant desisted in enacting a measure concerning early retirement due to a lack of suitable candidates to fill the vacancies, the Belgian courts' top members were able to assure its ranks remained closed. This allowed for the Cour de cassation's ability to exercise leadership and possibly organize a suspension of duties to reinforce the courts' negotiating position with the occupant.

Especially due to a legal framework the Belgian Legislator had created for the event of an occupation the Belgian courts were partly shielded from direct contact with the occupant's policies. The Cour de cassation's ability to lead the other courts also allowed for closed ranks and a strong negotiating position with the occupant. As some cases show, where they had to deal with the occupant's policies, a positivist attitude towards nationall and international law enabled the Belgian courts to resist mere compliance with the occupant's policies. In other cases, adherence to national and international law would have enabled courts to resist merely executing the occupant's policies if they had chosen to do so. Therefore, in strictly adhering to the law, Belgian courts had the opportunity to resist becoming a mere executive tool for the occupant's policies. 



\section{CHAPTER 3}

\section{THE LUXEMBOURG COURTS DURING THE OCCUPATION}

\section{1 'IN THE NAME OF THE PEOPLE'}

In spite of protests from Luxembourg judges and attomeys the Chef of the Civil administration in Luxembourg, Simon, ondered in late August 1940 that Justice should be done 'In the Name of the People" ${ }^{36 \%}$ This was contrary to article 49 Luxembourg Constitution, which prescribed that Justice had to be rendered 'In the Name of the Grand-Duke'. 570

International law did not provide any clear-cut answers on the subject. International treaty law, like the Hague Convention, did not have a provision dealing with this topic. Customary international law was ambiguous. Since occupation did not entail a transfer of sovereignty, this also meant in principle that Justice should be rendered in the name of the legitimate sovereign ${ }^{571}$ and could not be done in the name of the occupant. ${ }^{572}$ However, some jurisprudes acknowledged the possibility of finding a neutral formula, like having Justice rendered 'In the Name of the Law', as long as the courts' independence was recognized. ${ }^{573}$

The occupant's wish to have Justice rendered 'In the Name of the People' seemed to comply with international law, since this was a neutral formula. However, this was similar to the standard formula in the German Reich, where Justice was done "In the Name of the German People. ${ }^{574}$ This meant the formula was rather ambiguous and an acceptance could entail an acceptance of rendering Justice 'In the Name of the German People'. But in August 1940 this was not stated explicitly yet. Only in October 1941 the occupant would explicitly require the courts to render Justice 'In the Name of the German People'. ${ }^{775}$

Simon's intention with the formula "In the Name of the People" could have been clear from the beginning though. In Simon's opinion, after the flight of the Grand Duchess and her Government, the Luxembourg Constitution had ceased to

59 VoBI. Nr. 2 vom 24. September 1940, S. 6. See also Dostert, P., Verwaltung, po 14; Dostert. P., Selbstbehauptung, p. 77, 190; Majerus, Guerre, p. 35. Archives Nationales de Luxembourg, Tribunal d'arrondissement de Luxembourg Cote 3 C 61, p. 206a-249, p. 230.

$5 t$

Meurer, p. 240, Drooghenbroeck, p. 12 citing a report from a commission of the laternational Law Association on the principles of conduct of an occupant on occupied territory.

Rolin, Tome 1, p. 440-44I; Verraes, Tome I, p. 178; Oppenhein, War, p. 215.

Verraes, Tome 1, p. 178-179; Oppenheim, War, p. 215; François, p. 445.

See 1. Gesetz zur Oberleitung der Rechtsprechung auf das Reich vom 16. Februar 1934, Reichsgesetzblatt 1, 91. Its paragraph 1 detemined that courts in Germany had to render Justice 'In the Name of the Geman People'. However, before the Nazi administration had introduced this prowision the laws of the German States had required Justice to be rendered In the Name of the People:

See Chapter 3.9. See also Verordnung über die Einführung von Verfahrens- und Kostengesetzen in Luxemburg vom 18. Juli 1941, VoBl. 1941, S. 311. According to Archives Nationales de Luxembourg, Tribunal d'arrondissement de Luxembourg Cote $3 \mathrm{C}$ 61, Crimes de Guerre Affaire 37/49, Audience publique du 25 juin 1949, p. 94 this specific measure did not enter into force until 15 Octobier 1941. 
exist and Luxembourg civil servants now owed loyalty and allegiance to the Civil administration. On 27 August 1940, the same time the formula was introduced, Simon obliged all civil servants to sign a declaration of loyalty to him. ${ }^{576}$ Refusal to sign by 10 September would entail suspension from office, pending other unspecified measures. ${ }^{577}$ All judges, together with all other civil servants, signed the declarafion. ${ }^{578}$

Civil servants on an occupied territory are subordinated to the authority of the occupant ${ }^{579}$ and can be expected to swear an oath to obey the occupant's orders and not act to his prejudice. ${ }^{580}$ However, article 45 Hague Convention expressly prohibited an occupant to compel the inhabitants of an occupied territory to swear allegiance to the hostile power. The declaration of loyalty to Simon, as representative of the hostile power, was therefore contrary to international law.

In accepting to render Justice 'In the Name of the People' and declaring loyalty to the Chef of the Civil administration already at the beginning of the occupation, contrary to international and national law, the Luxembourg judges did not resist putting themselves in the service of the occupant. This was to the detriment of their service to the Grand Duchess and Luxembourg sovereignty.

\subsection{JUDICIAL ORGANIZATION}

As soon as the occupant had installed a Civil administration in Luxembourg, he started to assume control over the judicial organization of the Luxembourg courts. ${ }^{58}$

\footnotetext{
576 Wallerang: p. 56.

57 Majerus, Guerre, p. 33-35.

57 Propria Causa, p. 31.

57y Verraes, Tome I, p. 177-178; Rolin, Tome I, p. 452; Bordwell, p. 307.

5\$0 Spaight, p. 365-366; Beer Poortguael, p. 176-178; Oppenheim, War, p. 212; Verraes, Tome I, p. 179; Bondwell, p. 309 .

At the lowest trial court level for ciwlicommercial and criminal cases Luxembourg was divided into twelve different cantons in which a Court of the Peace was situated (Loi du 18 février 1885, sur l'organisation judiciaire, Mém. 1885, No. 23, p. 317-375. See also Loi du 15 octobre 1919, portant diverses modifications a la loi du 18 février 1885 sur l'organisation judiciare et a celle du 29 juillet 1913 sur la révision des traitements des fonctionnaires el employés de l'Etat, Mén. 1919, p. 1187-1189; Zwei Juristen, p. 3, 33-47; Holthöfer, p. 95-98). At the appeals level for civil/commercial cases Luxembourg was divided into two judicial districts that heard appeals from the 12 cantons, with one Tribusal for the district of Luxembourg and the other in the district of Diekirch (Fravenberg, p. 2; Majerus, Institutions, p. 46-50; Everling, p. 7-23). The civilicommercial appeals from the Courts of the Peace of Luxembourg. Esch, Remich, Capellen, Mersch and Grevenmacher went to the Tribunal darondisiement of Luxembourg; those from the Courts of the peace of Diekirch. Redingen Echtemach, Vianden, Clerf and Wiltz to the Tribunal in Diekirch (Zwei Juristen, p. 4). However, for some matters the Tribunaux would be a trial court.

The appeal conceming criminal cases would go to the Cour d'assises, which also had competence as a trial court regarding all serious offences. The Cour superieure (see infra) would assign 3 of its Justices as well as 3 from the Tribunam to serve at the Coum d'assises. Different to Belgium, there would be no jury (Fraumberg, p. 94)

Appeals from the Tribunowix were possible to the Cour superieure de Justice. The Cour superienre functioned as an ordinary appellate court as well as a cassation court (Articles 33 47 Loi du 18 février 1885 , sur l'organisation judiciaire, Mém. 1885, No. 23, p. 317-375. See also Loi du 15 octobre 1919 , portant diverses modifications a la loi du 18 février 1885 sur
} 
Hitler had authorized Simon to introduce Geman legislation conceming the administration of justice in Luxembourg, albeit in a form suitable to the Jocal circumstances.

Around August 1940 the Luxembourg Judiciary was attached to the circuit of the Higher Regional Court of Appeal in Cologne. The president of this German court, Bergmann, was instructed to take charge of the administration of the Luxembourg courts. ${ }^{583}$ This German president in effect replaced the President of Luxembourg's Cour superrieure, Gilissen, as head of the Luxembourg courts. ${ }^{584}$

The occupant had a duty to assure a proper administration of Justice, as well as to provide for an alternative to the national courts if the judges of the occupied country chose not to remain in office. ${ }^{585}$ Most international law jurisprudes also agreed that if the court system in the occupied country was operative, it should be left intact. $^{586}$ The occupant could take measures, though, to supervise the civil servants and therefore also the judges of the occupied state, ${ }^{57}$ but had to respect the courts' independence. $^{588}$

Practically the first measure the Chef of the Civil administration took as regards the administration in Luxembourg was to enact the language regulation. ${ }^{8 \%}$ Luxembourg had officially been bilingual French and German, although unofficially Lètzeburgesch or the Luxembourg language was also a lingua franca. However, for official purposes and governmental affairs French and German were used. Simon prohibited the use of Lëtzeburgesch ${ }^{590}$ and French, ${ }^{591}$ ordering the use of German as exclusive language, also for the administration of the courts.

l'organisation judiciaire et à celle du 29 juillet 1913 sur la révision des traitements des fonctionnaires et employés de l'Etat, Mén. 1919, p. 1187-1189). Its seat was in the city of Luxembourg (Goerens, p. 714). For cases of extreme gravity cassation was only possible before a plenary session of the court (Frauenberg, p. 37-51; Zweil Juristen, p. 59-61, 75-76).

The Cour superieure would hear in cassation civil/commercial and criminal cases (Frauenberg, p. 94) irrespective of which lower court's judgment was attacked and in all cases prescribed by law. Also complaints against judges, including those from the Cour superienre, belonged to its competencies.

5.2 Dostert, Pn Selbstbehauptung, p. 194.

38. Archives Parquet Général a la Cour Supérieure de Justice, Crimes de Guerre: Juges ef Procureurs allemands, Dossier A-II: Instruction générale Juges, Vernehmungsprotokoll Bergmann Alexander-Wilhelm vorm 6.4.1948, p. 18. See also Dostert, P., Selbstbehauptung, p. 190.

Annuare Officiel 1940, p. 87, 91 .

Meurer, p. 240-241;

Benwenisti, p. 16; Spaight, p. 357-358; Beer Poortugael, p. 175; Riolin, Tome 1, P. 441, 453; Oppenheim, War, p. 214 argued that there was no doubt the occupant may suspend judges, but then has a duty to appoint others in their place; Meurer, p. 237-238: Drooghenbroeck, p. 2, 10. Spaight, p. 361; Bordwell., p. 309; Rolin, Tome I, p. 449.

Oppenheim, War, p. 214; Verraes, Tome 1, p. 178, Drooghenbroeck, p. 2.

Verordnung über den Gebrauch der deutschen Sprache in Luxemburg vom 6. August 1940, VoB: 1940 , S. 1.

See also Dostert, P., Verwalung, p. 15 about the prohibition to use the Luxembourg language in October 1941.

Verordnung über das Verbot ces Gebrauchs der französischen Sprache in der Öffentlichkeit vom 1, Juni 1941, VoBl. Nr. 37 vom 10. Juni 1941, S. 240; Raths, Grand-Duché, p. 256; Dostert, P., Verwialtung, p. 16. 
According to an unconfirmed report, one Luxembourg court, which on special request would conduct proceedings in the Luxembourg language, had already been using German instead of French in June $1940{ }^{592}$ This was before the introduction of the Civil administration and its language regulation.

The language Regulation solicited public protests from the Administrative Commission, attorneys and civil servants. ${ }^{593}$ When the members of the Administrative Commission pointed out the language regulation was contrary to the Luxembourg Constitution the Chef of the Civil administration is reported to have replied: "I am the Constitution, I make legislation. ${ }^{1594}$

The President of the Luxembourg Tribunal, Paul Faber, supported by the President of the Luxembourg Bar Association Maurice Neumann, denounced the language regulation while his court was in session. ${ }^{595}$ After having opened the session on 12 August 1940, President Faber declared in German, with Justices Sevenig and Capus present on the bench, that the language regulation was contrary to the Hague Convention. Faber stated it was his duty to determine that the regulation was a violation of international law. Only through making this declaration he could have a clear conscience in applying it. ${ }^{596}$

The obligation to use German as the exclusive language of administration of course facilitated the occupant's control over the Luxembourg administration. However, under international law the occupant had a duty to protect an occupied country"s language. ${ }^{597}$ Furthermore, under article 43 Hague Convention it could neither be argued this was a public order measure nor that there was an impossibility for the occupant to respect the laws of the country. President Faber was the only member of the Luxembourg courts who protested, but he did not attach any consequences to his protest. Also, there were no immediate repercussions for his protest. ${ }^{598}$

President Bergmann of the Cologne court supervising the Luxembourg courts proposed to abolish the Cour supérieure and transfer all cases to the court in $\mathrm{CO}$ logne. Bergmann also proposed to merge Luxembourg's District Court with its German counterpart in Trier, but the German Reichsminister of Justice Schlegelberger

\$92 Archives Parquet Général à la Cour Supérieure do Justice, Crimes de Guerre: Juges et Procureturs allemands, Dossier A-II: Instruction générale Juges, Additions du I septembre 1948 atu tapport du 23 avril 1948 sur le mémoire de l'inculpé Bauknecht er à son complément du 21 mai 1948, Bericht des Inspekteurs der Sicherheitspolizei und des SD in Wiesbaden und Fïhrer des Sicherheitsstabes iber Maßnahmen und Verwalung in Luxemburg von 22. Julli 1940 , p. 17.

\$.3.3. Dostert, P., Besatzungspolitik, p. 378

Wehrer, p. 230: Dostert, P., Verwaltung, p. 13

sis. Raths, Grand-Duché, p. 257; Raths/Dostert, p. 59.

Archives Nationales de Luxembourg, Fonds Divers, Fonds Victor Bodson FD 094, No. 135, Rapport sur" le sort des magistrats et fonctionnaires des greffes et parquets depuis l"occupation, Auszug aus dem Sitzungsprotokoll der öffentlichen Sitzung (Feriensitzung) vom 12. Akgust 1940. der 1. Zivilkammer des Bezirksgerichts in Luxemburg

Verraes, Tome I, p. 181 .

Archives Parquer Général à la Cour Supérieure de Justice, Crimes de Guerre: Juges et Procureurs allemands, Dossier A-11: Instruction générale Juges, Bericht über die Versammlung vom 16. April 1941. 4 Uhr Nachmittags, Audienzsaal des Civilgerichts; Archives Nationales de Luxembourg. Aftaires politiques no. 385, Document 0056, Document 0065 . See also Majerus, Guerre p. 33; Als. G., p. 16. 
and a representative from the Civil administration, Münzel, countered Bergmann's plans. $59 \%$

Although the Civil administration objected to Bergmann's plans, it did enacted its own measures to re-organize the Luxembourg courts. Via regulation of 9 November 1940 the names of the courts were changed into the names of their German counterparts. ${ }^{\text {tik }}$ Luxembourg's lowest courts, the Courts of the Peace, were transformed into their German counterparts of Amtsgerichte or Cantonal courts and the two Tribunawx, one tier above, into Landgerichte or District Couts. However, Luxembourg"s Supreme Court, the Cour superiewre, was in essence abolished. Although allowed to remain in office, it was split up into separate chambers, which would henceforth function independently, have their seats in Luxembourg city and be called the Oberlandesgerichtliche Senate or Appellate Court"s Senates.

Initially the change of name was only a superficial measure and the Luxem bourg counts would still derive most their competencies from Luxembourg legislation. ${ }^{601}$ The regulation of 9 November 1940 nevertheless already obliged Luxembourg courts to try matters for which German courts were competent on the basis of German law. As legislation from the German Reich was gradually made applicable in Luxembourg from 1941 onwards, ${ }^{602}$ the courts were obliged to derive an increasing amount of competencies from German legislation as well. ${ }^{603}$

Even though these measures interfering with Luxembourg's judicial organization violated the international law obligation to leave the court system in the occupied country intact if it was operative, no official protest of the Luxembourg courts is known. No mention of any protest was found.

59. Dostert, P., Selbstbehauptung, p. 190, note 14. However, the case files in the Archives Parcuet Général à la Cour Supérieure de Justice, Crimes de Guerre: Juges et Procureurs allemands did not confirm this. Verordnung zur vorläufigen Regelung der Rechtspllege in Luxemburg von 9. November 1940, VoBl. Nr. 56 vom 15. November 1940, S. 297. See also Dostert, P., Verwaltung, p. 14. Münzel, p. 21; Dostert, P., Selbstbehauptung, p. 191.

602 See Chapter 3.8.

603 Verordnung über Strafmaßnahmen auf dem Gebiefe der Strafrechtspflege wom 4. Măr 1941, VoBl. Nr. 18 vom 4 März 1941, \$. 127.

Although the Greffe Cour Supérieure de Justice de Luxembourg, Registre anx délibérations 27-01-1938 - 15-05-1941mentioned the dismantling of the Cour superieure, no entry wass made concerning a protest. Furthermore, any Registre of the Oberlandergerichtiche Senate conceming the period 16-05-1941 until 13-09-1944 was lost. The Regristre of the Diekirch Tribural did not mention any deliberation on the topic (See Greffe Tribunal Diekirch, Registre aux déliberations du Tribunal d’arrondissement de Diekirch du 13 avril 1915 au 22 juin 1959). The Registre of the Luxembourg Tribunal was neither at the Tribunat itself (Author's Archive, lettre de M. le Procureur Gènéral d'Éat J.P. Klopp à Yuri Michielsen du 2 I má 2003) nor as part of the archives of the Luxembourg Tribunal at the Archives Nationales. Nei* ther the Archives Parquet Général à la Cour Superieure de Justice, Crimes de Guerre: Juges et Procureurs allemands nor the Archives Nationales de Luxembourg, Fonds Bodson, which provided references for other protests contained any reference to this issue. The archives of the occupant's administration in Luxembourg are lost (see also Dostert, Besatzungspolitik, p. 256). 


\subsection{MEASURES AGAINST LUXEMBOURG JUDGES OF JEWISH ANCESTRY}

On 5 September 1940 the Civil administration enacted the first measures specifically dealing with Luxembourg nationals of Jewish ancestry. ${ }^{605}$ Since the Administrative Commission was still in office in September 1940, it was charged with the execution of these measures. ${ }^{606}$

However, there were no judges at the Luxembourg courts with Jewish ancestry. ${ }^{607}$ except for one deputy Justice of the Peace who had left the country around the time of the invasion. Roger Cahen was a Justice of the Peace in Luxembourg in 1940,56 who emigrated to the United States before or soon after the outbreak of war, became a US citizen and changed his name to Roger Carter. ${ }^{609}$

Since the one member of the Luxembourg courts of Jewish ancestry had left the country before the occupation, no regulation was enacted dealing with the removal from office of Luxembourg judges of Jewish ancestry.

\subsection{LIMITATION OF COMPETENCIES}

On 20 August 1940 a Special Tribunal was established, which could try cases retroactively. ${ }^{60}$ A specific competence was granted in that the Special Tribunal could try matters concerning public order, as well as censorship of anti-German expressions. However, from the beginning of the occupation a general criminal competence was granted as well, which allowed the occupant, at any time, to circumvent the Luxembourg courts. The public prosecutor could bring any criminal case to the Special Tribunal, for which it would then be competent. ${ }^{611}$ Once the occupant would gain control over Luxembourg"s public prosecutor office, he would decide whether a case would be brought before the Luxembourg courts or whether they would be excluded from trying this case.

In spite of this general competence, during the course of the occupation, the Special Tribunal was granted additional specific competencies, to the exclusion of the Luxembourg courts. ${ }^{612}$ These included criminal acts against the German Reich and the NSDAP, illegal possession of arms, sabotage, listening to enemy broadcasts and high treason. 13 so for economic crimes the Special Tribunal and not the Luxembourg courts would be given competence. ${ }^{614}$

Fiilis

These measures mainly dealt with matriage laws and property. See Verordnung über Masnahmen auff dem Gebiete des Judenrechts vom 5. September 1940, VoB1. 1940, S. 10; Verordnung über das jürdische Vermögen in Luxemburg vom 5. September 1940, VoBl. 1940, S. 11 See also Majents, Guerre, p. 38.

Hohengarten, p. 30

6ostert, P., Selbstbehauptung, p. 193

Annusine Officiel 1940, p. 102

Information from judge Francis Delaporte, son of judge François Delaporte, who was a judge at the Luxembourg Thibunal in 1940.

Verordnung über die vorläufige Einriching einer deutschen Strafrechtspflege in Luxemburg,

VoBI., Nr. 1 vom 1. September 1940, S. 2. See also Ratisidoostert, p. 57.

Ibid, paragraph $2($ b).

Dostert, P., Selbstbehauptung, p. 190 and footnote 20.

Verordnung gegen heimtickische Angriffe auf das Deutsche Reich, die Partei und Beweging vom 15. Januar 1941, VoB1. 1941, S. 48;2. Verordnung uber heimtïckische Angriffe auf das Deutsche Reich. die Partei und Beweging vom 14. Oktober 1941, VoB1. 1941, S. 414; 
Most of the more important criminal cases had therefore been excluded from the competencies of the Luxembourg courts. Furthermore, due to the grant of a gereral competence, in principle already from August 1940 onwards, Luxembourg courts could at any time be circumvented.

\subsection{APPOINTMENTS; GERMAN JUDGES IN LUXEMBOURG COURTS}

Initially the Administrative Commission had been authorized to proceed with the Grand-Duke's powers of appointments to public office. ${ }^{6 / 5}$ Via Resolution of Prallament the Administrative Commission could exercise all governmental powers concerning the appointment, removal from office and retirement of all judicial officers, including those at the courts. ${ }^{616}$

On 15 August 1940 Gauleiter Simon accorded himself the right to appoint Luxembourg officials retroactively from 10 May 1940. Any kind of judicial recourse against his decisions was excluded. ${ }^{67}$ Subsequently Simon enacted a regulation, which stipulated that those authorized under German law to exercise judicial office would also be authorized to exercise this office in Luxembourg.

The German supervisor of the Luxembourg Judiciary and President of the Higher Regional Count of Appeal in Cologne selected judges with German nationality to exercise office in Luxembourg. The Chef of the Civil administration subsequently made the appointment, whereby a consultation of the person involved did not seem customary. ${ }^{619}$ Ordinarily these German judges, besides being appointed to Luxembourg courts, also served at tribunals the occupant had established in Luxembourg. ${ }^{620}$ Most German judges were recruited from the court in Trier, ${ }^{621}$ just across

Verordnung betreffende Malßnahmen auf dem Gebiete der Strafrechtspflege von 30 . Mai 1941, VoBL. 1941, S. 247; Verordnung zur Wahrung des inneren Friedens in Luxemburg vom 13. Oktober 1941, VoBI. Nr. 68 vom 18. Oktober 1941, S. 413; Verordmung über Waffenbesitz in Luxemburg vom 13. Oktober 1941, VoB1. 1941, S. 418; 2. Verordnung über Waffenbesitz in Luxemburg vom 24. Juni 1943, VoBI. 1943, S. 145; Verordnung zur Abwehr verväterischer Bestätigung in Partei und Bewegung vom 31, Oktober 1941, VoB1. 1941, S. 469: 4. Verordnung betreffende Maßnahmen auf dem Gebiete der Strafrechtsptlege vom 31. Oktober 1941, VoBl. 1941, S. 483; Verordnung über Maßnahmen gegen Wehrpflichtentziehung vom 10. Juli 1943, VoBI. 1943, S. 152.

Verordnung über Strafen und Strafverfahren bei Zuwiderhandlungen gegen Preisvorschriften (Preisstrafrechtsverordnung) vom 4. März 1941, VoBl. 1941, S. 135.

Fil.5 See also Reiland.

6.tt Résolution wotée par la Chambre des députés, le 11 juillet 1940 , conférant à la Commission administrative le droit de procéder atx nominations, démissions et mises à la retraite des magistrats, fonctionnaires et agents publies, Mém. 1940, No. 44, p. 497-498.

6i] Verordnung über Maßnahmen auf dem Gebiete des Beamtentechts vom 15. August 1940 , VoBl. Nr. 1 vom 1. September 1940, S. 2. See also Majerus, P., Guerre, p. 34, 38.

six Paragraph 4 Verordnung zur vorläufigen Regelung der Rechtspflege in Luxemburg vom 9. November 1940. VoBI. Nr. 56 vom 15 . November 1940, S. 297.

614 Archives Nationales de Luxembourg, Tribunal d"arrondissement de Luxembourg Cole $3 \mathrm{C} 61$, p. $206 \mathrm{a}-249$, p. 228.

fon Archives Parquet Général à la Cour Supérieure de Justice, Crimes de Guerre: Juges et Procureurs allemands, Dossier A-II: Instruction générale Juges, Vernehmungsprotokoll Fuhr Errnst wom 10.6.1947, p. 1; Archives Panquet Général à la Cour Supérieure de Justice, Crimes. de Guerre: Juges et Procureurs allemands, Dossier A-II: Instruction genérale Juges, Vernehmungsprotokoll Lütcke Walther wom 5.6.1947, p. I. 
the border from Luxembourg in Nazi-Germany, later the Gau Moselland, into which Luxembourg would be incorporated. ${ }^{622}$

At the level of the Appellate Court's Senates, the former Cour superieure, which on 10 May 1940 contained 11 Justices, ${ }^{623}$ six Justices with German nationality were appointed during the occupation. ${ }^{624}$ Also six judges of German nationality were appointed to the District Court, which was the former Tribunal level. ${ }^{625}$ At both the Luxembourg and Diekirch Tribunater together 19 judges and 7 deputy judges had held office on $10 \mathrm{May} 1940^{626}$ At the Court of the Peace level out of 13 Justices of the Peace and 22 acting Justices of the Peace in office before the occupation, ${ }^{627}$ three Justices of the Peace of German nationality were appointed during the occupation. ${ }^{628}$ Due to the fact that once the occupation progressed an increasing amount of Luxembourg judges would be removed from office, ${ }^{629}$ German judges came to be a dominant force within the Luxembourg courts.

The occupant's hold over the Luxembourg courts was strengthened since Bergmann, the German supervisor of the Luxembourg courts, also decided upon which courts Luxembourg and German judges would be assigned to or in which chamber they would serve. ${ }^{630}$ From the very few copies of judgments rendered during the occupation ${ }^{63 t}$ and publicly available ${ }^{6.32}$ judges of Luxembourg nationality

(42)

Archives Parquet Gencral à la Cour Superienre de Justice, Crimes de Guerre: Juges et Procureurs allemands, Dossier A-II: Instuction généralle Juges, Vemehmungsprotokoll Bergmann $A_{L}$-W vom 7.6.1947.

Archives Parquet Genétal à la Cour Supérieure de Justice, Crimes din Guerre: Juges et Procureurs allemands, Dossier A-Il: Instruction générale Juges, Vemehmungsprotokoll Fuhr Ernst vom 10.6.1947, p. 1. See also Wallerang, p. 59; Dostert, P. Selbstbehauptung, p. 193. Amuaire Officiel 1940, p. 91.

Archives Parquet Gênéal à la Cour Superieure de Justice, Crimes de Guerre. Juges Procureurs allemands, Dossier B-rX Rapport Géneral Beffort concemant les affaires des anciens magistrats allemands inculpés de crimes de guerre du 1 décembre 1947, p. II/54, II/62, I1/84, $1189,11 / 106$ and $11 / 112$.

Anchives Parquet Géneral à la Cour Supérieure de Justice, Crimes de Guerre: Juges et Procureurs allemands, Dossier B-IX Rapport Genéral Beffort concemant les affures des anciens mithistrats allemands inculpés de crimes de guerre du 1 décembre 1947, p. 11172, 11/93, 11/97, 1//102, II/106 and I//109. NB The list of judges mentioned seemed axhaustive, since those wethe ones prosecuted after the occupation for having served at Luxembourg courts.

Annuatre Officiel $1940, p, 95-96$

Anmuare ofticiel 1940, p. 100-104.

Archiwes Parquet Genénal a la Cour Supérieune de Justice, Crimes de Guerre: Juges et Procurens allemands, Dossier B-IX Rapport General Beffont concernant les affaines des anciens magistrats allemands inculpés de crimes de guerre du 1 décembre 1947, p. 11/106.

See Chapters $3.6,3.7$ and 3.9

Arohives Parquet Genéral a la Cour Superieure de Justice, Crines de Guerre: Juges at Procureuts allemands, Dossier A-II: lnstruction génerale Juges, Vernehmungsprotokol Bergmann
Alexander-Wilhelm wom $6,4,1948, \mathrm{p}, 23$.

Conseil Nathonal de ta Resistance, Archives personeltes de M. le President P. Dostert, Collection de jugennents, Urteil des Amtsgerichts vom 28\%10-1943, 3 Ds. 201/43; Stratsache gegen $1941,6 \mathrm{~K} . \mathrm{Ms} .8 / 41,1.315 / 41$. Us. 7/42, 1. 100/42; Strafsache gegen R. und B. von 18-11. B. vom 1-4-1944,3 Ds. 91/44, Unteil des Amtgeriohts in Luxemburg in der Strafsache gegen प̈. vom I 8 . Materz 1944, 3 Ds, 72/44.

No acoss was granted to cases the Luxembourg courts or the analagous jurisdiction estab-
lished by the occupant had decided during the occupation. 
seemed to have been in a minority when trying a case. Judges of Cerman nationality were in the majority or sole judge trying a case.

From February 1941 onwards, the Civil administration also considered delegating Luxembourg judges to the Special Tribunal it had established in Luxembourg. Whether any Luxembourg judges were active at this German Special Tribunal is not completely clear. It appears that a small number of Luxembourg judges, ${ }^{6,4}$ probably one or two, ${ }^{63}$ had expressed interest. Refusal on the part of the great majority of Luxembourg judges ${ }^{636}$ and the Civil administration's lack of trust of the Luxembourg judges seems to have prevented actual appointments of Luxembourg judges to this German Special Tribunal. ${ }^{67}$ Another reason was that German officials were of the opinion that Luxembourg judges were too lenient in sentencing, "which also meant Luxembourg judges could still decide on cases without their German counterparts.

Lack of trust, and possibly lack of necessity due to the small size of the Luxembourg Judiciary, meant that most probably hardly any new judges of Luxembourg nationality were appointed during the occupation. One case was found in which a former Luxembourg Justice of the Peace accepted a new appointment during the occupation to the now Cantonal Court of Esch. ${ }^{639}$ However, few if any Luxembourg judges who remained in office received a promotion or accepted one from the hands of the occupant. ${ }^{640}$ In at least two cases during the occupation a Luxembourg judge was transferred to a court in Germany. The Luxembourg judges were sent to a criminal chamber at a Cologne court and a labor court in Cologne. ${ }^{\text {inl }}$ Furthermore, Aloyse Müller, a long-time member of the Cour superietwe, ${ }^{642}$ accepted from the occupant an additional office as acting President of the Luxembourg District Court or former

63. Archives Nationales de Luxembourg, Tribunal d'arrondissement de Luxembourg Cote $3 \mathrm{C} 61$, p. $206 \mathrm{a}-249$, p. 227.

6:34 Archives Parquet Général à la Cour Supérieure de Justice, Crimes de Guerre: Juges et Procureurs allemands, Dossier A-II: Instruction générale Juges, Vernehmungsprotokoll Bergmann Alexander-Willuelm vom 6.4 .1948 , p. 27.

635. Archives Parquet Général à la Cour Supérieure de Justice, Crimes de Guerre: Juges et Procureurs allemands, Dossier A-II: Instruction générale Juges, Vernehmungsprotokoll Bauknecht Otto vom 13,04. 1948, p. 11 and Dossier A-II: Instruction générale Juges, Copy of letter from 6 January 1948 from Dr. A-W Bergmann to the Militär Auditeur G. Schommer.

6. Archives Parquet Général à la Cour Superieure de Justice, Crimes de Guerre: Juges ef Procureurs allemands, Dossier A-II: Instruction générale لuges, Vernehmungsprotokoll Bergmann A-W vom 7.6.1947.

(a) Archives Parquet Général à la Cour Supérieure de Justice, Crimes de Guerre: Juges of Procureurs allemands, Dossier A-II: Instruction génerale Juges, Vernelmungsprotokoll Bauknecht Oro vom 13.04 .1948 , p. 11 .

6: Archives Parquet Général à la Cour Supérieure de Justice, Crimes de Guerre: Itges et Proculreurs allemands, Dossier A-II: Instnction générale Juges, Vernehnungsprotokoll Bergmann Alexander-Wilhelm vom 6.4 .1948$, p. 21 .

69. Démission honorable par arrete Grand Ducal le 7 mai 1940 enu vue de sa nomination comme greffe à la Chambre des députěs, Mém. 1940, p. 339; Archives Nationales de Luxembourg. Justice de Paix Esch s/Alzette 1941, No. 204 Beamtenpflichten, Brief rom 9. August 1941 won Lutcke am Richter des Amrsgerichtes Esclv/Alzig, B 494, p. 19.

6rate Dostert, P. Selbstbehauptung. p. 191.

6.4 Archives Parquet Général à la Cour Superieure de Justice, Crimes de Guerre: Juges et Procu-

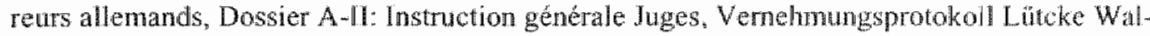
ther vom 5.6.1947, p. 4 and Archives Nationales de Luxembourg. Tribunal d"artondissement de Luxembourg Cote 3 C 61, p. 206a-249, p. 228.

Amnuaire Officiel 1938, p. 85, Annuaire Officiel 1940, p. 91 
Tribunal at the end of May $1941 .{ }^{\text {tas }}$ Muller took the place of Paul Faber, who in May 1941 would be removed from office and deported. ${ }^{644}$

The measures the Chef of the Civil administration took as regards the appointment of German judges to Luxembourg courts were contrary to international law. Not only did international law require the occupant to leave the court system intact if it was functioning, ${ }^{645}$ the appointment of foreign nationals directly violated Luxembourg's existence as a sovereign State, since foreign nationals would exercise Luxembourg"s State power. Although article 43 Hague Convention provided for a factual transfer of sovereignty of the occupied State to the occupant, the occupant's exercise of that sovereignty was limited to measures of public order. The occupant could supervise the courts of the occupied country ${ }^{646}$ and deprive them of some of their competencies. ${ }^{647}$ He even had a duty to replace the courts of the occupied country altogether if they did not function anymore. 648 However, no rule of international law allowed the occupant to appoint his own nationals to exercise judicial powers in the courts of the occupied State.

Although contrary to international law, no protest of the Luxembourg judges against appointment of German nationals to their courts was found. In practice the splitting up of the Cour superieure and the appointment of German judges directly to Luxembourg's courts will have rendered more difficult an effective organization of Luxembourg judges. Moreover, the small size of Luxembourg's judiciary, which included 76 judges and deputy judges ${ }^{649}$ meant that the occupant could easily replace all Luxembourg judges with German judges.

\subsection{IDEOLOGICAL. TRAINING}

In order to influence the Luxembourg judges handling of cases and 'germanize' them, all Luxembourg judicial officers were subjected to ideological courses. ${ }^{650}$ A lot of these trainings were held in Koblenz-Mettemich. ${ }^{651}$ The first one lasted three weeks and ended at the beginning of October 1940 . Four different groups were sent for three weeks each. A couple of days later the second training already started. ${ }^{65}$

According to a German report the encounter with National Socialism had had a devastating as well as a cleansing and an untangling effect on the Luxembourg law-

(4.).1.

trith

(⿻)

Luxemburger Wort vom 30. Mai 1941.

See Chapters 3.5 and 3.9.

See Chapter 3.2. See also Verraes, Tome 1, p. 180 who clamed the occupant was not allowed to change the judicial organization. See Meure, p. 240-241; Rolin, Tome 1, p. 437.

See Chapter 3.2.

See Chapter 2.4

Spaight, $\mathrm{p}$. 358; Beer Poortugael, p. 175; Oppenheim, War, p. 214.

See ANNEX 5

Dostert, P., Sellostbehauptung, p. 191. Archives Nationales de Laxembourg, Tribunal d'arondissement de Luxembourg Cote $3 \mathrm{C} 61$,
p. $206 \mathrm{a}-249$, p. 227 .

Bundesarchy Berlin, Reichsministerium der Justiz $\mathbb{R} 3001$, Bericht über die Reise des Herm Stanatssekretärs Dr. Schlegelberger nach dem ElsaB, Lothringen und Luxemburg in der Zeut vom 2. bis 8.12.1940, p. 10-11. 
yers. ${ }^{653}$ The German reports of these meetings presented the Luxembourg judges as eager to learn about Nazi-German law. ${ }^{6.54}$

In the Spring of 1941 these ideological trainings for all lawyers were completed. From the beginning of 1941 onwards, different professional groups of lawyers would be subjected to specific trainings pertaining to the exercise of their profession. ${ }^{655}$ After the introduction of German laws in Luxembourg from the beginning of 1941 onwards $^{656}$ more trainings were held to acquaint Luxembourg judges with these foreign laws. Furthermore, as part of the contimuing effort to nazify the mindset of the Luxembourg judges, the purchase and lecture of Hitler's 'Mein Kampf' was made compulsory on 1 June $1942 .{ }^{657}$ Judges had to swear to have read the book by September $1.6 \%$

However, the Germans had to admit that their efforts to change the mindset of Luxembourg judges were failing. Although some lawyers were more open to the training than others, the Germans found that Luxembourg lawyers were less able to pierce into the spirit of the legal texts and rather clung to a more formalist approach to law. The Germans conceded that it would take great effort to acquaint the Luxembourg judges with the German work methods. ${ }^{659}$

\subsection{REGULATION CONCERNING STATUTORY AGE LIMIT}

In October 1941 Gauleiter Simon enacted a regulation conceming early retirement of civil servants. ${ }^{66}$ Those civil servants, including judges, who had reached or would reach the age of 65 were to be retired. Similar to regulations concerning early retire-

653 Archives Parquet Général à la Cour Supérieure de Justice, Crimes de Guerre: Juges et Proculreurs allemands, Dossier A-II: Instruction générale Juges, Additions du I septembre 1948 an rapport du 23 avril 1948 sur le mémoire de l'inculpé Bauknecht et à son complément du 21 mai 1948, Meldung vom 10.10.1940 vom SS-Oberscharführer Knebel an den SD Abschnitt Koblenz, p. 18.

654 Archives Parquet Génêral à la Cour Supérieure de Justice, Crimes de Guerre: Juges et Procur reurs allemands, Dossier A-II: Instruction générale Juges, Additions du I septembre 1948 au rapport du 23 avril 1948 sur le mémoire de l'inculpé Bauknecht et à son complément du 21 mai 1948, Melding vom 10.10.1940 von SS-Oberscharfihrer Knebel an den SD Abschnitt Koblenz, p. 18; Meldung wom 12.11.1940 wom S5-Oberstumfïhrer Grünzfelder an den SSAbschnitt Koblenz, p. 20.

655 Münzel, p. 19-20.

650 See Chapter 3.8 .

657 Archives Nationales de Luxembourg, Tribunal d arrondissement de Luxembourg Cote $3 \mathrm{C} 61$. Crimes de Guerre Affaire 37/49, Audience publique du 25 juin 1949, p. 94; See allso Archives Parquet Général a la Cour Supérieure de Justice, Crimes de Guerre: Inges et Procureurs allemands, Dossier A-II: Instruction générale Juges, Vernehmungsprotokoll Liilcke Walther vom $5.6 .1947, \mathrm{p} .2$, though the exact date is not mentioned here.

6.58 Archives Nationales de Luxembourg, Justice de Paix Esch s/Alzette 1941, No. 204 Beamtenpflichten, Brief vom 20. Mai 1941 vom Landgerichtsdirektor Lütcke und Oberstaatsanwalt Hofmann am stellvertretenden Präsidenten des Oberlandesgerichtlichen Senates und Staatsanwalt, p. 17.

6.59 Bundesarchiv Berlin, Reichsministerium der Justiz R3001. Bericht über die Reise des Hern Staatssekretärs Dr. Schlegelberger nach dem Elsaß, Lothringen und Luxemburg in der Zeit vom 2. bis 8.12.1940, p. 10-11.

2. Verordmung über Maißnahmen auf dem Gebiete des Beamtenrechts vom 28. Oktober 1941, VoBl. 1941, S. 458. 
ment in Belgum and The Netherlands, ${ }^{6,2}$ exceptions could be made for individual cases. However, different from Belgium and The Netherlands no pretext conceming a rejuvenation of the civil servant apparatus was used.

This measure was contrary to Luxembourg law, where judges of the Tribunaux and Justices of the Cow superiewe, but not the Courts of the Peace would be appointed for life, limited to the age of $72{ }^{663}$ The regulation on early retirement also violated international law. Firstly, the occupant had to leave the courts in the occupied country, including their staffing, intact, if they were still able and willing to function. ${ }^{664}$ Furthermore, article 43 Hague Convention limited his powers to public order measures and this regulation could not be seen as such. This measure was applied to a maximum of eight Luxembourg judges, though the exact number is unclear, since this included public prosecutors. ${ }^{65}$ Whether the Luxembourg courts, or the judges who were still in office protested, pointing out a violation of international or national law, is unknown.

\subsection{INTRODUCTION OF GERMAN LAW INTO THE LUXEMBOURG LEGAL SYSTEM; JUDICLAL REVIEW?}

Hitler left it to Gauleiter Simon to decide on the pace of introduction of German law in Luxembourg and Simon did not wait long. Already from the beginning of his administration over Luxembourg the Chef of the Civil administration started introducing parts of German law directly into the Luxembourg legal system. Simon would use his regulatory powers to declare that certain parts of German law would henceforth have to be applied in Luxembourg. Therefore, German law was as such made directly applicable in Luxembourg. ${ }^{66}$ Its introduction nevertheless seemed to be based more on political expedience than a pre-determined plan for the nazification of Luxembourg, ${ }^{60 \text { ? }}$ considering the fact that no system can be discerned from those German laws that were introduced.

Initially German provisions concerning the organization of the economy were introduced. ${ }^{6}$ Geman tax laws were made applicable at the beginning of January $1941 .^{669}$ At the end of January 1941 several provisions from German civil law were

tis 1

(nithes.

$4: 3$
See Chapter 2.6.

See Chapter 4.6.

Article 91 Laxembourg Constitution of 17 October 1868 as modified by the Acts of Parliament of 15 May 1919; Article 179 Loi du 18 février 1885, sur l'organisation judiciaire, Mém. 1885, No. 23, p. $317-375$.

Benvenisti. p. 16; Spanght, p. 357-358; Beer Poortugael, p. 175; Rolin, Tome 1, p. 437, 441, 453: Oppenheim, War, p. 214 argued that the occupant may suspend judges and has a dury to appoint others in their place, but does not mention that the occupant may change the judicial organization: Meurer. p. 237.238. See also Chapter 3.2 .

See Chapter 3.11.

See also Dostert, P., Selbstbehauptung, p. 189

See also Miinzel, p. 21.

See e.g. Verordnung über die Einführung und Anwendung reichsrechtlicher Vorschriften auf dem Gebiete der Forst- und Holzwirtschaft in Luxemburg vom 25. November 1940, VoBl. 1940, S. 361.

Verordmung über Anwendung von steuerrechtichen Vorschriften in Luxemburg vom 31.

Dezember 1940, VoBL. 1940, S. 560. See also Dostert. H., p. 1. 
introduced, most notably German maniage and divorce laws. ${ }^{67}$ For all other civil law matters Luxembourg courts would render a judgment on the basis of Luxembourg law until the spring of $1942 .^{671}$ In March 1942 the whole German Civil Code would be introduced, as well as German company law and parts of commercial law. ${ }^{672}$

Very disparate German criminal laws were enacted from the spring of 1941 onwards $^{673}$ and in August and September more German criminal laws were introduced in Luxembourg. "Several regulations dealt with the prohibition to listen to foreign radio stations, the above-mentioned one about high treason and others. ${ }^{675}$ Some regulations went beyond introducing new penal provisions and sought to modify the legal foundations of Luxembourg's penal system. Provisions occurring in the German Penal Code, but not in the Luxembourg one, were added to the latter ${ }^{6}$.

From early 1941 onwards Simon inserted the analogy of penal provisions, retroactive effect, the attempt to commit a crime and the uncertainty of criminal provisions (umbestimmtheit der Straftabestände) into Luxembourg penal law. ${ }^{67}$ The provision granting retroactive effect was comparable to a regulation that would be introduced in The Netherlands $^{678}$ about two years later and a direct violation of the mulla poena principle. Also the analogy of penal provisions, making an act punishable if not punishable on the basis of a criminal provision, but according to its basic underlying idea and were punishable according to a 'healthy sense of people's justice' would later on be introduced in The Netherlands. ${ }^{679}$

However, two days before Christmas in 1941 the Gauleiter introduced a regulation, ${ }^{680}$ which simply stated that the whole German Penall Code, as well as some other German criminal laws, would enter into force in Luxembourg and would be applicable to Luxembourg nationals. Luxembourg penal provisions dealing with the same

670 Verordnung über die Einführung reichsrechtlicher Vorschriften auf dem Gebiet des Personenstands- und Eherechts vom 31. Januar 1941, VoBl. 1941, S. 118; Verordnung zur Durchfuihrung und Ergänzung der Verordnung über die Einfülurung reichsrechthicher Vorschriften auf dem Gebiet des Personenstands- und Eherechts vom 31. Januar 1941 vom 22. März 1941, VoBl. 1941, S. 162.

Archives Parquet Genéral à la Cour Superieure de Justice, Crimes de Guere: Juges at Procumreurs allemands, Dossier A-IV Instruction générale, Audition des témoins, Zeugenvernehmung Meynen Walter am 1 . Februar 1948, p. 2 .

Verordnung über die Einfuilhrung deutschen bügerlichen Rechts sowie zur Ergänzung vom 18.7.1941 über die Einführung von Verfalurens- und Kostengesetzen in Luxemburg vom 15. Mär 1942, VoBl. 1942, S. 624.

6n3 See e.g. Verordnung zur Einfuhrung einer Schlachtviehmarktregelung in Luxemburg von 30. Mai 1941, VoB1. 194II, S. 590.

in?4 Raths, Grand-Duche, p. 257 .

6.75 Verordnung betreffende das Abhören von Rundfunksendern vom 16. September 1940, VoBl. Nr. 2 vom 24. September 1940, S. 14, 4. Verordmang betreffende Maßnalmen auf dem Gebiete der Strafrechtspflege vom 31. Oktober 1941, VoBl. Nr. 75 vom 12. November 1941, S. 483. See also Chapter 3.4. See also Dostert, P., Selbstbehauptung, p. 194. Verordnung über Maßnahmen auf dem Gebiete der Strafrechtspflege vom 4. März $194 \|$, VoBI. Nr, 18 vom 4. Marz 1941, S. 127. vom 31. Dezember 1941, S. 544. 
matter were repealed. In case of a conflict between previous legislation of the Chef of the Civil administration and the newly enacted German laws the measures of the Civil administration would take precedent.

The Military administration had already published an opinion concerning legal provisions. This opinion stated that during the occupation the occupant would be competent to enact decrees with the force of law, which would be hierarchically superior to Luxembourg legislation. Luxembourg legislation would remain in force as long as not contrary to the aims of the occupation. ${ }^{682}$ The fact that according to the Civill administration its measures would in legal hierarchy trump German law meant that legally Nazi-Germany had still not annexed Luxembourg. However, the Civil administration was rapidly replacing $L$ uxembourg legislation with its own or German legislation.

For lack of published court cases during the occupation ${ }^{683}$ and the refusal of Luxembourg authorities to allow an examination of case law in the archives of the Luxembourg courts, it is impossible to deternime the reaction of the Luxembourg courts to the occupant's measures and the introduction of German law.

\subsection{PUSH WOR INTEGRATION OF LUXEMBOURG COURTS INTO THE GERMAN JUDICIAL SYSTEM}

A delegation of Luxembourg judges had a meeting with Dr. Lütcke, the depury of the German supervisor of the Luxembourg Judiciary, on 17 March 1941. The Luxembourg delegation consisted of Justice Nocké ${ }^{644}$ from the Appellate Court's Senates or former Cour supérieure, President Hansen from the Diekirch District Court and President Faber from the Luxemboutg District Court, both formerly Tribunaux. ${ }^{655}$

The meeting was probably a reaction against the Civil administration's intent to enact a regulation, requiring all Luxembourg civil servants, including judges, to give the appearance of being German civil servants. Those who did not give this appearance during and after office hours of an exemplary exercise of a German attitude would be suspended. The suspension would be awaiting other measures. The latter could of course mean a trial before the Special Criminal Tribunal. However, civil servants were also warned that in the interest of public service an appointment to a clifferent office of equal or lesser rank was possible. Furthermore, Gauleiter Simon would also be allowed to grant vacation, a transfer to a different public office or even dismoissal. His decision could not be appealed before the ordinary or administrative counts.

For Luxembourg judges this meant that a transfer to a different office and removal from office would be possible via mere decision of the occupant. In August 1941 the occupant transferred at least five judges from the former Luxembourg Tri-

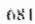

Partagrah 11,5. Verordnung betreffende Mafnahmen auf dem Gebiete der Strafrechtspllege,

Majeris, p. 23.

7.He Lux
pation

On Justice Nocké see Situmper.

An: Archives arquet Géneral ă Cour Superieure de Justice, Crimes de Guerre: Juges et Pracureurs allemands, Dossier A-I1; Instruction genérale Juges, Bericht über die Versammlung vom 16. April 1941.4 Uh Nachmittags, Audienzsal des Civilgerichts.
} 
bunal and one from the now abolished Diekirch Tribunat to the Esch Cantonal Court. ${ }^{697}$ Moreover, Luxembourg judges could not only be moved to a different public office in Luxembourg, but also in Germany. It is possible that this happened to the two judges mentioned earlier, that were transferred to Germany to take up office at courts in Cologne. 688

Although under international law the occupant had some powers to remove civill servants, including judges from office, ${ }^{t}$ article 43 Hague Convention also prescribed the occupant to respect the laws of the occupied country unless otherwise prevented. Furthermore, international law required an oceupant, if he made use of the courts of the occupied country, to respect their independence ${ }^{5}$ (s) Luxembourg's Constitution, under article 91, did not allow for a Tribunal judge's transfer to a different office, unless a new appointment were made and the judges in question consented.

During this meeting in March 1941 the Luxembourg judges were forewarned of the introduction of German penal law and also the de facto Nazi-German annexation of Luxembourg was announced. Notably as part of this de facto annexation German penal law would be introduced in Luxembourg. The Luxembourg judges would also be told that no one would be allowed to remain in office if not a member of the Volksdeutsche Bewegung (VdB), ${ }^{691}$ Luxembourg"s Nazi movement, and that passive resistance would not be tolerated. ${ }^{692}$

The Luxembourg judges submitted their misgivings concerning the occupant's envisaged measures and a possible resulting reshuffle within the Luxembourg Judiciary. The representative of the Civil administration was informed of the principle of irremovability for Luxembourg judges. Furthermore, President Faber also underlined the conflicts of conscience for the Luxembourg judges concerning the obligation to join the VdB and the planned overhaul of the Luxembourg court system, which he considered contrary to international law

Subsequently Bergmann, the German appointed head of the Luxembourg courts, scheduled a second meeting, this time including all Luxembourg judges, at the Palace of Justice for 16 April 1941. The representatives of the Civil administration replied to the objections the delegation of Luxembourg judges had put forward earlier against the occupant's plans. All Luxembourg judges still in office were present, as well as the German supervisor of the Luxembourg Judiciary, Bergmann, and his two depuries.

One of his deputies, Dr. Lütcke, although rather sympathetic to the Luxembourg judges" plight, was of the opinion that the oath of loyalty of the Luxembourg judges

\footnotetext{
ssis See infra.

68. Archives Nationales de Luxembourg, Justice de Paix Esch s/Alzette 1941, No. 204 Beamtenphlohteru. Brief vom 9. August 1941 von Lüted an Richter des Amtsgerichtes Esch/Alzig. B 494, p. 19.

dse See Chopter 3.5 .

689 See Chapter 2.6.

Siga Chapter 2.11 .

on the history of Luxembourg's extreme right see Blat, Extreme.

a9: Archives Nationales de Luxembourg, Tribunal d"arrondissenent de Luxembourg Cote 3 C 61 , Crimes de Guerre Affare 37/49, Audience publique du 25 juin 1949, 9.94 ; On the coercion to join the WdB see also Marx, p. 105.

69a Archives Parquet Général à la Cour Superreure de Justice Crimes de Guerre: Iuges ei Prowreurs allemands, Dossier A-Il: Instruction génerale Juges, Bericht xiber die Versammlung vom 16. April 1941, 4 Uhr Nachmitiags, Audienzsaal des Civilgerichis.
} 
to the Grand Duchess was no longer valid and Luxembourg had ceased to exist as an independent state. Faber had retorted that the proposal to swear an oath of loyalty to Adolf Hitler directly affected the independence of Luxembourg and was therefore problematic. In the view of the Luxembourg judges their loyalty lay with their Sovereign and obedience was due to the Civil administration. The Civil administration's reply was that judges who entertained doubts about their loyalty, meaning towards Hitler, would be treated as unreliable and removed from office. It was made clear that the Civil administration would not be flexible in this matter.

Faber also asked on which legal basis the Civil administration had grounded the measure that allowed for Luxembourg civil servants to be treated as German civil servants. His argument had been that Nazi-Germany was not allowed to do so, since an annexation of Luxembourg prior to a valid peace treaty was contrary to international law. The reply from the side of the German judges was that these were formal considerations that were no obstacle for the occupant and should therefore not be seen as obstacles. It was added that Luxembourg had been de facto annexed and due to their racial category, Luxembourg nationals were practically Germans. ${ }^{64}$

Up until. March 1941 the occupant's measures to intimidate Luxembourg judges seemed to have failed for the most part and therefore the Civil administration signaled it would enact new measures to bring the Luxembourg courts and its judges into the fold. By the end of March 1941, in spite of the joint protest from several Luxembourg judges, Simon issued the Regulation allowing for the removal from office of civill servants that did not offer enough guarantees to the Civil administration. ${ }^{695}$ Moreover, in order to set an example and inspire fear into the Luxembourg administration, which was meant to further quell any resistance, Gauleiter Simon issued an order on 2 May $1941{ }^{6.96}$ Within four weeks a number of civil servants from every section of the state apparatus had to be dismissed. The goal of the measure was not only to frighten the remaining majority of Luxembourg civil servants, but also to win them over for the Nazi-German cause. The names of those who would be removed from office had to be published in the newspapers, together with the office from which they were to be removed. Furthermore, on 20 August 1941 several public officers, including judges, were removed from office and sent to the site of Wittlich in the German Eifel to work on the construction of a freeway. ${ }^{697}$

For at least 20 Luxembourg judges information could be found they were removed from office during the course of the occupation. ${ }^{698}$ These included 5 from the Cour superieure, 14 from the Tribunaux and one from the Courts of the Peace.

\footnotetext{
Ibid

6.45 Verordnung über Maßnahmen auf dem Gebiete des Beamtenrechts vom 31. März 1941, VoBl Nr. 27 wom 4. April 1941, S. 186. See also Raths, Grand-Duché, p. 262.

wh Archives Nationales de Luxembourg, Tribunal d'arrondissement de Luxembourg Cote 3 C 61 , p. $206 a-249$, p. 244

Als. G., p. 17; Raths, Grand-Duché, p. 263.

swe The information for individual judges can be found throughout the following sources: Archives Parque Gécéral à la Cour Supérieure de Justice. Crimes de Guerre: Juges et Procureurs allemands, a. Dossier B-IX Rapport Général Beffort concernant les affaires des anciens magistrats allemunds inculpés de crimes de guerre du I décembre 1947, p. II/7, b. Gerichisfall $5 / 51$ General-Auditor beim Gerichtshof für Kriegswerbrechen gegen Nölle, u.a., p. 325-338, p. 335-336, c. Dossier A-11: Instruction générale Juges, Vernehmungsprotokoll Bauknecht Otto vom 13.04.1948, p. 10: Archives Nationales de Luxembourg, Affaires politiques no. 385, Documents 0051, 0056,0062, 0065,0069; Bulletin, p. 7; Als, G., p. 16.
} 
Twelve were tried before a German war tribunal and fourteen deported. According to one unconfirmed source, one judge was executed after a trial at a German Standgericht.

Those judges that remained in office were not only obliged to pledge allegiance to Simon and to loyally obey all his orders, ${ }^{699}$ but also to join the VdB. In case of refusal, judges were informed they would loose their tenures and other repressive measures might follow: ${ }^{700}$ It is interesting to note though that a statement had been made on 24 October 1940 to the effect that all new applications for membership to the $\mathrm{VdB}$ of national and municipal civil servants would be barred. Exceptions could. only be made on the personal recommendation of local leaders of the VdB for persons who had actively supported the movement. ${ }^{701}$ Now, judges, together with all other Luxembourg civil servants, were obliged to join the Nazi movement and as a consequence swear an oath of loyalty to Adolf Hitler.

There were few Luxembourg judges who refused this nazification of their Judiciary. By May 1941, of the judges who had remained in office, only two refused to become a member of the Luxembourg Nazi party. ${ }^{702}$ The exceptions were Faber, the President of the former Luxembourg Tribumal and Welter, a judge at the former Luxembourg Court of the Peace. ${ }^{703}$ They were removed from office at the end of May 1941. Furthermore, two Justices of the former Cour superieure refused to join the national socialist law chapter NSRB. ${ }^{704}$ However, like membership of the VdB, also membership of the NSRB, had been made compulsory and refusal could mean removal from office, appointment to office outside of Luxembourg or even deportation to camps. ${ }^{705}$ Members of the German secret police Gestapo and the Civil administration themselves estimated that probably between $2 \%$ and $10 \%$ of the members of the $\mathrm{VdB}$ were voluntary members. Other estimates were even lower. ${ }^{706}$

In order to integrate the Luxembourg courts more into the German court system Gauleiter Simon ordered the Gleichschaltung or enforced conformity of the Luxembourg Judiciary with the German judicial organization. ${ }^{707}$ The courts" judicial organization was abolished in that from 1 August 1941 onwards the Civil administration introduced the German judicial organization in Luxembourg. ${ }^{708}$ On 1 August $1941^{709}$

(2) Verordnung über die Mahnahmen auf den Gebiete des Beamtenrechts vom 31 . März 1941 , VoBl. Nr. 27 vom 4. April 1941, S. 186. See also Wallerang, p. 57-58.

7019 Majerus, Guerre, p. 41 .

70 Bekanntmachung über die Sperrung der V. d. B. für alle Beamten vom 24 . Oktober 1940, Luxemburger Zeitung Nr. 274 vom 25 . Oktober 1940.

702 Compte rendu des Séances de l'Assemblée consultative du Grand-Duché de Luxembourg. Session de 1945 (du 20 mars - 16 aont 1945), Volume unique, 11 me sérance de jeudi, le 14 juin 1945, p. 399. See also Propria Causa, p. 20.

7013. Archives Nationales de Luxembourg, Affaires politicues no. 107. See also Als, G., p. 16.

7aks Dostert, P., Selbstbehauptung, p. 192, note 31; Cerf, Epuration, p. 156.

7 Propria Causa, p. 31-32.

7the Cerf, Épuration, p. 32.

Thin Majerus, Guerre, p. 42.

7 Toge Verordnung über die Einführung von Verfahrens- und Kostengesetzen in Luxemburg vom 18. Juli 1941, VoBl. 1941, S. 311; Verordnung über die Einführung deutschen bürgerlichen Rechts sowie zur Ergänzang der Verordnung vom 18. 7. 41 über die Einfihrung von Verfahrens- und Kostengesetzen in Luxemburg vom 15. März 1942, VoBl. 1942, S. 77. See also Archives Parquet General à la Cour Supérieure de Justice, Crimes de Guerre: Juges et Procu- 
the Chef of the Civil administration ordered the Diekirch District Court or former Tribunal to be abolished. The Diekirch court rendered its last judgment on the 25 July 1941. ${ }^{7 / 6}$ Also the Vianden Cantonal Court, formerly Court of the Peace, was closed and its canton merged with the one of Diekirch. ${ }^{711}$ However, even though the German judicial organization was introduced, Gauleiter Simon also determined that appeals from the Appellate Court's Senates to courts in Germany having jurisdiction on the basis of the German laws on judicial organization were not permissible. Retaining these appeals within Luxembourg also meant Luxembourg had not been legally annexed yet. ${ }^{7 / 2}$

The introduction of the German judicial organization also indicated that during the second half of 1941 formalities at the court proceedings of the Luxembourg courts would now in appearance be nazified. Judgments had to be rendered 'In the Name of the German People, ${ }^{713}$ which one Luxernbourg judge apparently refused. ${ }^{7 / 4}$ Moreover, Justices Kolbach and Calteux of the former Cour superieure, by then reorganized into Appeals Court's Senates, ${ }^{715}$ formally protested against this interpretation of the formula. ${ }^{715}$ Neither whether these two Justices acted on behalf of their colleagues of the former Cour superieure nor the arguments they used is known. It is reported that this resistance was brutally suppressed, ${ }^{717}$ though not what the exact consequences were.

Having been made German civil servants Luxembourg judges, from October 1942 onwards, should also have received the so-called Richterbriefe. These letters were in essence instructions from the Ministry of Justice in Berlin directing judges in pronouncing judgments. Although these instructions did not concern pending cases,

reurs allemands, Dossier A-II: Instruction générale Juges, Vernehmungsprotokoll Bergmann

Alexander-Withelm vom 6.4 .1948$, p. 22.

Durchführungsbestimmmingen zur Verordnung vom 18.7 .1941 über die Einfuhrung von verfahrens- und Kostengesetzen, vom 30. Juli 1941, VoBI. 1941, S. 314.

Everling, p. 15-16

Durchführungsbestimmungen zut Verordnung vom 18.7.1941 über die Einführung von Vertahren und Kostengesetzen vom 30. Juli 1941, VoB1. 1941, S. 314. See also Dostert, P., Selbstbchauptung, p. 191, note 23 .

See paragraphs 5 and 7 Verordnung über die Einfuhrung von Verfahrens- und Kostengesetzen in Luxemburg vom 18. Juli 1941, VoBI. 1941, S. 311. See also Romeyk, p. 426.

See also Chapter 3.1. The Special Tribunal, which from the beginning functioned on the basis of German law, had also from the begimning rendered its judgments 'In the Name of the German Peoples.' Those few judgments of the Luxembourg courts that had been altered during the occupation dated from after I August 1941 and all contained the formula ' $/ m$ Namen des Dewtschen Volkes?". There is no proof that these former Luxembourg courts, although domnnated by German judges, rendered Justice "In the Name of the German People' before $1 \mathrm{Au}$ gust 1941. See Conseil National de la Résistance, Archives personelles de M. le Président $P$. Dostert, Collection de jugenments.

Archives Puquet Général à la Cour Superieure de Justice, Crimes de Guerre: Juges et Procureurs allemands, Dossier A-II: Instruction gémérale Juges, Verhör von Gaerner Jacob vom
19.4.1948, p. 9 . See Chapter 3.2 .

Archives Parquet Génćral à la Cour Supérieure de Justice, Crimes de Guerre: Juges el Procureurs allemands, Dossier A-11: Instruction générale Juges. Verhör von Gaener Jacob vom
19.4.1948, p. 9. Arebives Nationales de Luxembourg, Tribunal d'arrondissement de Luxembourg Cote 3 C 61 ,
p. 206 - 249. p. 230 . 
they contained a critique of cases where judgments had been rendered and instructions on how to act in similar future cases. ${ }^{718}$ Those Luxembourg judges the occupant did not deem politically reliable were excluded from receiving these instructions. This meant that of 20 Luxembourg judges still in office in October 1942, only 3 would receive the Richterbriefe. ${ }^{719}$

As a further indication of having been made German civil servants, Luxembourg judges had to wear on their robes the symbol of German sovereignty. And when opening every session Luxembourg judges were obliged to commence with the Nazi-German greeting of 'Heil Hitler!'? 200 '

However, the Civil administration had problems enforcing their order obliging all Luxembourg judges to perform the Nazi-German greeting, either when in office or in private capacity when seen in public. Several times circulars went out to the Luxembourg authorities reminding them of this regulation and threatening those who did not perform the Nazi-German greeting with removal from office. ${ }^{721}$

By mid 1941 of all Luxembourg judicial officers, public prosecutors as well as judges, ${ }^{722} 53 \%$ had been withdrawn or deported or both and $14 \%$ had been forced to resign. Ten others no longer exercised their functions and it was unknown whether they had been officially removed from office. Therefore, by mid 1941 only about $20 \%$ of all Luxembourg judicial officers that were in office on 10 May 1940 were still in office. ${ }^{723}$

The occupant's attempt to integrate Luxembourg courts into the German court system succeeded, but his attempt to nazify the Luxembourg judges failed. The Luxembourg judges protested to the introduction of the German judicial organization and becoming German civil servants, citing international and national law to point out the illegality of the Civil administration's envisaged measures. More than two-thirds of Luxembourg's judicial officers were not in office anymore by mid-1941, being in some way or other removed from office. These two-thirds must therefore have acted contrary to the occupant's policies. However, this also meant that about one third of Luxembourg judges was allowed and chose to remain in office. In spite of the nazified appearance of the Luxembourg courts, even the German authorities had to admit that of those who had joined the VdB, only a very small percentage of those judges that had remained in office had become a member of the Luxembourg Nazi party out of conviction.

\footnotetext{
7n: Archives Parquet Général à la Cour Supérieure de Justice, Crimes de Guerre: Jugess el Procureurs allemands, Dossier A-IV Instruction générale, Audition des témoins, Zeugenvernehmung Meynen Walter am 11. Februar 1948, p. 2. Dostert, P., Selbstbehauptung, P. 192 and footnote 35. NB This number probably does not include the deputy judges.

720. Archives Nationales de Luxembourg, Tribunal d'arrondissement de Luxembourg Cote $3 \mathrm{C} 61$, Crimes de Guerre Affaire 37/49, Audience publique du 25 juin 1949, p. 94.

zil Archives Nationales de Luxembourg, Jusfice de Paix Esch s/Alzetie 1941, No. 204 Beamtempflichten. Brief vom 26. November 1941 vom Chef der Zivilverwaltung, p. 9; Briel wom 28. Mai 1942 vom Chef der Zivilverwaltung, p. 20.

722 Though excluding deputy judges.

723 Dostert, P., Selbstbehauptung, p. 192, note 33.
} 


\subsection{THE COURTS, THE CIVL ADMINISTRATION'S PUSH FOR ANNEXATION AND THL NATIONAL STRIKE}

Throughout the occupation the Luxembourg population resisted a 'germanisation' of its country. In a referendum held on 10 October $1941^{724}$ the people of Luxembourg were asked questions about their ethnicity, ${ }^{725}$ their primary language ${ }^{726}$ and their nationality. ${ }^{727}$ About $96 \%$ answered 'Lëtzeburgesch" to all three questions. ${ }^{728}$ Although the occupant allowed the acknowledgement of the Luxembourg nationality, the remaining questions concerning ethnicity and language were supposed to be answered as "German". An acknowledgement of German ethnicity and language would of course have been a victory for the Civil administration, since it would have handed them the best possible argument to eradicate Luxembourg nationality. ${ }^{729}$ Rather than it being a victory for the occupant, it cemented the Luxembourg sense of distinctness of nationality from the Germans and increased solidarity between Luxembourg citizens of all social classes. 730

In spite of the outcome of the referendum, Simon proclaimed Nazi-Germany's annexation of Luxembourg on 30 August $1942 .{ }^{731}$ As a result of Simon's claim of annexation, Luxembourg nationals were drafted into the German army. ${ }^{732}$ One day later the Luxembourg resistance groups called for a general strike upon which Simon declared a state of emergency and instituted a court martial. In spite of the threat of heavy sanctions on 1 September a general strike hil Luxembourg. ${ }^{73}$

Information exists that Luxembourg judges were conscripted into the German army $^{734}$ and therefore the conscription also directly affected the Luxembourg judges that were still in office. However, once conscription into the German army was introduced at the end of August 1942, some judges joined other civil servants in returning their membership cards of the $\mathrm{VdB}$. These judges were summoned before the

729 Verordnung über die Anlegung einer Volkstunskartei in Luxemburg vom 10. Oktober 1941 , VoBl. 1941, S. 410. See also Conseil National de la Résistance, Dossier du 10 Octobre 1941 , Personenstandsautinahme (Plébiscite camoutlé).

The instructions with the question stated that the reply had to indicate to which 'people" or "Wolk' one belonged, like the German, Italian, French, Belgian, Polish etcetera, but not "tribal" affiliation or 'Stammeszwgehörigkeit', like Luxembourgish, Bavarian or Saxon.

Similarly to the question about 'people' or 'Volk' the question about primary language or 'Murtersprache' determined that German, Italian, French and Polish were seen as languages and could therefore be given as an answer, but Luxembourgish or 'Lëtzeburgesct' and dialect German or "platt-desusch" were seen as dialects and could therefore not be used as an answer. This question pertained to the current nationality of 'Stantsangeharigkeit'.

Haag, p. 9; Raths/Dostert, p. 66; Raths, Stéchprouwe, p. 76; Raths, Victoire, p. 90; Majerus, p. 54.

Raths, Letzebuerg, p. 4

Raths, D'Stëmmon, p. 89.

See also Chapter 1.3 .3$.

Verordnung über die Wehpflicht in Luxemburg wom 30. August 1942, VoBI. 1942, S. 253; Anordnung über die wehrpflichtige Jahrgänge in Luxemburg von 30. August 1942, VoB1. 1942, \$. 253. See also Raths/Dostert, p. 68 .

Raths, Grand-Duché, p. 269; Calmes/Bossaert, p. 363. See Compte rendu des Séances de l'Assemblée consultative du Grand-Duché de Luxembourg,
Session de 1945 (du 20 mars - 16 août 1945), Volume unique, 11 me séance de jeudi, le 14
juin 1945 , p. 399 ; Cour supérieure Justoe de juin 1945. p. 399; Cour supérieure de Justice de Luxembourg. Séance solennelle du 21 février 1946, Discours prononcé par M. le Président de la Cour. Linden Luxembourg, 1946, p. 27. 
Standgericht or court martial. ${ }^{735}$ This Standgericht had been established aspecially to quell any resistance against the introduction of conscription for Luxembourg nationals into the German army. ${ }^{736}$

Ten judges were arrested on 4 September 1942 and tried by the Standgericht in the night of 8 to 9 September $^{737}$ for returning their $\mathrm{VdB}$ membership cards, even though they specifically stated they would remain in office and not join the strike. Among these judges were two members from the former Coum superienre, then Appellate Court's Senate, six from the former Luxembourg Tribumal and two from the former Diekirch Tribunal, then both renamed District Courts. ${ }^{739}$ Due to the intervention of one of the senior German judges proceedings before the Standgericht were stayed and the ten Luxembourg judges were released. ${ }^{740}$ Nevertheless, via subsequent order of the President of the Standgericht seven of these judges and their families were deported to a camp in mid-September. ${ }^{71}$ Why the other three judges did not share the same fate as their seven colleagues is unknown. However, all three were removed from office during the occupation and one was eventually deported as well. ${ }^{742}$ It is reported in one source, but not confirmed in others, that one other Justice from the Appellate Court's Senate was arrested at the beginning of September 1942 , tried before the Standgericht and executed, ${ }^{743}$ possibly in connection with resistance against the conscription.

7 Cerf, Épuration, p. 156. This author gives a differing account. However, several post-war documents of Luxembourg authorities, as mentioned below, confirm the events as described here.

736 Archives Parquet Général à la Cour Supérieure de Justice, Crimes de Guerre: Juges et Procureurs allennands, Dossier B-IX Rapport Général Beffont concentant les affaires des anciens magistrats allemands inculpés de crimes de guerre du 1 décembre $1947, \mathrm{p} .11 / 7$. Archives Parquet Général à la Cour Supérieure de Justice, Crimes de Guerre: Juges et Procureurs allemands, Gerichtsfall $5 / 51$ General-Auditor beim Gerichtshof für Kriegsverbrechen gegen Nölle, u.a., p. $325-338$, p. 335.

738 Archives Parquet Général à la Cour Supérieure de Justice, Crimes de Guerre: Juges et Procureurs allemands, Gerichtsfall $5 / 51$ General-Auditor beim Gerichtshof für Kriegsverbrechen gegen Nölle, u.a., p. $325-338$, p. 326. Also, four public prosecutors and one scientific atd from the prosecutor's office were arrested. Archives Parquet Géneral à la Cour Supérieure de Justice, Crimes de Guere: Juges et Procu. reurs allemands, Gerichtsfall $5 / 51$ General-Anditor beim Gerichtshof fïr Kriegsverbrechen gegen Nölle, u.a., p. 325-338, p. 335.

Archives Parquet Général à la Cour Supérieure de Justice, Crimes de Guerre: Juges et Procureurs allemands, Dossier A-11: Instruction générale Juges, Vernelunungsprotokoll Luicke Walther vom 5.6.1947, p. 5; Archives Parquet Général à la Cour Superieure de Justice, Crimes de Guerre: Iuges et Procureurs allemands, Gerichtsfall $5 / 5 \|$ General-Auditor bein Gerichtshof für Kriegsverbrechen gegen Nölle, u.a., p. 325-338, p. 335.

741 Archives. Parquet Général à la Cour Supérieure de Justice, Crimes de Guerre: Juges el Procureurs allemands, Gerichtsfall $5 / 51$ General-Auditor beim Gerichtshof für Kriegsverbrechen gegen Nöle, u.a., p. $325-338$, p. 336.

Archives Parquet Général à la Cour Supérieure de Justice, Crimes de Guerre: Juges et Brocureurs allemands, Gerichtsfall $5 / 51$ General-Auditor beim Gerichtshof fiur Kriegsverbrechen gegen Nölle, u.a., p. 325-338, p. 336; Archives Nationales de Luxembourg. Affares politiques no. 385, Documents 0051, 0056, 0065 and 0069.

Archives Parquet Général à la Cour Supérieure de Justice, Crimes de Guerre: Iuges ef Procureurs allemands, Dossier B-LX Rapport Général Beffort concernant les affaires des anciens magistrats allemands inculpés de crimes de guerre du I décembre 1947, p. II/7. 
Of about $20 \%$ of Luxembourg judges ${ }^{744}$ that were still in office after the integration of their courts into the German court system and their courts" subsequent nazification many now joined in this protest against conscription of Luxembourg nationals into the German army. Without exception they, as many of their colleagues before them, were removed from affice. Their policy was, however, to retain their office, which is evident from the fact they had accepted all of the occupant's measures up until then. It is therefore hardly surprising that in spite of their protest these judges also clearly indicated to the occupant they would not join the strike, but continue the exercise of their office. What the reason for this seemingly fundamental decision was, is unclear ${ }^{745}$ Howewer, also this protest showed that for those who protested their functioning in Luxembourg's altered and nazified courts was not out of a conviction favorable to the occupant and his policies.

\subsection{MORE PLANS FOR FURTHER JUDICIAL INTEGRATION INTO NAZI-GERMANY AND END OF OCCUPATION}

During the course of 1942 and 1943 Simon continued the merger of Luxembourg organizations with their counterparts on the German side of the border that were also part of the Gau Moselland. ${ }^{746}$ The occupant also investigated several plans to reorganize the court system in Luxembourg.

Plans in 1943 to merge the Appellate Court's Senates, the former Cour supérieure, with a German court in Koblenz were not executed. Simon seemed to still follow Hitler's instructions not to annex Luxembourg legally and leave the jurisdiction for appeals within the borders of Luxembourg and his jurisdiction. ${ }^{747}$

Other plans to re-organize Luxembourg's court system were considered. The SS in Koblenz was brainstorming with the German Procurator of State in Luxembourg, Wienecke, on reducing Luxembourg's court hierarchy from a 4-tier system to a 3-tier system. ${ }^{748}$ It was discussed amongst others what their territory should be, where they should have their seats, how they should be called and what competencies they should have.

However, the occupation drew to a close without these plans ever being executed. On 31 August 1944 all German judges and public prosecutors in Luxembourg were given the instruction to await an order for an accelerated retreat from Luxembourg. ${ }^{\text {7aly }}$ Luxemboung City was liberated on 10 September 1944 , but due to the Ger-

\footnotetext{
ith Excluding the deputy judges. See Chapter 3.9
}

74: No written account from this period from the hand of any of the Luxembourg judges exists. Also, in 2003 virtually all of then were already deceased. Those that had experienced the occupation and might have been in a position to witness first hand the Luxembourg courts during the occupation, like e.g. attorneys, were unfortunately either unable or unwilling to talk.

See e.g. Verordnung über die Eingliederung des Bereichs der Ätzek ammer Luxemburg in die Arztekammer Moselland vom 22. August 1942, VoB1. Nr. 52 vom 8. September 1942, S. 267; Verordnung über die Eingliederung des Bereichs der Apothekerkammer Luxemburg in die Bezirksapothekerkammer Moseltand vorm 9. November 1943, VoBI. 1943, S. 676.

Romeyk, p. 426.

Archives Nationales de Luxembourg. Dossiers Epuration, EPU no 379 , Brief vom $\$ \$$-Untersurmführer zu Koblenz an den Herrn Staatsanwalt Wienecke vom 4. 3. 1944.

Archives Parquet Général à la Cour Supérieure de Justice, Crimes de Guerre: Juges et Procureurs allemands, Dossier A-IV Instruction générale, Audition des témoins, Zeugenvernehmung Meynen Walter am 1. Februar 1948, p. 2 . 
man counteroffensive during the Battle of the Bullge the whole country would not be permanently liberated until $\mathbb{L} 5$ February 1945 . $^{750}$

The balance of the Luxembourg courts at the end of the war, or rather those former Luxembourg courts that had been modified during the occupation, was as follows. ${ }^{751}$ It has to be noted that these figures do not include the deputy judges.

In 194011 Justices, a Procurator General of State and two Advocates General had held office at the Cour superneure. Four retired during the occupation, two had been deported, three removed from office and conscripted and one removed from office by arder of a German court martial. Of 14 justices therefore only 4 remained in office until the end of the occupation.

At the Luxembourg Tribunal in 194017 magistrates were in office, the figure including judges as well as public prosecutors. ${ }^{752}$ President Faber had been deported mid-1941 and 3 judges, as well as 3 public prosecutors had been deported to concentration camps after an order from a German court martial. Two other justices had been removed from office, two had retired and one had had the opportunity to leave the country. Therefore, of 17 magistrates 2 were still in office on 10 September 1944.

Of the Diekirch Tribunal, which had consisted of 5 Justices ${ }^{73}$ in 1940 , only 1 was still in office at the end of the occupation. Three Justices had been deported and one had retired.

One Justice of the Peace had been deported and one had been retired. The rest had remained in office. In 1940 there had been 13 Justices of the Peace in office. ${ }^{754}$

\subsection{CONCLUDING REMARKS ON THE LUXEMBOURG COURTS DURING THE OCCUPATION}

The thesis of this research can hardly be applied to Luxembourg. It is virtually impossible to see whether the Luxembourg courts' positivist attitude prevented them from resisting the occupants' policies for several reasons.

Many documents, especially pertaining to the Luxembourg courts, are missing. Only in limited instances mentioned above, it was possible to glimpse into the argumentation Luxembourg judges used to protest against certain measures from the German occupant. Even though from these instances it can be discerned that international or national law was invoked to argue against an occupation measure, exactly what kind of reasoning was used is difficult to ascertain.

\footnotetext{
750 Ranhs, Grand-Duché, p. 283; Haag, p. 10; Wehrer, p. 232-239; Majerus, p. 75-76, 79.

291 Compte rendu des Séances de l'Assemblée consultative du Grand-Duché de Luxembourg, Session de 1945 (du 20 mars - 16 août 1945), Volume unique, 11 me séance de jeudi, le 14 juin 1945 , p. 399 .

75. These figures of Minister of Justice Bodson are contrary to those mentioned in the Amuaire Ofticiel 1940, p. 95 . The figures mentioned there are 14 judges, 4 depury judges, one Procurator of State and 3 depury Procurators of State, which is a total of 22. Presumably the deputy judges were not included in Bodson's figure of 17 , since when presenting the figures of the Diekirch Tribumal these were also left out. This, however, still leaves a discrepancy of one judge or public prosecutor at the Cour superieure level.

75. As well as 3 deputy justices that were not mentioned in Bodson"s figures. See Annuaire Officiel 1940, p. 96.

7s-1 As well as 22 deputy Justices of the Peace, who were presumably also not part of Bodson"s figures, see ibid. See Armuaire Officiel 1940, p. 100-104.
} 
President Faber invoked international law to protest the language regulation. In his view, this allowed him to clear his conscience and therefore enable him to apply the regulation. Faber was the only judge protesting the language regulation, but no other judge deemed there was a violation of international law due to which his conscience did not allow him to exercise his office anymore.

The protests of Nocke, Faber and Hansen against the introduction of the German judicial organization and the subsequent nazification of the Luxembourg courts was also based upon a violation of international and national law. Howewer, also in this case, it does not appear that any judge resigned from office. President Faber, a consistent objector to occupation policies, was removed from office for his refusal to comply with the occupant's order to join the $V \mathrm{~dB}$ rather than resign from office himself.

The same held true for Justice Kolbach and judge Calteux's protest against the order to render Justice "In the Name of the German People'. Even when Luxembourg's sovereignty, contrary to international law, was explicitly abolished, the Luxembourg judges did not resign. Even those judges returning their VdB membership cards in protest of the conscription of Luxembourg nationals into the German army explicitly stated they would remain in affice.

A specific legal obligation from the Luxembourg Government, if there was one, was not found. Also an order from the Chef of the Civil administration that Luxembourg judges were not allowed to resign from office was not found. Considering the fact that on the basis of the existing sources no indication could be found that Luxembourg judges resigned from office, it must be assumed this was a deliberate and conscious choice on the part of the Luxembourg judges to remain in office. Whether it was a collective choice and therefore a policy of the Luxembourg judges is hard to say. The repercussions for those removed from office will have influenced that choice, though since there is no example known it is unclear what the repercussion would have been for those who resigned from office.

The Luxembourg judges were in a difficult position to protest against the occupant's measures that violated international and national law. Contrary to their counterparts in Belgium and also The Netherlands, their number was very small. The Chef of the Civil administration could have easily replaced then with judges from Germany and did so already at the start of the occupation. Also the break up of the Cour supervieure decapitated the leadership of Luxembourg's judicial hierarchy. A decisive influence of German judges in Luxembourg courts rendered a concerted action of all Luxembourg courts impossible.

If the Luxembourg courts would have had a positivist attitude towards legal measures during the occupation, international and national law would not have allowed them to execute at least some of the policies of the occupant, if not most of them. However, a positivist attitude alone would not have enabled Luxembourg courts to resist executing the occupant's policies, since they lacked the possibility of adding a credible threat of mass resignation to induce the occupant to modify his policies.

Besides, alrendy from the beginning of the occupation Luxembourg courts could be circumvented, since the occupant's tribunals were competent for any case the public prosecutor initiated at the latter's tribunals. Also specific competencies dealing with the more serious criminal matters were excluded from the Luxembourg courts' competencies. 
The question nevertheless remains why so many Luxembourg judges remained in office for so long? Even if there were a legal obligation under national law to do so, intemational law would have allowed them to resign in case of conscientious objection. What would, however, have been the consequence of a Luxembourg judge resigning from office? He would have prevented to having been used as an executor of policies of the occupant that in many cases were contrary to international law, national law and his conscience.

Nevertheless, in Luxembourg there was the certainty that the occupant would replace him with a German judge. If the Luxembourg judge and the German judge's rulings in concrete cases would be the same, there should not have been a reason for a Luxembourg judge to remain in office. Although it was impossible to examine case law, the occupant already considered Luxembourg judges as too lenient in sentencing. Furthermore, although some, but few, Luxembourg judges would be tried after the occupation had ended for active collaboration with the occupant after the occupa$\operatorname{tion}^{755}$ the occupant did not trust the Luxembourg judges. He had to admit his attempts at ideological training had failed. Almost all judges refused to sit as judge in the occupant's tribunal and the occupant desisted from appointing them to his tribuw nal. Moreover, even the occupant estimated that only a small minority joined Luxembourg's Nazi party out of conviction and even there it has to be remembered that there was an order from the occupant to do so.

Many Luxembourg judges remained in office a long time after the conscience of most people would judge they should have resigned. Already at various points during the beginning of the occupation when the Luxembourg State was rapidly being dismantled there might have been ample reason to resign. The measure rendering Luxembourg judges German civil servants, the nazification of court proceedings, the proclamation of annexation and the conscription should for many have constituted a reason to resign.

However, with some notable exceptions that were tried after the war, the Luxembourg judges' refusal to resign cannot be seen as simple collaboration. Luxembourg's size and the number of its judges, as well as the harshness of the occupant's administration hardly allowed for any other means of resistance. Remaining in office at least allowed Luxembourg judges to prevent the appointment of an additional German judge and a chance to influence the harshness of German justice in Luxembourg, for example by sentencing more leniently.

The peculiar circumstances of Luxembourg and its occupation therofore rendered unimportant any kind of attitude the Luxembourg courts had towards law as regards the question whether it aided the occupant in the execution of his policies. Those circumstances did not allow for the Luxembourg judges to organize so as to pose any kind of credible threat of mass resignation in order to attempt to resist the execution of the occupant's policies.

See Chapter 7.2.3. 



\section{CHAPTER 4}

\section{THE NETHERLANDS COURTS DURING THE OCCUPATION}

\section{1 "IN THE NAME OF THE QUEEN"?}

Before the occupation the Netherlands judges had dispensed justice "In the Name of the Queen'. Upon taking up office in the Netherlands, Reichskommissar SeyssInquart wanted to decree that instead justice would be done 'In the Name of the Law". In order to prevent the Netherlands courts from suspending their duties, Tenkink, the Netherlands Secretary General of the Ministry of Justice, at the Reichskommissar's request, contacted President Visser of the Netherlands Supreme Court.

After several contacts between Tenkink and the President of the Netherlands Supreme Court and a meeting of the Justices of the Netherlands Supreme Court, the Supreme Court of the Netherlands unanimously agreed to henceforth do justice "In the Name of the Law ${ }^{356}$ The reason why the Netherlands Supreme Court agreed to this neutral formula was that it thought the formula was not objectionable from the point of view of internationall law. Furthermore, the Instructions ${ }^{757}$ the Netherlands Government thad left ordered the Judiciary to remain in office as long as possible, but obliged the courts to cease its activities if the enemy were to force it to render justice in the name of a foreign sovereign. ${ }^{758}$ The Supreme Court interpreted the Instructions as only containing a negative provision, namely not to render justice in the name of a foreign sovereign. This did not bar a different formula. Another reason why the Netherlands Supreme Court did not reject the Reichskommissar"s formula was that he seemed to have recognized the independence of the Netherlands courts. ${ }^{759}$

Subsequently, in August 1940, via circular, ${ }^{760}$ the Queen's name would be banned from all official acts of state and titles of public office. The Commissioner of the Queen, the governmental representative at provincial level, was henceforth required to be called Commissioner of the Province. The President of the Leeuwarden District Court, Stheeman, in a judgment mid-1941 applied the provisions of the Expropriation Act in referring to this governmental representative as 'Commissioner of the Queen, also called Commissioner of the Province". President Stheeman was of

\footnotetext{
756 Archief Hoge Raad der Nederlanden, Notulen Algemene Vergaderingen van 1921-1958, A.gemeene Vergadering van den Hoogen Raad der Nederlanden op Vrijdag 30 Mei 1940, des voormiddags te 10 uur, p. 16 .

75? See Bosch, p. 387 ff. See also Chapter 1.4.1.

$75 \mathrm{~B}$ Instructions 11 and 31 , ibid.

759 Archief Hoge Raad der Nederlanden, Notulen Algemene Vergaderingen van 1921-1958, Algemeene Vergadering van den Hoogen Raad der Nederlanden op Vrijdag 30 Mei 1940, des voormiddags te 10 unr, p. 16; Mazel, p. 13. NB Although the occupant apparently guaranted the independence of the courts, this independence was not the same as the one guaranteed by the Netherlands Constitution and legislation (see e.g. Hejde for the regular independence of the courts). The difference was that the irremovability of judiges was not guaranteed anymore (see also Chapter 4.10 and Bellefroid, p. 51). NB in Belgium during the occupation of World War Two (see Chapter 2.1) as well as during the occupation of World War One justice wass rendered "In the Name of the King' (see Asch, p. 477).

7 Go Circulaire Secretaris-Generaal van het Departement van Justitie d d. 19 Augustus 1940, Afd. A.S., no. 1133 , cited in: Hermans, p. 23.
} 
the opinion that he was applying the law and that a circular could not change legislation Parliament had adopted. On 21 August 1941 he was removed from office ${ }^{76}$ and Maitland, a national socialist would replace him as President. ${ }^{362}$

Another consequence of the Supreme Court's acquiescence was that early in November 1940 the Netherlands administration issued a circular, changing the oath of office for newly appointed civil servants that normally would have to swear allegiance to the Queen and the Netherlands Constitution. ${ }^{76}$ The new oath, which newly appointed judges would also be obliged to take was: "I swear to fathfully apply and abide by the laws in force on the occupied Netherlands territory." In general the oath had to be taken in the hands of the Reichskommissar, together with a statement to faithfully execute the Reichskommisar's regulations and other instructions and not to act in a way contrary to the interests of Nazi-Germany and the German Armed Forces. ${ }^{764}$ Civil servants would, however, not be asked to support the Netherlands national socialist movement (NSB). ${ }^{765}$

The new oath of office's broad formulation meant that it could be interpreted as having also sworn obedience to the occupant's measures, since the oath stipulated laws in force on the occupied territory of the Netherlands and not just Netherlands laws. International law allowed civil servants of the occupied country to invoke a duty to their own country in order to refuse application of an occupation measure. ${ }^{766}$ However, this oath meant that Netherlands law could not exclusively be used as a basis for a duty of Netherlands civil servants towards their own country, since no specific allegiance was due to the Netherlands Constitution or laws. If replaced by occupation measures, the occupant would surely insist that those would have to be obeyed instead of Netherlands laws.

The Supreme Court did apparently not consider the formula under which justice was administered an integral part of dispensing justice. In a case in $1942^{767}$ in which it was requested to quash a judgment that had neglected the use of the formula "In the Name of the Queen' the Court denied the request. Its reasoning was that nowhere the omission of the formula was tied to any legal consequences, which also might ex-

761

Tresoar, Gerechtshof Leewwarden 1940-1949, Thegang 17, inv. 5 Correspondentie, Brief 22 Atigustus 1945 van de whd. President van het Gerechtshof te Leeuwarden aan de Minjster van Mustitie, no. 513. See also Hermans, p. 22.

Hermans, p. 144.

Article 29 Wer RO.

"Ik zweer, dat ik lwet in het bezette Nederlandsche gebied geldende recht getrouw zal toepassen en naleven." See Rijksarchief in Noord-Brabant, Kantongerecht Helmond 1940-1949, toegang 817, inv. 26 Afd. A.S. No. 1144, betreffende eedsaflegging; Rijksarchief in NoordBrabant, Arrondissementsrechtbank Breda 1940-1949, bogang 808, inv, 309 brief 11 November 1940 van Secretaris Generaal Tenkink aan de Autoriteiten. Colleges en Ambtenaren, ressorterende onder het Departement van Justitie, no. 979.

Rijksarchief in Noord-Holland, Gerechtshof Amsterdam 1940-1949, toegang 450, inv. Ingekomen stukken en afschriften wan uitgaande stukken van de president 6 maart $1940-26$ juli 1949. President bezettingstijd 30 maart -21 februari 1945. Brief van 26 februari 1941 van de Secretaris Generaal van Justitie aan Autoriteiten, Colleges en Ambtenaren, ressorteerende onder het Departement van Justitie, no. 1113 . See also paragraph 7 Verordmung $1940 / 3$ (see Chapter (.4.3).

See Chapter 3.1 and the international law literature cited there concerning oaths of office and duty of obedience. See especially Beer Poortugael, p. 176-177.

Hoge Raad (Sratkamer) 16 novernber $1942, N / 1943,15$. 
plain its forthcoming attitude to the German request at the beginning of the occupation to replace the formula. However, in spite of the Supreme Court's contention that there were no legal consequences to the omission of dispensing justice "In the Name of the Queen', this was a violation of the Netherlands Constitution. Its article 156 prescribed that in the Empire justice would be dispensed in the name of the Sovereign.

Under international law some jurisprudes did acknowledge the possibility of finding a neutral formula, like lhaving Justice rendered 'In the Name of the Law", as long as the courts' independence was recognized. This solution was, however, foreseen for cases where the occupant and the courts of the occupied country could not agree on retaining the formula mentioning the legitimate sovereign. ${ }^{768}$ Furthermore, the Instructions the Netherlands Government left before its flight to London were not legally binding and could never bind the courts as to their interpretation of law. ${ }^{769}$ Consequently, the Supreme Court could not justify basing its decision on these Instructions.

The Netherlands Supreme Court therefore seemed accommodating in its agreement to the removal of the formula, since it did not protest and international law did not necessarily require it to defer so easily. The consequences were that the Court allowed for the violation of the Constitution and certain acts of Parliament, the removal from office of a President of a District Court and the replacement of the oath of office. More importantly, it also agreed to have the symbol of Netherlands sovereignty erased from Netherlands public life.

\subsection{COURTS AND THE FIRST APPLICATIONS OF OCCUPATION MEASURES}

Quite soon after the invasion the Civil administration feared that their explicit recognition of the Judiciary's independence ${ }^{770}$ would entice the Netherlands courts to start reviewing the German regulations and consequently disapply them. Therefore, the occupant requested the Netherlands Supreme Court to review his regulations before their entry into force. The Netherlands Supreme Court declined, stating it only had jurisdiction to adjudicate in specific, concrete cases ${ }^{771}$ and not to review legislation before its entry into force. ${ }^{72}$ In spite of the acknowlegment that its constitutional position had changed due to the occupation, the Court nevertheless considered that in the exercise of its public duties it should not exceed its role as main arbiter in concrete cases. ${ }^{773}$

\footnotetext{
76 Verraes, Tome 1, p. 178-179; Oppenheim, War, p. 215, François, p. 445. See also Chapter 3.1.

$76^{\circ}$ See Chapter 1.4.1.

Tht See Chapter 4.1.

27) See also Kranenburg, p. 1

7. Jong (deel 6-2), p. 634-635. See also Enquêtecommissie Regeringsbeleid 1940-1945, Verhoor I. . Hooykaas, zitting van woensdag 19 maart 1952 , p. 595-605, p. 598-599. Hooykaas maintained the offer had existed and after the refusal of the Supreme Court claimed to have exercised review of German measures himself until the occupant discovered the Supreme Court was not involved. However, Donner, member of the Supreme Court at the beginning of the occupation, apparently denied ever having heard of this German offer for the Supreme Court to review occupation legislation before its entry into force (see Ruiter, p. 199 and p. 326 footnote Chapter 14 , number 44 ).

73.3. Dries, resp. p. 12, 17, 23, 54-55.
} 
Two months after the beginning of the occupation Netherlands courts were first confronted with occupation measures. These regulations had been enacted on the basis of the occupant's powers, but many of those the Secretaries General had issued while acting on a delegation of powers from the Reichskommissar.

The first reported cases date from mid-July and the begiming of August 1940. The Breda District Court ${ }^{74}$ and both the Cantonal courts of Heerlen ${ }^{755}$ and Zaandam $^{76}$ decided cases on the basis of Regulation $1940 / 13$ in which the Reichskommissar had delegated some of his authority to the Secretaries General to enact various measures. All three courts did not go into the validity of Regulation $1940 / 13$. It has to be mentioned though that the Zaandam Cantonal court stated inadmissibility, since the competent court was the Haarlem Cantonal court, effectively avoiding having to deal with the validity question. When considering land tenancy cases also the Amhem Court of Appeal, in the first reported appeals court case decided mid-1941, did not deviate from the practice of the lower courts. ${ }^{77}$ The Criminal Chamber of the Supreme Court in its first case examined, interpreted and applied an occupation measure as if it had its legal basis in Netherlands law. ${ }^{778}$ Also in the first reported case of the Civil Chamber of the Supreme Court the Procurator General, as well as the Supreme Court, did not distinguish between measures grounded in Netherlands legislation and those based upon the authority of the Reichskommissar. ${ }^{779}$

In 5 subsequent reported cases that were decided in $1940^{7060}$ neither validity, status nor applicability of the measures of the Reichstommissar or of those based on his authority were considered. Of all reported cases in 1941, 66 were decided on the basis of occupation legislation. ${ }^{781}$ The Supreme Court decided 7 , the Courts of Appeal 2, the District Courts 18 and the Cantonal Courts 39 cases. No court, in any of these cases, questioned either the validity or the applicability of these measures.

This in spite of the fact that under Netherlands law, the Secretaries General did not possess any powers to enact measures. Furthermore, although the occupant had the power to enact measures by virtue of the occupation and limited by article 43 Hague Convention, his measures obviously did not emanate from a Netherlands authority the Constitution had anthorized to enact measures. Although the Reichskommissar had usurped all powers the Netherlands Constitution and legislation granted to the King and the Government, ${ }^{2}$ it was doubtful whether this did not exceed the limits article 43 Hague Convention put on his powers as occupant. It was also questionable whether the occupant's powers based on the fact of the occupation were legal

\footnotetext{
7. Arrondisementsechbank Breda (Burg. Kamer) 16 juli $1940, N / 1940,997$.

\%o Kantongerecht Herlen 7 angustus 1940, NJ 1940,988

$7 \%$ Kantongerecht Zandan 13 angustus $1940, N / 1940,992$

\%\% Gerechtshof Amhem (Pachikamer) 30 juni 1941, NW 1941, 688; Gerechtshof Amhem (Pachtkamer) 16 juli $1941, N / 194 \mathrm{I}, 825$.

77\% Hoge Raad (Strafkmer) 16 december 1940, NJ 1941, 195; See also Wiel, p. 444.

Hoge Raad (Burg. Kamer), lo jamuari $1941, N J 1941,824$.

Katomgerecht Hoon (geen datum), $N J 1940,1072$; Kantongerecht Harlem 20 september 1940. NJ 1940, 973, Kantongerecht Apeldoorm 9 oktober 1940, NJ 1940, 960; Kantongerecht Rotterdan 25 oktober 1940, NJ 1940, 1052; Kantongerecht. "S-Gravenhage 25 oktober 1940, N4 1940, 972; See also Wiel, p. 443-444.

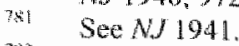

7s: Paragraph (1) Verordmung 1940/3 des Reichskommissars der besetztern niederändischen Gebicte uber die Ausubung der Regienungsefugnisse in den Niederlanden vom 29. Mai 1940, VoBI. $1940,5.8$
} 
powers and as such could be delegated. All of these questions could raise grounds of illegality of the occupation measures or at least the question of whether they could be applied in Netherlands courts.

None of these questions were raised, although application of the measures of the occupant and the Secretaries General violated Netherlands law as concerned measures dealing with criminal provisions and punishments. Article 1 Netherlands Code of Criminal Procedure allowed for sentencing and execution of that sentence as provided for by Statute of Parliament. In civil cases, courts were obliged, by virtue of article 48 Netherlands Code of Civil Procedure, to ex officio supplement any legal grounds parties had not addressed. If in civil court parties had not addressed the question of illegality or applicability, the Netherlands courts should have done so, unless they were convinced that no question concerning illegality or applicability of the occupation measures was warranted. Also the Judicial Organization Act $(1827)^{783}$ posed problems. One example was that just like the Belgian Cour de cassation the Netherlands Supreme Court could only quash a lower court's judgment for violation of national law. ${ }^{784}$ At least in the beginning of the occupation Netherlands courts did not confront any of these questions. ${ }^{75}$

\subsection{MEASURES AGAINST NETHERLANDS JUDGES OF JEWISH ANCESTRY}

Since the occupation in May the Civil administration had employed a "velvet glove" policy. Big changes or measures against Jews did not seem to materialize. However, the Reichskommissar did order his Commissioner General for Justice Affairs, to compile a list containing all Netherlands judges and lawyers of Jewish ancestry. ${ }^{780}$

The first measure from the occupant regarding Jews prohibited the Secretaries General to hire any more Netherlands Jewish nationals. The ones that were already employed were to be denied promotion. ${ }^{787}$ The Secretaries General considered accepting Seyss-Inquart's order, but reluctantly, since there was no 'Jewish Question" in The Netherlands. They informed the Reichskommissar in writing of the fact that his regulation concerning Netherlands Jewish nationals was contrary to Article 5 of the Netherlands Constitution. ${ }^{788}$ Article 5 stated that every Netherlands national had equal opportunity to be appointed to public office. ${ }^{78}$. This meant that according to the Netherlands Constitution no distinction could be nade between Netherlands nation-

783 Wet van 18 April 1827 (Stb. No, 20) op de Zamenstelling der Rechterlijke Magt en het Beleid der Justitie as anended via amongst others Wet op de Regterlijke Organisantie en het Beleid der Justitie van 18 april $1835, \mathrm{Stb} .10$ and the Wert houdende wijzigingen in de Wet op de Rechterlijke Organisatic en her Beleid der Justitie, Stb. 92, subsequently amended via KB 14 juni 1911 , Sib. 146.

734 Article 99(2) Wet RO granted the Supreme Court competence to quash for violation the law ("wet"). Article 112 Netherlands Constitution stipulated that in The Netherlands only the King and both Houses of Parliament ("wetgevende mach") jointly exercised the powers to enact these laws.

See further Chapters 4.9 and 4.17 concerning the courts and application of the occupation measures once the occupation progressed.

Jong (deel $4-1)$ ). p. 757 .

Hirschfeld, p. 144.

Article 5 of the Wethertands Constitution of 1938." "ledere Nederlander is tot elke landshediening beroembar." 
als on the basis of religion or ancestry in order to be appointed to public office. Also article 176 Netherlands Constitution protected members of every religion in the Netherlands. It stated, like anticle 5, that members of every religious group had the same civil and political rights and equal access to public office.

In September 1940 the Reichskommissar announced that, in contravention of existing legal provisions, civil servants could be dismissed. ${ }^{790}$ The Reichskommissar thus de facto annulled articles 5 and 176 of the Netherlands Constitution. Besides this, Seyss-Inquart requested the Secretaries General to compile a list of all Netherlands civil servants who were completely or partly Jewish. Since this information did not exist, the Secretaries General decided to hand out forms, the so-called Declaration of Aryan Ancestry, which required the civil servants to state whether they or their spouse were Jewish. If so, the names of their parents and grandparents as well as income and assets needed to be declared. Civil servants were ordered to fill out this declaration by 26 October or in some cases even earlier. ${ }^{7 \% 1}$

Hooykaas, at this point acting as deputy Secretary General to Tenkink stated that the did not consider the Aryan Declaration contrary to the Hague Convention and did not think international law could have been successfully invoked against the Geman order. ${ }^{792}$ However, the Secretaries General stuck to one legal scholar's ${ }^{793}$ interpretation of the Hague Convention without consulting other experts in the field. ${ }^{7 \% 4}$ Hooykaas nevertheless admitted that the Civil administration, especially the Reichskommissar himself, was very sensitive to arguments relating to the Hague Convention. An appeal to the Hague Convention was almost always successful.795. Schrieke, their national socialist successor during the occupation, avoided resorting to the Hague Convention claiming that although Seyss-Inquart had a legal department, legal arguments led nowhere. Most Commissioners General were not susceptible to legal arguments, so Schrieke, with the possible exception of Rauter. ${ }^{796}$

The Secretaries General failed to point out to the Civil administration that its regulations against civil servants of Jewish ancestry could not be seen as a public order measure under article 43 Hague Convention. Netherlands civil servants of Jewish ancestry, like all civil servants were required to sign a statement to faithfully exe-

Paragraph 1, Verordnung 1940/137 des Reichskommissars für die besetzten niederländischen Gebiete über die Regelung der rechtlichen und finanziellen Verhältmisse von Beamten, Angestellten und Arbeitern sowie gewisser vereidigter Personen vom 13. September 1940, VoBL 1940 S. 425. See Presser, p. 29.

Enquêtecommissie Regeringsbeleid 1940-1945, verhoor J.P. Hooykaas, zitting van woensdag 19 matart $1952, \mathrm{p}, 595-605$, p. $600-601$

See François. See also François's postwar contribution: François, Bezetting; Presser, p. 41 Enquëtecommissie Regeringsbeleid 1940-1945, Verhoor I.C. Tenkink, zitting van dinsdag 18 nuart 1952, p. 580-594, p. 584; Enquetecommissie Regeringsbeleid 1940.1945, Verhoor I.P. Hooykans, zitting van woensdag 19 mart 1952, p. 595-605, p. 597.

Enquetecommissie Regeringsbeleid 1940.1945 , Verhoor I.P. Hooykaas, zitting van woensdag 19 maant 1952, p. 595-605, p. 597, 599; Tenkink remarked that at least during the beginning of the occupation the occupant tried to uphold the appearance of compliance with the Hague Convention (see Enquêtecommissie Regeringsbeleid 1940-1945, Verhoor J.C. Tenkink, zitting van dinsdag 18 maart 1952 , p. $580-594,584$ ).

Anquetecommissie Regeringsbelleid 1940-1945, Verhoor J.J. Schrieke, zitting wan dinsdag I April 1952 p. 616 . However, Schrieke's idea of the Hague Convention was very much in line
with the occupant's. See Schrieke. 
cute the occupant"s orders and not to act contrary to his interests. ${ }^{7 \% ?}$ If in individual cases a civil servant violated this statement, he could be removed from office and disciplined. ${ }^{798}$ An argument could be made that nowhere international law allowed for the dismissal of a group of civil servants that had signed the statement and had acted accordingly. However, Tenkink did not even attempt to use international law in order to object. This even though he admitted the Reichskowwissar's susceptibility to these arguments and the fact that the Secretaries General could have foreseen the consequences of his request in light of the developments in Nazi-Germany before the war. $^{795}$

The Aryan Declaration provoked protests from universities and church leaders, but all, especially the legal community, expected a reaction from the Netherlands Supreme Court. ${ }^{800}$ Not only was the obligation to fill out this declaration deemed unconstitutional, contrary to the Hague Convention and the Netherlands sense of justice, ${ }^{801}$ but also the President of the Netherlands. Supreme Court, Visser, was of Jewish ancestry.

The Hague District Court's position was one of waiting for a reaction of the Supreme Court. ${ }^{802}$ On 16 October 1940 deputy judges van Bemmelen and Cleveringa approached the President of the District Court, Rueb, with the question which line of conduct the Judiciary should pursue concerning this declaration. Van Bemmelen and Cleveringa proposed to convene a meeting in Utrecht of all Presidents of District Courts in The Netherlands. The letter of invitation would be formulated such as to indicate the meeting was to discuss how to deal with the ambiguities of the declaration, since most judges had difficulty understanding it. It was thought that formulating the letter this way would assure that no harm would come to its author if the occupant were to intercept it. Once the meeting was held the matter could be discussed openly.

President Rueb indicated he was not opposed to the proposal, but wanted to consult the Vice-President of the Court of Appeal, van Romondt and the VicePresident of the Netherlands Supreme Court Kosters. The President of the appeals court was in hospital for surgery and since the President of the Supreme Court was Jewish it was thought inappropriate to implicate him in the matter. Van Romond was of the opinion that the Presidents of the Courts of Appeal and the Supreme Court should be invited to the Utrecht meeting, but allso considered that ultimately the Supreme Court had to take the lead. When on 22 October the President of the Court of Appeal reported back to the two deputy judges he informed them in a brief note that after consultation of several Justices and the Supreme Court itself it was thought only the Supreme Court should take the lead. Also at the universities, like Leiden where

74. Beer Poortugael, p. 176-177; Bordwell, p. 300; Spaight, p. 360-361; Verraes, Tome 1, p. 177 178: Oppenheim, War, p. 211-212.

74. Bordwell, p. 306.

79. Enquêtecommissie Regerimgsbeleid 1940-1945, Verhoor J.C. Tenkink, zitting van dinsdag 18 maart 1952 , p. $580-594$, p. 589.

800 Hirschfeld, p. 133; Polak, p. 19-20; Cleveringa, p. 335.

801 See also a letter from one of the Netherlands' foremost international lawyers Prof. mr. B.M. Telders to the Supreme Court, urging it to take a stance against the Aryan Declaration (see Archief Hoge Raad der Nederlanden, Archiefnap WO II, afschrift brief van Prof. mr. B.M. Telders aan de President van de Hoge Raad mir. L.E. Visser van 17 okiober 1940 ).

Cleveringa, p. 335-338. 
the Declarations were handed out on 25 October, attention was focused on the Supreme Court"s reaction, which still had not come.

When the Netherlands Supreme Court occupied itself with the matter, it decided after two meetings, probably with 12 votes in favor and 5 against, ${ }^{803}$ that there was no legal reason to refuse application of the Declaration of Aryan Ancestry. ${ }^{304}$ In order to avoid the appearance of bias, President Visser had largely refrained from participating in the discussion. ${ }^{8}$ The Supreme Court was of the opinion that dismissal of officials was possible not only on the basis of incompetence, but also because of lack of confidence on the side of the Civil administration. The only meaningful reaction of the Netherlands Supreme Court would have been to stay all proceedings, ${ }^{806}$ but that was a threat the Court thought it should not use too lightly. ${ }^{307}$

The Netherlands Supreme Court nevertheless did intend to formally protest against this measure via open letter to the Reichskommissax. In it the Supreme Court deplored the immoral, though not the illegal, nature of the dismissal of Netherllands civil servants of Jewish ancestry. After the intervention of Secretary General of Justice Tenkink the Vice-Presidents of the Supreme Court decided not to mail the letter. $^{308}$ It was thought that protesting would only increase the danger of further measures being taken against President Visser ${ }^{809}$ President Visser died of a heart attack on 17 February 1942 and at his funeral several members of the Supreme Court were present, though there are differing accounts of how many. What is certain is that some nembers were absent. ${ }^{B 10}$

The news of the Supreme Court's apparent meekness in signing the declaration did not stop some, though probably far and few in between, to personally take a stand. The Cantonal judge of Leiden, Ligtenberg, signed, but not without attaching a protest." This did not seem to have entailed any consequences relating to his office, since in 1942/1943 Ligtenberg still appeared to be in office as Cantonal judge in Leiden.. $^{812}$

In the beginning of October 1940 the Civil administration informed the Secretaries General of the fact that all civil servants of Jewish ancestry were to be relieved from their duties and awaiting other measures were to be registered separately. Al-

with

sols: Jong (deel 4-1) , p. 765

Sive Mazel, p. 32.

Polak, p. 20; Mok, Proza, p. 10

See also Rutgers, p. 760.

(4): Dries, p. 5,14 . Immediately after the occupation had ended van den Dries published a booklet about the Netherlands Supreme Court during the occupation, defending the attitude of the Netherlands Supreme Court in relation to the German Civil administration. This booklet was written with contributions from several and supported by all members of the Supreme Court appointed before the occupation and still in office in 1945 and can therefore be seen as repressenting the opinion of the prewar appointees of the Supreme Court, including the occupation appointe Smits (see Archief Hoge Raad der Nederlanden, Notulen Algemene Vergaderingen van 1921-1958, Algemeene Vergadering van den Hoogen Raad der Nederlanden op Maandag 2 Juli 1945, des voormiddags te 11/2 uur, p. 39. For Justice Donner's contribution and support
see also Ruiter, p. 217,220 ).

Hirschfeld, p. 133; Ruiter, p. 185, 324 endnote Chapter 14, number 7.

Dries, p. 42; See also Presser, p. 42.

Ruiter, p. 187

Cleveringa, p. 339.

Bestuursalmanak, p, 32 . 
though initially inclined to reject this demand of the Civil administration, the committee of Secretaries General considered that their refusal and subsequent inevitable resignation would lead to general chaos in all areas. The Secretaries General did not refuse their co-operation. On 21-22 February, almost three months later, these Netherlands civil servants of Jewish descent, about $1 \%$ of the civil service workforce, were handed their resignation. ${ }^{813}$

This did not deter some Netherlands civil servants of Jewish ancestry from resisting the occupant's orders and continuing to exercise their public office. Whether amongst these were members of the courts is unknown. However, the occupant was vigilant and determined to only allow these civil servants back to their workplace to arrange personall matters. In case of failure to comply the civil servants of Jewish ancestry were threatened with denial of pension payments and their superiors with disciplinary measures. ${ }^{814}$

At the Amsterdam Court of Appeal Justices Boas and Canes were suspended and subsequently removed from office on the basis of their ancestry. Both were killed in the holocaust. ${ }^{815}$ At least from the minutes of the meetings of the Amsterdam court in the second half of 1940 and the beginning of 1941 there was no proof that the court protested in any way against the removal from office of two of its members. ${ }^{316}$ "There was only a dutiful reply of the Presiclent of the appeals court 17 days after the occupant's request on 12 November 1940. The President informed the local representative of the Civil administration that the members of the Court of $\mathrm{Ap}$ peal of Jewish ancestry hac been relieved from their duties as of 23 November. ${ }^{817}$ The 's-Hertogenbosch Court of Appeal did also not protest against these measures. All members of the court signed the Declaration of Aryan Ancestry and in conformity with Regulation $1940 / \| 08^{818}$ the President provided the Secretaries General with this information. 819

At the Amsterdam District Court Justice de Beneditty suffered the consequences of the measures against Netherlands Jewish nationals. De Beneditty was one of the members of the Jewish Council in The Netherlands and had research done to examine the Jewishness of the Portuguese Jews in The Netherlands. On the basis of this the President, several judges and deputy judges of the Amsterdam District Court, in a petition to Reichskommissar Seyss-Inquart, attempted to save de Benedity. These members of the Amsterdam District Court tried to persuade the occupant to exempt de Benedity from the measures against the Netherlands Jews. Although this letter appeared in the archives of the District Court, it could not be ascertained

81: Hirschfeld, p. 144-145

81.4 Rijksarchief in Noord-Brabant, Gerechtshof "s-Hertogenbosch 1940-1949, toegang 823, inw. 1, brieven van 26 Februari 1941 en 23 April 1941 wan de Secretaris Generaal van Justitie atn de Autoriteiten, Colleges en Ambtenaren ressorterende onder het Departement van Justitio, No. 1124 and 1122, passing on instructions from the Commissioner General for Administration and Justice Affairs Winmer.

34: Kop, p. 11-12.

816 Rijksarchief in Noord-Holland, Gerechtshof Amsterdam 1940-1949, toegang 450 en 19501959 , toegang 561 ; Kop. p. 15.

si: Kop, p. 16-17.

4. Verordnung 1940108 des Reichskommissars für die besetzten niederländischen Gebiete über besondere verwaltungsrechtliche Maßnahmen vom 20 August 1940, VoB1. 1940, 5.338 .

n:4 Archief Gerechtshof 's-Hertogenbosch, Benoemingen 1938.1948, akte Ambtenaren van joodschen bloede. 
whether it was actually sent ${ }^{800}$ Like their colleagues, judges de Beneditty and Lier and depury judges Kisch and Bregstein were suspended on 23 November $1940^{82}$ and removed from office in February $19411^{822}$

According to the records of the Ministry of Justice ${ }^{823}$ a total of 28 judges of Jewish ancestry were removed from office. These were the President of the Supreme Court, at the Court of Appeal level two Justices in Amsterdam and one deputy Justice in The Hague. At the District Court level two judges and two deputy judges in Amsterdam, two judges in Rotterdam, a deputy judge in Alkmaar and one in Maastricht were affected. At the Cantonal court level two deputy Cantonal judges in The Hague, three in Rotterdam, one deputy Cantonal judge in Leiden, two Cantonal judges and six deputy Cantonal judges in Amsterdam and one deputy Cantonal judge in Groningen and Meppel each were removed from office. That meant that according to the figures of the Ministry of Justice 9 members and 19 deputy members of the courts fell within the national socialist definition of Jewishness.

According of figures of the Civil administration, which it only could have gotten from the Netherlands Ministry of Justice, out of 302 judges, 10 fit their definition of being Jewish. ${ }^{824}$ Presumably these did not include the deputy members, but that still meant there was a discrepancy between the figures of the Ministry of Justice and those of the Civil administration.

Another source that came from the Ministry of Justice claimed that out of 610 members of the courts, 579 had returned the Aryan Declaration and 29 indicated to fit the occupant's description of being Jewish. However, the last number included 7 spouses. ${ }^{825}$ It is interesting to note bere that of all services that reported to the Ministry of Justice on average over $98 \%$ returned the Declaration. The Judiciary was below that average, but not by much, since $95 \%$ filled out the Declaration of Aryan Ancestry. ${ }^{826}$

Initially it was considered to create an exception for some Jews, amongst whom the Presiclent of the Supreme Court Visser, ${ }^{827}$ but in the end the Civil administration

820

The order was given 21 Noyenber 1940. Sec Tresoar. Archief Procureur Gieneral bij het Gerechtshof te Leeuwarden, Nohulen van de Vergaderingen wan hei College wan Procureurs Genenal, voorl. Inventaris 2512 , Notulen van de vergadering van Procureurs Generall, fgd. Gewesteligk Direateunen van Politie op Dorderdag 21 November 1940, 493.

Rijksarchief in Noord-Holland, Arrondissementsrechtbank Amsterdam 1950-1959, toegang 510 . inv. Nomlen vergaderingen 1918-1957. Vergadering op Maandag 19 Mei 1941, des ma. middags 4 mur.

National Archief. Den Hagg, Archief wan mr J.P. Hooykaas 1940-1947. Nummer Toegang 2.09.56. unv. 22, Ljjst wan Ambtenaren on naar burgerlijk rech werkzaam gestelden, die met ingang van If mat 1941 ontagen zijn wanwege den Rijkscommissaris ingevolge de Anordnung van 21 Febuari $194123147 \mathrm{Ve} / 41$. NIOD. Arthief 33, doos 3, nap h, Brief 25 Jum 1942 Kammergerichtsrat Seiffert an die $\mathrm{Ab}$ rilung fur niederllindische Parsonalangelegenheiten.

National Archief, Den Hag. Archief van mr J.P. Hooykaas 1940-1947. Nummer Toegang 2.09.56, inv. 22, Tabel, opgemaalit door Secretaris Generaal Terkink met overzicht invullung "Arierwerklaning" bij verschillende juridische beroepsgroeper.

National Archief, Den Haag. Archief van mi J.P. Hooykaas 1940-1947, Nummer Toegang 2.09.56, inv. 22. Tabel, opgemakt door Secretaris Ceneraal Tenkink met overzicht wnulling. "Arierverklaring" buj verschillende juridische beroepsgroepen.

Treson, Archef Procureur General bij het Gerechtshof te Leeuwarden, Notulen van de Vergaderingen wan het College wan Procureurs General, voorl. Inventaris 2512 , Notulen van de 
apparently decided against this. In spite of the fact that they only represented about $3,5 \%$ of judges the Civil administration viewed Netherlands judges of Jewish ancestry as a threat to public security. Netherlands courts, although having a reason due to legal bases in international and nationall law, did not get beyond discussing the matter and failed to even protest.

\subsection{LIMITATION OF COMPETENCIES}

Already in July 1940 the competencies of the Netherlands courts were restricted due to the creation of German war tribunals on the territory of the occupied Netherlands. ${ }^{28}$ These newly created German criminal courts, the Dentsche Obergerich or German Appellate Court and the Deutsche Landgericht or Geman Trial Court including their public prosecutor obtained exclusive competence in matters which used to belong to the jurisdiction of the Netherlands courts. Firstly, the German criminal courts obtained jurisdiction in matters concerning the prosecution and adjudication of crimina acts German nationals or nationals from the German Protectorate of Bohemia and Moravia had committed. ${ }^{829}$ This jurisdiction was expanded to inchude the perpetrator or accessory, regardless of nationality, who had committed a criminal act against the Greater German Reich, the German Volk, the NSDAP, any of its suborganizations or affiliated organizations, a German national or a person employed by either one of the aforementioned. The German criminal courts' competencies also included acts perpetrated while in the service of German authorities or connected to this perpetrated on German sovereign territory, or buildings, spaces or development sites that were used by the Greater German Reich, the NSDAP, its sub-organizations or affiliated organizations. ${ }^{830}$ In cases of a minor criminal act and where the perpetrator involved was not a German national, the German courts could decide to refer the matter to the Netherlands judicial system for prosecution and adjudication. ${ }^{831}$.The Reichskommissar resolved the conflicts over competencies between German and Netherlands courts. ${ }^{832}$ Although international law was ambiguous as regards the occupant removing his own nationals from the competencies of the occupied country's courts, international law allowed him to exclude from their competencies cases inwolving attacks against him or his organizations. ${ }^{833}$

The competencies of the Netherlands courts were in fact further dimmished on 22 October 1940 . The Reichskommissar ordered the suspension of articles $\| 2$ and 13

vergadering van Procureurs-Generaal, fgd. Gewestelijk Directeuren van Politie op Donderdag 21 November 1940, p. 494

Verordnung $1940 / 52$ des Reichskommissars für die besetzten niederländischen Gebiete über die deutsche Gerichtsbarkeit in Strafsachen wom 17. Juli 1940, VoB1. 1940, S. 181, which was dater amended by Verordnung $1941 / 123$ wom 5 . Juli 1941 , VoBI. 1941, S. 522, Verordnung $1942 / 71$ and $1942 / 72$ wom 6 . Juli 1942, VoBl. 1942, S. 340 and Verordnung 1943/50 vom 14. Mai 1943, VoBl. 1943, S. 191.

829 Paragraph 2 (1) Verordnung 1940/52, ibid.

83. Paragraph $2(3)$ Verordnung 1940/52, ibid.

8.1 Paragraph 13 Verordnung 1940/52, ibid.

832 Paragraph 22(2) Verordinung 1940/52, ibid.

See Chapter 2.4 
of the Netherlands Code of Criminal Procedure. ${ }^{834}$ These articles included the Right to Jodge a complaint as a safeguard against the abuse of the discretionary decision power of the public prosecutor"s office to prosecute cases. 835 The public prosecutor"s discretionary decision power, contrary to the legality principle, did not obligate the public prosecutor to prosecute. It left the decision to prosecute within a margin of discretion of the public prosecutor, though limited by Guidelines of the Public Prosecution Service. ${ }^{36}$. The Right to lodge a complaint gave the opportunity to those dilrectly involved in the case to have recourse to the ordinary courts to challenge the public prosecutor's decistion.

Personnel changes at the public prosecutor"s office resulted in September 1940 in the dismissal of 3 of 5 Procurators General at the Conrts of Appeal, who at the same time were also directors of the police force. Two of these newly appointed Procurators General were members of the National Socialist Movement in the Netherlands, the NSB. ${ }^{837}$ Furthermore, the appointment of the Procurator General of the Arnhem Court of Appeal to the Supreme Court in September 1941 gave the occupant the opportunity to appoint a fourth Procurator General, also a national socialist. ${ }^{83} \mathrm{~A}$ decisive influence of the occupant over the public prosecutor's office meant that there was no guarantee that cases would be brought to the Netherlands courts and the Civil administration had full discretion concerning which cases it wanted the Netherlands courts to try. The Civil administration subsequently interfered several times into a pending criminal investigation, which was then stayed by order of the Reichskommissar. "Due to the occupant's annulment of article 12 Netherlands Code of Criminal Procedure no recourse to the courts could be had.

Netherlands courts did not respond to the abolition of the Right to complaint provisions, even though the occupant violated his duty under article 43 Hague Convention to maintain public order by allowing certain criminal acts not be tried. And although the Supreme Court recognized that introduction of the German courts and their competencies was in some penal matters to the exclusion of the Netherlands courts, ${ }^{80}$ the question was in how far the Netherlands courts would accept a limitation of their competencies.

In a case $e^{811}$ conceming a possible conflict of competencies between the Netherlands courts and the Geman war tribunals the Supreme Court, as well as Advocate General Rombach, had no problemas recognizing the competencies of the German courts. The Cantonal court of Wageningen as initial trial court had held that in this case the Nethertands courts were competent, since the railload where the defendant had made an illegal crossing while a train was approaching was in The Netherlands and fell under the Railway Act. In appeal the Arnhem District Court overturned that judgment. Having established the German army had built and was therefore owner of the railroad and also its crossing, the District Court denied having competence. The

\footnotetext{
xia Verordmug $1940 / 187$ des Reichskommissars fir die beserzten niedlenandischen Gebiete zur Vereinfachung der Strafreclutspllege vom 22. Oktober 1940, VoBl . 1940, S. 541.

S3.35 See also Bemmelon, P. 119

Articles $167(2)$ and 242 Code of Criminal Procedure.

The NSB was the most significant Netherlands Nazi movement

Mok, Proza, p. 10-11.

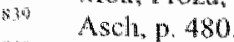

Sto As confirmed by the Suprenue Court: Hoge Raad (Strafkarmet) 5 oktober 1942, NJ 1943, 11

(4) Hoge Rad (Strarkamer) 22 november $1943, N$ J $1943,143$.
} 
basis for its and the Supreme Court's concurrent decision was a Regulation concerrying the competencies of the German courts in the occupied Netherlands. ${ }^{842}$ Paragrapl 1(2) stated that a non-German national who committed an offense would fall within the jurisdiction of the German courts. The offense had to, amongst others, have taken place on the grounds of the German Army.

The Supreme Court easily labeled the railway crossing "grounds' of the German army, although that provision could have been interpreted much more narrowly to refer to grounds surrounding buildings used by the Geman military. Also, the classification of the defendant's act as an offense (delict) rather than a misdemeanor (overtreding) is most peculiar, since regular traffic violations are usually misdemeanors. Classifying the crime a misdemeanor would have assured the Netherlands courts' competencies $^{844}$ and the trial of the defendant in a Netherlands court.

In a case before the 's Hertogenbosch District Court in $1941^{\text {s.5 }}$ this court needed to decide on whether it was competent to try a case under the Ams Act (1919). The case itself was an appeal from the Cantonal court. The facts of the case had occurred in the second half of 1939 and the first half of 1940 . The Regulation concerning the competencies of German courts in criminal matters dated from 17 July 1940. Furthermore, and more poignantly, the criminal provisions deemed to be applicable were occupation measures, namely the Weapons Regulation and the Regulation on the maintenance of public order that had both entered into force on 28 July 1941. Nevertheless, the District Court denied competence and not only granted retroactive force to the regulations, but also handed the defendant over to the German war tribunal.

In these examples, the Netherlands court interpreted the regulations granting the German war tribunals competence widely and even applied them retroactively. Neth erlands legislation was discarded. This in spite of the fact that credible legal arguments were available to assert their own competenctes and that the handing over of Netherlands nationals to German wat tribunals could have been avoided.

A reason why the Netherlands courts might have had no problem to hand over their own nationals to the German war tribunals might be deduced from the following case. On 5 March $1943^{846}$ the Netherlands Supreme Court decided to abolish a longstanding legal rule. ${ }^{87}$ According to article 264 Netherlands Civil Code divorce could amongst others be claimed on grounds of a crime committed when married and for which the spouse was sentenced to at least four years imprisonment. The Supreme Court's stance since $1851^{848}$ had been that the article could only be invoked in case

The facts of the case arose cunder Verordnung 1940/52, supra note 828 . However, also the successor regulathon enacted as annex to Kundmachung des Reichskommissars fü die bessetzten niederlandischen Gebiete uber die nunmehr geltende Fassung der Verordnung Nr. $52 / 1940$ über die Deutsche Genchtsbarkeit in Strafsachen vom 6. Juli 1942, VoB1 1942, S. 346 un paragraph $2(1)$ and $2(4)$ left misdemeanors to the compethencies of the Netherlands couts. See article 9 Wet van 9 juli 1900 houdende nadere regeling van den dienst en thet gebruk wan spoorwegen., warop untsluitend me beperkte snetheid word verwoerd, Stb. 1900, No. 118 gewijzigd bij de Wet van 15 december 1917, Stb. 1917, No, 701. Paragraph 2(1) Verordnung 1940/52, supra note 828. 
of a conviction by a Netherlands court. In 1943 a wife wanted to divorce her spouse who had been convicted of espionage by a Feldhriegsgericht or German war tribunal.

In cassation the supreme Court considered, amongst others, that judgments of foreign courts that offered enough legal guarantees would be granted authority in Netherlands courts as grounds for divorce under article 264 Netherlands Civil Code. In deciding this case in favor of the plaintiff, the Supreme Count clearly stated that it considered this German war tribunal to be equipped with sufficient legal safeguards. ${ }^{849}$ This in spite of the fact that the Supreme Court after the war admitted having knowledge during the occupation of the hardships a part of the Netherlands population had endured at the hands of the German war tribunals and the German police. 850

\subsection{APPOINTMENTS DURING THE OCCUPATION}

At the end of May 1940 the Secretaries General requested advice from one of the Netherlands' foremost public international lawyers, Prof. Telders, concening the appointment of judges during the occupation. ${ }^{851^{\prime \prime}}$ Telders pointed out that Article 43 Hague Convention implied the continuation of the organs of State of the occupied country and the exercise of their normal duties. Existing national law therefore had to be observed, in so far as no changes were made to these laws. This meant that according to Article 173 Netherlands Constitution the Queen had the competence to appoint members of the courts, which she could not delegate. The occupant, without the absolute necessity of Article 43 Hague Convention, could not appoint members of the courts. Any nember of the courts the occupant would appoint would not be a member of those courts in the sense of Netherlands legislation and could not participate in the functioning of those courts. The courts would have to function strictly on the legal bases Netherlands legislation provided and would have to reject any deviation from this principle in order to prevent creating a dangerous precedent. In order to avoid any absolute necessity for the occupant to appoint members of the courts, Telders advised that any vacancy would not be filled and other members of the court would take on extra cases. Telders was of the opinion that a legalistic approach due to strict adherence to Article 43 Hague Convention and Netherlands legislation would be the only way to maintain the courts and the administration under Netherlands control.

The Reichskommissar moved swiftly and announced his powers to appoint, suspend and dismiss high-tanking civil servants at the begining of June ${ }^{852}$ Concerning members of the courts he was to appoint the President, Vice-Presidents, and members of the Netherlands Supreme Court. Seyss-Inquart expanded these powers to

愘小

isto

sit

See also Cheweringa, p. 342

Drics, p. 49.

National Archief, Den Haag, Archief van mr J.P. Hooykaas 1940-1947, Nummer Toegang 2.09.56. inv. 12, Antekemingen van Prof. mr B.M. Telders met betrekking tot benoeming wan rechterbike ambtenaren aan de Secretarissen Generaal gericht van Mei 1940.

Erla $13,194 / 4$ des Reichskommissurs für die besetzten nicderländischen Gebiete uber den or ganisatorischen Aufbau der Dienststellen des Reichskommissars vom 3. Juni 1940, VoBL. 1940, S. 11: Verotonung 1940/108 Viete Verordnung des Reichshommissars fur die besetz-

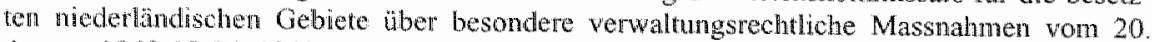
Alggas 1940, VoBl. 1940, S. 338. 
include the Presidents and public prosecutors of the Courts of Appeal ${ }^{853}$ All other appointments of public officials, insofar as this used to be a Royal power, were now exercised by the Secretary General competent to deal with the matter. This meant that the Secretary General of Justice, under the supervision of the Reichskommissar, appointed the Presidents and Vice-Presidents of the District Courts and the judges of the District and Cantonal Courts. ${ }^{84}$ Once Schrieke was appointed Secretary General of Justice in July 1941, every candidate would also be asked about his stance on national socialism and the occupation. ${ }^{5.55}$

Whereas the Civil administration had dealt with most of the leading figures of the prosecutor service in the fall of 1940, it then turned its attention to the courts. Netherlands national socialists had anticipated this move. The National Socialism and the Law Chapter of the Netherlands Nazi movement had sent a confidential circular to its members requesting them to indicate whether or not they were available for appointment to the courts. ${ }^{356}$ Problematic for the occupant was, however, that most judges supporting national socialism did not have the capabilities to be appointed as a judge. ${ }^{85}$

The first new appointments after the invasion were made at the end of November 1940 , whereby already national socialist judges were appointed. ${ }^{85.5}$ One member of the NSB, Couvée, ${ }^{859}$ had been appointed President of the Utrecht District Court. The Vice-President of the court attempted to rally the other judges to boycott the installation and not render the customary courtesy visit. ${ }^{360}$ Apparently the newly appointed NSB President was given a frosty reception. ${ }^{861}$ A deputy judge at the Cantonal Court of Tiel stayed his work due to his disagreement with the appointment of a

\$s. Paragraph 1 Erlaß 1940/4, Wid.

854 Paragraph 1(1) Verordnung 1940/3, supra note 184 and 1940/108 supra note 818; Nationaal Archief, Den Haag, Archieven van het Directoraat-Generaal voor de Bijzondere Rechtspleging, (1945-1952), met takkopvolgers en uitvoerende instanties (1945-1983) van hel Ministerie van Justitie, deel II: Uitvoerende instanties (Centraal Archief Bijzondere Rechtspleging), Nummer Toegang 2.09.09, inv. 74589, schriftur middelen wan cassatie J.J. Schrieke tegen het vomis van het Bijzonder Gerechtshof "s-Gravenhage wan 2 april 1946, p. 39. See also Biegel, p. 38, Bellefioid, p. 57.

Nationaal Archief, Den Haag, Archieven vam hel Directoraat-General voor de Bijzondere Rechtspleging, (1945-1952), met takkopwolgers en witwoerende instanties (1945-1983) van het Ministerie van Justitie, deel II: Uitwoerende instanties (Centraal Archief Bijzondere Rechtspleging), Nummer Toegang 2.09.09, inw. 74589, Dossier J.J. Schricke, vonnis Bijzonder Gerechtshof's-Gravenhage 2 april 1046, no. 473.

Frijtag. Recht, p. 109

Hirschfeld, p. 132.

sh Tresoar, Archief Procureur Generaal bij het Gerechtshof te Leenwarden, Notulen wan de Ver. gaderingen van het College van Procureurs Generaal, voorl. Inventaris 2512 , Notulen van de vergadering van Procureurs Generaal, fgd. Gewestelijk Directenuren van Politie of Donderdag 28 Nowember 1940, p. 526

Bis Bellinfante, p. 362.

g*t Tresoar, Archief Procureur Generaal bij het Gerechtshof te Leeuwarden, Notulen van de Vergaderingen van het College van Procureurs Generaal, woorl. Inventaris 2512. Notulen van de vergadering van Procureurs-Generaal, fgd. Gewestelijk Directeuren van Politic op Donderdag 19 December 1940 , p. 562.

Tresoar, Archief Procureur Generaal bij het Gerechtshof te Leeuwarden, Notulen van de Vergaderingen van het College wan Procureurs Generaal, voorl. Inventaris 2512, Notnlen van de vergadering van Procureurs-Generaal, fgd. Gewestelijk Directeuren van Politie op Maandag 23 December 1940, p. 585. 
national socialist Cantonal judge at the end of 1941 or the beginning of 1942 . The deputy judge was reported to the Sicherheitspolizei. ${ }^{862}$ One year later almost all members of this Cantonal Court had been replaced. ${ }^{863}$

During a meeting in May 1941 the Supreme Court deliberated on the presidential vacancy, recalling that in September 1941 Visser's nomal legal term under Netherlands law would expire and therefore the Supreme Court had not acted earlier, but was free to do so now. ${ }^{864}$ Several more vacancies occurred at the Supreme Court and the lower courts, especially after the Reichskommissar had enacted Regulation $1941 / 130,{ }^{865}$ which obliged every judge when reaching the age of 65 to retire. Justice van den Dries of the Supreme Court had held several meetings with Secretary General Schrieke concerning the new wacancies and the Court's List of Recommendarions. 866

The Civil administration only appointed one of the persons named on the List of Recommendations of the Netherlands Supreme Court, which had existed since before the occupation, namely P.H. Smits. ${ }^{867}$ Also the former Procurator General at the Arnhem Court of Appeal. J.A. de Visser, whom the Supreme Court had recommended, was appointed. However, contrary to constitutional convention, ${ }^{8}$ the rest of the vacancies were filled with people who neither occurred on the List of Recommendations nor were recommended by the Supreme Court. One newly appointed member was W.M.A. Weitjens, formerly a judge at the District Court in Amsterdam. Another new appointee, A.H. Helb, used to be a Justice at the Court of Appeal and the Peace Appellate Court in The Hague. Moreover, H.W.B. Thien and S.A. van Lunteren were also appointed to the Netherlands Supreme Court. The Reichshommissar also re-

62

Tresoar, Archief Procureur Generaal bij het Gexechtshof te Leeuwarden, Notulen van de Vergaderingen van het College van Procureurs Generaal, voorl. Inventaris 2513, Notulen van de vergadering van Procureurs-Generaal, fgd. Gewestelijk Directeuren van Politie op Donderdag 15 Januari 1942 , no. 81 .

The King app

appointed members of the Netherlands Supreme Court on the basis of a List of Recommendations, which the Supreme Court in collaboration with the Procurator General would submit. In accordance with Article 85 Judicial Organisation Act (1827) the Supreme Court would notify the Lower House of Parlianent that there was a vacancy and immediately inchuded the list. The six persons appearing on the list would all have been asked by the Supreme Court. Subsequently, according to constitutional convention, the Lower Chamber voted to affirm the first three candidates on the list in the order presented by the Netherlands Supreme Coutt and the Procurator General. However, formally Parliament was not bound by the List of Recommendations and could appoint anyone it deemed capable. Only rarely a discussion would take place about the persons the Supreme Court had presented, since Parliament would lack the opportunity to gather information about these lawyers. The List of Recommendations would then move on from the Lower Chamber to the Government. Contrary to Parliament the Crown, which is the Govemment headed by the King was obliged to appoint one of three candidates on the list. According to convention the first person on the list would nommally be appointed (see also Koppen/Kate, p. 29, 32, 36-38). 
placed President Visser of the Netherlands Supreme Court, who was dismissed on the basis of his Jewish ancestry, with Prof. dr. J. wan Loon who, although not nationalsocialist, was known as very pro-German. ${ }^{869}$ This was contrary to constitutional convention in that the President and Vice-Presidents of the Netherlands Supreme Court, with few exceptions, would be appointed on the basis of senionity. ${ }^{870}$

The Netherlands Supreme Court felt powerless to resist these appointments. After the war the prewar appointees claimed to have nevertheless contimued their duties as long as it could be arranged that the majority of the Court's thee chambers remained in safe hands. The prewar appointees" policy was to assure that the 'foreign elements" were only there for appearance sake, without any influence on the decision of cases. ${ }^{371}$ In only a handful of cases those appointed during the occupation without the consent of the prewar appointed members of the Supreme Court were able to be in the majority when deciding cases. ${ }^{872}$

After the appointment of President van Loon, the other members of the Supreme Court lost their influence on the List of Recommendations. Van Loon claimed he personally had made sure that Justices Smits and de Visser were appointed to the Netherlands Supreme Court ${ }^{873}$ and had allways looked for new candidates acceptable to a majority of the members. ${ }^{874}$ However, the new President disregarded the opinions of the other members of the Supreme Court and contrary to custom did not consult them in deciding upon the candidates to be placed on this list. ${ }^{875}$

The relationships between the members of the Supreme Court deteriorated rapidly and several other issues also became a matter of dispute. ${ }^{876}$ Consequently, the prewar appointees would hold meetings without informing the President. ${ }^{877} \mathrm{How}-$ ever, also within the camp of prewar appointees rifts would occur and they were not able to maintain a united front. ${ }^{878}$

\footnotetext{
46

gro Mazel, p. $60 \mathrm{ff}$ and Jong (deel 4-1), p. $413 \mathrm{ff}$.

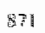

872

3

Article 170(2) Constitution 1938. See also Koppen/Kate, p. 45.

Dries, p. $45-46$.

See NI 1941-1945.

Ibid.

Loon, p. 14. I nevertheless agree with Ruiter, p. 207, 326 Chapter 15, footnote 14 that van Loon's publications about the war should not be completely discarded, but at least deserve some credibility. Although a special tribunal convicted Van Loon after the war and he was intemed, the judgment stated that he had worked tirelessly for every good Dutchman, Jews and countess other who approached him and used his goodwill with the occupant in favor of those in life threatening situations or fellow citizens in dire circumstances.

See Archief Hoge Raad der Nederlanden, Notulen Algemene Vergaderingen van 1921-1958, Algemeene Vergadering van den Hoogen Raad der Nederlanden op Maandag 1 September 1941, des namiddlags te 4 uur, p. 19.

\$87 Archinef Hoge Raad der Nederlanden, Notulen Algemene Vergaderingen van 1921-1958, A1gemeene Vergadering van den Hoogen Raad der Nederlanden op Dimsdag 6 Januari 1942, des namiddags te 4 uur, p. 20 en van Maandag 16 Februari 1942 des namiddags te 3 uur, p. 22 Archief Hoge Raad der Nederlanden, Notulen Algemene Vergaderingen van $1921-1958$, Algemeene Vergadering van den Hoogen Raad der Nederlanden op Woensdag 29 September 1942, des woomiddags te 10 uur, p. 32, op Donderdag 27 mei 1943 des namiddags to 3 uur te Nijmegen, p. 30 en op Woensdag 29 September 1942, des voormiddags te 10 uur, p. 32 , uur, p. 27.
} 
During mid-1941 the 'S-Hertogenbosch Court of Appeal was still actively in. volved in determining the appointments to the vacancies at its court. When one of the Justices had died the President corresponded with the Secretary General of Justice concerning the List of Recommendations, clearly indicating the count's preferences. It is also important to note that the court itself deviated from the conventional appointment procedure in proposing a non-Catholic for a vacancy formerly held by a Catholic. The President indicated the court's reasons in stating that the proposed candidate had excellent qualities. ${ }^{800}$ The Ministry of Justice delayed the appointment and more than $\&$ year later requested the court to submit a new List of Recommendations, partly due to the fact that the court's preferred candidate had been taken hostage. ${ }^{8}{ }^{2} 1$

Several courts, including the Amsterdam Court of Appeal ${ }^{882}$ and the Amsterdam District Court saw convention thwarted in that the Secretary General several times did not follow the List of Recommendations the courts had submitted. ${ }^{883}$ There is no indication the courts protested.

At the Leewwarden Court of Appeal a presidential vacancy had existed since 1 April 1941. Schrieke, in accordance with custom, wanted to appoint the VicePresident to the presidency, and the most senior member of the court to VicePresident. However, both justices in question, Beekhuis and Boeles were obliged to retire on the basis of Regulation 1941/130 concerning early retirement, even though the Leeuwarden court had recommended both to be appointed President and VicePresident respectively. Schrieke had even recommended their appointment to the Civil administration, but some German organ must have disapproved. It is possible

Although not an official criterion for appointment, religion was de facto an important criterion. A balance was struck between Catholics and non-Catholics in every organ of state, especially the Supreme Court. Until 1940, out of 17 members of the Supreme Court, even though more than one third of the population was Catholic, only 4 members of the Supreme Court were Catholic. In 1940, Taverne, van den Dries, Fick and Meckman were Catholic. This was also the case for Weitjens and Thien, appointed during the occupation. Protestant denominations usually filled the other offices at the Supreme Court, without any consistent policy concerning denomination. The first member of Jewish ancestry at the Supreme Court was ap. pointed in 1876, followed by the second in 1877 . In 1939, Visser, the only member with Jewish ancestry was appointed President of the Supreme Court (see Koppen/Kate, p. 76, 78, 153162).

Rijksarehief in Noord-Brabant, Vhiegenthart, A.J, als Hoge Autoriteit in 's-Hertogenbosch en als lid zuiveringscommissies, 1943-1959, loegang 1138, inw. 77 Brief 30 Juni 1941 van de President van het Gerechtshof te 's-Hertogenbosch aan de wat. Secretaris Generaal van Justitie.

Rijksarchief in Noord-Brabant, Vhiegenthart, A.J., als Hoge Autoriteit in "s-Hertogenbosch en alls lid zuiveringscommissies, $1943-1959$, toegang 1138 , inv. 77 Brief 18 November 1942 van de Secretaris Generaal van Justitie aan de President van het, Gerechtshof te "s-Hertogenbosch, no. $413 \mathrm{~B}$ and Brief 19 August 1942 van de Procureur Generaal bij en de President van het Gerechrshof te 's-Hertogenbosch aan de wnd. Secretaris Generaal van Justitie. Rijksarchief in Noord-Holland, Gerechtshof Amsterdam 1940-1949, toegang 450, inv. 2 Brief 14 Juni 1945 van de President van het Gerechtshof te Amsterdam aan de Secretaris Generaal van het Departement wan Justitie, no. 70. 
that both Justices also did not want to accept an appointment from the hands of the Civil administration. 84

Justice Viehoff was appointed to the court in April 1942 and a deputy member, Heymeijer in March of that year. Furthermore, Justice Cleveringa was taken hostage in July 1942, leaving the court understaffed. Schrieke tried to fill the vacancies, but the Justices at the court strictly adhered to the customary appointment procedure whereby the most senior member was to be appointed President. This was impossible in this case, since the most senior member, Cleveringa, was imprisoned. Furthermore, the members of the Court of Appeal discouraged any outsider whom Schrieke sent to apply for the position. When the Vice-President of the Assen District Court, Bondam, applied for the presidency of the Leeuwarden court, he maintained his motives were to prevent the appeals court from having to work with an NSB president. However, not willing to entertain the court's suggestions and not able to reply why he had not applied for the position of the most junior Justice, the Leeuwarden court questioned his motives and decided not to recommend him. " 8.5 .Justice Cleveringa, most likely due to his role in opposition to Bondam's appointment, was taken hostage shortly after, on 14 July 1942 . $^{886}$

As a result the docket of the court was piling up, leading to the fact that economic cases ${ }^{887}$ were not dealt with. ${ }^{888}$ The Leeuwarden court requested Schrieke not to fill the vacancies of President and Vice-President, but to appoint additional members to the court. Schrieke was not pleased with this request and was unwilling to grant it, since that would mean that the most senior person would be acting President. The current members of the court would have their way, since the appeals court could easily discourage applicants for the position it deemed unwanted. ${ }^{889}$ The Secretary General got so frustrated with the Leeuwarden Court of Appeal that he seriously considered dissolving it and establishing a new appeals court in the rivaling northern city of Groningen. ${ }^{890}$ A member of the Civil administration apparently prevented Schrieke from executing his plan. ${ }^{81}$

In any case Schrieke appointed, without following the conventional procedure with a List of recommendations, Justice Ten Raa, a member of the NSB. His installation in February 1943 was not very amicable, whereby he was not congratulated and no speeches were given. ${ }^{802}$ On 31 May 1943, Maitland, another national socialist and

\footnotetext{
Hermans, p. 56-57.

Hermans, p. $57-58$.

Hermans, p. 69.

sis 7 See Chapter 4.8 .

8 Tresoar, Archief Procureur Generaal bij het Gerechtshof te Leeuwarden, Notulen van de Vergaderingen van het College wan Procureurs Generaal, voorl. Inwentaris 2513, Notulen wan de vergadering van Procureurs-General, fgd. Gewestelijk Directeuren van Politie op Vrijdag g October 1942 in het Departement van Justitie, no. 105, p. 7 en Notulen van de vergadering van Procureurs-Generaal, fgd. Gewestelijk Directeuren van Politic op Vrijdag 23 October 1942 , no. 106, p. 1. See also 4.8 .

Ministerie van Justitie Depot 152, Rapport over Prof. Schrieke.

Nationaal Archief, Den Hag, Archief van mr J.P. Hooykaas 1940-1947. Nummer Toegang 2.09.56, inv. 42, Brief 31 Augustus 1942 van Hooykans aan de Secretaris Generaal van lustitie met begeleidende concept-Verordening tot opheffing Gerechtshof Leeuwarden en instelling Gerechtshof Groningen.

Hermans, p. 72-74.

Hermans, p. 61 .
} 
President of the Leeuwarden District Court, was appointed President of the Leeuwarden Court of Appeal. ${ }^{893}$ A third member of the NSB, Justice Okken, was finally installed in May $19433^{894}$

The occupant succeeded in appointing the President of the Supreme Court and six other members of the Supreme Court, of whom only two, Smits and de Visser, had been appointed with the approval of the Supreme Court. Concerning the Courts of Appeal at the end of 1943 roughly three quarters of the Justices in office still were prewar appointees, of whom $38 \%$ had been promoted. ${ }^{855}$ Moreover, at the end of 1943 almost one quarter of Court of Appeal Justices had been newly appointed. ${ }^{896}$ This meant, however, that taking into account the promotions and the new appointments during the occupation, that by the end of $194354 \%$ of Justices of the Courts of Appeal owed their appointment directly to the Reichskommissar. Also at the District Court level the occupant had made inroads into the leading positions. By the end of 1943 about $38 \%$ of the offices of President and Vice President had changed hands, although all except for one were due to promotions of prewar appointees. ${ }^{397}$ Overall out of 780 offices occupied in 1940 , by the end of $194310 \%$ were vacant. Of those offices prewar appointees still occupied $72 \%$ and almost $28 \%$ had been filled with new appointees. Of the prewar appointees about $13 \%$ had received a promotion. ${ }^{898}$ Around $37 \%$ of all judges at the end of 1943 in The Netherlands owed their appointment due to appointment by the Reichskommissar. Therefore, although the occupant had been successful in influencing the appointment of more than a third of all judges, of those in leading positions, especially the Supreme Court and the Courts of Appeal he had been most successful.

Already in the beginning of the occupation the occupant had succeeded in obtaining the powers to appoint members of the courts, and used those to even appoint national socialists. Individual members protested and passively resisted, but there was no collective action and the courts were unable to influence the occupant's personnel policy. However, one unspoken rule seemed to emerge at the courts during the occupation, which would have consequences for the judicial purge after the occupation. ${ }^{899}$ If a member of the courts had been taken hostage ${ }^{900}$ or had been removed from office, ${ }^{901}$ it was thought bad form to apply for the office that person had held.

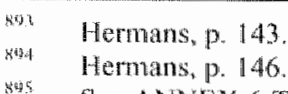

See ANNEX 6 Table 2. Out of a total of 62 Justices in 1943-1944, 29 prewar appointees (O) together with the 18 prewar appointees who had received a promotion during the occupation (P) were still in office. Out of a total of 47 prewar appointees still in office in $1943(\mathrm{O})+(\mathrm{P})$, 18 lad been promoted. 
In the fall of 1940 the Supreme Court failed to provide leadership conceming the matter of the Aryan Declaration. The removal of its President and the occupant"s success in appointing a pro-German President diwided the Court and further undermined any opportunity to provide leadership to the Netherlands courts, if it would have decided to do so. Moreover, the occupant succeded in influencing the appointement of more than one third of Netherlands judges at the end of 1943, reaping most of his success in the more leading positions. Also the lower courts lost their grip on the appointments, in some cases passively resisting, but in the end having to accept the occupant's personnel choices. The courts were unable to maintain a united front and resist deviations from Netherlands law and custom regarding appointments.

\subsection{REGULATION CONCERNING STATUTORY AGE LIMIT}

In Jully 1941 the Reichskommissar lowered the statutory age of retirement. The requirements on maximum age allowed to be a member of the Judiciary changed in the half a century preceding World War Two. Initially there was no maximum age. A Statute of Parliament ${ }^{902}$ in 1910 introduced a maximum age of 75 , but that was only applicable to appointments and not retirement from office. In 1932 this article 84 Judicial Organization Act $(1827)^{963}$ was amended in a way that all members of the Judiciary, including the Supreme Court would have to retire from office at the age of 70.904

Via Regulation $1941 / 130^{905}$ the Reichskommissam decided that members of the Netherlands courts reaching or past 65 years of age were to retire from office. The purpose of the measure, so the occupant, was to rejuvenate the Netherlands Judiciary, which was thought necessary and desirable for social as well as political reasons.

When the Secretary General of Justice, Hooykaas, was consulted on the envisaged measure, he indicated his approval. ${ }^{907}$ At least for the Cantonal and District Courts Hooykaas thought this proposal an improvement on the existing situation. For the Courts of Appeal he raised the objection that usually appointees were older and lowering the age maximum might impair the continuity of the administration of jusrice. Also for the Netherlands Supreme Court the Secretary General of Justice raised some objections, but Hooykaas did not fundamentally oppose it. In no way did Hooykaas object to any violation of Netherlands national law or incompatibility of the Civil administration"s measure with article 43 Hague Convention. He merely

1945 van de Voorzifter der Zuiveringscommissie Leetwarden aan het Hoofd van Sectie II Staf Militair Gezag.

301 Rijksarchief in Noord-Brabant, Vliegenthart, A.J., als Hoge Autoriteit in 's-Hertogenboseh en als lid zuiveringscommissies, 1943-1959, toegang 1138 , inv. 71 Dossiers Zuiveringsrad 's-Hertogenbosch.

ton Wet van 5 juli 1910, Stb. 1910, No. 180.

Q0: Article $173(2)$ and (3) Constitution 1938

904 For the Netherlands Supreme Court article 84 Wet RO, for the Courts of Appeal article 62 Wet RO, for the District Courts article 51 Wet RO and for the Cantonal Courts article 36 Wed RO. See also Koppen/Kate, p. 34.

wis Verordnung $1941 / 130$ des Reichskommissars für die besetzten niederländischen Gebiete über die Altersgrenze der Richter wom 18. Juli 1941, S. 538 .

Dries, p. 6: Frijtag, Recht, p. 110.

Wf? NIOD, Archief 21, doos 10b, map 1, Brief 27 Juni 1941 van Sectetaris Generaal van Justitie Hooykaas aan Kammergerichtsrat Seiffert. 
pointed out the practical difficulties involved in finding suitable candidates for the occurring vacancies. Also Schrieke, his national socialist successor who was appointed before this regulation was enacted, merely made some editorial comments.

The direct effect of the measure for the Netherlands Supreme Court was that 4 of its members had to retire during the occupation before reaching the statutory age of retirement under Netherlands law. The Civil administration, contrary to unwritten constitutional rules, appointed Prof. van Loon as President of the Netherlands Supreme Court. Being denied what would have customarily been his presidency Justice Kosters resigned in 1941, allowing for the occupant to appoint someone else favorable to his policies, possibly a national-socialist. In the same year, Justice Gelein Vitringa had to stand down. Justice Servatius was dismissed in 1942 after which Justice Meckman had to retire. Although Justices de Menthon Bake and Taveme had already passed the age of 65 in 1941 the Civil administration allowed them to remain in office. Taverne died on 9 May 1944.

The Netherlands Supreme Court did not protest against the early retirement regulation. However, two members of the Netherlands Supreme Court, van den Dries and Koster, met Schrieke, the newly appointed Secretary General at the Ministry of Justice. During this meeting, van den Dries informed the Secretary General of the fact that the Netherlands Supreme Court still supported the latest List of Recommendations to appoint new members to the Netherlands Supreme Court. ${ }^{909}$ Van Loon, who at that point had not yet been instated as President of the Supreme Court, claimed to have protested against the measure, after having consulted Vice-President Tavene. He credited himself with the fact that Justices Taverne and de Menthon Bake were allowed to remain in office due to his protests.

Regulation $1941 / 130^{411}$ also lowered the age of judges of the Courts of Appeal, District Courts and Cantonal Courts. In the last four months of 1941 the regulation affected 9 judges; in 1942 an additional 35 were removed from office, ${ }^{9 / 2}$

The regulation on early retirement violated international law. ${ }^{913}$ Furthermore, as the occupant stated himself, the measure was enacted to rejuvenate the Netherlands Judiciary, whereas article 43 Hague Convention limited his powers to public order measures. The measure further violated Netherlands law in deviating from the statutory age limit. Clearly the measure was designed to grant the occupant more influence over the Netherlands courts due to new appointments, which required his consent. The Netherlands Secretary General practically encouraged the occupant to enact the measure, as did his national socialist successor.

The Supreme Court did not protest and hoped that in spite of the occupant's violation of international and Netherlands law regarding retirement, the occupant would adhere to Netherlands legislation and custom regarding appointments. Just like the lower courts the Supreme Court, barring some passive resistance, left the irregular appointments, also of national socialists, unanswered. As a result of the occu-

\footnotetext{
NIOD, Archief 21, doos 10b, map 1, Brief Amtsgerichtsrat an die Abteilung Rechtsetzung vom 9. Jull 1941.

Dries, p. 44.45

Loon, p. 12.

Verordnung $1941 / 130$ des Reichsommissars fur die besetzten niederlandischen Gebiete uber die Altersgrenze dor Richter wom 18. Juli 1941, S. 538.

Frujtag, Recht, p. 110.

See Chapter 3.7 .
} 
pant's hold over the appointment procedure and his ability to make numerous new appointments due to the vacancies his early retirement regulation caused the courts would be divided. Like the Supreme Court, lower courts would also be divided, making it increasingly difficult to formulate a consensus to resist the occupant's policies and back up demands with a threat of mass resignation.

\subsection{Political COURTS, THE NE-BIS-IN-IDEM PRINCIPLE AND ANALOGY OF PENAL PROVISIONS}

Political courts with peace magistrates, up until then an unknown institution in the Netherlands, were created in August 1941. The Peace Courts' task, similar to their counterparts in the German Reich, was to adjudicate crimes that would endanger the political peace within the people's community (Volksgemeinschafi), which would touch the highest political interests of the people's community or had been committed for political reasons. ${ }^{9 / 4}$ The regulation also set aside the ne-bis-in-idem rule, allowing a Peace Magistrate, upon the request of the public prosecutor, to retry the facts of a res judicata or final judgement.

At district court level a chamber with one single judge was formed. ${ }^{115}$ The Secretary General of Justice appointed these peace magistrates. The rules of procedure that applied were borrowed from the procedure of the single judge at the District Court, some articles excepted. Against the preliminary investigation and the notice of summons and accusations no recourse could be had to the ordinary courts. An appeal against a judgment was possible to the Peace Appellate Court, though only against a sentence of imprisonment or a fine exceeding two hundred guilders. The Peace Appellate Court was composed of 3 Justices, also appointed by the Secretary General of Justice. The peace court jurisdiction was deliberately attached to the ordinary Netherlands judicial organization, even though in its proceedings it was completely independent. This way the new jurisdiction could make use of the facilities and services of the ordinary court system, like buildings, registrars, public prosecutor services and personnel. ${ }^{916}$

The peace courts were introduced at the instigation of some Netherlands officials, although the concept itself came from the office of the Reichskommissar. ${ }^{197} \mathrm{~A}$ member of the NSB, van Genechten, who had been appointed Procurator General in The Hague, had apparently been putting pressure on the authorities to introduce the peace jurisdiction. ${ }^{38}$ One of the reasons offered was that regular riots between civilians and the hated members of the NSB necessitated the introduction of this jurisdiction. If the ordinary courts dealt with cases they, out of principle, made no difference between national socialists and others. For members of the NSB it was unacceptable that the law and the courts of the traditional society used the same yardstick for the

\footnotetext{
wh Verordnung 1941/156 des Generalsekretärs in Ministerium für Justiz über die Bestellung von Friedensrichtert und die Einsetzung eimes Friedensgerichtshofs vom 12. August 1941, VoB1. 1941, S. 664. In Norway a similar institution had been introduced a year before (see Frijtag. Recht, p. 112).

\$1.5 Paragraph 101) Verordmung 194/156, ibid.

sis Carp, p. 9.

a) See Jong (deel 6-2), p. 648 and Mulder, p. 4.

918 Jong (deel $6-2)$, p. 647
} 
NSB, fighters of the revolutionary new society, and others." However, not only members of the NSB desired a political jurisdiction. Also to the Reichskommissar"s office it seemed advantageous to introduce such a jurisdiction. The ordinary Netherlands court system could then in principle prosecute and try the continuous hostilities against the Germans and their collaborators. Under the guidance of the newly appointed Secretary General of Justice Schrieke his predecessor Hooykaas adapted the concept of the Reichskommissar"s office to the Netherlands penal legislation as much as possible.

Schricke appointed almost exclusively members of the NSB to the Peace Appellate Court, who then also automatically became a member of the Hague Court of Appeal. J.H. Carp, a friend of the leader of the Netherlands national socialists, Mussert, was appointed President of the Peace Court. There were four military members, H.A. Seyffardt, W.I.D Havelaar, T.C. van Dierendonck and I.E. Hofman. Also H. Sluyterman and H.A. Helb were appointed, although neither one appeared to have been a member of the NSB. ${ }^{921} \mathrm{Mr}$ Helb was later on appointed member of the Netherlands Supreme Court ${ }^{922}$ Other members at the Peace Appellate Court were mrs S.J.M. Wijthoff, A. Semplonius and the court registrar J. Tuinstra. ${ }^{923}$ One judge Schrieke appointed Peace Magistrate to the Peace Court, the trial court level, was Maitland. Maitland had been a member of the District Court Winschoten ${ }^{924}$ and Cantonall judge in Emmen. ${ }^{925}$ Mr J.E.W. Duys, who before the war was a social democrat and Member of Parliament in the Lower Chamber, was appointed Peace Magistrate, but he had diad before he could take up office. The Secretary General of Justice also appointed mrs. van Vloten and W.U. Hazelhoff Roelfzema' ${ }^{926}$ to this political trial court. $^{92}$ ?

As the Civil administration expected, the introduction of the peace court jurisdiction encountered a lot of resistance from the Netherlands Judiciary. ${ }^{928}$ The Supreme Court protested, but mainly against the violation of the ne-bis-in-idem principle. Like most courts it presumed the institution of a political court system as part of the powers of the occupant to exclude certain crimes from the competencies of the occupied country's courts, as it saw confirmed in the Government's Instructions. ${ }^{929}$

At a meeting of the members of the Hague Court of Appeal it was proposed to demand the peace court decree would not be introduced, the refusal of which would result in en bloc resignation of the court. The proposal was not approved, mainly

As.t1 Asch, p. 486, Carp, p. 13

See Mulder, $\mathrm{p} .4$.

"21 See Mulder, p. III

wing See infrat

Asch, p. 491. See also Bestuursalmanak 1942-1943, p. 17 and Bestursalmanak 1943-1944, p. 11 , where different than in Asch also the three military nembers were listed.

The District Court of Winschoten had already been abolished before the war; see also Mulder, p. 13.

Maitland wists also appointed President of the Leeuwarden District Court (see Chapter 4, I). Schrieke later appointed Hazelhoff Roelfzema President of the Groningen District Court. See Mulder, p. 13. Although a letter of the Netherlands Minister of Justice-in-exile in London, G.J. vam Heuven Goedhart, no, 2647/P.18G, mentioned this Peace Magistrate to have been removed from office on the basis of article 4 Purge Decree E 14, no purge file was found. NIOD, Archief 21, doos 10, map 6. Brief Kammergerichtsrat Seiffert an die Abteilung Rechtsetzung vom 18. Oktober 1941

Dries, p. 7.
} 
since the appeals court did not feel directly involved. Also a meeting of several members of the Courts of Appeal and District Courts of the provinces of North and South Holland could not agree on a course of action. It was thought that only if at least $75-90 \%$ of the Judiciary would agree with the proposal it could have any effect. However, the participants of this meeting doubted whether their colleagues were willing to face the consequences of such an action. ${ }^{930}$

Advocate General Wijnveldt at the Supreme Court, Justice Halbertsma of the Hague Court of Appeal and. Justice Borgerhoff Mulder of the Hague District Court managed to direct a letter of protest to Schrieke, especially concening the violation of the ne-bis-in-idem principle. The criminal chamber of the Netherlands Supreme Court also addressed a letter to the Secretary General of the Ministry of Justice, which was signed by all members of the Netherlands Supreme Court. Furthermore, 370 members of the courts, officials of the public prosecutor's office and also highramking officials of the Netherlands Bar Association signed the letter. ${ }^{23}$

Some members of the courts took further steps. At the Hague Court of Appeal three Justices resigned. The first one was Justice Haga in September 1941, who was congratulated by the former President of the Supreme Court. Visser wrote Haga that as an individual, he had done what he deemed necessary under these circumstances, for which he deserved the utmost respect and Visser proceeded to wish him good luck 933

A discussion between Haga and the Secretary General of Justice, did not proceed as friendly. Schrieke accused Haga of irresponsibillity, since nore members of the courts might follow Haga's example, which meant that chaos would ensue. Haga denounced the criticism retorting fault lay with those who enacted the regulation. Schrieke's comment was that the regulation was issued in order to avoid worse, claiming the Germans might take over the administration of justice from the Netherlands courts. Haga's defiant response was: "Let them." "34

After his notice Haga established himself as an attorney in The Hague. Two other Justices of the Hague Court of Appeal, Van Berckel and Van Meeuwen, followed Haga's example, and resigned from office. Some officials of the public prosecutor"s office had also tendered their resignation, which was refused ${ }^{935}$ However, the Haga saga did not end here. According to an old custom an attomey allowed to plead before the Netherlands Supreme Court would be invited beforehand for a discussion. The occupant had in the meantime appointed van Loon as President of the Supreme Court. As a result Haga refused to have the customary discussion at the Netherlands Supreme Court upon which van Loon refused to swear Haga in. At the same time the Netherlands Supreme Court did not refuse to swear in the members of the newly formed peace courts.

\footnotetext{
4395 Ministerie van Justitie Depot 164, Intelligence report GB. 2830/44 Netherlands Intelligence Department, Rapport over houding rechterlijke macht.

9.1 Ministerie van Justitic Depot 152, Rapport over Prof. Schrieke.

4.3. Jong (deel 6-2), p. 650 .

Q3.3. Jong (deel 6-2), p. 650 , footnote 3 .

4; Jong (deel 6-2), p. 650 .

935. Ministerie van Justitie Depot 164 , Intelligence report $\mathrm{OB}$. 2830/44 Netherlands Intelligence Department, Rappont over houding rechterijke macht, which, however, only mentions Haga and Van Berckel's resignation. See also Mazel, p. 45 and 46 , footnote 21.

4.5. Mazel, p. 45, footnote 25 .
} 
Schrieke replied in November 1941 to the protest letters stressing that the nebis-in-idem principle was not absolute in either Dutch or German law. Besides, so Schrieke, if justice demanded it, an unlawfully acquitted accused should be condemned, even if the last judgment against him was res judicata. Although this might be contrary to the dignity of the State and the legal certainty of the individual, Schrieke argued this was supported by the legal consciousness of the people"s community. Those judges that had threatened to resign, either individually or en bloc, were lectured about the necessity to maintain a Netherlands court system to prevent the Reichskommissar from installing German judges if necessary. It was thought this had changed their mind, resulting in a decision to remain in office in spite of the objections to the peace court jurisdiction. ${ }^{938}$

Especially the public prosecutor service in some circuits and districts tried to nevertheless avoid any cooperation with the peace courts, aided by loopholes in the Regulation." ${ }^{9 y 9}$ The Jucliciary was warned though that the refusall to co-operate with the peace court jurisdiction would be viewed as sabotage against which the occupant would take harsh measures. 940

The work of the Peace Courts diminished rapidly. In 1942 the Peace Magistrate in 's-Hertogenbosch for example had still sentenced in 492 cases. This number decreased to 101 in 1943 and only 40 in 1944. The one in Leeuwarden rendered 70 judgments in 1942, eleven in 1943 and in 1944 there was only one single case. ${ }^{44}$ Already at the beginning of 1942 Peace Magistrate Maitland told his colleagues in an interview in the daily newspaper Nationaal Dagblad that the docket diminished, because the large masses increasingly understood the nationall socialist idea. Some asserted that although the population had modified its behavior, it had not adjusted to the $\mathrm{NSB}$. ${ }^{942}$

Due to the dwindling number of cases, the President of the Peace Appellate Court, Carp, tried to completely integrate the peace courts into the ordinary Netherlands court system. Both Schrieke and the Reichskommissar rejected this proposal. . $^{4.5}$ Even though their office was not integrated into the ordinary court system, once their docket diminished Peace Magistrates were increasingly moved to positions at ordi-

wy N1OD, Doc II, no. 658 Rechterlijke Macht, No. 2, Brief Secretanis General van het Departement van Justitie Schrieke aan Raadsheer Falbertsma, Adwocaat Generaal Wijnveldt and Ragdsheer Borgerhoff Mulder van 17 November 1941.

ws. Tresonr, Archief Procureur Gieneraal bij het Gerechtshof te Leeuwarden, Notulen van de Vergaderingen vam het College van Procureurs General, woorl. Inventaris 2511, Nomlen wan de vergadering van Procureurs-Generaal, fgd. Gewestelijk Directeuren vatu Politie op donderdag 13 Nowember 1941, p. 1051.

NIOD, Archief 21, doos 10, map 6, Brief Secretaris Generaal van het Departement van Justitic Schrieke aan Kammergerichtsrat Seiffert von 20 . Oktober 1941 and Brief Kammergerichtsrat Seiffert an Reichskommissar Seyss-Inquart vom 21. Oktober 1941.

Tresoar, Archief Procureur Generaal bij het Gerechtshof ie Leeuwarden. Notulen van de Vergaderingen van het College van Procureurs Generaal, voorl. Inventaris 2511. Notulen van de vergadering van Procureurs-Generaal, fgd. Gewestelijk Directeuren van Politie op donderdag 13 November 1941, p. 1051.

ad Jong (deel 6-2), p. 655 .

Jong (deel 6-2), p. 655-656 and Mazel, p. 48 
nary courts, sometimes at the explicit request of those courts. ${ }^{94}$ This meant that the ordinary courts obtained new members who had initially been appointed to the peace court jurisdiction for enjoying the trust and support of the NSB and the ocoupant ${ }^{94}$

The last session of the Peace Court 's-Hertogenbosch was on 29 May 1944. In January 1945 the Leeuwarden Peace Court had its last session, before it was also abolished. ${ }^{946}$ Due to a fire in the building of the Hague Court of Appeal all doctments of the appeals court, as well as the Peace Appellate Court were lost. ${ }^{94}$

The establishment of Peace Courts to adjudicate 'political crines' and the setting aside of the ne-bis-in-idem rule were precedents in the Netherlands legal order. The peace courts also served as a breeding ground for national socialist legal thought and their idea of renewal of the existing legal order. One of these ideas concerned the introduction of the principle of analogy in criminal law. Peace Magistrates held meetings on the topic, about which Netherlands lawyers had already had discussions in the past. ${ }^{648}$ At least one Peace Magistrate in the Circuit of Amhem in the beginning of 1942 ruled it a principle of Netherlands law. "This was actually not completely wrong in that the Netherlands Supreme Court in a case in $1921^{\text {a) } 50}$ had already recognized the analogous application of Article $310 \mathrm{NPC}$ in order to be able to include the theft of electricity under this provision. Also in other cases the Supreme Court had shown to deviate from a strictly legalistic or positivist approach to penal law in that it allowed for extra-statutory grounds for exclusion of sentencing on the basis of amongst others absence of culpability ${ }^{951}$ and the lack of material illegality."

In June 1943 Secretary General Schrieke's introduction of the analogy of penal provisions further undermined the Netherlands legal order. ${ }^{953}$ To article 1 NPC was added a provision stating that if the wording of a penal provision did not apply to a

34:4 Archief Gerechtshof 's-Hertogenbosch, Notulenboek Arrondissementsrechtbank 's-Hertogenbosch 1924-1967, Algemeene Vergadering der Arrondissementsrechtbank 's-Hertogenbosch op Vrijdag 8 mei 1942, p. 56 en Vergadering van 28 October 1943, p. 64; Tresoar, Archief Procureur Generaal bij het Gerechtshof te Leewwarden, Notulen van de Vergaderingen wan het College van Procureurs Generaal, voorl. Inventaris 2513, Notulen van de vergadering van Procureurs Gieneraal, fgd. Gewestelijk Directeuren van Politie op Vrijdag 6 Matart 1942, no. 86, p. 2.

Nationaal Archicf, Den Haag, Archieven van bet Directorat-Generaal voor de Bijzondere Rechtspleging, (1945-1952), mett takop*olgers en uitwoerende instanties (1945-1983) van het Ministerie wan Justitie, deel II: Uitwoerende instanties (Central Archief Bijzondere Rechtspleging), Nummer Toegang 2.09:09, inv. 67946. Dossier J.J. Schrieke, vonnis Bijzonder Gerechtshof ' $\$$-Gravenhage 2 April 1946 , no. 473 ; inv. 74589 , schriftur midelen van cassatie J.J. Schrieke tegen het vomis van het Bijzonder Gerechtshof 's-Gravenhage van 2 anpril 1946. p. 66.

Mulder; p. 43 .

Asch, p. 494 .

Scholtens, Staatsrecht, p. 47.

Tresoar, Archief Procureur Generaal bij het Gerechtshof te Lecuwarden, Notulen van de Vergaderingen van het College van Procureurs Generaal, voorl. Inventaris 2513. Notwlen valu de vergadering van Procureurs-Generaal, fgd. Gewestelijk Directeuren van Politie op Vrijdag 20 Februari 1942 , no. $84, \mathrm{p} .4$.

950 Hoge Raad 23 Mei 1921, NJ 1921, 564 (Electriciteitsarrest).

o51 Hoge Raad 14 Februari 1916, NJ 1916,681 (Melk-en-water artest).

952. Hoge Raad 20 Februari 1933, N/ 1933, 918 (Veeartsarrest).

453. Verordnung 1943/62 des Generalsekretärs im Ministerium für Justiz über die Amwendtung gesetzlicher Strafbestimmungen vom 9. Juni 1943, VoBU. 1943, S. 233. 
cortain act, but the basic idea underlying it did, then the penal provision would nevertheless apply, if the act were punishable according to "a healthy sense of justice".

The Supreme Court did not put up any resistance. ${ }^{954}$ Asked for an opinion before enactment of the regulation, the Supreme Court merely made some editorial remarks. The Court's rationale was that no explicit criminal provisions existed in The Netherlands concerning the external security of the State. After the occupation would have endled this regulation would allow for the prosecution of those crimes, whereby the Court naively had not expected the Government-in-exile would enact the necessary prowisions retroactively. ${ }^{955}$ Other courts do not seem to have protested.

It was difficult to accept the occupant's deviation from the ne-bis-in-idem principle, it being a violation of article 68 Netherlands Criminal Code and international law. Although Schrieke was right the principle was not absolute under Netherlands law, its exceptions were nevertheless narrowly described. Moreover, under article 43 Hague Convention there did not seem to be an absolute impossibility to adhere to Netherlands law to deal with crimes to maintain public order. And although international lawyers were divided over the extent to which criminal laws and civil laws could be altered, these changes would nevertheless always be temporary and based on military purposes necessary for the maintenance of public safety and public order." However, the jurisprudes' sillence about attributing to an occupant the authority to alter the legal order of the occupied country and its underlying principles ${ }^{95}$ ? probably indicated that authority did not exist. Moreover, the Netherlands courts had tried many of these crimes under Netherlands law, removing the necessity for the occupant under article 43 Hague Convention to enact a measure allowing for a retrial of these cases. The Netherlands courts did not protest the fact that the introduction of the peace courts allso violated the Judicial Organization Act (1827). Its article 1 only allowed for the courts listed to exercise the administration of justice in the Netherlands. The peace courts were nevertheless attached to the Netherlands organizational structure for their administration of justice. Furthermore, article 2 Judicial Organization Act (1827) only allowed for the courts enumerated to exercise the competencies of the Netherlands courts.

Contrary to the Peace Magistrate"s assertion, the analogous application of penal provisions had not been a general principle of the Netherlands legal system. Nevertheless, the Supreme Court in the past had introduced this principle into the Netherlands legal order and had also created a precedent in deviating from a strictly positivist approach to criminal law. As has been argued above, internationall lawyers did not seem to permit an occupant to alter the principles underlying the legal order of an

55.4 See also Mazel, p. 54; Mok, Proza, p. 11 .

Dries, p. 55-56. For the exile measures see also Chapter 6.4.2.

Asto Oppenheim, Peace, p. 214-215. For a contrating opinion see Spaight, p. 356; Bordwell, p. 300; Baer Poortugael, p. 174.

56 Verres, Tonne 1, p. 180.181; Spaight, p. 358; Beer Pootugael, p. 178.179; Rolim, Tome 1, p. 438-440; Oppenheim, War, p. 214-2 15 stated that the occupant may "... so far as it is necessary for military purposes or fon the maitntenance of public order and safety, temporarily alter the laws, especially the Criminal Law... However, also Oppanhem did not mention altering the principles underlyng the criminal legal order and also seenned to limit his statement to the moditication of specific legal provisions and only for military purposes; Bordwell, p. $301-302$; Vereijl, p. 227 stated the oceupant was not probibited from introducing additional penal provisions into the oceupied country's legal onder. 
occupied country, also not wia introduction of the principle of analogy of penal law. However, the fact that the Supreme Court in the past had allowed for a deviation from a strictly positivist approach to penall law would have undermined the courts" ability to resist the introduction of the occupant's measure of analogy of penal provisions.

\subsection{ESTABLISHMENT COURTS TO TRY ECONOMIC CRIMES AND JUDICIAL REVIEW?}

The Peace Courts were not the only new legal institution created in The Netherlands in 1941. In April 1941 Secretary General Hooykas signed a regulation introducing Economic Courts to try economic crimes. ${ }^{458}$ The initiative to create a separate jurisdiction to try economic crimes was a joint-decision of Secretaries General Hirschfeld and Hooykaas. The ordinary courts were swamped with crimes of black market trading, price inflation and economic sabotage. Both Secretaries General were therefore of the opinion that the introduction of this new jurisdiction would speed up the prosecution and conviction of economic crimes. Certain articles from the Netherlands Code of Criminal Procedure would not be applicable to these cases, ${ }^{959}$ speeding up proceedings, but also seriously limiting the rights of the defense. ${ }^{\circ 60}$ The Civil administration was keen on having the Netherlands legal system deal with violations of regulations concerning economic matters.

Like the Peace Courts, the Economic Courts were introduced as chambers to the ordinary courts. Attached to a District Court would be one judge dealing with criminal economic acts. ${ }^{962}$ The Secretary General of Justice would appoint the economic judges. ${ }^{96.3}$ After Schrieke had been appointed Secretary General of Justice an increasing number of members from the Netherlands National Socialist Movement NSB were appointed to positions at the economic courts. ${ }^{964}$

The Economic Courts had sole jurisdiction over offenses and misdemeanors punishable by Netherlands economic laws and regulations dealing with economic crimes. ${ }^{965}$ The procedural law to be applied was the code of criminal procedure used by a single sitting judge at district courts, excluding certain provisions. ${ }^{96}$ Only in case of a prison sentence or a pecuniary charge above 200 guilders an appeal could be made to a special economic division at the Court of Appeal. ${ }^{967}$ At the end of 1942 a newly established Economic Court of Appeal would deal with the appeals. ${ }^{96}$ The

\footnotetext{
45: Verordnung 1941/71 des. Generalsekretärs im Ministerium fü Justiz über die gerichliche Behandlung von Wirtschafsstrafsachen vom 7. April 1941, VoB1. 1941, S. 297.

lbid, paragraphs $3-6$.

See also Mok, Proza, p. 11.

See also Frijtag, Recht, p. 114-115.

Paragraph 1(1) Verordrung 1941/71, ibid.

Paragraph 1.2) Verordnung 1941/71, ibid.

Hirschfeld, p. 131.

Paragraph 2 Verordnung $1941 / 71$, supra note 958.

Paragraph 3 Verordnung 1941/71, ibid.

Paragraph 5 Verordnung 1941/71, ibid.

Tresoar, Archief Procureur Generaal bij het Gerechtshof te Leeuwarden, Notulen wan de Vergaderingen wan het College van Procureurs General, voorl. Inventaris 2511, Notulen van de vergadering van Procureurs-Generaal op Vrijdag 9 October 1942 in het Departenent van Justitie, no. 105, p. 1.
} 
Supreme Coun still served as cassation court for economic cases, also since it was expected that after the introduction of the Economic Court of Appeal only few economic cases would be brought to the Supreme Court and its role would be marginal.

When the ordinary Courts of Appeal would still deal with the appeals from the Economic Courts, most Courts of Appeal appeared to be systematically decreasing the sentences given in first instance. The Civil administration regarded the sentencing as too lenient and was therefore of the opinion that the Netherlands economic judges had failed. Having been asked about the leniency in sentencing and the reduction of the sentences from the Economic Courts, the Courts of Appeal denied the allegation. ${ }^{971}$ Frustrated about the leniency in sentencing, the German prosecutor service and German police intervened increasingly in cases pending before the economic courts. ${ }^{972}$ Cases decided upon before the Economic Courts were in some instances remopened before the German jurisdictions. ${ }^{973}$ Sentencing from the Netherlands economic jurisdiction later on increased dramatically. ${ }^{974}$

The Netherlands courts did not counter the introduction of the economic court system and the subsequent limitation of the ordinary courts' competencies. The Dordrecht District Court even enlarged the competence of the Economic Court in a case decided in 1941. ${ }^{975}$ The Regulation concerning the Adjudication of Economic Crimes $^{976}$ gave the Economic Court the competence to decide on the remand into

56. Tresoar, Archief Procureur Generaal bij het Gerechtshof te Leeuwarden, Notulen van de Vergaderingen van het College van Procureurs Generaal, woorl. Inventaris 2511 , Notulen wan de vergadering van Procureurs-Generaal op Vrijdag 19 Juni 1942 in het Paleis van Justitie te 's-Hertogenbosch, no. 98, p. 2.

क77) Tresoar, Archief Procureur Generaal bij hei Gerechtshof te Leeuwarden, Notulen van de Vergaderingen van het College wan Procureurs General, voorl, Inventaris 25 1, Notulen van de vergadering van Procureurs-Generaal op Donderdag 30 October 1941 in het Departement van lustitie, p. 1026 en Notulen van de vergadering van Procureurs-Generaal, fgd. Gewestelijk Directeuren van Politie op donderdag 13 Nowember 1941, p. 1052. See also Tresoar, Archief Procureur General bij luet Gerechtshof te Leeuwarden, Notulen van de Vergaderingen wan het College van Procureurs Generaal, voorl. Inventaris 2511, Notulen van de vergadering van Procureurs-Generaal, figd. Gewestelijk Directeuren van Politie op Donderdag 4 December 1941 , p. 1081-1082, brief: 15 November 1941 van de Secretaris General wan Justitie aan de Heerer Raadsheren in de Gerechtshoven belast met de berechting van strafzaken, rakende het economische leven, 6 e Afd., no. 1110.

w. Tresoal, Archief Procureur General bij het Gerechishof te Leeuwarden, Notulen van de Vergaderingen wan het College van Procureurs Generaal, voor. Inventaris 2511 , Notulen van de vergadering van Procureurs-Generaal, fgd. Gewestelijk. Directeuren van Poltie op Donderdag 4 December 1941, brief 1 December $1941 \mathrm{van}$ her Gerechtshof te "s-Gravenhage aan de Secretaris Ganeraal wan het Departement van Justitie, p. 1082; brief 1 December 1941 van de Advocaat-Generaal bij het Gerechtshof te Arnhem an de Procureur-General bij het Gerechtshof to Anhem, no. 112, p. 1084

NIOD, Archief 33, doos 16, map b, Brief Reichskommissar Seyss-Inquart an Generalkommissare Wimmer, Fischböck, Rauter and Schmidt vom 9. Mai 1942; Brief Kammergenchtsrat Seiffert an Generalkommissar Wimmer von 20 . Mai 1942.

Frijtug, Recht, p. 115.

Hirschfeld, p. 131.

Arrondissementsrechtbark Dordredu 30 jun 1941, NJ 1941,663.

Verordnung 1941/71 des Generalsekretärs im Ministerium fü Justiz über die genichtliche Beflanditung von Wirtschaftsstrafsachen von 7. April 1941, VoBl. 1941, 5 . 297, Verordnung $1942 / 39$ des Generalsekretärs im Ministerium fuir Justiz, wodurch die Verordnung $\mathrm{Nr}$. $71 /$ 
custody. However, the regulation did not explicitly state that the termination of the custody was also within the competence of the Econonic Court. According to the Netherlands Code of Criminal Procedure, the district courts, ex officio or at the request of the examining magistrate, the suspect or the even the public prosecutor decided on the termination of an order to remand a suspect into custody. "Forfeiting a possibility to exercise supervision over the Economic Courts, the Dordrecht District Court declared itself incompetent to decide on the issue. It simply stated that the fact that the economic courts were competent to decide on the remand into custody also implied the economic courts' competence to decide upon its termination. Article 72(c) second paragraph Code of Criminal Procedure allowed for a court to declare itself incompetent in case it was of the opinion another court was competent. How ever, the economic courts had not been explicitly declared competent to rule on the termination of the remand into custody. Furthermore, the economic courts were not established under the Judicial Organization Act (1827) and could therefore not be seen as a competent Netherlands court to decide upon the temination of a remand into custody.

In January 1942 the Supreme Court would be asked to rulle on the validity of the verdicts of the Economic Courts in a judgment that became known as the Toessingsarrest or Judgment on judicial review." The underlying question, however, was whether the occupant, under article 43 Hague Convention, was allowed to establish the Economic Courts. All members of the Supreme Court had been involved in studying this delicate matter from a legall perspective, knowing that at some point the Supreme Court would be confronted with the question of the legality of the occupant's measures. Vice-President Koster was in charge of writing the internal memo, most probably in the second half of $1940{ }^{979}$ Although the Criminal Chamber rendered the verdict, it can therefore be seen as indicative of the point of view of the whole of the Supreme Court.

On 27 October 1942 cassation was submitted to the Criminal Chamber of the Netherlands Supreme Court. According to the verdict of the Economic Court the accused, a fishmonger from Voorburg, had illegally sold a certain quantity of pork suitable and intended for human consumption without a valid license. This was contrary to Netherlands legislation, in this case the Distribution Act (1939) and a meat dispatching regulation issued by the Secretary General for Agriculture. ${ }^{980}$ The attorney for the accused requested that the judgment of the Bconomic Court be quashed, since

1941 über die gerichtiche Behandlung von Wirtschaftsstrafsachen abgeändert und ergänzt wird von 7. April 1942, VoB1. 1942, S. 191; 2. Verordnung 1942/92 des Generalsekretärs im Ministerum für Justiz, wodurch die Verordnung $\mathrm{Nr}$. 71/1941 über die gerrichtliche Behandlung von Wirtschaftsstrafsachen abgeăndert und ergänzt wird vom 13. August 1942, VoB1 1942, S. 405; 3. Verordnung 1943/40 des Generalsekretärs im Ministerium fuir Justiz, wodurch die Vertordnung Nr. 71/194I über die gerichtliche Behandlung won Wirtschatisstrafo sachen abgeändert wird vom $\mathbb{5}$. April 1943, VoBl. 1943, S. 168.

Article 69 e.a. Sv.

NJ 1942,271

Ruiter, p. 197, 326 and Chapter 14, footnote 40. The author referred to member and later President of the Supreme Court Donner's private archive, which contained the undated internal memo.

989 Verordnung 1940/143 des Generalsekretärs im Ministerium für Landwirtschaft und Fischerei zur Durchfihnrung des Zuteilungsgesetzes 1939 (Zuteilung von Fleisch und Fleischwaren) vom I1. September 1940, VoBl. 1941, S. 433. 
neither according to the Netherlands Judicial Organization Act (1827) nor the Nethcrlands Code of Criminal Procedure an Economic Court existed. The Economic Court had neglected to declare the inadmissibility of the case due to the fact that it was incompetent. Admittedly the Secretary General of the Ministry of Justice had given the Economic Court criminal jurisdiction in certain areas via Regulation 1941/71, but the Secretary General's authority was based on a Regulation 1940/23 of the Reichskommissar ${ }^{382}$ and both measures were, so the attorney of the accused, not binding.

The regulations were in direct violation of international law, which authorized the Civill administration to take all possible measures in order to protect public order and public life, while maintaining the country"s legislation in force, except in cases of absolute impossibility. According to the attorney of the accused this absolute impossibility was not present here. Even if the occupant gave a civil servant, whose country was occupled, the possibility to enact legislation, this could only occur within the context of the powers, which the occupant himself had. The attorney of the accused continued to argue with quotations from German and Belgian jurisprudence where courts of an occupied country had asserted authority to review the occupant's measures for compliance with international law. Netherlands legislation at issue, the Judicial Organization Act (1827) and the Netherlands Code of Criminal Procedure were compatible with the interests of the Civil administration and therefore there existed no 'absolute impossibility'. As a result the Netherlands Supreme Court was requested to declare the regulations in question contrary to international law.

The criminal chamber, consisting of the prewar appointees Taverne, de Menthon Bake, Servatius, van der Flier and the occupation appointee de Visser, ${ }^{983}$ announced its judgment on 12 January 1942. The Netherlands Supreme Court argued that according to article 43 Hague Convention the Civil administration was allowed to enact all possible measures for the protection of public order and public life, while maintaining the country's legislation in force, except in cases of absolute impossibility. According to the Führer's decree the Reichskommissar was empowered to exercise governmental powers and authorized to issue Regulations with the force of law. The authority of the Secretaries General on the basis of the Reichskommissar's Regulation $1940 / 3$ allowed for their regulations to have force of law as well. Moreover, under the present circumstances, the regulations of the occupant and the Secretaries General could not be denied the same nature as Netherlands legislation.

Concerning the right of judicial review the Netherlands Supreme Court argued that Netherlands courts lacked competence to review the content or fairness of legislation and could therefore not check for compliance with the Hague Convention. Neither the legislative history of article 43 Hague Convention nor of the Netherlands legislator indicated any such review competence. The Netherlands Supreme Court therefore judged that cassation was not admissible.

\footnotetext{
921 Verordnung $1941 / 71$ des Generalsekretärs im Ministerium für Justiz über die gerichtliche Behandlung von Wirtschaftsstrafsachen vom 7. April 1941, VoB1. 1941, S. 297.

w2. Verordinung 1940/23 des Reichskommissars für die besetzten niederländischen Gebiete über die Befugnisse der Generalsekretäre der niederländischen Ministerien vom 21. Juni 1940, VoBl. 1940 , S. 55.

4.3 See allso Leijten, p. 2046. However, Leijten wrongly claimed all Justices that had rendered the Judgment on judicial review were prewar appointees.
} 
The Supreme Court was not alone in its view on occupation legislation and the courts' powers of review. Several Presidents and Vice-Presidents of Courts of Appeal and District Courts supported this judgment and were of the opinion that the other courts in The Netherlands were also in agreement with this judgment. ${ }^{98.4}$

The Supreme Court defended its ruling, even after the occupation, arguing that the position of the courts, like that of other state organs, had changed due to the Civil administration's exercise of sovereignty. Although the Hague Convention did not regulate the balance of power between the courts and the Civil administration, international law allowed the occupant to dismiss state officials, including judges. Furthermore, it was customary that judicial officials would fulfill their duties in the interest of their country, as long as sufficient independence was left to them and they were not forced to dispense justice in the name of another sovereign. ${ }^{9.5}$

During the occupation the judges were in a conflicting situation. On the one hand, like before the occupation, they only owed responsibility for rendering justice to their conscience, free from any kind of influence or guidance. Nevertheless, on the other hand, the Civil administration had the power not to execute the judgments and to dismiss the judges from office. In relation to the occupant the courts were in a weakened position. The only weapon the courts still had was the threat to lay down their work. This, so van den Dries for the Supreme Court, was not a very sharp weapon and should be used wisely. These conditions also led to the fact that the Civil administration did not leave the entire area of competencies of the Netherlands courts intact, since it distrusted the Netherlands Judiciary too much. ${ }^{986}$

The reason for the Supreme Court's contention that the regulations could under the present circumstances not be denied the nature of Netherlands legislation provoked a lot of outrage. However, under article 99(1)(2) Judicial Organization Act (1827) the Supreme Court was only allowed to quash judgments of lower courts for violation of Netherlands law. ${ }^{987}$ The Netherlands Supreme Court was only competent to try cases in cassation of a Netherlands authority and not of a foreign power. If the Supreme Court had not allowed for the regulations of the occupant and those of the Secretaries General derived from his authority, it would not have been able to deal with cases involving occupation legislation. ${ }^{198}$ Since no Netherlands authority established under Netherlands law was enacting measures during the occupation, at strict interpretation of that article would bar the Court from hearing the case and assuring. uniformity of interpretation. ${ }^{989}$

The Court via van den Dries's postwar reply mentioned several reasons why courts during an occupation could not review the occupant's measures.

Rijksarchief in Noord-Holland, Gerechtshof Amsterdam 1940-1949, toegang 450, inv. 2 Correspondentie, Brief 1.5 Mei 1943 van de Presidenten van de Gerechtshoven van 's-Hertogenbosch en Arnhem, de Presidenten van de Arrondissementstechbanken van Almelo, "s-Gravethhage en Haarlem, de Vice-Presidenten van de Arondissementsrechtbanken van Amsterdam en Rotterdam aan de Reichskommissar Seyss-Inquart. See also N『OD. Archief 33, doos 17. map c.

985 Dries, p. 12-13.

ase Dries, p. 12-15.

487 See Chapter 4.2. See also Schmidt.

Sas See also Bellefroid, p. 53, Scholtens, Statsrecht, p. 25.

$48 \%$ Dries, p. $37-38$ and foomote 45. 
It stated that in peacetime national courts did not have the competence under inlemational law to examine actions of a foreign power or their functionaries for their legality. Also after the war this was the rule, unless a peace treaty stipulated something different. Therefore, national courts during wartime also did not have the authority to examine a foreign power" $s$ factual exercise of national sovereignty. 990

However, the powers the occupant exercised during an occupation were not his own sovereign powers. The Hague Convention allowed him, due to the fact of the occupation, to exercise the sowereign powers of the occupied State. ${ }^{991}$ His powers were therefore based on the fact of the occupation, the sovereign powers of the occupied State and international law, but not on his own sovereign powers.

Also the argument that since the Netherlands courts were not allowed to review acts of Parliament for compliance with the Constitution ${ }^{92}$ and therefore could not review occupation legislation for compliance with article 43 Hague Convention ${ }^{993}$ is a false one. First of all it has to be underlined that the Supreme Court recognized Netherlands courts could apply provisions of the Hague Convention. ${ }^{994}$ The courts would therefore also be able to apply article 43 Hague Convention. The Supreme Court's contention that review of the accupant's measures with article 43 was not possible, since also under national law courts could not review an Act of Parliament was erroneous. An Act of Parliament, duly enacted via constitutional procedures and safeguards was seen as an expression of the general will of the people. Courts, according to the prevailing theory at the time, had no business in appreciating the value of this expression of the general will. The case was different with occupation legislation. There were no constitutional procedures and safeguards involved, let alone an expression of the general will of the people living on the occupied territory. ${ }^{995}$

Another argument with which the Court sought to support its judgment referred to the fact that the legislative history of the Hague Convention did not expressly address the question of judicial review. ${ }^{996}$ There was only one remark made by the Swedish envoy, Baron de Bildt, which was not contradicted, namely that the occupant would be his own judge in determining the necessity to amend the existing legislation of the occupied country. ${ }^{99}$ ?

Although de Bildt's claim was not contradicted, no other delegate during the negotiations expressed his consent. There was also no express provision in the Hague Convention barring judicial review. Moreover, before the Hague Convention codified customary international law, courts were competent to rule on whether the occupant

Whin

4)

902

Dries, p. 16.

See e.g. Spaight, p. 322, 329.

See articles 124 Netherlands Constitution and 11 Wet Algemene Bepalingen (Wet van den $15 \mathrm{den} \mathrm{Mei} 1829$ (Stb. 1829, No. 28) houdende Algemeene bepalingen der wetgeving van het Koningrijk, gewijzigd bij de Wet van 26 April 1917, Stb. 1917, No. 303).

Dries, p. 17.

Already at the beginaing of the century, the Supreme Court had recognized that provisions: containing legal rights in treaties, approved of by Parliament, assented to by the Queen and duly published, were applicable without further legislative intervention (see Hoge Raad 25 Mei 1906, Wyhr, 8383). Furthermore, the Supreme Court had applied artide 53 Hague Convention in Hoge Rand 26 mei 1941, N/ 1941, 868. See also Rutgers, p. 749.760.

Nispen tot Sevenaer, p. 272.

Dries, p. 18

Mechelynck, paragraph 21, p. 345 . 
acted conform the customs of war. ${ }^{998}$ From the preamble it was clear that the contracting parties intended to replace the customary international law in force before the adoption of the Convention. However, contracting parties also realized this was but an incomplete code of the laws of wars. For cases not included in this convention 'the inhabitants and belligerents remain under the principles of the laws of nations as they result from the usages established anong civilized peoples, from the laws of humanity, and the dictates of the public conscience'. ${ }^{.99}$ The Hague Convention furthermore did not intend to leave '... unforeseen cases $(. .$.$) to the arbitrary judgment$ of military commanders. ${ }^{10000}$

The Court maintained that practice showed that, although the courts almost always remained in office during an occupation, it almost never came to judicial review of the occupant's measures. Some Belgian courts during the First World War reviewed occupation measures, but this was stopped by a judgment of the Cour de Cassation. The Cour de Cassation decided that the national courts did not have such a review competence. Concerning the Second World War there was still too little information. Only one judgment of the highest Norwegian court was published, in which a review competence for the national courts concerning occupation legislation was affirmed, however not whether occupation legislation was valid according to international law. ${ }^{1001}$

The reason why the Belgian Cour de cassation during the occupation of World War One denied competence to review the occupant's measures did, however, not lie in international law, but in Belgian national law. Belgian legislation implementing the Hague Convention stated the latter should be given full and complete effect. For the Cour de cassation this meant that the Belgian legislator had intended for the occupant's measures based on the Hague Convention to have force of law and therefore the Belgian courts were obliged to abstain from review. ${ }^{1002}$ Moreover, the Liège ${ }^{1003}$ as well as the Brussels ${ }^{1004}$ Cours d'appel during World War One assumed international law granted national courts of an occupied country at least some review powers concerning the occupant's measures. ${ }^{1005}$

The Court's contention that legal writings mostly did not expressly discuss the courts" powers of review though some opinions affirmed and some denied the possibility ${ }^{1006}$ is correct. ${ }^{100 ?}$ Usually the jus postliminii was being discussed and the powers of the courts to review the occupant's measures after the occupation had ended,

\footnotetext{
wa被

949 Nispen tot Sevenaer, p. 263.

Preamble IVth Hague Convention, indent 8. See also Nispen tot Sevenaer. p. 205, 305-306.

100ti Preamble IVth Hague Convention, indent 7

1004 Dries, p. 19-20. What van den Dries could not have known was that after the war it became known that during the Nazi occupation of Norway the Norwegian Supreme Court reviewed a decree inspired by the Civil administration for compliance with article 43 Hague Convention. The Norwegian Supreme Court unanimously decided the decree was contrary to article 43 . When this did not deter the Civil administration from nevertheless applying the illegal decree, the whole Suprene Court resigned (see Jansma, p. 6-12; Mok, p. 34).

Cass. 20 mai 1916, Pas, $1,1916,416$.

Cour d'appel die Liège 31 mai 1915; Pas, II, 82 .

Cour d'appel de Bruxelles 19 juillet 1915; Pas. 1919, II, 37.

See also Nispen tot Sevenaer, p. 186, 271.

Dries, p. 20-21.

See also Rutgers, p. 752 who denied courts review of the occupant's measures. See Bemmellen, $p .122$ who semed to confirm judicial review of the occupant's measures.
} 
from which the Court concluded it only could exercise review after the occupation had ended.

However, the disagreement amongst jurisprudes pointed to the fact that legal scholars had not settled the question. Therefore, the Court could not conclude from the writings of the international lawyers that the courts only obtained review competence after the occupation. ${ }^{108}$ Besides, the jus postlimini argument seems erroneous, since after the occupation the nature of the occupant"s measures would not change, but only the fact that he could not enforce them anymore. Likewise, during the occupation Netherlands courts could not review an Act of Parliament from before the occupation only because the Netherlands Govermment was unable to enforce it. Since the nature of the occupant's measures during and after the occupation was the same, the jus postliminit argument rather seems to support the argument that courts also had review powers during an occupation.

The Supreme Court was of the opinion that if it were to have exercised judicial review the Civil administration would most certainly have enacted legislation denying the Netherlands courts any power of review. If the courts were to have exercised review for a second time the Ciwil administration would have swept the case law aside. Instead of legal protection it would have introduced deteriorating conditions for the population for years. ${ }^{100 \%}$ Whether or not this would have been the case could not be ascertained in the case of The Netherlands, since the Netherlands courts generally did not challenge the occupant's measures. ${ }^{1010}$ Furthemore, this did not exclude a legal possibility to exercise judicial review.

Although the Netherlands Supreme Court had not reviewed occupation legislation, it was not obliged, so the Court, to apply all occupation measures. There was no reason to assume that the Netherlands Supreme Court had not taken this as a guiding principle. The Court was furthemore convinced that the Civil administration would not have left matters to a national Judiciary, from which it could not expect any cooperation. ${ }^{1011}$

A statement from Supreme Court Justice Losecaat Vermeer might provide more insight into the Court's mindset and absence of open defiance of the occupant. The Netherlands Suprene Court, according to Losecal Vermeer, different from the Belgian Cour de cassation, did not want to publish its correspondence [with the occupant - YM] in order to assure a place in post-war heaven. ${ }^{1012}$ According to Losecaat Vermeer there were two attitudes one could take with regard to the occupant. One was a principled one, but those taking a principled stance usually moved to the side, although they were urgently necessary. The others were those who, although scomed, quietly did a good job. Losecaat Vermeer referred to the Judgment on judiciall review, asking why it would be necessary to publicly state what was happening silently anyway?

\footnotetext{
$100 \mathrm{~s}$

In: Dris

(1) Do Dries, p. 32,33.

Hibu However, see Chapter 4.15 for some courts" deallings with chatlenges to the validity of occupation measures churing the last year of the occupation.

Han Ministerie wan Justite Depot 164, No. 11, brief Losecaat Vemeer an Cleveringa van 11 November 1943; Driss, p. 33; Ruiter, p. 221.

Hon Minsterie van Jastitie Depot 164, No. 11 , brief Losecart Vemeer aan Cleveringa van 11 November 1943.
} 
There was indeed no reason to believe the Supreme Court or the lower courts applied all occupation measures. This was, however, not a policy that all the courts applied consistently under the guidance of the Supreme Court. Rather, individual judges or courts would be left the decision on whether or not to apply an occupation measure, which could not guarantee that at least one court would apply a heinous neasure, especially where the occupant had influenced the appointment of judges. And where even a member of the Supreme Cout during the occupation considered $90 \%$ of the occupation measures contrary to the Hague Convention, ${ }^{1013}$ this number rendered even more difficult to maintain such a policy consistently concerning all illegal occupation measures.

Furthermore, if there were a more consistent policy in this field, it could only work if the courts consistently and forcefully protested and tried to prevent a limitation of their competencies. Only if courts could retain their competencies and the occupant would not transfer cases on the basis of his most blatantly illegal measures to a separate court system such a policy might work. This presumed a faithfil application of occupation measures. Netherlands courts not only acquiesced in a limitation of their competencies, but interpreted regulations widely, allowing for a limitation of their competencies as broad as possible. 1014

Moreover, the Judgment on judicial review rendered a refusal to apply an occupation measure more difficult. Judges could be seen as violating the law as stated by their own Supreme Court, exposing them to the occupant's claim of violation of duty under internationa! law and disciplinary sanctions. ${ }^{1015}$ The Judgment on judicial review therefore discouraged judges from covertly reviewing and not applying occupation measures.

Of course this in no way is meant to undervalue the courage of those who did adopt a policy to not apply certain occupation measures. This was merely meant to demonstrate that an inconsistent and unorganized approach to non-application could not substitute for a lack of guidance from a Supreme Court in reviewing the occupant's measures.

The Netherlands Supreme Court considered itself not in a position to stop the practice of illegitimate occupation legislation. If a court did not exercise judicial review, it did not think that a judge should resign when confronted with illegitimate occupation legislation. After all, civil servants, according to the Instructions should protest a violation of international law, but giving notice would only be possible if remaining in office would be more advantageous to the enemy than to the population. ${ }^{101.7}$

These Instructions, as stated before, had no legal status under Netherlands law, let alone have force of law and could therefore not bind the Supreme Court in its interpretation of law. This was the case where international law allowed for civil ser.

\footnotetext{
1013 Ministerie van Justitie Depot 164, No. 11, brief Losecaat Vermeer aan Cleveringa van 4 October 1943.

Hont Chapters $4.4,4.7$ and 4.8 .

wh. Spaight, p. 365-366; Beer Poortguaet, p. 176-178; Oppenheim, War, p. 212; Verraes, Tome I, p. 179; Bordwell., p. 309; Mechelynck, p. 336 .

inte See Chapter 1.4.1 and Instruction 1(1).

G67 Ministerie van Justitie Depot 164, No. 11, brief Losecal Vermeer aan Cleweringa van 11 November 1943; Dries, p. 33; Ruiter, p. 221.
} 
vants, including judges to resign from office for conscientious objections. ${ }^{1018}$ Moreover, the Court did not even once attempt to use a threat to resign in order to reinforce its protests.

The arguments mentioned above were not meant to posit that international law allowed for courts in an occupied country to review the occupant's measures. International law was ambiguous on the topic, like on most other topics, but if the Netherlands Supreme Court would have been willing it could have found arguments supporting review or at least constraints on the acceptance and execution of the occupant's measures. ${ }^{1019}$ A more positivist approach to international and national law would have made it possible for Netherlands courts to withhold unequivocal acceptance of all occupation measures and resist execution of at least some occupation policies.

Legal considerations did not seem to be at the basis of the Supreme Court's decision. The fact that it did not want to risk an open conflict with the occupant over something that was covertly happening anyway attests to that. At that period in time when the Judgment on judicial review was rendered, Justice Losecaat Vermeer also claimed the Supreme Court was cautious not to endanger preparations for the closure of the detention camp of Ommen. ${ }^{1020}$ Moreover, after this judgment had been rendered during some meetings several Supreme Court Justices explicitly referred to the Secretaries General and/or the Civil administration as "the Government" and "the Legislator". 1021

In any case, the Supreme Court's mindset did not include law as a means to directly challenge the occupant's authority to enact any kind of measure. This allowed for the execution of the occupant's policies, even the most heinous ones.

\subsection{THE COURTS' APPLICATION OF MEASURES AGAINST NETHERLANDS NATITONALS OF JEWISH ANCESTRY}

The consequences of the unequivocal acceptance of the occupant's measures were blatantly clear with regard to the regulations against Netherlands nationals of Jewish ancestry. In 1942 some of the lower courts were confronted with these regulations.

The examining magistrate at the Hague District Court suspended a case ${ }^{1022}$ on the basis of Regulation $1941 / 48,{ }^{1023}$ a provision of which had partly deprived Nether-

101 See Spaight, p. 358 who recognized the judges' refusal to sit; Rolin, Tome I, p. 446, who seemed to recognize resignation, but nevertheless thought this option might not be in the interest of the occupied country; Beer Poortugael , 176 who recognized the right of civil servants to lay down their office in case of conscientious objection; Oppenheim, War, p. 214 stated that an occupant "may nof compel [civil servants- JM] to carry on their functions..."; Bordwell, p. 307 who stated that civil servants are "entitled to resign $(. .$.$) if they feel that the$ continuance of their functions is inconsistent with their duty to their own country..."

to1. See also Boer e.a., p. 144:15, 1.8.

1020 Ministerie van Justitie Depot 164, No. 11, brief Losecaat Vermeer aan Cleveringa van 11 November 1943.

1021 Archief Hoge Raad der Nederlanden, Notulen Agemene Vergaderingen van 1921-1958, Algemeene Vergadering van den Hoogen Raad der Nederlanden op Maandag 4 Mei 1942 des namiddags te 3 uur, p. 24 en op Maandag 7 September 1942, des namiddags te 2 unar, p. 27.

102. Arrondissementsrechtbank 's-Grawenhage (Rechter-Commissaris Mr. van Rijn van Alkemade) 26 januari $1942, N J 1942,201$ 
lands Jewish nationals that owned a business of legal capacity. He neither questioned. the legality nor the objectionability of the regulation. Also the Fourth Chamber of the Hague District Court ${ }^{3024}$ applied regulations against Netherlands Jewish nationals, recognizing that at least in some areas Netherlands Jewish nationals had lost their legal capacity. Agaim, the legality or objectionability of the regulation was not questioned.

In a case in $1943^{1025}$ the Hague Court of Appeal accepted without question the Regulation on the removal of Jews from businesses. ${ }^{102}$ The custodian appointed for their business replaced the appellant who was a Netherlands national of Jewish ancestry. However, the case could not proceed, because the appellant had become inadmissible since the enactment of the regulation. Regardless of the fact that the custodian acted with the approval and according to the instructions of the appellant, the court considered that the appellant had appealed the case, although at that point the regulation had already deprived him of the legal capacity to do so. Without any further consideration, the Hague Court of Appeal gave legal effect to this regulation.

The final case that was reported regarding a regulation affecting Netherlands Jewish nationals was dealt with in a judgment of the Dordrecht Cantonal court in 1944. ${ }^{1027}$ The Cantonal Court also did not question a custodian's sale of a business formerly owned by a Netherlands Jewish national. In interpreting the Regulation on the removal of Jews from businesses the court only remarked that since it did not unequivocally state that the license to operate the business would automatically be transferred to the purchaser, a new license had to be obtained under Netherlands law. However, this meant that the court recognized the legality of the regulation and the subsequent legality of custodian "s transfer of ownership of the business. Not surprisingly, its ruling also implied recognition of a possible amendment to the regulation to transfer the license in the new owner"s name.

Needless to say the regulations mentioned above were contrary to the Hague Convention, especially its article 46 and Netherlands civil law concerning legal capacity. The courts neither inwoked legal reasons nor moral grounds leading to conscientious objection to refuse their application, ${ }^{1028}$ allowing for the occupant to use the Netherlands courts to execute these policies.

\subsection{THE COURTS, ATROCITIES IN DETENTION CAMPS AND REMOVALS FROM OFFICE}

In the 1920s in the proximity of Ommen, in the east of the Netherlands, the Netherlands Theosophists had erected some buildings on a campsite. The Civil administra-

1023 Verordnung 1941/48 des Reichskommissars für die besetzten niederländischen Gebiete über die Behandlung anmeldeptlichtiger Unternehmen vom 12. März $194 \|$ (Wirtschaftsentjudungsverordnung), VoBl. 1941, S. 164.

102. Arrondissementsrechtbank "s-Gravenhage (4e Kamer) 12 maart 1942, NJ 1942, 332.

to25 Gerechishof "s-Gravenhage (2e Kamer) 30 april 1943, NJ/1943, 699.

4n20 Verordnung 1941/48 des Reichskommissars für die besetzten niederländischen Gebiete über die Behandlung anmeldepflichiger Unternehmen wom 12. März 1941 (Wirtschafisentjudungsverordnung \, VoBH. 1941, S. 164.

52:. Kantongerecht Dordrecht 23 maart 1944, N/ 1944/1945, 318.

1028 As was an option under international law. See e.g. Rutgers, p. 760. 
rion had dissolved the organization the beginning of $1941 .^{1029}$ A Netherlands nationa: socialist then turned the campsite into a prison camp guarded by Netherlands guards. From June 1942 onwards Schrieke used the site as atention facility, since Netherlands prisons were overcrowded. The Germans authorities had requisitioned sections of Netherlands prisons for their own prisoners. In addition, economic crimes, especially the violation of special economic legislation dealing amongst others with ram tioning, had increased. A higher detention rate had led to a further shortage of detention facilities, prompting the use of facilities like the one in Ommen. 1030

The handing of the prisoners in Onmen was, however, below any standard at the time in The Netherlands, which was known to the Secretaries General. ${ }^{103}$ The Secretary General of Justice was informed about the conditions in these camps at least in October 1942, if not earlier. ${ }^{1032}$ Also Het Parool, an underground newspaper, wrote that the treatment of prisoners in Ommen لikened abuse. Prisoners were tormented through starvation, endless drilling and hard labot, but above all through flogging and kicking, which tumed healthy human beings into wrecks within a matter of months. 1033

Netherlands physicians, into whose hospital prisoners from Ommen and another camp - in Heerte - were admitted, informed the Netherlands judicial authorities. Disguised as physicians Armhem public prosecutors ${ }^{1034}$ thereupon decided to wisit the hospital in Hengelo to which 30 prisoners from Ommen and Heerte had been admitted. Infuriated about what they had seen and conscious about the fact that more information was needed, they petitioned twelve hospitals on possible admission of prisoners from Ommen or Heerte. Nine of the twelve hospitals sent exact numbers. Three of them tried to confront high-ranking members of the courts with the newly gathered information. In many cases, however, they got the response that execution of the punishments was the task of the German Civil administration. ${ }^{1035}$

A public prosecutor from Amsterdam, Wassenbergh, ensured that a delegation of the Ansterdam District Court during an official visit to Schrieke at the beginning of Decenber 1942 questioned him about Ommen. Schrieke's official stance was initially that the detention camp was a German camp and that Netherlands authorities would not be allowed to visit the camp. Even reassuring statements to the Amsterdam District Court would give the impression Netherlands authorities had some control over these detention camps and would therefore not be given. The Secretary General merely stated he had been given assurances that measures had been taken to remedy the situation.."

\footnotetext{
163\% Jong (dieel 6-2), p. 669

Inis Jong (deel 6-2), p. 678 .

leill long (deel 6-2), p. 680

1032 Tresoar, Archef Procureur Generaal bij het Gerechtshof te Leeuwarden, Notulen van de Ver. gaderingen wan het College van Procureurs Generaal, voorl. Inventaris 251 , Notulen van de vergadering van Procureurs-Generaal op Vrijdag 23 October 1942 in het Departement van Justitie, no. 106, p. 2.

Mer Parool from 25 September 1942; also Jong (deel 6-2), p. 681 .

1634 Mrs W. L. de Walle from Almelo, jhr F.A. Groenix van Zoelen from Zwolle and baron van der Feliz from Zutphen.

10.5. See Jong (deel 6-2), p. 687.

1036. Tresoar, Archief Procureur Generaal bij het Gerechtshof te Leetwarden, Notulen van de Vergaderingen wan het College van Procureurs Generaal, voorl. Inventaris 2511, Notulen van de
} 
Also, public prosecutors from the Amsterdam Court of Appeal and the Amsterdam District Court, the latter probably including Wassenbergh, questioned the NSB Procurator General Feitsma about the camps in Ommen and Heerte at the same time. ${ }^{103 ?}$

Not satisfied with Schrieke's vague response in December, Wassenbergh questioned three public prosecutors from the district of Arnhem. With this information, together with the President of the Amsterdam District Court, he invited the Presidents and Vice-Presidents of all District Courts and their public prosecutors to attend a meeting on 20 February $1943 .{ }^{1038}$ Almost all, except those from the Arrahem District Court accepted the invitation, in total 48 members of the Judiciary. ${ }^{1039}$ Amongst the guests was also Justice Viehoff of the Leeuwarden Court of Appeal. The meeting did not succeed in drafting a joint letter, but two of its members would visit the Geman Commissioner General for Justice, Wimmer. ${ }^{1040}$

The Leeuwarden Court of Appeal decided to take action. On 25 February 1943, three Justices of its criminal chamber rendered a verdict in appeal. ${ }^{1048}$ The Leeuwarden District Court had sentenced a man from Gerkesklooster to nine months imprisonment for theft. After Justices Viehoff, Wedeven and Heymeijer had re-examined the case in appeal, they concluded that the accused had been rightfully convicted. However, the Justices did not agree with the lower court's sentence. Justice Viehoff, ${ }^{1042}$ who had been appointed to the Court of Appeal by Schrieke in April 1942 from the prosecutor service, had written the judgment. ${ }^{1043}$ The Court of Appeal wanted to take into consideration that sentences imposed by Netherlands courts were executed in a way contrary to legislation and intent of legislator and judge. The execution of the sentences in the detention camps was done more severely than courts could possibly foresee or presuppose when determining the punishment. The Court of Appeal, taking into account execution of the detention and due to a conflict of conscience, was not able to sentence the accused to a detention, whereby its duration would be doubly proportionate to the weight of the crime committed. The accused was therefore condemned to a prison sentence, which after subtraction of his time spent in preventive custody ensured his immediate release.

The underground press was delighted, whereby Het Parool wrote: 'That's it! ${ }^{1 / 44}$ The Civil administration was not amused and after questioning them removed

vergadering van Procureurs-Generaal op Vrijdag 4 December 1942 in het Departement wan Justitie, no. 108, p. 7 .

\section{was? Ibid.}

103* Rijksarchief in Noord-Holland, Arrondissementsrechtbank Amsterdan 1950-1959, toegang 510 , inv. 2462-2463 Notulen vergaderingen 1918-1957, Vergadering, gehouden op Maandag 15 Maart 1943 , n.m. 3 uur.

1034 Rijksarchief in Noord-Holland, Arrondissementsrechtbank Amsterdam 1950-1959, toegang 510, inv. 2462-2463 Notulen vergaderingen 1918-1957, Vergadering, gehouden op Maandag 15 Mxart 1943, n.m. 3 uur.

(1)40) See also Jong (deel $6-2$ ), p. 689

\{04: Gerechishof te Leeuwarden, 25 februari 1943, NJ 1951,643.

rou2 See Mazel, p. 102.

nai, NIOD, Archief 33, doos 17, map c, Dossierstuk Althaus m.b.t. gesprekken met Viehoff on Wedeven 7 April 1943.

10.4 Het Parool from 5 April 1943. See also Jong (deel 6-2), p. 639; Mazel, p. $\| 03$. 
Justices Vichoff and Wedeven from office in April 1943 for grave neglect in the excreise of their office.

Wassenbergh, the Amsterdam public prosecutor, now tried to induce the entire: Judiciary to protest against the dismissals. In a letter from May $1943^{1046}$ several highranking members of the courts urged the Reichskommissar to find a solution to the problem of execution of sentences, as well as to reconsider his dismissal of the two Leeuwarden Justices. Seyss-Inquart was reminded of the fact that ever since the beginning of the occupation the Netherlands Judiciary had loyally exercised its duties. If the execution of judgments the courts had rendered would not in be conformity with Netherlands legislation and Netherlands legal opinion, this would be considered a breach of trust. The exercise of its duties would in turn be subject to uncertainties and impossibilities as to virtually render impossible the exercise of these duties.

The intention was for all eleven Presidents and Vice-Presidents of the Courts of Appeal and the 40 Presidents and Vice-Presidents of the District Courts to sign the letter. Only the Presidents of the Courts of Appeal of 's-Hertogenbosch and Arnhem, the Presidents of the District Courts of Almelo, The Hague and Haarlem, as well as the Vice-Presidents of the Amsterdam and Rotterdam District Courts signed the letter. ${ }^{1047}$ The Ciwil administration initially did not seem overly worried by this letter of protest. Most of the signatories were deemed politically too insignificant. ${ }^{1048}$ However, subsequently several other courts joined the protest, amongst others the Amsterdam Court of Appeal. ${ }^{1049}$

Also the Netherlands Supreme Court protested on 22 June 1943, although not as an institution as such, but merely through some of its members. The Supreme Court

104. Hermans, p. 115-128. What happened to the third Justice involved in rendering the judgment, deputy Itustice Heymeijer, is not completely clear. At first there were no sanctions against Justice Heymeijer. However, he wrote a letter to Schrieke in which he indieated he had also been involved in producing the "Ommen judgment". According to Jong (deel 6m2), p. 693, footnote 4) the letter led to the fact that he was removed from office as well. According to Hermans (p. 26-128) Heymejer in his letter of 16 April 1943 to Schrieke wrote he wonld not be available for the remunerated position of deputy Justice. Hemnans claimed Heymeijer's remuneration was stopped from I May 1943 onwards. After May 1943 Heymeijer did not exercise any duties at the court anymore, also due to the fact that he refused to co-operate with a newly appointed NSB and a pro-German Justice (see Hermans, p. 127-128).

1/46 Rijksarchief in Noord-Holland, Gerechtshof Amsterdam 1940-1949, toegang 450, inv. 2 Cor respondentie, Brief I-5 Mei 1943 van de Presidenten van de Gerechtshoven van 's-Hertogernbosch en Arnhem, de Presidenten van de Arrondissementsrechbanken van AImelo, "s-Gravenhage en Haram, de Vice-Presidenten van de Arrondissementsrechtbanken van Arnsterdam. en Rotterdam aan de Reichskommissar Seyss-Inquart. See also NIOD, Archief 33, doos 17, map $\mathrm{c}$.

1int Archief Gerechtshof Arnhem, Correspondentie van de President 1943-1950, Brief 1-5 Mei. 1943 van de Presidenten van de Gerechtshoven te 's-Hertogenbosch en Amben, de Presidenten wan de Arrondissementsrechtbanken te Almelo, "s-Gravenhage en Haarlem, de Vice-Presidenten van de Arrondissementsrechibanken te Amsterdam en Rotterdam aan de Reichskommissar Seyss-Inquart. See also NIOD, Archief 33, doos 17, map c; Jong (deel 6-2), p. 694695; Archief Ministerie van Justitie, Depot 164. Intelligence report GB. 2830/44 Netherlands Intelligence Department, Rapport over houding rechterlijke macht.

NIOD. Archief 33, doos 17, map c, dossierstuk Seiffert m.b.t. door leden der Rechterlijke Macht ondertekend stuk 25 May 1943.

10.4 Rijksarchief in Noord-Holland, Gerechtshof Amsterdam 1940-1949, toegang 450, inv. 2 Correspondentie, Afschrift brief 24 Maart 1943 van de President van het Gerechtshof te Amsterdam aan de Secretaris Generaal van het Departement wan Justitie. 
explained its almost 4-month delay in protesting against the dismissal by stating that the lower courts were informed much more quickly about the discrepancies in the prison camps than the Netherlands Supreme Court. ${ }^{1050}$ Seyss-Inquart received a letter stating that Justices Viehoff and Wedeven had merely acted according to their conscience and that the authors of the letter were deeply concemed about the two Justices' dismissal. ${ }^{1051}$ 'The Court also pointed out that the judgment of the Leeuwarden Justices was the expression of a conflict of conscience. The Reichskommissar was informed that these dismissals strongly interfered with the independence of the Judiciary and conflicted with Regulation 1940/3, in which that independence had been recognized. ${ }^{1052}$

The authors of the letter were those members of the Netherlands Supreme Court appointed before the occupation. The President of the Netherlands Supreme Court and the other members the Civil administration had appointed did not sign the letter. ${ }^{1053}$ Already in the beginning of May President van Loon had written a personal letter to Wimmer, the Commissioner General for Justice, protesting against the dismissal of the Leeuwarden Justices and demanding their reinstatement.

The Secretary General of Justice replied, almost a month later, to the Supreme Court's letter of protest. ${ }^{1055}$ Schrieke started off by stating that the Reichskommissar had noted and appreciated that the members of the Supreme Court appointed during the occupation had not signed the letter of protest. This, so Schrieke, was probably a recognition of the fact that according to international law the occupant was at liberty to appoint and dismiss civil servants, including members of the courts. The Reichsikommissar, nevertheless, by way of exception, had decided to address the objections some members of the court had raised.

The Court of Appeal's motivation in reducing the sentence of the accused was, so Schrieke, a violation of the court's official duty. Although the judges had argued the reduced sentence was given due to a conflict of conscience, Schrieke stated that a conflict of conscience could only lead to voluntary resignation from office. Such a conflict could not lead to a negation of the duties attached to the office. In addressing the fact that the execution of the sentence was contrary to the intent of the legislator and the court. Schrieke maintained the judges had encroached upon the province of the executive branch of government and passed judgment on the acts of the Civil administration. The latter was all the more intolerable, since there were other ways in which the authors of the judgment could have expressed their misgivings. In choosing this public way of expressing their misgivings the Justices endangered the fight against crime and politically demonstrated against the Civil administration. Their actions were a complete neglect of their official duties, on the basis of which the

\footnotetext{
1abo NOD, Archief 33, doos 17, map c , Brief verscheidene Raadsheren van de Hoge Raad der Nederlanden aan Reichskommissar Seyss-Inquart van 22 June 1943. See also Dries, p. 47-48. Van den Dries, p. $47-48$.

Van den Dries, p. 46-48.

Jong (deel 6-2), p. 695 .

ans Loon, p. 9 and NIOD, Doe 1-1077, a-9 Brief 6 Mei 1943 wan President van Loon aan de Commissaris Generaal.

1055 Archief Gerechtshof Amhem, Gerechtshof Amhem 1940-1949. Brief van 21 Jul 1943 van de Secretaris General van het Departement van Justitie aan de President van de Hoge Raad, Afdeling AS, no 483 TO. See also Archief Gerechtshof Arnhem, Correspondentie van de President $1943-1950$.
} 
Reichskommissur had decided to remove them from office. The fact that there were no other reasons for dismissal proved that the Reichskommissar was and would continve to be attached to the independence of the Judicjary.

The question was whether under international law the occupant was allowed to remove these judges from office. In principle this was the case, since the accupant could remove those civil servants from office that would not faithfully comply with his measures. Civil servants could invoke conscientious objection and refuse to comply with the occupant's order, but then the occupant was allowed to remove them from office. ${ }^{1056}$

However, in this case, the two Justices were removed from office for an ex officio act. The Justices applied Netherlands law and not the occupant's regulations and in sentencing had used the discretion inherent to their office to determine the appropriate sentence. The occupant's dismissal of the Justices was directed at the content of their judgment and not a procedural matter. This meant that the occupant directly interfered with the independence of the courts to judge a concrete case. Since the dismissal was directly related to the independence of the Justices in this case, all courts were affected, in that their independence was not guaranteed anymore. The Supreme Court failed to point this out.

The Supreme Court did point out that the dismissal was in direct opposition to the occupant's guarantee at the beginning of the occupation to recognize the independence of the courts. ${ }^{157}$ Although of course not the same kind of independence as granted under national law, since the irremovability of judges was not guaranteed anymore, ${ }^{1058}$ international law nevertheless obliged an occupant not to interfere with a court's independent appreciation of a pending case. ${ }^{1659}$

Schrieke would have been right about the fact that a conflict of conscience regarding compliance with an order from the occupant meant that the civil servant only had the option to resign. However, in this case the conflict of conscience was not used to refuse execution of an order from the occupant, but to interpret and apply Netherlands llegislation, namely Title XXII of the Netherlands Penal Code concerning theft. Furthermore, although the Leeuwarden Justices' reference to their conscience cannot be denied to entail a criticism of the occupant"s policies of execution of sentences, Netherlands criminal procedure also obliged courts to state the reasons for their judgment. ${ }^{\text {10(t) }}$

The occupant's dismissal of the Leeuwarden Justices was therefore a direct interference into the Netherlands administration of justice and the independence of the courts. If the Netherlands courts had adhered to international and national law, the occupant"s action should have made it impossible for them to continue the administration of justice. Some courts protested, but no credible threat was used to back up the protest. The fact that the courts remained in office allowed for this precedent to

\footnotetext{
1060 See Chapter 2.3. Bordwell, p. 306.

[4n: See Chapter 4.1 .

whi See ilso Bellefroid, p. 51

165 Where the occupant had not modified the laws in force, the civil and penal administration of justice would follow its regular course. SeeVerraes, Tome I p. 189-181; Spaight, p. 357-358; Den Beer Poortugael, p. 175. Oppenheim, War, p. 214 stated that the occupant "... must respect [the couts' - JM] independence according to the laws of the country.'; Scholtens, Stantstecht, p. 36 .

100) See articles $355,377(7), 402$ and 419 Sv (Netherlands Code of Criminal Procedure).
} 
stand, which meant that the independent appreciation of a concrete case was not assured anymore.

\subsection{THE COURTS AND ATROCITIES IN DETENTION CAMPS CONTINUED}

To the meeting in Amsterdam on 20 February 1943 Wassenbergh, together with the President of the Amsterdam District Court, had invited the Presidents and VicePresidents of all District Courts and their public prosecutors. Almost all those invited, except from the Armhem District Court, had accepted the invitation, in total 48 members of the Judiciary. ${ }^{106}$ On behalf of their colleagues who had attended the meeting two judicial officers visited the German Commissioner General for Justice, Wimmer ${ }^{1062}$ the day after the Leeuwarden judgment had been rendered. 1063 Due to Wimmer's absence, his representatives Seyffert and Rebman received the delegation and agreed to allow members of the courts to freely visit the camps. ${ }^{\text {How }}$ On 5 March a delegation of the Netherlands Judiciary visited the camps and reported on grave abuses committed against the detainees. ${ }^{\circ} 5$

The Amsterdam District Court succeeded in March 1943 in drafting a letter in collaboration with its prosecutor service, notifying Scllrieke that if the situation in the camps would not change no prosecution or sentencing of any accused would be undertaken, if he could be sent to those camps. ${ }^{1066}$ The letter was also sent to other Netherlands courts with the request to support this Amsterdam initiative ${ }^{1067}$ All eighteen other District Courts and all five Courts of Appeal supported the Amsterdam request. ${ }^{1068}$ The Supreme Court at that point was notably lacking and it has to be noted that some of the courts that protested only did so through some and not all of its members. ${ }^{1069}$ Other courts went further in that the Zwolle District Court threatened to reduce its sentencing by taking into account the harsher conditions of the

1069 Rijksarchief in Noord-Holland, Arrondissementsrechtbank Amsterdam 1950-1959, toegang 510 , inv. 2462-2463 Notulen vergaderingen 1918-1957, Vergadering, gehouden op Maandag 15 Maart 1943, n.m. 3 unr.

106 ? Jong (deel 6-2), p. 689

Jws Rijksarchief in Noord-Holland, Arrondissementsrechtbank Amsterdam 1950-1959, toegang 510, inw. 2462-2463 Notulen vergaderingen 1918-1957, Vergandering, gehouden op Marndag 15 Mart 1943, n.m. 3 uur.

fok Nationaal Archief, Den Hag, Archieven van het Directoraat-Generaal voor de Bijzondere Rechtspleging, (1945-1952), met taakopvolgers en atvoerende instanties (1945-1983) van het Ministerie van Justitie, deel II: Uitvoerende instanties (Centraal Archief Bijzondere Rechtspleging), Nummer Toegang 2.09.09, inv. 67946, Dossiat J.J. Schrieke, archiefstuk NG 46 A. See allso Hermans, p. 100-101.

Hermans, p. 102.

nus NIOD, Archief 33, doos 17, map c, Brief van de Arrondissementsrechtbank en de Officier van Justitie te Amsterdam aan de Secretaris General van het Departement van Justitie Schrieke van 15 maart 1943. See also Ministerie van Justitie Depot 164, Intelligence report GB. $2830 / 44$ Netherlands Intelligence Department, Rapport ower houding rechterlijke macht. Hermans, p. 104.

tows Hermans, p. 104.

1604 Rijksarchief in Noord-Holland, Arrondissementsrechtbank Alkmaar 1940-1949, toegang 485, inv. 4 Brief wan 24 madrt 1943 van de Officier van Justitie en substitut Officier wan Justitie bij en President, vier leden van de Arrondissementsreclubank Alkmaar aan de Secretaris Generaal van het Departement van Justitie. 
execution of its sentences. ${ }^{\text {wh }}$ The District Courts in Utrecht and Maastricht reacted by postponing judgments in certain penal cases. Not until it was clear whether or not the accused would be sent to a detention camp, Nazi-Germany or a Netherlands detention facility the two courts refused to resume these cases. ${ }^{1071}$

The Secretary General of Justice"s raply to this judicial storm was to announce the detention camps would be closed for Netherlands inmates. Although in his writton reply he announced the closing of the camps to Netherlands inmates, during a meeting with several members of the courts Schrieke confirmed that in future Netherlands inmates tried and convicted in The Netherlands would continue to be sent to German correctional facilities to execute the sentence. After this meeting the Secretary General considered the topic closed, forcing several members of the Judiciary to address the Reichshommissar directly. ${ }^{1072}$

In a letter firom May $1943^{1673}$ the Reichskommissar was urged to find a solution to the problem of execution of sentences. Also the Supreme Court sent alleter to the Secretary General urging him to end the atrocities in the detention camps in order to deal with the concerns of the courts. ${ }^{1074}$

Schrieke replied ${ }^{1075}$ stating that according to the Hague Convention the occupant had the authority to deviate from domestic legislation, also in case of execution of sentences. However, in the case of execution of sentences in the detention camps of Ommen en Heerte the Civil administration recognized the execution was not impeccable, which could lead to a breach of trust with the Netherlands Judiciary and therefore it did not hesitate to close these camps. Conceming the execution of Netherlands sentences in German correctional facilities, the occupation administration had arranged for several members of the Netherlands Judiciary to visit these facilities in

1010 Historisch Centrum Overijssel, Rechtbank Zwolle 1940-1949, toegang 108.2, inv. 3303 Correspondentie president, Brief van 25 maart 1943 van de Arrondissementsrechtbank te $Z$ wolle aan de Secretaris Generaal van het Departement van Justitie.

w7 NIOD, Archief 33, dicos 17, map e, Brief 7 April 1943 Ministerialrat Krug an Generalkommissar Wimmer and Hermans, $p, 110-111$ concerning the Utrecht District Court. See also conceming both couts Frijtag, Recht, $\mathrm{p}$. 119, although Ms. Frijtag prowides no reference for this infornation. The archives of the Maastricht District Court for the period 1940-1950 are lost. Apparently not only in detention camps, but also prison facilities in Nazi-Germany sentences from Neherlands courts would be executed. This detail was lacking from all Netherlands literature on the topic.

1023 Ripksarchief in Noord-Holland, Gerechtshof Amsterdam 1940 1949, toegang 450, inv. 2 Correspondentie, Brief $1-5 \mathrm{Mei} 1943$ van de Presidenten wan de Gerechtshoven van "s-Hertogenbosch on Arnhem, de Presidenten wan de Arrondissementsrechbanken van Almelo, "SwGraven hage en Haarlem, de Vice-Presidenten wan de Arrondissementsrechtbanken van Amsterdam en Roterdam an de Reichskommissar Seys-Inquart. See also NIOD, Archief 33, doos 17, mape.

wath

1074 NlOD, Archiet 33, doos 17, map c, Brief werscheidene Raadsheren van de Hoge Raad der Nederlanden aan Reichskommissar Seyss-Inquart van 22 June 1943. See also Dries, p. 46-43.

wrs Rijksarchief in Noord-Holland, Gerechtshof Amsterdam 1940-1949, toegang 450, inv. 2 Correspondentie, Asclurift Brief (onbekende datum doch na $5 \mathrm{Ma}$ 1943) van de Secretaris General wan het Departenent van Justitie aan de Presidenten van de Gerechtshoven te Armhem en "S-Htertogenbosch, de Presidenten wan de Arrondissementsrechbanken te "s-Gravenhage, Haarlem en Almelo, de Vice-Presidenten var de Arrondissementstechrbanken te Amsterdam en Rotterdam. See also Archief Gerechtshof Arnhem, Correspondentie van de President 19431950. 

Nazi-Germany, in order to examine the conditions under which Netherlands inmates
were held.

The result of the whole upheaval, however, was that from Aptil $1943^{107}$ onwards the detention camp of Ommen was not used for Netherlands prisoners anymore and that no more prisoners were led to Heerte. ${ }^{103}$ The dismissals of Vieboff and Wedeven did not come undone, but further measures against them were not taken either. Also against Wassenbergh, who had succeeded in mobilizing the Netherlands Judiciary, no measures wete taken. The Leeuwarden Court of Appeals created a fund to financially support their colleagues that had been removed from of fice. ${ }^{1679}$ Not until the following 17 August a circular from the Ministry of llustice went out announcing to all governmental authorities the definitive closure of the detention camps of Ommen and Heerte. "No further reference was found to a visit of Netherlands judicial authorities to Netherlands immates in prisons in Nazi-Germany and whether this practice continued is unclear.

In a final letter to Schrieke on this issue in September $1943,{ }^{1081}$ some members of the Netherlands Judiciary that had continued the resistance against the execution of sentences informed the Secretary General of Justice that the grounds for a conflict of conscience had been removed. The judges pointed out that the execution of Netherlands sentences in detention camps in The Netherlands was contrary to Netherlands law, which the occupant had not amended. A reintroduction of this type of execution, if not with sufficient guarantees that competent Netherlands authorities would administer these facilities, would once again lead to the question whether courts would be able to continue the exercise of their duties.

The last issue in this final letter to be addressed was the removal from office of the Leeuwarden Justices. Not satisfied with the response the Secretary General had given to the Supreme Court these judges maintained that courts in the Netherlands

1076 Rijksarchief in Noord-Holland, Gerechtshof Amsterdam 1940-1949, toegang 450, inv. 2 Correspondentie, Afschrift Brief (onbekende datum doch na 5 Mei 1943) van de Secretaris Generaal van het Departement van Justitie aan de Presidenten van de Gerechishoven te Amhem en "s-Hertogenbosch, de Presidenten van de Arrondissementsrechbanken te "s-Gravenhatge, Haarlem en Almelo, de Vice-Presidenten van de Arrondissementsrechtbanken te Amsterdam en Rotterdam. See also Archief. Gerechishof Arnhem, Correspondentie vall de President 1943 1950.

sin7 Archief Arrondissementsrechtbank Rotterdam, Arrondissementsrechibank Rotterdam $\$ 940$. 1949, Brief wan 17 april 1943 van Secretaris Generaal van Justitie aan de Heeren ProcureursGeneraal bij de Gerechtshoven en Officieren wan Justitie bij de Arrondissementspechtbanken, 3e Aft. A, no. 1132.

1078 Jong (deel 6-2), p. 696.

1479 Ministerie wan Justitie Depot 164, Intelligence report GB. $2830 / 44$ Netherlands Intelligence Department, Rapport over houding rechterlijke macht.

(isia) Rijksarchief in NoordoHolland, Arrondissementsrechbank Amsterdam 1950-1959, toegang 510, inv. 2462-2463 Notulen vergaderingen 1918-1957, Vergadering, gehouden op Maandag 20 December 1943, des namiddags 4 uur.

Ins: Archief Gerechtshof Arrhem, Gerechtshof Amhem 1940-1949, Correspondentie van de President 1943-1950, Afschrift brief van september 1943 van de Presidenten wan de Gerechtshoven te Arnhem en 's-Hertogenbosch en wan de Arrondissementsrechtbanken te "s-Gravenhage en Haarlem en de Vice-Presidenten wan de Arrondissementsrechtbanken te Ansterdam ens Rotterdam awn de Secretaris Generaal wan het Departement van Justitie, no. Illat. See also Rijksarchief in Noord-Holland, Gerechtshof Amsterdam 1940-1949, toegang 450, inw. 2 Correspondentie; Archief Gerechtshof Amhem, Correspondentie van de President 1943-1950. 
had a duty to consider all circumstances that could influence sentencing. This included the execution of the sentences and Netherlands legislation obliged courts to indicate special reasons that would impact sentencing. The judges therefore insisted that the Lecuwarden Justices had neither failed their duties nor encroached upon the province of the executive branch of government and should therefore be reinstated in their offices.

In spite of the absence of leadership from the Supreme Court, the Amsterdam court and prosecutor were able to induce the Netherlands courts to organize. The courts" main stance was that Netherlands judgments had to be executed according to Netherlands law if not amended via occupation legislation. Different to the protest against the dismisgals of the Leeuwarden Justices, in this case the courts backed their protests up with a credible threat. Several courts even acted on that threat and stayed proceedings in cases where their sentences might be executed in detention camps. This reliance on Netherlands and international law, together with the mass organization of virtually all judicial officers, allowed the courts to resist the occupant"s policies of execution of judgments and influence him to reverse that policy.

\subsection{THE COURTS AND MEASURES CONCERNING FORCED DEPLOYMENT OF LABOR}

Like in Belgium, the occupant introduced in The Netherlands in mid-1942 a policy of forced labor deployment for workers to be sent to Nazi-Germany. "When the Civil administration requested the courts lists of persons employed at the courts that could be missed for labor deployment in Nazi-Germany the courts at first refused cooperation. ${ }^{1083}$ The Procurator General to the Supreme Court, Berget; who had been appointed for life ${ }^{1084}$ and had refused to comply with the Civil administration's de. mand to provide a list for labor deployment, was removed from office in September

10:2 Verordnung 1941/42 des Reichskommissars tür die besetzten niederländischen Gebiete über die Dienstpflicht und die Beschränkung des Arbeitsplatzwechsels vom 28. Februar 1941, VoBl. 1941, S. 152; Verordnung $1942 / 22$ des Reichskommissars fuir die besetzten niederländischen Gebicte, wodurch die Verordnung Nr. 42/1941. über die Dienstpflicht und die Beschränkung des Arbeitsplatzwechsels abgeändlert wird vom 23. März 1942, VoBl. 1942, S. 155. Verordhung 1941/97 des Reichskommissars für die besetzten niederländischen Gebiete über den niederländischen Arbeitsdienst (Arbeitsdyenstwerordnung) vom 23. Mai 1941 , VoBd. 1941 , S. 370; Verordnung 1942/35 des Reichskommissars fü die besetzten niederlandischen Gebiete, wodurch die Arbeitsdienstverordnung abgeändert wird vom 28. März 1942. VoBl. 1942, S. 178. See also Chapter 2.11.

the See Rijksarchief in Noord-Brabant, Gerechtshof 's-Hertogenbosch 1940-1949, toegang 823, inv. I, brief 14 October 1942 van de President van het Gerechtshof te 's-Hertogenbosch aan de Secretaris Generaal van Justitie, no. 150 and brief 4 November 1942 van de President van het Gerechtshof te 's-Hertogenbosch aan de Directeur van het Gewestelijk Arbeidbureau; Archief Arrondissementsrechtbank Rotterdann, Arrondissementsrechtbank Rotterdam 19401949. brief 30 juli 1943 van de President van de Arrondissementsrechtbank Rotterdam aan de Secreturis Generaal van Justitie, no. 1025 en afschrift brief 12 februari (waarschijnlijk) 1944 van de President van de Artondissementsrechtbank Rotterdam aan de Directeur van het Gewestelijk Arbeidsbureau te Rotterdam, no. 147; Nationaal Archief, Den Haag, Archief van de Arrondissementsrechtbank Dordrecht (1935) 1940-1949 (1951), toegang 3.03.12.03, inv. 1, brief 15 februari 1943 van de President en Griffier van de Arrondissementsrechtbank te Dordrecht aan de Secretaris General van Justitie.

Article 84 Wet RO. 
1943. ${ }^{1085}$ Although the Supreme Court intended to protest against his dismissal, Berger indicated he would not appreciate such a protest, which made the Supreme Court reconsider. ${ }^{1086}$

One member of the Supreme Court had drafted letter after having had a meeting with the two Chambers of the Supreme Court, without the President. During a plenary meeting of the Supreme Court he tried to present the draft outlining objections to this compulsory labor deployment, but President van Loon prevented it from being discussed during the formal meeting. ${ }^{1087}$ Whether this was the letten with which the Supreme Court also wanted to protest against Berger's removal from office or a separate letter focusing on the Civil administration's request for a list for labor deployment as a violation of international law is not clear. No letter from the Supreme Court either protesting Berger's dismissal or the labor deployment lists has been found. President van Loon did have a personal meeting with the Secretary General, explaining that the Supreme Court would not hand over a list for labor deployment, which Schrieke accepted. ${ }^{1068}$ This might explain why, if there were a letter dealing solely with the issue of labor deployment and not Berger's dismissal, it has not been found.

The Supreme Court had knowledge of and even admired a letter from the Belgian Cour de cassation protesting the forced labor deployment. ${ }^{1080}$ The reason why the Netherlands Supreme Court nevertheless decided not to send a protest letter was that it was of the opinion it was not the courts' task to publicly denounce the occupant's abuses not involving the administration of justice. The Court thought the Civil administration in the Netherlands might take measures, which the Military administration in Belgium would not take and feared being removed from office. ${ }^{1090}$

In spite of the Supreme Court's inability and refusal to act, some courts went ahead and did manage to protest formally. The Leeuwarden, 1091 's-Hertogenbosch' 1092

10:5 Archief Ministerie van Justitie, Depot 164, Intelligence report GB. 2830/44 Netherlands Intelligence Department, Rapport over houding rechterlijke macht.

10 Ruiter, p. 214, 329 Chapter 15, footnote 38; Mazel, p. 126-127.

1057 Archief Hoge Raad der Nederlanden, Notulen Algemene Vergaderingen van 1921-1958, Algemeene Vergadering van den Hoogen Raad der Nederlanden op Woensdag 29 September 1943 , des voormiddags te 10 uur, p. 32.

106 Ruiter, p. 214, 329 footnote 37; Mazel, p. 126-127. No member of the Supreme Court had complied with the German order to give information concerning the forced deployment of liabor (see Archief Hoge Raad der Nederlanden, Notulen Algemene Vergaderingen van 1921. 1958, Algemeene Vergadering van den Hoogen Raad der Nederlanden op Woensdag 29 September 1943 , des voormiddags te 10 uur, p. 32).

See Chapter 2.10.

Dries, p. 57-58.

Tresoar, Gerechtshof Leeuwarden 1940-1949, toegang 17, inv. 3 Correspondentic, Brief 9 Februari 1943 van de wnd. President van het Gerechtshof te Leeuwarden aan de Secretaris Generaal van Justitie.

Rijksarchief in Noord Brabant, Gerechtshof' 's-Hertogenbosch 1940-1949, toegang 823, inv. I brief 8 februari 1943 van het Gerechtshof te 's-Hertogenbosch aan de Secretaris Gencraal van het Departement van Justitie, no. 215. It is, however, not entirely clear whether this letter was ever sent. A letter at the Rijksarchief in Noord-Brabant, Gerechtshof' 's-Hertogenbosch 19401949 , toegang 823 , inv. 1, dated 13 February 1943 of the President of "s-Hertogenbosch Court of Appeal to all members of the "s-Hertogenbosch Court of Appeal refers back to a letter previously sent to and a reply from the Secretary General of Justice, suggesting the letter of 8 February had been sent. 
and Amsterdam ${ }^{1693}$ Courts of Appeal, as well as some District Courts ${ }^{1094}$ pointed out that the forced labor deployment in Nazi-Germany was contrary to the Hague Convention. The latter allowed for labor deployment for the benefit of the occupation army, but the "s-Hertogenbosch court considered this was not the case in this situation. The Courts of Appeal refused to give the requested information.

After having received a reply from the Secretary General of Justice the President of the 's-Hertogenbosch court proposed to send a response, reiterating the court's position. ${ }^{1695}$ Another letter reiterating the court's protest was not found. ${ }^{10 \% 6}$ Nevertheless, by letter of 10 May 1943 the 's-Hertogenbosch Court of Appeal informed the director of the Regional Employment Agency of those employed at the court and thereby complied with the occupant's requirement to send a list of those persons eligible for forced labor in Nazi-Germany. The court did comment that none of its employees mentioned on the list could be missed. Due to a lack of justices, the court argued that there was already less supervision of the court registrar's office. If the court were deprived of these experienced employees, the functioning of court registrar's office and consequently the court would be at stake. ${ }^{1097}$ In May 1943 the Leeuwarden Court of Appeal also sent the requested information. ${ }^{1098}$ The archives did not indicate the Amsterdam appeals court complied later on, but as late as January 1945 its list for labor deployment had not been handed in. ${ }^{1099}$

The courts managed to protest and point out that the forced deployment of labor for work was contrary to the Hague Convention. Its article 52 allowed the occupation army to demand requisitions in kind and services from the inhabitants of the occupied country. The article also explicitly stated that this was the only exception to the rule that these requisitions could normally not be demanded. International law allowed for the courts to resist the occupant's policy of labor deployment. Those courts that sent in their lists of eligible persons allowed for the occupant to execute this policy, which would have been prevented with strict adherence to international law. The

11493 Rijksarchief in Noord-Holland, Gerechtshof Amsterdam 1940-1949, toegang 450, inv. 2 Ingekomen stukken en afschriften van uitgaande stukken van de president 6 maart $1940-26$ juli 1949. President bezetingstijd 30 maart - 21 februari 1945. Brief van 30 januari 1943 van de President wan het Gerechtshof te Amsterdam aan de Secretaris Generaal wan Justitie.

Rijksarchief in Noord-Folland, Arrondissementsrechtbank Amsterdam 1950-1959, toegang 510, inv. 2462-2463. Notulen vergaderingen 1918-1957. Vergadering, gehouden op donderdag 11 februari 1943, des namidags 3 uur.

I: Rijksarchief in Noord-Brabant, Gerechtshof "s-Hertogenbosch 1940-1949, toegang 823, inv. 1 brief 13 Februari 1943 van de President van het Gerechtshoft te 's-Hertogenbosch aan alle leden van het Gerechtshof te 's-Hertogenbosch.

1asts Rijksarchief in Noord-Brabant, Gerechtshof "s-Hertogenbosch 1940 1949, toegang 823 did not contain a second letter protesting the forced deployment of labor.

Iw? Rijksarchief in Noord-Brabant, Gerechtshof 's-Hertogenbosch 1940-1949, toegang 823, inv. 1 brief 10 Mei 1943 wan het Gerechtshof te 's-Hertogenbosch aan de Heer Directeur van het Gewestelijk Arbeidbureau te "s-Hertogenbosch, no. 253.

149: Tresoar, Gerechtshof Leeuwarden 1940-1949, toegang 17, inv. 3 Conrespondentie, Brief 8 Mei 1943 van de wnd. President van het Gerechtshof te Leeuwarden an de Directeur van het Gewestelijk Arbeidsbureau.

1044 Rijksarchief in Noord-Holland, Gerechtshof Amsterdam 1940-1949, toegang 450, inv. 2 Ingekomen stukken en afschriften van uitgaande stukken van de president 6 maart $1940-26$ juli 1949, President bezettingstijd 30 maart- 21 februari 1945 , brief van 12 januari 1945 van de Procureur Generaal bij hat Gerechtshof Amsterdam aan de President van het Gerechtshof te Amsterdam, no. 11/1/1945, 762. 
Supreme Court was an exception, but it is interesting to note that it negotiated this exception for itself and not all Netherlands courts.

\subsection{MOVING THE SEAT OF COURTS}

From 10 May 1943 the seat of the Netherlands Supreme Court was in Nijmegen. 1100 On 7 May Schrieke had issued a Regulation to move the Court's seat outside of The Hague. ${ }^{101}$ President van Loon claimed to have protested personally to Schrieke and the Civil administration. A written request sent on behalf of some of the members of the Supreme Court allso had no effect and a subsequent visit of two members of the Supreme Court was to no avail. ${ }^{1102}$

The protest of the Supreme Court did not appear to be a very strong one. The Court knew the Secretary General of Justice had not been able to muster a majority within the committee of Secretaries General for his proposal to move the Court's seat. The Supreme Court nevertheless sent its delegates to the Ministry of Justice with a protest, but also with proposed amendments to the decision to move, in case the Secretary General would not change his mind. ${ }^{1103}$

Schrieke's attempts to move the seats of the Hague Court of Appeal and District Court to Leiden did not succeed, largely due to resistance of the Presidents of both courts. ${ }^{1104}$ However, the seats of the "s-Hertogenbosch Court of Appeal and District Court had also been moved from 's-Hertogenbosch to Vught in the summer of 1942, where they remained until the beginning of 1945 . Also the District Courts of Middelburg and Breda might have been moved outside of their legally designated seats. No legal measure had been taken to instruct the move of these seats and no one had ever challenged the legitimacy of the decisions of these courts rendered outside their legally designated seats. ${ }^{1105}$

The Supreme Court's seat had been in The Hague since 1830 as determined via Royal Decree. ${ }^{1106}$ The Judicial Organization Act (1827) provided for the seats of the five Courts of Appeal to be established in The Hague, Amsterdam, Den Bosch, Am-

\footnotetext{
inot Scholtens, Statatsrecht, p. 44.

wor Statscourant 1943, no. 89

1102 Archief Hoge Raad der Nederlanden, Notulen Algemene Vergaderingen van 1921-1958, Algemeene Vergadering van den Hoogen Rad der Nederlanden op Maandag 1 Februari 1943. des namiddags te 3 uur, p. 29. See also Loon, p. 9.

1.103 Archief Hoge Raad der Nederlanden, Notulen Algemene Vergaderingen van 1921-1958, Algemeene Vergadering van den Hoogen Raad der Nederlanden op Maandag. I Februari 1943 des namiddags te 3 uur, p. 29.

1104 NIOD, Archief 33, doos 3, map f, 38, brief Secretaris Generaal vam het Departement van Justitie Schrieke aan Ministerialrat Krug van 2 mei 1944; brief President Gerechtshof "s-Gravenhage van Romondt aan de Secretaris Generaal van het Departement van Justitie Schrieke van 17 april 1944; brief President Arrondissementsrechibank "s-Grawenhage Rueb aan de Secretaris Generaal van het Departemeni van Justitie Schrieke van 25 april 1944.

105 Rijksarchief in Noord-Brabant, Vliegenthart, A.J., als Hoge Autoriteit in 's-Hertogenbosch en ats lid zuiveringscommissies, 1943-1959, toegang 1138, inv. 77 Dossiers Zuiveringsraad "s-Hertogenbosch, brief 11 mei 1945 van de President van het Gerechtshof te "s-Hertogenbosch aan de Minister van Justitie, no. 177.

\#106 Besluit van 21 Juni 1830 (Stb. 1830, No. 29), bepalende de zetels wan den Hoogen Raad en der Provinciale Gerechtshowen.
} 
hem and Leeuwarden. Each served the appeals from different provinces. ${ }^{10}$ Furthermore, within the circuits of the Courts of Appeal there were 19 District Courts and 62 Cantonal Courts. The Judicial Organization Act (1827) also designated seats to each district and Cantonal court.

The Judicial Organization Act (1827) specified that members of a court were neither allowed to be domiciled outside of the municipality where their court had its seat nor could leave that municipality except during vacation or with special permission. ${ }^{169}$ More seriously, the Judicial Organization Act (1827) stated that those courts established as Netherlands courts ${ }^{110}$ should exercise their competencies in accordance with amongst others the division of the judicial districts. "111 The seats were an integral part of the judicial districts. Therefore one could argue that only those courts Netherlands law recognized and had established with designated seats could exercise the competencies of Netherlands courts.

In case of the Supreme Court the occupant had enacted a regulation ordering the transfer of its seat. However, as the resistance of the Hague Court of Appeal and the Leiden District Court indicated, at that point there did not seem to be public order reason for this regulation. Moreover, since customary international law obliged the occupant to leave the courts intact as much as possible ${ }_{3}^{1 / 2}$ there was no basis in intemationall law for the occupant to move the Supreme Court's seat. The move of the

1107 Article 60 Wet RO. Furthermore, the Hague Court of Appeal served the provinees of Zuid.Holland and Zeeland, the Amsterdam appeals court those from Noord-Holland and Utrecht, the "s-Hertogenbosch court the ones from Noord-Brabant and Limburg, the Arhem Court of Appeal from Gelderland and Overijssel and the Leeuwarden court from the provinces of Friesland, Groningen and Drenthe. There was an exception in certain cases where the judicial administration borders did not completely cover the provincial border. Occupation legislation amended that, which postwar legislation ratified.

1108 Wet van 17 November 1933, houdende nieuwe vaststelling yan het rechtsgebied en de zetels der rechtbanken en kantongerechten, behorende tot het gerechtshof te "s-Hertogenbosch, Stb. 1933, no. 601; Wet van 17 November 1933, houdende nieuwe vaststelling van het rechtsgebied en de zetells der rechtbanken en kantongerechten, behorende tot het gerechtshof te Amhem. Stb. 1933, no, 602; Wet van 17 November 1933, houdende nieuwe vaststelling van het rechtsgebied en de zetels der rechtbanken en kantongerechten, behorende tot het gerechishof te 's-Graventrage, Stb. 1933, no. 603; Wet van 17 November 1933, houdende nieuwe vaststelling van het rechtsgebied en de zetels der rechtbanken en kantongerechten, behorende tot het gerechtshof te Amsterdam, Stb. 1933, no. 604; Wet van. 17 Novennber 1933, houdende nietuwe vaststelling van het rechtsgebied en de zetels der rechtbanken en kantongerechten, behorende tot hel gerechtshof te Leeuwarden, Stb. 1933, no. 605; Wet van 17 November 1933 , houdende wettelike bepalingen in verbend met de nieuwe waststelling van het rechtsgebied en de zetels der rechtbanken en kantongerechten, Stb. 1933, no. 606; Besluit wan 23 November 1933 tot bepaling van het tijdstip wan inwerkingtreding wan de wetten van 17 November 1933 , betrekkelijk de nieuwe vaststelling wan rechtsgebied en zetels van de rechtbanken en kantongerechten: inwerkingtreding per I Januari 1934, Stb. 1933, Nos. 601-606.; inwerkingtreding per I Januari 1934. See also Holthöfer, E., Beiträge zur Justizgeschichte der Niederlande, Belgiens und Luxemburg im 19. und 20. Jahrhundert, Vittorio Klostermann Frankfurt am Main, 1993, p. $22-25$.

11:99 Articles 15 and 16 Wet RO as amended by Wet van 29 Juli 1920, Stb. 1920, No. 624.

11 to Article I Wet RO named the Cantonal Courts, the District Courts, the Courts of Appeal and the Supreme Court as the Netherlands courts who could exercise the judicial powers in the Netherlands.

HIII Article 2 Wet RO.

412 See Chapter 3.2 . 
seats of the other courts was not even based on an official and published occupation measure, which meant that in violation of Netherlands law these courts exercised their competencies outside of their designated seats. In case of both the Supreme Court and the other courts it is therefore questionable whether the judgments these courts rendered from different seats than prescribed by Netherlands leguslation could be seen as judgments of Netherlands courts. In any case, contrary to international and national law these Netherlands courts did not resist the occupant's policy to move the courts" seats.

\subsection{INTRODUCTION OF THE FUHRERPRINZIP; RESIGNATION OF SUPREME COURT JUSTICE DONNER}

Regulation $1944 / 3^{1113}$ of the Secretary General of Justice provided for the introduction of the Fihrerprinzip or leader principle into the Netherlands legal order. Where normally the panel of the court would decide on for example composition and occupation of the chambers of the court, now the President could decide alone. Although this measure did not directly intervene in the content of judgments, indirectly it sought to influence the outcome of judgments. 1114

Naturally, there would only be an advantage for the Civil administration, where the president of a court was either pro-German or member of the NSB. At the time the regulation entered into force the President of the Netherlands Supreme Court, van Loon, the Presidents of two Courts of Appeal and some Presidents of District Courts could be seen as either one or the other. The majority of judges was not yet either a member of the NSB or could even be regarded as Nazi-Germany sympathizers. Judges loyal to the occupant could therefore almost always be prevented to form a majority by distributing them between the other members of the courts. However, via the Presidents, the Civil administration could now ensure that the majority of the judges in a given chamber could be Naz-Germany sympathizers, member of the NSB or a mix of those two. 1115

Although at the end of 1943 at Count of Appeal level $54 \%$ of Justices and at District Court level around $38 \%$ of Presidents and Vice Presidents owed their apm pointment to the Reichshommissar, ${ }^{116}$ it is by no means certain these would make use of those powers to further the occupant's policies. Presumably only those known to be critical of the occupant"s policies or unwilling to accept an appointment at the hands of the Reichskommissar would be excluded from a promotion or appointment. This also implies that judges appointed or promoted during the occupation camnot be said to have been in favor of the occupant and his policies. The fact that the occupant could only find few capable supporters to appoint or promote, ${ }^{117}$ meant that most could certainly not be seen as active sympathizers. On the other hand, of those appointed during the occupation to leading judicial offees $47 \%$ of appeals court Justices and $60 \%$ of Presidents and Vice Presidents of District Courts were not in office

1113 Verordnung 1944/3 des Generalsekretärs vom 28. Dezember 1943 , VoB1. 1944, $\$ 4$

114. Scholtens, Statatsrecht, p. 45

ins Asch, p. 484.

Iitti See ANNEX 6 Tables 2 and 3 and Chapter 4.5.

iii See Chapter 4.5 
anymore in 1946. 148 These figures of course also included retirements and judges who had deceased or resigned from office in the meantime. It nevertheless has to be noted that these figures mainly indicate those judges the Government removed from office after the occupation, since in the Government"s opinion these judges had falled in the proper exercise of their office. ${ }^{119}$ Therefore, it seems likely that the occupant could have gambled on a not insignificant minority of the leading judges he had appointed to use the Fuhrerprinzip to further his policies.

However, the introduction of the Führeprinzip certainly also encountered opposition. The prewar members of the Supreme Court, as well as members from several other courts ${ }^{1120}$ requested Schrieke to reconsider. In a letter on 21 January $1944^{1121}$ the remaining prewar members plus Justices Smits and de Visser pointed out that this measure would undermine the collegiate nature of the adjudication procedure. Furthermore, the Justices underlined the measure's incompatibility with article 43. Hague Convention, since no absolute prevention could exist with respect to the maintenance of public order and public safety.

In his reply ${ }^{1122}$ Schrieke labeled the measure introducing the Fithrerprinzip a measure dealing with internal administration, which could hardly be seen as covered by the concept of 'laws in force in the country' of article 43 . The independence of the courts was not jeopardized, so Schrieke, since the measure did not touch upon appointments, dismissals or even adjudication, but solely the division of the docket and other duties.

One member of the Netherlands Supreme Court, who had constantly and out of principle protested against measures the Civil administration enacted was Justice Donner. In the beginning of 1941 he was arrested three times, once even inside the building of the Netherlands Supreme Court. However, his arrests were not related to his work at the Supreme Court, but rather his work for the reformed church and even there the arrests were made on the wrong grounds. ${ }^{123}$ Only on 20 April 1943 Donner was released from his latest arrest on the 30 June 1941. After almost two years of absence he refused to work at the Netherlands Supreme Court any longer, not being

118 See ANNEX 6 Tables 2 and 3. Compare those promoted (P) or newly appointed (N) in 19431944 to those remaining in office in 1946 after a promotion $(\mathrm{P})$ or new appointment $(\mathrm{N})$ during the occupation.

1113 See diso Chapter 7.3.3.

12 Rijksarchief in Noord-Holland, Arrondissementsrechbbank Amsterdam 1950\%1959, toegang 510, inv. 2462-2463 Notulen vergaderingen 1918-1957, Vergadering, gehonden op Dinsdag 1 Februari 1944, des namiddags 4 uur en Correspondentie, Afschrift brief 25 Januari 1944 van leden wan her Gerechtshof te Amsterdam aan de Secretaris Generaal van het Departement van Justitie.

1.21 NIOD, Archief 33, doos 2, map f, inwentaris 1T., brief Raadsheren van de Hoge Raad der Nederlanden van den Dries, Fick. Nypels, Donner, van dler Meulen, Sinnighe Damsté, Hijink, Flier, Losecaat Vermeer, Smits en de Visser aan de Secretaris Generaal van het Departement van Justitie Schrieke van 21 jamuari 1944.

112. NlOD, Archief 33, doos 2, map f, inventaris III, concept brief Secretaris Generaal wan het Departement van Justitie Schrieke aan de Raadsheren van de Hoge Raad der Nederlanden van den Dries, Fick, Nypels, Donner, van der Meulen, Sinnighe Damsté, Hijink, Flier, Losecaat Vermeer, Smits and de Visser. The Civil administration had approved this proposed reply, but there is no proof in this archive it was sent.

112. Ruiter, p. $151-157$. 
able to operate in how the legal system had become. Especially the latest measure, the introduction of the Fuhrerprinzip was unacceptable to him. 124

At his own request Donner was given an honorable discharge in the spring of 1944, allowing for a vacancy for the occupant to fill. The Civil administration and the Secretary General of Justice were pleased to see Donner leave, regarding him a bad influence on the Netherlands Supreme Court. However, it was feared that other members of the Supreme Court might follow suit. For that reason Donner was refused his pension rights. Although the Civil administration considered this of little significance to Donner, since he had other means, the measure was seen as a deterrent for the other members of the Supreme Court that did not possess any independent means. Removing Donner from five other offices he held was to complement the deterrent. $^{1125}$

The disagreement over the leadership principle underlined the clash between Schrieke's national socialist and the Netherlands courts' traditional interpretation of international law. Traditionally the Hague Convention was understood as an attempt to limit the actions of the invader and the consequences of invasion, though not to give any rights or prerogatives to the belligerents, but rather to restrain any arbitrary exercise of power. ${ }^{1126}$ During an occupation the occupant could never become the legitimate sovereign and his factual powers were limited to the necessities of war. ${ }^{12}$ ? The ratification of the Hague Convention could not confer upon the occupant any powers the Convention itself did not confer upon him. ${ }^{1.28}$

From a national socialist perspective, as expressed by Secretary General Schrieke, war had its own rulles and the necessities of war could derogate from any peacetime rulle. ${ }^{1129}$ The Hague Convention as such did not seek to regulate war, but rather to soften the harshness of its consequences. Its article 43 gave an occupant a minimum standard for his administration to fulfill when administering the occupied territory, which was to assure public order and public safety. However, this was only a minimum standard, which the occupant was legally obliged to adhere to, but could go beyond. Articles 48 and 49 Hague Convention would support this contention in that they allowed the occupant to collect taxes in order to meet the costs of the administration of the occupied territory much in the way the legitimate Government was obliged to do. 1303

However, against Schrieke"s national socialist wiew it could be retorted that if article 43 were a compulsory minimum for the occupant, who could go beyond these minimum criteria, than separate provisions for e.g. the collection of taxes hardly

\footnotetext{
1424 NIOD, Archief 33, doos 17, map c, brief Raadsheer Donner aan de Secretaris Generaal van het Departement van Justitie Schrieke van 4 februari 1944.

1325 NIOD, Archief 33, doos 17, map c, Brief Ministerialrat Krug an die Abteilung tür niedertändische Personalangelegenheiten vom 24. Februar 1944. See also Ministerie van Justitie Depot 152, Rapport over Prof. Schrieke.

Preamble IVth Hague Convention, indent 3 stated that the purpose of the Convention was ".. confining [the general laws and customs of war - JM] within such limits as would mitigate their severity as much as possible... See also Nispen tot Sevenaer, "p. 177; Wisscher, p. 72; Rutgers, p. 751-752. 
seemed necessary. Moreover, if article 43 were only a minimum standard for an occupant to adhere to then there were no limits to his actions. This would put him in the place of the legitimate sovereign, which was something article 43 expressly prohibited. His exercise of sovereignty was factual and for the purpose of maintenance of public order and safety. Article 43 did not allow him to use his powers for any other end. The occupant was therefore to administer and not govern the occupied territory.

Schrieke's contention that article 43's concept of 'laws in force in the country' did not cover rules on administrative organization of courts was incorrect in that it also covered prescriptions not part of primary legislation. ${ }^{\text {I131 }}$ Moreover, as the Justices of the Supreme Court pointed out, the aim of the leadership principle could not be the maintenance of public order and safety. International law would therefore not have allowed for the Netherlands courts to aid the occupant in the execution of this policy.

\subsection{THE COURTS AND SOME LAST-MINUTE CHALLENGES TO THE VALIDITY OF OCCUPATION LEGISLATION}

At the end of August 1944 the constitutionality of a regulation was challenged before the Rotterdam District Court during an application for interim relief. ${ }^{1132}$ Via regulation the Reichskommissar had established the chamber of pharmacists, making its membership compulsory for all Netherlands pharmacists. ${ }^{1133}$ The Secretary General of Social Affairs needed to give his approval for the appointment of the president and governing council of the chamber of pharmacists, who could issue binding directives and levy a compulsory membership fee from its members. Newly installed pharmacist tribunals, whose members the Secretaries General of Social Affairs and Justice appointed for a period of six years, were competent to deal with infringements of the chamber's regulations and decisions to the exclusion of the ordinary courts.

In the case before the Rotterdam District Court pharmacist Evers requested the court to suspend the execution of a decision made on the basis of this pharmacy chamber regulation. A court bailiff, at the request of the president of the chamber of pharmacists, had announced confiscation of part of Evers's property for his continuous refusal to pay the compulsory membership fees of the chamber of pharmacists.

According to Netherlands civil procedure ${ }^{1 / 34}$ the ordinary courts were competent, in interim relief proceedings, to judge the legality of a measure of confiscation. The Vice-President of the Rotterdan District Court considered that in case of execution of the confiscation the damage to the pharmacist's reputation due to the solvency of his business was greater than the threat to the financial situation of the chamber of pharmacists. This was especially the case taking into consideration the small pecuniary claim at stake. A suspension of the confiscation was therefore ordered until a decision on the merits of the case could be rendered during a regular procedure.

\footnotetext{
113 Bemwenisti, p. 17 .

11.32 Arrondissementsrechtbank Rotterdam (Kort geding) (Mr. v. Oosten Slingeland) 28 augustus $1944, N J 1.944 / 1945,573$.

113. Verordnung $24 / 1942$ des Reichskommissars für die besetzten niederländischen Gebiete über die niederländische Apothekerschaft vom 13 März 1942, VoB1. 1942, S. 136.

$11: 4$ Articles 438 and 289 Netherlands Code of Civil Procedure.
} 
However, in this interim relief procedure parties requested the Vice-President to already render a judgment on the merits of the case, especially as regards the validity of the regulation. The Vice-President set aside the pharmacist's arguments of conscientious objection to and force majeure as regards the regulation. He argued that this was not one of the very specific cases where Netherlands legislation provided for an appeal to conscientious objection in order to be exempted from a general obligation. Furthermore, force majeure could not be invoked in the relation of the citizen to an organ of public law, which had been established in accordance with article 152 Netherlands Constitution. In referring to article 152 Netherlands Constitution the VicePresident explicitly recognized the chamber of pharmacists, which was established on the basis of an occupation measure as if it were a legal entity under Netherlands law, established by the Netherlands legislator.

The Vice-President then turned to the pharmacist's claim that the regulation was contrary to article 43 Hague Convention. The courts were entitled to review the validity of the legal rule at the basis of the dispute. The Vice-President acknowledged that article 43 Hague Convention might be interpreted in such a way that the pharmacy chamber regulation was not necessary to restore and maintain public order. However, despite acknowledging the measure's invalidity, the Vice-President stated that it was unlikely that this would be the main reason for which the courts would not apply the regulation. This statement was based on the fact that courts, according to article 124 Netherlands Constitution, were not allowed to examine the validity of acts of Parliament that were inviolable. Into this the Vice-President of the District Court inserted the interpretation that the acts of an independent authority that was allowed to enact generally binding measures for the whole territory were beyond judicial scrutiny. Restricting this constitutional provision to mere Acts of Parliament, i.e. those acts enacted jointly by Parliament and King, would go contrary to the intent of that provision. Even though the legislative history of the precursor of this constitutional provision did not contain a reference to occupation legislation, the legislator of 1848 , so the Vice-President, would have intended those measures to be included, if he were to have thought of such an occupation. For those reasons the Vice President would not review the validity of the pharmacy chamber regulation for compliance with either the Hague Convention or the Constitution.

The Vice-President's contention that the pharmacist chamber was established under Netherlands law was contrary to the Constitution"s attribution of the legislative powers to the Queen and Parliament. Also with his interpretation of the intent of the framers of the Constitution the Vice President sought a justification to apply an occupation measure he himself deemed illegal. Due to these two highly controversial interpretations and in spite of the measure's violation of article 43 Hague Convention, the Vice-President executed this policy of the occupant.

A judge at the Arnhem District Court was also confronted with interim relief proceedings in a similar case. ${ }^{113.5}$ Also in this case the judge allowed a suspension of the confiscation of the pharmacist's property for refusing to pay membership fees to the chamber of pharmacists. However, his approach was different. The judge reasoned that the pharmacist's action in an ordinary court would have a high likelihood

11:5 Arrondissmentsrechtbank Arnhem (Kont geding) (Jhr. Mr. van Nispen tot Sevenaer) 4 september 1944, NJ 1944/1945, 653. For an account of the Arnhem District Court during the occupation see Barendsen/Venema. 
of success and therefore a suspension of the confiscation measure was justified. Interestingly enough the justification of conscientious objection as regards the refusal to pay the membership fees was not discarded. The judge considered that the President of the chamber of pharmacists had not denied the applicant's allegation that his organization was organized on the basis of the Fuhrerprinzip and functioned according to national socialist doctrine. This was something to which many people objected, so the District Court judge. The regulation did not serve any military purpose and also deviated from and was contrary to the spirit of Netherlands legislation, which especially in the last decades had allowed for conscientious objections. Furthermore, the judge reiterated his independence from the case law of the Supreme Court, since he was not bound by precedent or stare decisis. For this reason he did not feel bound to the Judgment on Judicial Review, which the criminal chamber of the Supreme Court had rendered in 1942, basically denying courts the competence to review acts of the Civil administration. ${ }^{1136}$

Also, the judge agreed with the applicant that the exclusion of constitutional review of Acts of Parliament, enacted jointly by Parliament and King, was an entirely different matter from reviewing occupation measures. Besides, the criminal chamber of the Supreme Court was wrong in considering that the omission in the legislative history of the subject of judicial review of occupation measures meant an intent to terminate the existing practice of that review. Courts, in taking the oath to uphold the law, were bound to consider whether measures the legitimate authorities enacted should be applied. The validity of occupation measures could not be based on the factual situation of the occupation, but only on their compliance with article 43 Hague Convention as a treaty concluded by the legitimate government. The District Court judge asso considered it possible that the civil chamber of the Supreme Court, which ultimately had to decide on this case, might deviate from the decision taken by its criminal chamber. ${ }^{137}$ The violation of article 43 Tague Convention and the affirmation of the courts" powers of review were some of the reasons on the basis of which the confiscation measure was suspended. This District Court judge used international law as a basis to resist executing the occupant's policy.

The Hague District Court, "1.38 which had not been able to rule on the validity of occupation measures before December 1944, was obliged to do so in mid-January 1945. ${ }^{1134}$ A measure on the control of prices, which the Secretary General of Trade, Industry and Shipping and the Secretary General of Justice had enacted jointly, was tuled invalid. After having ascertained its powers of review for all measures except for Acts of Parliament, the Hague District Court considered that according to the Reichskommissar"s Regulation 1940/3 Netherlands legislation had remained in force. Via Regulation 1940/23 the Reichskommissar had recognized the competencies the Secretaries General had obtained at the beginning of the occupation, though to the

11.6. See Chapter 4.8 .

1197 This would not have been the case, since all prewar appointees at the Supreme Court had participated in drafting an internal memo concerning the courts' powers of judicial review of cccupation measures, which was at the basis of the Judgment on judicial review. Furthermore, many had contributed to and all had supported van den Dries" postwar published defense of the Judgment on Judicial review. See Chapter 4.8 .

I1.3 For more information of this court during the war see West de Veer.

11.39 Arrondissementsrechtbank 's-Gravenhage (le Kamer) 12 januari 1945, $\mathrm{NJ}$ 1944/1945, 678. See also foomote editors of the Nederlandsche Jurisprudentie, $N J 1944 / 1945$, p. 948. 
exclusion of the Netherlands Supreme Commander of the Land-and Naval Forces. These competencies were to maintain public order and to enact legal measures for the maintenance of public life, within the franework of the existing legislation. Since existing legislation did not include a penal procedural provision as contained in the measure the Secretaries General had enacted, the Hague District Court invalidated this measure.

The Hague District Court, in invalidating the occupation measure, did not consider Regulation $1940 / 23$ to entail a delegation of powers from the Reichskommissar to the Secretaries General. Rather, the court contended the regulation merely recognized the powers the Secretaries General had obtained from the Netherlands Supreme Commander of the Land- and Naval Forces, who of course in turn was presumed to have been delegated these powers from the Netherlands Government. " lation 1940/3 stated Netherlands legislation would still be in force, and Netherlands law did not contain such penal provisions, the Hague District Court allegedly used Netherlands law to constrain the powers of the Secretaries General and resist execution of this occupation measure.

Since the Government could not bave legally delegated to the Netherlands Supreme Commander these powers in the first place, "141 something the court did not ascertain, the Secretaries General could not have obtained these powers from him. The court's refusal to execute the occupation measure was therefore mistakenly based on Netherlands law. Furthermore, Regulations 1940/3 and 1940/23 clearly stated the occupant's intent to delegate his powers to the Secretaries General. ${ }^{1142}$ The preamble of both regulations in which the Reichskommissar allowed the Secretaries General to enact measures clearly stated his exercise of powers were obtained from Hitler. Moreover, in paragraph 1 Regulation 1940/23 Seyss-Inquart expressly stated $h e^{1 / 43}$ authorized the Secretaries General to enact measures containing penal provisions. The Hague District Court's refusal to execute the occupation measure was therefore not based on a positivist attitude to law, but a misunderstanding of the nature of the powers of the Secretaries General.

Near the end of the occupation in a few cases at least some courts started to look more closely at the powers of the occupant and the Secretaries General. In most cases courts applied occupation measures without question, probably based on the Supreme Court's Judgment on judicial review. However, in those few cases some courts did allow a challenge of the occupation measures' validity, they showed that, if willing, courts did have legal options available to resist execution of the occupant's policies.

\subsection{HOSTAGE TAKING AND EXECUTION OF JUDGES; JUSTICE HULSMANN AND VICE-PRESIDENT DONS}

In the beginning of February 1945 the Civil administration executed Justice Hülsmann, a member of the Amsterdam Count of Appeal and Vice-President Dons of the Amsterdam District Court. On Wednesday 7 February 1945 between 8 and 9 o'clock

\footnotetext{
llat See Chapter 1.4 .1 .

H.1 See Chapter 1.4.1.

1142 See also Lammers, p. 20.

$11+3$ My emphasis.
} 
in the morning Hülsmann and Dons were dragged out of their houses and taken to a meadow at the outskirts of Amsterdam and shot. ${ }^{114}$ This was a reprisal for the resistance's murder of the national socialist Procurator General in Amsterdam, Feitsma, which was in response again to the killing of judge van Harinxma thoe Slooten from the Leeuwarden District Court. ${ }^{1 / 45}$

It was known that judge Dons was on a German list of undesired persons. Justice Hülsmann had neglected to commemorate Feitsma's death at the first session of the court after the NSB public prosecutor's assassination. ${ }^{1146}$ Huilsmann had also had two audiences with Wimmer, the Commissioner General of Justice, concerning the detention camp at Ommen and on the removal from office of Viehoff and Wedewen. 11.47

The Amsterdam Court of Appeal continued the exercise of its public duties after the executions of Hülsmann and. Dons. At least publicly the court did not utter any protest, $^{1148}$ presuming the two judges were still held as hostages. The President of the Court of Appeal, Verdam, declared after the war that when his colleagues had been taken hostage the Civil Chamber had nevertheless decided to sit in session the next day. ${ }^{149}$ Public prosecutor Wassenbergh sent a deputy registrar to consult with President Verdam on what action to take. Verdam informed him that after consultation of the most senior Vice-President of the court, Meijlink, it had been decided to commemorate the assassinated NSB Public Prosecutor Feitsma if this would help the hostages.

Thursday afternoon there was another meeting on the situation when news reached the court of the execution of both Hülsmann and Dons. During the meeting it was unanimously decided to go on strike. The President of the District Court and the Bar Association would be informed of that decision. After a couple of days several members of the court backed out, afraid of the consequences to themselves and their families. After the weekend another meeting was held on Monday where a majority still wanted to proceed with the strike. However, it was also decided that on Tuesday a meeting would be held on what action to take if no strike were held. ${ }^{1150}$

On Tuesday no majority could be found for a strike anymore. Only Justices van der Does de Willebois and van Schaeck Mathon, together with President Verdam decided not to return to work and went into hiding. Justice Boon, acting President of one of the Chambers commemorated Vice-President Dons with a few words during a session. ${ }^{1151}$ Apparently Justice Hülsmann was not commemorated, since an appropri-

In:4 Nationaal Archief, Den Haag, Plaatsingslijst van het semi ambtelijk archief van de Secretaris General van het Ministerie van Justitie, Prof. mr J.J. Schrieke 1940-1944, Nummer Toegang 2.09.41.16, inv. 1, Brief 6 Februari 1945 van de SS Obergruppenfïhrer aan de Secretaris Generaal wan Justitie; Kop, p. 9.

Asch, p. 485. Bestuursalmanak, p. 26.

Kop, p. 9.

See allso Chapter 4.11. Kop, p. 18.

Kop, p. 20.

Ministerie van Justitie Depot 166 Zuivering kabinet, Doos 4, Dossier 255BR, zittingsrapport Rechterlijke Zniveringstaad Amsterdam 28 februari 1946 betreffende verhoor Mr. J. Verdam, President Gerechtsh of Amsterdam.

16. Ministerie van Justitie Depot 166 Zuivering kabinet, Doos 4, Dossier 255BR, brief Rechterlijke Zuiveringsraad Amsterdam aan Mimister van Justitie 9 april 1946. 
ate way to do so could not be found and the court wanted to avoid offending the Civil administration. ${ }^{152}$

The Amsterdam District Court also kept silent. Judge Dons's widow requested the President of the District Court not to do anything that might endanger the other members of the court. This was the reason the District Court did not hold an official commemoration. Furthermore, the court was of the opinion that not everyone could. go into hiding for lack of means and a suitable address. 1153

During the occupation several judges were taken hostage. Some have already briefly been mentioned. ${ }^{1154}$ Two members of one of the Courts of Appeal were taken hostage in June 1942 and were held in captivity until December 1942 and March 1943 respectively. The court did not react. ${ }^{1155}$ The Vice-President of the "s-Hertogenbosch District Court was taken hostage in 1942, apparently because the occupant was of the opinion the court was anti-German. The "s-Hertogenbosch Court of Appeal supported the letter of protest its District Court sent to the Secretary General of Justice. ${ }^{156}$ The District Court, excluding one of its members, assured the Sectetary General of Justice it was not conducting anti-German policies and after an investigation of its members could conclude that none of its individual members were antiGerman. The court's members deemed a hostile attitude to be alien to them and therefore requested its Vice-President to be released. ${ }^{115}$ In July 1942 one of the members of the Leeuwarden Court of Appeal, R.P. Cleveringa, had been taken hostage and interned. The acting President of the court requested the Secretary General to allow Cleveringa to return, stressing the dire personnel situation at his court. $15 \%$ Moreover, at some point during the occupation the Cantonal judge of Venlo, as well as his court registrar had died. The personnel from the court registry, as well as all the deputy Cantonal judges had been deported. The reason is not known either. ${ }^{115 \%}$

1152. Ministerie van Justitie Depot 166 Zuivering kabinet, Doos 4, Dossier 255BR. Zittingsrapport Rechterlijke Zuiveringsraad Amsterdan 28 februari 1946 betreffende verhoor mr I. Verdam, President Gerechtshof Amsterdam.

115. Ministerie van Justitie Depot 166 Zuivering kabinet, Doos 4, Dossier 255BR, Zittingsrapport Rechterlike Zuiveringsraad Amsterdam I maart 1946 betreffende verhoor mo I.C. de Vries, Vice-President Arrondissementsrechtbank Amsterdam.

115. See Chapter 4.5. NB The following list is not exhaustive, but due to a lack of information and no drect relevance for the research of this thesis, the exact number has not been researched.

115s Ministerie van Justitie Depot 164, Intelligence report GB. 2830/44 Netherlands Intelligence Department, Rapport over houding rechiterlijke nacht.

115 Rijksarchief in Noord-Brabant, Vliegenthart, A.J, als Hoge Autoriteit in "s-Hertogenboseh en als lid zuiveringscommissies, 1943-1959, toegang 1138, inv. 77 brief 19 August 1942 van de Procureur Generaal bij en de President van het Gerechtshof te "s-Hertogenbosch aan de whd. Secretaris Generaal wan Justitie.

1157 Rijksarchief in Noord-Brabant, Vliegenthart, A.J., als Hoge Autoriteit in 's-Heriogenboseh en als lid zuiveringscommissies, 1943-1959, toegang 1138 , inv. 77 Brief van 11 August 1942 van Tilman, Vollgraff, Schroeder, Huizinga, Ariens, van Thien, Tenminck en Loeff aan de Secretaris Generaal wan Justitie.

1158 Tresoar, Gerechtshof Leeuwarden 1940-1949, 1oegang 17, inv. 2 Correspondentie, Brief 19 November 1942 van de wnd. President aan de Secretaris Generaal van het Departement wan Justitie, no. 261 .

1159) Rijksarchief in Noord-Brabant, Vliegenthart, A.J., als Hoge Autoriteit in 's-Hertogenbosch en als lid zuiveringscommissies, $1943-1959$, toegang 1138 , inw. 77 brief 20 maart 1945 van de President van het Gerechtshof te 's-Hertogenbosch aan Mr. R.H. van Basten Batenburg, no 160. 
It was difficult for courts to do anything against the occupant's policies of hostage taking. The Hague Convention did not mention nules on hostages. "160 Taking hostages was still allowed under international law in the interest of safety of a line of communication threatened by resistance cells not belonging to the armed forces or for other reasons. ${ }^{1161}$ International law did not prevent a hostage suffering for acts or omissions he or she was not responsible for, be it legally or morally. ${ }^{1162}$

However, the execution of Justice Hülsmann and Vice-President Dons was a different matter under international law. Although the occupant was allowed to remove judges from office and discipline them, ${ }^{1163}$ this was an execution without a trial and as such contrary to the occupant's duty to respect the lives of persons under article 46 Hague Convention.

The reaction of both Amsterdam courts to the execution was very much inspired by fear. An act of resistance was conditional on the possibility to go into hiding, which only a few judges did. ${ }^{\| 64}$ One of the two Amsterdam courts, the District Court, was notably the one that together with its public prosecutor Wassenbergh had organized judicial resistance against the atrocities in the detention camps. ${ }^{1165}$ At least the district court had therefore proven it did not shy away from resisting the occupant's policies. However, with the courts in the south of The Netherlands as well as the seat of the Supreme Court in Nijmegen liberated at the end of 1944, the courts in the occupied north were isolated. Not having stayed their official duties before, it was questionable whether the other courts in the still occupied part of The Netherlands would follow a possible strike. This increased the isolation of and the risks for both Amsterdam courts. The occupant did not shy away anymore from openly executing members of the courts who opposed him. Although international law gave the courts a possibility to protest against and resist the occupant's policies, in practice they probably felt too intimidated and isolated near the end of the occupation.

\subsection{CONCLUDING REMARKS ON THE NETHERLANDS COURTS DURING THE OCCUPATION}

What is striking as regards The Netherlands is the administration's seemingly absolute compliance with the occupant's orders and lack of open defiance. The Judgment on judicial review exemplified this attitude for the Netherlands courts. Although the Supreme Court rendered this judgment, many lower courts actively supported it.

Even though international law offered other possibilities, the Court interpreted it such as to demonstrate the courts' inability to reject any occupation measure. Near the end of the occupation at least some lower courts challenged this ruling, underlining the fact that the Supreme Court legally had a choice. However, many other courts did not openly challenge this ruling.

In order to ewen be able to deal with occupation legislation in cassation, the Supreme Court, "under the present circumstances', deemed it to have the same nature as

\footnotetext{
160 See allso verzijl, p. 164-167.

ita! See also Chapter 2.1.4.

1/4.2 Oppenhem, War, p. 213; Bordwell, p. 305 .

16.3 Beer Poortugael, p. 176; Bordwell, p. 306. See also Chapters 2,3, 2.6 and 4.3.

ilon See also Boer e.a., p. 20

165 Sae Clapters 4.10 and 4.11
} 
Netherlands law. However, combined with the fact that some Supreme Court Justices referred to the occupant and the Secretaries General as "legislator" and "government", the Judgment on judicial review seens to testify to the Court"s mindset as regards the occupant and the way in which Netherlands courts should deal with his measures.

Although its constitutional position had changed due to the occupation, the Court nevertheless considered that in the exercise of its public duties it should not exceed its role as main arbiter in concrete cases. However, in only tending to concrete cases, the Court lost sight of the bigger issues at stake. Losecaat Vermeer seemed to suggest that the Judgment on judicial review was a tradeoff for the closure of the camps and not an important one, since the Court would silently review and not apply certain occupation measures anyway. In doing so the Court deprived itself of and rendered more difficult for the lower courts any principled stance against certain kinds of occupation measures that were contrary to international law, national law or both. The Judgment on judicial review also provided a justification for every occupation measure, making it virtually impossible to openly resist the application of illegal occupation measures, even those dealing with nationals of Jewish ancestry. Of course it has to be remembered here that many lower ranking courts at the time supported the Supreme Court's judgment.

The fact that the Supreme Court, like most other Netherlands courts, shied away from an open confrontation with the occupant made it problematic for individual judges to take a principled approach, as the case of the Leeuwarden Justices showed. The Netherlands courts were unable to organize themselves as to credibly oppose the dismissals and induce the occupant to change his decision. The courts' organization at that time was geared towards the execution of the sentences. As the protest against the Ommen detention camp showed, a principled approach worked where courts were able to organize and threaten to stay proceedings if the detention camps were not closed. In this case, the courts clearly pointed out that their conscience did not allow them to aide the occupant's policy of execution of sentences contrary to Netherlands law. It is interesting to note here that the conflict of conscience and not the violation of law was the primary cause for the protest and resistance. Nevertheless, this principled approach allowed the courts, together with a threat of staying their duties, not only to resist the occupant"s policy, but also induce him to change it.

The Netherlands courts also openly and directly challenged some other policies of the occupant's through protest, but there was no organized threat to stay their duties in order to resist their execution. In several instances these illegal occupation measures had been introduced and, after protests or not, accepted as if in accordance with the law. In the cases of the political courts" competencies in violation of the nebis-in-idem principle, the dismissal of the Leeuwarden Justices, the measures concerning forced deployment of labor and the introduction of the Fulherprinzip, although protests were made indicating some violation of law, no further steps were taken.

In other instances, like the Aryan Declaration, the analogy of penal provisions, the introduction of economic courts, the moving of seats of courts and the execution of two Amsterdam judges, in spite of a violation of international law, national law or both, the courts not even protested. Where a limitation of their competencies was concerned, the courts accepted the limitations, which might have been justified under international law. However, some lower courts also interpreted the regulation granting German courts competence widely even though other, credible legal options were 
available. This was not only to the detriment of their competencies, but also the accused involved.

The courts' neglect to protest or to take further action after a protest allowed for these occupation measures to remain in force and the Netherlands courts" omission to further act against them signalled at least a tacit acceptance. One judge in a case at the end of the occupation rightly remarked that in spite of their illegality the courts would apply them.

Nevertheless, the Supreme Court's contention was that courts did not need to apply occupation measures, stating that silently judicial review was practised anyway. However, leaving individual judges or courts to decide by themselves in concrete cases on the illegality of occupation measures could not guarantee that some courts would apply an illegal and even heinous measure. The regulations against Jews are one obvious example here. The inconsistency irherent in covert review meant that it could not be assured that occupation measures were not applied.

It was of course a courageous act of passive resistance, but its success in resisting execution of the occupant's policies was uncertain. Moreover, the Judgment on judicial review rendered passiwe resistance more difficult. It provided the occupant with an argument under international law to discipline judges who did not exercise their duties according to the law, as their own Supreme Court had interpreted it.

Barring individual exceptions, Netherlands courts, even where they perceived an occupation measure to be illegal, did not openly resist the execution of the occupant's policy and covertly could not assure consistency in resisting execution of an occupation policy.

The fact that the Supreme Court had proven unwilling and after the occupation appointments unable to lead resistance against occupation measures was certainly another factor in the courts' attitude towards the occupant. Even though the Amsterdam District Court and its public prosecutor were able to organize the courts for a joint protest concerning the detention camps, the threats and actions to stay their duties was something the individual courts had decided separately. The Amsterdam District Court's position in the judicial hierarchy would hardly have allowed it to substitute for a leadership role attached to the position of a supreme court. Only a suprene court with enough moral authority might have persuaded its lower courts to underwrite and possibly execute a threat of mass resignation. No such threat was made as regards the Leeuwarden Justices, but might have been necessary to persuade the occupant to reconsider.

The occupant in June 1940 had already assumed the powers for judicial appointments. The courts did not resist, also not when the occupant's measures, in violation of international law, ordered the removal from office of Netherlands judges of Jewish ancestry and over 65 years of age. After these removals from office the courts actively sought to fill the vacancies in a procedure that violated Netherlands law. The Leeuwarden Court of Appeal was a notable exception. However, and more importantly, if the occupant deviated from that procedure and appointed judges contrary to the List of Recommendations, even where these judges were members of the NSB, the courts acquiesced. At least in one instance the "s-Hertogenbosch appeals court deviated from a customary rule of appointment on its own initiative.

The deviation from Netherlands law and the courts' refusal to insist the occupant adhere to this procedure allowed for the Supreme Court as well as the lower courts to be divided. This division rendered agreement on concerted action as well as 
organization with other courts more difficult. Especially the occupant's success in appointing the President and several other Justices of the Supreme Court handicapped it from assuming leadership in resisting occupation policies. However, even within the first few months of the occupation, when no occupation appointments had been made, the Court did not lead resistance against the Aryan Declaration, even though lower courts and others expected it to. As the Ommen detention carnp incident underlined, also the Courts of Appeal did not assume leadership. The Leeuwarden appeals court reacted, but the Amsterdam District Court acted in organizing resistance.

Considering that the President and several members of the Supreme Count were occupation appointees, as well as the Presidents of two out of five Courts of Appeal, some of its members and some Presidents and members of the nineteen District Courts, the occupant had certainly increased his hold over the courts throughout the occupation. However, even though the occupant's personnel policy might have impaired the courts' ability to organize, it did not prevent them from organizing a concerted action regarding the Ommen detention camp incident in 1943. Also the introduction of the Führerprinzip as late as 1944 with its purpose to increase the occupant's control of the courts showed the occupant did not control the courts completely yet. The occupant's influence over the appointment procedure can therefore not fully explain the Netherlands courts' failure to organize more frequently to resist certain occupation measures.

In several instances the Netherlands courts used a positivist attitude towards law as a means to openly protest against an occupation policy. Except for the Ommen detention camp incident, strict adherence to international law, national law or both was not used as a means to openly resist the execution of the occupant's policies. And even in the Ommen case a conflict of conscience rather than a violation of law was what spurned the resistance. The occupant's hold over the appointment procedure only partly explains why the Netherlands courts were not able to organize in order to back up their protests with a credible threat. Individual courts might have used covert resistance based on international law, national law or both, in order not to execute the occupant's policies. However, this could not prevent an inconsistent approach to the occupant's measures and their execution. This inconsistency meant that only where judges managed to exercise covert review, Netherlands courts presumably relied on law, international or national, as a means to resist execution of the occupant's policies. In other instances, in spite of the occupation measure being in vilolation of international or national law, it would nevertheless be applied. Therefore, openly or covertly, Netherlands courts would sometimes display a positivist attitude to law in order to resist execution of the occupant's policies. Nevertheless, in most cases Netherlands courts would apply the occupant's measures and as a consequence execute his policies in violation of international law, national law or both. 



\section{CHAPTER 5}

\section{COMPARING THE BELGIAN, LUXEMBOURG AND NETHERLANDS COURTS' ATTITUDES TOWARD THE OCCUPANT'S 'NAZIFICATION' MEASURES}

\subsection{THE BELGIAN, LUXEMBOURG AND NETHERLANDS COURTS" POSITIVIST ATTITUDE}

\subsubsection{Preliminary remarks}

In order to make a valid comparison between the different jurisdictions, the question whether the courts had a positivist attitude during the occupation, which made it impossible for them to resist execution of occupation measures will have to be discussed. From the outset several general remarks have to be made. As stated in Chapter One, 1166 there were differences concerning the occupation regime and the national administration already at the beginning of the occupation. These differences also seemed to have played out during the occupation amongst others in the role the national administrations played between the accupant and the national courts. Although not the focal point of this research, it is necessary to dwell a bit on the national admiristrations' roles in this context also to further elaborate on some differences between the three jurisdictions.

It has to be borne in mind that in al॥ three countries the national administration was involved in the courts' relationship towards the accupant. In Luxembourg this, of course, ceased to be the case soon after the Civil administration was installed, at the end of 1940 at the latest. ${ }^{1167}$ However, in Belgium and The Netherlands the national administrations, with alterations, existed until the end of the occupation." 1168 Especially their Ministries of Justice would be involved in contacts between occupant and courts.

As compared to the Netherlands administration the Belgian administration seemed much more involved in fending off the occupant's attempts to influence the position and functioning of the courts. In Belgium the occupant seemed to have had less grip on the Belgian administration, possibly due to its attachment to a Belgian legal basis for its functioning, linked no doubt to the requirements of the Statute on Delegation (1940). The absence of preparations in. The Netherlands for such a clear cut legal basis, ${ }^{169}$ the omission of the Secretaries General to find and possibly extend one in Netherlands law and their early acceptance of a delegation of powers from the occupant ${ }^{178}$ also made the courts more dependent on the occupant. ${ }^{1171}$ This would impact the Belgian, Luxembourg and Netherlands courts" positivist approach in different ways.

\footnotetext{
16h See Chapter 1.5.

1167 See Chapter 1.3.3.

1 168 See Chapters 1.2 .3 and 1.4.3.

1100 Chapter 1.4.1.

1170 Chapter 1.4.3.

tin Chapter 1.5.
} 
Belgian courts were able to make a clear distinction between measures emanating from a Belgian authority, enacted under Belgian law and measures the occupant had enacted on the basis of his powers of occupation. The former were adhered to as Belgian law and therefore applied in courts and the latter were not recognized as Belgian measures, but seen as factual measures and therefore not applied in courts. Belgian courts would apply Belgian laws equivalent to these factual measures and give some effect to the occupant"s measures if there was no equivalent in Belgian law, but never apply the occupant's measures. "172 The Statute on Delegation (1940) of course enabled this independent functioning of the Belgian administration and a possibility for Belgian measures to be enacted. However, it also has to be stressed that the Statute on Delegation (1940) did not oblige Belgian courts to take such a strict positivist view in rejecting application of measures emanating from the occupant. This was a cleat choice on the part of the Belgian courts, due to which, from the beginning, application of the occupant"s measures was refused in court.

The Luxembourg and Netherlands courts were less in a position to choose for such an option. In applying measures not emanating from their national authorities and enacted in accordance with their national laws or based on a legal delegation of powers from the national authorities, from the outset of the occupation these courts would already be violating their own legal order. Even though the Luxembourg Government had provided for a legal basis in national law for measures to be enacted during the occupation, after the abolition of Luxembourg's State organs at national level, only the occupant was left to issue generally binding measures. 1173 A positivist approach of the Luxembourg courts in only applying laws a Luxembourg organ had issued on the basis of Luxembourg law would have meant that from the end of 1940 onwards no newly enacted measures would have been applied.

The same held true for The Netherlands, though already starting at the beginning of the occupation. Their acceptance of the occupant's delegation of powers meant that if the Netherlands courts would have taken a strictly positivist approach, no occupation measures could have been applied. "174

The Statute on Delegation (1940) at least aided the Belgian courts in taking a positivist stance from the beginning and maintaining it throughout the occupation with more credibility. Besides refusing application of the occupant's measures this would have also strengthened their hand in resisting application and execution of certain occupation measures the Secretaries-General had enacted. The Luxembourg and Netherlands courts' direct dependence on the occupant's measures for the administration of the country and in the case of the Netherlands also the occupant"s powers, meant that their courts from the beginning faced more difficulty in adopting a positivist stance. Consequently, their credibility in maintaining a positivist stance in order to resist the application and execution of certain occupation measures had been weakened from the start.

There also seem to have been ways in which the involvement of the national administrations during the occupation influenced the position and functioning of the courts. The reasons for this can possibly also partly be traced back to the difference in occupation regime, as well as the difference in preparation or lack thereof for a

\footnotetext{
1:73: Chapter 2.8 .

117. Chapter 1.3 .3

117- Chapter 4.2 .
} 
possible occupation. Certain examples seem to illustrate this. Although in Belgium the occupant sought to be consulted about appointments to the higher judicial offices, ${ }^{1175}$ in The Netherlands, from the beginning of the occupation, the occupant declared these appointments to be his exclusive prerogative. ${ }^{1176}$ For the lower judicial offices the Belgian administration attempted to fend off any intervention from the occupant, whereas in The Netherlands from the beginning of the occupation the occupant could veto any such appointment. ${ }^{177}$ Schuind made a promise from the occupant to not extend the early retirement regulation contingent on his acceptance of the appointment to the office of Secretary General of Justice. His successor de Foy, although having accepted the occupant's influence on appointments concerning lower courts, circumvented this through using a different procedure. ${ }^{1178}$ Where the Belgian courts, especially the higher offices, were shielded from new appointments, the Netherlands courts were confronted with a large number of judges in higher office owing their appointment to the occupant. The Secretaries General in Belgium initially resisted the occupant's attempts to introduce a separate jurisdiction dealing with economic crimes, ${ }^{179}$ whereas in The Netherlands the Secretaries General themselves initiated the introduction of such a separate court system. ${ }^{1180}$ Moreover, in case of the political courts in The Netherlands, the administration seemed to have aided rather than resisted the introduction of this court jurisdiction. ${ }^{1181}$

Some of these differences can possibly also be attributed to the occupant's success in appointing collaborators to the national administrations of the occupied countries. This was of course the case in The Netherlands with the appointment of Schrieke as Secretary General of Justice, as well as the appointments of several Procurators General. ${ }^{1182}$ It should nevertheless be stressed that the regulations dealing with the economic and the political courts were already prepared and the first one enacted before Schrieke was appointed. ${ }^{1183}$ Moreover, in Belgium the occupant also succeeded in influencing the appointments of members of the national administration, but failed in having a member of a collaborationist party appointed Secretary General of Justice. ${ }^{1184}$ Of course these conclusions about the national administrations are rather tentative, since this was not the focus of the research. Nevertheless, there are some indications that more than the Netherlands administration the Belgian administration's actions shielded the courts' position and functioning from the occupant's influence.

The special situation of Luxembourg during the occupation of World War Two is a complicating factor in using Luxembourg for comparison in the context of this thesis. Different from Belgium and The Netherlands the occupant considered Luxembourg not just occupied, but also from a certain date onwards annexed. Since the installation of the Civil administration his policies were geared towards annexation

\footnotetext{
I. Chapters 1.2 .3 and 2.5 .

Thapters 1.4 .3 and 4.5 .

11:? Compare Chapter 2.5 and 4.5 .

117. Chapter 2.5

$11 \%$ Chapter 2.4

ing Chapter 4.8

14 Chapter 4.7 .

lik2 Chapters 1.4 .3 and 4.4 .

Ilw Chapters 4.7 and 4.8 .

1130. Chapter 1.2.3.
} 
and not administration of an occupied territory. "185 Although Luxembourg was only factually annexed and not legally, this in a sense would therefore not affect the ability of Luxembourg's courts to invoke international and national law to protest and possibly resist the occupant"s measures. Some, though few, protests were made, whereby international or national law was used. ${ }^{186}$ However, linked to the severity of the occupation regime was the fact that Luxembourg as a State and hence its court system was of a very small size and virtually negligible in comparison to Germany. Different from Belgium and The Netherlands, Nazi-Germany would have had no problems replacing the entire court system in Luxembourg. Moreover, German judges were in fact introduced to Luxembourg's court system from the very beginning of the occupation. ${ }^{1187}$ Therefore, protesting against and resisting application of the occupant's measures using international and national law or not, was for the Luxembourg courts a much more hazardous affair than for their Belgian or Netherlands counterparts. The Luxembourg judges possibly faced far greater consequences for the continued existence of Luxembourg courts manned by Luxembourg nationals. Due to the special situation of Luxembourg, its role in this comparison can therefore only be very small.

Another preliminary remark has to be made about several measures the occupant only enacted in one of the three countries during the occupation, which can therefore not serve as a basis for comparison of the courts' reactions. The measure concerning a statutory age limit, whereby judges were retired from office earlier than prescribed by prewar legislation had only been enacted in Luxembourg and The Netherlands. However, only for The Netherlands more information is known. ${ }^{188}$ Although the same measure had been enacted in Belgium for the public prosecutor office, it did not affect the courts and no such measure was subsequently introduced for the judges. ${ }^{189}$ Conscription was only introduced in Luxembourg, "190 the occupant's prohibition to return from abandoning post immediately after the invasion only in Belgium ${ }^{\| 101}$ and only Luxembourg judges were submitted to ideological training. ${ }^{1192}$ Also only in Luxembourg many parts of German law had been introduced in their entirety. ${ }^{193}$ The principle of analogy had only been made applicable to all penal provisions in the Netherlands Penal Code. 194 The Netherlands courts' application of measures against Jewish nationals cannot be compared to any other jurisdiction. ${ }^{1195}$ Belgian courts refused application of the occupant's factual measures ${ }^{1196}$ and although presumably Luxembourg courts applied these measures, unfortunately no data concerning their application of occupation measures is accessible. ${ }^{1197}$ Also the moving of the seats of several courts in The Netherlands ${ }^{1 / 28}$ and the abolition of the

\footnotetext{
1 tos Chapters $1.3 .3,3.9,3.10$ and 3.11.

1.:36 Chapters 3.2 and 3.9 .

11in? Chapter 3.5 .

1.4\% Sea Chapter 3.7 for Luxembourg and Chapter 4.6 for The Natherlands.

1. 1 . Chapter 2.6.

1 . Chapter 3.10

11 को Chapter 2.2

1192 Chapter 3.6 .

14.3 Chapters 3.8 and 3.9

1194 Chapter 4.7

lis Chapter 4.9

ligs Chapter 2.8

119 Chapter 3.8 .

1198 Chapter 4.13
} 
Diekirch Tribunal ${ }^{109}$ cannot be used as a point of comparison between these two jurisdictions. Although contrary to legislation of judicial organization in both coun. tries, only in Luxembourg this was done in order to integrate the Luxembourg courts into the German judicial organization. Instead of a mere deviation from legislation on judicial organization, in Luxembourg national legisiation was set aside completely and replaced with German law. Also the language regulation was peculiar to the situation in Luxembourg. ${ }^{1200}$ This does not mean, however, that the courts' reactions to these occupation measures cannot serve to further clarify their stance in other areas.

\subsubsection{Similar measures in Belgium, Luxembourg and The Netherllands}

There are a few topics, however, where the three jurisdictions, with certain reservations, can be compared. One concerns the formula under which Justice was rendered. ${ }^{1201}$ In all three jurisdictions at the beginning of the occupation this formula was subject to change. In Luxembourg and The Netherlands the occupant introduced a modification from rendering Justice in the name of the legitimate sovereign to a different formula. The Sovereign and Governments had of course fled from these countries, which was different to Belgium where at least the King had remained. Moreover, in Belgium the exile Government enacted a measure altering this formula. Although not in factual control of the country anymore, Belgium's exile Parliament in the French town of Limoges had approved of the exile Government's actions so far, including the enactment of this measure. Also for the Belgian courts this measure could therefore be seen as an order that was meant to be obligatory. Furthermore, in spite of the King"s presence on the occupied territory it would not have been unthinkable that the occupant in Belgium would also have attempted to alter the formula. Under international law the King's stay on the territory did not make a difference as regards the occupant's possibility to attempt a change of the formula. A valid comparison can therefore be made between the three jurisdictions in question as regardis their attachment to the formula under which Justice was rendered. Although this comparison will highlight the differences in attachment to the formula, it can of course not show a difference in reaction towards the occupant.

Nevertheless, the formula under which Justice was rendered was not a trivial matter or one of mere semantics. As the Belgian courts clearly understood, attachment to this formula also demonstrated, especially during the occupation, an attachment to the Sovereign and therefore the sovereignty of the nation and the independent existence of its legal order. The Belgian courts' refusal to have the formula altered and their continuous annual pledge of loyalty to the King in captivity during the whole of the occupation has to be seen in this way. Not erasing the tangible symbol of that sovereignty from public life and amongst others also maintaining the regular oath of office served as a reminder of Belgium's continued independent existence as a State, even during an occupation. Belgian courts resisted the abolition of this symbol.

\footnotetext{
Iow Chapter 39.

120: Chapter 3,2 .

1, See Chapters 2.1,3.1 and 4.1
} 
Luxembourg"s experience is illustrative in that from all three jurisdictions, the abolition of its formula and the introduction and subsequent adaptation of the new formula symbolized its increasing loss of sovereignty. Initially a more or less neutral formula was introduced, already erasing a visual reminder of Luxembourg"s sovereignty from public life. The subsequent "clarification" of the formula then insisted that Luxembourg courts henceforth had to render Justice 'In the Name of the German Peoples. Some judges were removed from office in Luxembourg concerning the measures integrating Iuxembourg courts into the German judicial system, of which the latten measure was part, but others remained in office. This in spite of the fact that the measure was contrary to the constitution and the latter measure clearly violated international law, obliging the occupied country"s courts to render Justice in the name of a foreign sovereign. However, Luxembourg's special situation as discussed earlier, may explain the Luxembourg judges' reaction to the eradication of a visual symbolic reminder of their nation's sovereignty.

In The Netherlands this measure was not imposed until after consultation with the Netherlands authorities and the Supreme Court. International law gave an opportunity to resist this measure and national constitutional law prescribed that Justice be done in the name of the Sovereign. Moreover, like Belgium, but different from Luxembourg the Netherlands judicial system was of a considerably larger size and if organized had enough members to resist this 'request' from the occupant. However, the Supreme Court chose to accommodate the occupant in this respect, which subsequently allowed for all visible signs of Netherlands sovereignty to be erased from public life. The oath of office was changed and a mere circular was enough to ban the Queen's name from all official acts of State and titles of public office. The example of the President of the Leeuwarden District Court illustrated that those following the requirements of the law were not supported when removed from office. Even more strikingly, the Supreme Court ruled that the constitutional provision prescribing the formula could be ignored, since it entailed no legal consequence. Contrary to the Belgian courts, the Netherlands courts in no way honored any visible symbols of Netherlands sovereignty, independence and independent existence of its own legal order.

A difference in national laws cannot account for the difference in reaction between the Belgian, Luxembourg and Netherlands courts. All three constitutions called for Justice to be rendered in the name of the Sovereign. Moreover, both the courts in The Netherlands and Belgium had to contend with rules their Governments thad issued. The legal status of the Instructions of the Netherlands Government should have been clear in that these could not be binding upon the courts and their interpretation of Netherlands and international law. Nevertheless, the Supreme Court specifically indicated these were at the basis of its decision. The legal status of the Belgian Government's exile measure was at that point unclear, but if it could be said it was a legislative act, ${ }^{120}$ the Belgian courts resisted the application of a measure that would be binding under national law. However, international law, or the Belgian courts' interpretation of it during the occupation of World War One, might have contributed to their refusal to apply this exile measures during this occupation.

1202 As the exile Government claimed and the Belgian courts would confirm after the occupation. See Chapters 6.2 and 7.1 . 
The Belgian courts' approach was therefore most in line with a positivist one in this matter, even defying their own Government, but firmly and publicly adhering to Belgian sovereignty. The Luxembourg courts did not take a positivist approach, possibly linked to Luxembourg's particular situation, ultimately allowing Justice to be done in the name of a foreign sovereign. The Netherlands courts decidedly did not take a positivist approach, allowing for a removal of all signs of Netherlands sovereignty from public life.

Another point for comparison is how the courts reacted to their limitation of competencies. ${ }^{203}$ In all three jurisdictions the competencies of the ordinary courts were limited, usually in favor of the war tribunal the occupant established. For part of this limitation international lawyers were in virtual agreement that the occupant could exclude from the competencies of the occupied country's courts offences committed against its armed forces and organizations. ${ }^{1204}$ Not surprisingly, courts in Belgium, Luxembourg and The Netherlands did not protest against this limitation. Nevertheless, the courts' reactions against other limitations were markedly different.

Although the Belgian courts, like their Netherlands counterparts, accepted the establishment of a separate jurisdiction dealing with economic crimes, the Cour de cassation was initially excluded from dealing with some of these cases in last instance. The Netherlands Supreme Court was not, but the Procurators General appointed during the occupation who had devised this system were of the opinion that the Supreme Court's role would be negligible. The fact that the Cour de cassation was excluded must have meant that the Belgian situation was different in that the role of the Cour de cassation as regards these cases was not seen as negligible. The Cour de cassation also did not accept this exclusion and specifically nullified a provision in a decree of the Secretary General that prohibited recourse to cassation, ruling it contrary to Belgian constitutional law. ${ }^{1205}$ Of course it also has to be mentioned here that in The Netherlands the Courts of Appeal initially drastically reduced the sentences from the Economic Courts, opposing the occupant's policy in this area. However, recourse to the Courts of Appeal was soon abolished in favor of an Economic Court of Appeal, further limiting the ordinary courts' competencies. Moreover, the resistance of the Courts of Appeal dealt with the severity of the sentencing and not with legal objections to the establishments of the economic court. ${ }^{1206}$ On the other hand, the Cour de cassation's ruling also did not consider the economic jurisdiction illegal as such, but considered that the fact that no proper recourse could be had to the ordinary courts against that jurisdiction's decisions, since cassation was excluded was contrary to the Belgian constitution. Moreover, in the ensuing judicial crisis for which there is no direct parallel to any situation in Luxembourg or The Netherlands, the Cour de cassation consistently and persistently used law as a means to fend off the occupant's attempts to curb the Belgian courts" powers. This judicial crisis will be discussed in more detail later on. Suffice it to state here that the Netherlands courts did not take a positivist attitude and failed to put up any resistance against a limitation of their competencies, even though adherence to Netherlands law would have made it impossible for them to comply with the occupant's limitation of their

20.3. See Chapters $2.4,2.9$ and $2.15,3.4,4.4$ and 4.8 .

1204 See Chapter 2.4 .

1205 Chapter 2.9

1206 Chapter 4.8 
competencies. ${ }^{1207}$ By contrast, the Belgian courts' positivist attitude resulted in resistance against the occupation measure.

The difference in attitude between Belgian and Netherlands courts concerning limitation of competencies is more striking when looking at the extent to which courts accepted such a limitation. In the area of illegal possession of arms the Belgian courts, aided by the Belgian prosecutor service and administration, would constantly challenge the occupant"s exclusive competence in that area. A refusal to prosecute, as well as international law and nationall law regarding a prohibition to hand over nationals to the enemy were used in order to resist the occupant's policy in this field. 1208 In spite of violations of national and international law in certain instances, no protest from the Netherlands courts is known concerning the exclusion of competencies. ${ }^{1209}$ Also the Netherlands courts' reaction concerning the introduction of the peace courts was based on the violation of the ne-bis-in-idem rule, but not a limitation of the Netherlands courts" competencies as such. ${ }^{1210}$ More strikingly, some lower courts interpreted extensively and contrary to national law and even the regulation itself the occupant's measure concerning the competencies of German war tribunals, further limiting their own competencies. 1211

In the case of Luxembourg no protests or resistance is known against the limitation of the Luxembourg courts" competencies. ${ }^{1212}$ Not protesting might have been the attitude Luxembourg courts took in order to prevent a further limitation of their competencies or even a replacement of their personnel or the whole judicial system.

The appointment procedure during the occupation in all three countries of course deviated from the prewar procedure. Neither the Monarch nor Parlliament could exercise their role anymore in as far as they had had one in the prewar era. In Belgium, Luxembourg and The Netherlands the occupant would be involved in the appointment procedure, though the extent to which he would be able to influence appointments differed.

In Luxembourg, of course, the occupant would completely dominate the appointment procedure and appoint German judges to the Luxembourg courts. ${ }^{1213}$ This was most certainly contrary to Luxembourg law and the occupant's obligations under international law. Due to the Belgian administration's constant search for a legal basis for its measures in Belgian law, appointments would be made on the basis of Belgian law. ${ }^{1214}$ The Netherlands administration's acceptance of a delegation of powers from the occupant, without considering the possibility of adopting a legal basis in its own legislation, made it completely dependent on the occupant for appointments. ${ }^{215}$ At least part of the procedure would therefore be contrary to Netherlands law.

What is striking in Belgium is that during the occupation hardly any high ranking judicial offices became vacant, whereas in The Netherlands the occupant succeeded in lowering the retirement age and creating many judicial vacancies, also for

\footnotetext{
1207 Chapters $4.4,4.8$ and 4.17

1.30 Chapters 2.4 and 2.15 .

1 2us Chapters 4.4 and 4.8 .

1310 Chapter 4.7 .

1211 Chapter 4.4

1.12 Chapter 3.4.

21.4 Chapters 1.3 .3 and 3.5

ina Chapters 1.2.3 and 2.5

12.5 Chaptars 1.3 .3 and 4.5 .
} 
the higher judicial offices. Furthermore, few appointments seem to have been made during the occupation in Belgium of members of a collaborationist party. However, against these the Belgian courts did not seem to have raised an objection, even though these were presumably made contrary to the courts' Lists of Recommendations. It should be remarked here though that the Belgian prewar procedure differed from the one in The Netherlands. The one in Belgium worked on the basis of double Lists of Recommendations, of which the courts only submitted one, whereas in The Netherlands the courts submitted the only List. Customarily in Belgium the courts could therefore not rely on their preferred candidate being appointed. Netherlands courts, out of convention, could have this expectation. In The Netherlands during the occupation more judicial offices seem to have been filled with members of collaborationist groups. In several instances, at all levels of the court hierarchy, the occupant set aside the Lists of Recommendations that were part of the constitutional procedure for appointment. In allowing for a deviation from Netherlands law and custom Netherlands courts were unable to resist the occupant's appointment policies.

The appointment procedure during the occupation highlights that as compared to the Netherlands administration the Belgian administration seemed much more involved in fending off the occupant's attempts to influence the position and functioning of the courts. The Belgian courts were able to maintain closed ranks, especially in the higher offices, whereas the Netherlands courts saw many occupation appointees, with a higher percentage appointed to the higher than the lower offices. That more members of collaborationist groups were appointed in The Netherlands than in Belgium can possibly be attributed to the fact that there was a different occupation regime in both countries. A contributing factor was possibly also that the occupant had succeeded in appointing a member of the collaborationist movement as Secretary General in The Netherlands, but not in Belgium. Whether or not the judges who were a nember of collaborationist groups were appointed in accordance with Belgian law cannot be ascertained. However, if not, then just like the Luxembourg and Netherlands courts, a more positivist approach from the Belgian courts should not have allowed them to accept these appointments. Nevertheless, in Belgium high-ranking judicial officers resisted the occupant influencing the appointment procedure through remaining in office in accordance with Belgian law. Moreover, not having their preferred candidate appointed was less of a deviation from the procedure of the List of Recommendations in Belgium than in The Netherlands. In The Netherlands, contrary to national and international law at all levels of the judicial hierarchy the occupant introduced early retirement. A more positivist attitude would have required the courts to resist this measure.

\subsubsection{Measures common to Belgium and The Netherlands}

Measures against judges of Jewish ancestry were introduced in both Belgium and The Netherlands, but not in Luxembourg, due to the absence of judges of Jewish ancestry. The national administrations in both States already had a different attitude towards these measures. Whereas the Belgian authorities in principle refused any cooperation in the implementation of these measures, ${ }^{1216}$ the Netherlands administra- 
tion, after a brief protest, facilitated their enforcement from the beginning with the introduction of the Declaration of Aryan Ancestry. ${ }^{1217}$ However, even though in principle the Belgian administration refused co-operation, its recommendation to Belgian judges of Jewish ancestry to resign rather than be removed from office and the lack of indication of support for those unwilling to resign in practice amounted to an impossibitity for the judges involved to resist. The occupant's measure could be construed as a violation of international law and was contrary to the national laws of both Belgium and The Netherlands. The Belgian courts managed to protest pointing out the illegality of the measure, something the Netherlands courts were incapable of. However, courts in both jurisdictions failed to resist the actual implementation of this measure, even though in The Netherlands civil servants, possibly including judges, in vain attempted to ignore the measure.

The first application of occupation measures can also only be compared between Belgium and The Netherlands, lacking information from Luxembourg. ${ }^{1218}$ The difference between the two jurisdictions is of course that the Belgian occupation measures the courts applied were at least initially based in Belgian law. The occupant's measures were not applied whereas in The Netherlands al] occupation measures at a national level were based on the occupant"s powers. A comparison is nevertheless possible, because in both countries the measures the courts applied laid claim to being legislative acts. Many decrees of the Secretaries General were in fact, at the instigation of the occupant, implementations of the latter's policies. Moreover, in Belgium certain measures ander the Statute on Delegation (1940) contrary to Belgian law were nevertheless abided by due to an order from the occupant. Also, the measures enacted under the Statute on the King's special powers (1939) could not be seen as legally emanating from a Belgian authority and could therefore only be seen as based on the powers of the occupant. ${ }^{1219}$ In any case, in both jurisdictions courts had to determine their reaction towards measures enacted during an occupation that did not emanate from the institutions provided for in their respective constitutions. Moreover, in both occupied States a refusal to apply these occupation measures would result in a direct conflict with the occupant, since it would hamper his attempts to conduct his policies to administer the occupied country.

Neither in Belgium nor in The Netherlands courts resisted the first application of occupation measures. ${ }^{120}$ In Belgium immediate resistance was not apparent, since the measures the Secretaries General enacted were Belgian measures, based in Belgian law and if not contrary to the Constitution or the provisions of Belgian law there was no legal obligation to refuse application. This was different in The Netherlands. Since the occupation measures were not based in Netherlands law, Netherlands law did not allow for courts to apply them. Courts had a legal obligation to only apply penal provisions contained in or based on an act of Parliament. Civil law obliged courts to ex officio supplement any legal grounds parties had not addressed, including questions of illegality or applicability. However, in violation of Netherlands law courts nevertheless applied these first occupation measures.

\footnotetext{
1219 Chapter 4.3.

12: See Chapter 2.8 for Belgium, Chapter 3.8 for Luxembourg and Chapter 4.2 .

In Chapters 2.11 and 2.16.

$12 \pm$ See Chapter 2.8 for Belgium and Chapter 4.2 for The Netherlands.
} 
The difference in attitude between the Belgian and Netherlands courts becomes even more apparent when looking at how courts in both jurisdictions dealt with a direct request to exercise review of occupation measures. ${ }^{1221}$ Some lower courts in Belgium allowed for such a challenge and subsequently refused to apply an occupation measure contrary to Belgian law, although others did not. A few lower courts in The Netherlands only allowed for such a challenge towards the very end of the occupation. Both supreme courts also had a different attitude. The Belgian Supreme Court risked a crisis, since it initially refused application of an occupation measure that violated the Statute on Delegation (1940) it was based upon. The Netherlands Supreme Court gave the greatest possible leeway for the implementation of occupation measures, even if these might be contrary to international or national law and refused to review these measures.

However, the difference in practice as regards the refusal to apply occupation measures between the Belgian and Netherlands Supreme Courts was not as stark as it seems. The Belgian Supreme Court maintained its stance concerning measures based upon the Statute of Delegation (1940), but nevertheless abided by a measure contrary to this statute once the occupant enacted a measure obliging it to do so. The Cour de cassation's World War One case law in which it claimed that when implementing the Hague Convention the Belgian legislator had intended to endow an occupant's measures with force of law must have been debit to this. The Cour de cassation's reaction towards occupation measures moves a bit more into the direction of the Netherlands courts' reaction when considering its agreement to the resolution of the first judicial crisis. Allowing the committee of Secretaries General to base its measures on the Statute on the King's special powers (1939) contrary to Belgian constitutional law and refraining from reviewing these measures was in effect very similar to the Netherlands courts' refusal to review any occupation measure.

Nevertheless, the difference remained that from the beginning as regards their refusal to apply the occupant's measures and their dealings with the Statute on Delegation (1940) the Belgian courts would continue to use law in their efforts to oppose certain occupation measures. Relinquishing this attempt as regards measures based upon the Statute on the King's special powers (1939) and where the occupant ordered the courts to apply measures contrary to the 1940 Statute undermined, but did not negate this basic positivist attitude.

This basic attitude was lacking as regards the Netherlands courts. This is also apparent from the written protests of Netherlands courts. These were not only less frequent than in the case of Belgian courts, but were also less detailed in their use of international and national law. In cases concerning the forced deployment of labor and hostage taking the Cour de cassation ${ }^{1222}$ and not the Netherlands courts ${ }^{1223}$ managed to address a clear and firm protest to the occupant. The Leeuwarden Justices did not use law, but rather a conflict of conscience to justify resistance against the occupant's policy of executing sentences. Netherlands courts also failed to point out that the Leeuwarden Justices were in effect removed from office for an ex officio act, even though they reiterated that their removal from office was in any case illegal on

1224 For Belgium see Chapters 2.9 and 2.11 and for The Netherlands see Chapter 4.8 .

1223. Chapter 2.10 .

1223 Chapter 4.12 . 
other grounds. ${ }^{124}$ Belgian courts or more precisely the Cour de cassation was firm in its resolve to get judges who had been removed or suspended from office for ex officio acts reinstated and very much used law to this effect. In the case of judge Stévigny the Cour de cassarion even succeeded in having him reinstated in spite of an abuse of his powers of office to resist an occupation measure. In the latter case in negotiating with the occupant not law, but a concession to the occupant was used to resist the occupant's decision to remove judge Stevigny from office. ${ }^{225}$

It has to be noted though that in the case of atrocities in detention camps not only the Netherlands courts, but also the Belgian ones did not directly invoke law in order to protest the occupant's execution of sentences. The Netherlands courts clearly stated that their ground for protest was a conflict of conscience. This conflict arose, because sentences were not executed in accordance with Netherlands law, but the violation of Netherlands law in itself was not directly used to counter the occupant's policies in this respect. ${ }^{126}$ Also the Cow de cassation when protesting atrocities in the Breendonck camp did not directly irvoke Belgian law, although it referenced principles of law. The Belgian Count mainly appealed to the occupant's conscience, labeling the atrocities contrary to military tradition as well as basic requirements of justice. ${ }^{1227}$ Nevertheless, although not directly invoking law, in both jurisdictions the courts" protests succeded in changing the occupant's policies in this respect.

\subsection{POSITIVIST ATTITUDE AND ORGANIZATION OF COURTS TO RESIST EXECUTION OF OCCUPATION POLICIES}

In the case of the Belgian, Luxembourg and Netherlands courts during the occupation of World War Two a positivist attitude alone did not make it impossible to resist the execution of the occupant's policies. Rather, adherence to international law and national law would have made it possible for courts in Belgium, Luxembourg and The Netherlands to resist execution of at least certain occupation measures.

A positivist attitude in itself was, however, not enough. The examples of Luxembourg and the small size of its court system, The Netherlands where courts were unable to organize except for one occasion and Belgium where the Caur de cassation could rally support from the lower courts showed organization was a necessary factor. The courts' ability to organize allowed them to back their demand up with a threat to resign. This in turn was used to pressure the occupant who in case of mass resignation would have to provide personnel to assure a continuation of the administration of justice.

Again Luxembourg was in a different position here than Belgium and The Netherlands conceming an ability to organize and back a positivist attitude up with a threat of mass resignation. Less than half a year after the occupation had started Luxembourg's Supreme Court, the Cour superrieure, had been split up into different senates and therefore in effect abolished. ${ }^{1228}$ And although there was some personnel continuity, a German President of the Cologne Higher Regional Court of Appeal was

1224

1225

1326

1227

$122 i$
Chapter 4.10

Chapter 2.7 .

Chapters 4.10 and 4.11 .

Clapter 2.12.

Chapter 3.2 
appointed head of the Luxembourg courts and German judges were appointed to the newly created Appellate Court's Senates. Also at the Tribunal level Geman judges were appointed, especially in the leading positions. ${ }^{1229}$ The leadership of Luxembourg's courts having thus been decapitated, an organization of the Luxembourg court system had become virtually impossible. In spite of this some Luxembourg judges nevertheless managed to organize and protest against some of the occupant"s measures, but it is unknown and unlikely they were speaking on behalf of all Luxembourg judges still in office.

Although the Luxembourg courts were in an impossible position to mobilize in order to back up their resistance with a threat of mass resignation, this cannot be said for the Belgian and Netherlands courts. Both the Belgian and Netherlands supreme courts were left intact. Moreover, the size of the Belgian and Netherlands court systems already did not allow for the occupant to replace them easily.

The case of Belgium, especially as regards the first judicial crisis, but also to a certain extent the second one, demonstrated that the Cour de cassation's ability to lead the Belgian courts allowed for the Belgian courts to back up their claim against the occupant. ${ }^{1230}$ Also some other incidents, mainly dealing with the Court's protests to the occupant concerning removal from office for ex officio acts ${ }^{1231}$ showed that the occupant took these threats seriously.

By contrast in The Netherlands the Supreme Court did not fulfill this leadership role. It did not seize the opportunity to lead the Netherlands courts in resisting the Aryan Declaration. ${ }^{1232}$ Also in other instances, more specifically the crisis around the Ommen detention camp ${ }^{12.33}$ and the removal from office of the Leeuwarden Justices, ${ }^{1234}$ the Supreme Court reacted as if it were any other court in the Netherlands judicial hierarchy rather than the Supreme Court. Its reaction concerning the Ommen detention camp was also many weeks after its subordinated courts had already protested. However, not even a Court of Appeal, but a District Court had to lead the Netherlands courts in organizing resistance against the occupant in this instance.

Furthermore, different from the Cour de cassation, the Netherlands Supreme Court did not view the fact that it was the only State organ at central level still intact as a duty to protest against violations of international law. Rather, it used this argument to underline its impotence, pointing out that the Court's position had changed. ${ }^{12.35}$ And where the rights of subordinated courts had been violated under international or national law the Netherlands Supreme Court, contrary to its Belgian counterpart, did not intervene with the occupant on their behalf. The Netherlands Supreme Court might join in the protest or not as was also sometimes the case, but it did not present itself as the defender of the interests of the Netherlands courts.

The fact that the Netherlands Supreme Court also did not assume any kind of leadership role cannot be readily presumed to be related to the occupant's successful personnel policy. Certainly the Belgian Cour de cassation and Cours d'appel had

Chapters 3.3 and 3.5 .

Chapters 2.9 and 2.11 .

Chapter 2.7.

Chapter 4.3.

Chapter 4.11 .

Chapter 4.10 .

Chapters 4.2 and 4.8 . 
been able to mantain closed ranks during the occupation. In The Netherlands the occupant had succeeded to appoint Justices to the Supreme Court that were not unfavorable to his policies and which would undermine the Court's attempts to maintain a unified front. However, the Supreme Court had proven unable to lead the Netherlands courts from the beginning of the occupation, even before the occupant had appointed his appointees. The Court's consent to the abolition of the formula under which Justice was rendered illustrated its unwillingness to resist. The vote on the Aryan Declaration showed there was no unanimity. The appointment of van Loon, contrary to its wishes, demonstrated the Court's paralysis when confronted with the occupant's demands.

The Supreme Court was not the only Netherlands court unable to organize. Aside from the Amsterdam District Court's organization of joint resistance concerning the atrocities in the detention camps, other courts also falled to organize. The Hague Court of Appeal and subsequently the courts of the provinces of North and South Holland did not succed in organizing to resist the introduction of the peace court jurisdiction. ${ }^{1236}$ The Amsterdam Court of Appeal failed to organize as much as a protest against the assassination of one of its members and a member of the Amsterdam District Court. ${ }^{1237}$ In both instances individuals were left to act by themselves. Also the judgment of the Leeuwarden Justices was a courageous act of three individual Justices, even though it came forth from the Amsterdam District Court"s attempts to rally the Netherlands courts. However, also in the case of the Leeuwarden Iustices the Leeuwarden Court of Appeal did not lead resistance against their removal from office. ${ }^{23 \%}$ However, the increasing amount of occupation appointees to higher judicial offices might have influenced the higher courts' ability to organize.

The second judicial crisis in Belgium showed that the Brussels Cour d'appel was able to organize and even go on strike after the occupant had arrested three of its Justices. ${ }^{239}$ For this it got the support of its Cour de cassation, even after the Brussels court had already resumed its duties. The fact that the Cour d'appel's decision to stay its duties was in this case based upon an error does not undermine the argument that it was able to organize and enlist the aid of its supreme court.

The Cour de cassation"s leadership role, the Brussels Cour d"appel's ability to onganize and the Netherlands Supreme Court's view of its role during the occupation and the inability of the Netherlands Courts of Appeal to organize had nothing to do with the difference in occupation regime. This merely demonstrated the difference between the courts in Belgium and The Netherlands and their attempts in organizing themselves. The Belgian courts' ability to do so brought them occasional success in resisting some of the occupant's measures. The one time the Netherlands courts man aged to organize themselves showed that successful opposition to the occupant's policies was possible. However, contrary to their Belgian counterparts Netherlands courts were unable to systematically organize in order to support their opposition to the occupant's policies.

One other comment has to be made here about the Cour de cassation. The credibility of its ability to lead suffered due to the unsuccessful outcomes of the first

\footnotetext{
Chapter 4.7

12n? Chapter 4.16.

1.34 Chapters 4.10 and 4.11 .

(239) Chapter 2.11.
} 
and second judicial crisis. After the first one the Belgian courts had lost their powers of judicial review concerning measures the Secretaries General would enact on the basis of the Statute on the King's special powers (1939). The second judicial crisis continued due to an error of judgment on the part of the Cour de cassation, whereby it also appeared as if the Court caved in without having achieved any success. As a consequence, it was in a weakened position to rally the courts to resist the application of the illegal decree on the agglomerations as ordered via regulation of the Military administration. This loss of credibility must have affected its ability to lead the courts for the remainder of the occupation. The Cour de cassation certainly after the second judicial crisis did not attempt to enforce its protests with a threat to suspend its duties.

However, this loss of credibility might have diminished the Cour de cassation's ability to lead the Belgian courts, but it does not negate the fact that it intended to do so. This intention seemed to be lacking as regards the Netherlands Supreme Court. At least from its actions during the occupation and the fact that a District Court organized the Netherlands court in one instance and in other instances the Netherlands courts were left to protest individually, it cannot be discerned the Netherlands Supreme Court had an intention to lead. In fact, there is not one example during the occupation that the Supreme Court led the Netherlands courts in resisting an occupation measure.

\subsection{POSITIVISM AND ABILITY TO ORGANLE ALLOWED COURTS TO RESIST THE OCCUPANT'S POLICIES?}

The question whether the courts' positivist attitude during the occupation made it impossible for them to resist aiding the occupant in the execution of his policies cannot be given a straightforward answer. During the occupation courts seemed to have possibilities in national and international law, some more compelling and persuasive than others, that did not allow them to apply certain occupation measures. A positivist approach to law would therefore have required instead of prevented them from resisting execution of certain occupation measures. A deviation from the national and international law, which would have been a choice on the part of the courts, allowed for the execution of illegal occupation measures. In how far courts did not have a positivist attitude towards law during the occupation and did not resist execution of occupation measures was different as regards the Belgian, Luxembourg and Netherlands courts.

Of all three jurisdictions researched, Belgian courts were most positivist in their approach and most able to organize, allowing them to resist the execution of at least some occupation measures. However, the courts did not have a consistent positivist attitude and allowed for illegal measures to be applied. The Cour de cassation led the Belgian courts that were able to organize during the occupation, although gradually its credibility must have been eroded, due to which the courts would be less able to back their protests up with a threat to suspend their duties.

The Luxembourg courts cannot be part of the comparison. If the Luxembourg courts were to have had a positivist approach to law, national and international law would have given them opportunities to resist certain occupation measures. However, due to an impossibility to research Luxembourg case law from during the occupation and not enough information about the legal content of their protests, the attitude of 
the Luxembourg courts cannot be compared. Moreover, the decapitation of the leadership of the Luxembourg courts due to the abolition of the Cour superieure and the appointment of German judges to leading positions within the Luxembourg court system made it impossible for Luxembourg courts to organize resistance.

As compared to the Belgian courts, the Netherlands courts were less positivist in their approach. Netherlands courts were also less able to resist the execution of occupation measures. A more positivist approach would have required them to resist application of at least certain occupation measures. However, a lack of leadership from the Supreme Court and the Courts of Appeal seriously hindered the courts' abillity to organize and resist application of illegal measures, if they would have chosen to take a positivist stance. 


\section{CHAPTER 6}

\section{GOVERNMENTS IN AND RETURNING FROM EXILE}

\subsection{GOVERNMENTS-IN-EXILE DURING THE OCCUPATION}

At the beginning of the occupation the Governments and Heads of State of Luxembourg and The Netherlands had fled. Although the Belgian Government went into exile and attempted to persuade the Belgian King to join, the latter refused and remained in occupied Belgium. ${ }^{1240}$ During the occupation these Governments, under differing circumstances, would establish themselves as Govemments-in-exile.

Due to the fact that these exile Governments were not able to enforce any measures on the occupied territory their role was not discussed during the occupa tion. This did not mean, however, that during the occupation the exile Governments were not actively enacting measures and preparing a return to their countries after the occupation had ended. This chapter will therefore mainly deal with the Belgian, Luxembourg and Netherlands Governments during the exile period. It will first explore their status and powers under international law and then for each individual country, after a short history of their exile period, the national law these Governments used to base their measures on. Finally their retum from exile will also be described, as well as their Parliament's reaction to the exile measures immediately after the occupation. This in order to give some background to the exile measures aimed at "denazifying" the courts after the occupation, which will be discussed in the proceeding chapter.

The legal status of these Governments-in-exile could partly be explained on the basis of international law. Due to the occupation the occupant under article 43 Hague Convention would acquire in fact the powers of the legitimate Sovereign. However, the occupation did .... not confer upon the occupant sovereignty over the occupied territory. "241 The legitimate Sovereign would still possess sovereignty over the occupied territory, although not being in a position to enforce this power anymore. The Allied States recognized the exiled Govermments of Belgium, Luxembourg and The Netherlands under international law as the legitimate Governments exercising the Sovereignty of their occupied States. 1242

See Chapter 1.

Benvenisti, p. 8. See also Mechelynck, p. 334; Spaight, p. 322; Beer Poortugael, p. 174-175; Rolin, Tone I, p. 420, 439; Oppenheim, War, p. 206, 210, 341; Bordwell, p. 299.

124: Fayat, p. 10-12, who described the acts of the Bellgian exile Government with other Govern. ments, implying the latter"s recognition of the Belgian exile Government as the legitimate Government of the Belgian occupied State. See A.P. Senat, S.O. 1939/1940 et septembre/octobre/novembre 1944, séance des chambres réunies du mardi 19 septembre 1944, No. 62, p. 17. See also Government of Luxembourg, p. 44-51, where the actions of the US and UK Goverments implied recognition of the Luxembourg Government-in-exile. See Kerchove. p. 22-23, citing specific acts of recognition of the Netherlands Government by the US and UK Governments and Landsheer. See also e.g Verzijl, p. 221-223, who cited case-law of several courts in the US accepting measures of the exiled Netherlands, French and Norweglan Gow. ernments. The fact that all other Governments founding the United Nations in 1944 accepted the exilie Govenments of Belgium, Luxembourg and The Netherlands as fellow founding members implied recognition of their status as the legitimate representatives of their occupied States.
} 
the Luxembourg courts cannot be compared. Moreover, the decapitation of the leadership of the Luxembourg courts due to the abolition of the Cour superieure and the appointment of German judges to leading positions within the Luxembourg court system made it impossible for Luxembourg courts to organize resistance.

As compared to the Belgian courts, the Netherlands courts were less positivist in their approach. Netherlands courts were also less able to resist the execution of occupation measures. A more positivist approach would have required them to resist application of at least certain occupation measures. However, a lack of leadership from the Supreme Court and the Courts of Appeal seriously hindered the courts" ability to organize and resist application of illegal measures, if they would have chosen to take a positivist stance. 


\section{CHAPTER 6}

\section{GOVERNMENTS IN AND RETURNING FROM EXILE}

\subsection{GOVERMMENTS-IN-EXILE DURING THE OCCUPATION}

At the beginning of the occupation the Governments and Heads of State of Luxembourg and The Netherlands had fled. Although the Belgian Government went into exile and attempted to persuade the Belgian King to join, the latter refused and remained in occupied Beigium. ${ }^{1240}$ During the occupation these Governments, under differing circumstances, would establish themselves as Governments-in-exile.

Due to the fact that these exile Governments were not able to enforce any measures on the occupied territory their role was not discussed during the occupation. This did not mean, however, that during the occupation the exile Governments were not actively enacting measures and preparing a return to their countries after the occupation had ended. This chapter will therefore mainly deal with the Belgian, Luxembourg and Netherlands Governments during the exile period. It will first explore their status and powers under international law and then for each individual country, after a short history of their exile period, the national law these Governments used to base their measures on. Finally their return from exile will also be described, as well as their Parliament's reaction to the exile measures immediately after the occupation. This in order to give some background to the exile measures aimed at 'denazifying' the courts after the occupation, which will be discussed in the proceeding chapter.

The legal status of these Governments-in-exile could partly be explained on the basis of international law. Due to the occupation the occupant under article 43 Hague Convention would acquire in fact the powers of the legitimate Sovereign. However, the occupation did "... not confer upon the occupant sovereignty over the occupied territory. ${ }^{1241}$ The legitimate Sovereign would still possess sovereignty over the occupied territory, although not being in a position to enforce this power anymore. The Allied States recognized the exiled Governments of Belgium, Luxembourg and The Netherlands under international law as the legitimate Governments exercising the Sovereignty of their occupied States. ${ }^{1242}$

\footnotetext{
$12+44$

See Chapter 1.

12 a Benvenisti, p. 8. See also Mechelynck, p. 334; Spaight, p. 322; Beer Poortugael, p. 174-175; Rolin, Tome I, p. 420, 439; Oppenheim, War, p. 206, 210,341 ; Bordwell, p. 299.

12:2 Fayat, p. 10-12, who described the acts of the Belgian exile Government with other Govenments, implying the Latter's recognition of the Belgian exile Government as the legitimate Government of the Belgian occupied State. See A.P. Senat, S.O. $1939 / 1940$ et septembrefoctobre/novembre 1944, séance des chambres réunies du mardi 19 septembre 1944. No. 62 , p. 17. See also Government of Luxembourg, p. 44-51, where the actions of the US and UK Goverments implied recognition of the Luxembourg Govermment-in-exile. See Kerchove, p. 22-23, citing specific acts of recognition of the Netherlands Government by the US and UK Governments and Landsheer. See also e.g Verzijl, p. 221-223, who cited case-law of several courts in the US accepting measures of the exiled Netherlands, French and Norwegian Governments. The fact that all other Governments founding the United Nations in 1944 accepted the exile Governments of Belgium, Luxembourg and The Netherlands as felliow founding members implied recognition of their status as the legitimate representatives of their occupied States.
} 
Although the exile Governments were not in a position to enforce their measures on the occupied territory during the occupation, the question arose whether according to internationall law these exile measures were nevertheless valid on the occupied territory. Again, international lawyers were not in full agreement on this topic. Most agreed that because of the factual powers the occupant had acquired under international law the Governments-in-exile could not enact measures that would be valid on the occupied territory during the occupation. ${ }^{1243}$ This would mean that neither the occupant nor the population on the occupied territory would be bound by these measures. After World War Two, but dealing with that occupation, some international lawyers claimed that Governments-in-exile could validly enact measures for areas in which international law had not factually transferred sovereignty to the occupant. Even if the occupant, or the population, would not abide by that legislation during the occupation, it would be valid. When the occupation had ended this legislation might then be invoked retroactively. ${ }^{1244}$ On the other hand, the Governments-inexile could de jure avail themselves of all sovereign powers of their State, since the occupant only de facto exercised these powers over the occupied territory. The fact that the exile Governments were not in a position to enforce the measure taken on the basis of their powers did not mean international law did not recognize that these measures were legitimately taken. ${ }^{1245}$

Another aspect of international law affecting the exile Governments' powers was the doctrine of postliminium, which was a necessary corollary of article 43 Hague Convention. Military accupation was seen as only conferring a provisional interest, whereby the rights and duties of the occupant were recognized on the basis

124. Verraes, Tome I, p. 182 (in order not to put the population on the occupied territory in the difficult position of having to adhere to conflicting measures of the occupant and the Government-in-exile, the Government should accept a suspension of its powers); Beer Poortugael, p. 175 (the powers of the legitimate Government were suspended during an occupation); Rolin, Tome I, p. 428, 439 (the legal Government could enact measures for the unoccupied part of the country and its citizens atbroad. However, Rolin also argued that for the occupied part of the country the occupant, in order to protect public order and public life, allowed the legal government to enact new laws, as long as these did not encroach upon his military interests); Oppenheim, War, p. 208 e.a. (merely mentioned that the occupation prevented the legitimate Sovereign from exercising his powers, but did not comment on the validity of their measures enacted in exile on the occupied territory); Bordwell, p. 299 (mentioned that the authority of the legitimate Government during an occupation still continued. As long as it did not attempt to govern the territory, it could issue certain instructions that would be binding for its nationals on the occupied territory); Baker/MoKernan, p. 650 (the measures of the exile Govermment could not be valid on the occupied territory).

Glalln, p. 776; David, p. 455-456; Benvenisti, p. 17-18, footnotes 47-49. See also Benvenisti, p. 193-194, footnotes 10, 11 and 13 concerning the Belgian courts during and after the ocotpation of World War One. During the occupation of WW I Belgian courts clamed the decrees of the exiled Government could not be applied on the occupied territory. Since these decrees had not been published on the occupied territory the courts created a rebuttable presumption against then being sufficiently known. After the occupation of WW I all decrees enacted during exile were held to be retroactively applicable on the whole territory of Belgium. In Luxembourg this problem had not occurred during the occupation of World War One, since the whole territory had been occupied and the Grand-Duchess and Government had remained in Luxembourg. See also Kerchove, p. 70. 
of military necessity. ${ }^{1246}$ Postliminm in international law dealt with the legal effects of such measures after the occupation ended and prescribed that territory, individuals and property, after enemy occupation, should return during or after the war to their original Sovereign. More specifically, the international law aspects of postlimminm were revival of the former condition of things, validity of legitimate acts and invalidity of illegitimate acts. ${ }^{124 "}$ Postliminum did not arise in cases where the occupation was ended by means of a peace treaty whereby the occupied territory was ceded to the occupant. ${ }^{1248}$

The question whether occupation measures were valid until the end of the occupation or beyond was necessarily tied up with the validity awarded to these measures. If the supposition was that the occupation measures only had a de facto military force and not a legal one, their effect would cease to exist once the reason for their effect ceased to exist, notably at the time of the end of the occupation. Even if the occtpant's measures were given legal effect on the basis of the Hague Convention, they ceased to have any force at the time when the occupation ended. This meant, according to a majority of legal scholars, that the Sovereign into whose possession the teritory reverted after occupation had to recognize all acts legitimately taken during the occupation, though only for the duration of the occupation. ${ }^{1249}$

Political acts, as well as the execution of criminal sentences under legislation foreign to the domestic laws of the occupied State would be null and void once the occupation ended. ${ }^{1250}$ Also, any changes during the occupation to the constitution, laws or administration of the occupied territory would cease to be in force after the territory had been liberated. Measures the occupant took during the occupation contrary to the international law of occupation should according to the doctrine of postliminium be regarded invalid ex tunc or from the moment they had been enacted. $^{1251}$

Judicial acts done under his control, except for those of a political nature, as well as administrative acts for the period he was in control and various acts of private persons under domestic law remained valid. Moreover, if the occupant's measures were accepted as compulsory for reasons of social usefulness and consequently the legitimate authority accepted them via tacit or express ratification, these occupation measures did not necessarily lose their validity once the occupation had ended. ${ }^{25.2}$ The legitimate Government, after re-possessing the exercise of sovereignty over the occupied territory could opt, for practical or expedient reasons, to prolong the effects of accupation measures. ${ }^{1253}$

Although the histories of the Governments-in-exile would differ, customary international law prescribed some rules concerning their law-making powers, especially as regards their dealings with occupation measures. These international mules were binding upon exile Governments, but after the occupation their courts might 
have to detemine whether these customary intemational law rules would be applicable in the domestic legal order. However, during the exille period, the Governments of Belgum, Luxembourg and The Netherlands, once they had constituted themselves as exile Governments, would furthermore need to determine whether and if so which basis in their national laws they had at their disposal to enact exile measures.

\subsection{THE BELGIAN GOVERNMENT IN AND RETURNING FROM EXILE}

\subsubsection{Brief history of the Belgian Government-in-exile}

After the invasion the Belgian Government fled first to Ostende in Belgium and on 1.7 May 1940, on the advice of the French Government, to Le Havre. ${ }^{1254}$ Failing to convince the King to accompany them and continue the war from abroad, Belgium's Government arrived in Paris a few days later. ${ }^{1255}$ Minister Delfosse was absent due to the fact that the rapid German advance had frustrated his departure for France. ${ }^{1256}$

On 31 May, several Ministers of the Government were summoned to an unofficial meeting of the Belgian Parliament in Limoges, France. ${ }^{1257}$ of a total of 369 members of both Houses of Parliament, 143 were present. All members of Parliament, except for 2 , approved of the Government's actions so far, ${ }^{1258}$ which therefore included the Government's decision to declare the King in an impossibility to reign on $28 \mathrm{May} .{ }^{1259}$ However, the quorum for Parliament's decision-making process of article 38 Belgian Constitution was not met, since no majority of either House of Parliament was present. ${ }^{1260}$ Under the extraordinary circumstances this was less of a deviation from the Constitution than not convening Parliament at all.

Exploring several options in order to deal with their exile situation, ${ }^{126}$ the Government unanimously decided to amongst others vest Minister De Vleeschauwer with all governmental powers. ${ }^{1262}$ As a precaution he was sent to London to contact the British Government. De Vleeschauwer met Churchill in London and at the latter's insistence some members of the Belgian Government prepared to settle in London. ${ }^{126.3}$ However, several Ministers who decided to stay in France offered their resignation to Prime Minister Pierlot. ${ }^{1264}$ Since only the King and not Pierlot could con-

\footnotetext{
125it Judices 0.6

125. Fayat, p. 2.

125, Velaers/Goethem, p. 525 ; Judices, p. 7 claimed Minister Delfosse was present at the meeting held in Paris on 28 May 1940. See also Chapter 1.2.1.

125\% Velaers/Goethem, p. 277.

125 Fayat, Annex A. Also according to Velmers/Goethem, p. 278-279 89 out of 202 members of the Chamber of Representatives and 54 out of 167 members of the Senate were present and not allhad accepted the invitation for the meeting: Conway, Collaboratie, p. 22; However, Meyer, p. 303 claimed about 100 members of the Chamber of Representatives and 70 of the Senate were present in Limoges.

125. See Chapter 1.2.1.

12w Velaers/Goethem, p. 277

ret Valaets/Goethem, p. 358-364.

120 Velaer/Goethem, p. 364-365

126. Valaces Goether, p. 361-364, 515-526,561.

1204 Fayat, Annex B; Velaers/Goethem, p. 606-607 specified 8 Ministers, namely d"Aspremont Lymden, De Schryver, Matagne, Vandenpoorten, Ballhazar. Denis, Janson and Soudan. See also Goethern, p. 427-436 for the fate of those Ministers in France.
} 
stitutionally accept a resignation from a Minister, Pierlot only provisionally accepted these resignations, until the King was in a position to receive them. These Ministers would not be allowed to resume their functions again. ${ }^{1265}$

Some Ministers of the Government apparently still tried to return to Belgium. and had several high officers intervene with the King, but failled in their attempts. 260 The Military administration had also issued a Regulation probibiting Ministers of the Pierlot Government entry into Belgium. ${ }^{1267}$ Being hindered by the Vichy Government and the Govermment of Spain, Prime Minister Pierlot and Minister of Foreign Affairs Spaak finally ended up in London on 22 October $1940 .^{1268}$ Here they met De Vleeschauwer and the Minister of Finance Gutt. On 31 October 1941 these four Ministers officially established the Belgian Government-in-exile. ${ }^{269}$

Although there were contacts between the exile Govermment and those members of the Govermment still in France, the relationship between these two camps within the Belgian Government deteriorated. ${ }^{1270}$ Only a limited number of the Ministers who had chose to remain in France were later on allowed to join the exile Government in London. ${ }^{1271}$ Gradually the number of Ministers in the Government-inexile increased, first to 5 and subsequently to $7 .^{1272}$ Minister Delfosse joined them on 2 October 1942 , after his escape from Belgium and was made Minister of Justice. From 6 April 1943 onwards two Ministers joined the Government in London; A. De Schryver ${ }^{1273}$ and A Balthazar. They were appointed respectively as Minister of the Interior $^{1274}$ and Minister of Public Transport.

Two other Ministers, one of whom had left the Government, also arrived in London in 1943 and were given certain diplomatic posts. ${ }^{1275}$ In exile the Government would therefore function first with four, then five and finally seven members, whereas before the war the Belgian Government was comprised of 14 Ministers plus the King. ${ }^{1276}$

\subsubsection{Administration in exile; legal basis}

Although under international law the Belgian Government had been recognized as the bearer of Belgian sovereignty, from the perspective of Belgian law this was not

\footnotetext{
t26.5 Ganshof wan der Meersch, Regering, p. 401-402.

i2ta Velaers/Goetherm, p. 515-516, Judices, p. 8.

12\%) See Chapter 2.2

into Verthoyen, p. 27; Huyse/Dhondt, p. 61

$126 \%$ Fayat Annex A.

127y Goethem, p. 12-13,19-21

ly? Ste also Goethem, p. 42.

1272 See Vetaers/Goethem, p. $627-653$ conceming contacts between the Ministers that had estalb lished the Government-in-exile in London and those that had remained in France. For the fate of those Mimisters that had remained in France see Velaers/Goethem, p. $653 \mathrm{ff}$.

1273 See also Goethern, p. 9, 13.

not Gothem, p. 426

$12 \%$ Fayat, Annex B.

1276 Fayat, Annex A. However, according to another source the Bellgian Government in 1940 consisted of 18 Ministers (see A.P. de Belgique, Chambre des representants, session ordinaire de $1939-1940$ en seances du 20 septembre 1944 au 8 novembre 1944 , introduction). Nevertheless, when in exile in France the Govemmeth signed decrees with 14 Ministers (see Mon. 18 et 30 mai 1940).
} 
that clear. The legal basis of the Government-in-exile's legislative powers could neither be the Statute on Delegation (1940) nor the Statute on the King"s special powers (1939). The Council of Ministers was neither a collegiate of magistrates nor one of public officials that was normally hierarchically subordinated to a superior authority. Together with the King they formed the executive and therefore the Statute on Delegation (1940) could not serve as a legal basis. Moreover, the 1940 Statute did not delegate legislative powers, but merely powers of administrative supervision. ${ }^{1277}$ The Statute on the King"s special powers (1939) could not be used, since it only delegated legislative powers to the King in case of special circumstances and not to the Council of Ministers, which was a mere organ of the executive. ${ }^{128}$ Also a combination of these two could, at least for the Council of Ministers, not serve as a legall basis to enact measures with force of law during exile. ${ }^{179}$

On 22 November 1940 , Paul-Henri Spaak, the Belgian foreign minister, made a statement in London concerning the powers of the Government-in-exile. ${ }^{1280}$ The Belgian Government-in-exile contended a legal basis could be found in the Beigian Constitution. The prevailing opinion was that, similar to the occupation of 1914-1918, but this time withont the King, the Belgian Government could exercise legislative powers, the essential legal manifestation of Belgian sovereignty . Similar to 19141918 these legislative measures were called legislative decrees. The Government referred to articles 26,79 and 82 Belgian Constitution and the impossibility of the Belgian Parliament to convene. ${ }^{128}$ Article 26 Belgian Constitution stated that the King, the Chamber of Representatives and the Senate would jointly exercise Belgium's legislative powers. According to article 79 Belgian Constitution the Council of Ministers could exercise the King's powers in case of his death. On the basis of article 82 Belgian Constitution the Council of Ministers thad already concluded that the King was unable to exercise his functions. ${ }^{1282}$ Based on the practice of the occupation of World War One, which the Cour de cassation had sanctioned after that war, the Government claimed that it was the only legislative organ not under occupation and could therefore exercise Belgium's legislative powers. ${ }^{1233}$ In the exile Government"s opinion only the Council of Ministers could assure the continuity of the Belgian State, ${ }^{284}$

Due to the fact that the King and Parliament could not participate in the legislative process, two types of decrees would be enacted without their involvement. The Council of Ministers enacted Royal decrees without the King's participation and Legislative decrees without Parliament's involvement and the King's assent. ${ }^{1285}$ Therefore, as far as the Government was concerned, in conformity with article 79 Belgian Constitution the Council of Ministers exercised the constitutional powers of the King in the name of the Belgian people. All legislative decrees, those measures enacted without the co-operation of Parliament in times of emergency, and normally

See Chapter 2.9

See Chapter 2.9

Ockrent, p. 99-100.

Charles/Dasnoy, p. 26; Gotovitch/Gérard-Libois, p. 98-105

Ganshof van der Meersch, Regering, p. 394-395.

Arrêté-loi du 28 mai 1940, Moniteur des 18 et 30 mai 1940. See Chapter 1.2.1.

Wodon, p. 53 .

Velaers/Goethem, p. 276

Fayat, p. 2. 
with the signature of the King, would now be legislative decrees signed by the Ministers in Councill. ${ }^{1286}$

In his report to the Council of Ministers, which at the end of 1942 only consisted of 5 Minister's in total, Minister of Justice Delfosse outlined his reasons why the Government needed these legislative powers in exile. Exile measures were needed to update certain Belgian legal provisions, especially those dealing with the external security of the State. ${ }^{287}$ Delfosse argued that some of the texts lacked precision or severe enough punishment. This was due to the fact that the enemy employed new methods on the occupied territories to use all the resources of the country and to undermine internal resistance. Moreover, every act, without exception, which aided the enemy, was said to delay the deliverance of the country and directly harmed the heroic efforts of many compatriots. Certainly, when regarding the stake of the struggle and the courage of the population under occupation, the Government thought it would only be right that after the victory those aiding the enemy should not escape the pumishment warranted for treason due to imprecise or insufficient legal texts. ${ }^{28}$

\subsubsection{The Belgian Government returning from exile}

Belgilum was liberated in the fall of 1944, progressively from September onwards, although the Ardennes offensive delayed the complete deliverance of the country. King Leopold III had retreated with the Germans and at that point it was unknown he had been forcefully deported due to the occupant's installation of a Civil administration. ${ }^{289}$ On 11 September the Allies flew Pierlot and his Government over from exile to Belgium. Parliament was convened on 19 th September and the day after Prince Charles, in the absence of his brother King Leopold, was appointed Regent. new Government was formed, headed by Pierlot and including many members from the exile Government, but also including one member of the resistance. ${ }^{1291}$

Due to its impopularity this government fell in February 1945 and was replaced by a broad coalition government headed by the socialist Van Acker. ${ }^{292}$ "The Van

\footnotetext{
12: Fayat, p. 2; Ganshof van der Meersch, Regering, p. 393-394.

i2s. Arrété-loi du 17 décembre 1942 portant additions ou modifications áux articles 113,117 , 118 bis et 121 bis du Code penal, Mon. du 29 décembre. See also Fayat, p. 23-25; Dupréel, p. 149-152.

128: Arrêté-loi du 17 décembre 1942 portant additions ou modifications aux articles $113, \| 17$, 118 bis et 121 bis du Code penall, Mon. du 29 décembre; Huyse/Dhondt, p. 65.

1289 Donnison, p. 113; Huyse/Hoflack, p. 92, who stated that the King was deported to Germany on 7 June $\$ 944$. See also Jonghe, Vestiging, p. 107

$12 \%$ Duvieusart, p. 35; Huyse Hoflack, p. 92; Stephany.

129 Donisison, p. 117.

$12 \% 2$ See also Huyse/Dhondt, p. 61; Huyse/Hoflack, p. 221-224. The post-war Pierlot Government had amongst others Pierlot as Prime Minister and K. Verbaet as Minister of Justice. The Van Acker I Government succeeded it from. February 1945 until August 1945 with amongsi others Van Acker as Prime Minister and $\mathrm{Ch}$. du Bus de Warnaffe as Minister of Justice. From August 1945 until Jamuary 1946 the Van Acker II Government was in office with again Van Acker as Prime Minister and M. Grégoire as Minister of Justice. In March 1946 P.H. Spaak was Prime Minister of his first Government with $\mathrm{H}$. Rolin as Minister of Justice. Van Acker subsequently formed his third Government from March 1946-July 1946 with A. van Glabbeke as Minister of Justice. From August 1946 until March 1947 C. Huysmans was Prime Minister and A. Lilar Minister of Justice. P.H. Spaak's second Government was in office from March
} 
Acker Government would be the first Government to have to deal with the Question royale $e^{1293}$ when King Leopold was found in Salzburg at the beginning of May $1945^{1294}$

Immediately after the occupation when Parliament was convened on 19 September $1944,^{1245}$ it recognized the legitimacy of the Belgian exile Government ${ }^{1296}$ and arguably tacitly ratified the legislative powers the Government-in-exile had claimed to possess. However, no formal ratification of the Government's exile measures took place and therefore the exile measures could not claim to possess force of law on the basis of an express Act of Parliament.

\subsection{THE LUXEMBOURG GOVERNMENT IN AND RETURNING FROM EXILE}

\subsubsection{Brief history of the Luxembourg Government-in-exile}

After their flight from Luxembourg the Government, the Grand Duchess and her family reached Paris where they notified the Allied Governments of the invasion of Luxembourg. Since Luxembourg's neutrality had been guaranteed in subsequent treaties in 1839 and $1867,{ }^{1297}$ France, as guarantor of that independence, was requested to protect the Luxembourg population and restore its independence. A similar request was made to the Government of the United Kingdom. On 11 May the Luxembourg Government-in-exile and Court established themselves in Paris. ${ }^{1298}$

Days before the armistice between Nazi-Germany and France the French Government informed the Luxembourg Government of the desperate situation. Via Spain the exiled Government and Grand Ducal family ended up in Lisbon. ${ }^{2299}$ Here the request from the President of the Chamber of Deputies, Reuter, to return to Luxembourg had reached the Grand Duchess. ${ }^{13010}$ Prime Minister Dupong was apparently in favor and Minister Bech was more reticent. Minister of Justice Bodson was outright against, although meetings with a delegation from the Luxembourg Parliament were envisaged, which due to the circumstances of the war did not materialize. ${ }^{1301}$

1947 until June 1949 with initially P. Struye and from November 1948 H. Moreau de Melen as Minister of Justice. Until June 1950 G. Eyskens would be first Minister and A. Lilar Minister of Justice.

Only on 16 July 1951 the Quesrion royale would be solved with the abdication of the King in favor of his son. For more on the Question royale see e.g Duvieusart; Hoflack/Huyse, p. 96118 ; Velaers/Goethem, p. 970-996.

Donnison, p. 122; Duvieusart, p. 37; Hoflack/Huyse, p. 97.

1295 Fayat, p. 31. Although Parliament's term would have expired in 1943, the exile Government cnacted a legislative decree (Arrêté-loi du 1 \& mars 1943, Mon. 13 avril 1943), which, like diring the previous war, postponed the elections and extended the mandate of the members of both Houses of Parliament to a date to be picked by the Legislature itself (see Fayat, p. 2 , footnote 3 ).

1296 See A.P. Senat, S.O. $1939 / 1940$ et septembre/octobre/novembre 1944, séance des chambres réunies du mardi 19 septembre 1944, No. 62. See also Meyer, p. 299, 301, 303-304.

1207 See e.g Rolin, Tome III, p. 37-40; Verraes, Tome II, p. 31-39; Möller, p. 209, 219.

1294 Hagg, p. 5-10, p. 6; Heisbourg, p. 9; Government of Luxembourg, p. 42.

1299 Government of Luxembourg, p. $42-43$.

1360 See Chapter 1.3.1.

13 Cerf, Députes p. 504. 
From Portugal the Grand Ducal family, without the Grand Duchess, left for the United States on an American cruiser provided by President Roosevelt. The Minister of Foreign Affairs, Bech, was sent to London to establish contacts with the British Government. In August the Luxembourg Government and the Grand Duchess traveled to London to where they transferred the seat of the Luxembourg Government-inexile. Minister of Foreign Affairs Bech and Minister of Labor Krier would remain in London and represent Luxembourg's affairs in the United Kingdom. ${ }^{1302}$ In November Prime Minister Dupong and Minister of Justice Bodson were sent to the North American continent ${ }^{1303}$ in order to contact the Governments of the United States and Canada as well as Luxembourg's immigrant communities. Since the US had not entered the war against Nazi-Germany at that point, it was decided to establish Luxembourg's center of operations on that continent in Montreal. Also the fact that several Ministers did not speak English and furthermore preferred to send their children to catholic French-speaking schools facilitated the choice for Montreal. ${ }^{304}$ The Grand Duchess followed to North America shortly after and frequently visited the American Presiderit.

However, this meant that the Luxembourg Govermment-in-exile was spread out over two continents, which lead to a lack of co-operation and cohesion, especially to the detriment of the socialist Ministers. Prime Minister Dupong maintained that the disadvantages outweighed the advantages of having simultaneous presence at the US and UK seats of government. ${ }^{1305}$ Nevertheless, one of the main issues for the Luxembourg Government would be the maintenance of unity in government policy. ${ }^{1306}$

The Government-in-exile focused on several issues. Besides assuring Luxembourg"s independence in a post-war US dominated Europe, it tried to take care of the fate of its population and to prepare measures for the transition period between German rule and a return to a normal Luxembourg state of affairs after liberation.

\subsubsection{Administration in exile; legal basis}

The Luxembourg Government-in-exile used the powers contained in the Statutes of 28 September 1938 and 29 August 1939 concerning the extension of the powers of the executive. Before the war, the Government had obtained these powers from the Luxembourg Parliament. ${ }^{1307}$ One of the positions the Government took in justifying the claim that exile legislation would have force of law ${ }^{1308}$ was force majeure. Due to the enemy occupation of the territory the normal legislative procedure had become impossible. Linked to this the Government invoked the obligation to defend the exis-

\footnotetext{
1902 Haag, p. 7. Haag also reported a visit of the Grand Duchess to London before the seat of the Luxembourg Govemment was definitively established there.

1303 Heisbourg, p. 11; Government of Luxembourg, p. 44.

1304 Hage, p. 7.

19u: Heisbourg, p. 1 .

tho Koch-Kent, p. 276 ff.

1 Siv? See Chapter 1.3.1. See also Majerus, p. 9; Heisbourg, p. 3.

1\%s Compte Rendu des Séances de l'Assemble Consultative du Grand-Duché de Luxembourg, Session du 20 mars 1945 , p. 16.
} 
tence of the State and to assure its continuity ${ }^{1309}$ for the claim that its exile measures would have force of law.

Since Luxembourg courts under Luxembourg law were not allowed to exercise constitutional review of Acts of Parliament, the Government-in-exile could be certain that the delegation of powers from Parliament on the basis of the 1938 and 1939 Statutes would be upheld. According to article 48 Luxembourg Constitution, ${ }^{1310}$ the only authority to interpret the Constitution was Parliament. Moreover, article 237 Luxembourg Penal Code explicitly prohibited judges to exceed their authority by meddling into legislative and administrative matters. Judging on the validity of Acts of Parlianent, suspending their force or even deliberating whether these legislative acts should be executed was prohibited. ${ }^{1311}$ Administrative matters of the executive were beyond the discretion of the courts, whereby meddling into the competencies of the executive, making rules on administrative matters or failling to execute administrative orders was also prohibited. Violation of Article 237 LPC was punishable by imprisonment from one month to two years, a fine of 100 to 1000 francs and a suspension of the political rights of the judge or judges involved.

In order to facilitate the return of orderly administration under Luxembourg's legitimate Government, the Government-in-exile had enacted different types of legislation dealing with political, economic and financial affairs. Moreover, legislation was prepared dealing with issues like the purge of collaborators and institutional and material reconstruction. ${ }^{1312}$ The provisions in the Luxembourg Penal Code dealing with the external security of the state were modified. ${ }^{1313}$ The insufficiency of especially the penal provisions dealing with the external security of the state in the current situation was invoked as a grounds for amendment via Grand Ducall Decree. ${ }^{1314}$ Moreover, these adaptations to the penal provisions concerning external security of the state of 14 July 1943 were made retroactive to 10 May 1940 . In the Government's view this was indispensable. ${ }^{1,315}$

\subsubsection{The Luxembourg Government returning from exile}

The Germans retreated at the beginning of September 1944 and Luxembourg resistance groups tried to fill the power vacuum until the American troops entered the

\footnotetext{
190: Préambule arrêté grand-ducal du 7 juillet 1944 modifiant l'arrêté grand-ducal du 22 avril 1941 relatif aux mesures de dépossession effectuées par l'ennemi, Mém. 1944, p. 30; Préambulle arwaté grand-ducal du 14 juin 1944, modifiant l'organisation judiciaire afin de rendre possible, des la libération du territoire, la reprise de la justice, Mém. 1944, p. 34.

1311 Luxembourg Constitution of 17 October 1868 as modified by the Acts of Parliament of 15 May 1919. See also Loesch.

(nil Kayser, p. 29.

1.:12 See also Haag, p. 9.

1.31. Arrêté Grand Ducal du 14 juillet 1943 modifiant les dispositions du Code Pénal concernant les crimes et délits contre lia sûreté extérieure de l'État, Mém. du 18 septembre 1944, p. 24; Arrêté Grand Ducal du 25 mai 1944, Mém. 1944, p. 31.

134- Préambule Arrêté grand-ducal du 14 juillet 1943, modifiant les dispositions du Code pénal concernant les crimes et délits contre la sûretê extérieure de l"État, Mém. 1944, p. 24.

13:5 Préambule and Article 2 arrêté grand-ducal du 6 novembre 1944 modifiant et completant les arrêtés grand-ducaux des 14 juillet 1943 , concernant les crimes et délits contre la sûreté extérieure de l'État at 4 septembre 1944, relatif â la sécurité et à la protection des armées alliées sur le territoire du Grand-Duché, Mém. 1944, p. 100.
} 
country. ${ }^{1316}$ Luxembourg was liberated on 10 September 1944, when American troops entered the country. The Govermment retumed on 23 September and the Grand Duchess on 14 April 1945. The Grand Duchess's return was delayed due to the Gerw man Rundstedt counteroffensive of the Battle of the Bulge, whereby the Germans from 16 December 1944 onwards ${ }^{137}$ temporarily re-occupied the north of the country. ${ }^{1318}$ Not until 15 February 1945 the whole of the country would be liberated.

A Luxembourg military authority headed by Prince Felix and three Luxembourg officers initially took over the administration of the country. The Government had declared a state of emergency for the Luxembourg territory. ${ }^{1319}$ On 23 September the Government returned. from exile ${ }^{1320}$ and the day after returned to Luxembourg City to begin the re-establishment of the administration. ${ }^{1321}$

Parliament, which before the war had autliorized the Government to postpone elections, ${ }^{1322}$ was convened. The first public session of the Chamber of Deputies after the war was held on 6 December $19444^{1323}$ However, due to the fact there was no quorum, since only 25 of 55 of its members were present, ${ }^{1324}$ the session was closed after 3 minutes. ${ }^{1325}$ Not until 20 March 1945 Parliament would re-convene, and then only provisionally and as a consultative Parliament. ${ }^{1326}$ The first post-war elections for a new Chamber of Deputies were held on 21 October 1945, a year after the occupation had ended. On 27 February 1946 this newly elected Parliament ratified the measures the exile Government had taken, based upon the 1938 and 1939 Statutes and force majeure or state of necessity. ${ }^{1327}$

\footnotetext{
13i6 Proklamatio'n vun der Union vom 10. September 1944, Luxemburger Wort Nr. I vom 11. September 1944.

131 Majenus, Guerre, p. 75-76, 79.

1318 Raths, Grand-Duché, p. 283; Haag, p. 10; Conseil d'État, p. 232-239. However, the date given for the Grand Duchess's return from exile to Luxembourg in Conseil d'Etat is mid-February 1945 .

Mis Majerus, Guerre, p. 68-69.

11:20 Majerus, Guerre, p. $7 \mathbb{1}$.

1321 Donnison. p. 123.

1322 Loi du 28 septembre 1938, portant extension de la compétence du pouvoir exécutif, Mém. 1938, No. 65, p. 1099-1100.

133. Marx, p. 2.

132.4 Marx, p. 2 .

1325 Cerf, Députes, p. $498,505,506,508,510-521$. Of its members 5 had died during the war of natural causes and 4 due to war related causes. Another eleven deputies had been deported during the occupation and had not yet returned. Eight members of the Luxembourg Parliament were absent for reason of collaboration with the occupan, of which at least 2 were imprisoned.

132 Raths, Grand-Duché, p. 283. See allso Die 'Assemblèe Consultative' ... eine wichtige Etappe beim Wiederaufbau des Landes, in: Luxemburger Wort vom 21. März 1995, S. 4; Luxemburgs Parlament in der 2. Stunde Null, in: Letzebuerget Journal wom 17. Marz 1995, S, 4-5; Mark, p. 1-j4.

1327 Loi du 27 février 1946 concernant l'abrogation des lois de compétence de 1938 et 1939 et loctroi de nouveaux pouwoirs spéciaux au Gouvemment, Mém. 1946, No. 9, p. 119. See also Compte-rendu des séances de la Chambre des députés du Grand-Duché de Luxembourg. Session ordinaire de 1945-1946,9me séance du 18 décembre 1945, p. 197 et 13 me séance du 29 janvier 1946 , p. $329 \mathrm{ff}$.
} 


\subsection{THE NETHERLANDS GOVERNUENT IN AND RETURNING FROM EXILE}

\subsubsection{Brief history of the Netherlands Govermment-in-exile}

Atter the invasion of The Netherlands, the Queen as well as the Government had made it to London, where they would establish the seat of the Netherlands Government for the whole exile period. Initially, from the period of May 1940 until the autumn of that year, the Government was heavily divided on what course of action to take. However, after the defeat of France in the fall a common opinion formed that the Netherlands Government should align itself with the Allies until the surrender of Nazi-Germany. ${ }^{1328}$

Contrary to the unanimous opinion of his cabinet the Netherlands Prime Minister, de Geer, especially after the defeat of France, proposed to open negotiations with Nazi-Germany. De Geer failed to persuade his colleagues and the Queen dismissed him from office. From September 1940 until May 1944 Prof. Gerbrandy replaced De Geer as Prime Minister. In February 1941, contrary to Government orders and the wishes of the Queen, De Geer decided to return to the occupied Netherlands. ${ }^{1329}$ The Government-in-exile was therefore mostly associated with the Gerbrandy Government, which took all major decisions for The Netherlands concerning the immediate post-occupation era.

The modus operand that developed in London was not quite clear, since the Ministers were politically responsible for governmental policy and under the Constitution the Queen was inviolable. The Queen's inviolability meant she could not be held politically accountable for her actions. ${ }^{130}$ "Undeniably a shift in the Queen's constitutional position took place and her influence on cabinet decision-making during the exile perioc. undoubtedly and possibly inevitably increased ${ }^{1331}$ Especially in the beginning of the exile period, relations between the Ministers and with the Queen were not always uncomplicated. ${ }^{132}$ Several Ministers resigned from the exile Government and new ones would be appointed. The crises that plagued the exile Government would affect its standing abroad as well as in the occupied Netherlands. ${ }^{133}$

\subsubsection{Administration in exile; legal basis}

The Queen and the Government were the only organs of State in exile. Parliament was still on the occupied territory and therefore its role in the functioning of the exile administration was non-existent. Problematic for the Government was that it had never envisaged it would have to leave The Netherlands in case of war, since it expected a partial, but not a total occupation of the Netherlands territory in Europe. Therefore, no measures had been taken for the functioning of Government outside of The Netherlands. ${ }^{134}$

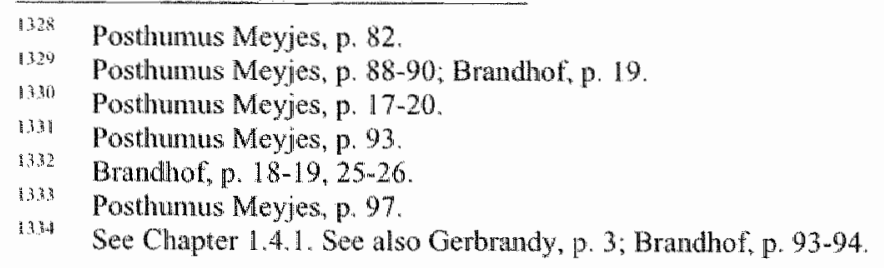


The War Act (1899) existed and had even been modified for the last time on 30 November $1939 .{ }^{1335}$ However, the Netherlands Government explicitly set this War Act (1899) aside with the London Emergency Decree D 60 concerning the Special State of Siege. The reason was, so the Government at that time and above all Prime Minister Gerbrandy, that against a totalitarian war and the totalitarian occupation measures, a just as totalitarian defense was necessary. ${ }^{1336}$

Therefore, during the exile period the Netherlands exile Government exercised several kinds of powers. According to the Constitution it possessed, in certain areas, the power to enact general administrative orders and Ministers could enact ministerial decrees. However, in order to enact measures with the force of law, Prime Minister Gerbrandy claimed that the Queen could exercise the legislative powers article 110 Netherlands Constitution attributed to the King and Parliament, if Parliament was unable to convene. This was called the doctrine of state emergency legislation. ${ }^{1.37}$ Out of about 704 Royal Decrees the Government enacted during exile, at least $460 \mathrm{can}$ be identified as based upon this doctrine. ${ }^{1.38}$

Under the powers the Government assumed during exile, it enacted measures aimed at the postwar period and the 'denazification' of the country. Different from Belgium and Luxembourg, the Netherlands Government created a completely new and separate purge jurisdiction, including new penall provisions. Distrustful of the ordinary courts it decided to establish special courts ${ }^{1339}$ to conduct a purge of collaborators, which would try cases on the basis of special, newly enacted, penal law. ${ }^{1340}$ This special court jurisdiction was competent for violations of Royal decree D 61 , dealing with extraordinary penal provisions. ${ }^{1341}$ These newly enacted penal provisions dealt with crimes against the external security of the State. For courts specific measures dealing with their 'denazification' would be enacted. ${ }^{1342}$

\subsubsection{The Netherlands Government returning from exile}

As part of the measures for after the liberation of The Netherlands, the Governmentin-exile created a Military Authority to prepare for the re-establishment of civilian rule. ${ }^{1343}$ The Military administration was also at the disposal of the Supreme Commander of the Allied forces, so the latter would not have to make use of the existing Netherlands administration, which was thought to be severely compromised during the occupation. ${ }^{1344}$ However, the Military Authority was unprepared for its task, mainly because of the fact that from the fall of 1944 until the spring of 1945 only the south of The Netherlands was liberated, while the north was still occupied and went

\footnotetext{
1335 Oorlogswet, Stb. 1899,128 . See also Chapter 1.4.1.

buth Dullenen, p. 8.

wr Brandhof, p. 90-91. See also Snijders and Pootjes on the Governmen's powers in exile.

$133 \%$ Brandhof, p. 99.

139 Koninklijk Besluit D 62 van 22 december 1943, houdende waststelling van het Besluit op de Bijzondere Gerechtshoven.

(34) Koninklijk. Besluit D 61 van 22 december 1943, houdende vaststelling van het Besluit Buitengewoon Strafrecht.

1341 See also Belinfante, p. 17-51.

1342 See Chapter 7.3.3.

1343 Militair Gezag, p. 91-98.

1344 Donnison, p. 129; Staatscommissie Bezettingsrecht, p. 105.
} 
through the Hunger Winter. The Military Authority's life span, as well as its tasks, was larger than initially foreseen. ${ }^{1345}$

During the occupation and also immediately afterwards there were periods during which certain Ministers questioned whether Parliament should re-appear in its pre-war form. ${ }^{1346}$ On the basis of state emergency legislation it was considered that Parliament's powers in the postwar era should be curtailed in favor of a stronger executive. However, there also was a counter-current, but only two Ministers, Alberda and Burger, ${ }^{1307}$ were in favor of reviving the prewar parliamentary system. Also the Extraordinary Advisory Council ${ }^{1348}$ and especially its catholic and social democrat members, but also journalists, and several Netherlands nationals independent of the Government supported Parliament's reinstatement. ${ }^{1349}$

After the occupation 34 members of the Upper House and 74 members of the Lower House were still available to be reconvened, excluding the NSB members. ${ }^{1350}$ However, the Government opted not to reconvene the prewar Parliament. It argued that the prewar Parliament was not representative anymore, since it was elected almost eight years ago, younger voters had not had the chance to express their choice and new political sentiments could have developed within the population during the occupation. Furthermore, the exile Government had promised the resistance a place in Wetherlands public life after the war. What the Government failed to see was that these arguments actually undermined its own legitimacy, ${ }^{1351}$ especially since it had been reconstituted several times during the exile period. ${ }^{\text {. }}$

Nevertheless, under the newly created Government after the occupation, headed by Prime Minister Schermerhorn, it was decided that the restoration of Parliament would occur in three phases. In the first phase there would be a temporary Parliament with limited powers. Its members were the pre-war members of the Netherlands Parliament as it was convened on 10 May 1940, as well as members legally appointed after that date. Excepted were those who also under normal circumstances would not have been able to attend and members that had been purged. ${ }^{153}$ This temporary Parliament would only have the power to vote on a law to install an interim Parliament with normal parliamentary powers, which would remain in session until the first free elections for a new Parliament could be held. The mandate of this temporary Parliament would expire on 15 August $1945 .{ }^{1354}$ Not until 26 October 1945 this legislation was enacted creating the interim Parliament. ${ }^{1355}$ The interim Parliament was opened on 20 November 1945, more than a year after the liberation of the south of the country and more than half a year after the occupation had ended for the whole of The

\footnotetext{
13.5 Militair Gezag. p. 91-98.

1.4h Bellinfante, p. 34 .

19. See also Welderen, p. 14-15.

134 The Extraordinary Advisory Council in London was a replacement for the Council of State, which had remained on the occupied territory (see Belinfante, p. 18).

1.44 Welderen, p. 6-7

1., Welderen, p. 8.

thst Welderen, p. 9; Posthumus Meyjes, p. 101-102, 104-116.

13.52 Brandhof, p. $94-95$.

1233 Welderen, p. 53.

1.5. Koninlijk. Besluit houdende vaststelling van het Besluit betreffende de Tijdelijke StatenGeneraal van 2 augustus 1945, Stb. 1944/1946, F 131.

135. Wet houdende regelen omtrent de voorlopige Staten-General van 26 oktober 1945, Stb. 1944/1946, F 241 .
} 
Netherlands. ${ }^{1356}$ Members of this Parliament, also called the emergency Parliament, were all member of the temporary Parliament if they so desired. New members would be appointed to fill up the vacancies, mainly appointed by the Upper and Lower Houses of Parliament. ${ }^{1357}$

In January 1946 the Lower House of the Netherlands Parliament debated the validity of the Government's exile measures. ${ }^{1358}$ Minister of Justice Kolfschoten represented the Government's opinion that these were all based upon unwritten constitutional law and gave the executive unlimited emergency powers. ${ }^{1359}$ Kolfschoten argued that the factual situation had created the state of emergency and that this state of emergency on the one hand set aside normal laws and on the other hand forced irregular laws into existence. ${ }^{1360}$ Since these exile measures had been validly enacted, they could not lose their validity after the state of emergency had ended. This was based on a general principle of Netherlands constitutional law that validly enacted measures did not loose their validity except when repealed by posterior validly enacted measures. The Minister of Justice was therefore of the opinion that legalization by Parliament was unnecessary. ${ }^{1361}$ Although these London Decrees were enacted outside of the framework of the Constitution, the Government nevertheless invoked. the Constitution to assure the continuation of their validity. The Minister of Justice also maintained that Parliamentary ratification and possible amendments would hamper progress in other urgent matters ${ }^{1362}$ and the Prime Minister feared the purge jurisdiction would suspend its activities until there was certainty about the applicable law. ${ }^{1363}$

The newly constituted interim Parliament debated the powers of the exile Government, also since several of its members wanted Parliament to ratify the Government's emergency measures and some wanted to prevent the courts from exercising judicial review. Although under article 124(2) Netherlands Constitution the courts were not allowed to review Acts of Parliament for compliance with the Constitution, the London Royal decrees could not be seen as such. ${ }^{1364}$ However, the Lower House of Parliament rejected two motions some of its members had introduced to ratify the

1358 The Extraordinary Adwisory Council had issued a recommendation on exile legisisation to the London Government. This recommendation of 23 April 1943 advised the Government about the procedure to follow as regards exile legislation upon return in The Netherlands. The Council's opinion was that Parliament would have to ratify part of the exile decrees upon return of the Government. The exile decrees the Council recommended for ratification included those, which created new penal provisions. Minister of Justice van Angeren vented his fury over this recommendation during the meeting of the Council of Ministers on 11 Jume 1943. In his opinion certain elements were attempting to undermine the prestige of the Government, which led to an unproductive and undesirable way of working. Three nonths later on 5 September 1943 in a report to the Queen the Government announced it would ignore the Extraordinary Advisory Councill's recommendation (see Belinfante, p. 19). HTK 10 januari 1946, p. 217-220. See also Dullemen, p. 13, 16 and 18. Snijders, p. $9-20$. HTK 10 januari 1946 , p. 217-220. See also Welderen, p. 113-115.

HTK 10 januari 1946 , p. $219-220$

13:9 The purge jurisdiction applied special criminal law enacted via Royal Decree. See HTK 11 januari 1946, p. 238

Welderen, p. 111,119
} 
London Decrees, ${ }^{365}$ indicating that the Lower House of Parliament considered ratification unnecessary and possibly implying that the exile measures had force of law. The newly elected Parliament did not address the issue of ratification again.

\subsection{CONCLUSION; RETURN OF THE GOVERNMENTS FROM EXILE AND THE POSITION OF THE COURTS}

What did this mean for the 'denazification' of the courts in Belgium, Luxembourg and The Netherlands? On the basis of international law there was no difference in the status of the exile Governments of Belgium, Luxembourg and The Netherlands. The limits under customary international law conceming the powers of exile Governments as regards the validity of their measures during occupation on the occupied territory and the validity of occupation measures during and after the occupation also spelt no differences of course. Courts would have to determine the applicability of this customary international law within the national legal order.

There were of course also differences in the legal bases of the exille Governments' powers according to their respective national laws. In Belgium, Luxembourg and The Netherlands courts would nevertheless have to decide on the validity of these measures in the postwar period.

Both the Belgian and the Netherlands Governments were in uncharted territory as regards the exille Governments" legislative powers. Belgium did have a precedent in World War One, but due to the absence of the King in exile the Belgian courts would have to decide whether the exile measures of World War Two would pass constitutional muster. For The Netherlands the situation was completely novel. Having no previous experience with occupation during World War One and failing to make adequate preparations for the functioning of the country during occupation and the Government whille in exile, the Netherlands courts would also have to decide on the constitutionality of these exile measures. Both the Belgian and the Netherlands Parliaments had not ratified their Government's exile measures. In Bielgium, Parliament's recognition of the legitimacy could be construed as indicating its approval of the exile measures. The fact that the Netherlands interim Parlianent voted down two resolutions to ratify the Netherlands Government's exile measures and the newly elected Parliament's omission to deal with the issue might also have indicated an approval of the exile measures. However, absent a formal parliamentary recognition, in both Belgium and The Netherlands the legal basis and the status of the measures their exile Governments had enacted would pose legal questions after the war.

The situation for Luxembourg was rather different. Already in 1938 and 1939 the Government had requested and acquired from Parliament additional powers that could be used during wartime and in case of occupation. Moreover, after the occupation had ended Parliannent had explicitly ratified the Government's exile powers. Therefore, the legal basis for exile measures would not be much of an issue in Luxembourg.

All three exile Governments anacted provisions dealing with the external security of the State, which might be applied to the courts as well in the postwar period. The Belgian and Luxembourg exile Governments were careful to depict their meas- 
ures as modifying or interpreting existing provisions. The Netherlands exile Government enacted completely novel provisions, also specifically for the courts. In any case, the Belgian and Luxembourg courts would be confronted with the question whether these provisions were merely interpretative or new. If the Belgian courts would consider these provisions as newly created law then, like the Netherlands courts, they would have to deal with the question of their retroactivity. Due to Parliament's ratification of all exile measures, also the question of retroactivity would differ in Luxembourg as compared to Belgium and The Netherlands.

Therefore, barring differences in measures specifically dealing with the "denazification' of courts, which will be discussed in Chapter 7, the question of validity would be common to Belgium and The Netherlands, but not Luxembourg. However, the courts in all three countries would have to decide on the applicability of customary international law within their jurisdiction limiting the powwers of exile Governments. Furthermore, the one question concerning retroactivity of their Governments' exile measures might be common to the courts of Belgium and The Netherlands, though Luxembourg courts would also in this case be in a different situation. 



\section{CHAPTER 7}

\section{'DENAZIFICATION' OF BELGIAN, LUXEMBOURG AND NETHERLANDS COURTS}

\subsection{BELGIUM}

\subsubsection{Belgian courts and judicial review of exile measures?}

In order to determine whether 'denazification' measures would apply, the Belgian courts first had to assess whether the exile Government was competent to enact legislative measures at all. On 6 November 1944, barely two months after the Belgian Government had returned from exile, the Cour de cassation was first confronted with a case involving exile measures. ${ }^{1366}$ One of the parties in a pending case sought to have a legislative decree nullified on several grounds, whereby it did not necessarily attack the exile Government's legal basis directly.

One of the parties requested annulment of the exile measure involved, since due to the fact that Belgium had been completely occupied, no organ of the State when having exited the country and gone abroad could have exercised any legislative powers. The Court did not think this was founded in either national or public international law. Rather, an enemy occupation of the territory left the sovereignty of the State intact. Under article 43 Hague Convention this was of course the case, since the occupant only factually exercised the sovereignty of the occupied country. As the Court stated correctly, no provision in Belgium"s Constitution or other legislation prescribed that Belgium's legislative powers should be exercised on the territory of the Kingdom.

Another ground put forward was that Prime Minister Pierlot, together with Ministers Spaak, Gutt and Delfosse had enacted the decree, but not the Council of Ministers, meaning all of the Ministers in the Government the King had appointed. Only the Council of Ministers in its entirety could enact measures having binding force. Interestingly enough the party involved did not claim the measures of the Council of Ministers would have force of law or force de loi, but rather binding force or force obligatoire. Although this was basically a challenge dealing with the minimum number of Ministers present in the Council of Ministers to make a binding decision, the Court did not directly deal with this challenge. Instead it stated that in principle, without a doubt, all of the King's Ministers assembled in Council had to exercise the powers in articles 79 and 82 Belgian Constitution.

Therefore, almost in a passing reference, without any legal argumentation, the Court recognized the exile Government's claim to Belgium's legislative powers. The Court's actual reply to the quorum challenge instead dealt with the force of law argument. It argued that the fact that certain Ministers were prevented to join their colleagues did not hinder the exercise of sovereignty, since this sovereignty could not be suspended. ${ }^{136 ?}$ 
Moreover, in sidestepping the quorum challenge, the Cour de cassation essentially allowed for a Council with as few as 4 out of 14 Ministers to exercise Belgian sovereignty. In following this reasoning as few as 2 Ministers could be said to constitute the Council of Ministers and would be able to exercise Belgium's legislative powers. However, although the Constitution recognized a Council of Ministers in its article 79 , it did not prescribe woting rules for the Council of Ministers. ${ }^{1368}$

Linked to this argument one of the parties contended that the decree should at least have stated the reasons why the Council of Ministers had been reduced to only four Ministers. This was essentially a form requirement. The Court remarked that the decree invoked articles 26 and 82 Belgian Constitution and that the Ministers that signed the decree had declared to be acting in Council. According to the Court this sufficed, since it meant that only these Ministers had the opportunity to enact the measure. Furthermore, there was no legal provision obliging a motivation concerning why certain Ministers were unable to take part in deliberations or decisions of the Council of Ministers.

One week later, on 13 November 1944 the Cour de cassation had to deal with another challenge to the Government's legislative decrees. ${ }^{1369}$ The Court again used few words to accept the validity of the exile measures. It stated that due to the fact that Parliament could not convene, the Ministers in Council could exercise, via logical application of articles 79 and 82 Belgian Constitution, the constitutional powers of the King. This included the King"s legislative powers to enact provisions required for the defense of the territory and the vital interests of the nation. In a case about two months later the Court stated that the fact that the King was in an impossibility to reign due to being a prisoner of war and Parliament could only be convened after the war had ended to confirm this impossibility, meant that for the defense of the territory and the vital interests of the nation the Council of Ministers could enact measures with the force of law. 170

In several major decisions at the end of 1944 shortly after the return of the exile Government, the Cour de cassation made it clear with very few words that it would uphold the exile measures and considered them to have force of law. Also lower courts at the beginning of 1945 did not challenge the legal powers the Government had claimed in exile. What was paramount in the Court's reasoning was that the defense of the Belgian territory and the life of the nation necessitated that Belgium's sovereignty and its concomitant legislative powers were continued during the war. ${ }^{132}$ This was in stark contrast to the Court's attempts during the occupation to review the measures of the Secretaries General, which also did not possess legislative powers under the Belgian Constitution. However, the Council of Ministers' continuation of these legislative powers was at least in violation of the Belgian Constitution.

Although article 79 Belgian Constitution allowed for the Council of Ministers, in the name of the Belgian people, to exercise the King"s powers this was only in

\footnotetext{
136

See ang Chapter II, Section II Belgian Constitution concerning the Ministers.

Cass. (2e Ch) 13 novembre 1944; Pas, 1945, 1, 33. See also IdT 1944-1945, p. 87-88.

See Cass. (2e Ch.) 11 décembre 1944; Pas., 1945, I., 65.

wh See e.g. Cour d"appel de Bruxelles 13 avril 1945; Pas., 1945, 11, 24; Cour d"appel de Liège 19 novenubre 1945; Pas., 1945, II, 43; Tribunal correctionnel de Liège 30 avril 1945; Pas., 1945, III, 74: Tribunal civil de Huy 13 juillet 1945; Pas, 1945, 1II, 88; Tribunal civil de Bnuxelles 5 juillet 1945; Pas., 1945, III, 94.

1.772 See also Ganshof van der Meersch, Regering, p. 394.
} 
case of the King's death. Furthermore, this was the only article in the Constitution allowing the Council of Ministers a temporary exercise of the King's powers and was therefore a minor exception. The incapacity of the King was seen as the main reason why the Government could enact legislative decrees without his assent. This in spite of the fact that the legislative history of that article showed that the article s intent was to be able to replace the King in case of him being affected by a mental illness. ${ }^{1373}$ However, besides deviating from its legislative history, the declaration of the King"s incapacity on the basis of Article 82 Belgian Constitution was not completely in line with the legislative intent of the article, ${ }^{1324}$ although its very broad interpretation would soon be accepted in postwar Belgium. ${ }^{175}$ The Government could not declare the King incapable by itself, but had the obligation, if it thought the King incapable, to convene Parliament within ten days. Although Parliament was unofficially convened in Limoges two days after the King had been declared in am impossibility to reign, Parliament's quonum could not be met. Neverthelless, the fact that this was not in conformity with Belgian law was thought justified on the basis of impossibility due to the circumstances. 1376

More importantly, neither the Cour de cassation nor the parties argued that the Councill of Ministers was a mere executive organ incapable of receiving a delegation of legislative powers. Article 26 specifically stated that only both Houses of Parliam ment and the Kings as jointly exercising Belgium's legislative powers. The fact that Belgium's national sovereignty could not be suspended probably warranted a departure from previous constitutional doctrine in order to allow the Council of Ministers to exercise Belgium's legislative powers. However, since legislative powers, due to their nature, could not be delegated ${ }^{1377}$ the Council of Ministers could not exercise these powers. ${ }^{1378}$ This in spite of the fact that the King had appointed every Minister, who had also been subject to a vote of confidence of Parliament. Such an extra-legal, political argument could not lend force to a claim that the Council of Ministers was anything more than an executive organ not allowed to legitimately exercise the comntry"s legislative powers. 1379

Although Parliament after the war recognized the exile Government as BeIgium's legitimate Government, it did not explicitly ratify the exile measures. ${ }^{1380}$ It is

w:3 Ganshof van der Meersch, Regering, p. 394.

1374 Velaers/Goethem, p. 275.

Bos Velaers/Goethem, p. 276-277.

1376 Arrêtés-loi Londres, p. 5. Immediately after the return of the exile Government in Belgium Parliament was convened to deal with this issue and Prince Charles was appointed Regent.

See supra.

137 Wodon, p. 47, 49-51. Wodon argued that the principle is not absolute. As a general principle he deemed this correct, but Wodon contended this did not exclude specific delegations for rather attributions as argued in Chapter 2.9) via 'lois particulières'. However, these specific delegations were always to the King. Moreover, in this case a general delegation of legislative powers was envisaged and not a specific one. See also D.P. Chambre, S.O. 1944/1945, 21 mars 1945, No. 74, p. 17.

$13 \% 8$ See Chapter 2.9.

1379 See Ockrent, p. 98-110, who asserted that this argument did lend force to that clam. For the claim that the Council of Ministers was a mere executive organ see Chapter 2.9 and Wodon, p. 62 .

i3 3 See Chapter 6.2.3. 
questionable whether implicitly Partiament gave these measures force of law. In any case the Cour de cassation did not use such an argument.

Therefore, although contrary to constitutional provisions and the legislative intent of one of them, the Belgian courts recognized the legal basis of the exile measures that would also be used for the "denazification' of the courts and treated them as if possessing force of law.

Next to having to deal with the legal basis of the exile measures, the courts would also rule on other aspects challenging the validity of exile measures. In the first reported post-occupation case ${ }^{1381}$ parties had also challenged the fact that the legislative decree did not fulfill the publication requirements and could therefore not be applied to facts arising before the liberation. ${ }^{1382}$ Since the legislative decree in question had been enacted in London on 17 December 1942, but had not been published in Belgium until after the occupation, it could not be known on the occupied. territory and was therefore not binding. This in spite of the fact that departments of the services of the Belgian Official Journal had followed the Government into exile and had set up a press to publish all governmental decrees and decisions. ${ }^{1,383}$

The Cour de cassation, however, argued that since the measures had been published in Belgium "s Official Journal in London on 28 and 29 December 1942, the publication requirement was satisfied. This was partly in line with the Court's postWW I case law, in which it had ruled that effective publication was not an essential element of publication of laws anymore. ${ }^{1384}$ The reasoning had been that publication in the Belgian Official Journal was not to inform the public of newly enacted legislation, but only to lend it authenticity, which sufficed in that from that moment on the newly enacted legislation was presumed known. ${ }^{385}$ However, there was a statutory obligation to delay the entering into force of a new measure at a minimum of 10 days after its publication. ${ }^{1386}$ What purpose would this 10-day delay serve if not to allow citizens to take the necessary measures to be able to comply with the newly published measure? ${ }^{1387}$ The case law after World War One was, moreover, an exception to the general rule and not a main rule. ${ }^{138}$ The Belgian Supreme Court in its postWorld War Two cases nevertheless took this exception and turned it into the main tule. ${ }^{1389}$

Therefore, although the Court's post-World War One case law was already a deviation from Belgian law, the extension of this case law after World War Two and

Cass. (2e Ch.) 6 novembre 1944, Poss., 1945, I, 23. See also JdT 1944-1945, p. 28.

See also Cass. 12 fevrier 1945, in: Dautricourt, Militaire, p. 257-258; Cass. 6 novembre 1944; Pas. 1945, 1, 23. See also Verzijt, p. 218-221.

Ganshof van der Meersch, Regering, p. 398.

1.s: Cass. 4 juin 1919; Pas. 1919, 1, 97; Cass. 11 décembre 1919; Pas., 1920, 1, 124; Cass. 9 décembre 1920; Pas., 1, 177; Cass. 25 janwier 1921; Pas., 1921, 1, 223.

1385 See also Cass. (2e Ch.) II décembre 1944; Pas, 1945, I, 65.

13\% See articles 3 and 4 Loi du 18 avril 1898 modifiée par la loi da 28 décembre 1909 , relative à l'emploi de la langue flamande dans les publications officielles, Mon. du 15 mai 1909.

1387 See also Page, p. 195. However, in case law the Cour de cassation had also determined that a royal decree (not a legislative act!) would not be null and void if not published within the month it was enacted, but this neglect would only trigger ministerial responsibility (see Cass. du 31 octobre 1921; Pas., 1922, I, 41). See also Rédaction JdT, effet rétroactif, p. 146-147. 
the widening of its scope meant that the Court allowed for the execution of these measures contrary to existing Belgian law.

One other question that remained was whether the penal provisions contained in the exile measures were "interpretative" or new penal prowisions and in the latter case could be seen as retroactively enforced. If these penal provisions were novel and would be given force retroactively, this was most probably contrary to customary international law ${ }^{1390}$ and certainly contrary to article 2 Belgian Penal Code. However, the Cour de cassation classified these penal provisions in exile measures as "interpretative'. 391

The exile decree modifying the articles of the Belgian Penal Code dealing with the external security of the State did add new categories of acts that could be beld punishable under these articles. ${ }^{1392}$ In such cases Belgian legislation obliged courts to conform to interpretative acts of Parliament in all cases where a point of law had not been definitively settled at the moment these laws had entered into force. ${ }^{1303}$ Since the Court had recognized the exile measures as being legislative measures and therefore at a par with Acts of Parliament, ${ }^{1394}$ Belgian law prohibited courts from challenging the exile Govermment's interpretative provisions. 1395

This was no different in case of at least one of these articles dealing with the external security of the State. An exile decree modifying Article 118 bis BPC concerning political collaboration might affect the 'denazification' of the courts. It deviated from certain interpretations pre-World War Two case law had already given to this article, where the burden of proof pertained to showing that the suspect had had an intention or real objective of aiding the enemy. ${ }^{13 \% 6}$ The decree modified this burden of proof by lowering the standard of proof to showing that the suspect knew or should have known his actions would cause risks for Belgium or his fellow citizens. ${ }^{1397}$ The Cour de cassation, dealing in appeal from the military purge courts with cases arising under article 118 bis BPC, unquestioningly adhered to the new standard of proof the exile decree set. ${ }^{1398}$

Moreover, in deviation of article 118 bis BPC the punishment was modified from "extraordinary detention" to "punishment by death", "1399 The increase of the sen-

$135 \%$ See Chapter 6.1 .

1394 Cass. (2e Ch.) 13 novembre 1944; Pas., 1945, 1, 33. See also JdT 1944-1945, p. 87-88. Cass. (2e Ch.) 18 décembre 1944; Pas, 1945, 1, 70; Cass. (2e Ch.) 5 feviner 1945; Pas., 1945. I, 107.

1392 Arrêté-loi du 17 décembre 1942 portant additions ou modifications aux articles 113,117 , 118 bis et 121 bis du Code penal, Mon. du 29 décembre. See also Fayat, p. 23-25; Dupreel, p. 149.152 .

$13 \% 3$ Aricle 28 Belgian Constitution and article $5 \mathrm{Loi}$ du 7 julltet 1865 , Mon. du 8 aotht.

1 yo4 See also Cass. (2e Ch.) 14 mai 1945; Pas., 1945, 1, 160 where the Coto de cassation ruled that the exile measures were legislative measures and therefore the courts could not exercise constitutional review.

1995 See also Cass., 23 juillet 1849; Pas, 1849, I, 443; Cass. 19 juillet 1921: Pas, 1921, 1, 445 et 456; Cass. 10 décembre 1928; Pas, $1929,1,36$

$13^{206}$ See e.g. Cass. (2e Ch.) 3 mars 1924; Pas., 1924, 1, 231; Cass. (2e Ch.) 10 février 1920; Pats., 1920,51 .

13,5 See also Huyse/Dhondt; p. 64. For the amendments see also Dupréel, p. 151 .

1328 Cass. (2e Ch.) 17 mai 1945; Pas., 1945, 1, 165 .

1359 Also for article 121 bis regarding denouncing anyone to the enemy the penalty was raised (see Arrête-loi du 17 décembre 1942 portant additions ou modifications aux articles 113,117 , 
tence in itself did not violate article $2 \mathrm{BPC}$, except where it might have been made retroactively. ${ }^{400}$ The modifications to the article were to take effect from the enactment of this exile measure onwards. ${ }^{\text {tol }}$ According to international law as it stood at the time of the occupation, measures of an exile Government could not claim any validity during the occupation on the occupied territory. ${ }^{1402}$ This was therefore at least contrany to international law, based on article 43 , but also intemational custom. However, Belgian courts could not refuse the application of a legislative act contrary to customary international law. ${ }^{1403}$ Since the Court had recognized exile measures as legislative acts, Belgian law did not allow the courts to use international law to determine a violation of the non-retroactivity principle. Since the exile measure modifying article $118 \mathrm{bis} \mathrm{BPC}$ did also not violate the mulla poena principle under Belgian law, law made it impossible to resist application of this exile measure dealing with the "denazification" of the courts.

Belgian jurisprudes after World War Two were newertheless unanimously of the opinion that the exile Government legally exercised Belgium's legislative powers on the basis of the higher principle that only the Government, under the extraordinary circumstances, embodied the continuity of the sovereignty of the nation. ${ }^{1404}$ The fact that at least part of Parliament could convene, like in Limoges, but subsequently chose not to was viewed as an implicit delegation of legislative powers to the Government. ${ }^{1405}$ Of course, already in Limoges Parliament could not meet its quorum and it was questionable whether it was actually possible for Parliament to convene in London where the Government claimed its powers in exile. However, on the basis of the Cour de cassation's unlimited acceptance of the exile measure's validity and the claim they possessed force of law, the exile measures would be applied.

\subsubsection{Measures abolishing occupation measures directed at the courts}

The Cour de cassation's unlinited acceptance also entailed the application of the measures regarding the "denazification" of the courts. In a legislative decree of 10 January 1941 the Government-in-exille had already decided that all measures the occupant had enacted would enter out of force the moment the Belgian territory was liberated. ${ }^{1406}$ This measure was analogous to a decree the Belgian Government had taken during World War One. All measures of Belgium's legitimate authorities were

118 bis et 121 bis du Code penal, Mon, du 29 décembre 1942). Moreover, a completely new article 123 sexies was inserted into Belgiumn's Penal Code, whereby violations of the security of the State might now result in loss of Belgian citizenship and several political and eivil rights for life (see Arrêtê-loi du 6 mai 1944, Mon. 2 septembre 1944).

See Wolf, Tribunal, p. 241 who claimed that the non-retroactivity principle was in any case not absolute.

1:01 Sée article 5 Arrêté-loi du 17 décembre 1942 portant additions ou modifications aux articles 113. 117, 118bis et 121bis du Code penal, Mon. du 29 décembre 1942. See also Huyse/Dhondt, p. 64; Dupréel, p. 151; Rédaction JolT, effet rétroactif, p. 146-147.

t.102 See Chapter 6.1 .

140: Article 107 Belgian Constitution and Cass. 26 novembre 1925, Pas. 1926, 1, 76.

\{tili Meyer, p. 299; Velaers/Goethem, p. 276-277. See also Velden on Belgian state emergency law.

1:40.5. Meyer, p. 304.

Itho Arrêté-loi da 10 janvier 1941, Mon. 25 février 1941. 
rendered compulsory from the moment of liberation onwards and had to be applied and executed by all administrative and judicial anthorities. ${ }^{140 \%}$

For the courts this meant that especially the regulations dealing with the linitation of the Belgian courts' competencies, ${ }^{1408}$ the suspended regulation prohibiting judicial review of decrees of the Secretaries General enacted on the basis of the Statute on Delegation (1940), ${ }^{1409}$ the regulations concerning forced labor deployment ${ }^{140}$ and the regulation concerning the application of the agglomeration decree ${ }^{14}$ would enter out of force. Since it was contrary to international law, the regulation concerning the removal from office of Belgian judges of Jewish Ancestry ${ }^{1412}$ would be retroactively null and void. The directive conceming nominations to judicial office ${ }^{14.3}$ would also enter out of force.

On 1 September 1944 the exjle Government enacted three legislative decrees, a decree of the Ministers acting in Council and 12 ministerial decrees dealing with measures the Secretaries General had enacted. ${ }^{1 / 4}$ The Government outright rejected the attribution of extensive legislative and regulatory powers to the Secretaries General, especially as regards the Statute on the King"s special powers (1939). ${ }^{415}$ One legislative decree ${ }^{14 / 6}$ annulled all measures of which the Government was of the opinion that they were enacted illegally in occupied Belgium, though some renained in force temporarily, as long as these measures were in conformity with the interpretation the Government had given to article 5 Statute on Delegation (1940) in its legislative decree of 1 May 1944. ${ }^{1417}$ According to the Government's interpretation the measures of the Secretaries General could not have force of law and the Secretaries General were not allowed to act as agents of the executive, but would only have been able to enact ministerial decrees. Those decrees and actions of the Secretaries General that fell outside of the scope of the exile Government's interpretation were for the most part retroactively declared null and void, though some would temporarily remain in force. ${ }^{148}$ The result was that by 1946 only about 100 of the flurry of decrees the Secretaries General had enacted would still be in force. These dealt mainly with aide to citizens as well as public organs for war damages incurred in 1940 , the restoration of the country and military pensions. ${ }^{1 / 19}$

\footnotetext{
1,463

See also Fayat, p. 22, 29 .

See Chapters 2.4 and 2.15.

1409 See Chapter 29.

睛U) See Chapter 2.10.

H41 See Chapter 2.11.

14:2 See Chapter 2.3.

140.3 See Chapter 2.5 .

94.

1413

Mon. I septembre 1944. See also Charles/Dasnoy, p. 29; Raskin, p. 330.

CEGES/SOMA, Papuers Vossen 1921-1952, MC 74, Mathieu, G., Ende sur la Delegation des Pouvoirs ent Temps de Guerre, p. 97

4t t6. Arrêté-loi du 5 mai 1944, Mon. 1 septembre 1944.

I4: Rapport au conseil Arrêté-loi da 1 mai 1944 interprétatif de l'article 5 do la loi du 10 mai 1940 relatif aux délégations de pouvoirs en temps de guerre, Mon. 1 septembre 1944.

1418 Arêtéloi du 5 mai 1944 interprétatif anx arrêtés pris et aux actes administratifs accomplis, durant l'occupation ennemie, par les secrêtaires gêneraux et par ceux qui on exercé leurs fonctions, Mon. 1 septembre 1944.

14: Actualite juridique, p. 111-112,223-224. See also Rédaction JdT, Sccrétaires; Rédaction JdT, Secretaires 11.
} 
The Secrataries General had hardly taken any decrees that altered the position or functioning of the courts. ${ }^{1420}$ However, the exile measures would also deal with the decisions of the Secretaries General of Justice concerning appointments of judges during the occupation, as will be discussed in the proceeding paragraph.

\subsubsection{Measures dealing with occupation personnel policy}

The exile Government was pleased with the functioning of the Belgian courts during the occupation of World War Two. ${ }^{1421}$ Nevertheless, in the area of personnel policy certain measures needed to be taken. On 29 January 1944 the Belgian Governmentin-exile outlined its policy concerning appointments the Secretaries General had made during the occupation. ${ }^{1422}$ As legally appointed Secretaries General in the light of the Statute on Delegation (1940) were seen those whom the Government had appointed before leaving the country. ${ }^{1423}$ The appointments these Secretaries General had made, if done within their powers under the Statute on Delegation (1940) as mentioned above, would therefore be seen as appointments legally made. However, the Government made it clear that those Secretaries General that were not regularly appointed during the occupation could not claim any powers emanating from the Minster of that Department. The Belgian Government-in-exile therefore anuulled all appointments of judges the Secretaries General of Justice had made during the occupation. ${ }^{1424} \mathrm{~A}$ Governmental decree regularizing appointments and promotions was stalled in the Council of Ministers for months. ${ }^{1425}$

Minister of Justice du Bus de Wamaffe commented in the Upper House of Parliament on the appointments made during the occupation. ${ }^{1426}$ Du Bus de Warnaffe had consulted numerous colleagues, members of the bars in Flanders and Wallonia, who were unanimously of the opinion that the majority of appointments made were good appointments with a regular margin of error and that these would have been made in normal times as well. ${ }^{1427}$ The Journal des Tribunaux, Belgium's foremost

\footnotetext{
1.426) See Chapter 2 .

1421 Rapport au conseil Arrêté-loi du 1 mai 1944 interprétatif de l'article 5 de la loi du 10 mai 1940 relatif aux délégations de pouvoirs en temps de guerre, Mon. 1 septembre 1944.

1.122 CEGES/SOMA, Archives Hayoit de Termicourt. MIC 48, no. 26, Ligne de conduite que le Gowvernement de Londres compte suive en matière de législation et de rẻglementation prise et des nominations ou désignations taites depuis l'occupation par les Secrétaires-généraux du 29 janvier 1944.

CEGES/SOMA, Papiers Vossen 1921-1952, MTC 74, Mathieu, G., Ende sur la Délégation des Powowrs en Temps de Guerre, p. 97.

142:4 Arrêté-loi du 5 mai 1944 interprétatif aux arrêtés pris et aux actes administratifs accomplis, durant l'oecupation ennemie, par les secrétaires généraux et par ceux qui ont exercé leurs fonctions, Mon. I septembre 1944: Arrêté-loi du 8 mai 1944 relatif aux fonctions publiques, Mon. I septembre 1944. See also Rijksarchief te Beveren, Rechtbank van Eerste Aanleg te Antwerpen A2000, no. 297 betreffende door bezetting uitgestelde benoemingen, Brief 24 September 1955 van de Voorzitter der Rechtbank te Antwerpen aan de Rechter C.J., no. 14373. Procès-verbal no. 23 des réunions du Consell des Ministres du 3 mai 1945.

1420 Protocols du Sénat du 11 février 1945.

142\% CEGES/SOMA, Papiers Schuind, Ménoire "Au ministère de la Justice pendant l'occupation allemande. L'action de M. Schuind, secrétaire-général.", MTC 51, p. 9-10.
} 
legal journal, shared this opinion. ${ }^{1428}$ Around 60 of these judges were even recruited to join the Military courts that were to conduct the purges in Belgium. ${ }^{1429}$

Parliament's Lower House heavily criticized the Government's policy in this area. The re-appointment of the occupation appointees was the subject of vehement debates in Parliament in February and March 1945. Especially the sociallist MPs thought their re-appointment inopportune, doubting the impartiality of especially those judges against whom the occupant had raised no objection. ${ }^{1430}$ Due to the shortage of judges a decision finally had to be made whether the judges appointed during the occupation were eligible for re-appointment. In the opinion of the Govermment almost two thirds of these judges were eligible and were in fact reappointed. 1311

The Belgian courts did not as such react to these measures, but due to the Cowr de cassation's acceptance of all exile measures could only acquiesce in the application of this 'denazification' measure. This was, however, in stark contrast to a ruling of the Brussels Cour d'appel and the conduct of the Cour de cassarion during the occupation. The Brussels appeals court had expressly endorsed irregular occupation appointments. When on 22 October 1942 the validity of decrees of Secretaries General Romsée, Leemans and Schuind, all appointed during the occupation, ${ }^{1432}$ had been challenged, the Brussels court had affirmed their validity. The fact that either a prewar appointed Secretary General had appointed these Secretaries General or a public official temporarily replacing a Secretary General who had voluntary resigned or was even forced out of office had been deemed enough to render their appointments valid. Leaving a department without a chef would have been contrary to the legislator's intent, so the Brussels appeals court, and the appointment of a new Secretary General could not have been done in any other way. The Brussels Cotr d'appel had concluded that a Secretary General appointed according to this procedure had been vested with the powers delegated to him via the Statute on Delegation $(1940))^{1433}$

The Cour de cassation in its consistent case law and Advocate General Hayoit de Termicourt in an opinion to the Court during the occupation had emphasized that only those Secretaries General who had remained in the country and in office could exercise the powers under the Statute on Delegation (1940). "However, at the same time the Court had not refused application of decrees these irregularly appointed Secretaries General had enacted on the ir own behalf or had co-operated in. The Cour de

1425 Les nominations des magistrats, in: لJdT 1944-1945, p. 25. See also Archives Auditorat Général, Cour militaire, Dossier Schuind, no. 572.B.47, Carton Overtuigingsstukken 333, Note complémentaire; Au Ministere de la Justice pendant l'occupation allemande; láction de $\mathrm{M}$. Schuind, Secrétaire général, p. 9.

1429 Archives Auditorat Général, Cour militaire, Dossier Schuind, no. 572. B.47, Carton Overtuigingsstukken 333. Note complémentaire; Au Ministère de la Jastice pendant l'oceupation allemande; I"action de M. Schuind, Secretaire général, p. 14.

Hist Huyse/Sabbe, p. 133; Huyse, Répression, p. 109 and p. 129 footnote 182.

143. Huyse/Hoflack, p. 133; Huyse/Sabbe, p. 133; Huyse, Répression, p. 109 and p. 129, footnote 182.

Mi. See Chapter 1.2 .3

4., Arrêt inédit du 22 octobre 1942, in: Ockrent, p. 44-46.

14.34 Cass. 7 avril 1941; Pas., 1941, 1, 136; Revue Administration, 1941, p. 315; Cass. 26 octobre 1941; Pas. 1941, 1, 382; Cass. 30 mars 1942; Pas, 1942, 1, 75. See also Ockrent, p. 44, footnote 1 ; Pacte, p. 121 . 
cassation had also accepted within the ranks of the ordinary courts the nominations these Secretaries General had made of judges who would now be removed from office.

On the other hand, both Secretary General Ernst de Bunswyck and his successor Schuind had made nominations and not appointments. They had clearly indicated the temporary nature of these nominations; ${ }^{1435}$ which of course had also been known to the courts. Therefore, the temporary nature of these occupation appointments meant that after the occupation there was no reason for the courts to resist the policy of the exile Government to remove these judges from office.

Removal from office for appointment during the occupation was one measure dealing with 'denazification' of the courts. The remaining prewar appointed judges who were in office during the occupation would also be investigated for and possibly subject to proceedings for collaboration with the enemy. Since there was not one special purge instituted against judges, the members of the ordinary courts would be subject to the same purge proceedings people in different sectors of society went through.

Moreover, there was not one, but rather 4 different kinds of purges instituted in Belgium. ${ }^{1366}$ The more important one in this context is the military purge jurisdiction. The ordinary courts' competence to try cases involving the external security of the State was transferred to the military courts. ${ }^{1437}$ The Government copied the wording of the Statute of 19 July $1934 .{ }^{1.438}$ The military justice system did not comprise of more than 47 persons after the occupation, ${ }^{1439}$ which meant the Government had to bring in waves of new judges, mainly from the ordinary courts, but also recently graduated law students. This led to staffing problems at the ordinary courts up until

1435 See Chapter 2.5 .

1430 Huyse/Dhondt, p. 23-60. There were proceedings before the War Councils and the Cours militaires. The War Councils were military tribunals entrusted with the task to try, in first instance, crimes conmitted against the external security of the State. The Conr militare was the military tribunal entrusted with the appeal of cases concerning crimes against the security of the state coming form the War Councils. The second kind of purge was the civic purge, which amongst others dealt with excluding collaborators from public life and the minor cases of military collaboration. The Auditeurs militaines or military prosecutors conducted these purges against which an appeall was possible to the ordinary courts. The third strand concerned the admunistrative purge, which was conducted against public officials and communal and provincial councilors working for the administration and accused of anti-patriotic behavior.

Finally, on the local level, the mayors and commissioners of police played a role in that they had the discretion to provide someone a certificate of good citizenship. This testified to the fact that the person in possession of such a certificate had not engaged in any unpatriotic actions against society. The certificate was required in numerous circumstances and not possessing it madie people societal invalids.

These different purge proceedings were not mutually exclusive. For more information on the purges see Conway, Justice Deák, p. 134. Pholien, Répression; Ganshof van der Meersch, RéAexions; Bekaert; Gilissen, Répression; Gilissen, Sécurité; Lenaerts; Struye; Tschoffen.

1438 See loi du 19 juillet 1934, Mon. du 27 juillet 1934. See also Vandenbossche/Prignon.

14:34 Lory, p. 12. 
the end of the $1940 \mathrm{~s}$, since many judges were still sitting at the military courts trying purge cases. ${ }^{1400}$

Proceedings would be held before the War Councils and the Cours militaires. The War Councils were military tribunals entrusted with the task to try, in first instance, crimes committed against the extemal security of the State. By 1946, 134 War Councils would be operating in the country ${ }^{144}$ each divided into different chambers composed of three military and three royally appointed civilian judges and a presiding civilian judge. The Cour militaime was the military tribunal entrusted with the appeal of cases concerning crimes against the security of the State coming from the War Councils. ${ }^{142}$ There were several chambers with three military and two civilian members and seats in Brussels, Gent, Antwerp and Liège, whereby a member of the Cour d"appel presided over the chamber. An exile measure suspended the right to appeal against verdicts of the War Councils to the ordinary courts, even if the War Council had ruled in last instance, but did reinstate recourse to the Cour de cassation for judgments the Coum militaire had rendered. ${ }^{443}$ At the end of January 1945, in a judgment where the transfer of competencies was attacked, the Cour de cassation merely noted and accepted the fact that recourse to the ordinary courts against verdicts of the War Councils had been excluded and not reinstated. ${ }^{144}$

The question was how this would affect the competencies of the ordinary courts concerning the trial of its own members for crimes committed against the extemal security of the State. Articles 479-503 Belgian Code of Criminal Procedure attributed competence to try these criminal acts a judge had committed in or outside of office to the ordinary courts. ${ }^{145}$ In May 1945 a judge of the Tongeren Tribunal disputed the military courts" competence to try his case. In cassation before the Cour de cassation he argued that the Belgian Code of Criminal Procedure only provided for the ordinary courts to try a Tribunal judge. For its decision the Cour de cassation referred to legislative intent and a similar decree from World War One. It concluded that to the exclusion of other jurisdictions, irrespective of who the accused was and no matter what the sentences imposed for those crimes, only the military courts were competent to try the cases concerning the external security of the State. ${ }^{146}$

Although the Cour de cassation unquestioningly accepted this limitation of the competencies of the ordinary courts, some judges appeared to look unfavorably on the purges. The President of the Liege Cour d'appel, Scheurette, as well as other judges opposed the purges, since they violated fundamental rights. Also the fact that some of the penal provisions used were considered retroactive and the military courts

\footnotetext{
1440 See Greffe Cour d’appel Liège, Registre des Assemblées générales du 10-11-1936 au 13-21958, Roulement pour l'année judiciaire 1947-1948, p. 110b and Roulement pour l'amée judiciaire 1948-1949, p. 1126.

14t Conway, Justice Dék, p. 134

4.42 Article 3 Loi du 19 juillet 1934 , Mon du 27 juilllet 1934

lant Cass. 22 janvier 1945 ; du 12 février 1945 ; Cass. 28 mai 1945, in: Dautricourt, Militaire, p. 250, 258-259, 265. See also Greffe Cour de cassation, Registre des Assentblées générales du. 15-9-1944-24-6m 1949, Audience publique et solennelle du 23 janvier 1945, p. 43 .

i.44 Cass. 22 janvier 1945, in: Dautricourt, Militare, p. 250-251. See also Cass. 28 niai 1945, in: Dautricourt, Militaire, p. 265.

It 4 See also Chapitre VII de la Loi du 20 avril 1810 sur l'organisation de l'ordre jucliciaire et l'administration de la justice.

1.446. Cass. 17 meil 1945, in: Dautricourt, Militaire, p. 261-265.
} 
had been given excessive powers solicited reactions from members of the ordinary courts. ${ }^{144}$ More lawyers expressed regrets that the ordinary courts had not been allowed to execute the purges. 1448

Besides this the Tribunaux, when dealing in appeal with cases the military prosecutors had decided upon, reversed more than 90 percent of these decisions. In about one quarter of those decisions the exclusion of civil rights was softened and more importantly in more than two thirds of the cases the decision was nullified. This meant that many of the politically inspired punishments of political collaborators were reversed. ${ }^{149}$ On the other hand more than 250 judges were transferred from the ordinary courts to the War Councils and the Cowrs militaire, making them almost three fourths of the total of these purge courts. Another 70 judges were transferred to the military prosecutor services, where their share totaled almost $\mathbb{5}$ percent. Therefore, at least 330 ordinary judges were directly involved in the purges, which amounted to almost 30 percent of the members of the ordinary courts. ${ }^{1450}$

After the war there were hardly any problems regarding the position of judicial officers appointed before the war. Only 29 of the prewar appointees were under investigation during the purges. Of these, only 5 were convicted, all for reasons of political collaboration in violation of article $118 \mathrm{bis} \mathrm{BPC}{ }^{145}$ Over $75 \%$ of prewar appointees were still in office in 1946 and the remaining $24 \%$ was most probably retained after having been appointed during the occupation. ${ }^{1452}$

\subsubsection{Concluding remarks on the Belgian courts and 'denazification' measures}

The Cour de cassation seemed eager to pronounce judgment on the validity of the exile measures. Although the Belgian Parliament had already been in session, it had not attempted to ratify the exille measures and it is doubtful whether it had implicitly recognized these measures had force of law. When the Cour de cassation dealt with the matter, it at least did not invoke this argument in assessing the exile measures' validity or legal status. Rather, contrary to its more positivist stance during the occupation it neither questioned the legal basis of the exile measures nor the exile Growernment's claim these measures had force of law. Besides the fact that the acceptance was unconditional, the Court also did not provide any kind of $\Downarrow$ egal argumentation about their validity. This in spite of the fact that constitutional provisions were used in a way contrary to their meaning and in one case the intent. Moreover, constitutional doctrine was violated in that the Court allowed for the Council of Ministers as organ of the executive to exercise legislative powers. An appeal to customary inter-

\footnotetext{
147. See Lory, p. 29.

14 s. See e.g. Polain; Huynen; Rédaction JdT I.

144 Huyse Hotlack, p. 142.

ifs Huyselfotlack, p. 143. The calculation of thirty percent is based on 1184 judges, including deputies, in the postwar period in office at the ordinary courts (see ANNEX 4).

145. Louveaux, p. 663 mentioned 652 judges, possibly excluding the deputies; Huyse/Hoflack, p. 132. The latter mentioned a different total amount of judges, namely 800 . NB in the province of Hainaut, of the 57 judges named in the 1943 Almanac of the Province of Hainaut, none were prosecuted after the occupation for collaboration (see Maerten, p. 138).

145. See ANNEX 4 and supra concerning the comments Minister du Bus de Wamaffe had made and the fact that two-thirds of the occupation appointees were re-appointed.
} 
mational law had not been made, but in earlher case law the Cour de cassation had already declared such an appeal inadmissible.

The unlimited acceptance of the exile Government"s claim to legislative powers would affect any challenges of the exille measures for violation of the principle of non-retroactivity of penal provisions as well as any other challenge, like publication requirements. The Court's unlimited acceptance of the exile measures also meant it had to accept a violation of Belgian law as regards the existing competencies of ordinary courts to try their members for acts committed outside of office or ex officio. Although the Cour de cassation would in final instance exercise its powers of cassation, its lower courts would be deprived of their powers in this area. Therefore, in violation of Belgian law the courts allowed for exile measures concerning the "denazification' of the courts to be executed.

\subsection{LUXEMBOURG}

\subsubsection{Luxembourg courts and judicial review of exile measures?}

In the first published judgments after the occupation had ended the Diekirch Tribunal, ${ }^{1453}$ the Luxembourg Tribunal ${ }^{1454}$ and in appeal ${ }^{1.55}$ or cassation ${ }^{145}$ the Cowr superrieure applied exile measures without question. At the beginning of 1947 the Luxembourg Tribunal considered that the Grand Ducal decrees enacted during the exile period had force of law. ${ }^{1457}$ No reason was given for this assertion. However, by that time Luxembourg's Parliament had ratified the exile Government's decrees in the beginning of 1946. ${ }^{1458}$ Nevertheless, the Luxembourg Tribunal and in cassation the Cour superrieure had applied exile measures without question before the Chamber of Deputies had ratified these measures.

In March 1948 the Cour superieure in appeal pronounced the first judgment specifically dealing with the validity of exile measures. ${ }^{1459}$ "The Court explicitly referred to Parliament's ratification of all exile measures ${ }^{1460}$ and argued that this lent these measures force of law. Article 95 Luxembourg Constitution therefore put all exile measures beyond the powers of the courts to exercise judicial review. In a

th53 See e.g. Tribunal d'arrondissement de Diekirch (civily du 24 juillet 1946, Pas. lux., Wome XIV, p. 250 .

list4 See e.g. Tribunal d'arrondissement de Luxembourg (civil) du 8 janvier 1946 , Pas. lux. Tome XIV, p. 232; (civil) du 26 juin 1946, Pas. Jux, Tome XIV, p. 234; (civil) du 31 juillel 1946. Pas. Iux, Tome XIV, p. 244.

1455 Cour Supérieure de Justice (appel civil) du 2 juillet 1947, Pas. lux, Tome XIV, p. 298.

1456 Cour Supérieure de Justice (cassation eriminelle) du 12 juillet 1945, Pas. lux., Tome XIV, p. 261 ; (cassation criminelle) du 4 juillet 1945, Pas, lux., Tome XIV, p. 26I; (cassation criminelle) du 21 novembre 1945, Pas. lux, Tome XIV, p. 263; (cassation criminelle) du 24 janvier 1946, Pas. lux., Tome XIV, p. 225; (cassation civile) du 17 mai 1949, Pas. lux., Tome XIV. p. 548.

1457 Tribunal d"arrondissement de Luxembourg (civil) du 5 mars 1947, Pas. Lux., Tome XIV, p. 289.

145\% See Loi du 27 février 1946 concernant l'abrogation des lois de compétence de 1938 et 1939 et l"octroi de nouveaux pouvoirs spéciaux au Gouvernment, Mém. 1946, No. 9, p. 119. See also Chapter 6.2.3.

1459 Cour Supérieure de Justice (appel correctionnel) du 6. mars 1948, Pas. lux., Tome XIV, p. 362.

See Chapter 6.2.3. 
judgment in cassation in July $1948^{1461}$ the Cour de cassation confirmed its ruling in appeal from March that same year.

In the postwar era the Cour superieure also dealt with the question of the retroactivity of the Grand Ducal decrees that contained penal provisions. In one case from $1949^{1462}$ the Count considered that the principle of non-retroactivity was not enshrined in any article of the Constitution, also not Article 14, since this provision only contained the principle of legality of penal provisions. Therefore, the Government could derogate from article 2 JPC via legislative decree in December 1944 and give articles 113-123 LPC as amended by Grand Ducal Decree retroactive effect from 10 May 1940 onwards. The Court stated that no Constitutional provision had been violated. The submission that the Grand Ducal decree giving retroactive effect was contrary to public intemational law was held inadmissible. Taking a positivist stance the Cour superieure stated it had been instituted to assure compliance with national legislation and therefore any principle not included in that legislation could not be invoked before it. Also, although the Court did not mention it in this judgment, the fact that it had recognized about a year before that all exile measures had force of law meant that courts could not review the legality of this exile measure containing retroactive penal provisions. Courts were not allowed to review acts of Parliament and therefore also not those acts Parliament had granted force of law. ${ }^{1463}$

Parliament's ratification of all exile measures based upon the 1938 and 1939 Statutes meant that these Grand-Ducal clecrees would all have force of law. In keeping with Luxembourg law and a positivist stance by denying application of customary international law, Luxembourg courts applied these exile measures without exercising judicial review.

\subsubsection{Measures abolishing occupation measures directed at the courts}

Different from Belgium, the Luxembourg exile Government could not suffice with a mere removal of occupation measures and appointees. Since the Luxembourg State and its organization had in effect been abolished during the occupation, "denazification' in Luxembourg simultaneously had to deal with the complete re-constitution of Luxembourg's organs of State, including the courts.

Alreadly via Grand Ducal decree of 22 April 1941 occupation legislation had been declared null and woid from the moment of liberation of the occupied territory. ${ }^{1464}$ The Luxembourg Government-in-exile was of the opinion that numerous measures the occupant had enacted were flagrant violations of the latter's factual powers under international law. The compulsory "germanisation" of given and family

Ind Cour Superieure de Justice (cassation criminelle) du 29 juillet 1948 , Pas. lux., Tome XIV, p. 422 .

14:2 Cour Supérieure de Justice (cassation criminelle) du 1. Décembre 1949, Pas. lux., Tome XTV, p. 596.

tan 63 See Chapter 6.3,2.

14tcu Arrêté grand-ölucal du 22 avril 1941 , déterminant l'effet des mesures prises par l'occupant, Mém. 1944, p. 21. This decree was modifned via Arrêté grand-ducal du 13 juillet 1944 modifiant l'arrêté grand-ducal du 22 avril 1941 déteminant l'effet des mesures prises par l'ennemi, Mém. 1944, p. 29 and Arrêté grand-ducal du 7 juillet 1944 modifiant l'arrêté grand-ducal du 22 avril 194 I relatif aux mesures de dépossession effectutes par 1'ennemi, Mém. 1944, p. 30. See also Heisbourg, p. 153. 
names was stricken from public records. ${ }^{1465}$ Also other occupation measures were seen as contrary to the principle of equality enshrined in the Constitution and the remainder as a violation of the constitutional principle of the right to private property. ${ }^{1466}$

The exile Government regarded the organization of Luxembourg's courts during the occupation as disastrous. Due to Nazi-Germany"s occupation the courts had been disorganized and provisional measures needed to be taken in order to resume normal judicial activities. ${ }^{1467}$ The removal of the occupation measures meant that Justice would be rendered again "In the Name of the Grand Duke", 1468 the language regulation would come undone, ${ }^{1469}$ the limitation to the courts" competencies would be removed ${ }^{1470}$ and the application of German law could be discontinued. ${ }^{1 / 71}$ Also the alterations to Luxembourg's judicial organization, ${ }^{142}$ which had resulted in the complete abolition of the Luxembourg courts, would be nullified. The Cour superieure would be re-constituted, ending its splitting up into different Appellate Court's Senates. 1473

The Luxembourg Tribunal ${ }^{1474}$ considered in applying the Grand Ducal decree of 22 April 1941 that the courts functioning in occupied Luxembourg had not been Luxembourg courts. Through an act of violence and contrary to intemational law the occupant had deprived Luxembourg nationals from recourse to the ordinary Luxembourg courts. The jurisdiction the occupant had established with certain analogies to the Luxembourg courts could not be considered the appropriate forum under Luxembourg law. The Grand Ducal Decree of 22 April 1941 rendered every judgment of those courts replacing Luxembourg's ordinary courts during the occupation nonexistent. This was despite the fact that some of these decisions, for reasons of public order, had been declared valid in principle after the occupation. Therefore, some of these cases would be allowed a second trial after the re-instatement of the ordinary Luxembourg courts.

The Government enacted. a Grand Ducal Decree ${ }^{1475}$ in which it allowed itself, in case of urgency, to temporarily deviate from the provisions concerning the maximum number of judges that could be appointed to the courts. New Presidents, Vice Presidents and judges could be appointed for a period of 6 months. The decree had retroactive effect until 10 September 1944. Moreover, contrary to the Judicial Organisation Act (1885) the President of the Court, in case of urgent necessity, coutd tempo-

\footnotetext{
1465. Article 3 Arrêté grand-ducal du 13 juillel 1944 modifuant l'arrêté grand-ducal du 22 avril 1941 déteminant l'effet des mesures prises par l'ennemi, Mén. 1944, p. 29. Préambule Arrêté grand-ducal du 22 avvil 1941, déteminant I"effel des mesures prises par l'occupant, Mém. 1944, p. 21.

1467 See Preambule and areté grand-ducal du 14 juin 1944, modifiant l'organisation judiciaire afin de rendre possible, des la libération du territoire, la teprise de la justice. Mém. 1944, p. 34.

See Chapter 3.1 .

See Chapter 3.2 .

See Chapter 3.4 .

See Chapter 3.8 .

See Chapters 3.2 and 3.9 .

See Chapter 3.2 .

14t4 Tribunal d'arrondissement de Luxembourg (civil) du 5 mars 1947, Pus. Hux., Tome XIV, p. 289

1473 Arrêté grand-ducal du 3 novembre 1944 portant modification de l'organisation judiciane, afin de rendre possible, des la libération, la reprise de la justice, Mém. 1944,1 . 85.
} 
rafily allow judges to serve at Courts of the Peace in different cantons for a maximum of six months.

Via regulation Schommer, Chef of the Mission for Civil Affairs of the Grand Ducal Government, preceding the return of the Govermment-in-exile, ordered the appointment of several judges on 19 September $19444^{147}$ Ernest Heuertz was appointed acting President of the newly revived Cour superieure and Paul Ruppert acting President of the Luxembourg Tribunal. Seven attorneys were appointed as deputy judges to serve in different jurisdictions where necessary. Two of these attomeys' appointments were reconfirmed via Grand Ducal Decree, whereby they were assigned to the Luxembourg Tribunat. The five remaining attorneys plus one other were attached to the Cour superieure as well as the Luxembourg Tribunal for the duration of 6 months. Heuertz and Ruppert were equally reconfirmed for a period of 6 months. However, Ruppert initially was not confurmed as acting President of the Luxembourg Tribunal, since he was appointed deputy judge to the Cour superieure and the Tribunal. ${ }^{1478}$ Due to the inability of the President of the Luxembourg Tribunal to exercise his duties, Ruppert was then appointed acting President a little bit over a week later. ${ }^{1479}$ Both were, at their own requests, honorably dismissed from their presidencies from 1 October 1945 onwards, whereby Ruppert remained honorary President of the Luxembourg Tribunal. ${ }^{1480}$

One of the many attorneys who had been appointed to the courts, François Delaporte, had initially been appointed to the public prosecutor office, first as a deputy public prosecutor. ${ }^{1481}$ Then, about a week later, the Government temporarily appointed him deputy Procurator of State for 6 months, confusingly from the position of deputy judge at the Luxembourg Tribumal. ${ }^{182}$ Another week later, the Government once again temporarily appointed Delaporte to the position of judge at the Luxembourg Tribunal for 6 months, apparently from the position of deputy judge at that court, ${ }^{143}$ although he had been appointed a week earlier to this deputy public prosecutor position.

Other provisional measures taken in order to resume nomal judicial activities after the occupation were also departure from the Judicial Organisation Act (1885). The Cour supervieure had to sit as an appeals court with three judges and in cassation with five. In case of necessity the Government authorized itself to disregard the age

1476. Arrêté grand-ducal du 25 novembre 1944, conférant aux juges de paix l'autorisation temponaire de desservir un on plusieurs autres cantons, Mém. 1944, p. 129.

1:77 Ordonnance concernant la designation de Magistrats provisoires du 19 septembre 1944 , Mém. 1940 , p. 50.

14: Arêté grand-ducal concernant l'organisation provisoire des différents services de la Justice du 27 septembre 1944, Mém. 1944, p. 53.

1 w̧ Arrêté grand-ducal du. 4 octobre 1944 concernant la désignation de magistrats provisoires, Mém. 1944, p. 57.

Hstu Avis-Magistrature, Mém. 1945, p. 702.

A4 Article 1(I) Ordonnance concernant la désignation de Magistrats provisoires du 19 septembre 1944, Mém. 1940, p. 50.

14:2 Article 4 arrête grand ducal concernant l'organisation provisoire des differents services de la Justice du 27 septembre 1944, Mém. 1944, p. 53.

14\$3. Article 2 arrêté grand-ducal du 4 octobre 1944 concernant la désignation de magistrats provisoires, Mém. 1944, p. 57. 
limit and restore to office retired judges. ${ }^{1484}$ Also; the Government authorized the courts or in urgent cases their presidents, to decide on the appointment of examining magistrates. 1485

Judges of the Tribunaux were also appointed to the Cour superiewre on a temporary basis for 6 months and only in case of urgent necessity, whereby they would also remain a member of their Tribumal. It was specifically stated that this would be to the detriment of the deputy Justices at the Cour superietme. The President of the Court was obliged to staff a case from amongst the Justices and the newly appointed judges of the Tribumaux. Only in case where this arrangement failed to provide him with enough judges for a case was he allowed to assign a deputy Justice from the Cour superieure to the case. ${ }^{1486}$

Via decree of 27 September 1944 Victor Bodson, Minister of Justice, reinstated the Diekirch Tribunal, which had been abolished during the occupation. ${ }^{1483}$ Harking back to Luxembourg's Judicial Organisation Act $(1885)^{1488}$ as amended by Grand Ducal Decree of 14 June 1944, Bodson appointed Edouard Lentz, judge at the Luxembourg Tribumal, and deputy judges Joseph Wolter and Georges Reuter of the same Tribunal to the Diekirch Tribunal. Due to the German counter-offensive in the Ardennes during the Battle of the Bulge the Diekirch Tribunal was forced to cease its activities in mid-December 1944. A Grand Ducal Decree of 15 January 1945 temporarily transferred the seat of the Diekirch court to Luxembourg. On 19 March 1945 the Tribunal was re-established in Diekirch. Judges Treinen and Steichen rendered the first civil judgment on 18 July 1945 and judges Pemmers, Treinen and Goldmann the furst criminal one on 31 August of that year. ${ }^{1489}$ Another Ministerial Decree instituted a vacation chamber at the Diekirch Tribunal, appointing judge Lentz and deputy judges Wolter and Reuter to assure continuity of court proceedings during the vacation of the regular judges. ${ }^{1490}$

\subsubsection{Measures dealing with occupation personnel policy}

Since no new members but one of Luxembourg nationality were appointed during the occupation, " $49 \|$ measures concerning the "denazification" could only deall with those prewar appointees that had held office during the occupation. In order to "denazify" members of the Luxembourg courts the regular disciplinaty proceedings under Luxembourg law, as well as newly instituted purge proceedings for violation of provi-

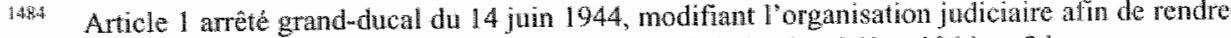
passible, dès la libération du territoire, la reprise de la justice, Mém. 1944, p. 34.

448s Arrêté grand-ducal du 2 octobre 1944 portant modification de l'organisation judiciaire afin de rendre possible, dès la libération du territoire, la reprise de la Justice, Mém. 1944, p. 57.

1486 Arrêté grand-ducal du 19 décembre 1944 portant modification de l'organisation judiciaire, afin de rendre possible, dès la libération, la reprise de la justice, Mém. 1944, p. 157.

14:37 See Chapter 3.9

a A A Articles 149 and 150 , as well as article 135 Loi du 18 février 1885 , sur l'organisation judiciaine, Mém. 1885 , No. 23, p. 317-375.

1489 Exerling, p. 16.

14\% Artêté ministériel portant institution d'une Chambre des vacations au tribunal d'arrondissement de Diekirch du 27 septembre 1944, Mém. 1944, p. 54. See also Arrêté grand-ducal du 16 novembre 1944, modifiant l'arrêté grand-ducal du 14 juin 1944, portant modification de l'organisation judiciaire, Mém. 1944, p. 111.

See Chapter 3.5.
} 
sions dealing with the external security of the State would be used. One problem concerning "denazification" was that membership of a national socialist organization could not be taken as a basis for purging a member of the courts. All but two judges had joined the $\mathrm{VdB}{ }^{142}$ A purge on the basis of membership of a national socialist organization would destroy the country.

In reporting to the consultatuve Parliament Minister of Jusitice Bodson stated that membership of the $\mathrm{VdB}$ had been exhorted via violence and threats. ${ }^{1493}$ These threats had to be taken seriously, so Bodson, in view of the reputation the Germans had in exterminating hundreds of thousands and dealing with millions of political adversaries, like the Jews, the Polish, the Czechs and the Austrians. Also a fictitious violation of the oath of loyalty to the Grand Duchess could not serve as a basis, since the alternative was extermination after a brief delay. The dilemma of every judge was therefore whether the country could be best served by being removed from office, deported, interned and executed or continue the exercise of office, in the interest of the Luxembourg people, even at the expense of concessions to the enemy? Bodson seemed to think the majority of the Luxembourg population during the occupation preferred the latter, knowing how to distinguish between those Luxembourg public officials that collaborated and those that did not. Finally, due to the demoralization of the country after the Nazi-German victory and in the absence of any kind of instructions emanating from a Luxembourg superior authority, public officers were thrown back onto the guidance of their own conscience. Membership of the VdB could therefore in and of itself not constitute a basis for purge and the general attitude during the occupation of the judge involved in proceedings had to be the aim for an investigation. ${ }^{1494}$

For the 'denazification', next to the regular purges, administrative purges had been instituted. Civil servants, professors and teachers, as well as members of the liberal professions were subject to such administrative, disciplinary proceedings. ${ }^{1495}$ The Government excluded members of courts from the scope of the administrative purge legislation, which was adopted for the purge of the other civil servants in March 1945. However, to those judges that had not retired on the basis of Luxembourg legislation, the existing procedures still applied. The Cour superieure would be competent on the basis of article 165 Judicial Organisation Act (1885) to conduct disciplinary proceedings against those judges who had failed their legal obligations in the exercise of their office. 1496

Judges in Luxembourg at the Tribunal and Cour supérieure level were appointed for life limited to 72 years of age ${ }^{1497}$ and removal from office was only possible via a legal judgment that determined either bad behavior or physical disabill-

14in2 Compte rendu des Sëances de l'Assemblée consultative du Grand-Duché de Luxembourg, Session de 1945 (du 20 mars -16 août 1945), Volume unique, 11 me séance de jeudi, le 14 juin 1945 , p. 398-399. Sec also Chapter 3.9 .

\{tis. See also Govermment of Luxembourg, p. 55; Marx, p. 95-110.

thas This was also the case for other professions. See Als, R., p. 9, 19-21.

fw Arse fré grand-ducal du 30 novembre 1944 autorisant le Gouvemement à procéder à une enquête administrative, Mém. 1944, p. 144. See also Als, R., p. 3; Cerf, Épuration, p. 11.

1446 Article 1 arrêté grand-ducal du 2 mars 1945 portant institution de l'enquête administrative prévue par l'artêté grand-ducal du 30 novembre 1944, Mém. 1945, p. 85.

1.4\%: Article 179 Loi du 18 février 1885 , sur l'organisation judiciaire, Mém. 1885, No. 23, p. 317 375. 
ity. ${ }^{1498}$ The Cour superieure opened disciplinary proceedings against three Justices of the Cour superieure, four of the Luxembourg Tribunal, two of the Diekirch Tribunal and ten members of the Courts of the Peace. ${ }^{1499}$ Since the files of these disciplinary proceedings have been lost ${ }^{1500}$ the outcome of these cases is unknown. ${ }^{150 !}$ However, the three Justices of the Cour supérieure, two of the judges of the Luxembourg Tribunal, one judge at the Diekirch Tribunal and four members of the Courts of the Peace were not in office anymore in 1946. ${ }^{1502}$ The Diekirch judge was nevertheless still on a List of Recommendations in $1946 .{ }^{1503}$ Of those judges against whom disciplinary proceedings had been opened and who were still in office in 1946, two from the Luxembourg Tribunal had been promoted to the Cour superteure and one member of the Court of the Peace to the Luxembourg Tribunal. ${ }^{1504}$

Besides these disciplinary proceedings also regular proceedings for violation of the external security of the State were used to 'denazify' Luxembourg courts. ${ }^{1505}$ The exile Government assigned the task of trying these cases to the re-constituted ordinary courts in Luxembourg. In order to enable the courts to deal with the new penal provisions concerning the external security of the State, the Government expanded their judicial competencies. The courts were given more latitude for the sentencing in these cases. However, the criminal Chamber of the Tribunaux, as well as the Cour d'appel (as part of the Cour superieure) were obliged to try these cases with 5 judges, of whom 2 lay judges. These lay judges were allowed to take part in the deliberations to reach a verdict. The President of the Cour d"appel appointed one lay judge and the Government the other on the recommendation of the Minister of Justice from a list drawn up by the Union of Resistance Movements. ${ }^{1506}$ Sole other prerequisite for becoming a lay judge was proven patriotic activities during the occupation. ${ }^{i 507}$

1498 Article 178 Loi du 18 février 1885, sur l'organisation judiciaire, Mém. 1885, No. 23, p. 317 . 375. See also Kayser, p. 29.

1499 Greffe Cour Supérieure de Justice de Luxembourg, Registre aux délibérations de la Cour du 14 Novembre 1944 au ler Juillet 1954, La Cour Supérieure de Justice du GrandaDuché de Luxembourg, reunie en assemblée générale, après due convocation, le samedi, 25 nowenbre 1944; La Cour Supérieure de Justice du Grand-Duché de Luxembourg, reunie en assemblée générale, après due convocation, le samedi, 25 novembre 1944; La Cout Superrieure de fustice du Grand-Duché de Luxembourg, reunie en assemblée générale, après due convocation, le jeudi, quatre janvier 1945; La Cour Supéneure de Justice du Grand-Duché de Luxembourg, reunie en assemblée générale, après due convocation, le jeudi, quatre jânvier 1945 .

The files of these disciplinary proceedings against judges have been lost according to the Parquet Général at the Cour superrieure.

1301 This is different from the figures in Dostert, P., Selbstbehauptung, p. 191, note 30 and Cerf, Epuration, p. 155 who argued that the Cour smpesieure tried 10 judges and public prosecutors, of whom 4 were removed from office, 4 were put into early retirement and 2 were disallowed their pensions.

1502 Compare with Anmuaire officiel 1946.

1503 Greffe Cour Superieure de Justice de Lnxembourg, Registre aux délibérations 27-01-193815-05-1941, assemblée générale du vendredi 22 février 1946.

1504-4 Compare with Annuaire officiel 1946.

1505 For war crimes in Luxembourg law see Hammes.

150 for For resistance movements in Luxembourg see Blau, Résistance.

150: Préambule Article 1 and article 3 arrêté grand-ducal du 6 novembre 1944 modifiant at complétant les arrêtés grand-ducaux des 14 juillet 1943 , concernant les crimes et délits contre la 
The files of wo judges purged in these regular proceedings were found. Both files also contained an excerpt from the disciplinary proceeding before the Cour superiewre. In one of the purge cases ${ }^{\text {15ng }}$ a member of the Courts of the Peace who had been appointed days before the occupation ${ }^{1510}$ had already been removed from office in a disciplinary proceeding in March 1945. ${ }^{131}$ The Court considered he had gravely compromised his professional character during the occupation and had violated his professional oath. The Luxembourg purge court condemned him for violation of the extemal security of the state under articles $31,80,118 \mathrm{bis}, 123$ septies and 1230 oties LPC. He was sentenced to 6 years imprisonment, a fine of 250,000 francs and a loss of his Luxembourg citizenship as well as indefinite Joss of his political rights. The purge court considered amongst others his early and voluntary membership of the $\mathrm{VdB}$, taking up office in the legal branch of the party and giving a speech on courts in the new people's State, requesting and obtaining membership of the NSDAP and consequently swearing allegtance to Hitler, accepting other public offices and trying to persuade his employees at the Court of the Peace to vote "sensibly" during the referendum contrary to Article $118 \mathrm{bis}$ LPC. This kind of political collaboration led to voluntarily participation in the enerny's transformation of Luxembourg's political institutions or legal organizations and upset during wartime the loyalty of the citizens towards the Sovereign and the State. On 18 March 1949 this judge was partly pardoned and his prison sentence was reduced to 3 years.

The second purge case ${ }^{1512}$ also dealt with political collaboration, whereby the defendant was accused of upsetting during wartime the loyalty of the citizens towards the Sovereign and the State as well as serving the policies and goals of the enemy. He had been a nember of the Cour superieure and had accepted an appointment as acting President of the Luxembourg Tribunal during the occupation. ${ }^{1511^{3}}$ Like the other judge he had become a member of the VdB voluntarily and early on and had held office in some of the party"s branches and had sought membership of the NSDAP, whereby he had pledged allegiance to Hitler. His acceptance of a vacant judicial office was thought inappropriate, especially since many had been dismissed from office and forced to work on the Autobahn in the Eiffel in Nazi-Germany. 1514 This Justice had also been involved in a commission to remove judges from office and he had advised his subordinates concerning the referendum to vote "sensibly". Moreover, the Justice had only availed himself of the German language and the Nazi greeting, even when his fellow Luxembourger approached him in their national lan-

sûreté extérieure de l'Rtat et 4 septembre 1944 , relatif ă la sécurite et à la protection des. arm mees alliés sur le territoire du Grand-Duché, Mém. 1944, p. 100.

This is also different from the figures in Dostert, P., Selbstbehauptung, p. 191, note 30 and Cerf, Epuration, p. 155 who argued that 3 judges were tried in the general purges.

Archives Nationales de Luxembourg. Aftaires politiques no. 114.

4 sio: Arrêté grand-ducal du 7 mai 1940, Mém. 1940, p. 339.

1511 Archives Nationales de Luxembourg. Affaires politiques no. 114, Extrait/Auszng 16699/54. His proceedings before the Cow supérieure had started on 25 November 1944 (see Greffe Cour superrieure de Justice, Registre aux déliberrations de la Cour da 14 Novembre 1944 an lar Juillet 1954, La Cour Supérieure de Justice du Grand-Duché de Luxembourg, reunie en assemblée génerale, après due convocation, le samedi, 25 nowembre 1944).

15:2 Archives Nwutionales de Luxembourg, Affaires politiques no. 107.

15:3. See also Luxemburger Wort, 30. Mai 1941.

1.54 See also Archives Nationales de Luxembourg, Dossiers Epuration, EPU no. 238, lettre de M. Thorn, avocat, au Ministre de la Justice du 14 October 1944. 
guage. After the occupation he had left Luxembourg together with the occupant on 30 August 1944 and had continued to hold office as a judge in Nazi-Germany. The Justice was sentenced to 7 years imprisonment, fined 100,000 francs, loss of Luxembourg citizenship and indefinite loss of his political rights. Already on 4 January 1945 the Cour supérieure had stripped him of his judicial office. ${ }^{1515}$

In the postwar period $56 \%$ of those judges who had held office on 10 May 1940 and were removed during the occupation were re-instated, of whom $46 \%$ were promoted to a higher office. Almost $44 \%$ of Luxembourg's judges, including deputies, were newly appointed after the occupation had ended."

\subsubsection{Concluding remarks on the Luxembourg courts and 'denazification' measures}

The exile Government's measures for the 'denazification" of the Luxembourg courts were based upon extraordinary powers Parliament had granted before the war. Due to force majeure or state of necessity the Government claimed these had force of law. Unquestioningly some courts accepted exile measures and applied them, even before Parliament had passed judgment on them.

Decisive in the courts' approach to these measures would become, however, that the mewly elected Parliament after the end of the occupation ratified all Governmental measures based upon the 1938 and 1939 Statutes granting extraordinary powers. This ratification placed the 'denazification' measures on the same footing as Acts of Parliament, granting them force of law and prohibiting courts from questioning their validity or legality. Excluding an appeal to customary international law the Luxembourg courts took a positivist stance and were therefore legally obliged to apply these 'denazification' measures.

\subsection{THE NETHERLANDS}

\subsubsection{Netherlands courts and judicial review of exile measures?}

The Supreme Court was in an impossibility to rule on the status of the Government"s exile measures. After the liberation of the southern Netherlands at the end of 1944 the seat of the Netherlands Supreme Court, which during the occupation had been moved to Nijmegen, ${ }^{1517}$ had also fallen into the hands of the legitimate Netherlands Government. The General of the Netherlands Military Authority, shortly after the end of the occupation, instructed the members of the Supreme Court to stay their duties. ${ }^{1518}$ The Government's dealings with the Supreme Court will be discussed later on, ${ }^{1519}$ but suffice it to say here that once the Supreme Court was functioning again it

1.515 Archives Nationales de Luxembourg, Affaires politiques no. 385, Document 0033. His disciplinary proceedings had commenced 25 November 1944 (see Greffe Cour supérieure de Justice, Registre anx délibérations de la Cour du 14 Novembre 1944 au ler Juillet 1954, Lá Cour Supérieure de Justice du Grand-Duché de Luxembourg, réunie en assemblè gènérale, après due convocation, le sanedi, 25 novembre 1944).

1516 See ANNEX 5.

$15: 7$ See also Chapter 4.13.

1513 Militair Gezag, p. 107.

See Chapters $7.3 .3,7.3 .4$ and 7.3 .6 . 
would not be until 1946 before the Court would issue a nuling on the validity of exile measures. 1520

Even before Netherlands courts, let alone the Supreme Court, were confronted with the question of the validity of exile legislation, at least some of its high-ranking and most influential members seemingly did not doubt its legal status. Explicitly in correspondence ${ }^{152 !}$ exile legislation was referred to as being of similar status as Acts of Parliament. ${ }^{1522}$ In different judgments lower courts that were first confronted with exile measures accepted that these were at a par with Acts of Parliament and that: courts could therefore not review their validity or constitutionality. ${ }^{1523}$

\subsubsection{Measures abolishing occupation measures directed at courts}

In spite of the fact that the Supreme Court was not able to rule on the validity of exile measures and Parliament would not get to the matter until January 1946 , 1524 the Government commenced their enforcement. Several exile decrees dealt with the status of occupation measures after the liberation. On the basis of detailed statements from lawyers in the occupied Netherlands, which were smuggled to London, the Government on 17 September 1944 had issued Royal Decree E $93 .{ }^{1525}$ Occupation measures, which had not been published in either the Netherlands Official Gazette, the German Civil administration Official Journal or the Food Distribution Journal, ceased to apply as soon as the occupation power had vacated that area of the Netherlands. Regarding the 'denazification' of the courts these were measures dealing with the transfer of seats of several courts during the occupation, which had never been published. ${ }^{1526}$ However, this Royal Decree did not repeal the measure from 7 May 1943 moving the Supreme Court's seat outside of The Hague. ${ }^{152 \%}$

1520 See Chapter 7.3.5.

1521 See e.g. Rijksarchief in Noord-Brabant, Vliegenthart, A.J, als Hoge Autoriteit in "s-Hertogenbosch en als lid zuiveringscommissies, $1943-1959$, toegang 1138 , inv. 77 brief 30 November 1944 van President van het Gerechtshof te 's-Hertogenbosch aan de Presidenten en Offcieren van Justitie bij de Arrondissementsrechtbanken te Breda, Maastricht en 's-Hertogenbosch, no. 13, 14, 15; Tresoar, Gerechtshof Leeuwarden 1940-1949, Correspondentie, brief 16 October 1946 van de President van het Gerechtshof te Leeuwarden aan de Directeur-Generaal voor Bijzondere Rechtspleging te "s-Gravenhage, no. 796.

The term used was 'wet', as if the Royal Decrees the Government-in-exile had enacted were 'wetten in formele zin' or Acts of Parliament.

1327 Arrondissementsrechtbank Rotterdam 24 december 1945, NJ 1946, 56. Arrondissementsrechibank Rotterdam 28 maart 1946, NJ 1946, 215; Arrondissementsrechtbank Rotterdan 18 september 1946, $N J$ 1946, 727; Gerechtshof 's-Gravenhage 15 december 1948, $N J 1949,566$. See Chapter 6.4.3.

Koninklijk Besluit van 17 september 1944, houdende vaststelling van het Besluit Bezettingsmatregelen, Stb. 1940/1945, E 93. See also Jong (deel 9-2), p. 1290-1291. Moreover, Koninklijk Besluit van 17 september 1944, houdende vaststelling van het Beshit herstel rechtsverkeer, Stb. 1940/1945, 731 covered the legal restoration in the field of property law, but is not relevant for this chapter.

1526 See Chapter 4.13 .

15:m See Chapter 4.13. This Royal Decree merely dealt with measures published in the Verordmungsblatt and not the Staatscouram in which the measure at issue had been published. Although this measure does not seem to have been repealed, under international law there was no tacit recognition of the measure (see Chapter 6.1 ), since in practice the official seat of the Netherlands Supreme Court was moved back to The Hague after the war. 
Most measures published in the Civil administration's Official Journal and taken on the national level were divided into three categories. Measures on the A-list were assumed never to have existed. These were mainly all of the 61 regulations directed at Netherlands nationals of Jewish ancestry. ${ }^{1528}$ Also the regulation concerning the statutory age limit ${ }^{1529}$ and the one instituting political courts with peace magistrates and introduction of the analogy of penal provisions ${ }^{1530}$ were nullified retroactively. Oddly enough also the regulations limiting the Netherlands courts' competencies concerning the German Reich and organizations were included here, although during the occupation this had not been contrary to international law..$^{1531}$

The measures on the B-list ceased to apply as soon as the occupant had vacated that area of the Netherlands. The B-list contained 423 regulations concerning Nazi organizations and federations. Also the suspension of articles 12 and 13 of the Netherlands Code of Criminal Procedure concerning the right to lodge a complaint came undone, ${ }^{1532}$ as well as the obligation to render Justice 'In the Name of the Law'. ${ }^{1533}$ The circulars of the Secretary General of Justice banning the Queen's name from all public acts and changing the oath of office ${ }^{1534}$ were already during the occupation contrary to Netherlands law and could therefore not be applied anymore. The measures concerning the occupation appointment procedure, ${ }^{1535}$ the Economic Courts ${ }^{1536}$ and the Führerprinzip ${ }^{1537}$ would also enter out of force once the occupant had retreated. For some reason the measures concerning forced deployment of labor ${ }^{1538}$ were not mentioned.

The 284 measures on the $\mathrm{C}$-list were those the Civil administration had taken in the area of the economy, which would provisionally remain in force. The State Committee on Occupation Legislation was established to advise the Government on abolition or exchange of this occupation legislation that still remained in force. No measure directly affecting the position or functioning of the courts was part of this list.

Furthermore, this decree determined that Netherlands legislation, as had existed on 15 May 1940, or had since been announced by the Queen and the Government was binding to its fullest extent.

\subsubsection{Measures dealing with occupation personnel policy}

Distrustful not only of its Supreme Court, but also the subordinate ordinary courts the Government-in-exile decided to establish special courts ${ }^{1539}$ to conduct a purge of

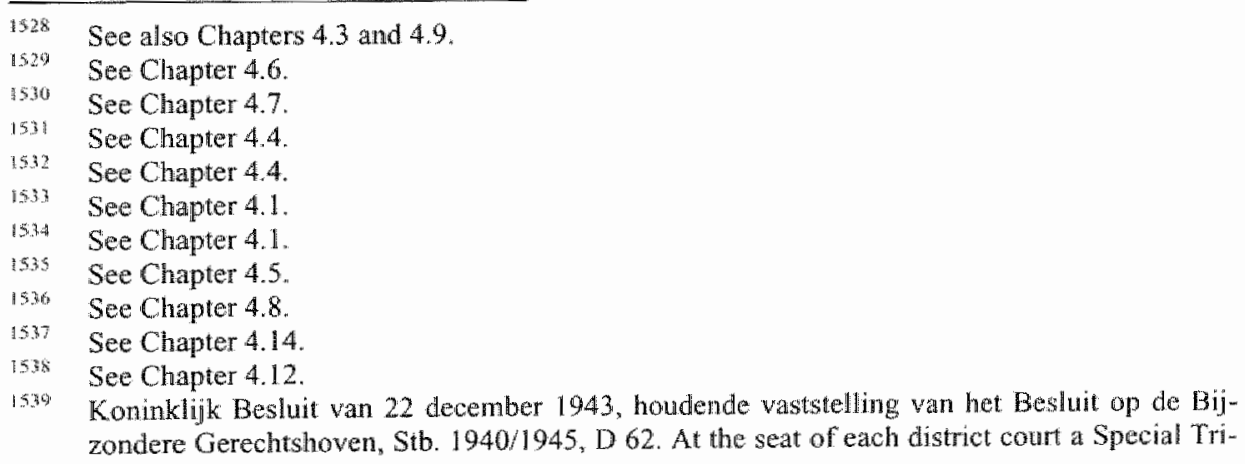


collaborators. ${ }^{1540}$ This special court jurisdiction was competent for violations of Royal decree $D 61,{ }^{1541}$ dealing with extraordinary penal provisions. ${ }^{1542}$ These newly enacted penal provisions dealt with crimes against the external security of the State. The nulla poena principle of article $\mathbb{1}$ Netherlands Penal Code would expressly not be taken into consideration, ${ }^{1543}$ which meant that these new penal provisions would be applied retroactively. ${ }^{1544}$ The nulla poena principle was not enshrined in the Netherlands Constitution, but rather as the first article of the Netherlands Penal Code. However, the Supreme Court had not yet ruled on the validity of exile measures on the occupied territory and whether courts were allowed to review the content of exile measures. ${ }^{1545}$ Also before Parliament had debated the exile measures ${ }^{1546}$ the legal status of these measures was still unclear. Nevertheless, contrary to the Penal Code, these exile measures were given retroactive effect.

The newly created general purge jurisdiction would also try judges for criminal acts committed unrelated to the exercise of their public office. The purge for ex off $i$ cio acts would become entangled with the Government's measures against the Supreme Court. Netherlands legislation provided that Netherlands judges were appointed for life, which had been limited to the age of $70{ }^{1547}$ For ex officio acts only the Supreme Court could remove judges from office and only on the basis of grounds stipulated by an Act of Parliament. ${ }^{1548}$ These grounds for dismissal were either having been sentenced to imprisonment or interned for having committed a serious offence, bankruptcy, serious misconduct, indecency or proven continuous neglect in the

bunal was created, operating in chambers consisting of a lawyer-President, two laymen and a lawyer-secretary. The laymen were citizens of the District in which the Special Tribunal resided, belonging to a cross-section of society.

At the seat of ewery Court of Appeal, a Special Appeals Court was established with chambers comprised of three civilian lawyers and two military members. Many members of the ordinary courts were appointed to these Special Appeals Courts, who made up one third to one half of all members. Many others were recruited from deputy judges. Justice van Berckel, a member of the Hague Court of Appeals who had resigned in protest against the introduction of the peace court jurisdiction was appointed President of the Hague Special Appeals Conrt. His colleague at the Hague District Court, van Meeuwen, who had resigned for the same reason, became the Special Appeals Court's Vice President. Justice Wedeven, involved in rendering the Ommen judgment, became President of the Special Appeals Court in Leeuwarden.

As highest judicial authority for the purge jurisdiction a Special Court of Cassation was established. None of the members of the Supreme Court were invited to join this highest instance of the purge jurisdiction. President of the Special Court of Cassation became Justice Haga, the other member of the Hague Court of Appeal who also had resigned out of protest against the introduction of the peace court jurisdiction during the occupation. Three other members of the highest purge court were Justices or deputy Justices at the Hagne Court of Appeal and the others were law professors from several universities (Bielinfante, p. 95-99; Staatsalmanak 1946).

See also Ronijn on the purges.

Koninklijk Besluit van 22 december 1943, houdende vaststelling van het Besluit Buitengewoon Strafrecht, Stb. 1940/1945, D 61.

See also Belinfante, p. 17-51.

Jong (deel 9-2), p. 1271; Bellinfante, p. 97-108.

Bemmelen, Répression, p. 550; Belinfante, p. 97.

See Chapter 7.3.1.

See Chapter 6.4.3.

See also Vorstman, p. 160

Articles 11 and 12 Wet RO. 
exercise of public office. Dismissal could also be based on grounds of proven incapacity on the basis of age, continuous psychic illness or mental derangenent.

The Government nevertheless enacted different exile measures dealing with the "denazification" of the courts. On 19 February 1944 a decree concerning the provisional organization of the Judiciary was announced. ${ }^{1549}$ In this decree E 13 , the Government considered that for the security of the State it was urgently necessary to enact provisional measures in order to guarantee a good administration of Justice until the Judiciary had been completely freed from the influences it had suffered during the occupation. Judges appointed during the occupation were ordered to remain in office. ${ }^{1500}$ The ones the occupant had removed from office were instructed to return to their former offices. ${ }^{451}$

The so-called Purge Decree E $14^{1552}$ was published soon after the occupation and contained new rules concerning the purge of the highest organs of State, the Netherlands administration, the Judiciary and others. Purge Decrees F 56 and F $68^{1553}$ were subsequently enacted to modify Purge Decree E 14. The Purge Decree of 1945 replaced purge decrees E $14, F 56$ and F $68 .^{1554}$ Royal Decree E 13 was not replaced. There was a striking difference between the purge decrees E $14, \mathrm{~F} 56$ and $\mathrm{F} 68$ and the new Purge Decree 1945. The scope of application was regulated in the first article. Judges explicitly fell within the scope of application of Purge Decree E 14.15 .5 Purge Decree 1945 explicitly excluded members of the courts, including the Procurator General to the Netherlands Supreme Court. ${ }^{1556}$

After the liberation of Nijmegen on 20 September 1944 the Military Authorities immediately suspended President van Loon and three days later the Minister of Justice removed him from office. Van Loon, however, on 17 September had already gone to the still occupied northern Netherlands. ${ }^{1557}$ In the beginning of October Hooykaas had contacted him on behalf of Secretary General Schrieke with the message that the seat of the Netherlands Supreme Court had been moved again to The Hague, so that its members present in the occupied area could resume their duties. Van Loon said he had protested directly, because he meant this to be a violation of international law. Soon after he contacted Justices Nypels and wan den Dries in The Hague, to whom he indicated the plans of the Secretary General and at the same time

\footnotetext{
isł9 Koninklijk Besluit van 19 februari 1944, houdende vaststelling wan het Besluit Tijdelijke Organisatie der Rechterlijke Macht, Stb. 1940/1945, E 13. Article 1 Koninklijk Besluit E 13, ibid.

15s Article 2. Koninklijk Besluit E 13 , ibid.

1552 Koninklijk Besluit wan 13 januari 1944, houdende vaststelling van het Zuiveringsbeslluit, Stb. 1940/1945, E 14.

1553 KoninkJijk Besluit $\mathrm{F} 56$ van 12 april 1945, houdende aanvulling van het Zuiveringsbeshuit, Stb. 1940/1945, F 56; Koninklijk Besluuit van 12 meil 1945, houdende aanvulling van het Zuiveringsbesluit, Stb. 1940/1945, F 68 .

1354 Koninklijk Besluit van 2 augustus 1945, houdende vaststeling van het Zuiveringsbesluit 1945, Sitb. 1944/1946, F 132.

15s5 Article 1(1)(a) Koninklijk Besluit van 13 januari 1944, houdende vaststelling van het Zuiveringsbesluit, Stb. 1940/1945, E 14 .

1.55\% Article 1(1)(a) Koninklijk Besluit van 2 augustus 1945, houdende vaststelling van het Zuiveringsbesluit 1945, Stb. $1944 / 1946$, F 132. On the special problems of the purge of the Supreme Court see Kollewijn.

1557 Jong (deel 10a-2), p. 659 and Mazel, p. 145.
} 
that Schrieke's proposal was contrary to international law. ${ }^{1558}$ However, the exile Government removed the occupation appointees of the Supreme Court from office. ${ }^{1559}$ This applied to President van Loon and Justices Smits, de Visser, Weitjens, ${ }^{1560} \mathrm{Helb},{ }^{156}$ Thien ${ }^{1562}$ and van Lunteren. ${ }^{1563}$ The position of Smits and de Visser was different in that Smits had been on the List of Recommendations before the war and both he and de Visser had been appointed with the explicit consent of the Supreme Court. ${ }^{1564}$ Smits would share the fate of the prewar appointees. Justice de Visser would be allowed to resume the office he had held previous to his appointment to the Supreme Court. ${ }^{1595}$

Van Loon would be tried at the special purge court in The Hague. Although the public prosecutor had charged van Loon, it seemed like he had indicted the Netherlands Supreme Court. The charges stated that during the occupation of the Netherlands the occupant's goal consisted in weakening or at least not kindling the spirit of resistance of the Netherlands population. The Netherlands Supreme Court at this time was the only central organ of State still functioning. President van Loon was accused of having deliberately failed to support and strengthen the spirit of resistance. In any case, withholding his support for resistance publicly left the impression of weakness and acquiescence in relation to the enemy. ${ }^{1566}$ Some more concrete charges were formulated, like the swearing-in of the peace court judges and not offering resistance in the case of the detention camps and the dismissal of Justices Viehoff and Wedeven, but the indictment sought to prosecute the policies of the Supreme Court during the occupation.

Justice Donner used his influence to prevent that van Loon's trial would also try the Supreme Court's occupation policies and tried to persuade the Minister of Justice Kolfschoten to have the indictment retracted. ${ }^{1567}$ Kolfschoten suspended the prosecution and the criminal proceedings, ${ }^{1568}$ arguing that the indictment was incorrect and incomplete and could not have assured a satisfactory prosecution. Van Loon's case, however, was still under investigation. ${ }^{159}$ An indictment with more individual

$4 \mathrm{~kg}$

Loon, p. 6 and Mazel, p. 145-146.

Ministerie van Justitie. Depot 164 Zuivering Hoge Raad der Nederlanden 1944-1946, Nota van Mr. Fick mei 1945; Verslag van het gebeurde te Nijmegen van 17 september 1944

For Weitjens's conviction by the Hague Special Purge Tribunal see Oordeel wan 10 mei 1948 , rolno. 3108 , not published. For his defense see Pleitnota van mr W.M.A. Weitjens van 26 April 1948, Tribunaal "s-Gravenlage, $7^{2}$ Kamer. See also Jong (deel 10a-2), p. 660 and Mazel, p. 141. See also Weitjens, Normen; Weitjens, NS; Weitjens, Ridders; Weitjens, Uniform; Weitjens, Wederhoor.

Jong (deel 10a-2), p. 660 and Mazel, p. 141. See also NRC 19 August 1941; Asch, p. 491.

Mazel, p. 142.

Mazel, p. 137, See also 'Onze Pers in beslag genomen. En toch! ...' in: Volk en Vaderland, 8 Januari 1943.

See Chapter 4.5 .

Mazel, p. 163-164; Jong (deel 10a-2), p. 661.

Ministerie van Justitie, Depot 164 Zuivering Hoge Raad der Nederianden 1944-1946, Tenlastelegging inzahe J. van Loon.

Ruiter, p. 230.

See Mazel, p. 168.

Rijksbegrooting voor het Dienstjaar 1946. 2. IV. 7, Bijlage A, IV de Hoofdstuk, Memorie van Antwoord, Afdeling II. 
charges was written and on 10 April $\mathbb{9 4 7}$ the Hague Special Tribunal convicted van Loon. $15 \% 0$

After the liberation of Nijmegen the Military Authority, acting on instructions from the Government in London, had also stayed the activities of the Supreme Court and all prewar appointees of the Supreme Court, except for Justice Nypels. ${ }^{1571}$ The latter was suspended and the payment of his salary was discontinued. ${ }^{15}$ The reason why Nypels was treated differently as compared to his pre-war colleagues was unknown and seemed to be a mistake rather than a policy decision. ${ }^{1573}$

Justice Donner objected to the measures the Netherlands Government had taken against the Supreme Court. Since the occupant had removed him from office ${ }^{1574}$ after the liberation Donner had been reinstated on the basis of Royal Decree E $94^{1575}$ and was now the only member of the Supreme Court still in office. The same applied to Procurator General Berger. ${ }^{1576}$ Donner and Berger sent a joint letter to Queen Wilhelmina, ${ }^{1577}$ deploring the suspension of the members of the Supreme Court. In their opinion the appointment of those members appointed during the occupation ceased at the moment the occupation ended. The Government"s measures against these Justices therefore made no sense. Measures taken against the prewar appointees were a clear violation of the Constitution, especially its article 173 paragraphs 2 and 4 . After the violation of law in The Netherlands during the occupation Berger and Donner stated they had hoped that with the disappearance of the Germans German measures would disappear as well. Any deviation from the Rechtsstaat should be limited to cases of umost necessity. In this case there were no grounds for a deviation from the Rechisstaat. Although the Supreme Court had been heavily criticized for its behavior during the occupation both Donner and Berger knew that the members of the Supreme Court had remained in office out of a sense of duty and in the interest of the population. This was in conformity with the Instructions the Government had left behind, from which deviation was only possible in case of a conflict of conscience. Even though there could be a difference of opinion about when this conflict of conscience could arise or should have arisen, this, so Donner and Berger, did not mean the Constitution could be set asidie for this reason. Not only did the Government's suspension of the individual members breach the Constitution, but also its suspension of the functioning of the institution of the Supreme Court was contrary to articles 169 and 172 Netherlands Constitution. The Government had also not given the Supreme Court the opportunity to give an account in public of their behavior during the occu-

\footnotetext{
1570 Mazel, p. 168-169.

[57) Ministenie wan Justitie, Depot 164 Zuiwering Hoge Rad der Nederlanden 1944-1946, Nota over den Hoogen Raad van Minister van Justitie Kolfschoten van 25 augustus 1945.

1572 Militair Gezag, p. 107.

157. Ministerie van Justitie, Depot 164 Zwivering Hoge Raad der Nederlanden 1944-1946, Nota van den Minister van Justitie aan den. Raad van Ministers m.b.t. het Hooge Raxdsprobleem 27 september 1946; Nota van Mr. Fick mei 1945, Verslag van het gebeurde to Nijmegen van 17 september 1944 .

153.4 See Chapter 4.14.

155 Besluit van 7 september 1944, houdende vaststelling van het Besluit Rechtsherstel ontalagen ambtenaren, Stb. 1940/1945, E 94.

1570 See also Chapter 4.12

157 Ministerie van Justitie, Depot 164 Zuiwering Hoge Raad der Nederlanden 1944-1946, brief van Raadsheer Donner en Procureur Generaal Berger aan Koningin Wilhelmina van 21 Octo* ber 1944.
} 
pation at the first session of the Court after the liberation. If the Govemment would have allowed this opportunity and it would appear that the Supreme Court would have lost the trust of the people, Donner and Berger were in no doubt that the Supreme Court would have taken the consequences and have woluntarily resigned from office. They requested that the Government's measures against both prewar and occupation appointees were repealed retroactively and that the tenure of the latter would cease regularly with the end of the occupation.

In March 1945, while the northern part of The Netherlands was still occtpied, the Procurator General at the Supreme Court once again intervened on behalf of the Supreme Court with the Minister of Justice. The Military Authority refused to respond to requests from the Supreme Court. The continuing suspension of the Supreme Court, as well as its prosecutor office, so the Procurator General, undermined the reputation of the Supreme Court, which the public regarded as a bunch of traitors. He pleaded with the Government to re-instate cassation, even if only for the liberated South of The Netherlands, stressing that although opinions might differ on how the Supreme Court had exercised its duties, their loyalty to the Fatherland and the Monarch should not be in doubt. ${ }^{1578}$

In spite of several and continuing attempts of the prewar members of the Supreme Court over the course of the period between September 1944 and the spring of 1945 to contact the Government, the Government did not respond. ${ }^{159}$ Not until close to the end of the occupation of the northern Netherlands on 5 May 1945 the Government informed the members of the Netherlands Supreme Court that their suspension was terminated. ${ }^{1580}$ The suspension of Nypels was not removed until 22 June after contacts between Donner and Minister of Justice Gerbrandy. ${ }^{1581}$

Although the personal suspension of the Justices had been lifted, the cassation procedure had not been re-instated yet. On 15 June 1945 a meeting took place between amongst others the Minister of Justice, his Secretary General van Angeren, former Secretary General of Justice Tenkink and a delegation of the Netherlands Supreme Court consisting of Justices van den Dries, Fick and Donner, as well as Procurator General Berger. ${ }^{1582}$ Several days later the Minister of Justice drafted a letter ${ }^{1583}$ in which he strongly disapproved of the Supreme Court's attitude during the occupa-

\footnotetext{
1578 Ministerie van Justitie, Depot 164 Zuivering Hoge Raad der Nederlanden 1944-1946, brief Procureur Generaal Berger aan de Minister van Justitie van 19 maart 1945.

15\% Ministerie van Justitie Depot 164 Zuivering Hoge Raad der Nederlanden 1944-1946, Nota van Mr. Fick mei 1945, Verslag van het gebeurde te Nijmegen van 17 september 1944; Nota van den Minister van Justitie aan den Raad van Ministers m.b.t, het Hooge Ratadsprobleen 27 september 1946. See also Ministerie van Justitie Depot 166 Zuivering kabinet, Doos 6 Zuivering Ressort Hoge Raad, brief Raadsheren Fick, Sinnighe Damste, Hijink, Losecaat Vermeer, Smits aan Secretaris Generaal van Angeren van 25 april 1945.

Ministerie van Justitie Depot 166 Zuivering kabinet, Doos 6 Zuivering Ressort Hoge Raad, beschikking Chef Staf Militair Gezag 19 april 1945, no. 791. Ministerie van Justitie Depot 164 Zuivering Hoge Raad der Nederlanden 1944-1946, Nota over den Hoogen Raad wan Minister van Justitie Kolfschoten van 25 augustus 1945. Jong (deel 10a-2), p. 661.

15\$2 Ministerie van Justitie, Depot 164 Zuivering Hoge Raad der Nederlanden 1944-1946, Nota van Mr. Fick mei 1945, Verslag van lhet gebeurde te Nijmegen van 17 september 1944 af, No. ta over den Hoogen Raad van Minister van Justitie Kolfschoten van 25 augustus 1945.

Ministerie van Justitie, Depot 164 Zuivering Hoge Raad der Nederlanden 1944-1946, concept-brief Minister van Justitie an de Hoge Raad der Nederlanden van 21 juni 1945.
} 
tion. The Minister harshly condemned not only the Court's official duties, but also its failure to resist and what he saw as the formalist attitude of the Court, which allowed for an erosion of the Netherlands legal tradition and European and Christian values. According to the Minister, the members of the Supreme Court should voluntarily offer their resignation. Former Secretary General of Justice Tenkink criticized the Minister of Justice's proposed letter ${ }^{1584}$ calling the request for voluntary resignation contrary to the Purge Decree, which itself in this area was contrary to the Constitution. Also Secretary General of Justice van Angeren did not agree with the Minister's sharp condemnation of the Supreme Court and strongly urged his Minister to reconsider sending the letter. ${ }^{155}$ Contrary to and not awaiting the advice of his highest civil servants, Minister of Justice Gerbrandy sent this letter to the Supreme Court on 21 June 1945 . 1586

The new Government, which took office only days after the Supreme Court had received Gerbrandy's letter, decided to open discussions with a delegation of the Court. On 2 July Justices van den Dries and Fick mett with the new Minister of Justice, Kolfschoten, in the presence of Justice Donner. The Supreme Court refused to resign now, since that would go contrary to its conscientiously conducted policy during the occupation and not solve the problem. ${ }^{1587}$ However, during the occupation it had also been the consistent intent of the Supreme Court to collectively resign after liberation, ${ }^{1588}$ as Donner had already stated in his letter to the Queen. The treatment received at the hands of the Gerbrandy Govenment immediately after the liberation was seen as insulting, leading to a reversal of the Supreme Court's decision and resulting in a collective refusal to resign.

At the request of the new Prime Minister three more meetings took place between on the one hand Prime Minister Schermerhorn and Ministers Kolfschoten and Logemann for the Netherlands Government and on the other Justices van den Dries, Fick and Losecaat Vermeer for the Supreme Court. Donner was only present during the last meeting. ${ }^{158 \%}$ During the discussions, which began on 9 August, the Netherlands Supreme Court indicated that it wanted to have its most senior member, van den Dries, for President. The Government, who viewed van den Dries as the defender of the behavior of the Netherlands Supreme Court during the occupation, ${ }^{15 * 0}$ thought this unacceptable. The eight prewar members of the Netherlands Supreme Court

1584 Ministerie van Justitie, Depot 164 Zuivering Hoge Raad der Nederlanden 1944-1946, brief Mr. Tenkink aan de Minister van Justitie van 22 juni 1945.

15ss Ministerie van Justitie, Depot 164 Zuivering Hoge Raad der Nederlanden 1944-1946, Notitie Secretaris General van Angeren aan de Minister van Justitie (ongedateerd).

$15 \$ 6$ Ministerie van Justitie, Depot 164 Zuivering Hoge Raad der Nederlanden 1944 1946, Nota over den Hoogen Raad wan Minister van Justitie Kolfschoten van 25 augustus 1945. See also Jong (deel 1.2-1), p. 380 .

15.7 Ministerie wan Justitie, Depot 164 Zuivering Hoge Raad der Nederlanden 1944-1946, No. 24, brief Minister van Justitie Kolfschoten aan Minister-President Schermerhom van 3 juli 1945.

$13 \$ 8$ Bijlage A der Rijksbegrooting voor het Dienstjaar 1946, MvA, IVe Hoofdstuk, Afd. II.

1589 Ministerie wan Justitie, Depot 164 Zuivering Hoge Raad der Nederlanden 1944-1946, Nota over den Hoogen Raad van Minister van Justitie Kolfschoten van 25 augustus 1945; Nota van den Minister van Justitie aan den Raad van Ministers m.b.t. het Hooge Raadsprobleem 27 sepcember 1946.

$15 \% 0$ See also Ministerie van Justitie, Depot 164 Zuivering Hoge Raad der Nederlanden 1944-1946, Memorandum n.a.v. Brief d.d. 21 juni 1945 van den Minister van Justitie a.i., Voorzitter van den Raad van Ministers, Prof. mr Gerbrandy. 
were convinced their behavior during the occupation had not been unacceptable and addressed a letter to the Government reiterating their stance and defending their behavior again.

The basis for a settlement was negotiated during the meeting of 18 August between Prime Minister Schermerhorn and Justice van den Dries. A purge authority would be created to purge the prewar members of the courts. Members of the ordinary courts would be appointed to this purge authority and Donner, Kirchberger and Polvliet were considered as possible candidates. Main consideration for the Supreme Court was that it would bave the guarantee, through being allowed to influence the composition of this authority that it would not have to go through this purge procedure. If the opponents of the policies of the Supreme Court during the occupation would comprise the majority of the members of this purge authority, then van den Dries indicated the Supreme Court might not co-operate if it were subjected to proceedings. In exchange for immunity from these purge proceedings the Supreme Court relinquished its constitutional right and duty to supervise the courts and be the sole authority empowered to remove judges from office. ${ }^{1591}$

In the autumn of October 1945 the Government decided to publish the letters the Supreme Court and the Government had drawn up after the three meetings. In its letter of 4 October, ${ }^{1592}$ the Government criticized the behavior of the Netherlands Supreme Court during the occupation, stressing that a more resilient attitude of the Netherlands Supreme Court would have been a valuable contribution to more energetic resistance of the population. ${ }^{1593}$ Although the Government in principle recognized the constitutional guarantee of irremovability, it also indicated that under the present circumstances in individual cases an exception to this principle was justified. The issue of the purge of the courts would be dealt with in a separate decree, with as little detriment as possible to the constitutional principle of irremovability. ${ }^{1594}$

At the same time as the Government decided to publish the correspondence in the press it indicated that on 10 October 1945 the cassation procedure would be reinstated. ${ }^{1595}$ In a letter ${ }^{1596}$ informing the Queen of the state of affairs concerning the Supreme Court the Minister of Justice elaborated on the Government's position. Although the Government considered objections to the Supreme Court's policies during the occupation justifiable, it also thought that staying the Supreme Court's official duties and the impossibility to start an investigation exacerbated the measures taken against the Supreme Court. This was especially the case as compared to what had been originally intended with the Purge Decree. Furthermore, the Gerbrandy Government's lifting of the measures, which had also been done without any investiga-

\footnotetext{
$15 \% 1$ Ministerie wan Justitie, Depot 164 Zuivering Hoge Raad der Nederlanden 1944-1946, No. 25 , Notulen van de bijeenkomst tussen Minister-President Schermerhorn en Raadsheer van den Dries van 18 angustus 1945 .

1592 Ministetie van Justitie, Depot 164 Zuivering Hoge Raad der Nederlanden 1944-1946. Brief Minister van Justirie Kolfschoten aan de Hoge Raad der Nederlanden van 4 october 1945.

I3r. Jong (deel 12-1), p. 382; Mazel, p. 161

1594 Ministerie van Justitie Depot 164 Zuivering Hoge Rad der Nederlanden 1944-1946, brief Minister van Justitie Kolfschoten aan de Hoge Raad der Nederlanden van 4 october 1945.

1595. Koninklijk Besluit van 1 oktober 1945, Besluit betreffende de rechtspraak in cassatie, Stb. 1944/1946, F 207 .

15\%6 Ministerie van Justitie, Depot 152, brief Minister van Justitie Kolfschoten aan Koningin Wilhelmina van 4 oktober 1945.
} 
tion, was some kind of anti-climax to the policies of the previous Government. The Schermerhorn Government, however, took into account the principle value and meaning of the constitutionally guaranteed independence and irremovability of the highest organ of the Judiciary, which could not be neglected and set aside without impunity.

There was criticism from many sides of the behavior of the Netherlands Supreme Court. ${ }^{1597}$ The law journal Nederlands Juristenblad (NJB) wrote that although the cassation procedure had been re-established, the Netherlands Supreme Court did not enjoy the trust of the population it should enjoy. It would be desirable that a higher instance than the Government would judge the behavior of the Netherlands Supreme Court during the occupation. This could be the new popular representation, which was to be ellected in the spring of 1946. In order to enable this, it was argued the Netherlands Supreme Court should submit its notice to the Government. ${ }^{1508}$

One day before the opening session of the interim Parliament, on 26 October 1945, the Government announced Royal Decrees F 242 and F 243 dealing with the 'denazification' of the members of the courts. ${ }^{159 \%}$ F 242 concerned judges, who had been appointed before the Second World War. F 243 dealt with the purge of the judges, who had been appointed during the occupation and the re-instatement of those judges the Civil administration had removed from office. Attached to every Court of Appeal was a Council for the Purge of the Judiciary, the members of which the Queen appointed and would be able to dismiss. ${ }^{1600}$ The councils for the judicial purge had the discretionary power to initiate an investigation against members of the Courts of Appeal, District Courts and Cantonal Courts. Their recommendation would then be submitted to the Special Tribunal for the Judiciary for cases concerning prewar appointees and the Minister of Justice for cases involving occupation appointees. 1601

In order to protect the independence of the prewar appointees as much as possible, ${ }^{1602}$ the Government had created the Special Tribunal for the Judiciary. The Queen ${ }^{1603}$ would appoint its President and members, who could only be removed from office upon their own request. ${ }^{1604}$ The most important power of the Special Tribunal for the Judiciary was the exclusive right to temove prewar appointees to the courts from office. ${ }^{1605}$ Besides this, the Special Tribunal for the Judiciary could advise the Government by virtue of article 6 of Royal Decree F 242 on other measures.

1997 See also Boer, ea.; Nispen tot Sevenaer, Beschouwing.

159.8. Redactie NJB 1945 .

15*9 Koninklijk Besluit van 26 oktober 1945, houdende nadere regelingen aangaande de zuivering der rechterlijke macht, Stb. 1944/1946, F 242 and Koninklijk Besluit van 26 oktober 1945, tot waststelling van nadere reglingen ten aanzien wan in de bezettingstijd benoemde en ontslagen leden der rechterilijke macht, Stb. 1944/1946, F 243. Article $8(1)$ of Royal Decree F 242

Iro: Article $8(2)$ of Royal Decree F 242

i $(x+1)$ See Mazel, p. 163

now 3 President was mr J.R.H. van Schaick, Secretary dr L.W.G. Scholten and members were Prof. mr P. Scholten, mr J.K. Onnen, mr G. Kirberger, mr R.P. Cleveringa, mr J. Verdam, Jhr. mr P.J.H.M. van der Does de Willebois, mr F.F. Viehoff, mr Th.L. van Berckel, mr F.J.W.M. de Nerée tot Babberich and mr H. de Bie. On 31 January mr Viehoff left the Special Tribunal for the Judiciary and was replaced by mr Cleveringa. Prof. mr Scholten died on 1 May 1946.

wout Article 7 of Royal Decree F 242.

1605 Article 3(1) juncto article 2(1) Royal Decree F 242 
On the basis of the purge councils" recommendation the Minister of Justice, without reason, could suspend any member of the courts the occupant had appointed. ${ }^{6066}$ Moreover, only the Minister of Justice would decide on a removall from office of an occupation appointee. 1607

The Special Tribunal for the Judiciary conducted 16 investigations against prewar appointees. ${ }^{1608}$ Two case filles, which concerned a president of a District Court and a deputy judge, were missing. "The outcome of four investigations entailed the dismissal of two vice presidents of a District Court and two judges. On the recommendation of the Special Tribunal these two judges were dernoted to positions of registrars at a District and Cantonal Court. In elleven cases no measure was taken. They involved one justice at a Court of Appeal, four presidents and two vice presidents of a District Court, two judges and two deputy judges. For one judge the Special Tribunal for the Judiciary recommended exclusion from promotion for three years. The case of another judge had not been decided upon yet. One other judge was removed from office, whereby the total number of the dismissals of prewar appointees for their conduct during the occupation came to five.

On the basis of Royal Decree F 243 the occupation appointees were dismissed, but ordered to remain in office after the occupation, unless they had been suspended and until they were factually given notice. ${ }^{1610}$ The number of occupation appointments to which this Royal Decree applied was 397 , including judges, court registrars and public prosecutors. Of these 397,22 were re-appointed and given a promotion, being part of the normal promotion cycle after the occupation. Two hundred and eighty-eight recommendations were given for reinstatement in the same office. Eleven judicial officers were recommended for a lower office, which for the courts included a member of a Court of Appeal and six judges of a District Court. ${ }^{1611}$ Forth-

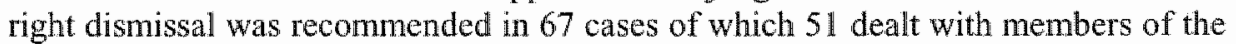
courts. These were a President, one Vice President, eight members and two deputy members of Courts of Appeal, three Presidents, one Vice President, nine members and six deputy members of District Courts, eight Cantonal judges and twelve deputy Cantonal judges. 1612

In 1946 as compared to $194070 \%$ of prewar appointees were still in office, of whom $8 \%$ had received a promotion either during the occupation or in the postwar period. ${ }^{1613}$ However, as compared to 1940 barely $88 \%$ of judicial offices was still occupied in 1946, possibly due to the difficulty of finding willing and suitable candi-

trim Afticle $3(2)$ juncto article 2(2) Royal Decree $F 242$.

16 Article $3(2)$ juncto article 2(2) Royal Decree F 242 .

tribs Bijlage A der Rijksbegrooting voor het Dienstjaar 1946, MvA, IVe Hoofdstuk, Afd. II.

(iw) The Government's numbers in the Rijksbegrooting (ibid) were those the Special Tribunal for the Judiciary had supplied. However, at the Ministry of Justice, which was the depository for the documents of the Special Tribunal for the Judiciary until their recent transfer to the Nationaal Archief, instead of 16 only 14 personnel files which had been decided on the basis of article 9, were present.

1610 Article 2 of Royal Decree $F 243$

1641 For a criticism of the policy of reappointment into a lower office see e.g. Kantonrechter.

161 Bijlage A der Rijksbegrooting voor het dienstjaar 1946, MvA, IVe Hoofdstuk, Afd. II. This meant that seven cases were unaccounted for!

161. See ANNEX 6 Table 1. Of a total of 780 prewar appointees in 1940501 prewar apponintees (O) plus 45 prewar appointees who had received a promotion (P) were still in office. Of a total of 546 prewar appointees $(\mathrm{O}+\mathrm{P}) 45$ had received a promotion $(\mathrm{P})$. 
dates during the occupation, the impact of the purges, resignations, retirements and deaths. ${ }^{164}$ At least twenty percent of those in office in 1946 had been appointed during the occupation.

\subsubsection{The postwar period, the Supreme Court and its occupation policy continued}

In order to occupy the vacancies in the Netherlands. Supreme Court, the interim Parliament at the end of 1945 had to decide on the new List of Recommendations. For three vacancies the Supreme Court had proposed Lists of Recommendations. On 13 December 1945 the Netherlands Supreme Court had put occupation appointee Justice Smits in first place for the first vacancy. During the vote in Parliament, only after three voting rounds the Lower Chamber voted in favor of putting Smits in first place, with the lowest possible majority. ${ }^{1616}$ However, as will be shown later on, his reappointment would still not be certain. For the second vacancy the first two candidates on the List of Recommendations withdrew their candidacy. Contrary to constitutional convention ${ }^{16: 7}$ Parliament proceeded to draw up its own List of Recommendations, deviating from the Supreme Court's List and placing two candidates in first and second place whom the Supreme Court had not recommended. The Supreme Coult's recommendations for the third vacancy were followed. ${ }^{1618}$

Many MPs also expressed their disappointment about the attitude of the rest of the courts during the occupation. ${ }^{1619}$ The Minister was in agreement, although he also pointed out that the courts' attitude should not solely be judged on the basis of their external policies or rather the lack of those. In the Minister's opinion numerous members of the Judiciary, the public prosecutor's offices as well as the courts, had deliberately omitted certain acts to save fellow countrymen. This was done fully knowing the possible consequence, but also without the knowledge of the accused involwed. 1620

The Special Tribunal for the Judiciary in conducting the purge of prewar appointees was considering to ex officio initiate an investigation against the Netherlands Supreme Court. The Minister of Justice intervened on 11 March 1946, indicating that after the meetings with the Supreme Court, the correspondence and the public renunciation of its occupation policies the Government considered the matter solved. ${ }^{1621}$

\footnotetext{
1974 See ANNEX 6 Table 1. Compare totals 1940 and 1946.

ws See ANNEX 6. Table 1. Compare those newly appointed during the ocempation (N) to the tout of 1946

164 HTK 1945/1946, 4de Vergadering van Donderdag 13 December 1945, p. 21. See also Bijlage A der Rijksbegrooting voor het Dienstjarn 1946, MW , TVe Hoofdstuk, A.P. II, p. 23.

14:17 See Chapter 4.5, note 868 .

164 HTK 1945/1946, 4de Vergadering wan Donderdag 13 December 1945, p. 21-22 en Bjlagen 111 1-2. See also Bijlage A der Rijksbegrooting woor het Dienstjaar 1946. MwA. TVe Hoofdstuk, Afd. LI, p. 23.

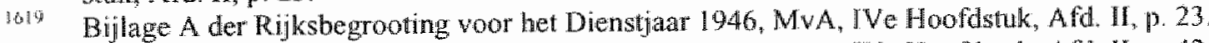

1020 Bijlage A der Rijksbegrooting voor het Dienstjaar $1946, \mathrm{MvA}, \mathrm{IV}$. Hoofdstuk, A fd. II, p. 42.

162! Ministerie van Justitie, Archief Hooge College voor de Rechterlijke Macht, brieven wan de Mimister van Justitie an het Hooge College voor de Recherlijke Macht van 26 septemben 1945 en 4 october 1945; Ministerie van Justitie, Archief Hooge College voor de Rechterligke Macht, Nota inzake zuivering vam de Leder wan den Hoogen Raad wan 25 April 1946, p. 1 Also published in: NJB 1946, p. $301 \mathrm{ff}$.
} 
Publicly the Government announced that the meetings between the Government and the Supreme Court between August and October 1945 were supposed to have been a substitute for purge proceedings. ${ }^{1622}$ Although the Government had publicly conderined the policies of the prewar members of the Supreme Court, the Minister of Justice stated that no one could suspect these members of the Supreme Court of unpatriotic behavior or a pro-German attitude. . $^{1623}$

Asserting its independence the Special Tribunal for the Judiciary nevertheless invited Justice van den Dries to discuss a possible investigation of the Netherlands Supreme Court during the war. Refusing to come in person van den Dries replied in a letter that after the Gerbrandy letter, the discussions and correspondence with the Schermerhorn Government and the governmental letter publicly condemning the Supreme Court, the Court would not defend itself for the third time. Besides, so van den Dries, this would contradict the position the Government had adopted in this matter. ${ }^{1624}$

Assuming the other members of the Supreme Court shared van den Dries's opinion the Special. Tribunal caved in. Since the Purge Decree of 26 October 1945 had been put into force after Gerbrandy's letter of 4 October $1945{ }^{1625}$ the scope of this decree did not exclude initiating an investigation against the Netherlands Supreme Court. However, the correspondence and the discussions between the Government and the Netherlands. Supreme Court, although not unambiguous in every regard according to the Special Tribunal for the Judiciary, could not be given a different interpretation than that of the Government and the Supreme Court. ${ }^{8626}$ Initially investigations had been started against Justice Smits, but the Special Tribunal for the Judiciary had convincingly determined his innocence and that his appointment had been regularly made. ${ }^{1627}$

When in July 1946 a new Government took office the problem of the Netherlands Supreme Court was still lingering for the new Minister of Justice van Maarseveen. The purge investigations of the prewar members of the Netherlands Supreme Court had not amounted to anything. Furthermore, the Government wanted to press ahead with new appointments to the Netherlands Supreme Court, since, already for almost nine months, it had operated with only nine members, including Smits, who had been allowed to remain in office awaiting his re-appointment. Even though the

\footnotetext{
1622

Bijlage A der Rijksbegrooting voor het Dienstjaar 1946, MvA, IVe Hoofdstuk, Afd. II, 42.

HTK 1945/1946, 17de Vergadering van 22 Jamuari 1946, p. 374.

Ministerie van Justitie, Archief Hooge College voor de Rechterlijke Macht, Nota inzake zuivering van de Leden van den Hoogen Raad, p. 2.

This was the date the Hooge College gave in its Nota inzake zwivering van Leden van den Hoogen Raad. Mazel gave a different date; see ibid.

1626 For a criticism of this decision see also Redactie NJB 1946, p. 317; NIOD, Doc II, no. 658 Rechterlijke Macht, No. 2, brief Groote Advies Commissie der Illegaliteit aan de Minister wan Justitie van 4 mei 1946; NIOD, Doc II, no. 658 Rechterlijke Macht, No. 2, uittreksel brief Minister van Justitie aan de Groote Advies Commissie der Illegaliteit 26 November 1945.

1627 Ministerie van Justitie, Depot 164 Zuivering Hoge Raad der Nederlanden 1944-1946, Nota van den Minister wan Justitie aan den Raad van Ministers m.b.t. het Hooge Raadsprobleem 27 september 1946; Archief Hooge College voor de Rechterlijke Macht, brief Hooge College voor de Rechterlijke Macht aan de Minister van Justitie van 15 april 1946. This was contrary to what Sandberg, p. 173 claimed. See also Amsterdamsch Dagblad 2 januari 1946, where in a front-page article a Public Prosecutor at the Special Court of Cassation came to Smits's defense.
} 
new Government considered it possible not to re-appoint Smits, it decided against that option. The reason was not only that Parliament had in the end agreed to his re appointment, but also that Smits should not be made a scapegoat for the Supreme Court's policies during the occupation, for which its members were thought collectively responsible. ${ }^{1628}$ Justice Donner also wrote the Govemment, trying to ascertain that it would not drop Smits's appointment and as such make a statement about the Supreme Court's policies during the occupation. ${ }^{1629}$

\subsubsection{The Supreme Court and judicial review of exile measures?}

In October 1946 the Netherlands Supreme Court would finally be in a position to rule on the validity of the exile measures. ${ }^{1630}$ It argued that, under stuch circumstances as had occurred, the Government or that part of the Government which was still operational, was equipped with the complete sovereign powers of the State, inchuding those belonging to State organs that were not operational. This naturally included the power to issue regulations of a general nature, usually belonging to the province of the Legislature. In executing this power the Government was of course, so the Supreme Court, not bound by existing legislation, not even to a certain kind of legistation commonly called constitution. However, international law could have placed limitations on these governmental emergency powers. If the govemmental emergency legislation did not contain an expiration date concerning its validify, it could only be replaced by posterior legal measures. The question whether courts were atlowed to review the London Royal Decrees in a concrete case the Supreme Count answered differently with reference to the legality to issue the measure and the legality of the content of the measure.

Courts were only able to judge whether the factual conditions for a "dictatorial period', which justified issuing emergency measures, had been fulfilled. This meant, so the Netherlands Supreme Court, that courts were only allowed to review whether the Legislator was actually unable to function and whether the dictator either according to national legislation or according to some specific emergency legislation was competent.

However, the courts could not review content or faimess of the measure. In this case the Queen was competent to issue these Royal Decrees, because under nomal circumstances she exercised legislative powers together with both Chambers of Parliament, the States-General. Only the resurrected, normal Legislature could abolish these decrees, so the Netherlands Supreme Court.

In issuing this ruling the Supreme Court was completely in line with academic opinion of one of the foremost legal scholars in The Netherlands. ${ }^{1631}$ Also the Special Court of Cassation ${ }^{16.32}$ and the Central Appeals Court for the public service and social

162 Ministerie van Justitie Depot 164 Zuiwering Hoge Raad der Nederlanden 1944-1946, Nota wan den Minister van Justitie aan den Raad van Ministers m.b.t. het Hooge Raadsprobleen 27 sep tember 1946 .

Ruiter, p. 231

1630 Hoge Raad 30 october 1946, NJ 1946, 737.

16.31 Pot, Staatsinood, p. 245. See also Welderen, p. 120-121

1632 Bijzondere Raad wan Cassatie 5 December 1945, N.O.R., 150. This was the thighest special purge court in The Netherlands established to adjudicate war crimes. 
security matters ${ }^{1603}$ accepted the legality of these London Royal Decrees without any limitation.

The question of retroactivity concerning whether legislation of the Governmentin-exile was applicable during the occupation on the occupled territory was answered in a case before the Hague Court of Appeal and the Supreme Court. ${ }^{1634}$ In Damhof ${ }^{1635}$ the Hague Court of Appeal looked at national law and decided that a Royal Decree enacted in exile, since it was enacted by the legitimate Netherlands Government and published according to the conditions established by law, albeit in London, had force of law during the occupation.

In Robaver ${ }^{1636}$ parties argued before the Suprene Court that international law prohibited the exile Government from enacting measures that would be applicable to Netherlands nationals on the occupied territory. The Court avoided the question, stating that an alleged violation of principles of international law could not give rise to cassation.

This was correct in that article 99 Judicial Organisation Act (1827) allowed cassation for amongst others violation of the law. ${ }^{1637}$ The Supreme Court had interpreted this provision in 1906 to include intenational treaty law duly concluded in accordance with national law ${ }^{1638}$ and under the circumstances of the occupation the occupant's measures. Netherlands legislation nevertheless did not allow courts to apply customary law when dealing with Netherlands law, ${ }^{1639}$ the principle of which could be transposed to international treaty law duly concluded according to Netherlands law and the application of any kind of customary international law.

However, article 43 Hague Convention had been incorporated into Netherlands law. The international law parties in this case referred to, although not codified, was nevertheless part of the customary law background to article 43 Hague Convention. ${ }^{1640}$ During the occupation the Supreme Court in its Judgment on judicial review had also invoked the customary law background of article 43 Hague Convention in order to interpret it. ${ }^{1641}$ Particularly whether courts could review occupation measures was not explicitly codified, but had to be interpreted from the article using customary international law as it had existed before the codification of that article. It could be argued that whether exile measures were applicable on the occupied territory also belonged to the same customary intemationall law background of article 43 Hague Convention, the interpretation of which could apply to this case. Although the Supreme Court was initially of the opinion that international law could have placed limitations on these governmental emergency powers, it chose not to do so. As

163 CRvB 25 maart 1946, AB 1946, 4. This was one of the highest administrative courts.

triat See also Jansma, p. 99-100.

W35. Genechtshof "s-Gravenhage (le Kamer) 3 maart 1949, NJ 1949, 575.

16.36 Hoge Raad 13 januari 1950, NJ 1950, 493. NB see also Hoge Raad 30 oktober 1946, NJ 1946, 737.

Ui.3. See also Chapter 4.8 .

this Hoge Raad 25 Mei 1906, WvhR, 8383 . The requirements in order to be able to invoke rights from a treaty to which The Netherlands were a party were ratification by Parliament, assented to by the Queen and due promulgation.

\#14

Anticle 3 Wet van den 15 den Mei 1829, Stb. 1829, No. 28 , houdende algenneene bepalingen der wetgeving wan het Koningrijk, zoals gewijzigd bij de Wet van 26 april 1917, Stb. 1917 , No. 303.

wisth See Chapter 6.1 .

thit See Chapter 4.8 . 
shown earlier, customary international law did place several limits upon an exile Government's powers. ${ }^{1642}$ However, in a later judgment the Supreme Court retracted. this earlier statement.

Moreover, the Supreme Court also denied the contention that the exile measures did not satisfy the legislative provisions concerning publication. The applicable Act of Parliament ${ }^{1643}$ provided for the fact that after publication Acts of Parliament should be known in all parts of the Kingdom. The Court argued that article 2 also stated that if an Act of Parliament did not contain a date for its entry into force, it was supposed to enter into force 20 days after its publication. This argument would therefore render the claim that this legislative provision prescribed an Act to be factually known in all parts of the Kingdom invalid. Moreover, so the Court, although the exile measures had not been published in the customary way, but rather in London, also did not impair their validity. The Government and Queen, in case of an emergency situation, were competent to chose a different method to publish their decrees.

The latter claim was certainly not founded in Netherlands law, since Netherlands legislation prescribed that all Acts, proclamations, publications and other decisions of the Sovereign would only be published in the Netherlands Official Journal. ${ }^{1644}$ Although this legislation did not prescribe that the Netherlands Official Journal had to be published in The Netherlands, it did oblige municipalities to obtain the journal in order to be informed of new legislation. This element showed that the purpose of publication was to distribute knowledge of new legislative provisions, tailure of which would result in violation of the law. Moreover, in practice, it was nearly impossible for citizens on the occupied territory to gain knowledge of the content of the exile decrees, not in the least because the exile Govemment was silent about most of them. Only a few were made public via radio, underground press or in any other way. ${ }^{1645}$

What was even more interesting about this case was that parties made a claim as regards article 43 Hague Convention. The claim itself is not important in this context, but the Supreme Court's reaction is. The Court neither denied nor affirmed a review competence under Article 43 Hague Convention, but in effect showed it had exercised review. Admittedly this was the civil chamber and not the criminal chamber which had rendered the Judgment on judicial review during the occupation. However, as shown earlier, the Court as a whole had previously supported the contention that courts could not review measures for compliance with the Hague Convention. ${ }^{164 t}$

The Supreme Court's ruling on the validity of exile measures was a violation of the Netherlands Constitution. For example article 21(2) Netherlands Constitution stated that the seat of Govermment could under no condition be placed outside the territory of the Kingdom of The Netherlands. This meant that in its functioning the

\footnotetext{
S6.72 Chapter 6.1.

16w. Article 2 Wet van den $15 \mathrm{den}$ Mei 1829, Stb. 1829, No. 28, houdende algemeene bepalingen der wetgeving van het Koningrijk, zoals gewijzigd bij de Wet van 26 aprill 1917, Stb. 1917. No. 303.

I6.44 Article 1(2) Besluit van den souwereinen vorst van den 18 den December 1813 No. 5. Stb. 1814, No. 1, betrekkelijk de daarstelling van een Staatsbliad der Vercenigde Nederlanden. Emphasis in original! See also Besluit van 22 December 1863. Stb. 1863, No. 149, ter nadere regeling van de wijze en den worm wan atkondiging van Wetten en Koninklijke Besluiten.

16.5. Brandhor, p. $408-409$.

1646 See Chapter 4.8 .
} 
Government was overstepping the bounds of the Constitution. The legislative intent of this article was, however, to assure that the Crown would not come under foreign influence and be estranged from the Netherlands population. ${ }^{1647}$ Moreover, moving the seat involuntarily, due to force majeure was not deemed contrary to the legislative intent of this constitutional provision. ${ }^{1648}$

More problematic was that the Constitution did not grant the Government and the Queen any legislative powers. Monarch and Parliament jointly exercised the highest legislative powers. ${ }^{1649}$ This meant that only in co-operation with Parliament the Monarch could enact legislation containing penal provisions. ${ }^{1650}$ Any legislative measures the Monarch enacted without the support of Parliament could not bind citizens, but merely deal with organizational issues concerning State service. ${ }^{1651}$ Therefore, this London legislation by Royal decrees appeared to be only supported by unwritten constitutional law, ${ }^{1652}$ which had never been used nor described. An argument in favor of this unwritten constitutional law might be that the Constitution was not an exhaustive text since it only dealt with peacetime situations. ${ }^{1653}$ However, the Constitution itself refuted this. Firstly, it did not state it was only meant for peacetime situations. Moreover, its amendment procedure was very clear in that the validity of the constitutional rules could only change through a certain, well-described procedure. ${ }^{1654}$ In violation of constitutional rules the Netherlands courts therefore allowed for the execution of exile measures.

\subsubsection{Solving the crisis around the Supreme Court}

Although the Supreme Court was functioning again and had even ruled on the validity of exile decrees, its personnel problems had not been solved yet. In order to put an end to the continuing crisis the new Government proposed Donner for the position of President of the Netherlands Supreme Court. Donner refused several times, but in the end accepted the appointment conditionally, also since the Minister of Justice threatened to appoint an outsider. ${ }^{1655}$

Donner firstly made his appointment conditional on the consent of all members of the Netherlands Supreme Court. Although van den Dries initially did not agree, he later gave in, together with all other members of the Netherlands Supreme Court. On 8 November 1946 Donner's second condition was fulfilled in that the Queen withdrew her objections to the first new appointments after the war. In the end it had taken more than a year before the Queen no longer refused to assent to Smits's re-

\footnotetext{
164? See also Bolhuis, p. 377 .

1648 HEK 1921-1922,502-527; Bolhuis, p. 378; Brandhof, p. 90.

16419 Article 1121938 Constitution. See also Savornin Lohman, p. 261.

1650 Article 571938 Constitution.

1651 See also Wijthoff, p. 161 .

1692 Dullemen, p. 8 .

16.53 As was the Govermment's position during debates over amending the Constitution in 1921/1922. See HEK 1921-1922, 502-527; Brandhof, p. 90.

106: Brongersma, p. 361-369

1695 See also Archief Hoge Raad der Nederlandlen, Notulen Algemene Vergaderingen van 1921. 1958. Algemeene Vergadering van den Hoogen Raad der Nederlanden op Vrijdag 17 Angustas 1945, des voormiddags te 10\% uur, p. 42 en op Donderdag 5 September 1946, des namiddags te $1 \frac{1}{2}$ uur, p. 49.
} 
appointment and the appointments of Feber and Rombach to the Supreme Court. ${ }^{1696}$ The Queen, however, appeared not to have given in without a condition of her own. Neither van den Dries, Fick, nor any of the other prewar appointees, except for Donner of course, should ever be appointed President of the Supreme Court. ${ }^{16 \%}$

On the same day Donner was appointed President, van den Dries and Fick were appointed Vice Presidents of the Netherlands Supreme Court. Their installation into their new office was a sober affair, whereby no speeches were given and no comments were made about the past. Also former President Visser, who had been removed during the occupation due to his Jewish ancestry, was not commemorated during the installation. 1658

At the end of November 1946 the Supreme Court decided to nevertheless hold a commemoration for President Visser and all members of the Judiciary that had fallen during the occupation. President Donner, with the consent of all members of the Supreme Court, made a promise to former President Visser"s daughter. She had offered to pay for a portrait of her father in presidential gown to be hung at the Supreme Court's gallery of portraits of Presidents. The current portrait showed Visser in a regular justice gown. Donner, with the consent of all members of the Court, suggested that Visser's portrait in justice gown would be hung in perpenuity in the President's office. ${ }^{169}$ This was a tribute to former President Visser and, whether intended or not, a reminder for every President and members of the Court when meeting in his office, of the occupation and the difficulties for the Supreme Court during that era.

\subsubsection{Concluding remarks on the Netherlands courts and 'denazification' measures}

The exile measures the courts were confronted with had no precedent in Netherlands legal history. Lower courts were first confronted with these measure, because the activities and members of the Supreme Court were suspended. Without question the lower courts applied these exile measures. Also the Supreme Court, when finally able to rule on the issue, ruled that courts could only assess whether the circumstances for emergency measures were fulfilled, but not their content. This in spite of the fact that neither the text of the Constitution nor any kind of legislation recognized these emergency measures. However, the Supreme Court did make certain reservations to accepting the validity of these exile measures, referring also to international law, but it did not limit the validity of exile measures. In a later judgment it nevertheless declared that principles of international law could not be applicable in Netherlands counts.

The role of the Netherlands Parliament was rather ambiguous. In spite of attempts of some of its members to have the exile measures ratified, a majority voted against two proposals to do so. This might of course indicate an implicit recognition of the legality of the exile measures and the Government's claim these possessed

\footnotetext{
1650 Koninklijk Besluit an 8 november 1946, no. 28. NB Rombach was the Advocate General who had written his opinion on the Judgment on judicial review. See Mazel, p. 165, 174. Ruiter, $p, 233$.

Ifss Ruiter, P. 234.

165\% Archief Hoge Rad der Nederlanden, Notulen algemene vergadering van 1921 -.. 1958, Algemeene Vergadering op Donderdag 21 November 1946 des voormiddags te 10 un., p. 51 .
} 
force of law. However, the recognition was not explicit and the Supreme Court did not use an argument that Paflianent had implicitly recognized the exile measures, if Parliament had actually intended to do so.

There were also other legal questions the courts encountered, dealing amongst other with non-retroactivity and publicity requirements. Also in these cases the Netherlands courts dewiated from existing legislation in applying the exile measures. Therefore, in violation of Netherlands law the courts allowed for exile measures conceming the "denazification" of the courts to be executed.

\subsection{COMPARING THE BELGIAN, LUXEMBOURG AND NETHERLANDS COURTS" ATTITUDES TOWARDS THEIR EXILE GOVERNMENT'S 'DENAZIFICA TION" MEASURES}

Also in comparing the reaction of the courts regarding the exile measures of their Gowernments in the post-war era, Luxembourg, like during the occupation, cannot be compared to the situations in Belgium and The Netherlands. The fact that the Luxembourg Parliament had ratified all exile measures, endowing them with force of law, meant that the Luxembourg courts, under Luxembourg law, were not allowed to exercise review. Similar to an Act of Parliament, Luxembourg courts were legally obliged to apply all exile measures. Also, Luxembourg courts refused to apply customary international law in dealing with the exile measures. Therefore, a positivist attitude of the Luxembourg courts could only have resulted in application of these exile measures.

The situations in Belgium and The Netherlands were different from the one in Juxembourg and in some instances comparable to one another. Parliament in both countries had not explicitly ratified their Government's exile measures. In spite of the differences in composition of their respective exile Governments, with notably Belgium having a King in enemy captivity, Parliaments in both Belgium and The Netherlands recognized the exile Governments as the legitimate Governments of their respective States. This also in spite of the fact that during the occupation the composition of both Governments had changed. ${ }^{16 \text { int }}$

Nevertheless, in Belgium an "implicit recognition, especially of the force of law of these measures, was less clear than in The Netherlands. The Belgian Parliament's recognition of the exile Government as Belgium's legitimate Government might have entailed recognition of the validity of these measures. However, in The Netherlands the fact that Parliament wice rejected a motion for explicit recognition of the exile measures indicated, more so than in Belgium, that Parliament might have considered the exile measures already possessed force of law. For comparing the situation of the courts the situation was nevertheless more similar, since neither the Belgian nor the Netherlands courts referred to a possible implicit recognition by their respective $\mathbb{P a r}-$ liaments of the force of law of the exile measures. This meant that both Belgian and Netherlands courts had to look within their own legal system in order to determine validity and the question of force of law in dealing with the exile measures. Moreover, courts in neither Belgium nor The Netherlands applied customary intemational law in dealing with this issue. 
Different than in The Netherlands the Belgian Cour de cassation's early judgment on the exile measures meant that early on there was certainty about the highest Belgian court's stance on these measures. In The Netherlands only lower courts would deal with exile measures until late in 1946 when the Supreme Court was finally in a position to render its judgment. The lower courts in Belgium had an early lead from their Cour de cassation to follow and unquestioningly applied the exile measures and granted them force of law. The Netherlands lower courts had no such lead, but also unquestioningly allowed for execution of the exile measures and treated them as if they possessed force of law.

The Belgian Cour de cassation and the Netherlands Supreme Court were in different positions at the end of the war. The Cour de cassation had retained a lot of its authority during the occupation, at least morally, and was neither as an institution nor through its members subject to purge proceedings. The Netherlands Supreme Court on the other hand had at least lost some of its moral authority during the occupation, something the harsh measures of the exile Government against the institution of the Court and its members accentuated. Arguably this put the Netherlands Supreme Court in a more difficult position as compared to Belgium's highest court, to possibly deny the validity of or determine the question of force of law concerning the exile measures.

As it turned out neither Court denied validity or force of law of their Government's exile measures. The Cour de cassation even appeared eager to settle the issue, using a minimum of legal argumentation, in spite of the fact that many legal objections could be made. If the Cour de cassation had applied Belgian law as it stood, it was highly questionable whether these exile measures would have possessed force of law, especially since Belgian law did not allow for a delegation of legislative powers. An extra-legal argument based upon necessity in order to save the nation or due to force majeure might have been a valid argument, but this was not a legal argument enshrined in Belgian law.

The Netherlands Supreme Court also did not refuse to apply the Netherlands Government's exile measures. What was interesting as compared to its Belgian counterpart was that the Netherlands Supreme Court did state that courts had a role in determining the validity of these exile measures. Courts at least had to determine whether the Legislator was actually unable to function and whether the dictator either according to national legislation or according to some specific emergency legislation was competent. Although the Supreme Court's outcome was not different as compared to the one from the Cour de cassation, the Supreme Court's conditions made it retain some control over a possible future enactment of such extra-constitutional measures.

The Belgian courts' dealings with their Government's extra-constitutional measures after World War One cannot completely explain the difference in approach after the Second World War. The measures after the Second. World War were different in nature from those after World War One in that during the latter period the King had been a fully functioning part of Government. The legal situation after the Second World War was therefore also novel for the Belgian courts.

However, as mentioned before, the outcome was not very different. Neither Belgian nor Netherlands law had provided for the Belgian and Netherlands Governments respectively to enact their exile measures with force of law. If the Belgian and 
CHAPTER 7

the Netherlands courts had taken a positivist stance their respective laws would not have allowed for the application and execution of their Governments' exile measures. 


\section{CHAPTER 8}

\section{CONCLUSION}

Did the courts' positivist attitude towards legal measures make it impossible to resist being a mere executive tool for the policies of the occupant and the government returning from exile? This was the main question around which an account of the courts in Belgium, Luxembourg and The Netherlands during and immediately after the occupation of World War Two was centered. The main conclusions have been elaborated on at the end of each chapter and in Chapters 5 and 7.4 Belgium, Luxembourg and The Netherlands, where possible, were compared. This chapter will nevertheless provide a more concise answer to the main question and offer some thoughts on the thesis of this research.

\subsection{BELGIAN COURTS DURING THE OCCUPATION AND POSTWAR PERIOD}

The experience of the Belgian courts during the occupation showed that the Statute on Delegation (1940) aided the courts in maintaining a positivist stance. Since a Belgian administration could enact measures on a legal basis independent from the powers of the occupant, the Belgian courts could continue to apply only Belgian law and were in a position to refrain from applying the occupant's factual measures. ${ }^{166 t}$ In principle a positivist stance of the Belgian courts enabled and did not make it impossible for them to resist becoming a mere executive tool for the occupant's policies. ${ }^{1662}$ Only where the courts, led by the Cont de cassation, deviated from strict adherence to either international or national law, it became more difficult to resist the occupant's policies as contained in decrees the Secretaries General had enacted. ${ }^{1663}$

Several factors allowed for the Cour de cassation and the other Belgian courts to back up their resistance against the occupant's measures with a collective threat of mass resignation. The ability of subsequent Secretaries General of Justice to keep new appointments in Belgian hands and the legal obligation to remain in office ensured that few of the occupant's supporters were appointed to the Belgian courts. The Cour de cassation's ability to lead the other courts and closed ranks reinforced a strong negotiating position with the occupant. However, both judicial crises resulted in a loss of power and therefore seemed to have ended in failure for the Belgian courts, which must have diminished the credibility of the Cour de cassation to successfully invoke a threat to lead other courts into suspending their duties. ${ }^{16}$ is

Nevertheless, in several instances strict adherence to law and the Cour de cassation's ability to lead the Belgian courts aided the courts in resisting the occupant's policies. In other instances, strict adherence to law would also have allowed Belgian courts to resist becoming a mere executive tool for the occupant's policies. There-

\footnotetext{
See Chapters 1.2.1, 1.2.2, 1.2.3,2.8 and 2.9

for 2 Chapters $2.4,2.7,2.8$ and 2.15 .

1663 Chapters 2.8,2.9 and 2.11.

los 4 Chapter 2.5 .

1605 Chapters 2.9 and 2,11.
} 
fore, a positivist attitude did not make it impossible for the Belgian courts to resist becoming a mere executive tool for the occupant's policies. ${ }^{1660}$

The Belgian courts and mainly the Cour de cassation did not question the legal basis the Government retuming from exile used and argued that the defense of the Belgian territory and the life of the nation necessitated that Belgium's sovereignty and its concomitant legislative powers were continued during the war. ${ }^{167}$. The Court's reasoning was contrary to several legislative and constitutional provisions and the legislative intent of one of the constitutional provisions. This was in stark contrast to the Court's attempts during the occupation to review the measures of the Secretaries General, who also did not possess legislative powers under the Belgian Constitution. No argument was made that the exile measures might be contrary to customary intemational law, but on the basis of existing Belgian law and case law Belgian courts would not have been able to refuse the application of a measure possessing force of law. However, in deviating from strict adherence to Belgian law Belgian courts became a mere executive tool for the exile Government's policies. 1658

\subsection{LUXEMBOURG COURTS DURING THE OCCUPATION AND POSTWAR PERIOD}

Luxembourg turned out to be a special case to which the main thesis question could not be applied during the occupation. Many documents dealing with the Luxembourg courts during the occupation were either missing or not publicly accessible. ${ }^{169}$ Furthermore, already from the beginning of the occupation Luxembourg courts could be circumvented, since the occupant's tribunals were competent for any case the public prosecutor initiated at the latter's tribunals. ${ }^{160}$ Numerous specific competencies granted during the occupation permanently removed many areas from the jurisdiction of the Luxembourg courts. ${ }^{1671}$ The introduction of the German judicial organization in effect abolished the remaining existing Luxembourg courts and established jurisdictions analogous to the former Luxembourg courts with some personnel continuity. ${ }^{1672}$ Besides, the appointment of German judges, ${ }^{1673}$ early abolition of the Cour superieure ${ }^{1674}$ and small size of the Luxembourg Judiciary, which could easily be replaced, made it extremely difficult to organize resistance against the occupant"s measures. A positivist attitude would therefore not have enabled Luxembourg courts. to resist executing the occupant's policies, lacking the possibility of adding a credible threat of mass resignation to induce the occupant to modify his policies. These factors in effect removed Luxembourg's experience during the occupation of World War Two from the scope of this research's thesis. ${ }^{1695}$

In the postwar period Luxembourg's Parliament ratified all exile measures. This endowed the exile measures with force of law. Luxembourg law did not allow courts

\footnotetext{
See also Chapter 2.16.

tot? Chapters 7.1.1 and 7.1.2.

lotes Chapter 7.2.4.

(66) Chapter 3.12 .

1670 Chapter 3.2.

167 Chapter 3.4 .

wo. Chapters 3.9 and 7.2 .2 .

$167 \%$ Chapter 3.5 .

167 Chapter 3.2.

1675 Chapter 3.12
} 
to review measures having force of law for compliance with the Constitution. Luxembourg courts also did not allow customary international law to be invoked. The Luxembourg courts" positivist stance in the postwar period made it impossible to resist becoming a mere executive tool for the exile Government's and, due to the ratification, Parliament's policies.

\subsection{NETHERLANDS COURTS DURING THE OCCUPATION AND POSTWAR PLRIOD}

Due to a delegation of powers from the occupant both national and the occupant's measures in The Netherlands would be based on the occupant's powers of war and occupation. ${ }^{1676}$ Contrary to Netherlands and international law courts applied these measures without question. ${ }^{1677}$ The Supreme Court declared that under the present circumstances, the regulations of the occupant and the Secretaries General could not be denied the same nature as Netherlands legislation. Problematic for the Court was that if it had not done so, Netherlands law would not have allowed it to hear cases involving occupation measures, since only violations of national law could be brought before the Court. Nevertheless, this was already a retreat from strict adherence to the law.

The Supreme Court also denied having competence to review the content of occupation measures, something many if not all Netherlands courts agreed with. However, article 43 Hague Convention and its interpretative background was not as unambiguous as the Court portrayed it to be. Netherlands courts could have found arguments supporting review or at least constraints on the acceptance and execution of the occupant's measures. ${ }^{1678}$ At the end of the occupation some courts allowed for challenges to a limitless acceptance of measures based upon the occupant's powers. 1679

Like in Belgium a collective threat of mass resignation would have reinforced demands of the courts against the occupant. However, due to the fact that neither the Supreme Court nor any of the Courts of Appeal led resistance against certain occupation measures, courts were unable to organize. Only in case of resistance against atrocities in a detention camp, a District Court managed to organize resistance, resulting in a closure of the camp. ${ }^{1680}$

Therefore, with more organization, a more positivist approach to international and national law would have made it possible for Netherlands courts to withhold unequivocal acceptance of all occupation measures and resist execution of at least some occupation policies. ${ }^{1681}$ Howewer, in deviating from international and national law, Netherlands courts became a mere executive tool for the occupant's policies.

The lower courts, and also the Netherlands Supreme Court when it was functioning again, accepted the validity and force of law of the measures the Netherlands Government had taken while in exile in London. This in spite of the fact that nowhere positive law allowed for measures to be taken outside the framework of the

\footnotetext{
$\$ 676$

Chapters $1.4 .1,1.4 .2$ and 1.4 .3

Chapters $4.2,4.3,4.4 .4 .6,4.7,4.13$ and 4.14

Chapters 4.8 and 4.2 .

1639 Chapter 4.15.

10.6 Chapters 4.10,4.1] and 4.17.

$168 \mathrm{~s}$

Chapter 4.17 .
} 
Netherlands Constitution. Parliament failed to explicitly ratify the exile measures, creating ambiguity and a supposition that it did consider ratification was not necessary for these measures to be valid and have force of law.

The Supreme Court did place reservations on the validity of exille measures and considered courts were competent to review whether the Legislator was actually unable to function and whether the dictator either according to national legislation or according to some specific emergency legislation was competent. It also initially ruled that international law could place limitations on the exercise of these governmental emergency powers, but in a later judgment denied this contention. However, in practice it did not put any limitations on the validity or force of law of the exile measures, even though there were several violations of national and international law to consider. ${ }^{162}$ Moreover, there were other issues challenging the validity of the exile measures, like non-retroactivity and publicity requirements. ${ }^{1683}$ A.lso in these cases the Netherlands courts deviated from existing legislation in applying the exile measures. Therefore, not taking a positivist stance made it impossible for Netherlands courts as regards Netherlands law to resist becoming a mere executive tool for the exile Government's policies.

\subsection{COMPARING THE BELGIAN, LUXEMBOURG AND NETHERLANDS COURTS DURING THE OCCUPATION AND POSTWAR PERIOD}

Only in a few situations the attitude of the courts of Belgium and The Netherlands during the occupation could be compared during the occupation. ${ }^{1664}$ Luxembourg's situation during the occupation of World War Two fell outside the scope of this research's thesis and could therefore only be part of the comparison in an even more limitative form. ${ }^{1685}$ In comparing the Belgian and Netherlands courts, however, Belgian courts were most positivist in their approach and most able to organize, allowing them to resist the execution of at least some occupation measures. Nevertheless, the Belgian courts did not have a consistent positivist attitude and allowed for illegal measures to be applied. Netherlands courts were less positivist in their approach and also less able to resist the execution of occupation measures. ${ }^{1686}$

Also during the postwar period Luxembourg courts were in a different situation as compared to their Belgian and Netherlands counterparts. Contrary to the Belgian and Netherlands Parliaments, Luxembourg*s Parliament explicitly ratified all exile measures, endowing them with force of law. The status of the Luxembourg exile measures was therefore unambiguous ${ }^{1 / 87}$ and Luxembourg courts therefore had no legal option to refuse application of these measures.

This legal situation was less clear in Belgium and The Netherlands, since neither State's Parliament had explicitly ratified their Government"s exile measures ${ }^{1685}$ and neither State's legal order contained explicit constitutional or legislative provi-

\footnotetext{
1628 Chapters 7.3 .5 and 6.1 .

16.8. Chapters 7.3.5 and 7.3.6.

10.4 Chapter 5.1.3.

loss Chapters 5.1.2, 3.12 and 5.1.1.

16ist Chapter 5.3 .

16:37 Chapters 7.2 and more specifically Chapter 7.2 .1 and 7.2 .4

1688

Chapters 6.2 .3 and 6.4 .3 .
} 
sions recognizing the exile Government's emergency powers. ${ }^{1689}$ Neither the Belgian nor the Netherlands courts denied validity or force of law of their Government's exile measures, although many arguments could be made for violation of national law. Contrary to its stance during the occupation the Cour de cassation in the postwar era even appeared eager to settle the issue, using a minimum of legal argumentation, whereas the Netherlands Supreme Court was much more cautious after the war. However, as mentioned before, the outcome was not very different.

The Netherlands courts did not allow for the application of customary international law, although the Supreme Court alluded to it in its first postwar judgement on exile measures, but later clearly ruled against it. ${ }^{1690}$ In Belgium customary international law was not invoked to invalidate exile measures, but Belgian courts could anyhow not refuse the application of a legislative act contrary to customary international law. ${ }^{16 \% 1}$ However, codified international law, such as the Hague Convention, could have been used to resist application of at least certain occupation measures, including the interpretative background of its provisions. In this respect, however, both the Belgian and Netherlands courts' positivist attitude did not allow for the application of customary international law to resist application of measures from their exile governments.

\subsection{COURTS, THE LAW AND REASONS NOT TO APPLY LAW DURING AN OCCUPATION AND POSTWAR PERIOD}

Although some courts more than others did not strictly adhere to positive law, what has to be stated very clearly here is that this research solely focused on law as an instrument to oppose application of occupation and exile measures. If positive law was available to refuse application of these 'extra-constitutional' measures, it is certainly legitimate to ask the question why courts did not use available legal instruments to refuse application of these measures? This is of course especially the case for many measures the occupant enacted, but the question can also be asked for certain exile measures that violated the constitutional order and fundamental rights as enshrined in it.

However, this research only sought to look at whether positive law provided courts with legal instruments to counter these measures and whether the use of these legal instruments did not allow them to resist application of these "extra-constitutional' measures. This research did not look at why these were not applied if they were available. Although legal rules are at the basis of the functioning of courts, courts might have other reasons than legal ones to decide to apply a legal rule or not, especially under such extreme circumstances as war and its immediate aftermath. This research touched upon, but did not go in depth on whether there were any other reasons for courts to apply "extra-constitutional' measures. What was also not researched was whether those reasons might justify the application of 'extra-constitutional' measures in violation of existing law. Undoubtedly there were various other,

1694 For Belgium see Chapters 6.2.2 and 7.1.1 and for The Netherlands see Chapters 6.4 .2 and 7.3 .5 .

Ifogh Chapter 7.3.5.

169. Chapter 7.1.1. 
non-legal reasons to nevertheless apply measures that violated the legal order, whether valid or not.

More so in The Netherlands than in Belgium, in the absence of prewar preparation of Govermment and Parliament for a possible occupation, courts were left in a position to face non-legal questions concerning applicability of illegal occupation. measures. The Netherlands administration and courts for example could not function during the occupation without measures based upon the powers of the occupant. The question of application of those measures was as much a legal as a non-legal question. If the Supreme Court had decided, in accordance with international and national law, that it could not apply the occupant's measures, as the Belgian courts had done, there were other, non-legal questions to face. During the extraordinary circumstances of the war and occupation measures needed to be taken to deal with the situation and the Netherlands Secretaries General had decided to use the occupant's powers to base their measures upon. In many cases no or insufficient other legal measures might have been available within the Netherlands legal order for the Netherlands courts to apply to cases arisen during the extraordinary circumstances of the war and occupation. It is therefore questionable whether, like the Belgian courts, Netherlands courts could have applied more or less equivalent Netherlands legislation where a German regulation existed. Presumably Belgium"s occupation during World War One left the Belgian courts a body of legislation that could be applied in order to deal with circumstances of war and occupation. But especially the Statute on Delegation (1940) enabled a separate Belgian administration to continue and enact measures dealing with the circumstances of war and occupation, allowing Belgian courts to refuse application of the occupant's measures. These choices were not available to Netherlands courts. Having less legal options, Netherlands courts were naturally faced with more non-legal questions, like the consequences of a possible decision to only apply measures emanating from the Netherlands constitutional order.

This did not mean the Cour de cassation did not face any non-legal questions. The Statute on Delegation (1940) and the administration of the Secretaries General with the enactment of decrees and the appointment of judicial officers created for the Belgian courts a measure of distance and independence from the occupant. The Secretaries General, as heads of the Belgian administration, would be the frrst to face most non-legal questions concerning whether and possibly how to accept the occupant's occupation policies and whether to enact a measure based upon Belgian law. The Belgian courts would of course be in the background with their powers of review and their notions of what kinds of measures the Secretaries General could enact. However, the Secretaries General were the first to make that choice.

As long as this system continued the Belgian courts would not be placed directly under the occupant's rule, as had been the case in the Netherlands from the begiming of the occupation. As a result, the Belgian courts would have a high vested interest in maintaining this system of administration and assuring the Secretaries General could continue their administration based in Belgian law. This made the Belgian courts very much dependent on the Secretaries General, since its independent position from the occupant relied on it. Besides the fact that its authority was already weakened, this might be another reason why the Cour de cassation allowed for the Secretaries General to use the Statute on the King's special powers (1939) as a basis for measures that would be beyond the courts' powers of judicial review. Although it 
would lose control over the measures the Secretaries General enatted in committee, the Belgian courts would not become directly dependent on the occupant.

Also for at least the immediate post-war period the administration and courts of Belgium, Luxembourg and The Netherlands could not function without certain measures the exile Government had prepared and all faced legal and non-legal questions concerning the applicability of these measures. Should courts nevertheless have strictly adhered to the law and have disregarded any other non-legall questions concerning applicability of the occupation and exile measures?

If non-legal questions concerning application of occupation or exile measures were to be considered, which ones should be taken into consideration as valid and which ones should be discarded? Salus rei publicae suprena lex esto would be a very vague legall standard to go by.

Codification of legal rules tries to pour policy decisions into a legal framework and provide general guidance for future cases. Of course, not for every future event general rules can be devised in advance. However, the question is whether Parliaments in co-operation with their Governments should at least enact some general rules in order to minimize the courts" confrontation with non-legal considerations when dealing with 'extra-constitutional' measures due to occupation or post-war impossibility of the normal constitutional organs to function. In the following and final chapter some remarks will be made about certain postwar developments on the international law of occupation and the role of national courts during an occupation. Moreover, also whether the Belgian or Netherlands Legislator addressed this issue in the postwar period will be touched upon. 



\section{CHAPTER 9}

\section{THE POSTWAR ERA AND MEASURES CONCERNING COURTS IN CASE OF AN ENEMY OCCUPATION}

\subsection{INTRODUCTION}

Can the idea of rules to limit war be reconciled with the idea of war at all? ${ }^{1692}$ Law is arguably a rational instrument and war is anything but a rational expression of the human psyche. When reason fails and passion takes over, why hope for reason in the form of law to restore the balance? And even if the attempt of using reason is the only available option to soften the effects of war and occupation, is law suitable or should the situation be left to those in charge during war and occupation to be dealt with expediently? If a choice is made for law, one could argue that an occupant's conception of law might be different from the occupied State's, making even the most clearly drafted text a legal minefield for lawyers. This would of course especially be the case where both sides have a different ideological background. Nevertheless, law seems to play a role in war and occupation, as also the developments in international and national law since World War Two attest to. Some general remarks will therefore be made about the role of law for an occupied State and more specifically its courts during an occupation.

This chapter will look at the main legal developments since World War Two at an internationall law level and possible postwar legal measures adopted in Belgium, Luxembourg and The Netherlands concerning the position and functioning of the courts during an enemy occupation. The research at hand indicated that law and a positivist approach to law would not have allowed courts to become a mere executive tool for the occupant's policies and would have required them to act differently in certain situations. ${ }^{1693}$ Therefore, whether to provide courts with a legal framework in order to guide their functioning during a possible enemy occupation is what will be touched upon in the final part of this chapter.

\subsection{INTERNATIONAL LAW DEVELOPMENTS SINCE WORLD WAR TWO}

After World War Two several major codifications concerning the laws of war were concluded. The Charter of the United Nations, as well as the European integration process can be seen as directly resulting from the Second World War and as an attempt to prevent the outbreak of war. More relevant in this context are those international law treaties trying to limit the effects of war once international organizations and States have been unable to prevent its outbreak. Some of these treaties also contain rules for the administration of occupied territory after the cessation of hostilities, but while the war still continues. ${ }^{1694}$ The four Geneva Conventions of $1949{ }^{1695}$ as

See also Best, Humanity, p. 296.

See Chapter 8.

See also Detter, p. 181-182.

First Geneva Convention for the Amelioration of the Condition of the Wounded and the Sick in Armed Forces in the Field of 12 August 1949 (entered into force 21 October 1950); Second Geneva Convention for the Amelioration of the Condition of the Wounded, Sick and Ship-
} 
well as the two Protocols of $1977^{1606}$ are the main international law treaties in this respect, ${ }^{16 \% 7}$ although many other treaties have been concluded dealing with other specific aspects of war.

The IVth Gerveva Convention of 12 August 1949 on the Protection of Civilians in Time of War (hereinafter Geneva Convention) contains rules further clarifying the Hague Convention. ${ }^{1699}$ Especially its articles $47-78$ are additional rules to articles 42 56 Hague Convention. ${ }^{1700}$ This means that for those parties already bound by the Hague Convention and now party to the Geneva Convention, parts of the Hague Convention are stijl the basis for their legal relations in case of war and occupation. ${ }^{1701}$ Only a select number of articles of the Geneva Convention still apply after

wrecked Members of Armed Forces at Sea of 12 August 1949 (entered into force 21 October 1950); Third Geneva Convention relative to the Treatment of Prisoners of War of 12 August 1949 (entered into foree 21 October 1950 ); Fourth Geneva Convention relative to the Protection of Civilians in Time of War of 12 Algust 1949 (entered into force 21 October 1950). See also Glalin, p. 696-697. For a background concerning the Geneva Conventions see Best, p. 80-114, Best, Humanity, p. 289-315 and Dongen, p. 117-147 concerning especially the VVth Geneva Convention.

Protocol additional to the Geneva Conventions of 12 August 1949, and relating to the Protection of Victims of Intemational Armed Conflicts of 8 June 1977; Protocol additional to the Geneva Conventions of 12 August 1949, and relating to the Protection of Victims of NonInternational Armed Conflicts of 8 June 1977. Both entered into force on 7 December 1978 (see Glahn, p. 698). As of 31 July 1998153 States are reported to have become a party to the Protocols, whereby 9 States only became a party to Protocol I and 2 States only to Protocol II (see <http://www.palestine-n .org/mission/3d_12 53 html $>(03-08-2004)$ ). For more background on the Protocols see Best, Humanity, p. 315-330.

See also Glahn, p. 758

See Glahn, p. 733-767.

David, p. 458-461; Benvenisti, p. 106 stated that most intemational law scholars after the adoption of the Geneva Convention continued to refer to article 43 Hague Convention as the framework for the occupant's prescriptive powers. The Geneva and Hague Conventions remain valid under all circumstances and are not subject to the condition of reciprocity (see Pictet, p. 90; Kallshoven " p. 59, 115; Detter, p. 404), especially since both are now seen as dew claratory of customary international law and therefore binding on all States whether party to these conventions or not (see Glahn, p. 769; Pictet, p. 89; Detter, p. 404).

Article 154 Geneva Convention. See also Verzijl, p. 161. Contrary to article 154 Geneva Convention Benvenisti, p. 31 claimed that Article 64 of the Geneva Convention is the successor to Article 43 Hague Convention.

Article 154 Geneva Convention states it is supplementary to Sections II and III Hague Conventions of 1899 and 1907. The 1907 Hague Convention was binding on all parties researched in this study. Moreover, at the end of 1955 all parties researched in this study had signed and ratified the Geneva Convention (see Verdrag van Genève betreffende de bescherming van burgers in oorlogstijd, van 12 augustus 1949, Trb. 1954, 192. Of the countries researched for this study, only the Netherlands made a reservation as regards article 68 paragraph 2 Geneva Convention (see Wet van 19 mei 1954 betreffende goedkearing van het Verdrag van Genève betreffende de bescherming van burgers in oorlogstijd, van 12 augustus 1949. Stb. 1954, 249 and Verdrag van Geneve betreffende de bescherming van burgers in oorlogstijd, van 12 allgustas 1949. Trb. 1954, 192). In the opinions of Pictet, p. 51 and Benvenisti, p. 103 the Geneva Convention has superseded the Hague Convention. Several rules in the Geneva Convention are indeed a deviation from former international law (see Chapters 2.14 and 4.16.) in that the taking of hostages has been prohibited (article 34 Geneva Convention) and the rules on the prohibition of conscription and the forced deployment of labor seem to have been slightly attered (articles 51 and 52 Geneva Convention; see also Chapter 3.10 for conscription and 
one year of occupation, including those dealing with the occupant's administration of the country of articles 61-77 Geneva Convention. ${ }^{170 ?}$

The occupant's powers to enact measures in derogation of the existing laws of the occupied country have been clarified in that he is allowed to enact provisions to fulfill his obligations under the Geneva Convention, maintain orderly government and ensure his security. ${ }^{1703}$ The main principle that the existing laws of the occupied country remain in force, although in derogation thereof the occupant may suspend or repeal them where they constitute a threat to his security or an obstacle to the appli= cation of this convention. ${ }^{1704}$ The Geneva Convention specifically mentions that the occupant can only derogate from criminal laws, but some authors maintain that the occupant is nevertheless entitled to also aiter non-criminals laws. "The occupant's measures containing penal provisions are only allowed to enter into force after having been duly published in the occupied country's language and cannot have retroactilve effect. 1706

Tribunals of the occupied territory are to continue functioning in respect of all offenses the laws of the occupied country covered, as long as their functioning is not an obstacle to the application of the Geneva Convention and necessary to ensure the effective administration of justice. ${ }^{1707}$ International law here provides for a possibility for courts to cease their duties in case the convention is violated and to relieve them of their duty to continue to function during the occupation. Also a second possibility is added, though the meaning of 'effective administration of justice' seems unclear. Arguably this deals with the courts" independent appreciation of cases and possibly the significance of the areas in which competence is left to them. In any case, this seems like an area where the convention allows courts to assess whether or not to continue their duties during an enemy occupation. However, the occupant may still close down all courts of the occupied country. 1708

Moreover, article 54 Geneva Convention prohibits the occupant to alter the status of civil servants, apply sanctions or take measures of coercion or discrimination if they abstain from exercising their functions for reason of conscience. Strangely enough article 54 Gieneva Convention is not applicable anymore after one year of occupation, ${ }^{709}$ but since the rules contained in this provision are part of customary international law ${ }^{1710}$ they would nevertheless remain binding upon parties. Moreover, like any other protected person under the Geneva Convention, civil ser-

Chapters 2.10 and 4.12 for forced deployment of labor; see also David, p. 464). Other rules concerning the laws of occupation seem to be a further codification of these rules.

See article 6 Geneva Convention. The articles still applicable after one year of occupation are articles $1-12,27,29-34,47,49,51,52,53,59,61-77,1.43$.

1703 Article 64 Geneva Convention.

13.4 Article 64 Geneva Convention. See especially Chapter 2.4, but also Chapters 3.4 and 4.4. See also Glahn, p. 786, 788 .

1705 See Benvenisti, p. 101-102.

$170 \%$ Article 65 Geneva Convention.

1707 Article 64 Geneva Convention.

170* See Chapter 2.11; see also Glahn, p. 788-789.

170: See article 6 Geneva Convention.

1710 See also Glahn, p. 790. 
wants can be compelled to work in certain cases ${ }^{131}$ and the occupant still has the right to remove them from their posts. ${ }^{172}$

Article 66 Geneva Convention states that the occupant may establish his own courts to try violations of his regulations, ${ }^{1713}$ thereby implying that the domestic courts of the occupied country might not apply the occupant's regulations. ${ }^{174}$ He can only use non-political military courts, as long as they sit in the occupied country. although the courts of appeal may sit outside of the occupied country.

It still remains unclear whether the courts of the occupied State can review the occupant"s measures for compliance with international law and more specifically in this case the Geneva Convention. Article 43 Hague Convention was silent on the issue and international lawyers divided. ${ }^{1715}$ Also the Geneva Convention does not have a specific provision dealing with this issue. Nevertheless, article 9 Geneva Convention states that the Protecting Powers scrutinize and cooperate in the application of the Geneva Convention. Moreover, its article 12 maintains that Protecting Powers, on their own initiative, may propose a binding settlement in case of disagreement between occupying power and occupied country on the application and interpretation of provisions of the Geneva Convention. ${ }^{1716}$ Does this settle the question of whether domestic courts can review the legality of the occupant's measures?

It first has to be remarked that the occupied country, including its courts, has to comply with the occupant's lawful regulations. ${ }^{1717}$ However, this is not the case for illegal regulations. Furthermore, since the end of the $19^{\text {th }}$ century rules of international law neither supported nor prohibited resisting an occupant. ${ }^{1718}$ From the point of view of international law there was therefore no reason not to resist application of the occupant's illegal measures. ${ }^{719}$ Even though the Geneva Convention prescribes that a binding settlement can be imposed, this does not negate the fact that initially either courts or the national administration might have exercised review with an outcome unfavorable to the occupant, triggering application of article 12 Geneva Convention. However, ultimately neither the occupant nor the occupied country, includ-

\footnotetext{
1711 Article 51(2) Geneva Corvention.

1712 Article 54(2) Geneva Convention.

1743 See also Glahm, p. 789.
}

1714 Basically only a treaty of peace can bring about a legal termination of war (Glahn, p. 727 ; David, p. 454) and transform the occupant."s factual status on the occupied territory into a legall one (see also Detter, p. 181). Until that time courts are obliged to comply with the occupant's measures, although they are obliged to apply with them.

See Chapter 4.8.

17ti See also Kalshoven, p. 56-58, 113-115.

1747 See Glahm, p. 779, 787; David, p. 455, 463-464 claimed that the duty to obey the occupant's measures could not be extended to those measures that would require a national of an occupied conniry to act against his own State.

171: Glahn, p. 779 .

17: Detter, p. 182 stated that the duty of obedience to the occupant would cease in case he has committed substantial violations of international law. This would imply that in case of these substantial violations of international law, allso for measures that do not violate international law no duty of obedience would exist anymore. However, in my opinion only for these wiolations of his international obligations the occupied country would be dismissed from the duty of obedience to the occupant. For any lawful act of the occupant a duty of obedience would of course still exist. 


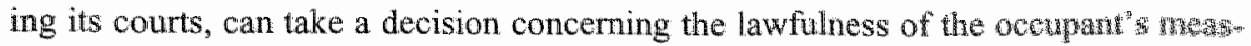
ures.

The practicability of this article has nevertheless been deemed very doubthut ${ }^{17}$ And where the occupant and occupied State cannot agree on a Protecting Power, the question concerning who is the final interpreter of the provisions of the Hague and Geneva Conventions, including all ambiguities concerning the courts" right of judicial review of the occupant's measures, will remain and has remained. ${ }^{1721}$

The international law developments since World War Two conceming the laws of occupation have therefore mainly codified and clarified rules that were already part of the customary law background of article 43 Hague Convention. Especially the occupant"s powers to enact measures have been further described. The trickiest issue, namely who is the final interpreter of the provisions of the laws of war and occupation, although addressed, appears not to have been solved. Moreover, the Convention requires courts to remain functioning, but also explicitly allows courts to assess whether or not to continue their duties during an enemy occupation and to cease functioning in certain circumstances.

\subsection{NATIONAL LAW DEVELOPMENTS IN BELGIUM, LUXEMBOURG AND THE NETHERL ANDS}

\subsubsection{National law developments in Belgium since World War Two}

In 1949, at the request of the Council of Ministers, Secretary General Mathieu of Nourishment and Imports conducted a study of the Statute on Delegation (1940) during the occupation and to draw useful conclusions from that. ${ }^{1722}$ The statute was thought to have been interpreted too extensively as a basis for the powers of the Secretaries General. ${ }^{1723}$ Mathieu partly blamed this on the deliberate vague drafting of the text, ${ }^{1724}$ which could have been prevented. The Council for legislative arfairs should have been consulted ${ }^{1725}$ and the successive govermments in the 1930 s should have been made aware of this bill, which had languished in certain files until the urgency of war required it to be introduced into Parliament. ${ }^{1726}$ The Chamber of Representatives and the Senate had also only had one reading of the bill on 10 May 1940 when it was almost unanimously accepted. ${ }^{127}$ However, the result of this vague text was that the Secretaries General, as well as the occupant, would conchude at the beginning of the occupation that the Statute on Delegation (1940) allowed for measures to be enacted with the force of law.

170 Dongen, p. 128; Best, Humanity, p. 323-324; Detter, p. 377-371,

172 See also David, p. 459 , who maintains that jucicial review by the courts of the occupied country of the occupant"s measures remains a controversial issus.

172 CEGES/SOMA, Papiers Vossen 1921-1952, MIC 74, Mathiea, G. Eude sur ha Détégation des Pouwoirs en Temps de Guerre.

172. See also Chapters $1.2 .3,2.9$ and 7.1 .2 .

1724 CEGES/SOMA, Papiers Vossen 1921-1952, MC 74, Mizhteu, O., Eude sut la Délégation des Powoirs en Temps de Guerre, $\mathrm{p} .7$.

1hat 1 bid, p. 22 .

1726 Ibid, p. 25

1727 Ibid, p. 28. 
Given the circumstances of having to choose for a delegation of powers from the occupant or leaving the administration of Belgium completely to him, the Secretaries General opted for this political solution. Although in contravention of existing law, ${ }^{1728}$ Mathieu deemed this at least the better than the other two bad solutions." ${ }^{129}$ However, although the Secretaries General had been able to prevent a formal delegation of powers from the occupant, they could not prevent his supervision and constraints. ${ }^{1730}$ This concession to the occupant, which had undermined the goal of the statute to allow for a purely Belgian administration for purely Belgian affairs to resist the occupant"s meddling into those affairs, had been justified on the basis of necessity. ${ }^{17 /}$ Restricting the occupant to those affairs that international law allowed him to deal with was increasingly circumvented through the use the Secretaries General sought to make of the label of force of law for their measures. National pragmatism dominated and the law was adapted afterwards to provide legal support. ${ }^{173}$ In attempting to avoid worse the Secretaries-General opted for a political solution, awarding themselwes exorbitant legall powers. ${ }^{1733}$

Mathieu also seriously criticized the Belgian courts. The fact that the courts had allowed the Secretaries. General to function as a committee and enact measures with the force of law, thereby giving up their right to review those measures ${ }^{1734}$ he deemed an act of Pontius Pilate. The occupant's regulation prohibiting judicial review of the measures the Secretaries General enacted had exposed the fact that these measures were not rooted in Belgian law anymore. ${ }^{1735}$ According to Mathieu the patriotic conscience had already been shocked, but it was superceded by the drama of the legal conscience. However, in the middle of this drama there was a ray of light. Jamar, the President of the Cour de cassation, had indicated the limits to the courts" concessions. He had stated that one should not forget to safeguard the soul of a people and its fundamental traditions that were as important as its material subsistence. ${ }^{1736}$

What Mathieu forgot to mention was that the system for the national administration during the occupation as created via the Statute on Delegation (1940) made it much more difficult for the courts to exercise their duties as guardians of the law as required by article 107 Belgian Constitution. The courts in Belgium were not independent as against the Secretaries General, since the courts' independence from the occupant was based upon the administration of the Belgian State via the Secretaries General. ${ }^{173 ?}$ If the Belgian constitutional system could not remain functioning, the courts might be placed directly underneath the German occupation administration, having to execute its regulations. This was something the Belgian courts were eager

\footnotetext{
1728 See also Chapter 2.9 .

$12 \%$ CEGES/SOMA, Papiers Vossen 1921-1952, MIC 74t, Mathieu, G., Etude sur la Délégarion: des Pouvairs en Temps de Guerre. p. 51.

Hinl loid, p. 52

UT: Ibid, $p, 53$.

hin: IBid, p 54

17.7 CEGES/SOMA, Papiers Vossen 1921-1952, MIC 74, Mathieu, G., Etude sur la Délégation des Pouvoirs en Temps de Guerre, p. 56.

17.1 See Chapters 2.9 and 2.11 .

173 CEGES/SOMA, Papiers Vossen 1921-1952, MIC 74, Mathieu, G., Etude sur la Délégation des Pownoirs en Temps de Guerre, p. 101. See also Chapter 2.9.

176 CEGES/SOMA, Papiers Vossen 1921-1952, MIC 74, Mathieu, G., Etude sur la Délégation des Powoirs en Temps de Guere. p. 101

17y? See also Chapter 8.5 .
} 
to avoid. ${ }^{1738}$ Moreover, the occupant"s threat of resorting to direct rule in occupied Belgium, which might also entail a splitting up of the Belgian State, ${ }^{1739}$ had been present ever since the very beginning of the occupation. The courts' possibilities in keeping the Secretaries General within the bounds of the law were therefore limited. The occupant's desire to administer occupied Belgium indirectly via the Secretaries General had to be balanced with the possibility and even threat of the occupant to resort to direct rule. The Statute on Delegation (1940) in essence put that responsibility with the courts. The Cour de cassation during the occupation and after two damaging judicial crises, whereby some unfortunate mistakes had been made during the second one, ${ }^{1740}$ put that responsibility with the Secretaries Generall acting in committee. 174

Although the Statute on Delegation (1940) had not fulfilled its aim to prevent the occupant from meddling into strictly Belgian affairs due to its implementation during the occupation, it had proven better suited to preserve the atm of unity of the Belgian administration. According to the occupant's own estimation the Belgian administration was practicing the Fuhrerprinzip, ${ }^{1742}$ expressing the occupant's difficulties in dealing with the Belgian administration's homogenous front. This must have been due to the statute's aim of a direct inferior exercising all powers of his superior when deprived of all communication with this superior, or if this superior had ceased its functions. Although this did not happen consistently within the Belgian administration, ${ }^{1743}$ it seemed to have occurred sufficiently and effectively enough to prevent the occupant from taking over certain levels of decision-making through insisting on influencing new appointments or inserting his own civil servants. ${ }^{1744}$

No postwar provisions have been enacted in Belgium dealing with a possible enemy occupation and the functioning of the national administration, including the courts, during such an occupation. ${ }^{1745}$ This was not to be expected, considering the fact that also the Statute on Delegation (1940) had on purpose not been introduced into Parliament until the day of the invasion. ${ }^{1746}$ This study Mathieu undertook on behalf of the Council of Ministers nevertheless indicates the Belgian Government

1734 CEgES/SOMA, Papiers Vossen 1921-1952, MIC 74, Mathieu, G., Etude sur la Delégation des Pounoirs en Temps de Guerre, p. 46-47.

See Chapter 1.2 .3

7740 See Chapter 2.11.

174 See Chapters 2.9 and 2.11 .

13a: See Chapter 1.2 .2 .

1743 See Chapter 12.3. The Secrevaries General themselves deviated from this legal system of having their direct inferior replace them in case of absence or impossibility.

1744 See e.g. Chapter 2.5 and how successive Secretaries General of Justice fended off the occupant's attempts to interfere with the judicial nomination procedure.

3745 No new constitutional provisions have been enacted, in spite of the new federal constitution (see Gecoördineerde Grondwet van 17 februari 1994 , Mon. 17 februari 1994). A minor exception is the Wet van 10 april 2003 tot regeling van de afschaffing vam de militaire rechtscolleges in vredestijd alsmede het behoud erwan in oorlogstijd, Mon. 7 mei 2003. According to its Title III, Chapter I, the ordinary courts remain competent during wartime to try criminal cases for which they were competent in peace time and also to try cases belonging to the competencies of the military courts if the occupant were to suspend the latter. Moreover, the Statute on the duties of public officials during wartime (1935) (see Chapter 1.2.1) is still in force.

1746 CEGES/SOMA, Papiers Vossen 1921-1952, MIC 74, Mathieu, G., Eurde sur la Délégation des Pouvoirs en Temps de Guerre, p. 23-26. See also Chapter 1.2.1. 
sought to adapt the Statute on Delegation (1940) if possible and examine whether it might be used for a possible future enemy occupation.

Mathicu's assessment of the Statute on Delegation (1940) and the useful conclusions that could be drawn mainly focused on the vagueness of the text. His criticism underlined that the text should have been clearer in that it did not delegate legislative powers. The fact that the Secretaries General, according to the necessity based upon the circumstances, allowed the occupant to approve all measures before enactment, undermined the statute's goal. The application of the provisions of the statute was also criticized. The Secretaries General did not stick to the law and the Cour de cassation did not hold them to it. What Mathieu failed to point out is that the system of the statute made the courts dependent on the Belgian administration if they did not want to be placed directly under the occupant and be required to execute his measures. The courts were therefore ultimately faced with the question of whether the national administration should remain functioning during the occupation. Nevertheless, at least according to the view of the occupant, the statute did have some success in uniting the Belgian administration in the face of interference from the occupant in Belgian personnel matters.

\subsubsection{National law developments in Luxembourg since World War Two}

According to the Luxembourg Government no evaluation concerning the functioning of the courts during the occupant is available. ${ }^{1747}$ None has been found in the different Luxembourg archives. Also, no new legislation has been enacted since World War Two dealing with a possible enemy occupation. ${ }^{1748}$

\subsubsection{National law developments in The Netherlands since World War Two}

In The Netherlands the administration did make an evaluation of the courts' functioning during the occupation. The Minister of Justice was of the opinion that the occupation had shown that although possessing legal capabilities, some members of the courts in leading positions lacked the suitability to exercise that kind of high office. ${ }^{1749}$ Only Puesidents from two of the five Courts of Appeal and ten of the nineteen District Courts were present during meetings at the Ministry of Justice to discuss the Minister's proposals to change the selection procedure. None present at the meeting objected to the Minister's contention of the shown lack of suitability of certain high-ranking nembers of the courts. ${ }^{1750}$

1\%, Author"s archive, letter of 21 November 2003 Mirister of Justice to Yuri Michielsen and letter of 19 March 2004 Minister of Justice to Yuri Michielsen.

17 . See $<$ http $/ /$ ww/w.legilux.public.lu/leg/textescoordonnes/compilation/recuell_lois_speciales/ TABLE_CHRON,pdP $>(2-8-2004)$.

174: Archief Gerechtshof Arnhem, Arrondissementsrechtbank Amhem 1940-1949, Comespondentive, brief 28 Jamuari 1947 van de Minister van Justitie aan de President van het Gerechtshof te Arnhem. NB The following proposals were discussed at the Ministry of Justice on 31 May and 1 June 1946 involving amongst others the Minister of Justice and the Presidents of the 's-Hertogenbosch and Leeuwarden Courts of Appeal and the Presidents of ten District Courts. No representative of the Supreme Court was present.

$1 \%$ Nationaal Archief, Den Haag, Archief van mr J.P. Hooykaas 1940-1947, Nummer Toegang 2.09.56, inv. 48, Beknopte notulen van het verhandelde bij de besprekingen ten Departemente 
The cause for the lack of suitability was found in the criteria applied to select lawyers eligible to be appointed to the courts. ${ }^{1751}$ Through higher salaries and a different 'spirit' of appointments it was hoped that more suitable members would be appointed to the courts. For the positions of President and Vice President of a District Court, the conventional rule of seniority was to be abolished and all members of all District Courts throughout The Netherlands were to serve as potential candidates for vacancies. The position as Vice President would serve as a trial for suitability for the presidential office. As an exception, suitable members not belonging to the courts, but for example to the public prosecutor service would also be eligible as candidates. ${ }^{1752}$ Interestingly enough these proposals did not deal with members of the Supreme Court and Courts of Appeal, who had mostly neglected or been unable to provide leadership during the occupation. ${ }^{1753}$

Several legislative provisions were enacted in the postwar era dealing with war and a possible enemy occupation. In 1950 a constitutional committee was established to consider the question of state emergency law and whether a possibility to enact such measures should be enshrined in a provision of the Constitution. ${ }^{1754} \mathrm{~A}$ general provision has so far not been inserted into the Netherlands Constitution, although the Constitution now does allow for legislation to be enacted to deal with situations requiring the maintenance of internal or external security of the State, which may deviate from certain constitutional provisions. ${ }^{1755}$

The War Act $(1996)^{1756}$ is one of these and a successor to the War Act (1899), ${ }^{1757}$ dealing with the maintenance of internal and external security and giving the Minister of Defense or a military authority narrowly circumscribed powers in specific areas. Its article 28 precluded amongst others courts from the scope of application of measures based upon this statute, but allowed courts to decide upon the

van Justitie met de Presidenten der Gerechtshoven en Rechtbanken op Vrijdag 31 Mei en Zaterdag 1 Juni 1946, de Oorspronkelijke Nota, houdende enkele opmerkingen in verband me: het opmaken van het tableau R.M. en meer in het algemeen de personeelsvoorziening bij de R.M. van 15 April 1946 en het Memorandum betreffende het Tableau Rechterlijke Macht.

Archief Gerechtshof Amhem, Arrondissementsrechtbank Arnhem 1940-1949, Correspondentie, Memorandum betreffende Tableau Rechterlijke Macht 31 Mei en I Juni 1946, p. I en brief 28 Januari 1947 van de Minister van Justitie aan de President van het Gerechtshof te Amhem.

1752 Archief Gerechtshof Arrhem, Arrondissementsrechtbank Amhem 1940-1949, Correspondentie, Memorandum betreffende Tablean Rechterlijke Macht 31 Mei en 1 Juni 1946, p. 1. NB Most recently, in 2002, the Judicial Organisation Act (1827) was amended (see Beschikking van de Minister van Justitie van 21 december 2001 , houdende plaatsing in het Staatsblad van de Wet op de Rechterlijke Organisatie, zoals deze luidt met ingang van 1 januari 2002, Stb. $2002,1)$ The administration of a court, consisting of several members of the courts and one judicial civil serwant whom the King has appointed for a period of 6 years (article 15(1)-(6)), is to decide on the List of Recommendations (article 47(3)(a)). See Chapters 4.5, 4.11, 4.17 and 5.2 .

Koninklijk Besluit van 17 April 1950, Stb. 1950, 25. See Welderen, p. 120.

Article 103 Netherlands Constitution. The constitutional provisions that can be deviated from are those concerning the competencies of regional and local administrations and certain basic rights.

1756 Wet van 3 april 1996, houdende hemieuwde vaststelling van de Oorlogswet voor Nederland ter aanpassing aan de Grondwet en aan de Coordinatiewet uitzonderingstoestanden (Oorlogswet woor Nederland), Stb. 1996, 368.

See Chapter 1.4.1. 
legality of some of these measures, in some cases ex officio. However, also this War Act of 1996 , similar to its predecessor of $1899^{1758}$ does not explicitly allow a delegation of governmental powers if the Government were to decide to go into exile again in case of an enemy occupation.

Two statutes deal with the administration and the courts during an occupation. In 1952 the Netherlands Parliament adopted a statute dealing with penal law during wartime. This Statute on War Criminal Law $(1952)^{1759}$ is applicable to crimes committed during a war or only punishable in case of a war. ${ }^{1760}$ In case of a war, article $12(2)$ determines that special tribunals will be competent to try these crimes, ${ }^{1761} \mathrm{ex}$ cluding the ordinary courts. ${ }^{1762}$ An appeal to the ordinary courts is not possible ${ }^{176.3}$ and the Supreme Court has been barred from hearing cases in cassation. ${ }^{1764}$

The Emergency Statute Administration of Justice (1964) ${ }^{1765}$ gives the Minister of Justice emergency powers to assure the continuation of the administration of Justice in case of war, threat of war or similar extraordinary circumstances. The presidents of courts are authorized to temporarily take measures deemed necessary to assure proper administration of Justice. Conditional on ratification from Parliament, the Minister is allowed under those circumstances to temporarily modify the courts' territorial jurisdiction, appoint judges to a different judicial office at a court and alter certain procedural requirements for civil and criminal cases. Via general administrative order the Government can determine which authority can exercise the powers contained in this statute in case where the occupied territory is cut off from contact with the Minister of Justice. ${ }^{1766}$ However, no other legislative provisions have been enacted that would allow for a Netherlands administration to continue functioning on the basis of Netherlands law, as well as the exercise of the powers in this statute, in case of an enemy occupation and the absence of the Government.

1398

1750

1760

170

176

月176.

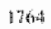

1765

Ibid.

Wet van 10 Juli 1952 , houdende vaststelling van de Wet Oorlogsstrafrecht alsmede van enige daarmede verband houdende wijzigingen in het Wetboek van Strafrecht en de Invoeringswet Militair Straf-en Tuchtrecht, Stb. 1952, 408; Wet wan 14 juni 1990 tot wijziging van de Wet op de rechterlijke organisatie, de Wet Oorlogsstrafreeht en de Noodwet rechtspleging, in verband met nieuwe regels inzake de militaire strafrechtspraak, Stb. 1990, 372.

Article 1(1) ibid.

Except for those the military tribunals will have competence (see article 12(1) and 12(2), ibid).

Article $12(2)$, ibid.

Articles 18(1) and $21(3)$, ibid.

Articles $18(2)$ and $21(2)$, ibid.

Wet van 23 september 1964 , houdende voorzieningen ter warborging wan de voortzetting van de rechtspleging in geval van oorlog, oorlogsgevaar of daaraan venwante of daarmee verband houdende buitengewone omstandigheden (Noodwet rechtspleging), Stb. 1964, 375; Wet van 14 juni 1990 , supra note 1759.

Article 18, ibid. 
Instead, in March 1962, new Instructions ${ }^{1767}$ replaced the $1937^{1768}$ ones, ${ }^{1769}$ providing civil servants with new instructions again in the form of a circular ${ }^{1770}$ concerning how to function during an enemy occupation. Any annexation of occupied territory or the establishment of a quasi national government is deemed void and although the occupant would obtain factual power over the country, her Majesty"s Government, wherever she might be, will remain the legal sovereign. The real interests of the people will have to be the civil servants' guide, which generally means a duty to remain in office. However, if remaining in office were to serve the interests of the occupant more than the Netherlands cause, a civil servant is required to resign from office. The Instructions refer to the relevant provisions of the Hague and Geneva Conventions, which are annexed. If the occupant were to violate his international obligations, the Netherlands authorities will have to protest against such a violation. A referral is, moreover, made to the Statute on War Criminal Law (1952), ${ }^{1771}$ which penalizes a violation of the laws and usages of war. ${ }^{1772}$ Senior civil servants are made responsible for the distribution of the Instructions or the necessary knowledge there of to their inferiors.

The new Instructions are very succinct, especially as compared to the old ones and do not include any specific reference to the courts. However, one interesting point still needs to be made concerning resignation from office during an enemy occupation, which is not dealt with by the Instructions. The Government, when dealing with the new Instructions, did not consider en masse resignation of civil servants an

1767 See Instruction I Aanwijzingen van Harer Majesteits regering ontrent de houding aan te nemen bij een vijandelijke bezetting, in: Nederlandse Staatscourant van 1 september 1980 , nr. 168 , p. 4 ; NB Sikkes, p. 64 clamed that the text of the new Instructions did not clearly state that they were meant to replace the old ones. See Chapters 1.4.1, 4.1 and 4.8.

176.) Already at the end of the 1940 s the Netherlands Government had established a confidential commission to review the 1937 Instructions. A new draft was presented in 1951 (see Ministerie van Binnenlandse Zaken en Koninkrijksrelaties, BSG/Kabinet/1990 (1948-1990), classificatie 02.388, Richtlijnen voor het geval ener vijandelijke bezetting (dossier t.b.v. dhr. Mijnlieff), brief 31 maart 1951 wan Dr. M.J. Prinsen an de Minister President, JJ/8), but due to objections of several Ministers to these draft-Instruetions (Ministerie van Binnenlandse Zaken en Koninkrijksrelaties, BSG/Kabinet/1990 (1948-1990), classificatie 02.388, Richtlijneth voor het geval ener vijandelijke bezetting (dossier t.b.V. dhr. Mijnlieff), brief 26 october 1951 van de Minister van Landbouw, Visserij en Voedselvoorziening aan de Minister-President) a new commission was established (see Ministerie van Binnenlandse Zaken en Koninkrijksrelaties, BSG/Kabinet 1990 (1948-1990), classificatie 02.388, Richtlinen voor het geval ener vijande lijke bezetting (dossier t.b.v. dhr. Mijnlieff) (1937-195:), brief 31 matt 1951 wan Dr. M.J. Prinsen aan de Minister-President, JJ/8), leading to a completely new draft, adopted in the

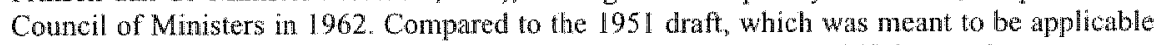
to all who would face legal questions during the occupation, the 1962 instructionss are more restrictive, not only in their scope of application, but also in that these only apply to civil servants (see Instruction I Aanwijzingen van. Harer Majesteits regering ontrent de houding aan te nemen bij een vijandelijke bezetting, in: Nederlandse Statscourant van 1 september 1980 , nr. 168 , p. 4. See also Ministerie var Binnenlandse Zaken en Koninkrijksrelaties, BSG/ Kabinet/1990 (1948-1990), classificatie 02.388, Aanwijzingen omtrent de houding aan te nemen in geval van een vijandelijke bezetting, inw. $1964-$, brief 13 maart 1974 Chef van de directie Politie aan de Secretaris Generaal).

1770 See Chapter 1.4.1 on the legal effects of a circular.

177 Wet van 10 Juli 1952 , supra note 1759.

1772 See articles $3-11$, Wet van 10 jull 1952 , ibid. 
option. The reason was that where the Government had gone into exile, it feared to be held responsible for the ensuing chaos from all civil servants resigning. ${ }^{1773}$ This nevertheless deprived civil servants, if they would manage to organize, of a potent weapon that might be used, even if only as a threat, to prevent the occupant from using the Netherlands administration for the execution of illegal occupation measures.

Although immediately after World War Two the Government had recognized the apparent unsuitability of some members of the courts in leading positions, the Supreme Court and the Courts of Appeal seemed to be excluded from these measures, in spite of the fact that their lack of leadership had been most apparent during the occupation. And even though several new legislative provisions have been enacted dealing with enemy occupation or the aftermath of such an occupation, the legislative provisions concerning the functioning of courts during such an occupation are few. No legislative provisions have been enacted allowing the national administration to function independently during an enemy occupation and in absence of the State's constitutional organs. The existing legislative provisions also do not indicate under which circumstances during an enemy occupation the courts should remain in office and when a point might be reached when courts should refrain from exercising their duties. The Instructions are not on a legislative footing, but similar to the 1937 Instructions a mere circular from the Government, addressing this issue for civil servants. Whether the Government intended to include judges is unclear, but judges are not directly mentioned anymore, which might indicate that the Government did not mean to issue these instructions for judges. Considering the fact that the Government did not want civil servants to resign en masse it seems highly unlikely it would entertain a legislative provision dealing with the circumstances under which courts should or should not remain functioning during an enemy occupation.

\subsection{LEGAL FRAMEWORK FOR THE COURTS TO FUNCTION DURING AN ENEMY OCCUPATION?}

\subsubsection{National administration during an enemy occupation}

Whatever the other policy considerations of a legislator might be, attempting to prevent his administration, including the courts, from aiding the occupant in executing illegal policies, resulting in a violation of international and national law can be considered one of them. The occupant's powers of war will of course not allow the national administration on the occupied territory, including the courts, to force the occupant to administer the occupied territory in conformity with his international obligations. However, the national administration, including the courts, will have to be able to deternine up until which point they can and will assist the occupant in the administration of the occupied territory.

\footnotetext{
1773 Ministerie van Binnenlandse Zaken en Koninkrijksrelaties, BSG/Kabinet/1990 (1948-1990), classificatie 02.388 Aanwijzingen omtrent de houding an te nemen in geval van een vijandelijke bezetting; Richtlijnen voor het geval ener vijandelijke bezetting (dossier t.b.v. dhr. Mijnliefi), alkte 1964.
} 
The first question should of course be whether a legal framework that would allow the national administration, including the courts, to function during an eneny occupation in absence of the regular constitutional organs is necessary and desirable?

A legislator has to make a choice whether a legislative framework should be set in place in case of enemy occupation and in absence of the constitutional organs or whether those left in charge of the national administration are to decide ad hoc and in accordance with their best judgment. Something is to be said for the latter approach, since the nature of war and occupation are unpredictable. Nevertheless, also in case of an occupation administration will continue. International law recognizes that even during an enemy occupation the occupant should administer in accordance with the existing laws, of which he can deviate only in case of necessity. In the interest of the occupied territory a legislator might therefore want to assure that its administration is done as much as possible in accordance with these existing laws. Where the constitutional organs are absent or cannot function, legislation allowing the national organs to continue functioning would provide a better safeguard than a basis in the occupant's powers that the national administration would adhere to existing laws.

The second question would be whether the occupant would accept such legislation? Considering the fact that since World War Two the State has increasingly expanded its regulative powers to include many areas of society, it also seems less likely an occupant would be able and willing to resort to direct administration of an occupied territory. At least according to article 43 Hague Convention, which is still the basis governing the relationship between the occupant and occupied State, ${ }^{1774}$ the occupant has to respect, '... unless absolutely prevented, the laws in force in the occupied country." A statute dealing with the functioning of the national administration during an enemy occupation would then be part of that existing legislation. Also the Geneva Convention points in the same direction. ${ }^{1775}$ Moreover, the Belgian situation during the Second World War demonstrated that, with certain reservations and at least in that instance an occupant accepted such legislation. If the occupant were not to accept the national administration to function during the occupation on the basis of such a statute it is questionable whether or not it should remain in office. If this statute were drafted in accordance with international law, an occupant's refusal to accept it would mean a first and serious violation of his international law obligations.

If a legislator on the basis of these reasons were to decide that such legislation should be enacted, the next question is then what elements such legislation should contain? As mentioned before, the legislation should of course be in conformity with international law and should also determine that the national administration could only function in keeping with the State's international law obligations and on the basis of national law. The national administration should be instructed to fulfill the obligations of international law and offer loyal cooperation to the occupant for all lawful acts. However, national affairs, which under international law do not belong to the province of the occupant, should be conducted by the national administration without the occupant or even in spite of the accupant.

See also Chapter 9.2

See Chapter 9.2

1376 See also CEGES/SOMA, Papters Vossen 1921-1952, MIC 74, Mathien, G., Etude sur la Dé"egation des Pownoirs en Temps de Guerre, p. 15.
} 
Those areas of law that under the international law of occupation do not belong to the province of the occupant should therefore be shielded from his influence. Only if the national administration on the occupied territory can function independently from the occupant, this might be possible. Where the national administration would be dependent on the occupant's factual powers to enact measures to deal with the situation of the occupation, it would be impossible to shicld any area from his influence. The national administration would therefore need a basis in national law to be able to enact its own measures. In order to assure that these measures would also respect the existing laws $s_{s}$ these measures could not possess force of law. Considering the fact that the occupant factually exercises sovereignty and therefore the occupied State's legislatiwe powers, this would not only be in conformity with, but also required by international law. ${ }^{1777}$

Where the occupant would be able to influence the personnel policy of the occupied country's administration, he would also increasingly be able to influence measures and their execution in areas that according to international law do not belong to his province. Another goal of legislation for the functioning of the national administration during enemy occupation should therefore also be to preserve unity in the national administration. Vacancies could occur due to the fact that the occupant exercised his right under international law to remove a civil servant from office or a civil servant, equally on the basis of international law, would exercise the right to resign from office. Like the Belgian Statute on Delegation (1940), where a superior is unable to be contacted or exercise his duties, his direct inferior should via delegation be able to exercise all of the superior's legal powers, filling any gaps within the hierarchy of the national administration. The national administration would remain functioning, though without the occupant being able to influence the appointment of new members. A legislative provision like the Belgian one during World War Two to require civil servants to remain in office ${ }^{1778}$ in order to prevent vacancies would still be possible, though under the Geneva Convention the civil servant would be able to resign from office for reason of conscience. ${ }^{179}$ All non-mobilized civil servants should therefore be required to remain in office with a prohibition to abandon post. Moreover, all demobilized civil servants should be required to return to their offices, as long as the occupant does not prevent them from doing so.

\subsubsection{Courts during an enemy occupation}

There is another reason to prepare legislation allowing the national administration to function during an enemy occupation in absence of the constitutional organs. In cases where national positive law might not be at hand to deal with unforeseen circumstances arising due to the war and occupation, the occupant's factual measures might have to be applied and 'factual circumstances' incorporated into the legal system to justify a deviation from the positive law: ${ }^{1780}$ This might require courts to deviate from

$177 \%$

1798

1770

17:

See Chapters 2.9 and 2.11 .

See Chapter 2.2.

See Chapter 9.2 .

See e.g Chapters 4.8 where the Netherlands Supreme Court accepted the occupant's factual measures as Netherlands law "under the present circumstances". See Chapter 7.1.1 for the incorporation of exile legislation on the basis of "necessity' dhe to "extraordinary circun- 
the existing legislation, since there is no altemative available. In cases where the remaining national administration could enact measures in execution of existing laws to deal with these unforeseen circumstances, courts would also contimue to function. in accordance with national legislation.

Since the occupant, until the conclusion of a peace treaty, has no legal powers over the occupied territory, his measures are factual and not legal. Although courts have to comply with these measures, it is their choice whether to apply these factual measures in legal proceedings. ${ }^{1781}$ Where a national administration during an occupation has been delegated powers to enact measures in conformity with national legislation, also courts will not have to depend upon the occupant's measures to deal with cases and controversies arising due to the occupation. This will allow courts to function only on the basis of national law, in conformity with that national law and not aid the occupant in executing measures that might possibly violate intemational and existing applicable national law.

So far these proposals did not deal with the trickiest issue of all, namely the interpretation of international and national law. No specific guidelines have been given. as to what constitute the occupant's 'lawful acts", but the recommendations focused on shielding the national administration from the influence of the occupant. The main idea was firstly that the national administration should comply with its international obligations and assist the occupant in the exercise of all of his law ful acts. For the areas where international law determined that the national administration would remain competent the idea was that the more independent the national administration could function from the occupant, the more it would function in keeping with the existing laws in force. The courts, which have to comply with, but need not apply the occupant's measures, would then only function in accordance with national law. Also here the idea is that this relative independence from the occupant will allow courts to function more in keeping with existing national laws. Similar to Belgium's Statute on Delegation (1940) these proposals seek to create an area in which, as much as possible, the national administration can function independently from the occupant, thereby avoiding the question concerning the lawfulness of the latter's acts.

However, inevitably this question will arise between the national administration and the occupant and it is questionable whether more elaborate international or national law rules can be devised that will solve the problen. The 1962 Netherlands Instructions to its civil servants recognized this and are therefore very succinct. And although a legislator might indicate certain areas of law of which the national organs during an occupation have to make sure these remain within their competencies, even there this question will not be solved. Apart from the question whether a national definition of these areas would be in accordance with international law and as such accepted by an occupant, the question of the lawfulness of the occupant's acts would still remain.

Law, by its very nature is tricky and slippery. For good reasons a whole profession has been created to deal with the drafting and interpretation of rules. As stated before, no matter how clearly a text might have been drafted (and for good reasons some text have not been drafted very clearly in order to keep them flexible and appli-

stances" in Belgium and Chapter 7.3.5 for The Netherlands where the basis for incorporation was "due to the circumstances that had occurred". 
cable to changing circumstances) there will always be disagreements over the meaning of texts. The question of the lawfulness of the occupant's acts and therefore where he can exercise the occupied State's legislative powers and where the national administration should attempt to retain control over as many areas as possible will therefore remain. What therefore also remains is that the national administration should attempt, in conformity with the international obligations of its State, to retain as many areas of law as possible in order for existing legislation to apply.

\subsubsection{The application of existing law during an enemy occupation}

Where the national administration during an enemy occupation will try to assure it will remain competent for as many areas of law as possible so existing legislation will apply, the latter can only be said to be applied properly if executed or interpreted in conformity with its spirit. A departure from application of its own legislation in a different spirit will change national legislation as well and cannot be said to still be 'existing legislation' in the sense of article 43 Hague Convention in anything but form. In the absence of a peace treaty the occupied State still exists, which is also the reason why existing legislation in principle needs to be respected, unless for military purposes relating to the occupation existing national legislation needs to be derogated from. ${ }^{1782}$ What would be the use of maintaining existing legislation if its spirit were altered?

Therefore, what can a legislator do if the national administration, including the courts, will function outside the legal framework, through interpreting provisions in a way as if it appears they are still functioning within the legall framework? Based on the necessity of circumstances argument or de novo interpretation of legal provisions, officials, for good or bad reasons, might break with past interpretation and doctrine or the intent of the legislator. Those areas of the law that were to remain beyond the influence of the occupant, might be bent into a direction that these are applied in conformity with the occupant's wishes, thus breaking the national spirit of that legislation.

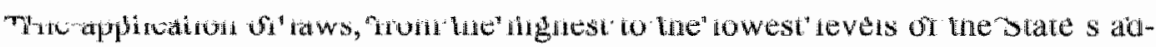
ministration, including the courts, is dependent on the spirit of those who apply them. Not only the mere existence of laws, but also upholding the tradition and spirit in which they were drafted is important. The spirit of the law is nowhere else, but in those who apply it. No law, no matter how well drafted, can oblige those who should apply it, to apply it in conformity with the traditions and spirit in which they were drafted. Especially under the difficult circumstances of an enemy occupation, upholding the spirit of the laws of one "s occupied country will not always be successful. That one is not always successful is not important. In the end, what is important, especially during an enemy occupation, is the constant, unceasing attempt to uphold the spirit of one's own laws. Possibly where legislation allows for the independent functioning of a national administration during an occupation, where the national administration is shielded from the occupant for the execution of purely internal matters, the

1?22 See Chapters 4.7 and 9.1 . 
confidence might be found to retain competencies over as many areas as possible and enact and interpret measures in accordance with the spirit of the existing legislation. 



\section{LIMBOURGISH SUMMARY'}

De 'nazificatie' en 'denazificatie' vaan de tribunalle vaan Belsj, Luxembörg en Nederland oonder en kort nao de bezètting vaan de Twiede Wereldoorlog stónge bij dit oonderzeuk centraol. Veur de 'nazificatie' woort bij dit oonderzeuk geloerd nao de maotregele die oonder de bezètting getroffe woorte veur wat betröf de positie en 't functionere vaan de tribunalle. Bij de 'denazificatie' woort daan geloerd nao wie de maotregele vaan de regering in ballingsjap mèt dees bezèttingsmaotregele nao " $t$ ind vaan d'n oorlog umginge. 't Begrip is dus väöl rejaoler gebruuk en heet $z$ 'ch neet allein gelimiteerd tot 'ne nationaol-sociallistischen inhaajd vaan die maotregele of tot die maotregele boemèt zoe'n doel gedeend woort. 't Oonderzeuk is geleid aon de hand vaan de vraogstèlling of tot 'n positiefrechteleke hajding vaan de tribunalle in Belsi, Luxembörg en Nederland 't oonmeugelek maakde um de touwpassing vaan bezèttingsmaotregele en ballingsjapsmaotregele te weerstoon.

De situatie in de drei oonderzeukde Staote waor in versjeie opziechte geliek en in aandere versjèllend, boemèt bij 'n vergelieking tösse de hajdinge vaan de tribunalle rekening gehawwe mós weure. In Nederland en Luxembörg waore regering zoe wie vors in ballingsjap gegaange oonder de invasie vaan 10 mei 1940, boebij in Belsj ouch de regering, meh neet de Keuning "t land verleet, dee veur kriegsgevaangesjap in Belsj koos. Polletiek zouw evels de Belzje Keuning oonder de bezètting, meh ouch nao de bevrijing, zien constitutionele bevooghede neet mie oetoefene.

Heidoor had Belsj woersjijnelek oonder de bezètting 'n militair bezèttingsadministratie, terwijl in Nederland en Luxembörg de mie ingriepende börgerleke variant opgelag woort, boebij dee in Luxembörg es de mies ingriepende vaan de drei ingedeild weurt. Belsj had de mieste maotregele genome wat betröf de veurbereijing op 'n vijandeleke bezètting, oonder aandere umtot 't Belsj Parlemint op d'n daag vaan d'n inval de Wèt veur wat betröf de dillegatie vaan bevooghede aongenome had, es garantie veur ' $t$ wijer functionere vaan de Belzje euverhede oonder de veraanderde umstandeghede. Ouch veur wat betröf de mobilisatie waore wètteleke maotregele genome, mèt oonder mie 'n verpliechting veur neet-gemobiliseerde ambtenere um op hunne pos te blieve. Ouch in Luxembörg waor "n wètteleke dillegatie vaan bevooghede veur de regering veurzeen, meh die reikde neet tot alle euverheidsorgane. De Nederlandse euverheid had" 'ne circulair opgestèld mèt aonwijzinge veur de ambtencere veur wat betröf de hajding aon te neume oonder "ne vijandeleken euverval, meh veur ' $t$ wijer functionere vaan de euverheidsorgane waore gein wètteleke maotregele getroffe. Oonder touwziech vaan de bezètter bleve in Belsj en Nederland de nationaol euverhede wijer functionere oonder de ganse bezètting. In Belsj naome de Sikkertatrisse Ginneraol 'ne wètteleke groondslaag in Belsj rech, naomelek de al ieder geneumde Wèt veur wat betröf de dillegatie vaan bevooghede, boebij in Nederland de Sikkertarisse Gimneraol 'n directe dillegatie vaan de bezètter accepteerde. In Luxembörg vörmde 't Parlemint nao 't vertrèk vaan Groethertogin en regering in euverlègk

Dees Limbörgse samevatting is gesjreve aon de hand vaan de Veldeke spelling en grammatica veur de Mestreechter variant vaan 't Limbörgs die besjreve weurt in Brounts, P., Dumoulin, $\mathrm{Ph}_{\text {. }}$ Speulentere spelle, Veldeke Krink Mestreech, 1992; Aarts, F., Mestreechs ens moojertaol; 'n besirijuing vaan 't dialek waan Mestreech, Veldeke Krink Mestreech, 2001 en de nuie Mestreechsen dictionair. Bij Raodsbeslunt vaan 5 november 1999 is dees spelling door Börgemeister en Wethawwers vaan Mestreech es officieel spelling erkind gewore. 
mèt de bezètter in ierste instantie 'n regeringskemissie, later geneump administratief kemissie. Die woort evels nao versjeie maonde eweg gedoon, boenao de bezètter practisch tot direk bestuur euverging. De bezètter deeg wijer alle nationaole organe vaan de Luxembörger Staot eweg en plaotsde de euverblievende Luxembörger euverheidsorgane oonmiddellek oonder ziech.

Heidoor stónge de Belzjè, Luxembörgse en Nederlandse tribunalle gedeiltelek in 'n aander verhajding tot hunne respektieveleke bezètter, boemèt bij 'n vergelieking vaan de hajding vaan dees tribunalle tot hunne bezètter rekening gehawwe mós weure. Door de groondslaag in Belsj rech veur "t functionere vaan de Belzje euverheid bleef 't Belsj groondwèttelek bestèl nog 't mies intak en waore de Belzje tribunalle " $t$ mins vaan de bezètter aofhaankelek. In Nederland, boe de Staot neet zoe wie in Luxembörg oontmanteld woort, meh boe de nationaol organe wijer functioneerde door de bevoogheidsdillegatie vaan de bezètter, waore dus ouch de tribunalle mie vaan de bezèttingsadministratie aofhaankelek. In Luxembörg waor die aofhaankelekheid evels 't groetste, boe vaanwege de aofsjaffing vaan de organe vaan Staot de tribunalle oonmiddellek oonder de bezètter geplaots woorte.

De aonhaankelekheid vaan de Belzje tribunalle aon de Belzje soevereiniteit en rechsorde bleek dudelek oet 't feit tot de tribunalle weigerde de besluut-wèt vaan de ballingsjapsregering touw te passe die de tribunalle opdroog um oonder de bezètting rech 'In Naom vaan 't Belzje Volk' te spreke. De formul 'In Naom vaan de Keuning' en d'n eid vaan trouw aon de Keuning woorte aongehawwe en aon de Keuning woort eder jaor aonhaankelekheid verklaord.

De wetsverpliechting tot neet-gemobiliseerde ambtenere op hunne pos móste blieve woort door de tribunalle touwgepas. Ouch rechters die hunne pos hadde verlaote nao d'n inval woorte door de Belzje tribunalle vervolg. De bezètter kóndigde evels ouch "ne maotregel aof tot zoonder zien touwstumming gevlöchde ambtenere neet nao hunne pos mochte retournere, wat mèt de mobilisatie al tot vacante functies bij de tribunalle leide.

Ouch aander maotregele zörgde veur wacante poste bij de tribunalle, zoe wie de maotregele tege Belzje rechters vaan Joedse komaof. De Raad voor de Wetgeving raojde de Sikkertaris Ginneraol vaan Justitie evels tot Belsj rech 't de Belzje euverheid neet touwstoont actief aon de oetveuring vaan dees maotregele mèt te wèrke. Internationaol rech in de vörm vaan artikel 43 Landoorlogreglemint. (LOR) zouw heibij woersjijnelek gesjónne weure. Es de betroffe rechters ziech evels zelf es Joed zouwe registrere, woort hun verzeuk dit vaanteveure aon hunne chèf te melle. De Belzje tribunalle prottesteerde tege dees bezèttingsmaotregel, boebij de sjenning vaan Belsj zoe wie internationaol rech oonderstriep woort. De bezètter weigerde evels in discussie te goon. En allewel 't liekende es-of de Belzje euverheid de raod vaan de Raad voor de Wergering volgde, raojde de Procureur Ginneraol vaan 't Breuselse Hof van Beroep de Joedse rechters in zie ressort mèt pensioen te goon, boebij in tegestèlling tot aofzètting oet 't amb door de bezètter teminste 'n pensioen oetbetaold woort. Dit urgent verzeuk door "nen hoeggeplaotsde Belzjen ambteneer maakde " $t$ praktisch oonmeugelek de oetveuring vaan dee maotregel te negere, um zoe mie umtot gein oondersteuning waor touwgezag veur dieginnege die dee maotregel neet wouwe naovolge.

Al bij d'n aonvaank vaan de bezètting woort de competentie vaan de Belzje tribunalle veur wat betröf euvertreiinge en misdrieve gepleeg door lede vaan 't Duits 
leger en instituties in Belsj geliniteerd. Umtot dit gans in euvereinstumming met internationaol rech waor, is "t logisch tot de Belzje tribunalle heitege neet geprottesteerd höbbe. En allewel de competentie veur wat betröf börgerleke gesjelle oonaongetas bleef; woort de straofrechteleke competentie op versjellende vlakke gelimiteerd, wie oonder aandere veur economische misdrieve, illegaol waopebezit en sabotaasj. Boete artikel 43 LOR bezaot internationaol rech gel speciaol verdragsartikel wat de competentie vaan tribunalle in bezet gebeed regelde en juriste hadde gein unaniem meining euver dit oonderwerp. Aon de hand vaan Belsj rech waor dit in competentie vaan de Belzje tribunalle. "t Hof van Cassatie zouw, um 't behaajd vaan $z$ 'n competentie, veur de Belzje tribunalle op groond vaan Belsj zoe wie intermationaol rech en mèt oondersteuning vaan de parkètte constant tege dees bezèttingsmaotregele prottestere.

De Sikkertaris Ginneraol vaan Justitie pasde e decreet vaan 1939 aon um mèt tijdeleke beneuminge de vacante plaotse bij de tribunalle op te völle. Allewel neet gans in euvereinstumming mèt Belsj rech, zörgde dee groondslaag in Belsj rech deveur tot de beneumingsproceduur groetendeils in Belzje han bleef. Opeinvolgende Sikkertarisse Ginneraol zouwe bij bemeujing vaan de bezêtter de beneuningsproceduur stèllègke en door vertraogingstactieke perbere einegen invlood vaan de bezètter op die proceduur te veurkoume. De wètteleke pliech veur ambtenere um op hunne pos te blieve en de weigering vaan de mieste um te vertrèkke leide detouw tot de hoeger functies binne de tribunalhiërarchie iers nao de bevrijing vrij kaome. Vaan de lieger functies woort nao de bevrijing bekans drei kwaart nog bezat door dezelfde persoene es beneump veur d'n inval. 'n Verordening vaan de bezètter tot verjónging vaan de kaders woort bij de tribunalle neet mètein doorgezat, ouch untot joonk naogeslach oontbraok. De polletiek en de maotregel vaan de bezètter veur wat betröf beneuminge bij de Belzje tribunalle leep daorum nörges op oet. Boe de bezètter e besluut trof um rechters die vaan anti-Duitse uutinge bliek gegeve hadde oet hun amb te zètte, leet heer zie besluut door de Belzje euverheid oetveure. Zoelang es tot dees rechters door Duitse kriegstribunalle berech woorte, beweerde de bezètter tot de Belzje tribunalle dit accepteerde. Boe dees rechters daodwerkelek Duitse verordeninge gesjonne hadde waor dit neet verwoonderlek, untof internationaol rech de bezètter heitouw einduideg de meugelekheid gaof. Evels, boe de rechters oet hun amb gezat woorte of gearresteerd veur 'n ex officio handeling zouw 't Hof van Cassatie met. succes en mèt gebruk vaan internationaol en Belsj rech, zoe wie de warsjouwing tot "t oonder zoe"n umstandeghede neet wijjer kós functionere, 't besluut vaan de bezètter aonvechte. De positiefrechteleke hajding vaan de Belzje tribunalle, met naome "t Hof wan Cassatie, waor 't dudelekste bij de touwpassing vaan bezèttings" maotregele. Maotregele vaan de bezètter woorte gezeen es feiteleke maotregele, neet vaan Belzjen oersprunk, boedoor Belsj rech de tribunalle neet touwleet um dees maotregele touw te passe. Boe 'n equivalent in Belsj rech bestoont woort dit touwgepas, wat door de bezètter ougluikend touwgestande woort. Boe dit neet "i geval waor, gaove de tribunalle e soort vaan feitelek effek aon die bezèttingsmaotregele, zonder dees evels touw te passe. Zoe woort 't illegaol agglomeratiedecreet vaan de Sikkertaris Gimneraol vaan Binnelandse Zake neet touwgepas en gesjëlle oontstande oonder dit decreet neet aofgehandeld. Evels, gehoerzamend aon 't Duitse bevel tot touwpassing woort wel de ripprizzentant vaan Groet-Antwerpe in de rechszaol es ripprizzentant vaan 'n illegaol geannexeerde gemeinte erkind. 
Dit war euvreges pas nao twie crissse die veur de geluifwierdegheid vaan 't leiersjap vaan "t Hof wan Cassatie sjaojelek waore. Boe de Sikkertarisse Ginneraol "ne maotregel aofkóndigde dee in strijd mèt Belsj rech waor en es iers de lieger tribunalle en denao 't Hof van Cassatie dees proofde aon de Groondwèt en wètgeving oontstoont "n patstêlling. Bezètter en Sikkertarisse Ginneraol waore vaan meining tot de maotregele door de lèggeneumde aofgekóndeg op groond vaan de Wet veur wat betröf de dillegatie vaan bevoogheid krach vaan wet hadde. Dit zouw evels neet allein met Belsj rech, meh ouch mèt artikel 43 LOR in strijd zien. 't Hof wan Cassatie gaof daan ouch neet touw. Meh, ouch in strijd mèt Belsj rech gaof 't Hof van Cassatie wel permissie aon de Sikkertarisse Ginneraol de Wet veur wat betröf de speciaol bevooghede vaan de Keuning oet 1939 es nuie groondslaag te gebruke veur collectief genome maotregele die daan wètskrach hadde. Es 't Hof van Cassatie hei 'n positiefrechteleke hajding haj aongenome, zouw 't de rechterleke prove vaan dees maotregele vaan de Sikkertarisse Ginneraol neet oet han gegeve mage höbbe. "n Insjattingsfout vaan 't Hof waf Cassatie bij d'n twiede juridische crisis, boebij zie oonterech meinde tot de bezètter $z$ 'ch mèt 'n loupende rechszaak bemeujde, leide detouw tot heer te verzwaak waor um te strije tege "nen Duitse maotregel dee verpliechde tot illegaol decrete vaan ne Sikkertaris Ginneraol op groond vaan de Wèt veur wat betröf de dillegatie vaan bevooghede toch touwgepas móste weure.

Oondaanks de veur de Belzje tribunalle oonveurdeilegen oetkoms vaan de twie juridische crisisse cóntinueerde 't Hof van Cassatie "t gebruuk vaan positief rech um tege versjeie maotregele waan de bezètter te prottestere en perbeerde dees trök te drejje. Dit waor "t geval veur maotregele veur wat betröf d'n Arbeitseinsatz in NaziDuitsland, de vreiseleke touwstande in kamp Breendonk, de in iersten instantie oonbestraofden inminging vaan 'nen SS'er in 'n loupende zaak bij de Rechtbank van Eerste Aanleg in Arlon en de gijzelnaomes valan rechters.

Belzje tribunalle gebruukde daan ouch positief rech, soms mèt succes, um weerstand te beje tege bezèttingsmaotregele. Dao boe de Belzje tribunalle touwlete tot aofgeweke woort vaan positiefrechteleke bepaolinge waor dèks geinen aandere weerstand mie meugelek tege de touwpassing waan de bezèttingsmatregele, of 't noe de maotregele vaan de bezetter of dieginnege vaan de Sikkertarisse Ginneraol op groond varan Belsj rech waore.

De Luxembörgse tribunalle woorte bij d'n aonwank geliek mèt 'n ganse rits bezèttingsmaotregle gecónfronteerd, die perbeerde hun positie en functionere te beinvlode. De formul boemèt rech gesproke woort, woort veraanderd vaan "In Naom vaan de Groethertogin" nao "In Naom vaan "t Volk', wat zoe liekende op de Duitse formuul tot "t gein neutraol formuul mie waor, boedoor volkerech zoe wie Luxembörgs rech gesjónne woorte. Dit woort geamplificeerd door de loyaoliteitsverklaoring die de Luxembörgse rechters in strijd mèt internationaol en Luxembörgs rech verpliech woorte te teikene. 't Opsplitse vaan 't hoegste Luxembörgse tribunal, de Cour superieure, de verpliechting vaan "t gebruuk vaan Duits es einegste rechstaol en de beneuming vaan Duitse rechters direk binne de Luxembörgse rechtersjap waore in strijd mèt Luxembörgs en internationaol rech. Gein inkel collectief prottes tege dees maotregele is bekind, allewel de president vaan 't Luxembörgse Tribunal prottesteerde tegen "t verpliech gebruuk vaan Duits es einegste rechstaol umtot dit 'n sjenning vaan internationaol rech inheel. Ouch nog veur 't ind vaan 1940 verordonneerde de bezèt- 
ter tot "t Openbaar Ministerie eder zaak aon de competentie vaan de Luxembörgse tribunalle kós oonttrèkke en bij de Duitse tribunalle aonhengeg kós make.

Luxembörgse rechters woorte wijer aon ideologische traininge oonderworpe en, nao inveuring vaan groete gedeiltes vaan "t Duitse rech, direk in de Luxembörgse rechsorde, ouch aon traininge in 't Duits rech. Behalve dees sjenning vasn internationaol rech woort ouch de Duitse rechterleke organisatie ingeveurd, boebij Luxembörgse rechters verpliech woorte vaan de Luxembörgse Nazi beweging (VdB) lid te weure en d'n eid op Hitler aof te lègke. 't Gaof inkele protteste, meh niemes naom oontslaag. De wienege die weigerde, zoe wie President Faber en Kantonrechter Welter, woorte oontslage en gedeporteerd. Zelfs wie de Luxembörgers aon de Duitse deenspliech oonderworpe woorte naom geinen inkele rechter oontslaag, allewel d'r väöl rechters waore die hun lidmaotsjapskaart vaan de $\mathrm{VdB}$ tröksjikde. Zie woorte daan ouch door e Duits standgerech veroordeild en gedeporteerd.

In 't oug loupend is de aonhajdende weigering vaan Luxembörgse rechters um oontslaag te neume, allewel d'r gein wètteleke bepaoling gevoonden is, die hun verpliechde in functie te blieve. Duitse rapporte besjrieve wie de ideologische training vaan de Luxembörgse rechters op niks oet leep. Mer einen inkele Luxembörgse rechter woort oonder de bezètting beneump en 'nen inkele kraog promotie. Oet wantrouwe woort geinen eine Luxembörgse rechter bij de Duitse tribunalle geplaots en zjus e paar kraoge de Richterbriefe in te zien. Zelfs de Gestapo sjatde tot 'in bekans te verwaarloeze minderheid vaan de rechters $z^{*}$ ch oet euvertuiging vaan de V $\mathrm{dB}$ lid had laote make. Wat heibij neet oet 't oug verlore moot weure, is tot " $t$ in totaol mer get vaan e zevetegtal Luxembörgse rechters gaof, de plaotsvervengers debij inbegrepe. De bezètter had hun gemekelek door Duitse juriste kinne vervaange, wat gezeen de beneuming van Duitse juriste binne de Luxembörgse rechtersjap neet oonwersjienlek waor. De besjöldeging vaan de bezètter tot de Luxembörgse rechters stèlselmaoteg liechtere straove oetdeilde, kin ein vaan de reijes zien boerum dees rechters oonder de bezètting in hun functie zien gebleve.

De vraogstèlling vaan dit oonderzeuk kós evels veur Luxembörg neet naogegaange weure. Umtot de rechszake die in Luxembörg oonder de bezètting zien aofgehandeld neet gepubliceerd zien en touwstumming tot touwgaank in de archieve neet gegeve woort, kós neetl oonderzeuk weure in wie wied Luxembörgse rechters $z$ 'ch vaan "n positiefrechteleke hajding bedeende um weerstand tege bezèttingsmatregelle te beje.

De bezètter in Nederland euverlag mèt de Nederlandse euverheid in wie wied de formuul boemèt rech gesproke woort veraanderd kós weure nao "In Naom vaan 't Rech". D'n Hoge Raad meinde einstummeg tot gei bezwoer bestoont um aon dit verzeuk tegemoot te koume, allewel tege de Nederlandse groondwètteleke bepaoling um 'In Naom vaan de Keuningin' rech te spreke verstoete woort Ouch nao internationaol rech hoofde neet zoonder mie aon dit werzeuk voldoon te weure. "t Besluut vaan d'n Hoge Raad waor evels genome op groond vaan de Aanwijzingen, die 'ne circulair vaan de Nederlandse regering waore veur de hajding aon te neume oonder " $n$ vijandeleke bezètting. In strijd mèt Nederlands rech woort evels dee circulair bove de Groondwèt geplaots en in strijd mèt zien oonaofhaankelekheid leet de Hoge Raad $z$ 'ch heidoor leije in $z^{\text {"nen }}$ oetlègk vaan internationaol rech. Es gevolg heivaan woort denao de naom vaan de Nederlandse Keuningin via circulair oet 't publieke leve gesjrap en d'n ambseid veraanderd, zoetot eder teike valu de Nederlandse soevereiniteit 
oet "t openbaar leve oetgeveeg waor. Tege "t oontslaag vaan President Stheeman, dee in "n oordeil neet dees sjeming vaan "t Nederlands rech touwstoont, woort neet geprottesteerd en wijer ouch geinen actie oondernome.

De tribunalle pasde euvriges väöl bezèttingsmaotregele oondaanks hun sjenning vaan "t Nederlands rech gewoen toww. Ouch tege maotregele tege Nederlandse rechters vaan Joedse komaof woort oondaanks sjenning vaan Nederlands en meugelek internationaol rech allein mer door "nen inkele geprottesteerd. De euverdrach vaan de competentie vaan misdrieve gepleeg tege de bezètter nao tribunalle die door de bezètter opgeriech waore, waor in euvereinstumming mèt internationaol rech. Ei Nederlands tribunal lag 'n verordening die hun competentie limiteerde evels zoe wied oet, tot ouch zake die de bezêtter aon de Nederlandse tribunalle euvergelaote had, toch aon bezèttingstribunalle woorte wijer geleid. Aander limitaties vaan de competentie vaan de Nederlandse tribunalle, zoe wie sjorsing vaan 't klachtrecht, lokde oondaanks sjenning vaan internationaol rech gei prottes oet. De inveuring vaan polletieke tribunalle geneump wrederechtspraak en de sjenning vaan intemationaol rech en de Nederlandse wètteleke bepaoling veur wat betröf ne-bis-in-idem zörgde veur. groeten ambras binne de Nederlandse rechtersjap, melh leide boete get individueel oontslaagnaomes ouch neet tot collectieven actie. Tege de inveuring vaan de economische rechspraok woort wel "n rechszaak aongebrach, boebij gestèld woort tot Nederlands en internationaol rech gesjóne waore. D'n Hoge Raad oordeilde evels tot artikel 43 LOR en de verordening vaan de Rijkscommissaris aontuinde tot de verordeninge vaan de bezètter wètskrach hadde, neet door de rechter geproof kóste weure en daorum door de tribunalle touwgepas móste weure. De wètteleke bepaoling tot heer allein wètgeving vaan Nederlandse oerspungk kós touwpasse woort door d'n Hoge Raad heibij opzij gezat. Internationaol rech waor oondudelek euver de proofcompetentie vaan de tribunalle vaan e bezat land, meh juriste en de Belzje rechspraktijk oet d'n Terste Wereldoorlog tuinde aon tot d'r genóg meugelekhede waore veur d'n Hoge Raad um proofrech neet zoe stèlleg te oontkinne. "t Rizzeltaot waor evels tot de Nederlandse tribunalle oonder aandere ouch de verordeninge tege Joede touwpasde, allewel die verstoetde tege internationaol en nationaol rech.

Vaanaof d"n aonvaank vaan de bezètting eisde de bezètter 't rech op um rechters te beneume. Beneuminge veur leiende functies bij de tribunalle woorte oonmiddellek door häöm gedoon en veur de liegere nao Sichtwermerk. Heidoor woorte al gaw NSB'ers beneump, meh hun aontal bleef vrij lieg door de oontouwreikende capaciteite vaan NSB juriste. Tot de bezètter vaan de wètteleke en gebrukeleke beneumingsproceduur aofwiekde woort door de tribunalle gelaote geaccepteerd. De bezètter lökde "t de mierderheid vaan de leijende functies te beneume, boe-oonder de president en versjeie raodshiere vaan d'n Hoge Racd, zoe wie väöl raodshiere bij de gerechtshoven. Ouch bij de lieger tribunalle had 'n aonzeenleke minderheid de beneuming aon de bezètter te daanke. De verordening veur wat betröf de verlieging vaan de pensioensgerechtegde leeftied vaan 70 nao 65 jaor zörgde veur väöl vacante functies, wat d"n invlood vaan de bezètter op nui beneuminge vergemekelekde. Allewel dee maotregel ouch in strijd waor mèt internationaol- en nationaolrechteleke bepaolinge, accepteerde de Nederlandse tribunalle häöm gelaote.

Dao waor bij protteste vaan de Nederlandse tribunalle veur wat betröf de wantouwstande in 't kamp vaan Ommen daan ouch naodrökkelek gein leing vaan d'n Hoge Raad of eine vaan cle vief gerechtshoven. D'n Amsterdamsen Officeer vaan Justitie en Arrondissementsrechtbank leide de prottesactie heitege. Drei raodshiere 
bij 't Liewardense Gerechtshof steunde die actie door in hun oordeil mèt de straofmaot rekening te hawwe, boenao twie vaan die raodshiere oet hun amb gezat woonte. Allewel de tribunalle prottesteerde waor gein collectief direiging vaan 'n sanctie traon verboonde. Dit oondaanks 't feit tot die oontslage oonmiddellek ingrepe in de rechspraok en in strijd mèt internationaol en nationaol rech waore, boedoor d' $r$ veur gein inkel tribunal nog de garantie vaan oonaofhaankelekheid bestoont. "t Collectief prottes vaan de Nederlandse tribunalle had wel es rizzeltaot tot de kampe geslote woorte,

Aander bezèttingsmaotregele woorte wel touwgepas. Versjeie tribunalle prottesteerde tege de maotregele veur wat betröf d'n Arbeitseinsatz en weigerden in ierste instantie mètwèrking, meh gaove oetindelek oondaanks sjenning vaan internationaol rech toch touw. D'n Hoge Raad regelde z'ch 'n oetzundering, meh sleipde die allein veur z'chzelf troet en neet veur de aander Nederlandse tribunalle. De bezètter verordonneerde ouch nog tot de zetel vaan versjeie tribunalle verplaots mós weure, boeoonder dee vaan d'n Hoge Raad. Dit waor in strijd mèt internationaol rech en volges Nederlands rech zouw dit kimne beteikene tot dees tribunalle neet mie es Nederlandse tribunalle gezeen kóste weure. De inveuring vaan "t Führerprinzip lokde ouch protteste oet die niks holpe, meh woort oondaanks sjenning vaan internationaol en nationaol rech ingeveurd. Donner, raodshier bij d'n Hoge Raad, en dee vaanaof d'n aonvaank vaan de bezètting oonophawwelek tege illegaol maotregele geprottesteerd had, deende heibij z'n oontslaag in.

Vaanaof de zomer vaan 1944, tege 't ind vaan de bezètting, perbeerde versjeie tribunalle de gelaote hajding vaan de Nederlandse rechtersjap te doorbreke en betwisde opelek de legaoliteit vaan versjeie verordeninge. Dit tuint aon tot d'r juridische meugelekhede in 't internationaol en Nederlands rech waore um de touwpassing vaan versjeie bezèttingsmaotregele te weerstoon. De mieste tribunalle wachde evels 't ind vaan de bezètting aof, zoe wie 't feit tot niks tege de gijzelnaome en "t vermaore vaan versjèllende rechters gedoon woort aontuint.

Nederlandse tribunalle lete daan ouch nao um 't positief rech te gebruke um weerstand tege bezèttingsmaotregele te beje. Allein in ei geval lökde 't um de Nederlandse tribunalle oonder leijing vaan 'n arrondissementsrechtbank te organisere um de polletiek vaan de bezètter te veraandere. In de mieste gevalle waore Nederlandse tribunalle te oongeorganiseerd um collectief tege bepaolde bezèttingsmaotregele weerstand te beje, boebij ouch neet altied 'n käös veur e positiefrechtelek standpunt gemaak woort. 'n Mie positiefrechteleke hajding zouw de Nederlandse tribunalle evels gedwónge höbbe um z'ch tege bepaolde bezèttingsmaotregele te were.

De vraog of 'n positiefrechteleke hajding ' $t$ veur de tribunalle oonmeugelek maakde um tege versjeie bezèttingsmaotregele weerstand te beje kin daorum ouch neet invoudeg beantwoord weure. Internationaol- en nationaolrechteleke bepaolinge gaove arguminte, boebij sommege euvertuigender es aandere waore, um bepaolde bezèttingsmaotregele neet touw te passe. 'n Positiefrechteleke hajding zouw tribunalle in die situaties dus ieder gedwónge höbbe de oetvoering vaan bepaolde bezèttingsmaotregele te weerstoon. Belzje tribunalle waore " $t$ mies positiefrechtelek in hun hajding. 't Leiersjap vaan 't Hof van Cassatie holp um hun hajding de collectief sanctie vaan 't meugelek opsjorte vaan hun wèrkzaomhede krach bij te zètte. De Luxembörgse tribunalle mote noedgedwónge boete de vergelieking valle. Dit vaanwege e gebrek aon informatie euver 't gebruuk vaan rech, de vreugtijege opheffing vaan de Cour' supérieure, de beneuming vaan Duitse rechters en "t gemaak boemèt de bezètter 't 
gering aontal Luxembörgse rechters kós vervaange. De Nederlandse tribunalle waore 't mins positicfrechtelek ingesteld, boebij e gebrek aon leiersjap vaan de hoegste tribunalle 't oonmeugelek maakde um bij 'n aongenome hajding de collectief sanctie vaan meugelek opsjorte vaan wèrkzaomhede krach bij te zètte.

De regeringe die bij $\mathrm{d}^{\prime} \mathrm{n}$ aonvaank vaan de bezètting in ballingsjap waore gegaange hadde maotregele aofgekondeg in aofwachting vaan hunnen trökkier nao de bevrijing. De juridische groondslarg veur dees ballingsjapsbeslute waor allermins oonbetwis of oonaonvechbaar. De Belzje zoe wie de Nederlandse ballingsjapsregering bereep $z$ 'ch op 'ne groondslaag dee neet in positief rech veraankerd laog. Neet 't Belzje en ouch neet 't Nederlandse Parlemint rattificeerde de maotregele nao de trökkier vaan hun regeringe oet ballingsjap, boebij wel 't Nederlandse Parlemint 't dudelekste aongaof de ballingsjapsmaotregele good te käöre. Luxembörg waor ouch hei weer in 'n aander positie. Neet allein oefende de ballingsjapsregering bevooghede oet die ze veur de bezètting vaan häör parlemint gekrege had, meh nao de bevrijing bekrachtegde "t nui parlemint oetdrökkelek dees ballingsjapsmaotregele en verliende ze daobij krach vaan wèt.

Kort nao de bevrijing vaan Belsj behandelde "t Hof wan Cassatie al "n zaak boe-in ballingsjapsmaotregele touwgepas woorte en meinde en passant tot de Ministerraod, op groond vaan nota bene de groondwètteleke groondslaag dee heer zelf al had aongedrage, zoonder twiefel alle wètgevende bevooghede oetoefende. Ouch in dao-op volgende zake, allewel in aofwieking vaan d'n teks, de historie en de intentie vaan de groondwètsbepaolinge, oordeilde 't Hof van Cassatie op dezelfde meneer. Door de indeiling vaan ballingsjapsmaotregele es 'wètte in formele zin' oontnaom 't Hof van Cassatie de Belzje tribunalle de meugelekheid te prove aon Belsj wètgeving of internationaol rech, ouch 't oongesjuevene.

De bezèttingsmaotregele die de Belzje tribunalle bij de oetoefening vaan hun take belemmerde, woorte door de ballingsjapsmaotregele eweggenome. Ouch de tijdeleke beneuminge door de Sikkertarisse Ginneraol woorte behandeld. Die rechters beneump veur d'n inval woorte door militair tribunalle oonderzeuk en zoe nudeg vervolg weur sjenning vaan Belsj straofrech veur wat betröf collaboratie oonder de bezètting. "t Hof van Cassatie accepteerde dat, ouch al waor dit in strijd mèt de bevooghede vaan de lieger Belzje tribunalle um zelf aon de hand vaan Belzje wètgeving rechters veur ex officio misdrieve te berechte.

Wie gezag waore de Luxembörgse tribunalle door dillegatie vaan bevooghede weur de bezètting en rattificatie door 't parlemint vaan ballingsjapsmaotregele denao in 'n aander positie es de Belzje en Nederlandse. Evels, veurtot 't Luxembörgse Parlemint $z$ "ch heimeuver had kinne oetspreke, hadde de Luxembörger Tribunal en de Cour supérieure in cassatie zoonder bedinkinge de ballingsjapsmaotregele al es wètgeving in formele zin bestempeld. In euvereinstumming mèt "n positiefrechteleke hajding woort e beroop op oongesjreve volkerech aofgeweze.

Vaanwege de gebäörtenisse vaan de bezètting móste de Luxembörgse tribunalle gans obbenuits opgezat weure. De wienege Luxembörgse rechters die aon " $t$ ind vaan de bezètting bij de veurmaolege Luxembörgse tribunalle nog in functie waore, woorte vervolg en op aander es de wèttelek bestaonde gronde oet hun amb gezat. Ouch woorte ze gezuverd veur hun neet-ex officio handele door de gewoen Luxembörgse tribunalle aongevöld mèt lekerechters. 
De lieger tribunalle in Nederland woorte es ierste mèt de legaoliteit vaan de ballingsjapsmaotregele gecónfronteerd, boebij d'n Hoge Raad door zoe'ne maotregel gesjors waor. Oondanks 't feit tot gein groondwètteleke bepaoling of aander wètgeving de regering 't rech gaof dees maotregele mèt wètskrach aof te kóndige, accepteerde iers de lieger tribunalle en, nao oongedoonmaking waan de sjorsing ouch d'n Hoge Raad', hun legaoliteit. Veur wat betröf de speciaole oonderdeile vaan de ballingsjapsmaotregele, veural veur wat betröf 't verbod vaan trökwèrkende krach vaan straofbepaolinge zoe wie bepaolinge vaan publicatie wiekde de Nederlandse tribunalle ouch aof vaan Nederlandse wètgeving.

De maotregele zörgde deveur tot bekans alle bezèttingsmaotregele die 't functionere of de positie vaan de tribunalle beinnvloodde trökgedrejd woorte. Nog op groond vaan häör ballingsjapsbevooghede kondigde de regering nao trökkier in $\mathrm{Ne}$ derland zuveringsmaotregelen aon veur de rechtersjap, boebij die lede beneump oonder de bezètting, behalve Smits en de Visser, ouch veur hun neet-ex officio handele oonderzeuk en vervolg woorte. De proceduur veur 't oonderzeuk nao de rol vaan veur de bezètting beneumde raodshiere vaan d'n Hoge Raad, zoe wie Smits en de Visser, zouw z'ch 't langste trèkke. Versjèllende oonderhajde mèt de regering hadde es rizzeltaot tot e compromis getroffe woort, boebij die oonderhajde gezeen woorte es e soort vaan verantwoording veur 't functionere vaan d'n Hoge Raad oonder de bezètting. In ruil veur immuniteit vaan wijer zuveringe stumde d'n Hoge Raad trin touw tot 'n zuveringsautoriteit veur de lieger tribunalle gevörmp woort, die de groondwètteleke bevooghede die aon d'n Hoge Raad touwkaome um rechters beneump veur de bezètting oet hun amb te zètte, zouw oetoefene. Toen dees zuveringsaultoriteit, geneump Hoge College voor de Rechterlijke Machi, d'n Hoge Raad um verantwoording vroog, weigerde d'n Hoge Raad, mèt hölp vaan de Minister vaan Justitie, um mèt te wèrke, meinende tot de gesprekke mèt de regering daoveur al zörg gedrage hadde. En allewel Smits obbenuits beneump en de Visser trök in zien aajd amb herstèld woort, zouw dee nao-oorlogse crisis roontelum d'n Hoge Raad neet ophawwe tot de Keuningin, tege de gebrukeleke proceduur in, Donner es president vaan d'n Hoge Raad beneumde.

In wie wied 'n positiefrechteleke hajding ' $t$ veur de tribunalle oonmeugelek maakde um bepaolde ballingsjapsmaotregele neet touw te passe kin allein veur Luxembörg invoudeg beantwoord weure. De bevoogheidsdillegatie veur d'n oorlog aon de regering en de bekrachtiging vaan ballingsjapsmaotregele door "t parlemint nao de bevrijing zörgde deveur tot die maotregele wètskrach hadde en door de Luxembörgse tribunalle zoonder proofmeugelekheid touwgepas móste weure. In Belsj zoe wie Nederland waor de situatie neet zoe dudelek, umtot gein dudeleke dillegatie vaan bevooghede bestoont, bestaonde positiefrechteleke bepaolinge de oetoefening vaan de wètgevende mach door de regering neet touwlete en 't parlemint de ballingsjapsmaotregele neet bekrachteg had. Belzje zoe wie Nederlandse tribunalle zouwe in aofwieking vaan bestaonde positiefrechteleke bepaolinge de ballingsjapsmaotregele vaan hun regering touwpasse, boebij 'n positiefrechteleke hajding hun gedwónge zouw höbbe teminste sommege vaan dees maotregele te weerstoon.

Dit oonderzeuk riechde $z$ 'ch veural op 't rech en de vraog of aon de hand vaan positiefrechteleke bepaolinge tribunalle bezèttingsmaotregele of ballingsjapsmaotregele móste touwpasse. De oetkoms waor tot 'n positiefrechteleke hajding in eder geval in 
Belsj en Nederland 't neet oonmeugelek maakde mie weerstand te beje bij de touwpassing van bepaolde bezèttings- en ballingsjapsmaotregele, meh de tribunalle zelf́s dwóng teminste sommege vaan dees maotregele neet touw te passe. D'r woort neet speciaol geloerd of d'r aander, neet-juridische reies waore um in aofwieking vaan positief rech dees maotregele toch touw te passe, allewel dees soms nao väöre gebrach woorte, zjus of neet. Es touwgif woort daan geloerd of de wètgever gei wèttelek raomwerk kós vörme, boedoor tribunalle oonder 'n bezètting ouch neet veur zoe'n neet-juridische vraoge geplaots zouwe weure, umtot dees par excellence door "ne wètgever opgelos behure te weure. Oondaanks internationaolrechteleke oontwikkelinge en versjëllende nationaolrechteleke bepaolinge in Belsj en Nederland, evels neet in Luxembörg, waor nörges zoe'n raomwètgeving aongenome. Gezeen de historie vaan de Belzje Wèt veur wat betröf de dillegatie vaan bevooghede, die pas op ' $t$ lèste momint in 't Belsj Parlemint waor aongenome, liekent dat ouch neet veur de hand ligkend.

't Veurstèl woort eveis gedoon um nationaol wètgeving aon te numme, die deveur kin zörge tot oonder ' $n$ vijandeleke bezètting de nationaol organe kinne wijer functionere in euvereinstumming mèt internationaol en nationaol recht, boebij de bezètter geholpe weurt in de administratie vaan 't bezat land. Die zake die de bezètter evels oonder internationaol rech neet touwkoume, zouwe op groond vaan nationaol rech, zoonder zien inminging, door nationaol organe aofgehandeld mote weure. Maotregele op groond vaan dees wètgeving zouwe gein wètskrach kinne höbbe, ouch umtot dit verstoet tege artikel 43 LOR. Zoelang dees nationaol wètgeving in euvereinstumming mèt internationaol rech is, zouw 'ne bezètter dees neet aon de kant kinne sjuive, tenzij heer $z$ ' $c h$ aon sjenning vaan internationaol rech sjöldeg maak. Internationaol rech, allewel ' $t$ ' $n$ verdudeleking gief euver de bevooghede vaan de bezètter, kin zjus wie dit veurstèl veur 'n nationaol wèt gein dudeleke umlijning geve vaan die bevooghede, ouch neet vaan die bevooghede die aon de nationaol euverheid oonder de bezètting blieve touwbehure. Ouch veur die bevooghede die oonder " $n$ bezètting oonder de nationaol euverheid blieve valle, kin dees wèt neet veursjieve tot die in euvereinstumming mèt bestaonde tradities touwgepas mote weure en neet volges de wèl vaan de bezètter. Touwpassing vaan internationaol rech door de bezètter binne 't raomwerk vaan zien bevooghede en vaan nationaol rech door de nationaol euverheid euvereinstummend mèt eige treditie en wètgeving is aofhaankelek vaan de geis vaan diegimnege die dit rech mote touwpasse. De veurgestèlde nationaol wètgeving hoop daorum allein de nationaol organe en de oetoefening vaan hun touwkoumende bevooghede vaan de bezètter aof te sjerme, zoetot de nationaol organe de zekerheid vinde um zoeväöl meugelek hun eige bevooghede te besjerme en maotregele touw te passe in euvereinstumming mèt traditie en geis vaan de bestaonde wètgeving. 


\section{DUTCH SUMMARY}

De 'nazificatie' en 'denazificatie' van de gerechten in België, Luxemburg en Nederland gedurende en vlak na de beëindiging van de bezetting van de Tweede Wereldoorlog stonden bij dit onderzoek centraal. Voor 'nazificatie' werd hierbij gekeken naar alle maatregelen die gedurende de bezetting getroffen werden ten aanzien van de positie en het functioneren van de gerechten. Bij 'denazificatie' werd dan gekeken naar maatregelen van de regeringen in ballingschap die met deze bezettingsmaatregelen na beëindiging van de oorlog omgingen. Het begrip is dus veel ruimer gehanteerd en heeft zich niet alleen beperkt tot de vraag of deze een nationaal-socialistische inhoud hadden of een dergelijk doel dienden. Het onderzoek is gevoerd aan de hand van de vraagstelling of een positiefrechtelijke houding van de gerechten in België, Luxemburg en Nederland het onmogelijk maakte om toepassing van bezettingsmaatregelen en ballingschapsmaatregelen tegen te gaan.

De situatie in de drie onderzochte Staten was in sommige opzichten gelijk en in andere verschillend, waarmee voor een vergelijking tussen de houdingen van de gerechten rekening gehouden moest worden. In Nederland en Luxemburg waren zowel regering als vorst in ballingschap gegaan bij de invasie van 10 mei 1940, terwijl in België de regering ook het land verliet, doch de Koning voor de krijgsgevangenschap in België koos. Politiek zou echter de Belgische Koning gedurende de bezetting, doch ook na de bevrijding zijn constitutionele bevoegdheden niet uitoefenen.

België had waarschijnlijk hierdoor gedurende de bezetting een militaire bezettingsadministratie, terwijl Nederland en Luxemburg de meer ingrijpende burgerlijke variant werd opgelegd, waarbij de Luxemburgse geclassificeerd werd als de meest ingrijpende van de drie. België had de meeste maatregelen genomen, onder andere doordat het parlement op de dag van de invasie de Wet betreffende delegatie van bevoegdheden aannam, ter verzekering van het doorfunctioneren van de Belgische overheden onder de gewijzigde omstandigheden. Ook betreffende de mobilisatie waren wettelijke maatregelen genomen, onder meer met de verplichting voor nietgemobiliseerde ambtenaren om op hun post te blijven. In Luxemburg was eveneens een wettelijke delegatie van bevoegdheden voorzien voor de regering, maar deze strekte zich niet uit tot alle overheidsorganen. De Nederlandse overheid had slechts een circulaire opgesteld met aanwijzingen voor ambtenaren betreffende de houding aan te nemen gedurende een vijandelijke overval, doch geen wettelijke maatregelen genomen.

Onder supervisie van de bezetter bleven in België en Nederland de nationale overheden doorfunctioneren gedurende de gehele bezetting. In België namen de Secretarissen Generaal een wettelijke grondslag in Belgisch recht, namelijk de reeds vermelde Wet betreffende de delegatie van bevoegdheden, terwijl in Nederland de Secretarissen Generaal een directe delegatie van bevoegdheden van de bezetter aanvaardden. In Luxemburg creëerde het parlement na het vertrek van Groothertogin en regering in overleg met de bezetter in eerste instantie een regeringscommissie, later genoemd administratieve commissie. Deze werd echter na enkele maanden opgeheven, waarna de bezetter praktisch tot direct bestuur overging. De bezetter hief verder de nationale organen van de Luxemburgse Staat op en plaatste de overblijvende Luxemburgse overheidsorganen direct onder zich.

Hierdoor stonden de gerechten van België, Luxemburg en Nederland gedeeltelijk in een andere relatie tot hun respectievelijke bezettingsadministratie, waarmee in 
een vergelijking van de houding van deze gerechten tot hun bezetter rekening gehouden moest worden. Door de grondslag in Belgisch recht voor het functioneren van de Belgische overheid bleef het Belgisch constitutioneel bestel het meest behouden en waren de Belgische gerechten het minst afhankelijk van de bezetter. In Nederland, waar de Staat niet ontmanteld werd zoals in Luxemburg, doch waar de nationale organen verder functioneerden door de bevoegdheidsdelegatie van de bezetter, waren dus ook de gerechten meer afhankelijk van de bezettingsadministratie. Die afhankelijkheid was echter het grootst in Luxemburg, waar door de afschaffing van de organen van Staat de gerechten direct onder de bezetter geplaatst werden.

De gehechtheid van de Belgische gerechten aan de Belgische soevereiniteit en rechtsorde bleek duidelijk uit het feit dat de gerechten weigerden de besluit-wet van de ballingschapsregering om gedurende de bezetting recht "In Naam van het Belgische Volk' te spreken toe te passen. Aan de formule "In Naam van de Koning" en de eed van trouw aan de Koning werd niet getornd en aan de Koning werd elk jaar adhesie betuigd.

Aan het wettelijke gebod dat niet-gemobiliseerde ambtenaren hun post niet mochten verlaten werd door de gerechten de hand gehouden. Ook rechters die hun post hadden verlaten na de invasie werden door de Belgische rechterlijke macht vervolgd. De bezetter vaardigde echter ook een maatregel uit dat zonder zijn toestemming gevluchte ambtenaren niet op hun post mochten terugkeren, wat samen met de mobilisatie al tot vacante functies bij de gerechten leidde.

Ook andere maatregelen zorgden voor vacante posten bij de gerechten, zoals de maatregelen tegen Belgische rechters van Joodse afkomst. De Raad voor de Wetgeving adviseerde de Secretaris Generaal van Justitie echter dat Belgisch recht het de Belgische overheden niet toeliet actief aan de uitwoering van deze maatregelen mee te werken. Internationaal recht in de vorm van artikel 43 Landoorlogreglement (LOR) zou hierbij waarschijnlijk ook geschonden worden. Wanneer de betroffen rechters zich echter zouden registreren als Jood, werd hen gevraagd dit van tevoren bij hun superieur te melden. De Belgische gerechten protesteerden tegen deze bezettingsmaatregel, waarbij de schending van Belgisch en internationaal recht werd onderstreept. De bezetter weigerde echter in discussie te gaan. En hoewel de Belgische overheid het advies van de Raad voor de Wetgeving scheen op te volgen, raadde de Procureur Generaal van het Brusselse Hof van Beroep de Joodse rechters in zijn ressort met pensioen te gaan, waarbij in tegenstelling tot verwijdering uit het ambt door de bezetter tenminste een pensioen verkregen zou worden. Dit dringende verzoek door een hooggeplaatste Belgische ambtenaar maakte het praktisch onmogelijk zich aan de uitvoering van deze bezettingsmaatregel te onttrekken, temeer daar geen steun was aangekondigd voor diegenen die miet aan deze maatregel wilden gehoorzamen.

Al in het begin van de bezetting werd de competentie van de Belgische gerechten inzake overtredingen en misdrijven gepleegd door leden van het Duitse leger en instituties in Belgie beperkt. Omdat dit geheel in overeenstemming was met international recht is het logisch dat de Belgische gerechten niet protesteerden hiertegen. En hoewel hun competentie inzake burgerlijke geschillen onaangetast bleef, werd de strafrechtelijke competentie van de Belgische gerechten op verschillende terreinen beknot, zoals voor economische misdrijven, illegaal wapenbezit en sabotage. Behalve artikel 43 LOR bevatte internationaal recht geen specifiek verdragsartikel dat de competentie van gerechten in bezet gebied regelde en juristen hadden geen unanieme 
menig over dit onderwerp. Naar Belgisch recht was dit een competentie van de Belgische gerechten. Het Hof van Cassatie zou voor de Belgische gerechten op basis van Bielgisch en internationaal recht en met steun van de parketten constant tegen de maatregelen van de bezetter protesteren om deze competentie te behouden.

De Secretaris Generaal van Justitie paste een decreet van 1939 aan om met tijdelijke benoemingen de vacante plaatsen bij de gerechten op te vullen. Hoewel niet geheel in overeenstemming met Belgisch recht zorgde deze basis in het Belgische recht ervoor dat de benoemingsprocedure grotendeels in Belgische handen bleef. Bij inmenging door de bezetter zouden achterenvolgende Secretarissen Generaal van Justitie de benoemingsprocedure stilleggen of door vertragingstactieken proberen enige invloed van de bezetter op de procedure af te wenden. Door de wettelijke verplichting voor ambtenaren om op hun post te blijven en de weigering van de meeste om op te stappen kwamen de hogere functies binnen de gerechtelijke hiërarchie pas na de bevrijding vacant. De lagere functies waren na de bevrijding voor bijna drie kwart nog bezet door dezelfde personen. Een verordening van de bezetter ter verjonging van de kaders werd bij de gerechten niet doorgezet, mede wegens een gebrek aan jonge aanwas. Het beleid en de maatregelen van de bezetter ten aanzien van de benoemingen bij de Belgische gerechten faalde hierdoor. Waar de bezetten een besluit trof om rechters die van anti-Duitse gezindheid blijk hadden gegeven wit hun ambt te verwijderen, liet hij dit besluit door de Belgische overheid witvoeren. Zollang deze rechters door Duitse krijgsgerechten berecht werden, beweerde de bezetter dat de Belgische gerechten dit aanvaardden. Wanneer deze rechters daadwerkelijk Duitse verordeningen geschonden hadden was dit niet verwonderlijk, omdat internationaal recht de bezetter hiertoe eenduidig de mogelijkheid gaf. Echter, waar rechters uit hun ambt werden verwijderd of gearresteerd voor een ex officio handeling zou het Hof van Cassatie met succes en met gebruik van internationaal en Belgisch recht, evenals de waarschuwing dat het onder die omstandigheden niet kon functioneren, de beslissing van de bezetter aanvechten.

De positiefrechtelijke houding van de Belgische gerechten, met name het Hof van Cassatie, was het duidelijkste bij de toepassing van bezettingsmaatregelen. Maatregelen van de bezetter werden gezien als feitelijke matregelen, niet van Belgische oorsprong, waardoor Belgisch recht de gerechten niet toeliet deze toe te passen. Waar een equivalent in Belgisch recht bestond werd dit toegepast, wat door de bezetter gedoogd werd. Waar dit niet het geval was gaven de gerechten een soort feitelijk effect aan die maatregelen van de bezetter, zonder ze toe te passen. Zo werd het illegale agglomeratiedecreet van de Secretaris Generaal van Binnenlandse Zaken niet toegepast en geschillen die naar aanleiding daarvan rezen niet afgehandeld. Echter, gehoorzamend aan het Duitse gebod tot toepassing werd wel de vertegenwoordiger van Groot-Antwerpen in de rechtszaal als vertegenwoordiger van een illegal geannexeerde gemeente erkend.

Dit was overigens pas na twee voor de geloofwaardigheid van het leiderschap van het Hof van Cassatie schadelijke juridische crises. Waar de Secretarissen Gieneraal een maatregel afkondigden die strijdig was met Belgisch recht en eerst de lagere gerechten en vervolgens het Hof van Cassatie deze toetsten aan Grondwet en wetgeving ontstond een patstelling. Bezetter en Secretarissen Generaal waren van mening dat de maatregelen door de Secretarissen Generaal afgekondigd op basis van de Wet betreffende delegatie van bevoegdheden kracht van wet hadden. Dit zou echter strijdig zijn met niet alleen Belgisch recht, doch ook artikel 43 LOR. Het Hof van Cassa- 
tie gaf dan ook niet toe. Echter, ook in strijd met Belgisch recht het het Hor van Cassatie onder zware druk well toe dat de Secretarissen Generaal de Wet betreffende de specialle bevoegdheden wan de Koning uit 1939 zouden benutten om collectief matregelen met kracht van wet af te kondigen. Wanneer het Hof van Cassatie hier een positiefrechtelijke houding aangenomen zou hebben, zou het de toetsing van deze maatregelen van de Secretarissen Generaal niet uit handen hebben mogen geven. Een inschattingsfout van het Hof van Cassatie bij de tweede juridische crisis, waarbij het onterecht meende dat de bezetter in een lopende rechtszaak bij het Brusselse Hof van Beroep ingreep, leidde er vervolgens toe dat het te verzwakt was om de strijd aan te binden tegen een Duitse maatregel die het gebood ook illegale decreten van cen Secretaris Generaal op basis van de Wet betreffende delegatie van bevoegdheden toe te passent.

Ondanks de voor de Belgische gerechten onvoordellige uitkomst van die twee juridische crises bleef het Hof van Cassative positief recht gebruiken on tegen verschillende maatregelen van de bezetter te protesteren en te proberen deze tegen te gaan. Dit was het geval voor maatregelen betreffende de Arbeisseinsatz in NaziDuitsland, de gruwelijkheden in kamp Breendonk, de in eerste instantie onbestrafte inmenging van een SS'er in een lopende zaak bij de Rechtbank van Eerste Aanleg te Aarlen en gijzelnames van rechters.

Belgische gerechten gebnuikten dan ook positief recht, soms met succes, om maatregelen van de bezetter tegen te gaan. Daar waar de Belgische gerechten toelieten dat afgeweken werd van positiefrechtelijke bepalingen was vaak geen andere weerstand meer mogelijk tegen de toepassing van bezettingsmaatregelen, of het nu die maatregelen afkomstig van de bezetter of die van de Secretarissen Generaal op basis van Belgisch recht waren.

De Luxemburgse gerechten werden direct in het begin met een hele reeks maatregelen van de bezetter geconfronteerd, die tot doel hadden hun positie en functioneren te beïnvloeden. De formule waaronder recht werd gesproken werd veranderd van 'In Naam der Groothertogin' naar 'In Naam van het Volk', wat wegens zijn gelijkenis met de Duitse formule geen neutrale formule was en daardoor het volkenrecht en Luxemburgs recht schond. Dit werd versterkt door de loyaliteitsverklaring die de Luxemburgse rechters in strijd met internationaal en Luxemburgs recht verplicht werden te ondertekenen. Het opsplitisen van het hoogste Luxemburgse gerecht, de Cour superieure, de verplichtstelling van Duits als enige rechtstaal en de benoeming van Duitse rechters direct binnen de Luxemburgse rechterlijke macht waren in strijd met Luxemburgs en internationaal recht. Geen enkel collectief protest tegen deze matregelen is bekend, hoewel de president van het Luxemburgse Tribunal, Faber, protest tegen de verplichting tot Duits als enige rechtstaal aantekende wegens schending van internationaal recht. Echter, ook nog voor het einde van 1940 verordende de bezetter dat het Openbaar Ministerie voor elke zaak aan de competentie van de Luxemburgse voorbij kon gaan en deze bij de opgerichte Duitse gerechten aanhangig kon maken.

Luxemburgse rechters werden verder aan ideologische trainingen onderworpen en, na de introductie van grote delen van het Duitse recht direct in de Luxemburgse rechtsorde, aan trainingen in het Duitse recht. Buiten deze schending van internationaal recht werd ook de Duitse rechterlijke organisatie ingevoerd, waarbij Luxemburgse rechters verplicht werden van de Luxemburgse Nazi beweging (VdB) lid te 
worden en de eed op Hitler af te nemen. Er waren enkele protesten, maar niemand nam ontslag. De weinige die weigerden, zoals President Faber en kantonrechter Welter, werden ontslagen en gedeporteerd. Zelts toen Luxemburgers aan de Duitse dienstplicht werden onderworpen nam geen enkele rechter ontslag, doch velen stuurden hun lidmaatschapskaart van de VdB terug. Ook zij werden door een Duits standgerecht veroordeeld en gedeporteerd.

Opvallend is de aanhoudende weigering van Luxemburgse rechters om ontslag te nemen, hoewel er geen wettelijke bepaling gevonden werd die hen gebood in functie te blijven. Dat dit echter niet als een collaboratie met de bezetter aangemerkt kan worden blijkt uit het volgende. Volgens Duitse rapporten liep de ideologische training van Luxemburgse rechters uit op niets. Slechts een enkele Luxemburgse rechter werd gedurende de bezetting benoemd en een enkele gepromoveerd. Uit wantrouwen werd geen enkele Luxemburgse rechter aan de Duitse gerechten in Luxemburg toegevoegd en minder dan een handvol had inzage in de zogenaamde Richterbriefe. Zelfs de Gestapo schatte dat een bijna verwaarloosbare minderheid van de rechters uit overtuiging van de $\mathrm{VdB}$ lid geworden was. Wat hierbij niet uit het oog verloren moet worden is dat er in totaal maar een zeventigtal Luxemburgse rechters, inclusief plaatsvervangers, in functie waren. De bezetter had hen gemakkelijk door Duitse juristen kunnen vervangen, wat gezien de benoeming van Duitse rechters binnen de Luxemburgse rechterlijke macht een reëel gevaar was. De aantijging van de bezetter dat de Luxemburgse rechters stelselmatig mildere straffen uitdeelden, kan inzicht: verschaffen in de reden waarom Luxemburgse rechters gedurende de bezetting in functie zijn gebleven.

De vraagstelling van dit onderzoek kon echter voor Luxemburg niet getoetst worden. Wegens het feit dat de rechtszaken afgehandeld in Luxemburg gedurende de bezetting niet gepubliceerd zijn en toestemming tot toegang in de archieven niet gegeven werd, kan niet nagegaan worden in hoeverre Luxemburgse rechters van een positiefrechtelijke houding gebruik maakten om weerstand tegen bezettingsmaatregelen te bieden.

De bezetter in Nederland overlegde met de Nederlandse autoriteiten in hoeverre de formule waaronder recht werd gesproken veranderd kon worden naar 'In Naam van het Recht'. De Hoge Raad zag unaniem geen bezwaar om aan dit verzoek tegemoet te komen, boewel dit de Nederlandse grondwettelijke bepaling om "In Naam der Koningin" recht te spreken schond. Ook volgens internationaal recht hoefde niet zonder meer aan dit verzoek voldaan te worden. Het besluit van de Hoge Raad was evenwel gebaseerd op de Aanwijzingen, welke een circulaire van de Nederlandse regering waren woor de houding aan te nemen tijdens een vijandelijke overval. In strijd met Nederlands recht werd deze circulaire boven de grondwet geplaatst en strijdig met zijn onafhankelijkheid liet de Hoge Raad zich hierdoor leiden in zijn interpretatie van. internationaal recht. Als gevolg hiervan werden de naam van de Koningin via circulaire uit het publieke en juridische leven geschrapt en de ambtseed veranderd, zodat elk teken van Nederlandse soevereiniteit uit het openbare leven verdwenen was. Tegen het ontslag van President Stheeman, die in een oordeel niet deze schending van Nederlands recht navolgde, werd niet geprotesteerd en er werd geen verdere actie tegen ondernomen.

Bezettingsmaatregelen werden verder ondanks hun schending van Nederlands recht door de gerechten toegepast en ook tegen de maatregelen tegen Nederlandse 
rechters van Joodse afkomst werd ondanks schending van Nederlands en mogelijk international recht slechts door een enkeling geprotesteerd. Het overbrengen van de competentie om misdrijven gepleegd tegen de bezetter te berechten naar gerechten die door de bezetter opgeticht waren, was in overeenstemming met internationaal recht. Een Nederlands gerecht interpreteerde een verordening die de competentie. beperkte echter zo ruim, dat ook zaken die de bezetter aan de Nederlandse gerechten gelaten had in strijd met Nederlands recht, maar zelfs met de maatregelen van de bezetter, toch aan bezettingsgerechten werden doorgegeven. Andere ingrepen in de competentie van de Nederlandse gerechten, zoals de schorsing van het klachtrecht, waren wel een schending van internationaal recht, doch lokten geen protest van de Nederlandse gerechten uit. De introductie van politieke gerechten genaamd de vrederechtspraak en de schending van internationaal recht en Nederlandse wettelijke bepaling betreffende ne-bis-in-idem brachten grote beroering teweeg binnen de Nederlandse rechterlijke macht, maar leidde buiten individuele ontslagnames ook niet tot collectieve actie. De introductie van de economische rechtspraak werd juridisch aangevochten, waarbij schending van Nederlands en internationaal recht betoogd werd. De Hoge Raad oordeelde echter dat volgens artikel 43 LOR en de verordening van de Rijkscommissaris de verordeningen van de bezetter kracht van wet hadden, niet getoetst konden worden en daardoor door de gerechten toegepast moesten worden. De wettelijke bepaling dat hij alleen wetgeving van Nederlandse oorsprong kon toepassen werd door de Hoge Raad hierbij opzij gezet. Internationaal recht was onduidelijk over de toetsingscompetentie van de gerechten van het bezette land, maar juristen en de Belgische rechtspraktijk uit de Eerste Wereldoorlog gaven de Hoge Raad genoeg mogelijkheden om een toetsingsrecht niet zo stellig te ontkennen. Het resultaat was echter dat Nederlandse gerechten ook onder andere de verordeningen tegen de Joden in strijd met internationaal en nationaal recht toepasten.

Vanaf het begin van de bezetting eiste de bezetter het recht op rechters te benoemen. De leidende functies bij de gerechten werden direct door hem benoemd en de lagere na Sichtvermerk. Hierdoor werden al snel leden van de NSB benoemd, doch hun aantal bleef wegens ontoereikende capaciteiten van NSB juristen vrij laag. Dat de bezetter van de wettelijke en gebruikelijke benoemingsprocedure afweek werd door de gerechten gelaten aanvaard. De bezetter slaagde er echter wel in de meerderheid van de leidende functies bij de gerechten te benoemen, waaronder de president en enkele leden van de Hoge Raad en vele raadsheren bij de gerechtshoven. Ook bij de lagere gerechten had een aanzienlijke minderheid de benoeming aan de bezetter te danken. De verordening betreffende de verlaging van de pensioensgerechtigde leeftijd van 70 naar 65 jaar zorgde voor vele vacante functies, wat de invioed van de bezetter op nieuwe benoemingen vergemakkelijkte. Ondanks strijd met nationaal en internationaal rechtelijke bepalingen aanvaardden de Nederlandse gerechten ook deze maatregel gelaten.

Bij de protesten van de Nederlandse gerechten betreffende de wantoestanden in het kamp Ommen was dan ook nadrukkelijk geen sprake van leiding coor de Hoge Raad of én van de vijf gerechtshoven. De Amsterdamse Officier van Justitie en Arrondissementsrechtbank leidden de protestactie hiertegen. Drie raadsheren bij het Leeuwardense Gerechtshof steunden deze actie door in hun vonnis met de strafmaat rekening te houden, waarna twee van die raadsheren uit hun ambt verwijderd werden. Hoewel de gerechten protesteerden was er geen dreiging van collectieve sanctie aan verbonden. Dit ondanks het feit dat deze ontslagen een directe ingreep in de recht- 
spraak waren, strijdig met internationaal en nationaal recht, en waardoor voor geen enkel gerecht de onafhankelijkheid nog gegarandeerd was. Het collectieve protest van de Nederlandse gerechten tegen de wantoestanden in de kampen zoals Ommen had wel als resultaat dat deze gesloten werden.

Andere bezettingsmaatregelen vonden wel hun doorgang. Sommige gerechten protesteerden tegen de maatregelen betreffende de Arbeitseimsatz cn weigerden in eerste instantie medewerking, maar verleenden ondanks de schending van intemationaal recht uiteindelijk toch hun medewerking. De Hoge Raad verkreeg een uitzondering, maar bedong die alleen voor zichzelf en niet alle Nederlandse gerechten. De bezetter verordende ook nog dat de zetel van verschillende gerechten verplaatst werd, waaronder die van de Hoge Raad. Dit was in strijd met internationaal recht en onder Nederlands recht zou dit kunnen betekenen dat deze gerechten niet meer als Nederlandse gerechten gezien konden worden. De introductie van het Führerprinzip lokte ook tevergeefse protesten uit en werd ondanks strijdigheid met internationaal en nationaal recht geïntroduceerd. Donner, raadsheer bij de Hoge Raad, die vanaf het begin onophoudelijk tegen illegale bezettingsmaatregelen had geprotesteerd en verschillende mallen gearresteerd was geweest, diende hierbij zijn ontslag in.

Vanaf de zomer van 1944, tegen het einde van de bezetting, probeerden sommige gerechten de gelaten houding van de Nederlandse rechterlijke macht te doorbreken en betwistten openlijk de geldigheid van sommige verordeningen. Dit toont aan dat er juridische mogelijkheden in het internationale en Nederlandse recht aanwezig waren om de toepassing van tenminste sommige bezettingsmaatregelen tegen te gaan. De meeste gerechten wachtten echter het einde van de bezetting af, getuige het feit dat behalve door sommige individuele rechters niets tegen de gijzelname van en moord op sommige rechters gedaan werd.

Nederlandse gerechten lieten dan ook na om positief recht te gebruiken om weerstand te bieden tegen maatregelen van de bezetter. Alleen in één geval lukte het de Nederlandse gerechten on onder leiding van een arrondissementsrechtbank te organiseren en beleid van de bezetter te veranderen. In de meeste gevallen waren de $\mathrm{Ne}$ derlandse gerechten te ongeorganiseerd om collectief tegen bepaalde bezettingsmaatregelen weerstand te bieden, waarbij niet altijd woor een positiefrechtelijk standpunt gekozen werd. Een meer positiefrechtelijke houding zou de Nederlandse gerechten echter gedwongen hebben in elk geval bepaalde bezettingsmaatregelen tegen te gaan.

De vraag of een positiefrechtelijke houding het woor gerechten onmogelijk maakte bepaalde bezettingsmaatregelen tegen te gaan kan niet eenvoudig beantwoord worden. Internationaal- en nationaal-rechtelijke bepalingen gaven argumenten, sommige overtuigender dan andere, om bepalalde bezettingsmatregellen niet toe te passen. Een positiefrechtelike houding zou gerechten in die gevallen dus eerder gedwongen hebben de uitvoering van bepaalde bezettingsmaatregelen tegen te gaan. Belgische gerechten waren het meest positiefrechtelijk in hun houding, waarbij het leiderschap van het Hof van Cassatie hen ondersteunde on hun houding de collectieve sanctie van mogelijke opschorting van werkzaamheden kracht bij te zetten. De Luxemburgse gerechten moesten noodgedwongen buiten de vergelijking vallen. Dit vanwege een gebrek aan informatie over het gebruik van recht, de vroegtijdige opheffing van de Cour supérieure, de benoeming van Duitse rechters en het gemak waarmee de bezetter het geringe aantal Luxemburgse rechters kon vervangen. De Nederlandse gerechten waren het minst positiefrechtelijk ingesteld, waarbij een gebrek aan leiderschap 
van de hoogste gerechten het onmogelijk maakte bij een aangenomen houding de collectieve sanctie van mogelijk opschorten van hun werkzaamheden kracht bij te Zetten.

De regeringen die aan het begin van de bezetting in ballingschap waren gegaan hadden maatregelen afgekondigd in afwachting van hun terugkeer na de bevrijding. De juridische basis voor deze ballingschapsbesluiten was allerminst onbetwist of onaanvechtbaar. Zowel de Belgische als de Nederlandse ballingschapsiegering beriep zich op een basis die niet in positief recht verankerd was. Zowel het Belgisch als het $\mathrm{Ne}$ derlands parlement bekrachtigde deze maatregelen niet na de terugkeer van hun regering uit ballingschap, waarbij het Nederlandse parlement evenwel het duidelijkste signaal gaf de ballingschapsmaatregelen goed te keuren. Luxemburg was hier weer in een andere positie. Niet alleen oefende de ballingschapsregering bevoegdheden uit die ze voor de bezetting van haar parlement verkregen had, doch na de bevrijding belkrachtigde het nieuwe parlement uitdrukkelijk deze ballingschapsmaatregelen en verleende ze daarmee de status van wet in formele zin.

Vlak na de bevrijding behandelde het Hof van Cassatie all een zaak waarin ballingschapsmaatregelen werden toegepast en vermeldde terloops dat de Ministerraad, op grond van nota bene de constitutionele basis die hij zelf had aangedragen, zonder twijfel alle wetgevende bevoegdheden uitoefende. Ook in daarop volgende zaken, hoewel dit in afwijking was van de tekst, geschiedenis en intentie van de aangehaalde grondwetsbepalingen, oordeelde het Hof van Cassatie op dezelfde manier. Door de classificatie van ballingschapsmaatregelen als 'wetten in formele zin' ontnam het Hof de Belgische gerechten van de mogelijkheid te toetsten aan Belgische wetgeving of ongeschreven internationaal recht.

De ballingschapsmaatregelen zouden die bezettingsmaatregelen die de Belgische gerechten in de uitoefening van hun werkzaamheden belemmerden wegnemen en behandelden ook de tijdelijke benoemingen gedaan door de Secretarissen Generaal tijdens de bezetting. Ook die rechters benoemd voor de inval werden door de millitaire gerechten onderzocht en zo nodig vervolgd voor schending van het Belgische strafrecht betreffende collaboratie gedurende de bezetting. Het Hof van Cassatie accepteerde dit in strijd met de bevoegdheden van de lagere Belgische gerechten om zelf volgens Belgische wetgeving rechters voor ex officio misdrijven te berechten.

Door de delegatie van bevoegdheden voor de bezetting en de ratificatie van het parlement na de bezetting van de ballingschapsmaatregelen waren de Luxemburgse gerechten, zoals al eerder aangehaald, in een andere positie dan de Belgische en $\mathrm{Ne}$ derlandse. Echter, voordat het Luxemburgse Parlement zich hierover had kunnen uitspreken hadden het Luxemburgse Tribunal en de Cour superieure in cassatie al zonder bedenkingen de ballingschapsmaatregelen als wetgeving in formele zin aanvaard. In overeenstemming met een positiefrechtelijke houding werd een beroep op ongeschreven international recht afgewezen.

Door de gebeurtenissen van de bezetting moesten de Luxemburgse gerechten geheel nieuw opgezet worden. De weinige Luxemburgse rechters die an het eind van de bezetting nog bij de voormalige Luxemburgse gerechten in functie waren werden vervolgd en op andere dan de wettelijke bestaande gronden verwijderd vit hun ambt. Ook werden zij gezuiverd voor hun niet-ex officio handelen door de gewone Luxemburgse gerechten, aangevuld met lekentechters. 
De lagere gerechten in Nederland werden als eerste met de geldigheid van de ballingschapsmaatregelen geconfronteerd, waarbij de Hoge Raad door zo'n maatregel geschorst was. Ondanks het feit dat geen bepaling van de Grondwet of andere wetgeving de regering het recht gaf deze maatregelen met kracht van wet af te kondigen, accepteerden eerst de lagere gerechten en, na opheffing van zijn schorsing, de Hoge Raad hum geldigheid. De Hoge Raad maakte enig voorbehoud, maar hindarde hun toepassing niet. Ook met betrekking tot specifieke onderdelen van de ballingschapsmaatregelen, wooral betreffende het verbod wan terugwerkende kracht van straf-en publicatiebepalingen, weken de Nederlandse gerechten af van Nederlandse wetgeving.

De maatregelen zorgden ervoor dat bijna alle bezettingsmaatregelen die het functioneren of de positie van de gerechten beïnloedden opgeheven werden. Nog op basis van haar ballingschapsbevoegdheden kondigde de regering na haar terugkeer in Nederland zuiveringsmaatregelen aan voor de rechterlijke macht, waarbij die leden benoend tijdens de bezetting, behalve Smits en de Visser, ook voor hun handelen buiten hun functie onderzocht en vervolgd werden. De procedure voor het onderzoek naar de rol van de voor de bezetting benoemde leden van de Hoge Raad, alsmede Smits en de Visser, zou echter het langste aanslepen. Verschillende gesprekken met de regering mondden uit in een compromis, waarbij die gesprekken gezien werden als een soort van verantwoording voor het functioneren van de Hoge Raad gedurende de bezetting. In ruil woor immuniteit van verdere zuivering stemde de Hoge Raad erin toe dat een zuiveringsautoriteit voor de lagere gerechten geschapen werd, die de aan de Hoge Raad toebehorende constitutionele bevoegdheid tot het verwijderen van rechters uit hun ambt, die benoemd waren voor de invasie, zou uitoefenen. Toen deze zuiveringsautoriteit genaamd het Hoge College voor de Rechterlijke Macht, de Hoge Raad ter verantwoording riep, weigerde de Hoge Raad, gesteund door de Minister van Justitie, mee te werken, argumenterende dat de gesprekken met de regering daarvoor al zorg gedragen hadden. En hoewel Smits herbenoemd werd en de Visser terug in zijn oude anbt geinstalleerd werd, zou deze naoorlogse crisis rond de Hoge Raad pas eindigen na de benoeming door de Koningin, tegen de gebruikelijke procedure in, van Donner tot president van de Hoge Raad.

In hoeverre een positiefrechtelijke houding het voor gerechten onmogelijk maakte bepaalde balingschapsmaatregelen tegen te gaan kan alleen voor Luxemburg eenvoudig beantwoord worden. De bevoegdheidsdelegatie voor de oorlog aan de regering en de bekrachtiging van de ballingschapsmaatregelen na de bevrijding door het parlement maakte dat die maatregelen kracht van wet hadden en door de Luxemburgse gerechten zonder mogelijkheid tot toetsing toegepast moesten worden. In zowel Belgie als Nederland was de situatie niet zo eenduidig, omdat geen duidelijke delegatie van bevoegdheden bestond, bestaande positiefrechtelijke bepalingen de uitoefening van de wetgevende macht door de regering niet toelieten en het parlement de ballingschapsmaatregelen niet bekrachtigd had. Zowel de Belgische als de Nederlandse gerechten zouden in afwijking van bestaande positiefrechtelijke bepalingen de ballingschapsmaatregelen toepassen, waarbij een positiefrechtelijke houding hen gedwongen zou hebben in elk geval sommige van deze te weerstaan.

Dit onderzoek richtte zich vooral op recht en de vraag of volgens positiefrechtelijke bepalingen gerechten bezettingsmaatregelen of ballingschapsmaatregelen moesten 
toepassen. De uitkomst was dat een positiefrechtelijke houding in elk geval in België en Nederland het niet onmogelijk had gemaakt meer weerstand te bieden bij de toepassing van bepaalde bezettingsmaatregelen en ballingschapsmaatregelen, maar hen juist dwong deze niet toe te passen. Er werd niet specifiek gekeken of er andere, nietjuridische redenen waren om in afwijking van positief recht deze maatregellen toch toe te passen, hoewel mogelijke redenen soms wel naar voren gebracht werden. Als een toegift werd er dan gekeken of de wetgever geen wettelijk kader zou kunnen schapen, waardoor gerechten tijdens een bezetting ook niet voor zulke niet-juridische vragen gesteld zouden worden, omdat dit par excellence de taak van de wetgever is. Ondanks internationaal-rechtelijke ontwikkelingen en verschillende nationaalrechtelijke bepalingen in België en Nederland, doch niet in Luxemburg, was nergens een zodanige kaderwet aangenomen. Gezien de geschiedenis van de Wet betreffende delegatie van bevoegdheden in België, die pas op het laatste moment door het parlement aangenomen werd, lijkt dat ook niet voor de hand liggend.

Het voorstel werd echter gedaan om nationale wetgeving aan te nemen die ervoor kan zorgen dat gedurende een vijandelijke bezetting de nationale organen kunnen doorfunctioneren in overeenstemming met internationaal en nationaal recht en daarbij de bezetter ter zijde te staan in de administratie van het bezette land. Die zaken die de bezetter echter volgens internationaal recht niet toekomen zouden op basis van nationaal recht, zonder zijn inmenging, door de nationale organen afgehandeld moeten worden. Die maatregelen op basis van deze wetgeving zouden geen kracht van wet kunnen hebben, ook omdat dit strijdig met artikel 43 LOR is. Zolang die nationale wet in overeenstemming is met internationaal recht zou de bezetter deze niet opzij kunnen zetten, hetzij door zich aan schending van dat internationale recht schuldig te maken. Internationaal recht, hoewel een verduidelijking gevend over de bevoegdheden van de bezetter, kan net als dit woorstel voor een nationale wet geen duidelijke omlijning geven van die bevoegdheden, noch die die aan de nationale overheid tijdens de vijandelijke bezetting blijven toebehoren. Ook voor die beleidsgebieden die onder de nationale bevoegdheid blijwen vallen kan zo'n wet ook niet bepalen dat bestaande nationale wetgeving conform de vigerende tradities toegepast wordt en niet naar de wil van de bezetter gebogen wordt. De toepassing van internationaal recht, zodat de bezetter die zaken tijdens een bezetting behartigt die hem toekomen en de nationale overheid de haar overblijvende bevoegdheden verdedigd en conform haar eigen traditie haar eigen wetgeving toepast, is afhankelijk van de geest van diegenen die dit recht moeten toepassen. De voorgestelde nationale wetgeving hoopt daarom alleen de nationale organen en de uitoefening van de hun toekomende bevoegdheden van de bezetter af te schermen, zodat de nationale organen het vertrouwen vinden om zoveel mogelijk hun eigen bevoegdheden te beschermen en maatregelen toe te passen in overeenstemming met de traditie en geest van de bestaande wetgeving. 


\section{ANNEX 1 \\ LIST OF TRANSLATIONS BELGIUM'}

FRENCH, DUTCH / GERMAN

Abandon de poste

Abatage clandestine

Amtliche Bekanntmachung

Anordmung

Arbeitseinsatz

Arrêté-loi / Besluitwet

Arrêté du Chef de l'Administration

Militaire

Assemblée générale

Auditeur général / Auditeur-generaal

Auditeur militaire / Auditeur militair

Auditorat militaire / Militair auditoraat

Avocat Général / Advocaat Generaal

Bâtonnier/Stafhouder (of the bar)

Beschikking van de Chef van het

Militair Bestuur

Besluitwet / Arrêté-loi

Certificat de civisme

Chambre des Représentants /

Kamer van Volksvertegenwoordigers

Chambres / Kamers (of a court)

\section{ENGLISH}

Abandonment of office or post

Illegal slaughter

official statenent

Directive

Labor deployment

(legislative) Decree

Decision of the Chef of the Military Administration

Plenary meeting

Chief military prosecutor

Military prosecutor

Military prosecutor service

Advocate General

President of the bar association

(*Dean of the Bar)

Decision of the Chef of the Military Administration

(legislative) Decree

Certificate of good citizenship

Chamber of Representatives

Chamber (*section, division) 
Chef du Cabinet (du Ron)

Circulaire

Code pénal / Strafwetboek

Code d"instruction criminelle /

Wetboek van Strafwordering

College wan Secretarissen Generaal /

Comité des Secrétaires-généraux

Commission belge pour l'Etude des

Problemes d'Apres Guerre (CEPAG)

Commission Permanente de la

Mobilisation de la Nation

Comités d'Application

Corporation Nationale de l'Agriculture et de l'Alimentation CNAA

Conseil de Guerre / Krijgsraad

Conseil de Législation / Raad voor de Wetgeving / Gesetzgebungsrat

Conseil de l'ordre du barreau de Bruxelles

Conseil provincial/ Provincieraad

Conseiller

$\sim$ complément

Contestation (cf. Article 92 Belgian

Constitution)

Contravention

Convention de la Haye
Chef of the King's Cabinet

Circular

Belgian Penall Code (BPC)

Belgian Code of Criminal Procedure

Committee of Secretaries General

Belgian commission for the study of post-war problems

Permanent Commission concerning Mobilisation of the Nation

Committees of application

CNAA or Agricultural Council

War Council

Council for legislative affairs

Supervisory council of the Brussels bar association

Provincial Council

Justice

$\sim$ temporary

Dispute

Misdemeanor

Hague Convention 
Cour d'appel / Hof van Beroep

Cour de cassation / Hof van Cassatie

Cour des Comptes / Rekenhof /

Rechnungshof

Cour militaire / Militair Gerechtshof

Crime

Délit

Démence

Dénonciation

Députation permanente /

Bestendige Deputatie

Désignation (appointment during

occupation on the Basis of Statute of 1935)

Détournement de pouvoir

Deutschfeindliche Kundgebungen

Dienstpfichtverweigerer

Droit de grâce

Droits des biens

Épuration administrative

Épuration civique

Feldkommandant

Force de loi

Force obligatoire
Cour d'appel ${ }^{2}$

Cour de cassation

Court of Audit

\section{Cour militaine}

Serious offense

Offense

Insanity

Denunciation

Provincial executive

Nomination

Abuse of powers

Anti-German expressions

Conscientious objector to conscription

Right to Pardon

Property rights

Administrative purge

Civic purge

Local military commander

Force of law

Binding force

Since the terminology in French for the Belgian courts is easily understandable for an English native speaker l have for the most part opted to refer to these courts where possible on the basis of the French language terminology. 
Fuhrererlafs

Gendarmerie/Rijkswacht

Gouverneur (provincial)

Haut Commissaire à la Sécurité de l'État / Hoog Commissariaat voor 's lands Veiligheid

Hof van Beroep / Cour d'appel

Hof van Cassatie / Cour de cassation

Hoog Commissariat voor 's lands Veiligheid/Haut Commissaire à la Sécurité de l'État

Inciviques

Industriële economie

Instruction (ordered by examining magistrate)

L'intégrité de la personne (civil right)

Journal de mobilisation

Juge d'enfants

Juge d"instruction / Onderzoeksrechter

Juge de Paix / Vrederechter

Justizreferent der Feld-Oberfeldkommandantur

Kamer van Volksvertegenwoordigers / Chambre des Représentants

Kriegsgericht
Führer Decree

National police

Provincial Governor

High Commissioner for State Security

Courd dappel ${ }^{\hat{3}}$

Cour de cassation ${ }^{4}$

High Commissioner for State Security

Collaborators

Industrial economy

Criminal investigation

Personal integrity

Manual of mobilisation

Juvenile chamber

Examining magistrate

Justice of the Peace

German legal departments monitoring. the Belgian Judiciary at regional and local level

Chamber of Representatives

German war tribuna]

3 lbid. 
Krijgsraad / Conseil de Guerre

Kwaad opzet

Landesverband der Ernährungsund Landwirtschaft

\section{Lebensmittelmarkenfalschung}

Libération anticipée

Ligne de conduite

Livret de mobilisation civil /

Mobilisatieboekje

Loi / Wet

Loi de délégation 1940
War Council

Mal intent

Council for nourishment and agriculture (CNAA)

Food coupon falsification

Early release

Policy

Booklet on civil mobilization

Act, Statute

Statute on Delegation (1940)

\section{Article 5}

Lorsque par l'effet des opérations militaires, un magistrat ou un fonctionnaire, un corps de magistrats ou de fonctionnaires, en dehors les cas prévus par les articles 2 et 3 , qui précèdent, est privé de toute communication avec l'autorité supérieure dont il dépend, ou si cette autorité a cessé ses fonctions, il exerce dans le cadre de son activité professionelle et pour les cas d'urgence toutes les attributions de cette autorité.

If, due to military operations, a magistrate or public official, a collegiate of magistrates or public officials, beyond the scope of the cases foreseen by articles 2 and 3 that are preceding, are deprived of all communication with the superior authority they depend on, or if this authority has ceased its functions, he exercises within the scope of his professional activities and in urgent matters all the attributes of his superior.

Loi du 7 septembre 1939

Loi du 5 mars 1935 , concernant les devoirs des fonctionnaires en temps de guerre

Loi sur la détention préventive

Loi sur la mise en retraite des magistrats

Mandat d'arrêt

Mettre en disponibilité (d'un juge)
Statute on the King's special powers (1939)

Statute on the duties of public officials during wartime (1935)

Statute concerning remand in custody

Statute concerning retirement from office of magistrates

Arrest warrant

Removal from office 
Militair Gerechtshof / Cour militaire

Militärstab

Ministère des Affaires économiques /

Ministerie van Economische Zaken

Ministère de l'Agriculture et de

Ravitaillement / Ministerie van

Landbouw en Voedselwoorziening

Ministère des Finances / Ministerie van Financiën

Ministère de Justice / Ministerie van Justitie

Ministère du Santé Public / Ministerie van Volksgezondheid

Mobilisatieboekje / Livret de mobilisation civil

Moniteur/Staatsblad

Oberfeldkommandant

Oberfeldkommandantur

Oberstkriegsgerichtsrat

Oberkriegsverwaltungsrat

Office du Commerce Extérieur

Oberkommando des Heeres (OKH)

Oberkommando der Wehmacht (OKW)

Onderzoeksrechter / Juge d'instruction

Orde van Advocaten / Ordre des avocats

Ordnungsstrafverfahren

Ordre des avocats / Orde van advocaten 314
Cour militaire

Military unit

Ministry of Economic Affairs

Ministry of Agriculture and Food supply

Ministry of Finance

Ministry of Justice

Ministry of Public Health

Booklet on civil mobilization

Belgian Official Journal

Regional military commander

Regional military command post

President of the German war tribunal

Legal affairs official

Bureat of foreign commerce

High Command of the German Army (OKH)

High Command of the German Armed Forces (OKW)

Examining magistrate

Bar association

criminal adjudicatory proceedings

Bar association 
Präsidialburo

Preiswucher

Premier Président

Prescriptions légales

Président

$\sim$ at the Cour de cassation or Cour d'appel

$\sim$ at a Tribunal de première instance

Procureur Général / Procureur Generaal (at the Cour de cassation and the

Cours d'appel)

Procureur du Roi / Procureur des Konings Plaatswervangend

Projet de loi

Provincieraad / Conseil provincial

Prijzenregeling

Raad van Advies bij de Regering

Raad voor dle Wetgeving / Conseil de législation

Ravitaillement

Rechtbank van eerste aanleg/ Tribunal de premiere instance

Rechrskrafinges Urteil

Reichstommissar

Règlement concernant les lois et coutumes de la guerre sur terre

Rekenhof / Cour des Comptes /

Rechmungshof
Presidium

Price usury

President

Legal provisions

Vice President

President

Procurator General.

King's Prosecutor junior

Bill

Provincial Council

Pricing

Governmental Advisory Council

Council for legislative affairs

Rationing or supply (of food)

Tribunal

Res judicata judgnnent

Reichskommissar

Annex to the IVth Hague Convention, Hague Convention (Regulations respecting the Laws and Customs of War on Land)

Court of Audit

Prosecution 


\section{Ruhestowd}

Rundschreben

Rijkswacht / Gendarmerie

Schutz des Arbeitsfriedens

Schwarzshlachtungen

Sciemment

Sénat / Senaat

Sluikslachting

Stafhouder / Bâtonnier (of the bar)

Strafwetboek / Code pénal

Suppléant (Juge de Paix)

Sureté extérieure de l'État

Travaux préparatoires

Tribunal de première instance /

Rechtbank van eerste aanleg

Tutelle administrative

Verordnungsblat fin die besetzten Gebiete

Vertagung (der Gerichrhandlwng)

Verwaltungabteilung

Verwalmangstab

Verachtende omstandigheden

Voeding / ravitaillement

Volontairement
Suspension

Circular(s)

National police

Protection of labor peace

lllegal slaughter

Knowingly

Senate

Illegal slaughter

President of the bar association ( Dean of the Bar)

Belgian Penal Code

Deputy (Justice of the Peace)

External security of the state

Legislative history

Tribunal

Administrative supervision

Journal for Occupied Belgium

Stay court proceedings

Administrative department

Civil-administrative unit

Mitigating circumstances

Nourishment

Willingly 
Vrederechter/Juge de Paix

Wehrmacht

Wetboek van Strafvordering / Code d'instruction criminelle

Wet / Loi

Wirtschaftsabreilung
Justice of the Peace

German Armed Forces

Belgian Code of Criminal Procedure

Act, Statute

Economy department 



\section{ANNEX 2 \\ LIST OF TRANSLATIONS LUXEMBOURG}

\section{FRENCH / GERMAN}

Amtsgericht (former Juge de Paix)

Apothekerkammer Luxemburg

Arrêté gouvernemental

Arrêté-loi

Arrêté

Ärztekammer Luxemburg

Assemblée consultative

Ausnahmezustand

Chambre des Députés

Commission administrative

Commission de Gouvernement

Commission d'enquête

(du Ministère de l'Épuration)

Conseil d'État

Conseillers de Gouvernement

Contravention (Délit, Crime)

Contresignature

Cour martiale/ Standgericht

Cour supérieure

Crime

\section{ENGLISH}

Cantonal court

Luxembourg Association of Apothecaries

Governmental decree

(legislative) Decree

Decision

Luxembourg Association of General Practitioners

Consultative Parliament

State of emergency

Parliament, Chamber of Deputies

Administrative Commission

Commission of Government

Commission of enquiries

Council of State

Councillors of Government

Misdemeanor

Countersign

Court martial

Cour supérieure

Serious offense 
Crimes contre la sécurité de l'Etat

Délit

Destitution

Deutscher Rechtswahrerbund (DRB)

Dol général

Etat de siège

IVme Convention de la Haye du 18 octobre 1907, concernant les droits et devoirs des puissances et personnes neutres en cas de guerre sur terre

Formliches Urteil

Gau

Gauleiter

Gemeinde

Generalstaatsanwalt

Gestapo

Gesundes Volksempfinden

Gleichschaltung

Grand-Duché

Grand Duchesse

Grève générale

Juge do Paix

Juridiction d"instruction

Juridiction de jugement

Körperliche Unfahigheit
Crimes against the security of the state Offense

Removal from office

German Association for the Maintenance of the Law

General misrepresentation

State of emergency

IVth Hague Convention of 18 october 1907 concerning the rights and. obligations of neutral powers and persons in case of land warfare

Legal judgment

Gau (territorial administrative unit)

Gauleiter

Municipality

Procurator General (of State)

German secret police

Healthy sense of people's justice

Gleichschaltung or enforced conformity

Grand Duchy

Grand Duchess

General strike

Court of the Peace

Prosecution

Adjudication

Physical disability 
Landgericht (former Tribunal

d'arrondissement)

Landkreis

Loi

Loi sur l'organisation judiciaire

Mémorial

Ministère de l'Épuration

Mise à la retraite anticipée

Nationalsozialistischer Rechtswahrerbund

Oberlandesgerichtliche Senate

(former Cour supérieure)

Oberlandesgericht (in Germany)

Pourvoi

Procureur d'État / Staatsanwalt

Procureur Général (d'État)/

Generalstaatsanwalt

Regierungskommission

Reichsstrafgesetzbuch

Règlement

Règlement concernant les lois et coutumes de la guerre sur terre

Révocation

Richterbriefe

Sanction du souverain
District Court

County

Act, Statute

Judicial Organisation Act (1885)

Luxembourg Official Journal

Ministry of Purges

Early retirement

national socialist law chapter NSRB

Appellate Court's Senates

Higher Regional Court of Appeal /

Provincial Court of Appeal /

Higher Superior Court

Appeal

Procurator of State

Procurator General (of State)

Commission of Government

German Penal Code

Regulation

Annex to the IVth Hague Convention, Hague Convention (Regulations respecting the Laws and Customs of War on Land)

Removal from office

Instructions from the German Ministry of Justice directing judges

Royal assent 
Schlechtes Betragen

Sciemment

Sonderdienststrafgericht

Sondergericht

Sprachenverordnung

Staatsanwalt / Procureur d'État

Standgericht / Cour martiale

Strafrechtsanalogie

Suppléant

Tribunal d'arrondissement

Unbestimmtheir der Straftatbestände

L'Union des Mouvements de Résistance

Volontairement

Versuch (to commit a crime)

Verwaltungskommission

Volkszugehörigkeit

Vorschlagsliste
Bad behavior

Knowingly

Special Criminal Tribunal dealing with disciplinary charges against civil servants

Special Court

Language Regulation

Procurator of State

Court martial or Standgericht

Analogy of penal provisions

Deputy

Tribunal

Uncertainty of criminal provisions

Union of Resistance Movements

Willingly

Attempt to commit a crime

Administrative Commission

Racial category

List of Recommendations 


\section{ANNEX 3}

\section{LIST OF TRANSLATIONS NETHERLANDS}

\section{DUTCH / GERMAN}

Aanbevelingslijst

Aanwijzingen

Commentaar op de

Advocaat

Advocaat-generaal

Afwezigheid van alle schuld

Algemene Maatregel van Bestuur

Ambtshalve

Apologie

Apothekerskamer

Ariërverklaring

Arrest

Arrondissement

Arrondissementsrechtbank

Beaufragte (of the Reichskommissar)

Bekrachtiging

\section{ENGLISH}

List of Recommendations

Instructions

Commentary to the $~$

Attorney

Advocate General

Absence of culpability

General administrative order

(* Order in Council (of State))

Ex officio

Apologie

Chamber of pharmacists

Declaration of Aryan Ancestry, Aryan Declaration

Judgment

District

District Court

Representarive

Assent

\footnotetext{
* Indicates a different translation in Boele-Woelki, K. e.a. (red.), Nederlandse rechthegrippen vertaald Frans-Dunts-Engels, Asser Institut "s-Gravenhage, 1998. However, the translation used in my main text will be the first translation. Boele-Woelki seems to translate more to ward the English legal system, whereas my translations tend to take the American legal systems more into account.
} 
Belastingkamer

Besluit Bestrijding Plundering in Oorlogstijd

Besluit Bezettingsmaatregelen

Besluit Herstel Rechtsverkeer

Besluit Hervatten Executie Straffen

Besluit Oorlogspleegkinderen

Besluit Staking Executie Straffen

Besluit Vijandelijk vermogen

Besluit Vordering Woonruimte

Besluit Tijdelijke Organisatie van de Rechterlijke Macht

Bewindvoerder

Bezettingsmaatregelen

Bezettingsmacht

Buitengewone Raad van Advies

Buitengewoon Besluit Arbeidsverhoudingen

Burgerlijk Wetboek

Bijzonder Gerechtshof

Bijzondere Raad van Cassatie

Cassatie

Centrale Raad van Beroep
Tax Chamber

(*tax division)

Decree Combating Plunder during Wartime

Decree Occupation Measures

Decree Recovery Legal Relations

Decree Resumption Execution Sentences

Decree War Foster Children

Decree Staying Execution Sentences

Decree Enemy Property

Decree Requisitioning Housing

Decree on the Temporary

Organization of the Judiciary

Custodian

(*administrator bonis)

Occupation measures

Occupant, Civil administration

Extraordinary Advisory Council

Extraordinary Decree Labor Relations

Netherlands Civil Code

Special Appeals Court

( ${ }^{*}$ Special Criminal Court)

Special Court of Cassation

Cassation

Central Appeals Court for the public service and social security matters 
Circulaire

College (collegiate decision-making)

College van curatoren van een gemeentegymnasium

College van Secretarissen Generaal

Commentaar op de Aanwijzingen

Commissaris der Koningin

Commissaris der Provincie

Contra seign (of Ministers of legislation)

Dagvaarding

for a defendant in a criminal case

$\sim$ for a witness in a civil trial

Deken van de Orde van Advocaten

Dellict

Denazificatie

Deurwaarder

Deutsches Landgerichi

Deutsches Obergericht

Distributiewet

Doctrine

Dolle Dinsdag

Dossier

Duitsgezind

Economisch Hof

Economische rechter / Wirtschafisrichter

\section{Circular}

Chamber, panel

Board member of the municipal grammar school

ommittee of Secretaries General

See 'Aanwijzingen'

Commissioner of the Queen

ommissioner of the Province

countersign

notice of summons and accusations subpoena

President of the Bar Association

( ${ }^{*}$ Dean of the (national or district) Bar)

Offense

Denazification

Court bailiff

German Trial Court

German Appellate Court

Distribution Act (1939)

Jurisprudence

("scholarly writings)

Mad Tuesday

case-file

Pro-German

Economic Court of Appeal

Economic judge/court 
Eerste Kamer

Eidesstattiche Erklärung

Eigendom of daaruit voortspruitende rechten (art 2 Wet RO)

Eis (door OM)

Enkelvoudige kamer

Feldkriegsgericht des Kommandeurs der Truppen des Heeres in den Niederlanden

Friedensgericht

Friedensgerichtshof

Friedensrichter

Führer

Fïhrerprinzip

Gemeenschap van goederen

Gemeente

Gemeenteraad

Generalkommissar / Commissaris-

Generaal

$\sim$ zur besondere Verwendung

$\sim$ für Finanz und Wirtschaft

$\sim$ des Sicherheitswesens

$\sim$ für Verwaltung und Justiz

Generalsekretär

Gerechtshof

Gestaakt (van uitoefening publieke functie)

Gesundes Rechtsempfinden

Getuigenis

Getuigenis onder ede
See 'Kamer, Eerste'

See 'Gezworen verklaring'

Ownership or rights flowing therefrom

Recommended or requested sentence

See 'Kamer, enkelvoudige'

Field War Tribunal of the Commander of the German Army in The

Netherlands

See 'Vredegerecht'

See "Vredegerechtshof"

See "Vrederechter"

Führer

Führerprinzip, leader principle

Community of property

Municipality

Municipal Council

Commissioner General

$\sim$ for Special Assignments

$\sim$ for Finances and Economic Policy

$\sim$ for Security

$\sim$ for Administration and Justice

See 'Secretaris-Generaal'

Court of Appeal

See 'Staken'

See 'Gezond rechtsgevoel'

Testimony

(*statement of witness)

Sworn testimony 
Gewestelijk Arbeidsbureau

Gewone rechter (Art. 161)

Gezond rechtsgevoel

Gezworen verklaring

Gnademrecht / Gratierecht

'goed' en 'fout"

Griffier / Kanzleischreiber

Groote Advies Commissie der Illegaliteit

Handelingen Tweede Kamer

Hechtenis

Preventieve

Voorlopige

Hoge Raad

Hoger beroep

Hooge College voor de Rechterlijke Macht

Huurbescherming

Hunprijsbescherming

Illegale pers

Intemeren

Jurisprudentic

Justitie (Openbaar Ministerie)

Kamer (of courts)
Regional Employment Agency

ordinary court

Healthy sense of justice

Swom statement

Right to be pardoned, pardon procedure

right (side)/ wrong (side)

cout registrar

High Advisory Council of the

Resistance

Protocols of the Lower Chamber of the Netherlands Parliament

("official reports)

Custody

Preventive custody

Remand in custody

Netherlands Supreme Court

Appeal

Special Tribunal for the Judiciary

Rental protection

(* security of tenure)

Rent control

underground press

to intern

case law

public prosecution service

Chamber

(*of a District Cout, section;

of a Court of Appeal, section;

of the Supreme Court, division) 
Eerste

Enkelvoudige

Kantongerecht

Kantonrechter

Kantonrechter plaatsvervanger

Klaagrecht (Artt. 12, 552a Sr.)

Koninklijk Besluit

( $\sim$ enacted during exile)

Koninklijke Marechaussee

Koninkrijk der Nederlanden

Kort Geding

Landoorlogreglement

Landoorlogverdrag (IV cle Haagse

Conventie)

Landadvocaat

Militair Gezag

Ministerie van

Algemene Zaken

$\sim$ Binnenlandse Zaken

$\sim$ Buitenlandse Zaken

$\sim$ Defensie

$\sim$ Economische Zaken

$\sim$ Financiën
Upper Chamber

( ${ }^{*}$ Upper House)

single chamber

(*single-judge section)

Cantonal Court

(*subdistrict court)

Cantonal judge

(*subdistrict court judge)

Deputy Cantonal judge

(*deputy judge of subdistrict court)

Right to lodge a complain

Royal Decree

Royal Decree

(*emergency decree)

Royal Military Police

(*Royal Netherlands Military

Constabulary)

Kingdom of The Netherlands

Application for interim relief

(*Interim injunction proceedings)

Annex to the IVth Hague Convention, Hague Convention (Regulations respecting the Laws and Customs of War on Land)

Hague Convention

State attorney

(*state advocate (under general retainer))

(Netherlands) Military Authority

Ministry, Department of

$\sim$ General Affairs

$\sim$ the Interior

$\sim$ Foreign Affairs

$\sim$ Defence

$\sim$ Economic Affairs

$\sim$ Finance 
$\sim$ Handel, Nijverheid en Scheepvaart

$\sim$ Justitie

$\sim$ Landbouw

Onderwijs, Cultuur en Wetenschappen

$\sim$ Sociale Zaken en Werkgelegenheid

- Volksgezondheid, Welzijn en Sport

Ministerraad

Misdrijf

Nalatigheid

Nationaal Socialistische Beweging

NSB

NSB'ers

Nazificatie

Nederlands Beheersinstituut

Nederlandsch-Duitsche Kultuurgemeenschap

Nederlandse Jurisprudentie

Nederlands Juristenblad

Nederlandse Staatscourant

Noodwet Rechtspleging

NSDAP

Officier van Justitie

Substituut

Onschendbaar

Onschendbaarheid der Koningin $\sim$ Trade, Industry and Shipping

$\sim$ Justice

$\sim$ Agriculture

$\sim$ Education, Culture and Science

$\sim$ Social Affairs and Employment

$\sim$ Health, Welfare and Sport

Council of Ministers

(*Cabinet)

Serious offense

(*indictable offence)

Neglect of office

National Socialist Movement

NSB

member of the NSB

Nazification

Netherlands Assets Administration

Netherlands-German Cultural Society

Netherlands Court Reports

Netherlands Law Journal NJB

Netherlands Official Gazette

Emergency Statute Administration of Justice (1964)

National Socialist German Workers Party

Public prosecutor (at a District or Cantonal Court)

junior

Inviolable

Inviolability of the Queen 
Ontbreken van de materiële weder-

rechtelijkheid

Onteigeningswet

Oorlogswet

Openbaar Ministerie/Staatsanwaltschaft

Opperbevelhebber van Land- en Zeemacht

Opportuniteitsbeginsel

Opsporingsdienst

Overtreding

Personeelsbeleid

Personeelszuivering

Politierechter

Preventieve hechtenis

Procureur-generaal (to Supreme Court

And Court of Appealy

Privaatrechtelijke aanspraken m.b.t.

Staatsaansprakelijkheid

Raad van Toezicht en Discipline van de

Orde van Advocaten

Raad voor het Rechtsherstel

Afdeling Effectenregistratie

Afdeling Beheer

Afdeling Voorzieningen

Afdeling Voorzieningen Rechtspersonen

Afdeling Rechtspraak

Afdeling Onroerend Goed
Lack of material illegality

Expropriation Act

War Act (1899)

Public Prosecution Service or

Department

Supreme Commander of the Land-and Naval Forces

Principle of prosecutorial discretion

Special Police

Misdemeanor

Personnel policy

Personnel cleansing or purge

Single sitting judge at a District Court (*single judge in the district court)

See 'Hechtenis'

Procurator General

Civil claims relating to state liability

Supervisory and Disciplinary Board of the Netherlands Bar Association (*(District) Bar Council)

Council for Restoration of Rights

Department of Securities Registration

Department of Administration

Department of Assistance to Natural

Persons

Department of Assistance to

Public Entities

Department of Adjudication

Department of Immovables 


\begin{tabular}{|c|c|}
\hline $\begin{array}{l}\text { Raadsheer (in Supreme Court or Court } \\
\text { of Appeal) }\end{array}$ & Justice \\
\hline plaatsvervanger & Deputy Justice \\
\hline Raad van State & Council of State \\
\hline Rechter & Judge \\
\hline (in algemene zin) & Court \\
\hline$\sim$ plaatsvervanger & Deputy Judge \\
\hline Rechter-commissaris & Examining magistrate \\
\hline Rechterlijke Macht & Judiciary \\
\hline Rechterlijke zuiveringsraad & See 'Zuiveringsraad' \\
\hline Rechtsbedeling & Administration of Justice \\
\hline Rechtspleging & Administration of Justice \\
\hline Rechtspraak & Adjudication \\
\hline Rechtsfront & $\begin{array}{l}\text { National Socialism and the Law } \\
\text { Chapter, NSL Chapter }\end{array}$ \\
\hline Rechtsstaat & $\begin{array}{l}\text { Rechtsstaat } \\
\left({ }^{*} \text { rule of law }\right)\end{array}$ \\
\hline Rechtvaardigingsgrond & $\begin{array}{l}\text { Justification } \\
(* \text { defence of justification) }\end{array}$ \\
\hline Reichsgesetzblatt & German Official Journal \\
\hline Reichskommissar & $\begin{array}{l}\text { Reichskommissar } \\
\text { High Commissioner or Governor } \\
\text { General }\end{array}$ \\
\hline Reichskommissariat & $\begin{array}{l}\text { Reichskommissariat or Reichskommis- } \\
\text { sar's office or administration }\end{array}$ \\
\hline Rijksbegroting & State Budget \\
\hline Rijkscommissaris & See 'Reichskommissar' \\
\hline Rijkscommissariaat & See 'Reichskommissariat' \\
\hline Schikking (Artikel 74 Sr.) & Out-of-court settlement \\
\hline Schorsing (of a person from office) & Suspension \\
\hline
\end{tabular}


Schuldvorderingen of burgerlijke rechten

\section{Schuthaft}

Secretaris-Generaal (van het Departement) van

Staatsblad van het Koninkrijk der Nederlanden

Staatscommissie Bezettingsrecht

Staatscourant

Staatsnoodrecht / Staatsnotrecht

Staat van beleg

Staken (van uitoefening publieke functie)

Staten-Generaal

Tijdelijke

Voorllopige

Stral

Strafkamp

Strafsenaat

Strafzaken rakende het economische leven

Tenlastelegging

Toetsingsarrest

Transactie (strafrecht)

Travaux préparatoires

332
Claims or civil rights

(Art 2 Wet RO)

Protective custody

Secretary General (of the Department) of

(See 'Ministerie' for the different Ministries/Departments)

Netherlands Official Journal (*Blletin of Acts and Orders (of the Kingdom of the Netherlands))

State Committee on Occupation Legislation

Netherlands Official Gazette

(*Netherlands Government Gazette)

State emergency legislation

(*emergency powers legislation)

State of emergency

To stay (from the exercise of public office)

Parliament, *States General temporary interim

Sentence

Prison camp / detention camp

Criminal Chamber

Economic crimes / offences

Indictment

Judgment on judicial review

Out-of-court settlement (in criminal matters)

Legislative history 
Tribunaal

Tweede Kamer

Untersuchungshaft

Veemgericht

Verdachte

(before summons)

(after summons)

Verhoor (of witness or suspect)

Verhoren

Veroordeling

( voorwaardelijke)

Verordnung

Verordening

Verordening betr. Duitsche rechterlijke macht in Strafzaken

Verordening betr. handhaving van de Openbare Orde

Verordening verwijdering wan joden uit het Bedrijfsleven.

Verordeningenblad

Verordungsblatt

Verpachting (van land)

Vervolging

Vervreemding (van land)

Voedselvoorzieningsblad

Volksgemeenschap
Special Tribunal

Lower Chamber

(*ower House)

See "Preventieve hechtenis"

Underground resistance court

Suspect

Accused

Examination, Hearing

(*interview)

To question

Conviction

conditional sentence

(*suspended sentence)

See "Verordening"

Regulation

Regulation concerning the competencies of German courts in criminal matters

Regulation on the maintenance of public order

Regulation on the removal of Jews from businesses

Journal for the Occupied Netherlands

See "Verordeningenblad"

Tenancy (of land)

Prosecution

Transfer (of land)

Food Distribution Journal

People's community 
Volksgemeinschaft

Volnacht

Vounis ( rechterlijk)

Voogdijraad

Voorlopige hechtenis

Voorwaardelijke veroordeling

Vorladung

Vredegerecht

Vredegerechtshof

Vrederechter

Vuurwapenwet

Wangedrag

Wapenverordening

Wehrmacht

Wet Algemene Bepalingen

Wetboek Burgerlijke Rechtsvordering

Wet Oorlogsstrafrecht

Wet op de Rechterlijke Organisatie

Wetboek van Strafrecht

Wetboek van Strafvordering

Wethouder

Wirtschaftsstrafsachen

Zivilverwaltung
See 'Volksgemeenschap'

Power of Attomey

Judgment

Council dealing with guardianship issues

See 'Hechtenis'

Conditional sentencing

See 'Dagvaarding'

Peace Court

Peace Appellate Court

Peace Magistrates

Arms Act (1919)

Serious misconduct

Weapons Regulation

German Armed Forces

Act on General Provisions

Netherlands Code of Civil Procedure

Statute on War Criminal Law (1952)

Judicial Organisation Act (1827)

Netherlands Penal / Criminal Code

Netherlands Code of Criminal

Procedure

Municipal Councillor

(*alderman)

See "strafzaken rakende het economische leven'

See 'bezettingsmacht' 
Zuiveringsbesluit

Zuiveringsraad

Rechterlijke
Purging Decree

Purging Council

Council for the Purge of the Judiciary 



\section{ANNEX 4}

OVERVIEW PERSONNEL POLICY BELGIUM

\begin{tabular}{|l|l|l|l|l|}
\hline & \multicolumn{1}{|c|}{ Totals } & \multicolumn{1}{|c|}{ O } & \multicolumn{1}{c|}{ P } & \multicolumn{1}{c|}{ N } \\
\hline 1940 & 1258 & 1258 & - & - \\
\hline 1946 & 1184 & 731 & 172 & 281 \\
\hline
\end{tabular}

\section{EXPLANATION TERMINOLOGY:}

Total in office: all judges, including deputies, on the bench in a given year.

$\mathbb{N}$ or New appointees: all judges, including deputies, newly appointed in the postwar period.

O or Old appointees: Those judges, including deputies, appointed before the occupation and who remained in the same office during the occupation and/or returned to the same office in the immediate postwar period.

P or Promotion: all judges, including deputies, promoted in the postwar period.

No officially published figures concerning newly made appointments and promotions during the occupation are available.

\section{SOURCES:}

Ammaire administratif $1940,1946$. 



\section{ANNEX 5}

OVERVIEW PERSONNEL POLICY LUXEMBOURG

\begin{tabular}{|c|c|c|c|c|}
\hline & TOTALS & 0 & $P$ & $\mathbf{N}$ \\
\hline 1940 & 76 & 76 & - & - \\
\hline 1946 & 73 & 22 & 19 & 32 \\
\hline
\end{tabular}

\section{EXPLANATION TERMINOLOGY:}

Total in office: all judges, including deputies, on the bench in a given year.

N or New appointees: all judges, including deputies, newly appointed in the postwar period.

O or Old appointees: Those judges, including deputies, appointed before the occupation and who remained in the same office during the occupation and/or retumed to the same office in the immediate postwar period.

P or Promotion: all judges, including deputies, promoted in the postwar period.

No officially published figures concerning newly made appointments and promotions during the occupation are available.

\section{SOURCES:}

Annuaire officiel $1940,1946$. 



\section{ANNEX 6}

\section{OVERVIEW PERSONNEL POLICY NETHERLANDS}

\section{TABLE 1 Supreme Court, Courts of Appeal, District Courts and CANTONAL COURTS}

\begin{tabular}{|l|l|l|l|l|}
\hline & $\begin{array}{c}\text { TOTAL IN } \\
\text { OFFICE }\end{array}$ & \multicolumn{1}{|c|}{ O } & \multicolumn{1}{|c|}{$\mathbf{P}$} & \multicolumn{1}{|c|}{ N } \\
\hline 1940 & 780 & - & - & - \\
\hline 1941 & 744 & 737 & 2 & 5 \\
\hline $1943-1944$ & 707 & 445 & 65 & 197 \\
\hline 1946 & 683 & 501 & 45 & 137 \\
\hline
\end{tabular}

TABle 2 COURTS OF APPEAL

\begin{tabular}{|c|c|c|c|c|c|c|c|c|c|}
\hline & $\begin{array}{c}\text { TOTAL } \\
1940\end{array}$ & $\begin{array}{c}O \\
43 / 44\end{array}$ & $\begin{array}{c}P \\
43 / 44\end{array}$ & $\begin{array}{c}N \\
43 / 44\end{array}$ & $\begin{array}{l}\text { TOTAL } \\
43 / 44\end{array}$ & $\begin{array}{c} \\
\| 946 \\
94\end{array}$ & $\begin{array}{c}p \\
1946\end{array}$ & $\begin{array}{c}N \\
1946 \\
\end{array}$ & $\begin{array}{c}\text { TOTAL } \\
1946\end{array}$ \\
\hline $\begin{array}{l}\text { Amster: } \\
\text { Dam }\end{array}$ & 20 & 4 & 9 & 6 & 19 & 0 & 5 & 4 & 9 \\
\hline Arrohem & 10 & 6 & 1 & 0 & 7 & 6 & 1 & 0 & 7 \\
\hline $\begin{array}{l}\text { The } \\
\text { Hague }\end{array}$ & 18 & 9 & 5 & 6 & 20 & 8 & 4 & 3 & 15 \\
\hline $\begin{array}{l}\text { Den } \\
\text { Bosch }\end{array}$ & 8 & 7 & 0 & 0 & 7 & 6 & 0 & 0 & 6 \\
\hline $\begin{array}{l}\text { Leeu- } \\
\text { warden }\end{array}$ & 8 & 3 & 3 & 3 & 9 & 2 & 1 & $\mathbb{1}$ & 4 \\
\hline Totals & 64 & 29 & 18 & 15 & 62 & 22 & $\| \mathbb{1}$ & 8 & 41 \\
\hline
\end{tabular}

TABle 3 District Courts - Presidents and Vice President's

\begin{tabular}{|c|c|c|c|c|c|c|c|c|c|}
\hline & $\begin{array}{c}\text { TotAL } \\
1940\end{array}$ & $\begin{array}{c}O \\
43 / 44\end{array}$ & $\begin{array}{c}P \\
43 / 44\end{array}$ & $\begin{array}{c}N \\
43 / 44\end{array}$ & $\begin{array}{l}\text { Total. } \\
\mathbf{4 3 / 4 4}\end{array}$ & $\begin{array}{c} \\
1946 \\
\end{array}$ & $\begin{array}{c}P \\
1946 \\
19\end{array}$ & $\begin{array}{c}\mathbb{N} \\
1946\end{array}$ & $\begin{array}{c}\text { Toral. } \\
1946\end{array}$ \\
\hline $\begin{array}{l}\text { Presi- } \\
\text { Dents }\end{array}$ & 18 & 8 & 8 & 1 & 17 & 6 & 5 & I & 12 \\
\hline $\begin{array}{l}\text { Vice } \\
\text { Presi- } \\
\text { dents }\end{array}$ & 23 & 17 & 6 & 0 & 23 & 16 & 0 & 0 & 16 \\
\hline Totals & 41 & 25 & 14 & 1 & 40 & 22 & 5 & 1 & 28 \\
\hline
\end{tabular}




\section{EXPLANATION TERMINOLOGY:}

Total in office: all judges, including deputies, on the bench in a given year.

$N$ or New appointees: all judges, including deputies, newly appointed during the occupation. The figure for 1946 expresses those who had been newly appointed during the occupation and were still in office in 1946.

O or Old appointees: Those judges, including deputies, appointed before the occupation and who remained in the same office during and after the occupation. For 1946 these figures include those removed from office during the occupation and who returned to office in the postwar era on the basis of Royal Decree $\mathbb{E} 94$.

P or Promotion: all judges, including deputies, appointed before and promoted during the accupation. The figure for 1946 expresses those who had been given a promotion dluring the occupation and were still in office in 1946

The occupation figures effectively run through 1943. No publication was made of the composition of the courts afterwards until 1946.

\section{SOURCES:}

Staatsalmanak 1940, 1946; Gids voor de Rechterlijke Macht 1941; Bestuursalmanak 1942-1943, $1943-1944$. 


\section{BIBLIOGRAPHY}

\section{GeneraL}

\section{Baker/ Mckernan}

Baker, J.R., McKernan, L.W., Selected Topics commected with the Laws of Warfare as of Atgust 1, 1914, Government Printing Office Washington, 1919.

\section{Beer Poortugael}

Beer Poortugael, J.C.C., den, Oorlogs-en Neutraliteitsrecht op den grondslag van de Conferentie van Genève in 1906 en de mee Hagsche Wredes-Conferentien, van Cleef 's-Gravenhage, 1907.

\section{Benvenisti}

Benvenisti, E., The Intemarional Law of Occupation, Princeton University Press Princeton, 1993.

Best

Best, G., War and Law Since 1945, Clarendon Press Oxford, 1994.

\section{Best, Humanity}

Best, G. Humanity in Warfare; The Modern History of the International Law of Armed Conflicts, Weidenfeld and Nicolson London, 1980.

\section{Bordwell}

Bordwell, P., The Law of War between Belligerents; a history and commentary, Callaghan Chicago, 1908.

\section{David}

David, E., Principes de droit des conflits amés, 2ième edition, Bruylant Bruxelles, 1999 .

\section{Detter}

Detter, I., The Law of War, $2^{\text {nd }}$ edition, Cambridge University Press, 2000.

\section{Dongen}

Dongen, van, Y., The Protection of Civilian Populations in Time of Armed Conflict, Thesis Publishers Amsterdam, 1991.

\section{Donmison}

Donnison, F.S.V., Civil Affairs and Military Government North-West Europe 19441946, Her Majesty's Stationary Office London, 1961.

\section{François}

François, J.P.A., Handboek van het volkenrecht, deel 2, Tjeenk Willink Zwolle, 1933. 


\section{Ghan}

Glahn, von, G., Law Among Nations; an introduction to public internationall law, $6^{\text {th }}$ revised edition, MacMillan Publishing Company New York, 1992.

\section{Hart}

Hart, H.L.A., The Concept of Law, $2^{\text {nd }}$ edition, Clarendon Oxford, 1998.

\section{Herdeg}

Herdeg. W., Grundzüge der deutschen Besatzungsvenwaltung in den west- und nordetropäuschen Ländern während des zweiten Weltkrieges, Institut für Besatzungsfragen Tübingen, 1953.

\section{Kalshoven}

Kalshoven, F., Zwijgt het rechts als de wapens spreken?, in: Clingendael-reeks deel 9, Staatsuitgeverij 's-Gravenhage, 1985

\section{Kelsen}

Kelsen, H., Die philosophischen Grundlagen der Naturrechtslehre und des Rechtspostivismus, Panverlag Charlottenburg, 1928.

\section{Kerchove}

Kerchove d'Exaerde, de, F., Quelques questions en droit international public relatives aux fondements juridiques de la présence et de l'activité du Gouvernment belge en exile à Londres (octobre 1940-septembre 1944), Mémoire ULB Année académique 1987-1988.

\section{Mechelynck}

Mechelynck, A., La Convention de La Haye concernant les Lois et les Coummes de la Guerre sur Terre d'après les Actes et les Documents des Conférences de Bruxelles de 1874 et de La Hoye de 1899 et 1907, Maison d'Éditions et d'Impressions Gand, 1915.

Meurer

Meurer, C., Das Kriegspecht der Haager Konferenz, Schweitzer Verlag München, 1907.

\section{Möller}

Möller, A., International Law in Peace and War, Part II, Levin \& Munksgaard Copenhagen, 1935.

\section{Nispen tot Sevenaer}

Nispen tot Sevenaer, van, C.M.O., L'Occuption allemande pendant la derniere guerre mondiale; considerations sur le caractere du powvoir de la puissance occupante et de ses mesures selon les principes generaux du droit et selon la 4 e Convention de La Haye, Martimus Nijhoff La Haye, 1946. 


\section{Oppenheim, Vol I}

Oppenheim, M.A., International Law, a treatise, Volume I, $2^{\text {nd }}$ edition, Longmans Green London, 1912.

\section{Oppenheim Vol II}

Oppenheim, M.A., International Law, a treatise, Volume II, 6th revised edition, Longmans Green London, 1944.

\section{Oppenheim, Peace}

Oppenheim, L., International Law; A Treatise; Peace (Volume II), $2^{\text {nd }}$ edition, Longmans Green New York, 1912, p. 214-215.

\section{Oppenheim, War}

Oppenheim, M.A., International Law, a treatise, Vol. II War and Neutrality, $2^{\text {nd }}$ edition, Longmans Green London, 1912.

\section{Pictet}

Pictet, J., Development and Principles of International Humanitarian Law, Martinus Nijhoff Dordrecht, 1985.

\section{Rolin, Tome I}

Rolin, A., Le Droit Modeme de la Guerre; Les Principes, les Conventions, les Usages et les Abus, Tome I, A. Dewit Bruxelles, 1920.

\section{Rolin, Tome III}

Rolin, A., Le Droit Moderne de la Guerre; Les Principes, les Conventions, les Usages et les Abus, Tome III, A. Dewit Bruxelles, 1921.

\section{Spaight}

Spaight, J.M., War Rights on Land, MacMillan London, 1911.

\section{Verraes, Tome I}

Verraes, F., Les Lois de la Guerre et de la Neurralité, Tome I, Schepens Bruxelles, 1906.

\section{Verraes, Tome II}

Verraes, F., Les Lois de la Guerre et de la Neutralité, Tome II, Schepens Bruxelles, 1906.

\section{Verzijl}

Verzijl, J.H. W., International law in historical perspective, parl $I X-A$ The laws of war, Sijthoff \& Noordhoff Alphen aan den Rijn, 1978.

\section{Visscher}

Visscher, Ch., de, L'occupation de guerre d'après la jurisprudence de la Cour de cassation de Belgique, The Law Quarterly Review, vol. 34, 1918, p. 72-81. 


\section{BELGIUM}

\section{Achualite Juridique}

L'actualité juridique; Que subsiste-t-il, depuis te 15 février 1946, de la législanion édictée par les Secrétaires Généraux?, in. Joumal des Tribunaux 1946, p. 111-112, $223 \sim 224$.

\section{Annuaire administratif}

Annuaire administratif et judiciaire de Belgique et de la capitale du Royaume, Bruylant Bruxelles, 1940 and 1946.

\section{Arrêtés-loi Londres}

Commentaires Législatifs; Les: arrêtés-loi de Londres, in: Journal des Tribunaux $1944-1945$, p. 5.

\section{Bekaert}

Bekacrt, H., Problèmes sociaux de l'incivisme, in: Revue de Droit Pénal et de Criminologie $1946-1947$, p. 203-232.

\section{Charlles/Dasnoy}

Charles, J.L., Dasnoy, P., Les Secretaires Generaux face a l'occupant; procesverbaux des reunions du comite des Secretaires Generaux (1940-1944), Editions Arts et Voyages Bruxelles, 1974.

\section{Conway, Collaboratie}

Conway, M., Collaboratie in Belgï̈; Léon Degrelle en het Rexisme 1940-1944, Globe Groot-Bijgaarden, 1994.

\section{Conway, Justice BEG}

Conway, M., Justice in postwar Belgium. Popular passions and political realities, in: BEG/CHTP, nr 2, 1997 , p. 7-34.

\section{Conway, Ilustice Déak}

Conway, M., Justice in Postwar Belginm: Popular Passions and Political Realities, in: Deak. I. (ed), The Politics of Retribution in Europe; World War II and its After. math, Princeton University Press New Jersey, 2000, p. 133-156.

\section{Dabin}

Dabin, J., Actualité du Controle Juridictionnel des Lois, Larcier Bruxelles, 1973.

\section{Dautricourt, Militaire}

Dautricourt, J., Y., La Jurisprudence Militaire; De Militaire Rechtspraak, Larcier Bruxelles, 1946. 


\section{Dautricourt, Répression}

Dautricourt, J., L'article 115 du Code Pénal et la Répression de la collaboration économique; Étude revisée et complètée d'après l'arrêté-loi dir 25 mai 1945 précisant l'application de l'alinéa 4 de l'article 115 du Code Pénal, en cas d'occupation ennemie et d'après la jurisprudence acruelle, Larcier Brixelles, 1945.

\section{Delandsheere/Ooms}

Delandsheere, P., Ooms, A., La Belgique sous les Nazis, Tomes I-III, Edition universelle Bruxelles, 1946, 1947.

\section{Doorslaer}

Doorslaer, Van, R., De Belgische politie en magistratuw en het probleem van ordehandhaving, in: Verhoeyen (e.a.), België in de Tweede Wereldoorlog, deel 9, Het minste kwaad, Pelckmans Kapellen, 1990.

\section{Drooghenbroeck}

Drooghenbroeck, P., van, Powvoir judiciaire et puissance occupante, publisher unknown, Nivelles, 1946.

\section{Duvieusart}

Duvieusart, J., La Question Royale; Crise et dénouement: juin, juillet, août 1950, Éditions Crisp Bruxelles, 1975.

\section{Dayat}

Fayat, $H$. , Législation belge en exil; Aperç de l'action législative et exécutive du Goivernement belge en exil (I6 maï 1940-8 septembre 1944), VUB Brussel, 1993.

\section{Ganshof van der Meersch, Collaboration}

Ganshof van der Meersch, M., La collaboration économique; Une circulaire de $M$. Ganshof van der Meersch, in: Journal des Tribunaux 1946, p. 269.

\section{Ganshof van der Meersch, Réflexions}

Ganshof van der Meersch, M., Réflexions sur la répression des crimes contre la sureté extérieure de l'Éfat Belge, in: Revue de Droit Pénal et de Criminologie 1946-1947, p. $97-182$.

\section{Ganshof van der Meersch, Regering}

Ganshof van der Meersch, M., Enkele juridische aspecten van de actie der regering tijdens de oorlog 1940-1944, in: Liber Amicorum August de Schrijver, Luykx Brussel, 1968 , p. 393-433.

\section{Geet}

Geet, Van, W., De Rijkswacht tijdens de bezetting 1940-1944. Nederlandsche boekhandel Antwerpen, 1985. 


\section{Gilissen, Juridiction militatre}

Gilissen, I., La juridiction militaire belge de 1830 à nos jours, in: Actes du Colloque d'Histoire Militaire Belge (1830-1980), Travaux du Centre dHistoire Militaire 1981, p. $467-490$.

\section{Gilissen, Répression}

Gilissen, J., Etude statistique sur la répression de lincivisme, in: Revue de Droit Pénall et de Criminologie 1950-1951, p. 513-628.

\section{Gilissen, Sécurité}

Gilissen, J., Collaborations avec l'ennemi, sécurité de l'Etat, incivisme, notions à contenu variable, in: Les notions à contenu variable en droit, Bruylant Bruxelles, 1984, p. 297-327.

\section{Goethem}

Goethem, Van, H., August de Schryver; Oorlogsdagboeken 1940-1942, met inleiding en commentaar over de Belgische Ministers in Frankrijk en Londen, Lannoo Tielt, 1998.

\section{Gorissen}

Gorissen, J.A. (ed), Belgitu under occupation, Moretus Press New York, 1947.

\section{Gotovitch/Gêrard-Libois}

Gotovitch, J., Gerard-Libois, J., L'An 40; La Belgique occupée, Crisp Bruxelles, 1971 .

\section{Mancquet}

Hancquet, R., Les pouvoirs des secrétaires généraux pendant l'occupation, Goemaere Brussel, 1946.

\section{Hoon}

Hoon, de, De Belgische Grondwet; Officieele tekst en vertaling en toelichting, Office de Publicité Brussel, 1927.

\section{Muynen}

Huynen, S., L'extension de la compétence des juridictions militaires dans les cas de connexité, in: Journal des Tribunaux 1944-1945, p. 196-197.

\section{Huyse}

Huyse, L., The Criminal Justice System as a Political Actor in Regime Transitions: The Case of Belgium, 1944-1950, in: Deák, I. (ed), The Politics of Retribution in Europe; World War II and its Aftermath, Princeton University Press New Jersey, 2000, p. $157-172$.

\section{Huyse/Dhondt}

Huyse, L., Dhondt, S., La Répression des collaborations (1942 - 1952): un passé woujouxs présent, Crisp Bruxelles, 1991. 


\section{Huyse/Hoflack}

Huyse, $\mathbb{L}$., Hoflack, $\mathrm{K}$, (red.), De democratie heruitgewonden; Oud en nieuw in poliniek Belgïë 1944-1950, Van Hallewyk Leuven, 1995.

\section{Isacker}

Isacker, van, K., Jonghe, de, A.., Wijngaert, van den, M., Basistekst van de Werkgroep-Bestum wan het bezette land, Wetenschappelijke kommissie voor de geschiedenis van de Tweede Wereldoorlog in Belgie, BRT, 1971.

\section{Janssens}

Janssens, E., La magistrature belge sous l'occupation (1940-1944), Universite Catholique de Louvain, 1993-1994.

\section{Janssens-Brigode}

Janssens - Brigode, A., $<<$ Le Pacte $>>$, in: Journal des Tribunaux 1945, p. 121.

\section{Jonghe}

Jonghe, de, A., Hitler en het Politieke Lot van België (1940-1944), deel 1, De Nederlandsche Boekhandel, Antwerpen, 1972.

\section{Jonghe, Vestiging}

Jonghe, de, A., De vestiging van een burgerlijk bestum in Belgïe en NoordFrankrijk; de slotbespreking in het Führerhauptquartier 12 juli 1944 (dokument), in: Bijdragen van het Navorsings- en Studiecentrum voor de Geschiedenis van de Tweede Wereldoorlog No. 1, 1970, p. 69-132.

\section{Jonghe, Personeelspolitiek}

Jonghe, $\mathrm{A}_{\text {. }}$, de, De personeelspolitiek van de Militärverwaltung te Brussel gedurende het eerste halffar der bezetting (juni-december 1940); Bijdrage tot de studie van de Duitse Flamenpolitik in Wereldoorlog II, in: Belgisch Tijdschrift voor de Nieuwste Geschiedenis (1972), III, 1-2, p. 1-49.

\section{Judices}

Judices, Juridische aspecten van de reprexsie en epuratie in België, Van der Sticht Sas van Gent, 1945.

\section{Leclercq}

Leclercq, P., Linterpréfation de la loi du 10 mai 1940, in: Journal des Tribunaux 1946, p. $65-70$.

\section{Leclerco, Loil}

Leclercq, P., L'Equivoque d'une Loi..., Soulevans un coin du voile, Larcier Bruxelles, 1946.

\section{Lenaerts}

Lenaerts, J., 20 jaar later: Terugblik op een repressie, in: Rechtskundig Weekblad 1967, p. $561-578$. 


\section{Leopold III}

Leopold II, Kroongetwige. Over de grote gebeurtenissen tijdens mijn koningschap, LannooTjelt, 2001.

\section{Lory}

Lory, $J .$, Le rôle des autorités judiciaires dans la répression légale de l'inciviswe. Septembre 1944-Février 1945, Séminaire d'Histoire contemporaine 1984-1985.

\section{Louveaux}

Louveaux, C.L., La Magistrature dans la toumente des années 1940 - 1944, Revue de Droit Pénal et de Criminologie, 1981, n. 7.

\section{Maerten}

Maerten, F., Du Murmure aw Grondement, La Résistance politique et idéologique dans la Province de Hainaut pendant la Seconde Guerre mondiale (mai 1940 - septembre 1944), Tome 7 Volume 1, Hannonia Mons, 1999.

\section{Mast, Indépendence}

Mast, A., J, L'indépendence des magistrats, in: Journal des Tribunaux 1946, p. 181.

\section{Mast, Monopole}

Mast, A.l., Le monopole jurisdictionel du pouvoir judiciaire, in: Journal des Tribunaux 1946, p. 345 .

\section{Meyer}

Meyer, de., J., Over de legitimiteit van de beshitwetten van de oorlogsregeringen in 1914-1918 en in 1940-1945, in: Liber Amicorum August de Schrijver, Luylox Brussel, 1968, p. 297-304.

\section{Ministère des Affaires Étrangères de Belgique}

Ministère des Affaires Etrangères de Belgique, La relation officielle des événements $1939-1940$, Hazel Watson \& Viney London.

\section{Ockrent}

Ockrent, R., Les Crises constitutionelles du Pouvoir législatif en Belgique; Les pouvoirs des Secrétaires généraux sous loccupation ennemie et la Délégation du Pouvoir législatif au Roí; Avant projer du réforme constitutionelle, ULB Institut de Sociologie Solvay Office de publicité Bruxelles, 1944.

\section{Outrive, e.a.}

Outrive, van, L., Cartuyvels, Y., Ponsaers, P., Sire, ik ben ongerust, geschiedenis van de Belgische politie 1794-1991, Kritak Leuven, 1992, p. 131-152.

\section{Pacte}

Le $<<$ Pacte $>>$, in: Journal des Tribunaux 1946-1947, p. 121-123.

\section{Page}

Page, H., de, Traité élementaire de droit civil I, 2e édition, Bruylant Bruxelles, 1939. 


\section{Passelecq}

Passelecq, F., La magistrature belge contre le despotisme ahemand, Berger-Levrault Paris, 1918.

\section{Philippart}

Philippart, R., La Séparafion des Powworss, in: Journal des Tribunaux 1946, p. 577.

\section{Pholien, Chronique}

Pholien, J., Chronique judiciaire, Le discours du Procureur Général Pholien, in: Journal des Tribumaux 1944-1945, p. 45

\section{Pholien, Répression}

Pholien, J., La Répression. Méditations sur la nécessité d'une politique dans la répression pour faits de guerre, Lumière Bruxelles, 1944.

\section{Pirenne/Vauthier}

Pirenne, J., Vauthier, M., La législation et administration allemandes en Belgique, Presses Universitaires de France Paris, 1925.

\section{Polain}

Polain, M., La compétence exorbitante des jurisdictions militaires, in: Journal des Tribunaux 1945, p. 253.

\section{Raskin}

Raskin, E., Gerard Romsée; Een ongewone man, een ongewoon leven, Hadewijch Antwerpen, 1995.

\section{Rédaction JdT, I}

Journal des Tribunaux du 7 janvier $1945, \mathrm{p} .1$.

\section{Rédaction JdT, effet rétroactif}

Rédaction, Les lois pénales non pas d'effet rétroactif, in: Journal des tribunaux 1945, p. 145-147.

\section{Rédaction JdT, Loi}

Rédaction Journal des Tribunaux, L'merprétation de la loi du 10 mai 1940 , in: Journal des Tribunaux $1946, p, 66$.

\section{Rédaction JdT, Secrëtailres}

Rédaction Journal des Tribunaux, Qwe subsiste-t-il, depuis le 15 fewrier 1946, de la législation édictée par les Secrétaires Généraux?, in: Joumal des Tribunaux 1946. p. 110 .

\section{Rédaction JdT, Secrétaires II}

Rédaction Jounal des Tribunaux, Que subsiste-t-il, depuis le 15 février 1946, de la législation édictée par les Secrétaines Généraux?, in: Journal des Tribunaux 1946, p. 228 . 


\section{Reeder/Hailer}

Reeder, E., Hailer, W., Die Miliärverwaliung in Belgien und Nordfrankreich, Wittich Verlag Darmstadr, 1943.

\section{Reiny}

Rémy, A., Het Statuut van de Magistratuur, redevoering uitgesproken door den Heer A. Rémy, Procureur-generaal, in de plechtige heropeningsziting wan 15 september" 1938, en warwan het Hof het drukken bevolen heeft, Gilles-Fretin Gent, 1938.

\section{Remy}

Remy, E. Documentations et réflexions sur l'administration de la Justice en territoire occupé, in: Belgique Judicialire du 19 janvier 1919, p. 65-96.

\section{Rousseau}

Rousseau, M., La section spéciale de la cour d'appel de Douai 1940-1944. Un aspect de la justice française en Zone Interdite, in: Revue du Nord numéro 2 spéciale horssérie 1988, L'Occupation en France en Belgique 1940-1944, Tome 2, p. 859-886.

\section{Saerens}

Saerens, L., Vreemdelingen in een wereldstad; Een geschiedenis van Amtwerpen en zijn Joodse bewolking (1880 - 1944), Lannoo Tielt, 2000.

\section{Sluszny}

Sluszny, M., La loi du 20 juin 1947 relative ä la compétence des juridictions militaires en matière de crimes de guerre, in: Journal des Tribunaux 1947, p. 413.

\section{Smolders, Jurisprudence}

Smolders, Th., La jurisprudence belge depuis le 10 mai 1940 Tome I, Larcier Bruxelles, 1941, p. 11-19.

\section{Snolders, Législation Tome I}

Smolders, Th., La législation belge depuis le 10 mai 1940; Textes, Commentaines et Mrispradence Tome I, Larcier Bruxelles, 1941.

\section{Smolder, Légisslation Tome II}

Smolders, Th., La législation belge depuis le 10 mai 1940; Textes, Commentaines et Jurisprudence Tome II, Larcier Bruxelles, 1941.

\section{Soenens}

Soenens, M., Le Controle Judiciaire de la Constitutionalité des Lois; Discours prononcé par $M$. Soenens, premier Avocat-général à l'audience solennelle de rentrée le. 15 septembre 1927, van Caeneghem-Vercauteren Gand, 1927.

\section{Stephany}

Stephany, P., La Belgique sous la régence (1944-1950). Une époque et son histoire, Gerpinnes Quonum, 1999. (SOMA) 


\section{Struye}

Struye, P., La répression de l'incivisme, in: Revue Générale Belge November 1945. p. 24-34.

\section{Tayart de Borms}

Tayart de Borms, V., Les pleins pouvoirs en matière judiciaire, in: Revue belge de la Police administrative et judiciaire juin 1936, p. 132-133.

\section{Tschoffen}

Tschoffen, P., La répression de lincivisme, in: Journal des Tribunaux 1946, p. 221.

\section{Umbreit}

Umbreit, H., Les pownoirs allemands en France et en Belgique, in: Revue du Nord numéro 2 spéciale hors-série 1987, L'Occupation en France en Belgique 1940-1944, p. 5-40.

\section{Vandenbossche/Prignon}

Vandenbossche, J., Prignon, G., La compétence et la procédure des Conseils de Guerre et de la Cour Militaire, in: Joumal des Tribunaux 1944, p. 73.

\section{Velaers/Goethem}

Velaers, J., Goethem., H., van, Leopold III; de Koning, het Land, de Oorlog, 2e druk, Lannoo Tielt, 1994.

\section{Velden}

Velden, van der, H., Het staatsnoodrecht en de nomatieve wetenschap, Beekhuis, J.H. Herstel van onrecht, tijdens de bezetring gepleegd, in: Rechtskundig Weekblad $1947-1948$, p. 593.

\section{Verhoeyen}

Verhoeyen, E., België Bezet 1940-1944; een synthese, BRTN educatieve uitgaven Brussel, 1993.

\section{Visscher}

Visscher, Ch., De, L'Occupation de Guerre, in: The Quarterly Law Review XXXIV (1918), p. 72 .

\section{Wodon}

Wodon, L., Considérations sur la Séparation et la Délégation des Pouvoirs en Droit Public Belge, Palais des Académies Bruxelles, 1942. 


\section{LUXEMOURG}

Als, R.

Als, R. L Enguête administrative, Linden Luxembourg, 1946.

Alsi, $\mathrm{G}$.

Als, G., Robert Als (1897-1991) au serwice de son pays, Rapidpress Luxembourg, 2003.

\section{Annuaire Officiel}

Annuaire officiel du Grand-Duché de Luxembourg, Publications de loffice de statistique, 1938,1940 and 1946.

\section{Blau, Extrềme}

Blau, L., Histoire de l'extrême-droite au Grand-Duché de Luxembourg au XXe siècle, Le Phare Luxembourg, 1998.

\section{Blau, Résistance}

Blau, L., La Résistance au Grand-Duché de Luxernbourg (1940-1945); sociologie, idéologies et programmes, Mémoire de Maîtrise, Metz, 1984.

\section{Bulletin}

Bulletin Francois Laurent (Tome 1), In Memoriam Paul Pemmers (1884-1958).

\section{Calmes/Bossaert}

Calmes, C., Bossaert, D., Geschichte des Großherzogtums Lwemburg, Eiditions St. Paul Luxembourg, 1995.

\section{Cerf, Députés}

Cerf. $\mathrm{P}$. Les députés luxembourgeois sous l'occupation allemande. Mai 1940-seplembre 1944, in: Hémecht 30 (1978), no. 4, p. 497-529.

\section{Cerf, Epuration}

Cerf, P., De l'épuration au Grand-Duché de Luxembourg après la seconde guerre mondiale, St. Paul Luxembourg 1980.

\section{Dostert, H.}

Dostert, H., Walidité de notre législation fiscale introduite pendant l'occupation, in: Etudes fiscales, No. 1 (1963), p. 5-10.

\section{Dostert, P. Besatzungspolitik}

Dostert, P., Die deutsche Besatzungspolitik in Luxemburg und die luxemburgische Resistenz, in: Hémecht (1987), H. 3, p. $375-392$.

\section{Dostert, P., Résistance}

Dostert, $\mathbb{P}_{\text {. }}$ La Résistance luxembourgeoise pendant la seconde guerre mondiale et la reprise politique de 1944/1945, in: Fémecht (1996) Beiheft, p. 25-50. 


\section{Dostert, P., Selbstbehauptung}

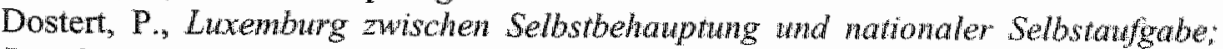
Die deutsche Besatzungspolitik und die Volksdeutsche Bewegung 1940-1945, Diss. Phill Freiburg, Luxembourg, 1985.

\section{Dostert, P., Verwaltung}

Dostert, P., Von reichsdewtscher Venwaltung zur Befreiung, in: Lëtzebuerg 40 Joër fräi, Ministère des Affaires culturelles, 1984, p. $11-23$.

\section{Everling}

Everling, R., Le tribunal d'arrondissement de Diekirch: Histoine et evolution, in: Feuille de liaison de la conference Saint Yves (1979), No 45.

\section{Eyschen, P.}

Eyschen, P., Das Staatsrecht des Großherzogtums Luxemburg, Mohr Tübingen, 1910.

\section{Eyschen, M.P.}

Eyschen, M.P., Introduction historique au droit public du Grand-Duché de Luxembourg, Belinfante La Haye, 1911.

\section{Fletcher}

Fletcher, W.A., The German Administration in Luxemburg 1940 - 1942: Toward a 'de facto' annexation, The Historical Journal, XIII, 3 (1970), p. 533-544.

\section{Frauenberg}

Frauenberg, $\mathbb{R}$, Notions élémentaires sur organisation politique, judiciaire et communal du Grand-Duché de Luxembourg (4me édition), Schroel Luxembourg, 1937.

\section{Goerens}

Goerens, F., L'organisation judiciare du Grand-Duché du Luxembourg en matièe chivile, in: Revue juridique et politique (1969) no 4, p. 711-716 and p. 907-910.

\section{Government of Luxembourg}

Luxembourg and the German invasion before and afier, published by authority of the Government of Luxembourg, Hutchinson London, 1942.

\section{Haag}

Haag, E., Die Luxewburger Regierung während des Zweiten Welthriegs, in: Lëtzebuerg 40 Joër fräi, Ministère des Affaires culturelles, 1984, p. 5-10.

\section{Hamnes}

Hammes, Cli., L., Le crime de guerre en droit Imembourgeois, in: Revue de Droit Pénal et de Criminologie 1946-1947, p. 233-245.

\section{Heisbourg}

Heisbourg, G., Le Gouvernement luxembourgeois en Exil, Vol. II, IV, St. Paul Luxembourg, 1987, 1991. 


\section{Hohengarten}

Hohengarten, $\mathbb{A}$, Die narionalsozialistische Judenpolitik in Luxemburg, St. Paul Luxembourg, 2002.

\section{Molthơfer}

Holthöfer, E., Beiräge zur Justizgeschichte der Niederlande, Belgiens und Luxemburgs im 19. wnd 20. Jahrhundert, Klostermann Frankfurt am Main, 1993.

\section{Kayser}

Kayser, $\mathrm{P}_{*}$ Considérations sur le troüsieme pouwoir, in: Pasicrisie Luxembourgeoise No. $4(1993)$, p. $23-39$.

\section{Koch-Kent}

Koch-Kent, H., Années d'Exil 1940-1946, in: Vu et Entendu (Vol. 2), Hermann Luxembourg, 1986.

\section{Loesch}

Loesch, A., Le controle juridictionnel des arrêtés-lois, Imprimerie de la Cour Joseph Beffort Luxembourg, 1934.

\section{Majerus, Guerre}

Majerus, P., Le Luxembourg pendant la seconde guerme mondiale; extrait de l'ouvrage <<le Luxembourg indépendant>> essai d'histoire politique contemporaine et de droit intenational public (1945), Luxembourg, 1980.

\section{Majerus, Institutions}

Majerus, P., The Institutions of the Grand Duchy of Luxembourg, Grand Duchy of Luxembourg Ministry of State Press and Information Service, 1984.

\section{Majerus, Luxembourg}

Majenus, P., Le Luxembourg indépendant; Essai d'histoire, politique contemporaine et de droit international public, Beffort Luxembourg, 1946.

\section{Marx}

Marx, R., L'Assemblée Consultative de 1945, Mémoire présenté par Remi Marx Aspirant-professeur à l'Athénée de Luxembourg, 1984.

\section{Muinzel}

Münzel, F., Dhe Aufbauarbeit des Chefs der Zivilverwaltung, Moselland Luxemburg, 1941.

\section{Propria Cansa}

Les avocats du barreau de Luxembourg restés en fonctions jusqu'à la liberation, In Propria Causa; Histoine d unépuration, Luxembourg, 1946.

\section{Raths, D'Stëmmon}

Raths, A., D'Stëmmong ërnert der Lëtzebuerger Populatioun, in: Rappel (1991), No. 9-10, Numéro spécial. 


\section{Raths, Grand-Duché}

Raths, A., Le Grand-Duché pendant la 2 e guerre mondiale 1939-1945, in: Rappel (1980) no $3 / 5$, p. $251-285$.

\section{Raths, Grève}

Raths, A., La grève de 1942, in: Rappel (1973) no 8/9, p. 277-298.

\section{Raths, Lëtzebuerg}

Raths, A., 10. October 1941: 3 mol "Lëtzebuerg", in: Rappel (1991), No. 9-10, Numéro spécial.

\section{Raths, Naziherrschaft}

Raths, A., Die letzten Tage der Naziherrschaf in Luremburg, in Rappel (1974) no 1. $1 / 12$, p. $427-454$.

\section{Raths, Simon}

Raths, A., Wer war Gauleiter Gustaw Simon?, in: Rappel (1975) no 3, p. $79-87$.

\section{Raths, Stéchprouwe}

Raths, A., De Gauleiter gët onsécher a léisst Stéchprowwe maachen, in: Rappel (1991), No. 9-10, Numéro spécial.

\section{Raths, Victoire}

Raths, A., Eng grouss Victoire fir Lëtzebuerg, in: Rappel (1991), No. 9-10, Numéro special.

\section{Raths/Dostert}

Raths, A., Dostert, P., Chronologie 1939-1945, in: Lëtzebuerg 40 Joër fräi, Ministère des Affaires culturelles, 1984, p. 57-78.

\section{Reiland}

Railand, G., De la réception des membres de la Cour supérieure de Justice, in: Pasicrisie Luxembourgeoise No. 2 (1996), p. 1-13.

\section{Romeyk}

Romeyk, H., Der Gau Moselland und seine Beziehungen zu Luxemburg, in: Hémecht (1987), H. 3, p.411-426.

\section{Stumper}

Stumper, R., In Menoriam Henri Nocké (1886-1959). Buck Luxembourg. 1959.

\section{Wallerang}

Wallerang, M., Luxemburg umter nationalsozialistischer Besatzung; Luxemburger bexichten, Herbert Schwedt Mainz, 1997.

\section{Wampach}

Wampach, G., Le Luxembourg neutre, St. Paulusgesellschaft Luxembourg, 1901. 


\section{Wehrer}

Wehrer, A., L'histoire du Luxembourg dans une Europe divisée (963-1945): notre politique étrangère d'une guerre mondiale à l'autre, in: Le Conseil d'État du Grand Duché de Luxembourg, liwre jubilaire 1957, p. 195-239.

\section{Zweil I uristen}

Zwei Juristen, Das Gerichtswesen vom Großherzogum Luxemburg; Fü das Volk erläutert von zwei Juristen, St. Paulus-Gesellschaft Luxemburg, 1920. 


\section{THE NETHERLANDS}

Asch

Asch van Wijck, L.H.K.C., De Nederlandsche Rechtspratik in Bezettingstijd, in: Onderdrukking en Verzet: Nederland in Oorlogstijd (deel 1), Van Loghum Slaterus / Meulenhof Arnhem, 1947, p. 475-516.

\section{Barendsen/Venema}

Barendsen, J. en Venema, D., De Rechbank Amhem en de Duitse bezerting, Wolf Legal Publishers Nijmegen, 2004.

\section{Barnouw}

Barnouw, D., Rost van Tonningen: Fout tot het bittere eind, Walburg Pers Zutphen, 1994.

\section{Belinfante}

Belinfante, A.D., In plaats van bijltjesdag: De geschiedenis van de bijzondere rechtspleging na de iweede wereldoorlog, van Gorcum Assen, 1978.

\section{Bellefroid}

Bellefroid, J.H.P., Beknopt overzicht der Staatsinrichting van Nederland ijdens de bezetring, Dekker \& Van de Vegt Nijmegen-Utrecht, 1942.

\section{Bemmelen.}

Bemmelen, van, J.M., Het Strafrecht en het Strafprocesrecht in het bezette Nederlandsche Gebied, in: NJB 1947, 7, p. 117-129.

\section{Bemmelen, Répression}

Bemmelen, van, J.M., La répression de l'incivisme et des crimes politiques en Hollande, in: Journal des Tribunaux 1945, p. 549-551.

\section{Bestuursalmanak}

Bestwursalmanak voor het bezette Nederlandsche Gebied 1942-1943 en 1943-1944, Algemene Landsdrukkerij "s-Gravenhage, 1942.

\section{Biegel}

Biegel, F.M., Bezettingsrecht; een korte schets van het staatsrecht en de staatsinrichting gedurende de Duitsche bezetting van Nederland ( 2 e druk), Samsom Alphen aan den Rijn, 1940.

\section{Boer, e.a.}

Boer, de, M.H., e.a., De Hooge Raad. Antwoord aan Mr. N.C.M.A. van den Dries, Uitgeverij Vrij Nederlands Amsterdam, 1945.

\section{Bohtlingk}

Bohtlingk, F.R., Verzameling van de Nederlandse staarsregelingen en grondwetten, $15 \mathrm{e}$ druk, Uitgeverij N. Samsom Alphen aan den Rijn, $\mathbb{9 6 4 .}$ 


\section{Bolhuis}

Bolhuis, J.I., Sophistisch gesol met arikel 21 der Grondwet, in: Onderdrukking en Verzet: Nederland in Oorlogstijd (deel 1), Van Loghum Slatens / Meulenhof Amhem, 1947, p. $377-380$.

\section{Bosch}

Bosch Ridder van Rosenthal, L.H.N., De Aanwijzingen, in: Onderdrukking en Verzet: Nederland in Oorlogstijd (deel 1), Wan Loghum Slaterus / Meulenhof Amhem, 1947, p. $385-397$.

\section{Brandhof}

Brandhof, van den, J.C.E., De besiuiwergeving van de kabinetten De Geer en Gerbrandy, Kluwer Deventer, 1986.

\section{Brongersma}

Brongersma, De grens van het staatswoodrechr, NJB 1945, 37, p. $361-369$.

\section{Buys}

Buys, J.T., De Grondwet; Toelichting en Kritiek, Gouda Quint Arnhem, 1887.

\section{Carp}

Carp, J.H., Een half jaar rechtspraak van het Vredegerechtshof, Nenasu Utrecht, 1942.

\section{Clarenbeek}

Clarenbeek, T.J., De Oorlogswet voor Nederland, proefschrift Universiteit van Amsterdam, 1978.

\section{Cleveringa}

Cleveringa, R.P., Telders' geschriften over volkenrecht, in: De Gids (1964), p. 323353.

\section{Dassen}

Dassen, J.M.H., De grondwersherziening 1938, Leiter-Nypels Maastricht, 1938.

\section{Donker}

Donker, L.A., Wetgeving, in: Onderdrukking en Verzet: Nederland in Oorlogstijd (deel 1), Van Loghum Slaterus / Meulenhof Arnhem, 1947, p. 354-376.

\section{Dries}

Dries, N.C.M.A., van den, De Hooge Raad der Nederlanden tijdens de Bezeting, Uitgeverij E.J., Brill Leiden, 1945.

\section{Dullemen}

Dullemen, A.A.L.F., van, Staatsnoodrecht en democratie, Uitgeverij Samsom Alphen aan den Rijn, 1947. 


\section{Eggens}

Eggens, J. (red.), Nederlandsch recht in oorlogstijd; In Engeland ontsraan en toegepast, The Netherlands Publishing Company London, 1945.

\section{Enquêtecommissie Regeringsbeleid 1940-1945}

Enquêteconmissie Regeringsbeleid 1940-1945, Verslag houdende de witkomsten van het onderzoek, Deel $7 c$, Leiding en voorlichting aan de ambtenaren en burgers in de bezette gebieden, het contact met de politiek ten aanzien van de verzetsbewegingen in Nederland (punten $G$ en $H$ van het Enquêtebeshluit), Verhoren, Staatsdrukkerij 's-Gravenhage, 1955.

\section{François, Bezetting}

François, J.P.A., De Bezetting en het Volkenrecht, in: Onderdrukking en Verzet: Nederland in Oorlogstijd (deel 4), Van Loghum Slaterus/Meulenhof Arnhem, 1947, p. $247-266$

\section{Frijtag, Recht}

Frijtag Drabbe Kuenzel, von, G., Het Recht van de Sterkste; Duitse Strafrechtspleging in Bezet Nederland, B. Bakker Amsterdam, 1999.

\section{Frijtag, Strafrechtspleging}

Frijtag Drabbe Kuenzel, von, G., De rechter en de zaak, Politiek en strafrechtspleging in bezer Nederland, in: De rechtspraktijk in beeld, Van Justinianus tot de Duitse bezetting, Tilburg University Press Tilburg, 1997.

\section{Gallin}

Gallin, I., Rechtsetzung ist Machtsetzung; Die deutsche Rechtsetzung in den Niederlanden 1940 - 1945, Peter Lang Frankfurt am Main, 1999.

\section{Gerbrandy}

Gerbrandy, P.S., Eenige Hoofdpunten van her Regeeringsbeleid in Londen gedurende de Oorlogsjaren 1940-1945, Algemeene Landsdrukkerij 's-Gravenhage, 1946.

\section{Gids voor de Rechterlijke Macht}

Gids voor de Rechterlijke Macht in het Koninkrijk der Nederlanden, Noorduijn Gorinchem, 1941.

\section{Groot-van Leeuwen}

Groot-van Leeuwen, L.E., De rechterlijke macht in Nederland, Gouda Quint Arnhem, 1991 .

\section{Haar Romenij}

Haar Romenij, H.M.B., ter, Zuivering, in: NJB 1945, 322.

\section{Heide}

Heide, ter, J., De onafhankelijkheid van de rechterlijke macht, Agon Elsevier Amsterdam, 1970. 
Hermans.

Hermans, H.L.C., Om des Gewetens Wille; de geschiedenis van een arrest in oorlogsilid, Friese Pers Boekerij Ljouwert, 2003.

\section{Hirschfeld}

Hirschfeld, G., Nazi Rule and Dutch Collaboration; The Netherlands under German Occupation 1940-1945, Berg Oxford, 1988.

\section{Jansma}

Jansma, T.J., Het bezettingsrecht in de practijk van de Tweede Wereldoorlog, Veenman Wageningen, 1953.

\section{Jong}

Jong, de, L., Het Koninkrijk der Nederlanden in de Tweede Wereldoorlog, Uitgeverij Martinus Nijhoff 's-Gravenhage,

\section{Kantonrechter}

Kantonrechter, De Zuivering van de Rechterlijke Macht en het Kantonrechters-ambt, in: NJB 1946, 428 .

\section{Kollewijn}

Kollewijn, R.D., De Zuivering van de Hoge Raad, in: NJB 1946, 423.

\section{Kop}

Kop, P.C., Slachtoffers van het Duitsche geweld; De gedenkplaten in het paleis van justitie, in: Prinsengrachtreeks 1995/1.

\section{Koppen/Kate}

Koppen, van, P.J., Kate, ten, J., Tot raadsheer benoemd; Anderhalve eeuw benoemingen in de Hoge Raad der Nederlanden, Gouda Quint Arnhem, 1987.

\section{Kranenburg}

Kranenburg, R., Het Nederlandsch Staatsrecht, 2e Deel, 3e Druk, Tjeenk Willink Haarlem, 1930.

\section{Kwiet}

Kwiet, K.., Reichskommissariat Niederlande; Versuch und Scheitern nationalsozialistischer Neuordmung, Deutsche Verlagsanstalt Stuttgart, 1968.

\section{Lammers}

Lammers, C.J., Macht en gezag van de Duitse bezetter, Noord-Hollandsche Amsterdam, 1990.

\section{Landsheer}

Landsheer, B., The legal stafus of the Netherlands, in: Michigan Law Review, February 1943 , Vol. 41 , No. 4. 


\section{Leijten}

Leijten, J.C.M., Jan Downer, rechter, in: NJB 2003, 39, p. 2042-2046.

\section{Loon}

Loon, van, J., Ter informatie, Een anmoord op de brochure van Mr. N.C.M. van den Dries: "De Hooge Raad der Nederlanden tijdens de Bezetting", 1946.

\section{Mazel}

Mazel, P.E., In naam van het recht; De Hoge Raad en de Tweede Wereldoorlog, Uitgeverij Gouda Quint Arnhem, 1984.

\section{Militaïr Gezag}

Afwikkelingsbureau Militair Gezag, Overzicht der Werkaamheden van het Militair Gezag gedurende de Bijzondere Staat van Beleg; 14 september 1944 - 4 maart 1946.

\section{Mok}

Mok, L., Collaboratie: personen en patronen; de bezerting als overgangstijd, Coutinho Muiderberg, 1990.

\section{Mok, Proza}

Mok, L., Over mooi proza, klerken en moed, in NIB 2004, 1, p. 10-14.

\section{Mulder}

Mulder G.E., Schin van recht, De geschiedenis van de vrederechispraak gedurende de Duise bezeting, Quint Gouda, 1995.

\section{Nispen tot Sevenaer, Beschouwing}

Nispen tot Sevenaer, van C.M.O., Waarom de Hoge Raad zo faalde, Een beschouwing naar aanleiding van Mr. Van den Dries' pleidoor voor "de Hooge Raad tijdens de Bezetting", Uitgeverij Thieme \& Cie Zutphen, 1945.

\section{Oud}

Oud, P.J., Het Constirutioneel Recht van het Kaninkrijk der Nederlanden, Deel I, Tjeenk Willink Zwolle, 1947.

\section{Polak}

Polak, J.A., Leven en werken van m L E. Visser, Polak en Van Gennep Amsterdam, 1974.

\section{Pot, Staatsrecht}

Pot, van der, C.W., Handboek van het Nederlandsche Staatsrecht, Tjeenk Willink Zwolle, 1940 .

\section{Pot, Staatsnood}

Pot, van der, Het probleem van de staatsnood vroeger en thans, Wolters Groningen, Batavia 1946. 


\section{Pootjes}

Pootjes, J.W., Aawklacht eedbreuk; De grondwet geschorden in Londen, De Vredestichters Hilversum.

\section{Posthumus Meyjes}

Posthumus Meyjes, H.C., De Enquêtecommissie is van oordeel.., Een samenvating vam het parlementaire onderzoek naar het regeringsbeleid in de oorlogsjaren, Van Loghum Slaterus/Meulenhoff Amhem/Amsterdam, 1958.

\section{Presser}

Presser, J, Ondergang: de vervolging en verdelging van het Nederlandse Jodendon 1940-1945, deel 1, Statatsdrukkerij "s-Gravenhage, 1965.

Prins

Prins, M.I., Staatsnoodrecht, Uitgeverij Erven Martin G. Cohen Amsterdam, 1911.

\section{Randwijk}

Randwijk, wan, H.M., "Fout" en "Goed", in: Onderdrukking en Verzet: Nederland in Oorlogstijd (deel 1), Van Loghum Slaterus / Meulenhof Amhem, 1947, p. 381 384.

\section{Redactie NJB}

Nederlands Juristenblad, redactic, 1945,272 and 1946, 692.

\section{Romijn}

Romijn, P., Snel, streng en rechwaardig; politiek beleid inzake de bestraffing en reclassering van 'foure' Nederianders, 1945-1955, De Haan, 1989.

\section{Rosenthal}

Rosenthal, JJ.M. (red), Onderdrwkking en verzet, Nederland in oorlogstijd, Uitgeverij J.M. Meulenhoff Amsterdam, 1947.

\section{Rutgers}

Rutgers, V.H., Toestingsrecht?, in: NJB 1941, 41, p. 749-760.

\section{Ruiter}

Ruiter, de, J., Jan Donner jurist, een biografte, Boom Amsterdam, 2003.

\section{Sandberg}

Sandberg, H.W.., Groote Advies-Commissie der Mlegaliteit; Witboek over de Geschiedenis wan het georganiseerde Verzet voor en na de Bevrijding, Amsterdamsche Boek- en Courantmatschappij Amsterdam, 1950.

\section{Savornin Lohman}

Savornin Lohman, de, A.F., Onze Constitutie, Kemink Utrecht, 1920. 


\section{Schmidt}

Schmidt Auf Altenstadt, von, P., De Rechterlijhe wacht in oorlogstid; zwigen is fout, in: Trema, nummer 7, september 2004, p. 276-285.

\section{Scholtens, Staatsrecht}

Scholtens, A.L., Overzicht van de tijdelijke wijzigingen in ons staatsrech (19401945) (4e druk), Samsom Alphen aan den Rijn, 1947.

\section{Scholtens, Secretarissen-Generaal}

Scholtens, A.L., De Secretarissen-Generaal, in: Onderdrukking en Verzet: Nederland in Oorlogstijd (deel 1), Van Loglum Slaterus/Meulenhof Arnhem, 1947, p. $389-417$.

\section{Schrieke}

Schrieke, IIJ, Bezet Nederland en het Haagsche Landoorlogsreglement van 1907, Elsevier Amsterdam, 1944.

\section{Sikkes}

Sikkes, J.H., ... in geval van een vijandelijken inval, Ambtelijk gedrag in bezetingstijd en de daarvoor geldende aanwijzingen, Kluwer Deventer, 1985.

\section{Snijders}

Snijders, F.J.H., De bevoegdheid van de Regeering op her gebied van uitvoering en wetgeving, in: Nederlandsch recht in oorlogstijd in Engeland ontstaan en toegepast, The Netherland Publishing Company London, 1945, p. 9-20.

\section{Staatsalmanak}

Staatsalmanak voor het Koninkrijk der Nederlanden 1940 and 1946, Uitgeverij Martinus Nijhoff' 's-Gravenhage, 1939 and 1946.

\section{Staatscommissie Bezettingsrecht}

Verslag wan de Staatscommissie Bezettingsrecht, Staatsdrukkerij en Uitgeverijbedrijf 's-Giravenhage, 1955.

\section{Telders}

Telders, B.M., Verzamelde Geschriften, Deel IV, Martinus Nijhoff 's-Gravenhage, 1947.

\section{Thorbecke}

Thorbecke, J R, Aanreekeningen op de Grondwet, Müller Amsterdam, 1839.

\section{Vorstman}

Vorstman, F., Hoofdlinen der Staatsinrichting van het Koninkrijk der Nederlanden, 5e druk, Tjeenk Willink Haarlem, 1939, p. 160.

\section{Waalewijn}

Waalewijn, A., Achter de bres; De Rijkswaterstaat in Oorlogstijd, SDU 's-Gravenhage, 1990. 


\section{Warmbrunn}

Wambrunn, W., The Duth under German Occupation 1940 1945, Stanford University Press, 1963.

\section{Weitjens, Normen}

Weitjerns, W.M.A. Normen

\section{Weitjens, NS}

Weitjens, W.M.A., Onze Nationaal Socialisten

\section{Weitjens, Pleitnota}

Weiljens, W.M.A., Pleitnota, Tribunaal 's-Gravenhage, 7e Kamer, 26 april 1948.

\section{Weitjens, Ridders}

Weitjens, W.M.A., Ridders in toga

\section{Weitjens, Uniform}

Weitjens, W.M.A., Menschen zonder uniform

\section{Weitjens, Wederhoor}

Weitjens, W.M.A., Hoor en Wederhoor

\section{Welderen}

Welderen, van, J.W., Schets eener Parlementaire Geschiedenis van Nederland, deel 5, 1940-1946, Martinus Nijhoff 's-Gravenhage, 1956.

\section{West de Veer}

West de Veer, van, J.F., De Rechtbank te 's-Gravenhage van 1811-1966, Arrondissementsrechtbank 's-Gravenhage, 1967.

\section{Wiel}

Wiel, van de, A.M., Rechtspleging onder bijzondere omstandigheden; De Hoge Raad en de Duitse Bezetting, in: Recht en Kritiek, 1983, p. 437-467.

\section{Zee}

Zee, van der, N., Om erger te voorkomen. De voorgeschiedenis en uitvoering van de vernietiging van het Nederlandse jodendom tijdens de Tweede Wereldoorlog, Meulenhoff Amsterdam, 1997. 


\section{INTERNET SOURCES}

\section{GENERAL}

http://www.palestine-un,org/mission/3d_12_53.html (03-08-2004)

\section{LUXEMBOURG}

http:/www.legilux.public.lu/leg/textescoordonnes/compilation/recueil_lois_speciales TABLE_CHRON.pdf (2-8-2004) 



\section{ARCHIVAL SOURCE LIST}

\section{BELGIUM}

Auditorat général à la Cour militaire

Archives Auditorat Général, Cour militaire, Dossier Schuind, no. 572.B.47.

CEGES/SOMA

CEGES/SOMA, Abschlußbericht der Militärverwaltung.

CEGES/SOMA, Jahresbericht 1940/194』 des Militärbefehlshabers in Belgien und in Nordfrankreich.

CEGES/SOMA, Tätigkeitsberichte der Militärverwaltung.

CEGES/SOMA, Archives Hayoit de Termicourt, MIC 48.

CEGES/SOMA, Papiers Schuind, MIC 51.

CEGES/SOMA, Papiers Vossen 1921-1952, MIC 74.

CEGES/SOMA, CEPAG, ref. AA 830/192.

CEGES/SOMA, Documents Zéro, ref. AA 1078.

CEGES/SOMA, Ministerie van Justitie Secretariaat-Generaal AA 1467.

CEGES/SOMA, ref. BA L 1/3, Gotovitch.

Greffe Cour d'appel de Liège

Greffe Cour d'appel de Liège, Régistre des Assemblées générales du 10-11-1936 au 13-2-1958.

\section{Greffe Cour de cassation}

Greffe Cour de cassation, Registre des Assemblées générales du 17 juin 1937 - 28 décenıbre 1940.

Greffe Cour de cassation, Registre des Assemblées générales du 28 décembre 1940 8 juillet 1942.

Greffe Cour de cassation, Registre des Assemblées générales du 13 septembre 1942 11 juillet 1944.

Greffe Cour de cassation, Registre des Assemblées générales du 15-9-1944 - 24-61949.

\section{Griffie Beroepshof Gent}

Griffie Beroepshof Gent, Register Algemeene Vergaderingen 9 oktober 1941 - 27 juni 1967.

Rijksarchief te Beveren

Rijksarchief te Beveren, Parket bij de Rechtbank van Eerste Aanleg te Mechelen 0000 .

Rijksarchief te Beveren, Rechtbank van Eerste Aanleg te Antwerpen A 2000.

Rijksarchief te Beveren, Rechtbank van Eerste Aanleg te Oudenaarde 1918-1972 A 2000 . 


\section{LUXEMBOURG}

Archives Nationales de Luxembourg

Archives Nationales de Luxembourg, Justice de Paix. Esch s/Alzette 1941.

Archives Nationales de Luxembourg, Tribunal d'arrondissement de Luxembourg Cote 3 C 61 .

Archives Nationales de Luxembourg, Affaires politiques no. 107.

Archives Nationales de Luxembourg, Affaires politiques no. 114.

Archives Nationales de Luxembourg, Affaires politiques no. 385.

Archives Nationales de Luxembourg, Dossiers Épuration, EPU no. 238.

Archives Nationales de Luxembourg, Dossiers Épuration, EPU no. 379.

Archives Nationales de Luxembourg, Fonds Divers, Fonds Victor Bodson FD 094.

Conseil National de la Résistance

Conseil National de la Résistance, Archives personelles de M. le Président P. Dostert, Collection de jugements.

Conseil National de la Résistance, Archives personelles de M. le Président P. Dostert, Papiers Wehrer.

Greffe Cour Supérieure de Justice de Luxembourg

Greffe Cour Supérieure de Justice de Luxembourg, Registre aux délibérations 27-011938-15-05-1941.

Greffe Cour Supérieure de Justice de Luxembourg, Registre aux délibérations de la Cour du 14 Novembre 1944 au Ier Juillet 1954.

Greffe Tribunal Diekirch

Greffe Tribunal Diekirch, Registre aux délibérations du Tribunal d'arrondissement de Diekirch du 13 avril 1915 au 22 juin 1959.

Parquet Général à la Cour Supérieure de la Justice

Archives Parquet Général à la Cour Supérieure de Justice, Crimes de Guerre: Juges et Procureurs allemands. 


\section{THE NETHERLANDS}

\section{Archief Anrondissementsrech bank Rotterdam}

Archief Arrondissementsrechtbank Rotterdam, Arrondissementsrechtbank Rotterdam 1940-1949.

\section{Archief Gerechtshof Arnhem}

Archief Gerechtshof Arnhem, Correspondentie van de President 1943-1950.

Archief Gerechtshof Arnhem, Gerechtshof Amhem 1940-1949.

Archief Gerechtshof 's-Hertogenbosch

Archief Gerechtshof 's-Hertogenbosch, Notulenboek Arrondissementsrechtbank 's-Hertogenbosch 1924-1967.

\section{Archief Hoge Raad der Nederlanden}

Archief Hoge Raad der Nederlanden, Archiefmap WO II.

Archief Hoge Raad der Nederlanden, Notulen Algemene Vergaderingen van 1921. 1958.

Historisch Centrum Overijssel

Historisch Centrum Overijssel, Rechtbank Zwolle 1940-1949, toegang 108.2.

Ministerie van Binnenlandse Zaken en Koninkrijksrelaties

Ministerie van Binnenlandse Zaken en Koninkrijksrelaties, BSG/Kabinet/1990 (1948-1990), classificatie 02.388.

\section{Ministerie van Justitie}

Ministerie van Justitie Depot 152.

Ministerie van Justitie Depot 164.

Ministerie van Justitie Depot 166.

Ministerie van Justitie, Archief Hooge College voor de Rechterlijke Macht.

\section{Nationaal Archief}

Nationaal Archief, Den Haag, Archieven van het Directoraat-Generaal voor de Bijzondere Rechtspleging, (1945-1952), met taakopvolgers en uitvoerende instanties (1945-1983) van het Ministerie van Justitie, deel II: Uitvoerende instanties (Centraal Archief Bijzondere Rechtspleging), toegang 2.09.09.

Nationaal Archief, Den Haag, Plaatsingslijst van het semi ambtelijk archief van de Secretaris Generaal van het Ministerie van Justitie, Prof. mr J.J. Schrieke 1940-1944, toegang 2.09.41.16.

Nationaal Archief, Den Haag, Archief van mr J.P. Hooykaas 1940-1947, toegang 2.09.56.

Nationaal Archief, Den Haag, Archief van de Arrondissementsrechtbank Dordrecht (1935) 1940-1949 (1951), toegang 3.03.12.03. 
NIOD

NIOD, Archief 21.

NIOD, Archief 33.

NIOD, Doc I-1077, a-9.

NIOD, Doc II, no. 658 Rechterlijke Macht.

\section{Rijksarchief in Noord-Brabant}

Rijksarchief in Noord-Brabant, Arrondissementsrechtbank Breda 1940-1949, toegang 808.

Rijksarchief in Noord-Brabant, Kantongerecht Helmond 1940-1949, toegang 817.

Rijksarchief in Noord-Brabant, Gerechtshof 's-Hertogenbosch 1940-1949, toegang 823.

Rijksarchief in Noord-Brabant, Vliegenthart, A.J., als Hoge Autoriteit in 's-Hertogenbosch en als lid zuiveringscommissies, 1943-1959, toegang 1138.

\section{Rijksarchief in Noord-Holland}

Rijksarchief in Noord-Holland, Gerechtshof Amsterdam 1940-1949, toegang 450.

Rijksarchief in Noord-Holland, Arrondissementsrechtbank Alkmaar 1940-1949, toegang 485 .

Rijksarchief in Noord-Holland, Arrondissementsrechtbank Amsterdam 1950-1959, toegang 510.

Rijksarchief in Noord-Holland, Gerechtshof Amsterdam 1950-1959, toegang 561.

\section{Tresoar}

Tresoar, Archief Procureur Generaal bij het Gerechtshof te Leeuwarden (nog geen toegang).

Tresoar, Gerechtshof Leeuwarden 1940-1949, toegang 17.

\section{OTHER-GERMANY}

Bundesarchiv Berlin

Bundesarchiv Berlin, Reichsministerium der Justiz R3001. 


\section{TABLE OF LEGISLATION}

\section{A. InTERnational Treaty LAW}

IVth Hague Convention respecting the Laws and Customs of War on Land and the Annex to the Convention concerning Regulations respecting the Laws and Customs of War on Land, The Hague 1907.

First Geneva Convention for the Amelioration of the Condition of the Wounded and the Sick in Armed Forces in the Field of 12 August 1949.

Second Geneva Convention for the Amelioration of the Condition of the Wounded, Sick and Shipwrecked Members of Armed Forces at Sea of 12 August 1949.

Third Geneva Convention relative to the Treatment of Prisoners of War of 12 August 1949.

Fourth Geneva Convention relative to the Protection of Civilians in Time of War of 12 August 1949.

Protocol additional to the Geneva Conventions of 12 August 1949, and relating to the Protection of Victims of International Armed Conflicts of 8 June 1977.

Protocol additional to the Geneva Conventions of 12 August 1949, and relating to the Protection of Victims of Non-International Armed Conflicts of 8 June 1977.

\section{B. NATIONAL LAW}

\section{Belgium}

\section{Acts of Parliament}

Loi du 20 avril 1810 sur l'organisation de l'ordre judiciaire et l'administration de la justice.

Loi du 25 juillet 1867, relative à la mise à la retraite des magistrats, Mon. du 27 juillet 1867 .

Loi du 18 juin 1869 réimprimée en vertu de l'arrêté royal du 22 février 1892, Mon. le 13 mars 1892.

Loi du 15 avril 1878 apportant des modifications aux lois relatives à l'organisation des Cours d'assises et au Code d'instruction criminelle, Mon. du 17 avril 1878.

Loi du 18 avril 1898 modifiée par la loi du 28 décembre 1.909, relative à l'emploi de la langue flamande dans les publications officielles, Mon. du 15 mai 1909.

Loi du 13 juin 1924.

Loi du 3 janvier 1933 relative à la fabrication, au commerce et au port des armès et au commerce des munitions, Mon. du 22 juin 1933.

Loi du 19 juillet 1934, Mon. du 27 juillet 1934.

Loi du 5 mars 1935, concernant les devoirs des fonctionnaires en temps de guerre, Mon. du 15 mars 1935.

Loi du 7 septembre 1939 donnant au Roi des pouvoirs extraordinaires, Mon. du 8 septembre 1939, p. $472-476$.

Loi du 10 mail 1940 concernant délégations de pouvoir.

Gecoördineerde Grondwet van 17 februari 1994, Mon. 17 februari 1994.

Wet van 10 april 2003 tot regeling van de afschaffing van de millitaire rechtscolleges in vredestijd alsmede het behoud ervan in oorlogstijd, Mon. 7 mei 2003. 


\section{Executive decrees}

Arrêté-loi du 6 novembre 1939 relatif au remplacement temporaire des magistrats appelés ou rappelés sous lés armes, Recuil des lois et arrêtés royaux 1939, p. \&18.

\section{Decrees Secretaries General}

Arrêté No. 433 du 20 décembre 1940 modifiant l'arrêté-loi du 6 novembre 1939 , relative au remplacement temporaire des magistrates appelés ou rappels sous les armes, Recueil des arrêtes des Secrétaires Généraux 1940 Tome II, p. 1970.

Arrêtể No. 141 du 15 féurier 1941 instituant une procédure administrative en matière de répression des infractions concemant le ravitaillement, le rationmement et la fixation des prix, Recueil des arrêtes des Secrétaires Généraux 1941 Tome I, p. 686.

Arrêtẻ No. 161 du 20 février 1941 transfêrant à la Corporation nationale de l'agriculture et de l'alimentation les attributions de l'Office national des debouches agricoles et horticoles, Recueill des arrêtes des Secrétaires Généraux 1941 Tome I, p. 812.

Arrêté No. 162 du 25 février 1941 pris en exécution de celui du 15 février 1941, instituant une procédure administrative en matière de répression des infractions concernant le ravitaillement, le rationnement et la fixation des prix, Recueil des arrêtes des Secrétaires Gếnéraux 1941 Tome $\mathrm{I}, \mathrm{p} .816$.

Arrêté No. 663 du 30 juillet 1941 instituant des commissions d'arbitrage près la Corporation nationale de l'agriculture et de l'alimentation, Recueill des arrêtes des Secrétaires Généraux 1941 Tome II, p. 3456.

Arrêté No. 806 du 15 septembre 1941 créant le Grand-Anvers, Recueil des arrêtes des Secrétaires Génếraux 1941 Tome III, p. 686.

Arrêté No. 1031 du 30 décembre 1941 concernant l'unification du Grand-Anvers, Recueil des arrêtes des Secrétaires Généraux 1941 Tome III, p. 5090.

Arrêté du 19 juin 1942 réprimant les abatages clandestins et le commerce illicite en viande, Pasinomie 1942, 467.

Arrêté No. 778 du 11 décembre 1942 concernant la répression du faux et de certaines autres infractions en matière de timbres et autres titres de ravitaillement Recueil des arrêtes des Secrétaites Généraux 1942 Tome III, p. 3720.

\section{Decrees exile Govermment}

Arrêté-loi du 28 mai 1940, Moniteur belge du 18-30 mai 1940.

Arrêté-loi du 10 jain 1940, déterminant la formule du serment préscrit par le décret du 20 juillet 1831 , Mon. du $9-11$ juin 1940.

Arrêté-loi du 23 août 1940, abrogent les arrêtés-lois du 28 mai réglant la formule exécutoire des arrêts et jugements des cours et tribunaux, des ordonnances, mandats de justice et de tous actes emportants exécution parée et du 10 juin 1940 déterminant la formule du serment préscrit par le décret du 20 juillet 1831 , Mon. du 26 août 1940. Arrêté-loi du 10 janvier 1941, Mon. 25 février 1941.

Arrêté-loi du 17 décembre 1942 portant additions ou modifications aux articles 113 , $117,118 b i s$ et 121 bis du Code penal, Mon. du 29 décembre 1942.

Arrêté-loi du 18 mars 1943, Mon. 13 avril 1943.

Arrêté-loi du 1 mai 1944 interprétatif de l'article 5 de la loi du 10 mai 1940 relatif aux délégations de pouwoirs en temps de guerre, Mon. 1 septembre 1944. 
Arrêté-loi du 5 mai 1944 interprétatif aux arrêtés pris et aux actes administratifs accomplis, durant l'occupation ennemie, par les secretaires généraux et par ceux qui ont exercé leurs fonctions, Mon. 1 septembre 1944.

Arrêté-loi du 6 mai 1944, Mon. 2 septembre 1944.

Alrêté-loi du 8 mai 1944 relatif aux fonctions publiques, Mon. 1 septembre 1944.

Arrêté-loi du 26 mai 1944, Mon. 2 septembre 1944.

\section{Luxembourg}

\section{Acts of Parliament}

Loi du 18 février 1885, sur l'organisation judiciaire, Mém. 1885, No. 23, p. 317-375.

Loi du 15 octobre 1919 , portant diverses modifications à la loi du 18 février 1885 sur l'organisation judiciaire et à celle du 29 juillet 1913 sur la revision des traitements des fonctionnaires et employés de l'État, Mém. 1919, p. 1187-1189.

Loi du 23 septembre 1938 , portant extension de la compétence du pouvoir exécutif, Mém. 1938, p. 103.

Loi du 29 août 1939, portant extension de la compétence du powvoir exécutif, Mém. 1939, p. 837.

Loi du 27 février 1946 concernant l'abrogation des lois de compétence de 1938 et 1939 et l'octroi de nouveaux pouvoirs spéciaux au Gouvernment, Mém. 1946 , No. 9, p. 119.

\section{Decrees exile Government}

Arrêté grand-ducal du 22 awril 1941, déterminant l'effet des mesures prises par l'occupant, Mém. 1944, p. 21.

Arrêté Grand Ducal du 14 juilllet 1943 modifiant les dispositions du Code Pénal concernant les crimes et délits contre la sûreté extérieure de l'État, Mém. du 18 septembre 1944 , p. 24.

Arrêté Grand Ducal du 25 mai 1944, Mém. 1944, p. 31.

Arrêté grand-ducal du 14 juin 1944, modifiant l'organisation judiciaire afin de rendre possible, dès la libération du territoire, la reprise de la justice, Mém. 1944, p. 34.

Arrêté grand-ducal du 7 juillet 1944 modifiant l'arrêté grand ducal du 22 avril 1941 relatif aux mesures de dépossession effectuées par l'ennemi, Mém. 1944, p. 30.

Arrêté grand-ducal du 13 juillet 1944 modifiant l'arrêté grand-ducal du 22 avril 1941 déterminant l'effet des mesures prises par l'ennemi, Mém. 1944, p. 29.

Ordonnance concemant la désignation de Magistrats provisoires du 19 septembre 1944, Mém. 1940, p. 50.

Arrêté grand-ducal concernant l'organisation provisoire des différents services de la Justice du 27 septembre 1944 , Mém. 1944, p. 53.

Arrêté ministernel portant institution d'une Chambre des vacations au tribunal d'arrondissement de Diekirch du 27 septembre 1944, Mém. 1944, p. 54.

Arrêté grand-ducal du 2 octobre 1944 portant modification de l"organisation judiciaire afin de rendre possible, dès la libération du territoire, la reprise de la Justice, Mếm. 1944, p. 57.

Arrêté grand-ducal du 4 octobre 1944 concernant la désignation de magistrats provisoires, Mém. 1944, p. 57. 
Arrêté grand-ducal du 6 novembre 1944 modifiant et complétamt les arrêtés grandducaux des 14 juillet 1943 , concernant les crimes et délits contre la sûreté extérieure de l'État et 4 septembre 1944 , relatif à la sécurité et à la protection des armées alliées sur le territoire du Grand-Duché, Mém. 1944, p. 100.

Arrêté grand-ducal du 16 novembre 1944 , modifiant l'arrêté grand-ducal du 14 juin 1944, portant modification de l'organisation judiciaire, Mém. 1944, p. 111 .

Arrêté grand-ducal du 25 novembre 1944, conférant aux juges de paix l'autorisation temporaire de desservir un ou plusieurs autres cantons, Mém. 1944, p. 129.

Arrêté grand-ducal du 30 novembre 1944 autorisant le Gonvernement à procéder à une enquête administrative, Mém. 1944, p. 144.

Arrếté grand-ducal du 2 mars 1945 portant institution de l'enquête administrative prévue par l'arrêté grand-ducal du 30 novembre 1944, Mém. 1945, p. 85.

\section{Netherlands}

\section{Acts of Parliament}

Wet van 18 April 1827 op de Zamenstelling der Rechterlijke Magt en het Beleid der Justitie, Stb. 1827 , No. 20.

Wet op de Regterlijke Organisatie en het Beleid der Justitie van 18 april 1835 , Stb. 1835, No. 10 .

Wet houdende wijzigingen in de Wet op de Rechterlijke Organisatie en het Beleid der Justitie, Stb. 92 ,

Wet van 23 Mei 1899 , houdende bepalingen ter uitvoering van art. 187 der Grondwet, Stb. $1899,128$.

Wet van 9 juli 1900 houdende nadere regeling van den dienst en het gebruik van spoorwegen, waarop uitsluitend met beperkte snelheid wordt vervoerd, Stb. 1900 , No. 118.

Wet van den 15 den Mei 1829 (Stb. 1829, No. 28) houdende Algemeene bepalingen der wetgeving van het Koningrijk, gewijzigd bij de Wet van 26 April 1917, Stb. 1917, No. 303.

Wet van 5 julli 1910, Stb. $1910, \mathrm{No} .180$.

Wet van 15 december 1917, Stb. 1917, No. 701 .

Wet van 29 Juli 1920, Stb. 1920, No, 624.

Wet van 17 November 1933, houdende nieuwe vaststelling van het rechtsgebied en de zetels der rechtbanken en kantongerechten, behorende tot het gerechtshof te 's-Hertogenbosch, Stb. 1933, no. 601.

Wet van 17 November 1933, houdende nieuwe vaststelling van het rechtsgebied en de zetels der rechtbanken en kantongerechten, behorende tot het gerechtshof te Armhem, Stb. 1933, no. 602.

Wet van 17 November 1933, houdende nieuwe vaststelling van het rechtsgebied en de zetels der rechtbanken en kantongerechten, behorende tot het gerechtshof te 's-Gravenhage, Stb. 1933, no. 603.

Wet van 17 November 1933, houdende nieuwe vaststelling van het rechtsgebied en de zetels der rechtbanken en kantongerechten, behorende tot het gerechtshof te Amsterdam, Stb. 1933, no. 604 .

Wet van 17 November 1933, houdende nieuwe vaststelling van het rechtsgebied en de zetels der rechtbanken en kantongerechten, behorende tot het gerechtshof te Leeuwarden, Stb. 1933, no. 605. 
Wet van 17 November 1933, houdende wettelijke bepalingen in verband met de nieuwe vaststelling van het rechtsgebied en de zetels der rechtbanken en kantongerechten, Stb. 1933, no. 606.

Besluit van 23 November 1933 tot bepaling vam het tijdstip van inwerkingtreding van de wetten van 17 November 1933, betrekkelijk de nieuwe vaststelling van rechtsgebied en zetels van de rechtbanken en kantongerechten, Stb. 1933, Nos. 601- 606.

Wet houdende regelen omtrent de voorlopige Staten-Generaal van 26 oktober 1945, Stb. 1944/1946, F 241.

Wet van 10 Juli 1952, houdende vaststelling van de Wet Oorlogsstrafrecht alsmede van enige daarmede verband houdende wijzigingen in het Wetboek van Strafrecht en de Invoeringswet Militair Straf-en Tuchtrecht, Stb. 1952, 408.

Wet van 19 mei 1954 betreffende goedkeuring van het Verdrag van Genève betreffende de bescherming van burgers in oorlogstijd, van 12 augustus 1949 , Stb. 1954, 249.

Wet van 23 september 1964, houdende voorzieningen ter waarborging van de voortzetting van de rechtspleging in geval van oorlog, oorlogsgevaar of daaraan verwante of daarmee verband houdende buitengewone omstandigheden (Noodwet rechtspleging), Stb. 1964, 375.

Wet van 14 juni 1990 tot wijziging van de Wet op de rechterlijke organisatie, de Wet Oorlogsstrafrecht en de Noodwet rechtspleging, in verband met nieuwe regels inzake de militaire strafrechtspraak, Stb. 1990, 372 .

Wet van 3 april 1996, houdende hernieuwde vaststelling van de Oorlogswet voor Nederland ter aanpassing aan de Grondwet en aan de Coordinatiewet uitzonderingstoestanden (Oorlogswet voor Nederland), Stb. 1996, 368.

\section{Executive decrees or acts}

Besluit van den souvereinen vorst van den 18 den December 1813 No. 5 , betrekkelijk de daarstelling van een Staatsblad der Vereenigde Nederlanden, Stb. 1814, No. 1.

Besluit van 21 Juni 1830, bepalende de zetels van den Hoogen Raad en der Provinciale Gerechtshoven, Stb. 1830, No. 29.

Besluit van 22 December 1863 , ter nadere regeling van de wijze en den vorm van afkondiging van Wetten en Koninklijke Besluiten, Stb. 1863, No. 149.

Koninklijk Besluit van 14 juni 1911, Stb. 1911 , No. 146.

Circulaire Secretaris-Generaal van het Departement van Justitie d.d. 19 Augustus 1940 , Afd. A.S., no. 1133.

Koninklijk Besluit van 17 April 1950, Stb. 1950, 25.

Aanwijzingen van Harer Majesteits regering omtrent de houding aan te nemen bij een vijandelijke bezetting, in: Nederlandse Staatscourant van I september 1980, nr. 168.

Beschikking van de Minister van Justitie van 21 december 2001, houdende plaatsing in het Staatsblad van de Wet op de Rechterlijke Organisatie, zoals deze luidt met ingang van 1 januari 2002, Stb. 2002, 1. 


\section{Decrees exile Government}

Koninklijk Besluit D 61 van 22 december 1943, houdende vaststelling van het Besluit Buitengewoon Strafrecht.

Koninklijk Besluit D 62 van 22 december 1943, houdende vaststelling van het Besluit op de Bijzondere Gerechtshoven.

Koninklijk Besluit van 13 januari 1944, houdende vaststelling van het Zuiveringsbesluit, Stb. 1940/1945, E 14.

Koninklijk Besluit van 19 februari 1944, houdende vaststelling van het Besluit Tijdelijke Organisatie der Rechterlijke Macht, Stb. 1940/1945, E 13.

Besluit van 7 september 1944, houdende vaststelling van het Beshuit Rechtsherstel ontslagen ambtenaren, Stb. 1940/1945, E 94.

Koninklijk Besluit van 17 september 1944, houdende vaststelling van het Besluit Bezettingsmaatregelen, Stb. 1940/1945, E 93.

Koninklijk Besluit van 17 september 1944, houdende vaststelling van het Besluit herstell rechtsverkeer, Stb. 1940/1945, 731.

Koninklijk Besluit $\mathrm{F} 56$ van 12 april 1945, houdende aanvulling van het Zuiveringsbesluit, Stb. 1940/1945, F 56.

Koninklijk Besluit van 12 mei 1945, houdende aanvulling van het Zuiveringsbesluit, Stb. 1940/1945, F 68 .

Koninlijk Besluit houdende vaststelling van het Besluit betreffende de Tijdelijke Staten-Generaal van 2 augustus 1945, Stb. 1944/1946, F 131.

Koninklijk Besluit van 2 augustus 1945, houdende vaststelling van het Zuiveringsbesluit 1945, Stb. 1944/1946, F 132.

Koninklijk Besluit van 1 oktober 1945, Besluit betreffende de rechtspraak in cassatie, Stb. 1944/1946, F 207.

Koninklijk Besluit van 26 oktober 1945, houdende nadere regelingen aangaande de zuivering der rechterlijke macht, Stb. 1944/1946, F 242.

Koninklijk Besluit van 26 oktober 1945, tot vaststelling van nadere reglingen ten anzien van in de bezettingstijd benoemde en ontslagen leden der rechterlijke macht, Stb. 1944/1946, F 243.

\section{OCCUPANT"S MEASURES}

\section{Belgium}

Heeresgruppen-Verordnungsblatt für die besetzten Gebiete, Oproep aan de bevolking van Nederland en België d.d. 10 mei 1940 (Opperbevelhebber van het Duitse leger). Verordnung über Waffenbesitz im Besetzten Gebiet vom 10.5.1940, VoBl. 19401944, S. 3.

Bekanutmachung für das besetzte Gebiet vom 10.5.1940, VoBl., 1940-1944, S. 4 .

Verordnung über die Einführung deutschen Strafrechts und strafrechtlicher Bestimmungen in den von deutschen Truppen besetzten Gebiete der Niederlande und Belgiens vom 10.5.1940, VoBl. 1940-1944, S. 7.

Verordnung über die Ausübung öffentlicher Tätigkeiten in Belgien vom 18. Juli 1940, VoBl. S. 131.

Bekanntmachung über die Ausübung öffentlicher Tätigkeiten in Belgien vom 19. September 1940, VoBl. 1940, S. 224. 
Verordnung über das Ordnungsstrafrecht in Belgien vom, vom 18. Dezomber 1940 , VoBl. 1940-1944, S. 445 .

Verordnung zur Ergänzung der Verordnung über die Ausübung öffentlicher Tätigkeiten in Belgien vom 19. Dezember 1940, VoB1. 1940, S. 445.

Verordnung gegen die Uberalterung der offentlichen Verwaltung in Belgien vom 7. März 1941, VoBl. 1941, S. 529.

2. Verordmung über das Ordmungsstrafrecht in Belgien vom 2. August 1941, VoBl. 1940-1944, S. 691 .

Verordnung über Ablieferung von Waffen vom 27. Dezember 1941, VoBl. 19401944, S. 813.

Verordmung gegen die Fälschung von Lebensmittelmarken und -bezugscheimen vom 16. März 1942, VoBl. 1940-1944, S. 859.

Verordnung über die Anwendung von Verordnungen der Generalsekretäre, vom 14. Mai 1942, VoBl. 1940-1944, S. 915.

Verordnung uber Waffengebrauch vom 7. September 1942, VoBl. 1940-1944, S. 1026.

Verordnung zur Änderung der Verordnung über die Sicherstellung des Kräftebedarfs fuir Arbeiten von besonderer Bedeutung vom 6. Oktober 1942, VoBl. 1940-1944, S. 1059 .

Verordnung zum Schutz des Arbeitsfriedens vom 10. Dezember 1942, VoB1. 19401944, S. 1109.

Verordnung über die Neugliederung von Gemeinden, vom 26. Januar 1943, VoBl. 1940-1944, S. 1139.

Verordnung zum Schutze des inneren Friedens und der Besatzungsmacht (Schutzverordnung) vom 28. April 1943, VoB1. 1940-1944, S. 1293.

\section{Luxembourg}

Verordnung über Maßnahmen auf dem Gebiete des Beamtenrechts vom 15. August 1940, VoB1. Nr. I vom I September 1940, S. 2.

Verordnung über die Auflösung der politischen Parteien in Luxemburg vonm 23.8.1940, VoBl. 1940, S. 3 .

Verordmung über die vorläufige Einrichtung einer deutschen Strafrechtspflege in Luxemburg, VoBl., Nr. I vom 1. September 1940, S. 2.

Verordmung über Maßnahmen auf dem Gebiete des Judenrechts vom 5. September 1940, VoB1. 1940, S. 10.

Verordnung über das jüdische Vermögen in Luxemburg vom 5. September 1940, VoBL. 1940, S. 11.

Verordnung betreffende das Abhören von Rundfunksendern vom 16. September 1940, VoB1. Nr. 2 vom 24 September 1940, S. 14.

Verordnung über die Ausübung der Gerichtsbarkeit in Luxemburg vom 26. August 1940, VoB1. Nr. 2 vom 24. September 1940, S. 6.

Verordnung über die Auflösung der Abgeordnetenkammer und des Staatsrates in Luxemburg vom 22. Oktober 1940, VoBl. Nr. 52 vom 29 Oktober 1940, S. 278.

Verordnung über die Einrichtung eines Sonderstrafgerichts in Luxemburg vom 22 . Oktober 1940, VoBl. 1940 , S. 278.

Bekanntmachung über die Sperrung der V. d. B. für alle Beamten vom 24 Oktober 1940 , Luxemburger Zeitung Nr. 274 vom 25 Oktober 1940. 
Erste Durchfuhrungsverordnung zur Verordnung über die Einrichtung eines Sonderdienststrafgerichts vom 22. 10. 1940, VoBl. Nr. 66 vom 11. Dezember 1940, S. 375. Verordnung zur vorläufigen Regelung der Rechtspflege in Luxemburg vom 9 . November 1940, VoB1. Nr. 56 vom 15. November 1940, S. 297.

Verordnung über den Verwaltungsaufbau in Luxemburg vom 14 . November 1940 , VoBI. 1940, S. 291

Erste Durchführungsverordnung zur Verordnung vom 14 . November 1940 über den Verwaltungsaufbau in Luxemburg (Gemeinderecht) vom 15. November 1940, VoBl. 1940, S. 292.

Zweite Durchführungsverordnung zur Verordnung vom 14. November 1940 über den Verwaltungsaufbau in Luxemburg (Landkreise, Verschiedenes) vom 16. November 1940, VoBl. 1940, S. 295.

Bekanntmachung vom 25. November 1940 über die Verwaltungskommission, Mém. 1940, No. 63, p. 729.

Verordmung über die Einführung und Anwendung reichsrechtlicher Vorschriften auf dem Gebiete der Forst- und Holzwirtschaft in Luxmburg vom 25. November 1940 , VoB1. 1940, S. 361 .

Verordnung über Anwendung von steuerrechtlichen Vorschriften in Luxemburg vom 31. Dezember 1940, VoBl. 1940, S. 560.

Verordnung gegen heimtückische Angriffe auf das Deutsche Reich, die Partei und Beweging vom 15. Januar 1941, VoBl. 1941, S. 48 .

Verordnung über die Einführung reichsrechtlicher Vorschriften auf dem Gebiet des Personenstands- und Eherechts vom 31. Januar 1941, VoB1. 1941, S. 118.

Verordnung über Strafmaßnahmen auf dem Gebiete der Strafrechtspflege vom 4. März 1941, VoBI. Nr. 18 vom 4 März 1941, S. 127.

Verordnung über Strafen und Strafverfahren bei Zuwiderhandlungen gegen Preisvorsclnriften (Preisstrafrechtsverordnung) vom 4. März 1941, VoB1. 1941, S. 135.

Verordnung zur Durchführung und Ergänzung der Verordnung über die Einführung reichsrechtlicher Vorschriften auf dem Gebiet des Personenstands- und Eherechts vom 31. Januar 1941 vom 22 März 1941, VoB1. 1941, S. 162.

Verordnung über Maßnahmen auf dem Gebiete des Beamtenrechts vom 31 März 1941, VoBl. Nr. 27 vom 4. April 1941, S. 186.

Verordnung zur Einführung einer Schlachtviehmarktregelung in Luxemburg vom 30. Mai 1941, VoBl. 1941, S. 590.

Verordnung über das Verbot des Gebrauchs der französischen Sprache in der Öfentlichkeit vom 1. Juni 1941, VoBI. Nr. 37 vom 10. Juni 1941, S. 240

Verordnung über die Einführung von Verfahrens- und Kostengesetzen in Luxemburg vom 18. Juli 1941, VoBl. 1941, S. 311 .

2. Verordnung über heimtückische Angriffe auf das Deutsche Reich, die Partei und Beweging vom 14. Oktober 1941, VoB1. $1941, \mathrm{~S}_{n} 414$.

Verordnung betreffende Maßnahmen anf dem Gebiete der Strafrechtspflege vom 30. Mai 1941, VoBI. 1941, S. 247.

Durchfïhrungsbestimmungen zur Verordmung vom 18.7.1941 über die Einführung von Verfahtrens- und Kostengesetzen, vom 30. Juli 1941, VoBl. 1941, S. 314.

Verordnung über die Anlegung einer Volkstumskartei in Luxemburg vom 10. Oktober 1941, VoBl. 1941, S. 410.

Verordnung zur Wahrung des inmeren Friedens in Luxemburg vom 13. Oktober 1941, VoBl. Nr. 68 vom 18. Oktober 1941, S. 413. 
Verordnung über Waffenbesitz in Luxemburg vom 13. Oktober 1941, VoB1. 1941, S. 418.

2. Verordnung über Maßnahmen auf dem Gebiete des. Beantenrechts vom 28 Oktober 1941, VoBl. 1941, S. 458.

Verordnung zur Abwehr verräterischer Bestätigung in Partei und Bewegung vom 31 . Oktober 1941, VoB1. 1941, S. 469.

4. Verordnung betreffende Maßnahmen auf dem Gebiete der Strafrechtspllege vom 31. Oktober 1941, VoBl. Nr. 75 vom 12. November 1941, S. 483.

5. Verordnung betreffende Maßnahmen auf dem Gebiete der Strafrechtspflege, VoBI. Nr. 87 vom 31 December 1941, S. 544.

Anordnung über die gemeindliche Neugliederung des Kreises Diekirch vom 27. Februar 1942, VoBl. 1942, S. 62.

Verordnung über die Einführung deutschen bürgerlichen Rechts sowie zur Ergänzung vom 18.7.1941 über die Einführung von Verfahrens- und Kostengesetzen in Luxemburg vom 15 März 1942, VoB1. 1942, S. 624.

Verordnung über die Eingliederung des Bereichs der Aertzekammer Luxemburg in die Aerztekammer Moselland vom 22. August 1942, VoB1. Nr. 52 vom 8 . September 1942 , S. 267.

Verordmung über die Wehrpflicht in Luxemburg yom 30. August 1942, VoBl. 1942, S. 253.

Anordnung über die wehrpflichtige Jahrgänge in Luxemburg vom 30 . August 1942 , VoB1. 1942, S. 253.

2. Verordnung über Waffenbesitz in Luxemburg vom 24. Juni 1943, VoBI. 1943, S. 145 .

Verordnung über Maßnahmen gegen Wehrpflichtentziehung vom 10. Juli 1943, VoB1. 1943 , S. 152.

Verordnung uber die Eingliederung des Bereichs der Apothekerkammer Luxemburg in die Bezirksapothekerkammer Moselland vom 9. November 1943, VoBI. 1943, S. 676.

\section{The Netherlands}

Heeresgruppen-Verordnungsblatt für die besetzten Gebiete, Oproep aan de bevolking wan Nederland en België d.d. 10 mei 1940 (Opperbevelhebber van het Duitse leger).

Führer-Erlasses vom 18. Mai 1940, Reichsgesetzblatt, Teill I, S. 778.

Verordnung 1940/1 des Führers über die Ausübung der Regierungsbefugnisse in den Niederlanden vom 18. Mai 1940, VoBl. 1940, S. 2.

Verordnung 1940/3 des Reichskommissars der besetzten niederländischen Gebiete über die Ausübung der Regierungsbefugnisse in den Niederlanden vom 29. Mai 1940, VoBl. 1940, S.8.

Erlass $1940 / 4$ des Reichskommissars für die besetzten niederländischen Gebiete über den organisatorischen Aufbau der Dienststellen des Reichskommissars vam 3. Juni 1940, VoBl. 1940, S. 11 .

Verordnung 1940/22 des Reichskommissars für die besetzten niederländischen Gebiete zur Sicherung der Tätigkeiten des Staatsrats sowic einiger öffentlichrechtlicher Vertretungskörperschaften vom 21.Juni 1940, VoB1. 1940, S. 54. 
Verordnung 1940/23 des Reichskommissars für die besetzten niederländischen Gebiete über die Befugnisse der Generalsekretäre der niederländischen Ministerien vom 21. Juni 1940, VoB1. 1940, S. 55.

3. Verordnung 1940/79 des Reichskommissars für die besetzten niederländischen Gebiete über besondere verwaltungsrechtliche Maßnahmen vom 1. August 1940 , VoBl 1940, S. 246.

Verordnung 1940/108 Vierte Verordnung des Reichskommissars für die besetzten niederländischen Gebiete über besondere verwaltungsrechtliche Maßnahmen vom 20 August 1940, VoBl. 1940, S. 338.

Verordnung 1940/143 des Generalsekretärs im Ministerium für Landwirtschaft und Fischerei zur Durchführung des Zuteilungsgesetzes 1939 (Zuteilung von Fleisch und Fleischwaren) vom 11. September 1940, VoBI. 1940, S. 433.

Verordnung 1940/137 des Reichskommissars für die besetzten niederländischen Gebiete über die Regelung der rechtlichen und finanziellen Verhältnissen von Beamten, Angestellten und Arbeitern sowie gewisser vereidigter Personen vom 13. September 1940, VoBl. 1940, S. 425.

Verordnung 1940/187 des Reichskommissars für die besetzten niederländischen Gebiete zur Vereinfachung der Strafrechtspflege vom 22 Oktober 1940, VoBl. 1940, S. 541 .

Verordnung 1940/194 des Reichskommissars für die besetzten niederländischen Gebiete über die Feststellung und Änderung von Haushaltsplänen und über die Feststellung von Rechnungen des Staates, der Staatsfonds und der Staatsbetriebe vom 31. Oktober 1940, VoBl. 1940, S. 560.

Verordnung 1941/42 des Reichskommissars für die besetzten niederländischen Gebiete über die Dienstpflicht und die Beschränkung des Arbeitsplatzwechsels vom 28. Februar 1941, VoBl. 1941, S. 152.

Verordnung 1942/22 des Reichskommissars für die besetzten niederländischen Gebiete, wodurch die Verordnung Nr. 42/1941 über die Dienstpflicht und die Beschränkung des Arbeitsplatzwechsels abgeändert wird vom 23 März 1942, VoBl. 1942, S. 155 .

Verondnung 1941/71 des Generalselkretärs in Ministerium für Justiz über die gerichtliche Behandlung von Wirtschafsstrafsachen vom 7. April 1941, VoBl. 1941, S. 297. Verordnung 1941/97 des Reichskommissars für die besetzten niederländischen Gebiete ïber den niederländischen Arbeitsdienst (Arbeitsdienstverordnung) vom 23. Mai 1941, VoBI. 194I, S. 370.

Verordnung 1941/48 des Reichskommissars für die besetzten niederländischen Gebiete über die Behandlung anmeldepflichtiger Unternehmen vom 12. März 1941 (Wirtschaftsentjudungsverordnung), VoBl. 1941, S. 164.

Verordnung 1941/130 des Reichskommissars für die besetzten niederländischen Gebiete über die Altersgrenze der Richter vom 18. Juli 1941, S. 538.

Verordnung 1941/152 des Reichskommissars für die besetzten niederländischen Gebiete über besondere verwaltungsrechtliche Maßnahmen vom 11. August 1941, VoBl. 1941, S. 637.

Verordnung 1941/156 des Generalsekretärs im Ministerium für Justiz über die Bestellung von Friedensrichtern und die Einsetzung eines Friednsgerichtshofs vom 12 . August 1941, VoB1. 1941, S. 664. 
Verordnung 24/1942 des Reichskommissars für die besetzten niederländischen Gebiete über die niederländische Apothekerschaft vom 13 März 1942, VoBI. 1942, S. 136.

Verordnung 1942/35 des Reichskommissars für die besetzten niederländischen Gebiete, wodurch die Arbeitsdienstverordnung abgeändert wird vom 28 März 1942, VoB1. 1942, S. 178.

Verordnung 1942/39 des Generalsekretärs im Ministerium für Justiz, wodurch die Verordnung $\mathrm{Nr}$. 71/1941 über die gerichtliche Behandlung von Wirtschaftsstrafsachen abgeändert und ergänzt wird vom 7. April 1942, VoBI. 1942, S. 191.

Kundmachung des Reichskommissars für die besetzten niederländischen Gebiete über die nunmehr geltende Fassung der Verordnung Nr. 52/1940 über die Deutsche Gerichtsbarkeit in Strafsachen vom 6. Julli 1942, VoBl. 1942, S. 346.

2. Verordnung 1942/92 des Generalsekretärs im Ministerium für Justiz, wodurch die Verordnung Nr. 71/1941 über die gerichtliche Behandlung von Wirtschaftsstrafsachen abgeändert und ergänzt wird vom 13. August 1942, VoBl. 1942, S. 405.

3. Verordnung 1943/40 des Generalsekretärs im Ministerium für Justiz, wodurch die Verordnung Nr. $71 / 1941$ über die gerichtliche Behandlung von Wirtschaftsstrafsachen abgeändert wird vom 15. April 1943, VoBl. 1943, S. 168.

Verordnung 1943/62 des Generalsekretärs im Ministerium für Justiz über die Anwendung gesetzlicher Strafbestimmungen vom 9. Juni 1943, VoBl. 1943, S. 233.

Verordnung 1944/3 des Generalsekretärs vom 28. Dezember 1943, VoBl. 1944, S 4. 



\section{TABLE OF CASES}

\section{BELGIUM}

Cour de cassation / Hof van Cassatie.

Cass. 23 juillet 1849 ; Pas., 1849, I, 443.

Cass 20 mai 1916; Pas., I, 1916, 416; Belgique judiciaire 1919, cons. 167 e.a.

Cass. 11 février 191.9, Revue Administration, 1919, p. 193.

Cass. 11 février 1919; Pas., 1919, 1, 9.

Cass. 4 juin 1919; Pas., 1919, I, 97.

Cass. 11 décembre 1919; Pas., 1920, I., 124.

Cass. (2e Ch.) 10 février 1920; Pas., 1920, 51.

Cass. 9 décembre 1920; Pas., I, 177.

Cass. 25 janvier 1921 ; Pas., $1921,1,223$.

Cass. 19 juillet 1921; Pas., 1921, 1, 445.

Cass. 19 juillet 1921; Pas., 1921, I, 456.

Cass. du 31 octobre 1921; Pas., 1922, I, 41.

Cass. (2e Ch.) 3 mars 1924; Pas., 1924, I, 231.

Cass. 26 novembre 1925, Pas. 1926, I, 76.

Cass. 10 décembre 1928; Pas., 1929, I, 36.

Cass. 24 mars 1.941; Pas. 1941, I, 93.

Cass. 24 mars 1941; Pas. 1941, I, 95

Cass. (2e ch.) 7 avril 1941, published in: Smolders, Jurisprudence, p. 11-14

Cass. 7 avril 1941; Pas., 1941, 1, 136; Revue Administration, 1941, p. 315.

Cass. 7 avril 1941; Pas., 1941, I, 136; Revue Administration, 1941, p. 315.

Cass. 8 avril 1941; Pas. 1941, I, 139.

Cass. 5 mai 1941; Pas. 1941, I, 172.

Cass. 5 mai 1941; Pas. 1941, I, 175.

Cass. 20 octobre 1941; Pas. 1941, I, 382.

Cass. 26 octobre 1941; Pas. 1941, I, 382.

Conclusions de M. l'avocat général précédent l'arrêt du 3 novembre 1941; Pas. 1941 ,

I, 407; Revue Administration, 1942, p. 113.

Cass. 30 mars 1942; Pas. 1942, 1, 75.

Cass. (2e Ch.) 30 mars 1942; Pas. 1942, I, 82.

Cass. 27 janvier 1943; Pas. 1943, 1, 33; Revue Administration, 1943, p. 173.

Cass. 1 février 1943; Pas. 1943, I, 44.

Cass. 10 février 1943; Pas., 1943, I, 61 .

Cass. 28 juillet 1943; Pas., 1943, I, 303.

Cass. 28 juillet 1943; Pas., 1943, I, 305.

Cass., 25 août 1943; Pas., 1943, 1, 337.

Cass. (2e Ch.) 6 novembre 1944; Pas., 1945, I, 23.

Cass. (2e Ch.) 13 novembre 1944; Pas., 1945, I, 33.

Cass. (2e Ch.) 27 novembre 1944; Pas., 1945, I, 54.

Cass. (1re Ch.) 30 novembre 1944, in: JdT 1946-1947, p. 124- 125.

Cass. (2e Ch.) 11 décembre 1944; Pas., 1945, I, 65.

Cass. (2e Ch.) 18 décembre 1944; Pas., 1945, I, 70.

Cass. 22 janvier 1945, in: Dautricourt, Militaire, p. 250-251.

Cass. (2e Ch.) 5 février 1945; Pas., 1945, 1, 107. 
Cass. 12 ferrier 1945, in: Dautricourt, Militaire, p. 257-258.

Cass. (2e Ch.) 14 mai 1945; Pas, 1945, 1, 160 .

Cass. (2e Ch.) 17 mai 1945; Pas., 1945, I, 165.

Cass. 17 mei 1945, in: Dautricourt, Militaire, p. 261-265.

Cass. 28 mai 1945, in: Dautricourt, Militaire, p. 265.

\section{Cours d'appel/Beroepshoven}

Cour d"appel de Liège 31 mai 1915; Pas., II, 82 .

Cour d'appel de Bruxelles 19 juillet 1915; Pas. 1919, II, 37.

Cour d'appel de Bruxelles (9e Ch.) 15 décembre 1941, cited in: CEGES/SOMA, Conseil da Législation, MIC 74, Mathieu, G. Eude sur la Délégation des Ponvoirs en Temps de Guerre, p. 70.

Cour d'appel de Bruxelles 22 octobre 1942, in: Ockrent, p. 44-46.

Cour d'appel de Bruxelles 13 avril 1945; Pas., 1945, II, 24.

Cour d'appel de Liège 19 novembre $1945 ;$ Pas., 1945, II, 43.

\section{Tribuncux / Gerechten van Eerste Aanleg}

Tribunal correctionel de Charleroi du 6 novembre 1941; Pas. 1943, III, 58.

Tribunal correctionnel de Liège 30 avril 1945; Pas., 1945, III, 74.

Tribunal civil de Bruxelles 5 juillet 1945; Pas., 1945, III, 94.

Tribunal civil de Huy 13 juillet 1.945 ; Pas., 1945, III, 88.

\section{Justices de Paix / Vredegerechten}

Justice de Paix, Louveigné, 20 février 1942, cited in: CEGES/SOMA, Conseil de Législation, MIC 74, Mathieu, G., Etude sur la Délégation des Pouvoirs en Temps de Guerre, p. 66.

Justice de Paix Walcourt, 20 février 1942, cited in: CEGES/SOMA, Conseil de Légilslation, MIC 74, Mathieu, G., Etude sur la Délégation des Pouvoirs en Temps de Guerre, p. 67.

Justice de Paix Schaerbeek (le canton), 15 avril 1942, cited in: CEGES/SOMA, Documents Zéro, ref. AA 1078, no. 1034/55.

\section{LUXEMBOURG}

Cour supérieure de justice

Cour Supérieure de Justice (cassation criminelle) du 4 juillet 1945, Pas. lux., Tome XIV, p. 261.

Cour Supérieure de Justice (cassation criminelle) du 12 juillet 1945, Pas. lux., Tome XIV, p. 261.

Cour Supérieure de Justice (cassation criminelle) du 21 novembre 1945, Pas. Iux., Tome XIV, p. 263.

Cour Superieure de Justice (cassation criminelle) du 24 janvier 1946, Pas. Jux., Tome XIV, p. 225.

Cour Supérieure de Justice (appel civil) du 2 juillet 1947, Pas. lux., Tome XIV, p. 298.

Cour Supérieure de Justice (appel correctionnel) du 6 mars 1948, Pas. Iux., Tone XIV, p. 362. 
Cour Supérieure de Justice (cassation criminelle) du 29 juillet 1948 , Pas. lux., Tome XIV, p. 422 .

Cour Supérieure de Justice (cassation civile) du 17 mai 1949, Pas. lux., Tome XIV, p. 548 .

Cour supérieure de Justice (cassation criminelle) du 1. Décembre 1949, Pas. Iux., Tome XIV, p. 596.

\section{Tribunaux d'arrondissement / Landgerichte}

Strafsache gegen B. und R. vom 29-5-1942, 6 K. Ms. 7/42, I. 100/42, in: Conseil National de la Résistance, Archives personelles de M. le Président P Dostert, Collection de jugements.

Strafsache gegen $R$, und B. vom 18-11-1941, 6 K. Ms. 8/41, I. 315/41, in: Conseil National de la Résistance, Archives personelles de M. le Président P. Dostert, Collection de jugements.

Tribunal d'arrondissement de Luxembourg (civil) du 8 janvier 1946, Pas. lux, Tome XIV, p. 232.

Tribunal d'arrondissement de Luxembourg (civil) du 26 juin 1946, Pas. lux, Tome XIV, p. 234.

Tribunal d'arrondissement de Diekirch (civil) du 24 juillet 1946, Pas. Iux., Tome XIV, p. 250.

Tribunal d'arrondissement de Luxembourg (civil) du 31 juillet 1946, Pas. Iux., Tome XIV, p. 244.

Tribunal d'arrondissement de Luxembourg (civil) du 5 mars 1947, Pas. lux., Tome XIV, p. 289.

\section{Justices de Paix / Amtsgerichie}

Urteil des Amtsgerichts vom 28-10-1943, 3 Ds. 201/43, in: Conseil National de la Résistance, Archives personelles de M. le Président P. Dostert, Collection de jugements.

Urteil des Amtgerichts in Luxemburg in der Strafsache gegen B. vom 1-4-1944, 3 Ds. 91/44, in: Conseil National de la Résistance, Archives personelles de M. le Président P. Dostert, Collection de jugements.

Urteil des Amtsgerichts in Luxemburg in der Strafsache gegen F. vom 18 . Maerz 1944, 3 Ds. 72/44, in: Conseil National de la Résistance, Archives personelles de M. le Président P. Dostert, Collection de jugements.

\section{THE NETHERLANDS}

\section{Hoge Raad / Supreme Court}

Hoge Raad 2 oktober 1851 , Nederlandsche Regtsspraak XL par. 1 .

Hoge Raad 25 mei 1906, WVhR, 8383.

Hoge Raad 28 juni $1915, N J 1915,713$.

Hoge Raad 14 februari 1916, NJ 1916, 681.

Hoge Raad 23 mei 1921, NJ 1921, 564.

Hoge Raad 20 februari 1933, NJ 1933, 918.

Hoge Raad (Strafkamer) 16 december 1940, N/1941, 195.

Hoge Raad (Burg. Kamer) 10 januari 1941, NJ $1941,824$.

Hoge Raad 26 mei 1941, NJ 1941,868. 
Hoge Raad (Strafkamer) 5 oktober 1942, NJ 1943, 11.

Hoge Raad (Strakkamer) 16 november $1942, N J 1943,15$.

Hoge Raad 5 maart 1943, NJ 1943, 203.

Hoge Raad (Strafkamer) 22 november 1943, NJ 1943, 143.

Hoge Raad 30 october 1946, NJ 1946, 737.

Hoge Raad 13 januari 1950, NJ 1950, 493.

\section{Gerechtshoven / Counts of Appeal}

Gerechtshof Arnhem (Pachtkamer) 30 juni 1941, $N_{J} J 1941,688$.

Gerechtshof Amhem (Pachtkamer) 16 juli 1941, NJ 1941, 825.

Gerechtshof te Leeuwarden, 25 februari 1943, NJ 1951, 643.

Gerechtshof 's-Gravenhage (2e Kamer) 30 april 1943, NJ 1943, 699.

Gerechtshof' 's-Gravenhage 15 december 1948, NJ 1949, 566.

Gerechtshof 's-Gravenhage (le Kamer) 3. maart 1949, $N J 1949,575$.

\section{Arrondissementsrechtbanken / District Courts}

Arrondissementsrechtbank Breda (Burg. Kamer) 16 juli 1940, NJ 1940, 997.

Arrondissementsrechtbank 's-Hertogenbosch (2e Kamer) 13 november 1941, NJ 1942,88 .

Arrondissementsrechtbank 's-Gravenhage (Rechter-Commissaris Mr. van Rijn van Alkemade) 26 januari 1942, NJ 1942, 201.

Arrondissementsrechtbank 's-Gravenhage (4e Kamer) 12 maart 1942, NJ 1942, 332.

Arrondissementsrechtbank Ratterdam (Kort geding) (Mr. v. Oosten Slingeland) 28 augustus 1944, NJ 1944/1945, 573 .

Arrondissmentsrechtbank Arnhem (Kort geding) (Jhr. Mr. van Nispen to Sevenaer) 4 september $1944, N J 1944 / 1945,653$.

Arrondissementsrechtbank 's-Gravenhage (le Kamer) 12 januari 1945, NJ $1944 / 1945,678$.

Arrondissementsrechtbank Rotterdam 24 december 1945, NJ 1946, 56.

Arrondissementsrechtbank Rotterdam 28 maart 1946, NJ 1946, 215.

Arrondissementsrechtbank Rotterdam Is september 1946, NJ 1946, 727.

\section{Kantongerechten / Cantonal courts}

Kantongerecht Heerlen 7 augustus 1940, NJ 1940, 988.

Kantongerecht Zaandam 13 augustus 1940, NJ 1940, 992.

Kantongerecht Hoom (geen datum), NJ 1940, 1072.

Kantongerecht Haarlem 20 september 1940, NJ 1940, 973.

Kantongerecht Apeldoorn 9 oktober 1940, NJ 1940, 960.

Kantongerecht Rotterdam 25 oktober $1940, N J 1940,1052$.

Kantongerecht 's-Gravenhage 25 oktober 1940, NJ 1940, 972.

Kantongerecht Dordrecht 23 maart $\mathbb{1 9 4 4}$, NJ 1944/1945, 318.

Centrale Raad van Beroep / Central Appeals Court for the public service and social security matters

CRvB 25 maart $1946, A B 1946,4$.

CRvB 11 mei $1948, A B 1948,507$.

CRvB 30 september $1958, A B 1960,459$. 
Bijzondere Raad van Cassatie / Special Court of Cassation Bijzondere Raad van Cassatie 5 december 1945, N.O.R., 150. 



\section{CURRICULUM VITAE}

J.N.M.E. (Yuri) Michielsen was born in Mestreech (Maastricht) The Netherlands on 20 July 1970. He graduated from Maastricht University"s European Law School program in June 1998. During his law studies Yuri competed in the 1996/1997 European Law Moot Court Competition where he was awarded 'Best Speaker' and was a member of the "Winning Team'. This allowed him to do an internship at the Legal Service of the European Commission in 1997/1998. In June 2000 Yuri received his LL.M from the Harvard Law School. From September 2000 until December 2004 he was a junior researcher at the Maastricht University Faculty of Law. His interests for future research projects include Maastricht legal history and extending his research on courts and the law during the occupation of World War Two to other jurisdictions. 